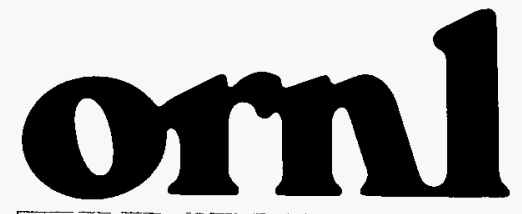

OAK RIDGE NATIONAL LABORATORY

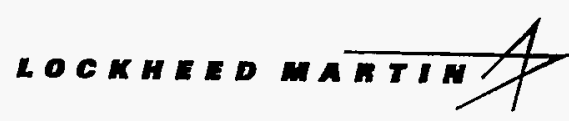

\section{ENVIRONMENTAL SCIENCES DIVISION}

Report on the Biological Monitoring Program at Paducah Gaseous Diffusion Plant December 1993 to December 1994

L. Adams Kszos

\section{Environmental Sciences Division}

Publication No. 4390

May 1996
MANAGED AND OPERATED BY LOCKHEED MARTN ENERGY RESEARCH CORPORATION FOR THE UATED STATES DEPARTMENT OF ENERGY ORNL-27 (3-8)

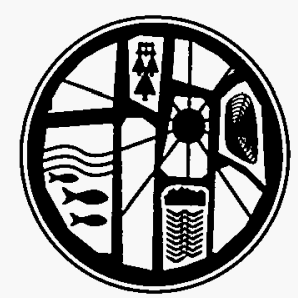


This report has been reproduced directly from the best available copy.

Available to DOE and DOE contractors from the Office of Scientific and Technical Information, P.O. Box 62, Oak Ridge, TN 3783\%; prices available from (423) 576-8401, FTS 626-8401.

Available to the public from the National Technical Information Service, U.S. Department of Commerce, 5285 Port Royal Rd., Springfield, VA 22161.

This report was prepared as an account of work sponsored by an agency of the United States Government. Neither the United States Government nor any agency thereof, nor any of their employees, makes any warranty, express or implied, or assumes any legal liability or responsibility for the accuracy, completeness, or usefulness of any information, apparatus, product, or process disclosed, or represents that its use would not infringe privately owned rights. Reference herein to any specific commercial product, process, or service by trade name, trademark, manufacturer, or otherwise, does not necessarily constitute or imply its endorsement, recommendation, or favoring by the United States Government or any agency thereof. The views and opinions of authors expressed herein do not necessarily state or reflect those of the United States Government or any agency thereof. 
ENVIRONMENTAL SCIENCES DIVISION

\title{
Report on the Biological Monitoring Program at Paducah Gaseous Diffusion Plant December 1993 to December 1994
}

\author{
Editor \\ L. Adams Kszos \\ Contributors \\ R. L. Hinzman \\ L. A. Kszos \\ M. J. Peterson \\ M. G. Ryon \\ M. R. Smith \\ G. R. Southworth \\ J. R. Sumner . \\ Environmental Sciences Division \\ Publication No. 4390 \\ Date of Issue - May 1996 \\ Prepared for \\ D. L. Ashburn \\ Environmental Management \\ Lockheed Martin Energy Systems, Inc. \\ Prepared by the \\ OAK RIDGE NATIONAL LABORATORY \\ Oak Ridge, Tennessee 37831-6285 \\ managed by \\ LOCKHEED MARTIN ENERGY RESEARCH CORP. \\ for the \\ U.S. DEPARTMENT OF ENERGY \\ under contract DE-AC05-96OR22464
}





\section{DISCLAIMER}

Portions of this document may be illegible in electronic image products. Images are produced from the best available original document. 



\section{CONTENTS}

$\underline{\text { Page }}$

LIST OF FIGURES $\ldots \ldots \ldots \ldots \ldots \ldots \ldots \ldots \ldots \ldots \ldots \ldots \ldots \ldots \ldots \ldots \ldots \ldots \ldots$ vii

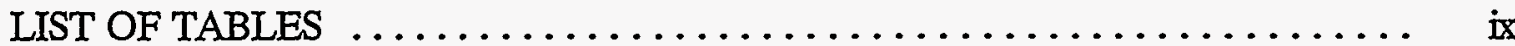

LIST OF ACRONYMS $\ldots \ldots \ldots \ldots \ldots \ldots \ldots \ldots \ldots \ldots \ldots \ldots \ldots \ldots \ldots \ldots \ldots \ldots \ldots$

ACKNOWLEDGMENTS $\ldots \ldots \ldots \ldots \ldots \ldots \ldots \ldots \ldots \ldots \ldots \ldots \ldots \ldots \ldots \ldots \ldots \ldots$ xv

EXECUTIVE SUMMARY $\ldots \ldots \ldots \ldots \ldots \ldots \ldots \ldots \ldots \ldots \ldots \ldots \ldots \ldots \ldots$ svii

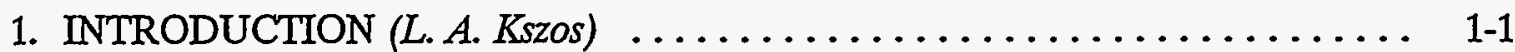

2. DESCRIPTION OF STUDY AREA $\ldots \ldots \ldots \ldots \ldots \ldots \ldots \ldots \ldots \ldots, 2-1$

2.1 SITE DESCRIPTION $(R, L$. Hinzman $) \ldots \ldots \ldots \ldots \ldots \ldots \ldots \ldots, 2-1$

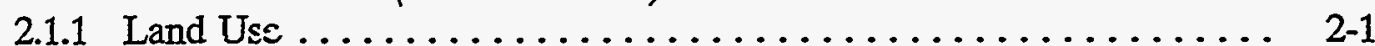

2.1 .2 Geohydrology $\ldots \ldots \ldots \ldots \ldots \ldots \ldots \ldots \ldots \ldots \ldots \ldots \ldots \ldots \ldots \ldots \ldots, 2-2$

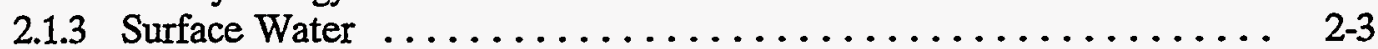

2.2 WATER QUALITY AND PGDP EFFLUENTS $(R$. L. Hinzman) ...... 2-6

2.3 DESCRIPTION OF STUDY SITES (J. G. Smith, M. J. Peterson,

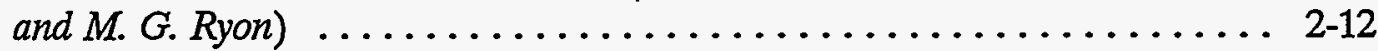

3. TOXICITY MONITORING (L. A. Kszos and J. R. Sumner) ............ 3-1

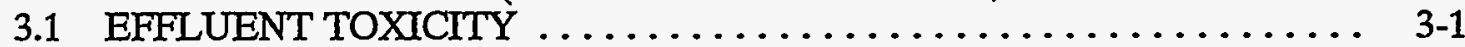

3.1.1 Introduction $\ldots \ldots \ldots \ldots \ldots \ldots \ldots \ldots \ldots \ldots \ldots \ldots \ldots, 3-1$

3.1.2 Materials and Methods ........................ 3-2

3.1.3 Results ............................... 3-5

3.1.3.1 Continuously flowing outfalls $001,006,008,009$,

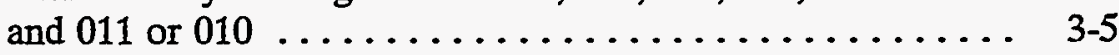

3.1.3.2 Intermittently flowing outfalls $013,015,016,017$,

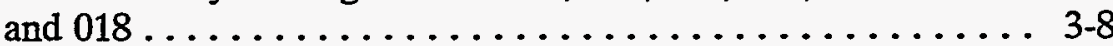

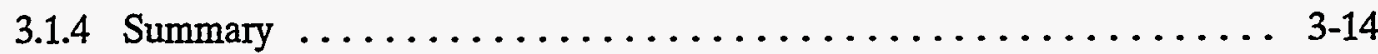

3.1.4.1 Continuously flowing outfalls $\ldots \ldots \ldots \ldots \ldots \ldots \ldots, 3-14$

3.1.4.2 Intermittently flowing outfalls $\ldots \ldots \ldots \ldots \ldots \ldots \ldots \ldots, 3-14$

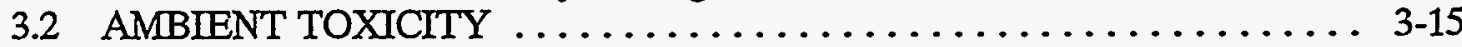

3.2 .1 Introduction $\ldots \ldots \ldots \ldots \ldots \ldots \ldots \ldots \ldots \ldots \ldots \ldots \ldots \ldots \ldots \ldots \ldots, 3-15$

3.2.2 Materials and Methods .......................... 3-15

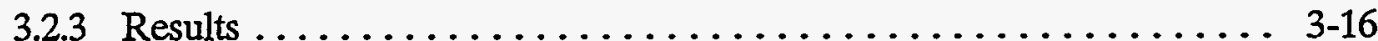

3.2 .4 Discussion $\ldots \ldots \ldots \ldots \ldots \ldots \ldots \ldots \ldots \ldots \ldots \ldots \ldots \ldots \ldots \ldots \ldots, 24$

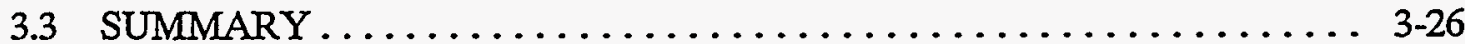

4. BIOACCUMULATION (G. R. Southworth amd M. J. Peterson) ......... 4-1

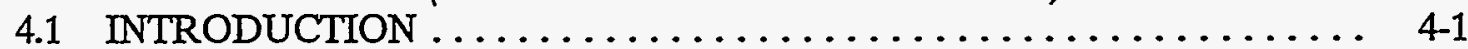




\section{CONTENTS (continuéd)}

42 STUDY SITES

4.3 MATERIALS AND METHODS $\ldots \ldots \ldots \ldots \ldots \ldots \ldots \ldots \ldots \ldots \ldots \ldots \ldots \ldots \ldots, 4,2$

4.4 RESULTS $\ldots \ldots \ldots \ldots \ldots \ldots \ldots \ldots \ldots \ldots \ldots \ldots \ldots \ldots \ldots \ldots \ldots \ldots, 4,4$

4.4 .1 PCBs $\ldots \ldots \ldots \ldots \ldots \ldots \ldots \ldots \ldots \ldots \ldots \ldots \ldots \ldots \ldots \ldots, 4,4$

4.4 .2 Mercury $\ldots \ldots \ldots \ldots \ldots \ldots \ldots \ldots \ldots \ldots \ldots \ldots \ldots \ldots, 4.7$

4.4.3 Screening studies $\ldots \ldots \ldots \ldots \ldots \ldots \ldots \ldots \ldots \ldots \ldots \ldots \ldots, 4-10$

4.4.3.1 Metals ........................... 4-10

4.4.3.2 Chlorinated pesticides .................... 4-10

4.4.3.3 Radionuclides ........................ 4-11

4.5 Future studies $\ldots \ldots \ldots \ldots \ldots \ldots \ldots \ldots \ldots \ldots \ldots \ldots, 4,12$

5. ECOLOGICAL MONITORING STUDIES $\ldots \ldots \ldots \ldots \ldots \ldots \ldots \ldots \ldots$. $5-1$

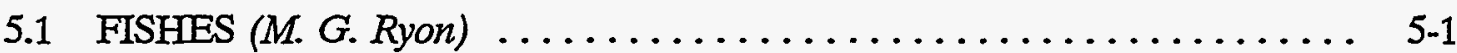

5.1 .1 Introduction $\ldots \ldots \ldots \ldots \ldots \ldots \ldots \ldots \ldots \ldots \ldots \ldots \ldots \ldots \ldots \ldots \ldots \ldots \ldots, 1$

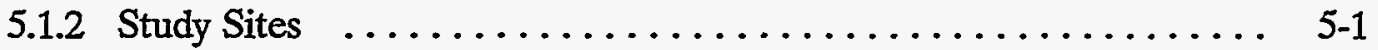

5.1.3 Materials and Methods $\ldots \ldots \ldots \ldots \ldots \ldots \ldots \ldots \ldots \ldots \ldots$ 5-2

5.1.3.1 Quantitative field sampling procedures $\ldots \ldots \ldots \ldots \ldots \ldots$ 5-2

5.1.3.2 Qualitative field sampling procedures $\ldots \ldots \ldots \ldots \ldots \ldots, 5-3$

5.1.3.3 Data analysis ......................... $5-3$

5.1 .4 Results $\ldots \ldots \ldots \ldots \ldots \ldots \ldots \ldots \ldots \ldots \ldots \ldots \ldots \ldots \ldots, 5-4$

5.1.4.1 Quantitative sampling ................... 5-4

5.1 .4 .2 Qualitative sampling $\ldots \ldots \ldots \ldots \ldots \ldots \ldots \ldots \ldots, 5-9$

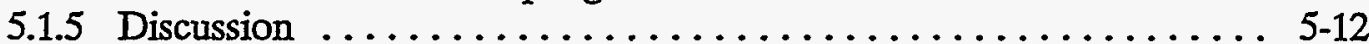

5.2 BENTHIC MACROINVERTEBRATES (M. $R$ Smith) ........... 5-17

5.2 .1 Introduction $\ldots \ldots \ldots \ldots \ldots \ldots \ldots \ldots \ldots \ldots \ldots \ldots \ldots, 5-17$

5.2 .2 Materials and Methods ............................ 5-17

5.2 .3 Results ............................... 5-19

5.2.3.1 Tasonomic composition .................... 5-19

5.2 .3 .2 Abundance $\ldots \ldots \ldots \ldots \ldots \ldots \ldots \ldots \ldots \ldots \ldots \ldots .6 .20$

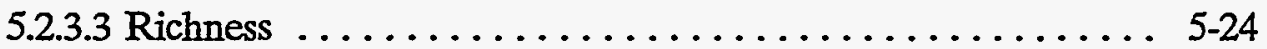

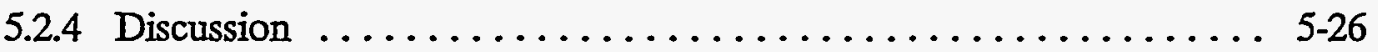

5.2.5 Summary and Conclusions $\ldots \ldots \ldots \ldots \ldots \ldots \ldots \ldots \ldots \ldots \ldots \ldots \ldots \ldots$

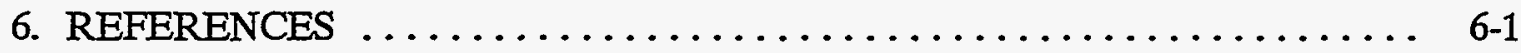

Appendix A: SUMMARY STATISTICS FOR WATER QUALITY

PARAMETERS AT KPDES PERMITTED OUTFALLS ....... A-1

Appendix B: TOXICITY MONITORING $\ldots \ldots \ldots \ldots \ldots \ldots \ldots \ldots \ldots$ B-1 


\section{CONTENTS (continued)}

Page

Appendix C: CONCENTRATIONS OF CONTAMINANTS IN INDIVIDUAL FISH AND QUALITY ASSURANCE SUMMARY . ........ C-1

Appendix D: SPECIES CHARACTERISTICS, DENSITY, AND BIOMASS

FOR FISH COMMUNITY DATA COLLECTED FROM BIG BAYOU CREEK, LITTLE BAYOU CREEK, AND MASSAC CREEK DURING MARCH AND SEPTEMBER 1994

Appendix E: CHECKLIST OF BENTHIC MACROINVERTEBRATE TAXA COLLECTED FROM BIG BAYOU CREEK, LITTLE BAYOU CREEK, AND MASSAC CREEK IN PADUCAH, KENTUCKY, SEPTEMBER 1991 TO MARCH 1994 



\section{FIGURES}

Figure

$\underline{\text { Page }}$

2.1 Map of Paducah Gaseous Diffusion Plant (PGDP) in relation to

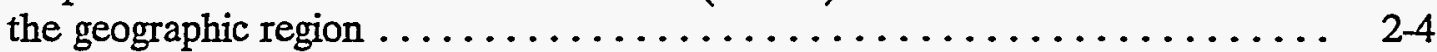

2.2 Location of Biological Monitoring Program (BMP) sites and Kentucky Pollutant Discharge Elimination System (KPDES) permitted outfalls for the Paducah Gaseous Diffusion Plant (PGDP) $\ldots \ldots \ldots \ldots \ldots \ldots \ldots .2-5$

3.1 Summary of conductivity (mean $\pm \mathrm{SD}$ ) at Big Bayou Creek, Little Bayou Creek, and Massac Creek sites ..................... 3-18

3.2 Summary of $\mathrm{pH}$ (mean $\pm \mathrm{SD}$ ) at Big Bayou Creek, Little Bayou Creek, and Massac Creek sites

3.3 Summary of alkalinity (mean $\pm S D$ ) at Big Bayou Creek, Little Bayou Creek, and Massac Creek sites

3.4 Summary of hardness (mean \pm SD) at Big Bayou Creek, Little Bayou Creek, and Massac Creek sites ...

5.1 Species richness, biomass, and density at Big Bayou Creek

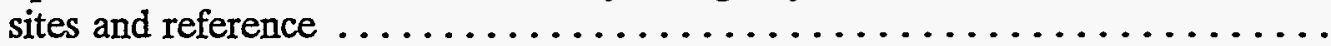

5.2 Species richness, biomass, density at Little Bayou Creek site and reference

5.3 Species richness, catch per effort, and total specimens at Little Bayou Creek qualitative site

5.4 Mean total density, mean total richness, and mean richness of the Ephemeroptera, Plecoptera, and Trichoptera (EPT richness) of the benthic macroinvertebrate communities in Big Bayou Creek, Little Bayou Creek, and Massac Creek, September 1991 to March 1994 . . . . . . . . . . . . . . .

5.5 Mean relative abundance (i.e., percent density) of selected benthic macroinvertebrate taxa in Big Bayou Creek, Little Bayou Creek, and Massac Creek, September 1991 



\section{TABLES}

$\underline{\text { Table }}$

$\underline{\text { Page }}$

2.1 Kentucky Pollutant Discharge Elimination System (KPDES) permitted outfalls at Paducah Gaseous Diffusion Plant ................ 2-8

2.2 Exceedances in 1994 for parameters for which perimit limits are still in effect

2.3 Locations and names of sampling sites included in Paducah Gaseous Diffusion Plant Biological Monitoring Program for the Instream Monitoring Task

2.4 Sampling schedule for the four components of the Biological Monitoring Program at Paducah Gaseous Diffusion Plant for January-December 1994

3.1 Summary of toxicity test dates for continuous outfalls $\ldots \ldots \ldots \ldots \ldots \ldots$

3.2. Summary of toxicity test dates for intermittent outfalls $\ldots \ldots \ldots \ldots \ldots \ldots$

3.3 Results of effluent toxicity tests for Outfalls $001,006,008$, 009, and 011

3.4 Summary of water chemistry analyses of full-strength samples from continuously flowing outfalls from $1991-94 \ldots \ldots \ldots \ldots \ldots \ldots \ldots$. . . . . .

3.5 Summary of a toxicity identification test using fathead minnow larvae of full-strength effluent from Outfall 009, December 1994

3.6 Results of effluent toxicity tests for Outfalls $013,015,016$, 017, and 018

3.7 Ranking of intermittent outfalls based upon frequency of chronic toxicity unit (TUc) $>1.0$ and mean TUc for 26 tests

3.8 Summary of water chemistry analyses of full-strength samples from intermittently flowing effluents from 1991-94

3.9. Comparison of fathead minnow survival and growth in filtered $(1.2 \mu \mathrm{m})$ and nonfiltered water from outfall 018

3.10. Summary of fathead minnow survival and growth measured for toxicity tests of ambient sites in 1994 


\section{TABLES (continued)}

3.11 Mean conductivity ( $\mu \mathrm{S} / \mathrm{cm} ; n=7$ ) measured at each site and comparison of means (Tukey's Studentized Range test) . . . . . . . . . . . . . 3-22

3.12 Mean $\mathrm{pH}$ (S. U.; $n=7$ ) measured at each site and comparison of means (Tukey's Studentized Range test) ................. 3-23

3.13 Mean alkalinity ( $\mathrm{mg} / \mathrm{L}$ as $\mathrm{CaCO}_{3} ; n=7$ ) measured at each site and comparison of means (Tukey's Studentized Range test) . . . . . . . . . 3-24

3.14 Mean hardness ( $\mathrm{mg} / \mathrm{L}$ as $\left.\mathrm{CaCO}_{3} ; n=7\right)$ measured at each site and comparison of means (Tukey's Studentized Range test) . . . . . . . . 3-25

3.15 Mean temperature $\left({ }^{\circ} \mathrm{C} ; n=7\right)$ measured at each site and comparison of means (Tukey's Studentized Range test)

4.1 Mean concentrations of PCBs ( $\mu \mathrm{g} / \mathrm{g}$ wet $w \mathrm{t})$ in longear sunfish from streams near PGDP, October 1993

4.2 Mean concentrations of PCBs ( $\mu \mathrm{g} / \mathrm{g}$ wet wt) in longear sunfish from streams near PGDP, March 1994

4.3 Mean concentrations of total mercury ( $\mu \mathrm{g} / \mathrm{g}$ wet wt) in longear sunfish from streams near PGDP, May 1994

4.4 Mean metal concerirations ( $\mu \mathrm{g} / \mathrm{g}$ wet $w \mathrm{t}) \pm \mathrm{SE}$ in longear sunfish from streams at PGDP, April 1994

5.1 Lengths, mean width, mean depth, surface area, and pool-riffle ratio of fish sampling sites in Big Bayou Creek, Little Bayou Creek, and a reference stream, Massac Creek, for March and September 1994

5.2 Species composition of quantitative samples in Big Bayou Creek, Little Bayou Creek, and a reference stream, Massac Creek, March and September 1994

5.3 Total fish density (individuals $\left./ \mathrm{m}^{2}\right)$, biomass $\left(\mathrm{g} / \mathrm{m}^{2}\right)$, and species richness for March and September 1994 at sampling sites in Big Bayou Creek, Little Bayou Creek, and a reference stream, Massac Creek ...

5.4 Fish annual production ( $\left.\mathrm{g} / \mathrm{m}^{2} / \mathrm{yr}\right)$ in Big Bayou Creek, Little Bayou Creek, and a reference stream, Massac Creek, March 1993 to March 1994 


\section{TABLES (continued)}

$\underline{\text { Page }}$

5.5 Species composition of the qualitative fish sampling conducted on Little Bayou Creek, March 22, 1994 


\section{ACRONYMS}

$\begin{array}{ll}\text { ANOVA } & \text { analysis of variance } \\ \text { BMAP } & \text { Biological Monitoring and Abatement Program } \\ \text { BMP } & \text { Biological Monitoring Program } \\ \text { BBK } & \text { Big Bayou Creek kilometer } \\ \text { DCBP } & \text { decachlorobiphenyl } \\ \text { DOE } & \text { U.S. Department of Energy } \\ \text { ESD } & \text { Environmental Sciences Division } \\ \text { EPA } & \text { U.S. Environmental Protection Agency } \\ \text { EPT } & \text { Ephemeroptera, Plecoptera, Trichoptera } \\ \text { FDA } & \text { U.S. Department of Agriculture Food and Drug Administration } \\ \text { GC/ECD } & \text { gas chromatography/electron capture detection } \\ \text { GLM } & \text { general linear model } \\ \text { HINDS CR } & \text { Hinds Creek } \\ \text { IC } & \text { inhibition concentration } \\ \text { KDOW } & \text { Kentucky Division of Water } \\ \text { KPDES } & \text { Kentucky Pollutant Discharge Elimination System } \\ \text { LUK } & \text { Little Bayou Creek kilometer } \\ \text { MAK } & \text { Massac Creek kilometer } \\ \text { MMES } & \text { Martin Marietta Energy Systems, Inc. } \\ \text { MMUS } & \text { Martin Marietta Utility Systems, Inc. } \\ \text { MS-222 } & \text { tricaine methanesulfonate } \\ \text { NCBP } & \text { National Contaminant Biomonitoring Program } \\ \text { NOEC } & \text { no-observed-effect concentration } \\ \text { NPDES } & \text { National Pollutant Discharge Elimination System } \\ \text { ORNL } & \text { Oak Ridge National Laboratory } \\ \text { PCB } & \text { polychlorinated biphenyl } \\ \text { PGDP } & \text { Paducah Gaseous Diffusion Plant } \\ \text { QA } & \text { quality assurance } \\ \text { RGA } & \text { regional gravel aquifer } \\ \text { RCW } & \text { recirculating cooling water } \\ \text { SAS } & \text { statistical analysis system } \\ \text { TRC } & \text { total residual chlorine } \\ \text { TU } & \text { toxicity unit(s) } \\ \text { TUc } & \text { chronic toxicity unit(s) } \\ \text { USEC } & \text { United States Enrichment Corporation } \\ \text { USFWS } & \text { U.S. Fish and Wildife Service } \\ \text { USGS } & \text { U.S. Geological Service } \\ \text { WKWMA } & \text { West Kentucky Wildlife Management Area } \\ & \end{array}$




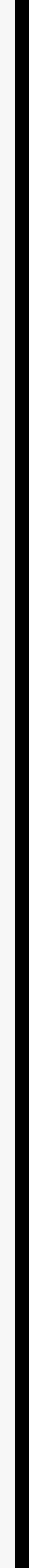




\section{ACKNOWLEDGMENTS}

We thank all those individuals who assisted with the field sampling, including T. Grizzard, W. C. Kyker, J. M. Loar, W. K. Roy, E. M. Schilling, L. M. Stubbs, and R. L. Hinzman of the Oak Ridge National Laboratory (ORNL) Environmental Sciences Division (ESD); B. A. Carrico, B. F. Clark, R. P. Hoffmeister, R. B. Petrie, M. R. Smith, and W. S. Wilkerson of JAYCOR; and R. A. Redden (University of Tennessee). We thank the staff of the ORNL ESD toxicology laboratory, including L. F. Wicker, P. W. Braden, G. W. Morris, and B. K. Beane, as well as T. L. Phipps, J. R. Sumner, and K. J. McAfee of Advanced Sciences Inc., and L. S. Ewald of Oak Ridge Research Institute for their commitment to travel and for providing outstanding technical assistance. We thank Paducah Community College for the use of their facilities for toxicity monitoring. We thank D. A. Etnier (University of Tennessee) for verifying identification of selected fish specimens. Benthic macroinvertebrate samples were processed by staff of the Aquatic Resources Center in Franklin, Tennessee, including R. O. Brinkhurst, R. D. Kathman, J. T. Garner, A. T. Dossett, and T. Askgaard. We thank P. L. Henry for electronic publishing support and E. B. Bryant for editorial support. Finally, we are grateful to T. L. Ashwood and M. S. Greeley, who reviewed a draft report and provided many helpful comments and suggestions.

This project was funded by Environmental Management, Martin Marietta Energy Systems, Inc. The Paducah Gaseous Diffusion Plant and Oak Ridge National Laboratory are managed by Martin Marietta Energy Systems, Inc., under contract DE-AC05$84 O R 21400$ with the U.S. Department of Energy. 


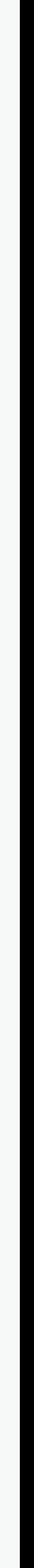




\section{EXECUTIVE SUMMARY}

On September 24, 1987, the Commonwealth of Kentucky Natural Resources and Environmental Protection Cabinet issued an Agreed Order that required the development of a Biological Monitoring Program (BMP) for the Paducah Gaseous Diffusion Plant (PGDP). The PGDP BMP was implemented in 1987 by the University of Kentucky. Research staff of the Environmental Sciences Division (ESD) at Oak Ridge National Laboratory (ORNL) served as reviewers and advisers to the University of Kentucky. Beginning in fall 1991, ESD added data collection and report preparation to its responsibilities for the PGDP BMP. The goals of BMP are to (1) demonstrate that the effluent limitations established for PGDP protect and maintain the use of Little Bayou and Big Bayou creeks for growth and propagation of fish and other aquatic life, (2) characterize potential environmental impacts, (3) document the effects of pollution abatement facilities on stream biota, and (4) recommend any program improvements that would increase effluent treatability. In September 1992, a renewed Kentucky Pollutant Discharge Elimination System (KPDES) permit was issued to PGDP. As of this writing, a new Agreed Order is in draft form. The renewed permit requires toxicity monitoring of continuous and intermittent outfalls on a quarterly basis. A BMP is not required in either the draft Agreed Order or the renewed permit; however, biological monitoring of the U.S. Department of Energy (DOE) facilities at PGDP is required under draft DOE Order 5400.1. Data collected under BMP will also be used to support two studies proposed in the draft Agreed Order.

The BMP for PGDP consists of three major tasks: (1) effluent and ambient toxicity monitoring, (2) bioaccumulation studies, and (3) ecological surveys of stream communities (i.e., benthic macroinvertebrates and fish). This report includes ESD activities occurring from December 1993 to December 1994, although activities conducted outside this time period are included as appropriate. 


\section{Study Area}

The PGDP is owned by the United States Department of Energy (DOE). Production facilities are leased to the United States Enrichment Corporation (USEC) and are managed by Martin Marietta Utility Systems, Inc. (MMUS). The environmental restoration and waste management activities are managed by Martin Marietta Energy Systems, Inc. (MMES). The plant was constructed in 1951 and is an active uranium enrichment facility consisting of a diffusion cascade and extensive support facilities. Enriched uranium is transferred to the Portsmouth (Ohio) Gaseous Diffusion Plant. Most of the uranium produced is used for national defense and commercial reactors in the United States and abroad.

PGDP is located in the western part of the Ohio River basin. Surface drainage from PGDP enters Big Bayou Creek and Little Bayou Creek which are two small tributaries to the Ohio River. Big Baycu Creek is a perennial stream with a drainage basin extending from $~ 4 \mathrm{~km}$ south of PGDP to the Ohio River. Part of its $14.5-\mathrm{km}$ course flows along the western boundary of the plant. Little Bayou Creek originates in the Western Kentucky Wildlife Management Area and flows for $10.5 \mathrm{~km}$ north toward the Ohio River; its course includes part of the eastern boundary of PGDP. Four continuously flowing outfalls (001, 006, 008, and 009) discharge to Big Bayou Creek. Outfalls 002, 010, 011, and 012 are combined at the C617 pond and discharged via Outfall 011 (or 010) into Little Bayou Creek. Effluent from Outfalls 013, 015, 016, 017, and 018 regularly discharge into Big Bayou and Little Bayou creeks when it rains.

Three sites on Big Bayou Creek-Big Bayou Creek kilometer (BBK) 12.5, BBK 10.0, and BBK 9.1-one site on Little Bayou Creek, Little Bayou Creek kilometer (LUK) 7.2; and one off-site reference station on Massac Creek, Massac Creek kilometer (MAK) 13.8, were routinely sampled to assess the ecological health of the stream and to evaluate ambient toxicity. Three additional sites (BBK 2.8, LUK 9.0, and LUK 4.3) were sampled as part of the bioaccumulation monitoring task. Toxicity monitoring and benthic macroinvertebrate sampling were conducted quarterly, and fish community and bioaccumulation sampling were conducted twice annually: in the spring and fall. KPDES outfalls evaluated for effluent toxicity included 001, 006, 008, 009, 010 (or 011), 013, 015, 016,017 , and 018. 


\section{Toxicity Monitoring}

Ceriodaphnia and fathead minnow toxicity tests of effluents from the continuously flowing outfalls (001, 006, 008, 009, and 011), the intermittently flowing outfalls $(013,015$, 016,017 , and 018) were conducted quarterly as required by the KPDES permit. Fathead minnow toxicity tests of water from ambient sites (BBK 12.5, BBK 9.1, LUK 7.2, and MAK 13.8) were conducted concurrently with the continuously flowing outfalls. Tests with Ceriodaphnia and fathead minnows were typically conducted concurrently. The $25 \%$ inhibition concentrations (IC25; that concentration causing a $25 \%$ reduction in fathead minnow growth or Ceriodaphnia survival compared with the control) were determined for each test. The chronic toxicity unit rating $(\mathrm{TUc}=100 / \mathrm{IC} 25)$ is required as a compliance endpoint in the renewed permit (September 1992 to present). The higher the TUc, the more toxic an effluent. Because Little Bayou and Big Bayou creeks have been determined to have a low flow of zero, a TUc $>1.0$ would be considered a roncompliance (for the continuously flowing outfalls) and an indicator of potential instream toxicity.

During 1994, no toxicity was evident in effluent samples from 001. Effluent from Outfall 008 had TUcs $>1.0$ two times; however, follow-up tests demonstrated that the toxicity was transient. Outfalls 006 and 011 had high TUcs for fathead minnows during two consecutive tests in March; however, no toxicity was observed in subsequent testing. Outfall 006 had a TUc $>1$ for Ceriodaphnia during August; however a retest of the effluent did not demonstrate toxicity. Outfall 009 had the greatest number of exceedances during 1994. The effluent exceeded the a TUc $>1$ four times with an average TUc of 4.32. Identification prosedures conducted during December 1994 showed that minnow mortality in the effluent may be due to suspended solids or to a particle-bound contaminant. However, the results were inconclusive since other treatments also improved minnow survival. Although PGDP does not have a compliance limit for the intermittent outfalls, TUc > 1 was used as a benchmark. In 1994, Outfalls 015 and 017 exceeded the TUc > 1 three times; Outfalls 013, 016, and 018 exceeded this limit once. The ranking of outfalls for tests conducted to-date (1991-94) in terms of TUc and frequency of TUc $>1$ showed Outfall $017>$ Outfall $015>$ Outfall $13>$ Outfall $18>$ Outfall 016 .

For ambient tests conducted in 1994, there was no evidence of chronic toxicity to fathead minnows for any of the ambient sites. Thus, toxicity to minnows observed in effluent from the continuously flowing outfalls was not observed in instream samples. The 
influence of effluent from Outfall 001 on the water chemistry of Big Bayou Creek was evident in the increase in $\mathrm{pH}$, conductivity and hardness between BBK 10.0 and BBK 9.1. In addition, alkalinity is lower at BBK 10.0 than at BBK 12.5.

\section{Bioaccumulation}

The objectives of the bioaccumulation monitoring were (1) to continue polychlorinated biphenyl (PCB) tracking studies in fish from Big Bayou Creek and Little Bayou Creek; (2) to track elevated mercury concentrations in fish in Big Bayou Creek; and (3) to conduct screening analyses to detect other contaminants that may be of concern to consumers of fish from these streams.

Longear sunfish and spotted bass were collected for PCB and mercury analysis from Big Bayou Creek, Little Bayou Creek, and Massac Creek during October 1993 and May/June 1994. Hinds Creek (Anderson County, Tennessee) served as a source of uncontaminated reference fish. PCB contamination was again evident in longear sunfish collected from both Big Bayou and Little Bayou creeks. Mean PCB concentrations in sunfish from sites downstream of PGDP discharges exceeded concentrations in fish from the reference sites. In spring 1994, the highest mean concentration occurred in fish from the site in Little Bayou Creek immediately downstream from Outfall 011 (LUK 9.0). In Big Bayou Creek, the highest mean PCB concentration was again found in fish from BBK 9.1, below Outfall 001, but fish from BBK 10.0 also contained PCB contamination. In fall 1993, spotted bass from Big Bayou Creek averaged $0.23 \mu \mathrm{g} / \mathrm{g} \mathrm{PCBs,}$ about 50\% higher than longear sunfish. PCB concentrations in spotted bass from Little Bayou Creek were higher, averaging $0.44 \mu \mathrm{g} / \mathrm{g}$ in fish from LUK 4.3-LUK 7.2. Results of the October 1993 and May 1994 sampling reaffirm the variable nature of PCB contamination in stream sunfish and suggest continuing inputs to both Big and Little Bayou creeks from PGDP discharges or contaminated sediments in the immediate vicinity of those discharges. The strong downstream gradient in PCB contamination in sunfish, along with the close association between degree of contamination and proximity to outfalls demonstrated to be PCB sources in the past, suggests that the pattern of contamination is sustained by continuing low-level contamination of waters discharged to the creeks, rather than a result of residual PCB contamination in sediments of the creeks themselves. PCB residues in upstream ditch or pond sediments could act as primary continuing sources, or various 
in-plant sources of fugitive PCBs may continue to contribute concentrations below levels detectable in aqueous phase monitoring.

The results of mercury monitoring in longear sunfish in April 1994 confirmed the findings of previous studies that concentrations in fish from Big Bayou Creek were somewhat higher downstream from PGDP than upstream. Mean mercury concentrations in sunfish were somewhat lower than those observed previously, ranging from a maximum of $0.24 \mu \mathrm{g} / \mathrm{g}$ at BBK 9.1 to $0.08 \mu \mathrm{g} / \mathrm{g}$ at BBK 12.5, upstream from PGDP. In 1993, mercury concentrations in longear sunfish at those sites were 0.37 and $0.10 \mu \mathrm{g} / \mathrm{g}$ respectively. Mean mercury concentrations in fish from the sites in Big Bayou Creek downstream from PGDP exceeded that in local reference site fish again in 1994. Results of mercury monitoring in sunfish from LUK 7.2 again indicated background mercury concentrations typical of reference site fish. Mercury concentrations in spotted bass from BBK 9.1 averaged $0.61 \pm 0.06 \mu \mathrm{g} / \mathrm{g}$. One fish in the collection approached the FDA action level $(1 \mu \mathrm{g} / \mathrm{g})$, but the rest were below $0.7 \mu \mathrm{g} / \mathrm{g}$. The slightly elevated concentrations of mercury in fish from Big Bayou Creek below PGDP may be a result of mercury in PGDP effluents, but they may also be a consequence of differences in the biogeochemical processing of mercury downstream from the plant.

Concentrations of metals measured in filets of longear sunfish from Big Bayou Creek and Little Bayou Creek were typical of those observed in previous monitoring and generally differed little (with several exceptions) from concentrations observed in fish from the Hinds Creek, Tennessee, reference site. Concentrations of arsenic, cadmium, copper, lead, selenium, and zinc were lower than the national geometric mean concentrations observed for whole body analyses of fish in the USFWS National Contaminant Biomonitoring Program. Concentrations of antimony, cadmium, chromium, nickel, selenium, and silver were well below screening levels used in the EPA Integrated Risk Information System (IRIS). Those metals for which IRIS screening levels are not published (copper, lead, thallium, uranium, and zinc) were found at concentrations similar to or lower than typically occur in food such as marine fish or mammalian muscle. Measurement of detectable concentrations of uranium in fish from Little Bayou Creek is consistent with the observed elevated concentrations of uranium in this creek and the results of previous monitoring of fish. No chlorinated pesticides were detected in fish from Big Bayou Creek or Little Bayou Creek. 


\section{Ecological Monitoring}

Quantitative sampling of the fish community was conducted at three sites in Big Bayou Creek, one site in Little Bayou Creek, and at one offsite reference station (Massac Creek) during March and September, 1994. Qualitative sampling at one site in Little Bayou Creek was conducted during March, 1994.

Data on the fish communities of Big Bayou Creek and Little Bayou Creek downstream of PGDP were compared to data from reference sites located on Big Bayou Creek above PGDP and on Massac Creek. These comparisons indicated a slight but noticeable degradation in the communities downstream of PGDP. Data indicated that the effects on the fish community were greatest just downstream from PGDP at BBK 10.0. The fish community at this site had a low mean and total species richness in comparison with MAK 13.8. There were no sensitive species, while tolerant species were more abundant here than at the reference site. Compared to sampling in 1991 and 1992 , BBK 10.0 has experienced a slight decline in biomass. The fish community at BBK 9.1 showed signs of impact similar to the level seen at BBK 10.0. Mean and total species richness were lower than at MAK 13.8. Although there were fewer sensitive species and at lower densities at BBK 9.1 than at MAK 13.8, more sensitive species were found at BBK 9.1 than at BBK 10.0. The tolerant species were common and abundant. Density was less than or equal to that at MAK 13.8, and species richness were slightly increased from 1993.

The fish community at LUK 7.2 was similar to the BBK 12.5 reference, with perhaps some species deficiencies. The mean species richness values were similar to those of the reference site but with a noticeable decline in fall 1994. Since 1991, species richness and biomass have increased slightly. However, in the fall 1994 sample species richness declined to the lowest level seen in sampling at LUK 7.2. This precipitous decline was not seen in density or biomass values. During the fall sampling, a noticeable increase in sediment level was observed at LUK 7.2. The downstream qualitative site, LUK 4.3, did not appear to be affected by plant operations.

Analysis of benthic macroinvertebrate data for the Big Bayou Creek sites indicates that, although there are differences between the three sampling locations on this stream, there is no strong evidence for a significant impact at any site. Periodically high densities at BBK 9.1 and BBK 10.0 suggest the presence of an occasionally organically enriched 
environment. However, persistently similar values for total and EPT richness at all three Big Bayou Creek sites, suggests that if these sites are impacted, the extent is minor relative to reference conditions. The site located on Little Bayou Creek (LUK 7.2) may be moderately impacted by a toxicant, as evidenced by low density and richness values. The suspected source of this toxicant has been identified as Outfall 011. However, the presence of poor habitat at this site cannot be discounted. Although MAK 13.8 does not appear to support large numbers of benthic macroinvertebrates, the relatively diverse community present validates its usefulness as a reference site. 



\title{
1. INTRODUCTION
}

\author{
L. A. Kszos
}

On September 24, 1987, the Commonwealth of Kentucky Natural Resources and Environmental Protection Cabinet issued an Agreed Order that required the development of a Biological Monitoring Program (BMP) for the Paducah Gaseous Diffusion Plant (PGDP). A plan for the biological monitoring of the receiving streams (Little Bayou Creek and Big Bayou Creek) was prepared by the University of Kentucky (Birge et al. 1987), reviewed by staff at PGDP and Oak Ridge National Laboratory (ORNL), and submitted by the U.S. Department of Energy (DOE) to the Kentucky Division of Water (KDOW) for approval. The PGDP BMP was implemented in 1987 and consisted of ecological surveys, toxicity monitoring of effluents and receiving streams, evaluation of bioaccumulation of trace contaminants in biota, and supplemental chemical characterization of effluents. The goals of the BMP are to (1) evaluate the acceptability of PGDP effluents under the Kentucky Pollutant Discharge Elimination System (KPDES) regulatory program, (2) characterize the potential environmental impacts of PGDP effluents, and (3) make recommendations on any changes necessary to improve effluent discharges. The PGDP BMP was patterned after plans that were implemented in 1985 for the Oak Ridge Y-12 Plant (Loar et al. 1989) and in 1986 for ORNL (Loar et al. 1991) and the Oak Ridge Gaseous Diffusion Plant (presently the Oak Ridge K-25 Site, Kszos et al. 1993). Because research staff from the Environmental Sciences Division (ESD) at ORNL were experienced in biological monitoring, they served as reviewers and advisers throughout the planning and implementation of the PGDP BMP. Data resulting from BMP conducted by the University of Kentucky were presented in a 3-year draft report issued in December 1990 (Birge et al. 1990) and an annual report issued in December 1991 (Birge et al. 1992).

Beginning in fall 1991, ESD added data collection and report preparation to its responsibilities for the PGDP BMP. The BMP has been continued because it has proven to be extremely valuable in (1) identifying those effluents with the potential for adversely affecting instream fauna, (2) assessing the ecological health of receiving streams, 
(3) guiding plans for remediation, and (4) protecting human health. For example, BMP revealed the accumulation of polychlorinated biphenyls (PCBs) in fish from selected reaches of the Bayou watershed, a finding that prompted issuance of a fish consumption advisory for Little Bayou Creek by the Kentucky Department for Environmental Protection. Continuation of the program will also provide a data base that can be used to determine the adequacy and efficacy of remedial actions that are implemented and to detect any new or unsuspected toxicants that are released in effluents.

In September 1992, a renewed KPDES permit was issued to PGDP. As of this writing, a new Agreed Order is in draft form. The renewed permit requires toxicity monitoring of continuous and intermittent outfalls on a quarterly basis. A BMP is not required in either the draft Agreed Order or the renewed permit. However, biological monitoring of the DOE facilities at PGDP, at Oak Ridge, Tennessee, and at Portsmouth, Ohio, is required under DOE Order 5400.1. Data collected under BMP will also be used to support two studies proposed in the draft Agreed Order: (1) temperature variability and instream effects of elevated temperature from outfalls 001 and 011 and (2) development of site-specific metal limits for outfalls.

The BMP for PGDP consists of three major tasks: (1) effluent and ambient toxicity monitoring, (2) bioaccumulation studies, and (3) ecological surveys of stream communities (i.e., benthic macroinvertebrates and fish). This report includes ESD activities occurring from December 1993 to December 1994, although activities conducted outside this time period are included as appropriate. 


\section{DESCRIPTION OF STUDY AREA ${ }^{1}$}

\subsection{SITE DESCRIPTION (R. L. Hinzman)}

The PGDP is owned by the United States Department of Energy (DOE). Production facilities are leased to the United States Enrichment Corporation (USEC) and are managed by Martin Marietta Utility Systems, Inc. (MMUS). The environmental restoration and waste management activities are managed by Martin Marietta Energy Systems, Inc. (MMES). The plant was constructed in 1951 and is an active uranium enrichment facility consisting of a diffusion cascade and extensive support facilities (Kornegay et al. 1992a). The uranium enrichment gaseous diffusion process involves more than 1800 stages with operations housed in 5 buildings covering 300 ha. Including support facilities, the plant has $\sim 30$ permanent buildings located on a 1385-ha site (Oakes et al. 1987). Support facilities include a steam plant, four electrical switchyards, four sets of cooling towers, a chemical cleaning and decontamination facility, water and wastewater treatment plants, a chromium reduction facility, maintenance and laboratory facilities, and two active landfills. Several inactive facilities are also located on the site. Currently, the Paducah cascade processes are being used for the enrichment of uranium up to $2 \%{ }^{235} \mathrm{U}$. This product is then transferred to the Portsmouth (Ohio) Gaseous Diffusion Plant for further enrichment (Oakes et al. 1987). Most of the uranium produced is used for national defense and commercial reactors in the United States and abroad.

\subsubsection{Land Use}

The area surrounding PGDP is mostly rural, with residences and farms surrounding the plant. Immediately adjacent to PGDP is the West Kentucky Wildlife Management Area (WKWMA), 2821 ha comprising natural habitat, state-maintained forage crops, and ponds, for use by hunters and fishermen. About 20 of the 35 ponds support fishing, and -200 deer are harvested annually.

\footnotetext{
${ }^{1}$ Sections 2.1 and 2.2 contain large excerpts from: T. G. Jett, Surface Water, Section 4. pp 4.3-4.13. IN Kornegay et al. 1993. Paducah Gaseous Diffusion Plant Environmental Report for 1992. ES/ESH-22/V3. Oak Ridge National Laboratory. Oak Ridge, Tenn.
} 
The population within the $80-\mathrm{km}$ radius of the plant is about 300,500 people. The unincorporated communities of Grahamville and Heath are within 2-3 km, east of the facility. The largest cities in the region are Paducah, Kentucky, and Cape Girardeau, Missouri, located about 16 and 64 air $\mathrm{km}$ away respectively (U.S. Department of Commerce 1991).

\subsubsection{Geohydrology}

PGDP is located in the Jackson Purchase region of western Kentucky. It lies in the northern margin of the Mississippi Embayment portion of the Gulf Coastal Plain Province. The Mississippi Embayment was a large sedimentary trough, oriented roughly north-south, which existed during the Cretaceous and Tertiary periods. The sedimentary sequence overlying the Mississippian age bedrock in the vicinity of PGDP consists mainly of fine- to medium-grained clastic materials, including (from youngest to oldest) a basal gravel (i.e., Tuscaloosa Formation) or rubble zone, the McNary Formation, the Porters Creek Clay, and undifferentiated Eocene sands.

Following deposition of the embayment sediments, the embayment was either uplifted and/or sea level lowered, resulting in the development of an erosional surface that truncated the sediments. Subsequently, during the late Tertiary and Quaternary periods, a unit designated as the Continental Deposits was laid down in the region. The Continental Deposits have been interpreted as originally being deposited in an alluvial fan that covered most of the Jackson Purchase region (Olive 1980). The Continental Deposits have been informally divided into a lower gravel region and an upper silt or clay unit; each unit varies in thickness from 0 to $32 \mathrm{~m}$. The clay facies are believed to consist of discontinuous fine sand lenses enclosed by clay; however, this interpretation is based on limited data, and the degree of interconnectedness of the interbedded sand lenses cannot be verified at this time (Kornegay et al. 1992a). Immediately overlying the Continental Deposits, Pleistocene loess (originating as windblown material generated by glacial activity) was deposited in a layer of variable thickness (3-10 m). Recent Ohio River alluvial deposits occur at lower elevations along the river's floodplain.

Current understanding of local groundwater hydrology in the vicinity of PGDP is dominated by the recognized importance of the Continental Deposits. This hydrologic unit is termed the regional gravel aquifer (RGA) and is the uppermost aquifer underlying 
most of PGDP and the contiguous area north. This groundwater flow system is primarily developed in Pleistocene sands and gravels of the lower member of the Continental Deposits, $\sim 13$ to $33 \mathrm{~m}$ beneath PGDP. The Continental Deposits rest upon terraces cut by the ancestral Tennessee and Tennessee-Ohio rivers. Terrace escarpments occurring under the south end of TGDP form the southern limit of the RGA.

Groundwater flow in the loess and the upper member of the Continental Deposits is primarily oriented downward because of the interbedded sand and gravel lenses and the significantly lower potentiometric surface of the RGA. Within the RGA, flow is directed north, discharging into the Ohio River. The hydrology of the RGA was first investigated by the U.S. Geological Service (USGS) in the mid 1960s. Resuits of these studies indicated that the gravel is saturated over most of its areal extent in the region of the plant, and wells completed within it are reported to be capable of producing yields of up to $3790 \mathrm{~L} / \mathrm{min}$. For a more detailed description of the geohydrology of the area, see Kornegay et al. 1992a; CH2M Hill 1991; D'Appolonia 1983; TERRAN 1990; GeoTrans 1990.

\subsubsection{Surface Water}

The PGDP is located in the western part of the Ohio River basin. The confluence of the Ohio River with the Tennessee River is $-24 \mathrm{~km}$ upstream of the site, and the confluence of the Ohio River with the Mississippi River is $-90 \mathrm{~km}$ downstream of the site. Surface drainage from PGDP is two small tributaries of the Ohio River, Big Bayou Creek and Little Bayou Creek (Fig. 2.1). These streams meet $\sim 4.8 \mathrm{~km}$ north of the site and discharge to the Ohio River at kilometer 1524 (Fig. 2.2), which is $-56 \mathrm{~km}$ upstream of the confluence of the Ohio and Mississippi Rivers. The PGDP is located on a local drainage divide; surface flow is east-northeast toward Little Bayou Creek and west-northwest toward Big Bayou Creek. Big Bayou Creek is a perennial stream with a drainage basin extending from $\sim 4 \mathrm{~km}$ south of PGDP to the Ohio River; part of its $14.5-\mathrm{km}$ course flows along the western boundary of the plant. Little Bayou Creek originates in the WKWMA and flows for $10.5 \mathrm{~km}$ north toward the Ohio River; its course includes part of the eastern boundary of the plant. The watershed areas for Big Bayou Creek and Little Bayou Creek are about 4819 and 2428 ha respectively. These streams exhibit widely fluctuating 


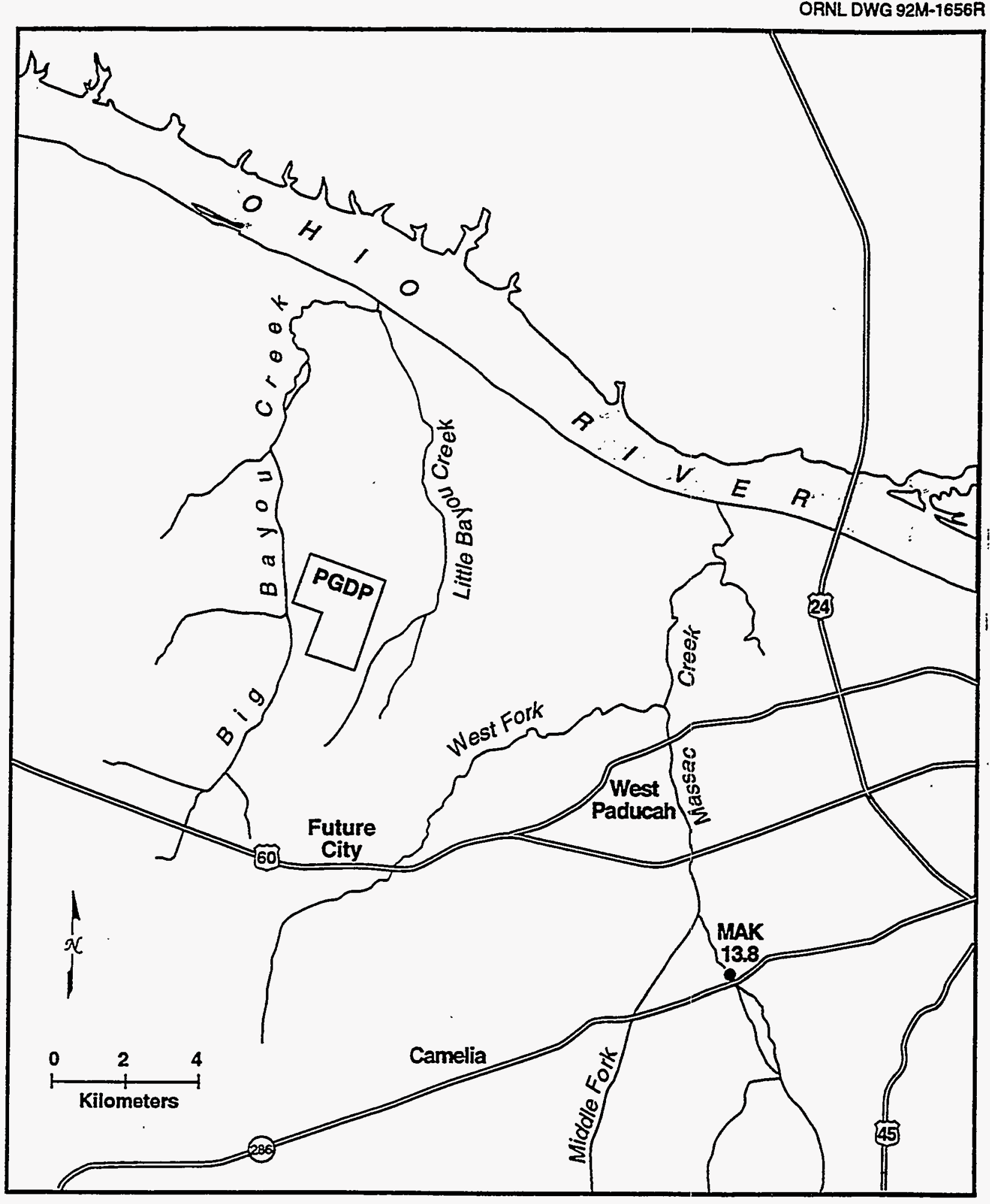

Fig. 21. Map of Paducah Gaseous Diffusion Plant (PGDP) in relation to the geographic region. The reference site for PGDP biological monitoring activities is located on Massac Creek at kilometer (MAK) 13.8. 
ORNL-DWG 95M-7164R

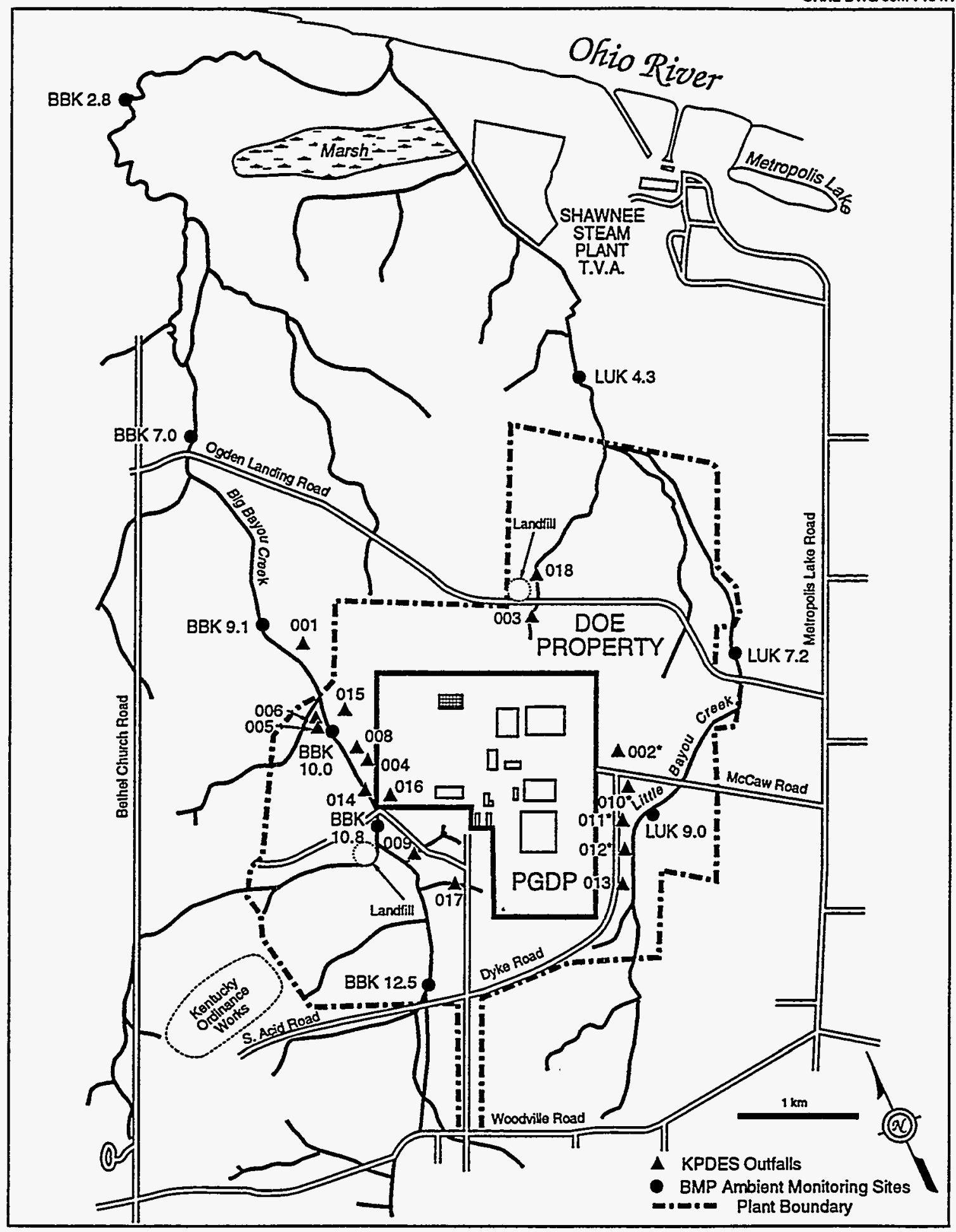

${ }^{\star}$ Combined at $\mathrm{C} 617$ pond and discharged through $011 / 010$

Fig. 2.2. Location of Biological Monitoring Program (BMP) sites and Kentucky Pollutant Discharge Elimination System (KPDES) permitted outfalls for the Paducah Gaseous Diffusion Plant (PGDP). BBK = Big, Bayou Creek kilometer; LUK = Little Bayou Creek kilometer; T.V.A. = Tennessee Vailey Authority; DOE = U.S. Department of Energy. 
discharge characteristics that are closely tied to local precipitation and facility effluent discharge rates. Natural runoff makes up a small portion of the flow; and, during dry weather, effluents from PGDP operations can constitute about $85 \%$ of the normal flow in Big Bayou Creek and 100\% in Little Bayou Creek. During the dry season which extends from summer to early fall, no-flow conditions may occur in the upper section of Little Bayou Creek (Birge et al. 1992). Precipitation in the region averages about $120 \mathrm{~cm}$ per year. Precipitation was $83 \mathrm{~cm}$ in 1991 (69\% of normal), with one major $s t o r m$ ( $25 \mathrm{~cm}$ in 24-48 hours). Precipitation was $104 \mathrm{~cm}$ in 1992 (87\% of normal) with three major storms. Precipitation in 1993 was greater than $150 \mathrm{~cm}$ (November data are missing; $>125 \%$ of normal). There were five major storms in 1993. Two of the storms occurred in February; one storm had $20 \mathrm{~cm}$ of snow and $2 \mathrm{~cm}$ of rain, the other had $18 \mathrm{~cm}$ of snow and $3 \mathrm{~cm}$ of rain. Precipitation in 1994 was $138 \mathrm{~cm}$ (115\% of normal) with two major storms. The lower Bayou drainage has low to moderate gradient, and the lower reaches are within the flood plain of the Ohio River. The drainage basin is included in ecoregion 72 (Interior River Lowland) of the contiguous United States (Omernik 1987). Vegetation is a mosaic of forest, woodland, pasture, and cropland.

The majority of effluents at PGDP consist of once-through cooling water, although a variety of effluents (uranium-contaminated as well as noncontaminated) result from activities associated with uranium precipitation and facility-cleaning operations. Conventional liquid discharges such as domestic sewage, steam-plant wastewaters, and coal-pile runoff also occur. Routine monitoring activities provide data to quantify total discharges to surface water in order to demonstrate compliance with federal, state, and DOE requirements. Monitoring also assists with evaluating the effectiveness of effluent treatment and control programs.

\subsection{WATER QUALTTY AND PGDP EFFLUENTS (R. L. Hinzman)}

The Clean Water Act is currently administered for PGDP by the Kentucky Division of Water (KDOW) through the KRDES Wastewater Discharge Permitting Program. A National Pollutant Discharge Elimination System (NPDES) permit (KY0004049), issued by Region IV of the U.S. Environmental Protection Agency (EPA), became effective February 15, 1975. The NPDES permit was revised February 4, 1977, and expired in 1980. Although PGDP had applied for a new permit, no system was in place at KDOW 
to replace the NPDES permit and a new permit could not be issued. PGDP operated under the original 1975 NPDES permit until the state of Kentucky issued the KPDES permit (KY0004049). On November 5, 1986, the state permit was adjudicated because the permit limits were not achievable. As part of the negotiations associated with the adjudication process, an Agreed Order was proposed that included interim limits while a biological monitoring study was conducted at PGDP. The KPDES permit expired in October 1991; however, monitoring continued under the KPDES Agreed Order. By submitting permit renewal documents in May 1991, PGDP complied with regulations that allow the continued discharge of wastewater under the auspices of the expired permit. KDOW issued KPDES Permit No. KY0004049 to PGDP in September 1992. This permit became effective November 1, 1992, and is enforced by the KDOW. At the request of PGDP, the state of Kentucky granted a stay of permit limits for $\mathrm{pH}$, metals, toxicity, and temperature in October 1992. PGDP is working with KDOW to approve an Agreed Order concerning the establishment of final limits for these parameters. All other conditions stated in the permit are in effect (Kornegay et al. 1993).

Monitoring of 17 individual outfalls is conducted in accordance with the KPDES Agreed Order. Table 2.1 lists all outfalls and their contributing processes; Fig. 2.2 shows the location of the outfalls. Eight of the 17 outfalls discharge continuously to the receiving streams. Outfalls 001, 006, 008, and 009 discharge continuously to Big Bayou Creek; Outfalls 002, 010, and 012 are combined at the C-617 pond and discharge through Outfall 010 continuously to Little Bayou Creek. After PCBs were detected in sediments from Outfall 011 in June 1994, the combined C-617 lagoon discharge was diverted on a full-time basis to Outfall 010 . Outfall 011 has been a stormwater outfall since the change (C. C. Travis, Environmental Waste Management Division, Environmental Compliance Department, personal communication).

Detections of PCBs at Outfall 011 and 012 are believed to be the result of the mobilization of PCB contaminated sediment into the sewer and drainage system. A total of eleven PCB exceedances were recorded for Outfalls 011 and 012 during 1994 (Table 2.2). Concentrations of PCBs ranged from $0.1-0.6 \mu \mathrm{g} / \mathrm{L}$ (the maximum daily permit limit is $0.000079 \mu \mathrm{g} / \mathrm{L}$ ). While the mobilization of PCBs in sediment may be attributable to the line ruptures described below, no definite connection can be made. Increased construction activity associated with Environmental Restoration and Waste 
Table 2.1. Kentucky Pollutant Discharge Elimination System (KPDES) permitted outfalls at Paducah Gaseous Diffusion Plant

\begin{tabular}{|c|c|c|c|}
\hline Location $^{a}$ & Discharge source & Flow $^{b}$ & Contributing processes \\
\hline 001 & $\begin{array}{l}\text { C-616, C-600, C-400, C-410, C-635, } \\
\text { C-335, C-337, C-535, C-537, C-746-A, } \\
\text { C-747-A, C-635-6 }\end{array}$ & $6.2 \pm 4.3$ & $\begin{array}{l}\text { Recirculating cooling water blowdown treatment } \\
\text { effluent, coal-pile runoff, once-through cooling } \\
\text { water, surface runoff, roof and floor drains, } \\
\text { treated uranium solutions, sink drains }\end{array}$ \\
\hline 0,02 & C-360, C-637, C-337-A & $0.4 \pm 0.6$ & $\begin{array}{l}\text { Once through cooling water, roof and floor } \\
\text { drains, sink drains, extended aeration sewage } \\
\text { treatment system }\end{array}$ \\
\hline 003 & North edge of plant & 2.8 & $\begin{array}{l}\text { Storm overflow of north/south diversion ditch } \\
\text { discharges }\end{array}$ \\
\hline 004 & $\begin{array}{l}\text { C-615 sewage treatment plant, C-710, } \\
\text { C-728, C-750, C-100, C- } 620, C-400\end{array}$ & $1.5 \pm 0.2$ & $\begin{array}{l}\text { Domestic sewage, laboratory sink drains, motor } \\
\text { cleaning, garage drains, laundry, machine coolant } \\
\text { treatment filtrate, condensate blowdown, once- } \\
\text { through cooling water }\end{array}$ \\
\hline 005 & C-611 primary sludge lagoon & $\mathrm{NM}^{c}$ & $\begin{array}{l}\text { Water treatment plant sludge, sand filter } \\
\text { backwash, laboratory sink drains }\end{array}$ \\
\hline 006 & C-611 secondary lagoon & $2.7 \pm 1.1$ & $\begin{array}{l}\text { Water treatment plant sludge, sand filter } \\
\text { backwash, laboratory sink drains from outfall } 005\end{array}$ \\
\hline 007 & Outfall eliminated & $N M^{c}$ & . \\
\hline 008 & $\begin{array}{l}\text { C-743, C-742, C-741, C-723, C-721, } \\
\text { C-728, C-729, C-400, C-420, C-410, } \\
\text { C-727, C-411, C-331, C-310, C-724, } \\
\text { C-744, C-600, C-405, C-409, C-631, } \\
\text { C-720 }\end{array}$ & $4.5 \pm 3.2$ & $\begin{array}{l}\text { Surface drainage, roof and floor drains, once- } \\
\text { through cooling water, paint shop discharge, } \\
\text { condensate, instrument shop cleaning area, metal- } \\
\text { cleaning rinse water, sink drains }\end{array}$ \\
\hline 009 & $\begin{array}{l}\text { C-810, C-811, C-331, C-333, C-310, } \\
\text { C-100, C-102, C-101, C-212, C-200, } \\
\text { C-300, C-320, C-302, C-750, C-710, } \\
\text { C-720 }\end{array}$ & $1.7 \pm 4.6$ & $\begin{array}{l}\text { Surface drainage, roof and floor drains, } \\
\text { condensate, once-through cooling water, sink } \\
\text { drains }\end{array}$ \\
\hline 010 & $\begin{array}{l}\text { C-531, C-340, C-533, C-532, C-315, } \\
\text { C-333, C-331 }\end{array}$ & NA & $\begin{array}{l}\text { Switchyard runoff, roof and floor drains, } \\
\text { condensate, sink drains, once-through cooling } \\
\text { water, }\end{array}$ \\
\hline 011 & . & NA & Stormwater runoff \\
\hline 012 & C-633, C-533, C-333-A & $0.6 \pm 1.2$ & $\begin{array}{l}\text { Roof, floor, and sink drains, condensate, surface } \\
\text { runoff, extended aeration sewage treatment } \\
\text { system }\end{array}$ \\
\hline 013 & Southeast comer of the plant & $5.3 \pm 8.1$ & Surfece runoff \\
\hline 014 & C-611 U-shaped sludge lagoon & $\mathrm{NM}^{c}$ & Sand filter backwash, sanitary water \\
\hline 015 & West central plant areas & $1.5 \pm 3.7$ & Surface runoff \\
\hline 016 & Southwest comer of the plant & $4.7 \pm 6.3$ & Surface runoff \\
\hline 017 & Extreme south area of the plant & $0.8 \pm 1.8$ & Surface runoff \\
\hline 018 & Landfill at north of plant & $4.97^{d}$ & Surface runoff \\
\hline
\end{tabular}

aNumeral indicates outfall designation. Locations also identified in Fig. 2.2 of this report.

${ }^{b}$ Mean discharge in millions of liters per day \pm 1 standard deviation. $\mathrm{NA}=$ not available.

$\mathrm{NM}=$ Not monitored

${ }^{d}$ Mean value based on 11 KPDES measurements for 1994 , see Table A-15.

Note: This table was taken from Kornegay et al. 1993 (Paducah Gaseous Diffusion Plant Environmental Report for 1992. ES/ESH-36. Oak Ridge National Laboratory, Oak Ridge, Tennessee) and Birge et al. 1992 (Biological Monitoring Program for the Paducah Gaseous Diffusion Plant. Annual Report for Study Period October 1990 through March 31, 1992. University of Kentucky, Lexington, Kentucky). 
Table 2.2. Exceedances in 1994 for parameters for which permit limits are still in effect

\begin{tabular}{lllll}
\hline Parameter & Outfall & Date & Limit (daily maximum) & Result \\
\hline Residual chlorine & 002 & $3 / 14 / 94$ & $0.019 \mathrm{mg} / \mathrm{L}$ & $0.1 \mathrm{mg} / \mathrm{L}$ \\
PCB & 011 & $4 / 18 / 94$ & $0.000079 \mu \mathrm{g} / \mathrm{L}$ & $0.2 \mu \mathrm{g} / \mathrm{L}$ \\
PCB & 011 & $4 / 26 / 94$ & $0.000079 \mu \mathrm{g} / \mathrm{L}$ & $0.1 \mu \mathrm{g} / \mathrm{L}$ \\
PCB & 011 & $5 / 23 / 94$ & $0.000079 \mu \mathrm{g} / \mathrm{L}$ & $0.1 \mu \mathrm{g} / \mathrm{L}$ \\
PCB & 011 & $6 / 06 / 94$ & $0.000079 \mu \mathrm{g} / \mathrm{L}$ & $0.1 \mu \mathrm{g} / \mathrm{L}$ \\
PCB & 011 & $6 / 24 / 94$ & $0.000079 \mu \mathrm{g} / \mathrm{L}$ & $0.6 \mu \mathrm{g} / \mathrm{L}$ \\
PCB & 011 & $7 / 06 / 94$ & $0.000079 \mu \mathrm{g} / \mathrm{L}$ & $0.15 \mu \mathrm{g} / \mathrm{L}$ \\
PCB & 011 & $8 / 29 / 94$ & $0.000079 \mu \mathrm{g} / \mathrm{L}$ & $0.1 \mu \mathrm{g} / \mathrm{L}$ \\
PCB & 012 & $8 / 29 / 94$ & $0.000079 \mu \mathrm{g} / \mathrm{L}$ & $0.1 \mu \mathrm{g} / \mathrm{L}$ \\
PCB & 011 & $9 / 24 / 94$ & $0.000079 \mu \mathrm{g} / \mathrm{L}$ & $0.13 \mu \mathrm{g} / \mathrm{L}$ \\
PCB & 011 & $10 / 13 / 94$ & $0.000079 \mu \mathrm{g} / \mathrm{L}$ & $0.1 \mu \mathrm{g} / \mathrm{L}$ \\
PCB & 012 & $10 / 13 / 94$ & $0.000079 \mu \mathrm{g} / \mathrm{L}$ & $0.26 \mu \mathrm{g} / \mathrm{L}$ \\
Residual chlorine & 011 & $10 / 13 / 94$ & $0.019 \mathrm{mg} / \mathrm{L}$ & $0.06 \mathrm{mg} / \mathrm{L}$ \\
\hline
\end{tabular}

Note: $\mathrm{PCB}=$ polychlorinated biphenyl. Data provided by C. C. Travis, Environmental Waste Management Division, Environmental Compliance Department.

Management projects may be another possible explanation for the mobilization of PCBs. However, this activity does not appear to have increased suspended sediment levels in the plant effluents, so no direct correlation can be made (C. C. Travis, Environmental Waste Management Division, Environmental Compliance Department, personal communication).

Two exceedances of the chlorine permit limit were recorded in 1994 (Table 2.2). On March 14, 1994, a recirculating cooling water (RCW) line ruptured at Outfall 002. The $\mathrm{RCW}$ line is underground and contains water at approximately $60^{\circ} \mathrm{C}$. The failure released approximately $310,000 \mathrm{~L}$ of water into the drainage system and lasted less than four hours. Measured total residual chlorine (TRC) values were $0.1 \mathrm{mg} / \mathrm{L}$ (the daily maximum limit is $0.019 \mathrm{mg} / \mathrm{L}$ ). An underground potable water line ruptured in May, releasing about $946,000 \mathrm{~L}$ of potable water which overflowed the 012 lift station and discharged through Outfall 012; there was no exceedance associated with this discharge. A second chlorine 
exceedance occurred October 13,1994, at Outfall 011. The concentration of TRC was $0.06 \mathrm{mg} / \mathrm{L}$. No cause was determined for this exceedance.

Summary statistics (mean, maximum, minimum, and the number of observations) for KPDES chemical parameters for 1994 observed at each outfall are given in Appendix A (Tables A.1 to A.15). Water quality in 1994 differed little from water quality in 1993. In general, water quality in the outfalls was characterized by occasional increases in concentrations of some metals. Metals of concern included $\mathrm{Cd}, \mathrm{Cr}, \mathrm{Cu}, \mathrm{Pb}, \mathrm{Ni}$, and $\mathrm{Zn}$. Maximum values for one or more of these metals have exceeded EPA water quality criteria at most outfalls in 1994 (Tables A.1-A.15; EPA 1986). Currently, KDOW has issued a stay on limits for the aforementioned metals. The PGDP and KDOW have agreed that PGDP will conduct a study to determine whether alternative metal limits are justified based on concentrations of dissolved metals in the outfalls; current limits are based on concentrations of total metals. The KDOW will review the information developed to determine metal limits. Maximum $\mathrm{pH}$ levels exceeded water quality criteria at Outfalls 001, 006, 010, 011, and 014 in 1994. The PGDP has met the interim limit for $\mathrm{pH}(6.0-10.5)$ in all cases, however, the permit limit currently under negotiation is 6.0-9.0 and would have been exceeded at these outfalls. However, instream $\mathrm{pH}$ measurements have been within the limits set by the permit (see Sect. 3.2). The KDOW is reviewing the instream $\mathrm{pH}$ data collected by PGDP to determine whether in-stream monitoring of $\mathrm{pH}$ would be an acceptable option for PGDP to pursue. The PGDP is exploring engineering controls for temperature at outfalls 001 and 011; these controls may enable PGDP to meet permit limits for temperature at these sites. In addition, ESD staff are conducting a temperature study to evaluate the effects of elevated temperatures on the biota of Big Bayou and Little Bayou creeks. Mean hardness values at Outfall 001 were about twice as high in 1992 and 1993 than in previous years (Table 5.3 in Birge et al. 1992). Hardness was reduced substantially in 1994 (mean hardness was $99 \mathrm{mg} / \mathrm{L}$ in 1994 compared with $364 \mathrm{mg} / \mathrm{L}$ in 1993). A discussion of current instream water quality monitoring occurs in Sect. 3.2 of this report. Discussions of previous water quality monitoring efforts can be found in Birge et al. 1992.

Flow from the north/south diversion ditch is normally channeled through Outfall 001 by a lift station that pumps the effluent through the C-616 full-flow lagoon. However, during rainfalls with flows that have maximum daily averages greater than a 10 -year 
occurrence interval, the lift station overflows to Outfall 003 . This is the only time that Outfall 003 is monitored. Outfall 005 is not monitored regularly because its effluent flows into the C-611 secondary lagoon. Outfall 006, the C-611 secondary lagoon, is monitored for the same parameters as those required for Outfall 005. Outfall 007, a septic field for the C-611 water treatment plant, is not permitted for discharge. Monitoring of Outfall 014 occurs only when the C-611 sludge lagoon is dredged (i.e., every 2 or 3 years), and the filter backwash is discharged to the outfall.

Corrective measures have been taken to reduce the number of KPDES noncompliances at PGDP. Emphasis has been placed on erosion control at construction sites, effluent ditches, and landfills. A best management practices plan for the control of suspended solids, prepared in 1991, details measures taken to prevent erosion and investigates erosion-related problems and corrective measures. The plan was submitted to and approved by the KDOW. The Plant Effluent Chlorine and Temperature Control Project became operational in October 1991, providing common lagoon (C-617) for Outfalls 002, 010, 011, and 012. This lagoon, designed to contain effluent from the outfall except during heavy rainfall, provides sodium thiosulfate feed for chlorine removal and increased holding time for temperature reduction. In addition, sodium thiosulfate feed stations were installed permanently at Outfalls 009 and 004 . Once-through cooling water that originally flowed through Outfall 001 is now routed through the C-616 full-flow lagoon to allow for chlorine dissipation. In response to temperature noncompliances, leaking steam traps in several buildings were repaired or replaced and temperature noncompliances ceased.

In 1993 the chromium based inhibitor was replaced with a phosphate based inhibitor at the chromium reduction facility. The only notable change in water quality in Outfall 001 was a reduction in hardness values from 1993 to 1994 . Whether this change resulted from the modification is unknown.

Dredging of the sludge lagoon at the C-611 water treatment plant was initiated in September 1993. Currently the clarifier bottoms are being discharged directly into the full flow lagoon for settling. This change did not resulted in permit violations, and no changes in water quality were noted as a result of this action. The sludge lagoon was returned to service March 25, 1994. 
2.3 DESCRIPTION OF STUDY SITES (J. G. Smith, M. J. Peterson, and M. G. Ryon) Three sites on Big Bayou Creek (Fig. 2.2), Big Bayou Creek kilometer (BBK) 12.5, BBK 10.0, and BBK 9.1; one site on Little Bayou Creek (Fig. 2.2), Little Bayou Creek kilometer (LUK) 7.2; and one off-site reference station on Massac Creek (Fig. 2.1), Massac Creek kilometer (MAK) 13.8, were routinely sampled to assess the ecological health of the stream. Sites BBK 12.5, BBK 9.1, LUK 7.2, and MAK 13.8 were routinely sampled to evaluate ambient toxicity. A summary of the site locations is given in Table 2.3. Three additional sites (BBK 2.8, LUK 9.0, and LUK 4.3; Fig 2.2) were sampled as part of the bioaccumulation monitoring task. Hinds Creek in East Tennessee also served as a reference site for the bioaccumulation monitoring task. A description of the sampling locations for the bioaccumulation monitoring is provided in Sect. 4. Site selection and sampling locations for the ecological monitoring studies are described below. Ambient toxicity monitoring sites were chosen to correspond with those used for ecological monitoring. Biological monitoring activities conducted through December 1994 are outlined in Table 2.4. Toxicity monitoring and benthic macroinvertebrate sampling were conducted quarterly, and fish community and bioaccumulation sampling were conducted twice annually (in the spring and fall). KPDES outfalls at which effluents were evaluated for toxicity included 001, 004, 006, 008, 009, 011, 013, 015, 016, 017, and 018.

Prior to ORNL's initiation of the instream monitoring task for the PGDP BMP, a site selection study was conducted in early December 1990. This study included visits to 24 potential reference stream sites located in the vicinity of PGDP but outside its boundaries (see Table 2.4 in Kszos et al. 1994), and 5 stream sites adjacent to the boundary of PGDP: LUK 7.2, LUK 4.3, BBK 12.5, BBK 9.1, and the tributary draining Outfall 003. The site selection study also involved the collection of qualitative benthic macroinvertebrate and fisi samples at some of the sites to aid in final site selection (Tables 2.5 and 2.6 in Kszos et al. 1994). Because these samples were qualitative, the results served primarily to document which taxa were present at these sites at the time of the survey. However, these qualitative data did provide some minimal information on the relative health of each stream sampled and, thus, helped in making final site selections.

Based on the site visits, biota surveys, and previous work conducted by the Ưniversity of Kentucky (Birge et al. 1990), five stream sites were included in the instream monitoring task of the BMP. A list of the selected sites and a summary of their locations are given in 
Table 2.3. Locations and names of sampling sites included in Paducah Gaseous Diffusion Plant Biological Monitoring Program for the Instream Monitoring Task

Current site name

Location $^{b}$

Former name/site

Big Bayou Creek

BBK 12.5

-200 m downstream of bridge on South Acid Road

BB1

BBK 10.0

$\sim 50 \mathrm{~m}$ upstream of Outfall 006

BB4

BBK 9.1

$-25 \mathrm{~m}$ upstream of flume at gaging station at Bobo Road

BB7

Little Bayou Creek

LUK 7.2

$-110 \mathrm{~m}$ downstream of bridge on Route 358

LB3

Massac Creek

MAK 13.8

$\sim 40 \mathrm{~m}$ upstream of bridge on Route $62,10 \mathrm{~km}$ SE of PGDP

Not sampled

${ }^{\circ}$ Site names are based on stream name and distance of the site from the mouth of the stream. For example, BB7 is designated as Big Bayou Creek Kilometer (BBK) 9.1 and is located $9.1 \mathrm{~km}$ upstream of the mouth; LUK = Little Bayou Creek kilometer; and MAK = Massac Creek kilometer.

${ }^{b}$ Locations are based on approximate distances from a major landmark (e.g., bridge or outfall) to the bottom of the reach.

'Site designations formerly used by the University of Kentucky.

Table 2.4. Sampling schedule for the four components of the Biological Monitoring Program at Paducah Gaseous Diffusion Plant for January-December 1994

\begin{tabular}{lcccc}
\hline Month & $\begin{array}{c}\text { Toxicity } \\
\text { monitoring }\end{array}$ & $\begin{array}{c}\text { Benthic } \\
\text { macroinvertebrates }\end{array}$ & Fishes & Bioaccumulation \\
\hline Jan. & & & & \\
Feb. & $\mathrm{X}$ & $\mathrm{X}$ & $\mathrm{X}$ & \\
Mar. & $\mathrm{X}$ & $\mathrm{X}$ & $\mathrm{X}^{a}$ & $\mathrm{X}$ \\
Apr. & & & & \\
May & $\mathrm{X}$ & $\mathrm{X}$ & $\mathrm{X}$ & $\mathrm{X}$ \\
June & $\mathrm{X}$ & & & \\
July & & $\mathrm{X}$ & & \\
Aug. & & & & \\
Sept. & & & & \\
Oct. & & & & \\
Nov. & & & & \\
Dec. & & & & \\
\hline
\end{tabular}

${ }^{\circ}$ Qualitative survey of Massac Creek watershed.

${ }^{b}$ Big Bayou Creek kilometer 2.8 only. 
Table 2.3; their locaticiss in relation to the PGDP are shown in Fig. 2.1 and Fig. 2.2.

Final sampling locations within each selected site were made in June 1991 during a habitat characterization study. This study included measurements of vegetative cover, bank structure, channel morphology, substrate and cover variables, and flow conditions.

Pertinent results of this study for each site are presented in sections 2.3.1-2.3.3 and Table 2.7 in Kszos et al. 1994. 


\section{TOXICITY MONITORING}

\section{A. Kszos and J. R. Sumner}

The toxicity monitoring task for BMP consists of two subtasks. The first measures the toxicity of effluents as required by the KPDES permit. The second monitors ambient water toxicity of three sites in Big Bayou Creek, one site in Little Bayou Creek, and one reference site in Massac Creek. The effluent toxicity data are presented in Sect. 3.1; the ambient toxicity data are presented in Sect. 3.2.

\subsection{EFFLUENT TOXICITY}

\subsubsection{Introduction}

The EPA supports the use of aquatic test organisms to determine the chronic toxicity of a test water (Weber et al. 1989). Toxicity monitoring at PGDP uses the Cladoceran (Ceriodaphnia dubia) Survival and Reproduction Test (hereinafter referred to as the Ceriodaphnia test) and the Fathead Minnow (Pimephales promelas) Larval Survival and Growth Test (hereinafter referred to as the fathead minnow test; Weber et al. 1989) concurrently to characterize the toxicity of the continuous and intermittent effluents that discharge into Big Bayou and Little Bayou creeks. These two tests are EPA-approved for use to estimate (1) the chronic toxicity of effluents collected at the end of the discharge pipe and tested with a standard dilution water; (2) the toxicity of receiving water downstream from or within the influence of the outfall; and (3) the effects of multiple discharges on the quality of the receiving water (Weber et al. 1989). These tests are also part of the Biological Monitoring and Abatement Programs at ORNL, the Oak Ridge K-25 Site, and the Oak Ridge Y-12 Plant.

The ESD Toxicology Laboratory at ORNL began evaluating the toxicity of continuous and intermittent outfalls at PGDP in October 1991. As required by a draft Agreed Order, Ceriodaphnia and fathead minnow tests were conducted quarterly. In September 1992, a renewed KPDES permit was issued to PGDP. Under the requirements of this permit, Ceriodaphnia and fathead minnow tests were continued on a quarterly basis. 


\subsubsection{Materials and Methods.}

Toxicity tests of effluents from the continuously flowing outfalls (001, 006, 008, 009, and 011$)$ and the intermittently flowing outfalls $(013,015,016,017$, and 018$)$ were conducted according to the schedule shown in Tables 3.1 and 3.2 respectively. After PCBs were detected at Outfall 011 in June 1994, effluent from the C-617 lagoon was diverted from Outfall 011 to Outfall 010. As a result, effluent from Outfall 010 was tested for toxicity in August and October 1994 instead of Outfall 011. This report includes all tests conducted from 1991 to 1994 by ESD. Most of the outfalls have been evaluated at least 13 times.

Prior to September 1992, tests of the continuously flowing outfalls were conducted using seven consecutive, daily grab samples collected at the KPDES discharge points. Subsequent tests used seven 24-h composite samples as required by the renewed KPDES permit. Samples from the continuously flowing outfalls were collected by personnel from ESD and transported to a nearby offsite laboratory at the Paducah Community College. During one test period, October 1994, samples from the continuously flowing outfalls were collected by personnel from PGDP, refrigerated, and shipped to ESD using 24-h delivery. The intermittently flowing outfalls are rainfall dependent; thus, tests were conducted using one grab sample. Samples from the intermittently flowing outfalls were collected by personnel from PGDP, refrigerated, and shipped to ESD using 24-h delivery. All samples were collected and delivered according to established chain-of-custody procedures (Kszos et al. 1989). Time of collection, water temperature, and arrival time in the laboratory were recorded.

Tests with Ceriodaphnia and fathead minnows were typically conducted concurrently following procedures outlined in Weber et al. (1989) and Kszos et al. (1989). These tests are static-renewal tests, meaning that test water is replaced daily for 6 or 7 consecutive days. The fathead minnow test consists of four replicates per test concentration with ten animals per replicate. Each day before the water was replaced, the number of surviving larvae was recorded. At the end of $7 \mathrm{~d}$, the larvae were dried and weighed to obtain an estimate of growth. The Ceriodaphnia test consists of ten replicates per test concentration with one animal per replicate. Each day the animals were transferred from a beaker containing old test solution and placed in a beaker containing fresh test solution. At this 
Table 3.1. Summary of toxicity test dates for continuous outfalls

\begin{tabular}{|c|c|c|}
\hline Outfall & Test date & Species \\
\hline $001,006,008,009,011$ & October 24-31, 1991 & Ceriodaphnia and Fathead minnow \\
\hline $001,006,008,009,011$ & February 13-20, 1992 & Ceriodaphnia and Fathead minnow \\
\hline $001,006,008,009,011$ & May 21-28, 1992 & Ceriodaphnia and Fathead minnow \\
\hline $001,006,008,009,011$ & August 13-20, 1992 & Ceriodaphnia and Fathead minnow \\
\hline $001,006,008,009,011$ & October 22-29, 1992 & Ceriodaphnia and Fathead minnow \\
\hline $001,006,008,009,011$ & February 11-18, 1993 & Ceriodaphnia and Fathead minnow \\
\hline $001,006,008,009,011$ & May 20-27, 1993 & Ceriodaphnia and Fathead minnow \\
\hline $001,006,008,009,011$ & August 19-16, 1993 & Ceriodaphnia and Fathead minnow \\
\hline $001,006,008,009,011$ & October $14-21,1993$ & Ceriodaphnia and Fathead minnow \\
\hline 008 & December 2-9, 1993 & Fathead minnow \\
\hline $001,006,008,009,011$ & March 10-17, 1994 & Ceriodaphnia and Fathead minnow \\
\hline 006,011 & March 25-April 1, 1994 & Fathead minnow \\
\hline 006,011 & April 28-May 5, 1994 & Ceriodaphnia and Fathead minnow \\
\hline $001,008,009$ & May 25-June 2, 1994 & Ceriodaphnia and Fathead minnow \\
\hline 008,009 & June 16-23, 1994 & Fathead minnow \\
\hline $001,006,008,009,010$ & August 11-18, 1994 & Ceriodaphnia and Fathead minnow \\
\hline 006 & September 8-16, 1994 & Ceriodaphnia \\
\hline 008,009 & September 8-16, 1994 & Fathead minnow \\
\hline $001,006,008,009,010$ & October 27-November 4, 1994 & Ceriodaphnia and Fathead minnow \\
\hline 001 & November 16-23, 1994 & Ceriodaphnia \\
\hline 009 & November 16-23, 1994 & Fathead minnow \\
\hline
\end{tabular}

Table 3.2. Summary of toxicity test dates for intermittent outfalls

\begin{tabular}{|c|c|c|}
\hline Outfall & Test Date & Species \\
\hline $013,015,016,017,018$ & 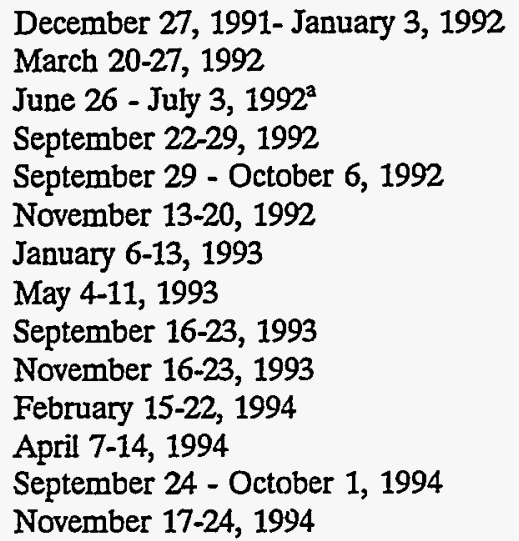 & $\begin{array}{l}\text { Ceriodaphnia and Fathead minnow } \\
\text { Ceriodaphnia and Fathead minnow } \\
\text { Ceriodaphnia and Fathead minnow } \\
\text { Fathead minnow } \\
\text { Ceriodaphnia } \\
\text { Ceriodaphnia and Fathead minnow } \\
\text { Ceriodaphnia and Fathead minnow } \\
\text { Ceriodaphnia and Fathead minnow } \\
\text { Ceriodaphnia and Fathead minnow } \\
\text { Ceriodaphnia and Fathead minnow } \\
\text { Ceriodaphnia and Fathead minnow } \\
\text { Ceriodaphnia and Fathead minnow } \\
\text { Ceriodaphnia and Fathead minnow } \\
\text { Ceriodaphnia and Fathead minnow }\end{array}$ \\
\hline
\end{tabular}

${ }^{a}$ Outfall 016 was not tested due to lack of flow. 
time, survival and the number of offspring produced were recorded. A control consisting of dilute mineral water augmented with trace metals was included with each test. On each day of a test, subsamples of each effluent were routinely analyzed for $\mathrm{pH}$, conductivity, alkalinity, water hardness, and total residual and free chlorine (Kszos et al. 1989).

During December 1994, various treatments were used to investigate the type(s) of compounds causing toxicity in effluent from Outfall 009. Subsamples of the effluent were treated as follows: (1) ultraviolet radiation (UV) for 20 minutes to kill naturally occurring pathogens and viruses; (2) aerated for 1-h to remove volatiles; (3) filtered through $0.2 \mu \mathrm{m}$ nuclepore filters to remove suspended particles; (4) $C_{18}$ solid phase extracted to remove suspended particles and organics; (5) adjusted from ambient $\mathrm{pH}$ and maintained at $\mathrm{pH} 6$ or 8 throughout the test period to determine if the toxicity was $\mathrm{pH}$ sensitive; (6) treated with a chelating agent (1.0 mg/L EDTA) to bind divalent metals; or (7) treated with sodium thiosulfate to remove oxidants. The nontreated and treated samples were then tested for toxicity with fathead minnow larvae.

During tests conducted in May 1993, February 1994, April 1994, and September 1994, subsamples of effluent from 018 were filtered through glass microfiber filters $(1.2 \mu \mathrm{m})$ to remove suspended solids. Fathead minnow tests were then conducted using nontreated and filtered effluent samples. The amount of suspended solids in the effluent was measured by filtering a known volume of effluent through a pre-dried, pre-weighed filter.

A linear interpolation method (Weber et al. 1989) was used to determine the $25 \%$ inhibition concentration (IC25, that concentration causing a 25\% reduction in fathead minnow growth or Ceriodaphnia survival compared to a control). A computer program (A Linear Interpolation Method for Sublethal Toxicity: Inhibition Concentration (ICp) Approach, version 2.0) distributed by the EPA (Environmental Research Laboratory, Duluth, Minnesota) was used for the calculation. The chronic toxicity unit (TUc=100/IC25) is required as a compliance endpoint in the renewed permit (September 1992 to present). The higher the TUc, the more toxic an effluent. Because Little Bayou and Big Bayou creeks have been determined to have a low flow of zero, a TUc $>1.0$ would be considered a noncompliance and an indicator of potential instream toxicity. Summary statistics (e.g. mean, standard deviation) were calculated using SAS (SAS 1985a, 1985b). 


\subsubsection{Results}

\subsubsection{Continuously flowing Outfalls 001, 006, 008, 009, and 011}

Mean survival and growth of fathead minnows and survival and mean reproduction of Ceriodaphnia for each outfall and test are provided in Appendixes B.1 and B.2. A summary of the TUcs for all toxicity tests conducted during 1991-94 are provided in Table 3.3. For tests conducted to date, effluent from Outfall 001 exceeded the permit limit of TUc > 1.0 for two tests (Ceriodaphnia in May 1992 and October 1993). Effluent from Outfall 006 exceeded the permit limit five times, twice in 1992 and three times in 1994. Two of the 1994 exceedances occurred during March for fathead minnows. The resulting TUcs were high (5.97 and 18.32). However, when the effluent was tested again during April, August, and October 1994 the TUcs for Outfall 006 were < 1.0. The third exceedance in 1994 was for Ceriodaphnia, where the TUc was 1.36 during August. Outfall 008 exceeded the permit limit during four fathead minnow tests. The effluent has not demonstrated toxicity to Ceriodaphnia. During the two exceedances for Outfall 008 in 1994, the TUcs for fathead minnows were just above the permit limit (1.30 and 1.56), and follow-up tests resulted in a TUcs $<1.0$. Outfall 009 exceeded the permit limit seven times with six occurring for fathead minnow tests. Outfall 011 exceeded the permit limit three times, once in February 1992 and twice in March 1994. For the two exceedances during March 1994 the TUcs for fathead minnows were high (23.53 and 32.57); however, for tests conducted during April, August, and October 1994, the TUc $<1$.

Water quality measurements ( $\mathrm{pH}$, conductivity, alkalinity, and hardness) for each outfall and test are provided in Appendix B.3. A summary of water quality parameters for the continuously flowing outfalls is provided in Table 3.4. The $\mathrm{pH}$ of the effluent samples ranged from a minimum of 6.8 (Outfall 006) to a maximum of 9.7 (Outfall 006). Effluent from Outfall 006 had the highest mean $\mathrm{pH}$ (8.75 S.U.). Mean alkalinity ranged from 34 (Outfall 008) to $51 \mathrm{mg} / \mathrm{L} \mathrm{CaCO}_{3}$ (Outfall 009). Mean hardness and conductivity were highest in effluent from Outfall 001 (402 $\mathrm{mg} / \mathrm{L} \mathrm{CaCO}_{3}$ and $1256 \mu \mathrm{S} / \mathrm{cm}$ respectively). Mean hardness at the remaining outfalls ranged from 75 to $85 \mathrm{mg} / \mathrm{L} \mathrm{CaCO}$ and mean conductivity ranged from 224 to $262 \mu \mathrm{S} / \mathrm{cm}$.

Due to four exceedances occurring for Outfall 009 in 1994 alone, steps were taken to identify the possible toxicant(s) in the effluent. During December 1994, subsamples of effluent from Outfall 009 were treated by various methods and tested for toxicity with 
Table 3.3. Results of effluent toxicity tests for outfalls $001,006,008,009$, and 011

\begin{tabular}{|c|c|c|c|}
\hline \multirow[b]{2}{*}{ Outfall } & \multirow[b]{2}{*}{ Test Date } & \multicolumn{2}{|c|}{ Chronic Toxicity Units (TUc) ${ }^{a}$} \\
\hline & & Fathead Minnow & Ceriodaphnia \\
\hline \multirow[t]{14}{*}{001} & October 1991 & $\mathrm{ND}^{b}$ & $<1$ \\
\hline & February 1992 & $<1$ & $<1$ \\
\hline & May 1992 & $\mathrm{ND}^{b}$ & 4.5 \\
\hline & August 1992 & $<1$ & $<1$ \\
\hline & October 1992 & $<1$ & $<1$ \\
\hline & February 1993 & $<1$ & $<1$ \\
\hline & May 1993 & $<1$ & $<1$ \\
\hline & August 1993 & $<1$ & $<1$ \\
\hline & October 1993 & $<1$ & 1.09 \\
\hline & March 1994 & $<1$ & $<1$ \\
\hline & May 1994 & $<1$ & $<1$ \\
\hline & August 1994 & $<1$ & $<1$ \\
\hline & October 1994 & $<1$ & $\mathrm{I}^{\mathrm{d}}$ \\
\hline & November 1994 & $\mathrm{NT}^{\mathrm{c}}$ & $<1$ \\
\hline \multirow[t]{16}{*}{006} & October 1991 & $\mathrm{ND}^{b}$ & $<1$ \\
\hline & February 1992 & 1.39 & 1.56 \\
\hline & May 1992 & $\mathrm{ND}^{b}$ & $<1$ \\
\hline & August 1992 & $<1$ & $<1$ \\
\hline & October 1992 & $<1$ & $<1$ \\
\hline & February 1993 & $<1$ & $<1$ \\
\hline & May 1993 & $<1$ & $\mathrm{I}^{d}$ \\
\hline & June 1993 & $\mathrm{NT}^{\mathrm{c}}$ & $<1$ \\
\hline & August 1993 & $<1$ & $<1$ \\
\hline & October 1993 & $<1$ & $<1$ \\
\hline & March 1994 & 5.97 & $<1$ \\
\hline & March 1994 & 18.32 & $N T^{c}$ \\
\hline & April 1994 & $<1$ & $<1$ \\
\hline & August 1994 & $<1$ & 1.36 \\
\hline & September 1994 & $\mathrm{NT}^{\mathrm{c}}$ & $<1$ \\
\hline & October 1994 & $<1$ & $<1$ \\
\hline
\end{tabular}


Table 3.3 (continued)

\begin{tabular}{|c|c|c|c|}
\hline \multirow[b]{2}{*}{ Outfall } & \multirow[b]{2}{*}{ Test Date } & \multicolumn{2}{|c|}{ Chronic Toxicity Units (TUc) ${ }^{a}$} \\
\hline & & Fathead Minnow & Ceriodaphnia \\
\hline \multirow[t]{17}{*}{008} & October 1991 & $\mathrm{ND}^{b}$ & $<1$ \\
\hline & February 1992 & 9.77 & $<1$ \\
\hline & May 1992 & $\mathrm{ND}^{b}$ & $<1$ \\
\hline & August 1992 & $<1$ & $<1$ \\
\hline & October 1992 & $<1$ & $<1$ \\
\hline & February 1993 & $<1$ & $<1$ \\
\hline & May 1993 & $<1$ & $\mathrm{I}^{d}$ \\
\hline & June 1993 & $\mathrm{NT}^{c}$ & $<1$ \\
\hline & August 1993 & $<1$ & $<1$ \\
\hline & October 1993 & 4.08 & $<1$ \\
\hline & December 1993 & $<1$ & $\mathrm{NT}^{\bullet}$ \\
\hline & March 1994 & $<1$ & $<1$ \\
\hline & May 1994 & 1.30 & $<1$ \\
\hline & June 1994 & $<1$ & $\mathrm{NT}^{c}$ \\
\hline & August 1994 & 1.56 & $<1$ \\
\hline & September 1994 & $<1$ & $\mathrm{NT}^{c}$ \\
\hline & October 1994 & $<1$ & $<1$ \\
\hline \multirow[t]{17}{*}{009} & October 1991 & $\mathrm{ND}^{b}$ & $<1$ \\
\hline & February 1992 & 7.87 & $<1$ \\
\hline & May 1992 & $<1$ & $<1$ \\
\hline & August 1992 & $<1$ & $<1$ \\
\hline & October 1992 & 2.16 & 1.05 \\
\hline & February 1993 & $<1$ & $<1$ \\
\hline & May 1993 & $<1$ & $\mathrm{I}^{d}$ \\
\hline & June 1993 & $\mathrm{NT}^{e}$ & $<1$ \\
\hline & August 1993 & $<1$ & $<1$ \\
\hline & October 1993 & $<1$ & $<1$ \\
\hline & March 1994 & $<1$ & $<1$ \\
\hline & May 1994 & 1.09 & $<1$ \\
\hline & June 1994 & $<1$ & $\mathrm{NT}^{e}$ \\
\hline & August 1994 & 2.09 & $<1$ \\
\hline & September 1994 & $<1$ & $\mathrm{NT}^{c}$ \\
\hline & October 1994 & 10.73 & $<1$ \\
\hline & November 1994 & 3.38 & $N T^{c}$ \\
\hline
\end{tabular}


Table 3.3 (continued)

\begin{tabular}{|c|c|c|c|}
\hline \multirow[b]{2}{*}{ Outfall } & \multirow[b]{2}{*}{ Test Date } & \multicolumn{2}{|c|}{ Chronic Toxicity Units (TUc) ${ }^{a}$} \\
\hline & & Fathead Minnow & Ceriodaphnia \\
\hline \multirow[t]{14}{*}{011} & October 1991 & $\mathrm{ND}^{b}$ & $<1$ \\
\hline & February 1992 & 7.69 & $<1$ \\
\hline & May 1992 & $\mathrm{ND}^{b}$ & $<1$ \\
\hline & August 1992 & $<1$ & $<1$ \\
\hline & October 1992 & $<1$ & $<1$ \\
\hline & February 1993 & $<1$ & $<1$ \\
\hline & May 1993 & $<1$ & $<1$ \\
\hline & August 1993 & $<1$ & $<1$ \\
\hline & October 1993 & $<1$ & $<1$ \\
\hline & March 1994 & 23.53 & $<1$ \\
\hline & March 1994 & 32.57 & $\mathrm{NT}^{c}$ \\
\hline & April 1994 & $<1$ & $<1$ \\
\hline & August $1994^{e}$ & $<1$ & $<1$ \\
\hline & October $1994^{\circ}$ & $<1$ & $<1$ \\
\hline
\end{tabular}

${ }^{a}$ Chronic toxicity unit $=130 / \mathrm{IC25}$; IC25 $=$ the concentration causing a $25 \%$ reduction in fathead minnow growth or Ceriodaphnia reproduction. IC $=$ inhibition concentration.

${ }^{b} \mathrm{ND}=$ not determined.

TT $=$ not tested.

$d_{\mathrm{I}}=$ Invalid test due to low reproduction in the control water.

'Outfall 010 tested for toxicity instead of Outfall 011.

fathead minnow larvae. Minnow survival in the nontreated effluent was $43.8 \%$

(Table 3.5). Removing suspended particles through filtration or $\mathrm{C}_{18}$ solid phase extraction of Outfall 009 effluent increased minnow survival to $93.8 \%$. Minnow survival was also improved in effluent adjusted from ambient $\mathrm{pH} 7.66$ to $\mathrm{pH}$ 8. Minnow growth was high in both the treated and nontreated effluent.

\subsubsection{Intermittently flowing Outfalls 013, 015, 016, 017, and 018}

Mean survival and growth of fathead minnows and survival and mean reproduction of Ceriodaphnia for each outfall and test are provided in Appendixes B.4 and B.5. A summary of the TUcs for all toxicity tests conducted during 1991-94 is provided in Table 3.6. Although PGDP does not have a compliance limit for the intermittent outfalls, TUc $>1.0$ was used as a benchmark. Out of the thirty exceedances of TUc $>1.0$ for the 
Table 3.4. Summary of water chemistry analyses of full-strength samples from continuously flowing outfalls from 1991-94

\begin{tabular}{|c|c|c|c|c|}
\hline Sample & $\begin{array}{c}\mathrm{pH} \\
\text { (Standard units) }\end{array}$ & $\begin{array}{c}\text { Alkalinity } \\
\left(\mathrm{mg} / \mathrm{L} \text { as } \mathrm{CaCO}_{3}\right)\end{array}$ & $\begin{array}{c}\text { Hardness } \\
\left(\mathrm{mg} / \mathrm{L} \text { as } \mathrm{CaCO}_{3}\right)\end{array}$ & $\begin{array}{l}\text { Conductivity } \\
(\mu \mathrm{S} / \mathrm{cm})\end{array}$ \\
\hline \multicolumn{5}{|l|}{ Outfall 001} \\
\hline Mean $( \pm S D)$ & $8.34(0.63)$ & $34.5(9.8)$ & $402.4(109.5)$ & $1256.2(317.2)$ \\
\hline Range & $7.12-9.54$ & $23-85$ & $134-680$ & $489-1867$ \\
\hline$n$ & 98 & 98 & 98 & 98 \\
\hline \multicolumn{5}{|l|}{ Outfall 006} \\
\hline Mean $( \pm S D)$ & $8.75(0.54)$ & $50.3(14.4)$ & $85.2(22.8)$ & $223.5(41.7)$ \\
\hline Range & $6.80-9.72$ & $30-88$ & $50-204$ & $163-329$ \\
\hline$n$ & 111 & 111 & 111 & 111 \\
\hline \multicolumn{5}{|l|}{ Outfall 008} \\
\hline Mean $( \pm S D)$ & $7.39(0.22)$ & $34.4(11.4)$ & $75.4(15.4)$ & $261.7(43.6)$ \\
\hline Range & $6.86-8.20$ & $18-65$ & $44-112$ & $177-461$ \\
\hline$n$ & 118 & 118 & 118 & 118 \\
\hline \multicolumn{5}{|l|}{ Outfall 009} \\
\hline Mean $( \pm S D)$ & $7.70(0.31)$ & $51.2(25.5)$ & $84.6(24.1)$ & $257.2(118.1)$ \\
\hline Range & $7.10-8.83$ & $30-233$ & $44-210$ & $116-1020$ \\
\hline$n$ & 119 & 119 & 119 & 119 \\
\hline \multicolumn{5}{|c|}{ Outfall 011 or 010} \\
\hline Mean $( \pm \mathrm{SD})$ & $7.77(0.27)$ & $39.3(13.7)$ & $8.8(21.7)$ & $253.6(54.7)$ \\
\hline Range & $7.27-9.15$ & $21-77$ & $52-158$ & $168-491$ \\
\hline$n$ & 98 & 98 & 98 & 98 \\
\hline
\end{tabular}

effluents, toxicity to Ceriodaphnia was only observed in three tests (January 1993 and February 1994 for Outfall 013 and September 1994 for Outfall 018). In 1994, fathead minnows continued to be more sensitive than Ceriodaphnia to the effluents (Kszos et al. 1994). For tests conducted to date, effluent from Outfall 013 most frequently exceeded a TUc $>1.0$ (eight times) in comparison to the other outfalls. Outfall 013 was followed by Outfalls 015, 017, and 018, each having six exceedances. Outfall 016 had the fewest exceedances, with four for fathead minnows. The average TUcs using all tests where the limit was exceeded for Outfalls $013,015,016,017$, and 018 were 3.9, 7.3, 7.1, 17.4, and 7.0. 
Table 3.5. Summary of a toxicity identification test using fathead minnow larvae of full-strength effluent from Outfall 009, December 1994

\begin{tabular}{lccc}
\hline & $\begin{array}{c}\text { Mean survival } \\
\text { Treatment }\end{array}$ & $\begin{array}{c}\text { Mean growth } \\
\text { (mg) }\end{array}$ & Growth SD (mg) \\
\hline Control & 100 & 0.40 & 0.00 \\
Nontreated & 43.8 & 0.50 & 0.12 \\
UV-treated & 18.8 & 0.35 & 0.16 \\
Aerated & 37.5 & 0.35 & 0.00 \\
Filtered & 93.8 & 0.49 & 0.03 \\
C18-Solid Phase Extraction & 93.8 & 0.50 & 0.01 \\
Adjusted to pH6 & 56.3 & 0.59 & 0.14 \\
Adjusted to pH8 & 87.5 & 0.45 & 0.01 \\
EDTA & 50.0 & 0.54 & 0.00 \\
Sodium thiosulfate & 37.5 & 0.50 & 0.07 \\
\hline
\end{tabular}

$a$ UV-treated with ultraviolet radiation for 20 minutes; Aerated for 1-h; Filtered through a $0.2 \mu \mathrm{m}$ nuclepore filter, $1.0 \mathrm{mg} / \mathrm{L}$ EDTA (chelating agent) added to bind divalent metals; Sodium thiosulfate added to remove oxidants.

Ranking the outfalls provided a means to compare the frequency of toxicity and mean TUcs of the outfalls. Each outfall was ranked in terms of frequency of TUc $>1.0$ ( 5 = highest frequency and $1=$ lowest frequency) and by mean TUc ( $5=$ highest mean and $1=$ lowest mean). The ranks were then summed to obtain an overall ranking (Table 3.7). Outfall 017 had the highest overall rank sum (8) and was followed by Outfalls 015 (7) and 013 (6). Outfall 013 had the greatest frequency of TUc > 1.0 (31\%); however, had the lowest mean TUc (3.9) in comparison to the other outfalls. Outfall 017 had the highest mean TUc (17.4).

Water quality measurements ( $\mathrm{pH}$, conductivity, alkalinity, and hardness) for each outfall and test are provided in Appendix B.6. A summary of water quality parameters for each outfall is provided in Table 3.8. In general, water from the intermittent outfalls had higher alkalinity and hardness than the continuous outfalls. Mean alkalinity ranged from 
Table 3.6. Results of effluent toxicity tests for Outfalls $013,015,016,017$, and 018

\begin{tabular}{|c|c|c|c|}
\hline \multirow[b]{2}{*}{ Outfall } & \multirow[b]{2}{*}{ Test Date } & \multicolumn{2}{|c|}{ Chronic toxicity unit (TUc) ${ }^{a}$} \\
\hline & & Fathead minnow & Ceriodaphnia \\
\hline \multirow[t]{13}{*}{013} & December 1991 & $<1$ & $<1$ \\
\hline & March 1992 & 5.82 & $<1$ \\
\hline & June 1992 & 1.02 & $<1$ \\
\hline & September 1992 & $<1$ & $<1$ \\
\hline & November 1992 & 1.96 & $<1$ \\
\hline & January 1993 & $<1$ & 6.99 \\
\hline & May 1993 & 1.3 & $<1$ \\
\hline & September 1993 & 1.39 & $<1$ \\
\hline & November 1993 & $<1$ & $<1$ \\
\hline & February 1994 & 11.31 & 1.04 \\
\hline & April 1994 & $<1$ & $<1$ \\
\hline & September 1994 & $<1$ & $<1$ \\
\hline & November 1994 & $<1$ & $<1$ \\
\hline \multirow[t]{13}{*}{015} & December 1991 & $<1$ & $<1$ \\
\hline & March 1992 & 7.91 & $<1$ \\
\hline & June 1992 & $<1$ & $<1$ \\
\hline & September 1992 & $<1$ & $\mathrm{ND}^{b}$ \\
\hline & November 1992 & $<1$ & $<1$ \\
\hline & January 1993 & 1.52 & $<1$ \\
\hline & May 1993 & 3.62 & $<1$ \\
\hline & September 1993 & $<1$ & $<1$ \\
\hline & November 1993 & $<1$ & $<1$ \\
\hline & February 1994 & 2.04 & $<1$ \\
\hline & April 1994 & 11.15 & $<1$ \\
\hline & September 1994 & $<1$ & $<1$ \\
\hline & - November 1994 & 17.54 & $<1$ \\
\hline \multirow[t]{12}{*}{016} & December 1991 & $<1$ & $<1$ \\
\hline & March 1992 & 1.74 & $<1$ \\
\hline & September 1992 & $<1$ & $<1$ \\
\hline & November 1992 & 1.32 & $<1$ \\
\hline & January 1993 & 2.04 & $<1$ \\
\hline & May 1993 & $<1$ & $<1$ \\
\hline & September 1993 & $<1$ & $<1$ \\
\hline & November 1993 & $<1$ & $<1$ \\
\hline & February 1994 & $<1$ & $<1$ \\
\hline & April 1994 & $<1$ & $<1$ \\
\hline & September 1994 & $<1$ & $<1$ \\
\hline & November 1994 & 23.47 & $<1$ \\
\hline
\end{tabular}


Table 3.6 (continued)

\begin{tabular}{clcc}
\hline & & \multicolumn{2}{c}{ Chronic toxicity unit (TUc) } \\
\cline { 3 - 4 } Outfall & Test Date & Fathead minnow & Ceriodaphnia \\
\hline \multirow{2}{*}{017} & December 1991 & $N^{b}$ & $<1$ \\
& March 1992 & 4.54 & $<1$ \\
& June 1992 & $<1$ & $<1$ \\
& September 1992 & 5.01 & $<1$ \\
& November 1992 & $<1$ & $<1$ \\
& January 1993 & $<1$ & $<1$ \\
& May 1993 & 23.8 & $<1$ \\
& September 1993 & $<1$ & $<1$ \\
& November 1993 & $<1$ & $<1$ \\
& February 1994 & 2.83 & $<1$ \\
& April 1994 & 1.79 & $<1$ \\
& September 1994 & $<1$ & $<1$ \\
& November 1994 & 66.23 & $<1$ \\
& December 1991 & & $<1$ \\
& March 1992 & $<1$ & $<1$ \\
& June 1992 & 5.27 & $<1$ \\
September 1992 & $<1$ & $<1$ \\
November 1992 & $<1$ & $<1$ \\
January 1993 & 1.43 & $<1$ \\
May 1993 & 8.47 & $<1$ \\
September 1993 & 21.7 & $<1$ \\
Novembor 1993 & $<1$ & $<1$ \\
February 1994 & $<1$ & $<1$ \\
April 1994 & $<1$ & $<1$ \\
September 1994 & 1.39 & 3.47 \\
November 1994 & $<1$ & $<1$ \\
\hline
\end{tabular}

${ }^{\circ}$ Chronic toxicity unit $=100 / 1 \mathrm{C} 25$; IC25 $=$ the concentration causing a $25 \%$ reduction in fathead minnow growth or Ceriodaphnia reproduction. IC = inhibition concentration.

${ }^{b} \mathrm{ND}=$ not determined.

57 to $120 \mathrm{mg} / \mathrm{L} \mathrm{CaCO}_{3}$ and mean hardness ranged from 110 to $175 \mathrm{mg} / \mathrm{L} \mathrm{CaCO}_{3}$. Minimum $\mathrm{pH}$ ranged from 6.91 to 7.75 S.U. and maximum $\mathrm{pH}$ ranged from 7.96 to 8.27 S.U. Mean conductivity ranged from 200 to $380 \mu \mathrm{S} / \mathrm{cm}$.

Filtering effluent samples from Outfall 018 significantly (ANOVA; $\mathrm{p}=0.0007$ ) improved fathead minnow survival by $5-52.5 \%$ when compared with the nonfiltered samples (Table 3.9). The difference was largest during April 1994, which was also the period with the highest concentration of suspended solids $(0.13 \mathrm{~g} / \mathrm{L})$. Mean growth in the filtered effluent was not significantly different from nonfiltered effluent (Table 3.9). 
Table 3.7. Ranking of intermittent outfalls based upon frequency of chronic toxicity unit (TUc) $>1.0$ and mean TUc for 26 tests

\begin{tabular}{cccccc}
\hline Outfall & $\begin{array}{c}\text { Frequency (\%) } \\
\text { of TUc }>1.0\end{array}$ & $\begin{array}{c}\text { Rank }^{a} \text { of Frequency } \\
(\text { TUc }>\text { 1) }\end{array}$ & $\begin{array}{c}\text { Mean } \\
\text { TUc }\end{array}$ & $\begin{array}{c}\text { Rank of } \\
\text { Mean TUc }\end{array}$ & $\begin{array}{c}\text { Sum of } \\
\text { Ranks }\end{array}$ \\
\hline 013 & 31 & 5 & 3.9 & 1 & 6 \\
015 & 23 & 3 & 7.3 & 4 & 7 \\
016 & 17 & 1 & 7.1 & 3 & 4 \\
017 & 23 & 3 & 17.4 & 5 & 8 \\
018 & 23 & 3 & 7.0 & 2 & 5 \\
\hline
\end{tabular}

${ }^{\circ}$ Highest rank $=5$; lowest rank $=1$.

Table 3.8. Summary of water chemistry analyses of full-strength samples from intermittently flowing effluents from 1991-94

\begin{tabular}{|c|c|c|c|c|}
\hline Sample & $\begin{array}{c}\mathrm{pH} \\
\text { (Standard units) }\end{array}$ & $\begin{array}{c}\text { Alkalinity } \\
\left(\mathrm{mg} / \mathrm{L} \text { as } \mathrm{CaCO}_{3}\right)\end{array}$ & $\begin{array}{c}\text { Hardness } \\
\left(\mathrm{mg} / \mathrm{L} \text { as } \mathrm{CaCO}_{3}\right)\end{array}$ & $\begin{array}{l}\text { Conductivity } \\
(\mu \mathrm{S} / \mathrm{cm})\end{array}$ \\
\hline \multicolumn{5}{|l|}{ Outfall 013} \\
\hline Mean $( \pm S D)$ & $7.49(0.27)$ & $57.1(14.7)$ & $153.4(99.0)$ & 307.1 (192.9) \\
\hline Range & $6.91-7.96$ & $28-81$ & $42-360$ & $84-704$ \\
\hline$n$ & 14 & 14 & 14 & 14 \\
\hline \multicolumn{5}{|l|}{ Outfall 015} \\
\hline Mean $( \pm S D)$ & $7.76(0.26)$ & $86.2(25.5)$ & $146.0(39.6)$ & $317.0(118.8)$ \\
\hline Range & $7.20-8.18$ & $42-119$ & $76-244$ & $153-656$ \\
\hline$n$ & 13 & 13 & 13 & 13 \\
\hline \multicolumn{5}{|l|}{ Outfall 016} \\
\hline Mean $( \pm S D)$ & $7.81(0.24)$ & $97.6(20.6)$ & $175.4(90.6)$ & $379.5(222.0)$ \\
\hline Range & $7.35-8.20$ & $60-122$ & $72-446$ & $138-856$ \\
\hline$n$ & 13 & 13 & 13 & 13 \\
\hline \multicolumn{5}{|l|}{ Outfall 017} \\
\hline Mean $( \pm S D)$ & $7.95(0.16)$ & $120.1(22.9)$ & $174.7(36.3)$ & $353.4(80.8)$ \\
\hline Range & $7.75-8.27$ & $70-146$ & $92-230$ & $175-466$ \\
\hline$n$ & 14 & 14 & 14 & 14 \\
\hline \multicolumn{5}{|l|}{ Outfall 018} \\
\hline Mean $( \pm S D)$ & $7.72(0.26)$ & $74.6(65.1)$ & $110.1(40.9)$ & $200.1(90.2)$ \\
\hline Range & $7.23-8.13$ & $36-295$ & $52-162$ & $55-342$ \\
\hline$n$ & 14 & 14 & 14 & 14 \\
\hline
\end{tabular}


Table 3.9. Comparison of fathead minnow survival and growth in filtered $(1.2 \mu \mathrm{m})$ and nonfiltered water from outfall 018

\begin{tabular}{lcccc}
\hline Test Date & Treatment $^{\circ}$ & $\begin{array}{c}\text { Mean Survival } \\
(\%)\end{array}$ & $\begin{array}{c}\text { Mean Growth } \\
( \pm \text { SD) }(\mathrm{mg})\end{array}$ & $\begin{array}{c}\text { Total } \\
\text { Suspended } \\
\text { Solids }(\mathrm{g} / \mathrm{L})\end{array}$ \\
\hline May 1993 & $\mathrm{N}$ & 70.0 & $0.35(0.07)$ & 0.04 \\
& $\mathrm{~F}$ & 92.5 & $0.39(0.07)$ & \\
February 1994 & $\mathrm{N}$ & 95.0 & $0.45(0.04)$ & 0.05 \\
& F & 100 & $0.43(0.06)$ & \\
April 1994 & N & 42.5 & $0.41(0.24)$ & 0.13 \\
& F & 95.0 & $0.41(0.03)$ & \\
September 1994 & N & 85.0 & $0.40(0.08)$ & Not measured \\
& F & 92.5 & $0.43(0.07)$ & \\
\hline
\end{tabular}

$\mathrm{N}=$ none; $\mathrm{F}=$ filtered.

\subsubsection{Summary}

\subsubsection{Continuously flowing outfalls}

During 1994, no toxicity was evident in effluent samples from 001. Effluent from Outfall 008 had TUcs > 1.0 two times; however, follow-up tests demonstrated that the toxicity was transient. Outfalls 006 and 011 had high TUcs for fathead minnows during two consecutive tests in March; however, no toxicity was observed in subsequent testing during April, August, and October 1994. Outfall 006 had a TUc $>1$ for Ceriodaphnia during August; however a retest of the effluent did not demonstrate toxicity. Outfall 009 had the greatest number of exceedances during 1994. The effluent exceeded a TUc $>1$ four times with an average TUc of 4.32. Identification procedures conducted during December 1994 showed that minnow mortality in the effluent may be due to suspended solids or to a particle-bound contaminant. However, the results were inconclusive since other treatments ( $\mathrm{pH}$ adjustment to 8 ) also improved minnow survival.

\subsubsection{Intermittently flowing outfalls}

After ranking the outfalls, Outfall 013 was identified as having the greatest frequency of toxicity in comparison to the other outfalls. Outfall 017 ranked highest for mean TUc 
and for the overall sum of ranks. For 1991-93 data, Outfall 018 had the highest overall rank sum; however, when 1994 data was included, the outfall had a low overall rank sum (5) in comparison to the other outfalls. Survival of minnows in filtered effluent from Outfall 018 was higher than in non-filtered effluent but growth was not different. These results indicate that suspended solids may directly (e.g. deposition on gill surfaces) or indirectly (e.g., contaminant desorption from particles) reduce the survival of the minnows. Additional tests will be conducted in 1995 to further evaluate minnow survival and growth in filtered effluent from Outfall 018 and other outfalls.

\section{AMBIENT TOXICITY}

\subsubsection{Introduction}

Ambient toxicity monitoring at PGDP employed the Ceriodaphnia test described in Sect. 3.1. Toxicity monitoring was incorporated into BMP in order to (1) evaluate area source contributions to stream toxicity, (2) characterize patterns of toxicity in Big Bayou and Little Bayou creeks, (3) document changes in water quality attributable to changes in operations at PGDP, and (4) provide data to evaluate whether the effluent limitations established for PGDP protect and maintain the use of Big Bayou and Little Bayou creeks for growth and propagation of fish and other aquatic life. The sites chosen for testing on Big Bayou Creek were changed during the past year. Because there was no evidence of consistent chronic toxicity to fathead minnows or Ceriodaphnia at ambient sites, testing with Ceriodaphnia was discontinued at all sites and testing with fathead minnows was discontinued at BBK 10.0. Unless otherwise noted, the discussion below is limited to 1994 data.

\subsubsection{Materials and Methods}

Ambient toxicity was evaluated using the fathead minnow test and the Ceriodaphnia test (prior to 1994) as described in Sect. 3.1 for continuously flowing outfalls with the following exceptions: (1) no dilutions were tested, and (2) each test used seven consecutive, daily grab samples of stream water. Tests which included evaluating a water sample that had been exposed to ultraviolet light were discontinued in 1994. Two ambient sites on Big Bayou Creek (BBK 12.5 and BBK 9.1; Fig. 2.2), one site on Little Bayou Creek (LUK 7.2, Fig. 2.2), and one site on Massac Creek (MAK 13.8, Fig. 2.1) were 
evaluated for toxicity. Prior to 1994, an additional site on Big Bayou Creek (BBK 10.0) was also evaluated for toxicity (Kszos et al. 1994). Water chemistry analyses continued on samples from BBK 10.0. These sites are similar to those selected for the ecological monitoring component of BMP (Sect. 5). Toxicity tests with minnows were conducted on a quarterly basis in 1994. See Kszos et al. (1994) for discussion of previous toxicity test results. Water sampling and water chemistry analyses were conducted as described for continuously flowing outfalls in Sect. 3.1.2.

Significant differences in Ceriodaphnia reproduction and fathead minnow survival and growth among sites for all tests were evaluated using the General Linear Models (GLM) procedure in SAS (SAS 1985a, 1985b). Because significant differences existed from test to test in Ceriodaphnia reproduction and fathead minnow survival and growth, the GLM procedure was inappropriate for separating differences among all sites. Thus, separate GLM analyses (followed by a separation of means using Tukey's Studentized Range Test) were conducted for each test period. Unless otherwise noted, statements of significance (probability) are based on $p=0.05$.

\subsubsection{Results}

Mean survival and growth of fathead minnows for each site and test in 1994 are provided in Table 3.10. During 1994, survival at the reference sites (BBK 12.5 and MAK 13.8) ranged from $67.5 \%$ to $92.5 \%$ and $45 \%$ to $75 \%$. Survival in water from sites below discharges from PGDP (BBK 9.1 and LUK 7.2) was not significantly different from the reference sites. In fact, during the August 1994 test period, survival at MAK 13.8 (57.5\%) was significantly lower than survival at BBK 12.5 (67.5\%) and BBK 9.1 (85.0\%).

Minnow growth was quite variable from tests to test; growth in the reference sites (BBK 12.5 and MAK 13.8) ranged from 0.31 to $0.63 \mathrm{mg} / \mathrm{larvae}$ and 0.39 to $0.68 \mathrm{mg} / \mathrm{larvae}$. Minnow growth in water from BBK 9.1 ranged from 0.38 to $0.80 \mathrm{mg} /$ larvae and in water from LUK 7.2 ranged from 0.33 to $0.72 \mathrm{mg} /$ larvae. The analysis of minnow growth in water from Big Bayou and Little Bayou creek sites showed that growth in sites downstream of PGDP discharges (BBK 9.1 and LUK 7.2) was never lower than the reference sites (BBK 12.5 and MAK 13.8).

A summary of water quality measurements ( $\mathrm{pH}$, conductivity, alkalinity, hardness, and temperature) for each site and test in 1994 is provided in Appendix B.7. The change in 
Table 3.10. Summary of fathead minnow survival and growth measured for toxicity tests of ambient sites in 1994

\begin{tabular}{llcccc}
\hline Test Date & \multicolumn{1}{c}{ Site } & $\begin{array}{c}\text { Mean } \\
\text { survival } \\
(\%)\end{array}$ & $\begin{array}{c}\text { Survival } \\
\text { SD } \\
(\%)\end{array}$ & $\begin{array}{c}\text { Mean } \\
\text { growth } \\
(\mathrm{mg})\end{array}$ & $\begin{array}{c}\text { Growth } \\
\text { SD } \\
(\mathrm{mg})\end{array}$ \\
\hline Mar. 1994 & BBK 12.5 & 77.5 & 9.6 & 0.45 & 0.07 \\
& BBK 9.1 & 67.5 & 33.0 & 0.59 & 0.24 \\
May 1994 & LUK 7.2 & 77.5 & 22.2 & 0.49 & 0.10 \\
& MAK 13.8 & 75.0 & 19.2 & 0.47 & 0.11 \\
& BBK 12.5 & 82.5 & 9.6 & 0.52 & 0.07 \\
Aug. 1994 & BBK 9.1 & 90.0 & 14.1 & 0.51 & 0.02 \\
& LUK 7.2 & 82.5 & 17.1 & 0.48 & 0.06 \\
& MAK 13.8 & 45.0 & 17.3 & 0.46 & 0.04 \\
& BBK 12.5 & 67.5 & 26.3 & 0.31 & 0.03 \\
& BBK 9.1 & 85.0 & 17.3 & 0.38 & 0.04 \\
& LUK 7.2 & 62.5 & 17.1 & 0.33 & 0.04 \\
& MAK 13.8 & 57.5 & 9.63 & 0.39 & 0.03 \\
& BBK 12.5 & 92.5 & 9.6 & 0.63 & 0.07 \\
& BBK 9.1 & 65.0 & 23.8 & 0.80 & 0.11 \\
& LUK 7.2 & 82.5 & 15.0 & 0.72 & 0.04 \\
& MAK 13.8 & 62.5 & 22.2 & 0.68 & 0.11 \\
\hline
\end{tabular}

${ }^{a} \mathrm{BBK}=$ Big Bayou Creek kilometer; LUK = Little Bayou Creek kilometer; MAK = Massac Creek kilometer; $\mathrm{SD}=$ Standard deviation.

water chemistry (hardness, conductivity, $\mathrm{pH}$, and alkalinity) with distance downstream in Big Bayou Creek for tests conducted in 1992-94 is illustrated in Figs. 3.1-3.4. A summary of water chemistry for MAK 13.8 and LUK 7.2 for each year is also provided in Figs. 3.1-3.4. Figure 3.1 shows that each year (1992-94), mean conductivity has increased twofold from BBK 10.0 downstream to BBK 9.1 and there is little change in conductivity from BBK 12.5 downstream to BBK 10.0. Mean conductivity at the reference site (MAK 13.8) has been approximately $135 \mu \mathrm{S} / \mathrm{cm}$ each year (Fig. 3.1). The statistical comparison of mean conductivity in 1994 (Table 3.11), showed that BBK 9.1 was 
ORNL-DWG $96-4966$
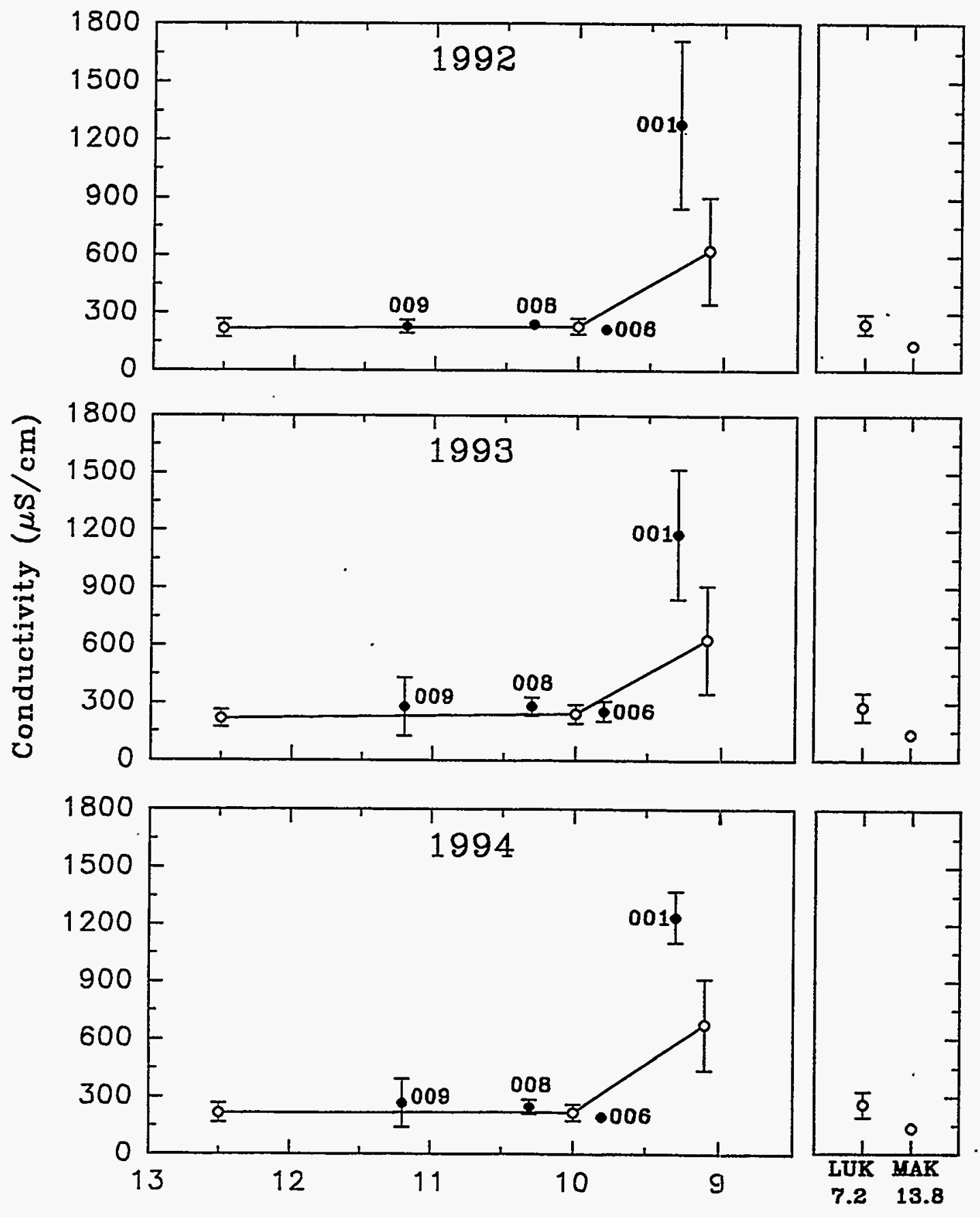

Big Bayou Creek kilometer

Fig. 3.1. Summary of conductivity (mean \pm SD) at Big Bayou Creek, Little Bayou Creek ( $\mathrm{LUK}$ ), and Massac Creek (MAK) sites. Mean ( $\pm \mathrm{SD}$ ) value of continuously flowing outfalls is also shown. 
ORNL-DWG 96-4967

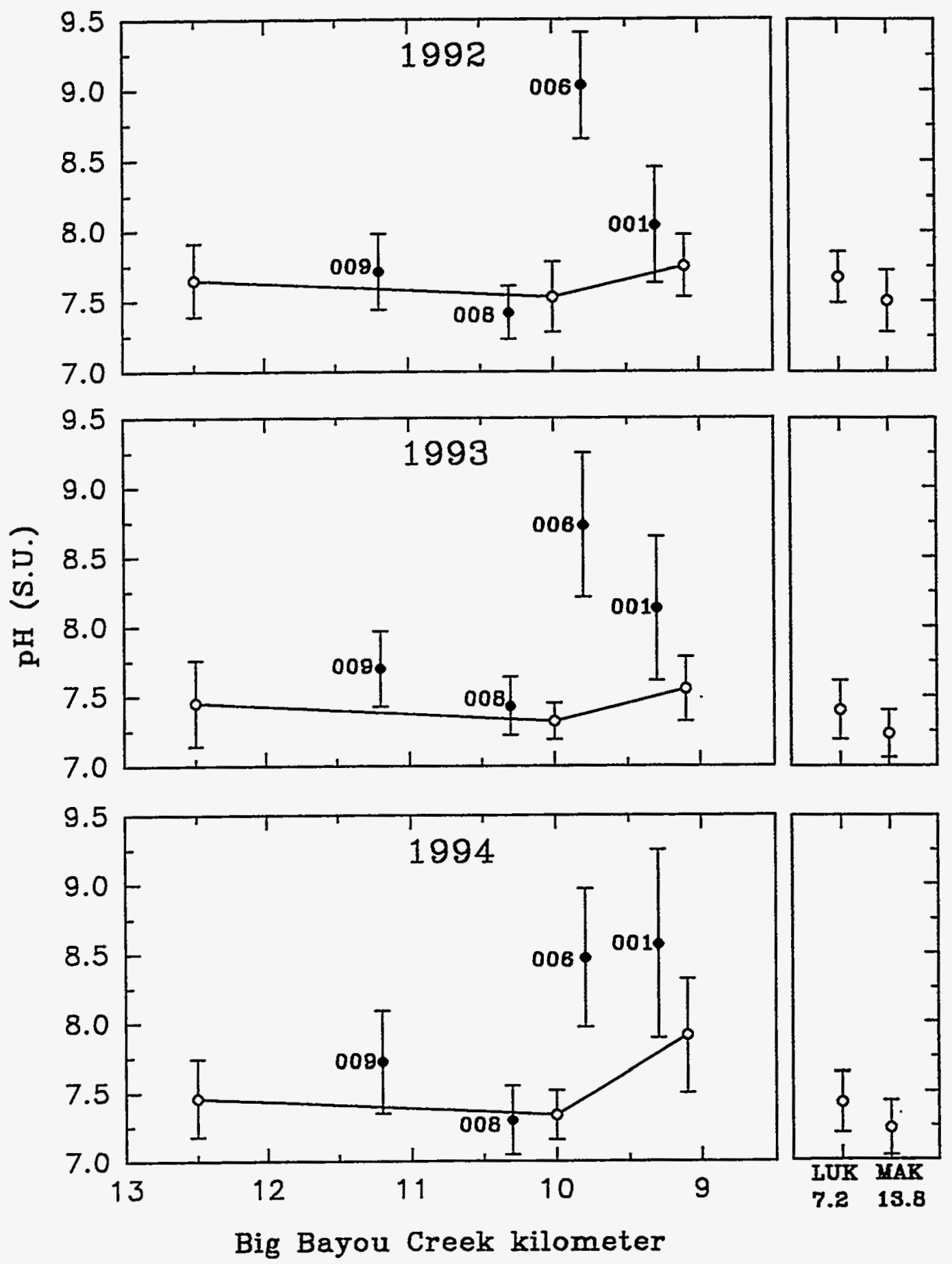

Fig. 3.2. Summary of $\mathrm{pH}$ (mean $\pm \mathrm{SD}$ ) at Big Bayou Creek, Little Bayou Creek (LUK), and Massac Creek (MAK) sites. Mean ( \pm SD) value of continuously flowing outfalls is also shown. 

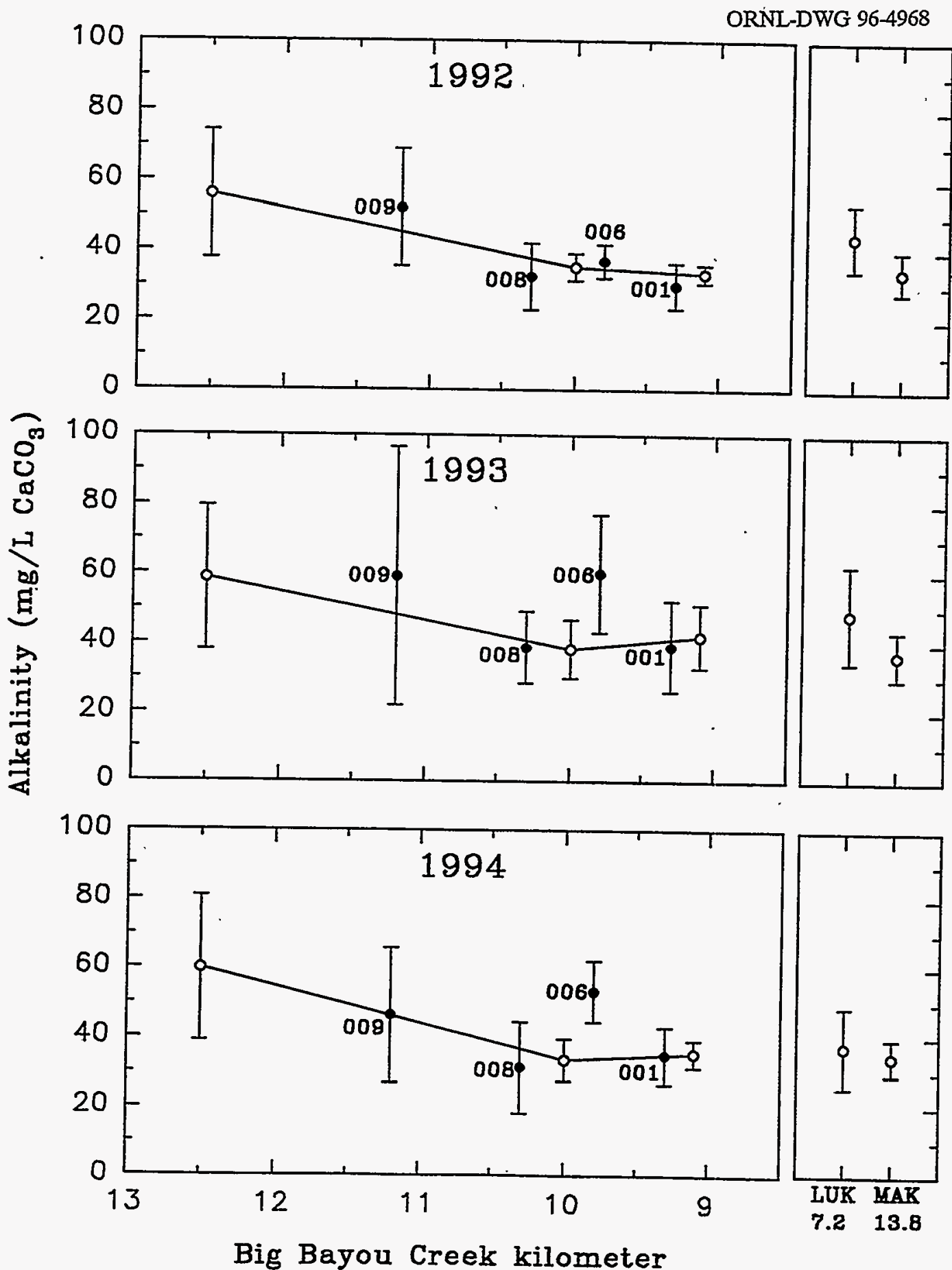

Fig. 3.3. Summary of alkalinity (mean \pm SD) at Big Bayou Creek, Little Bayou Creek (LUK), and Massac Creek (MAK) sites. Mean ( \pm SD) value of continuously flowing outfalls is also shown. 


\section{ORNL-DWG 96-4969}
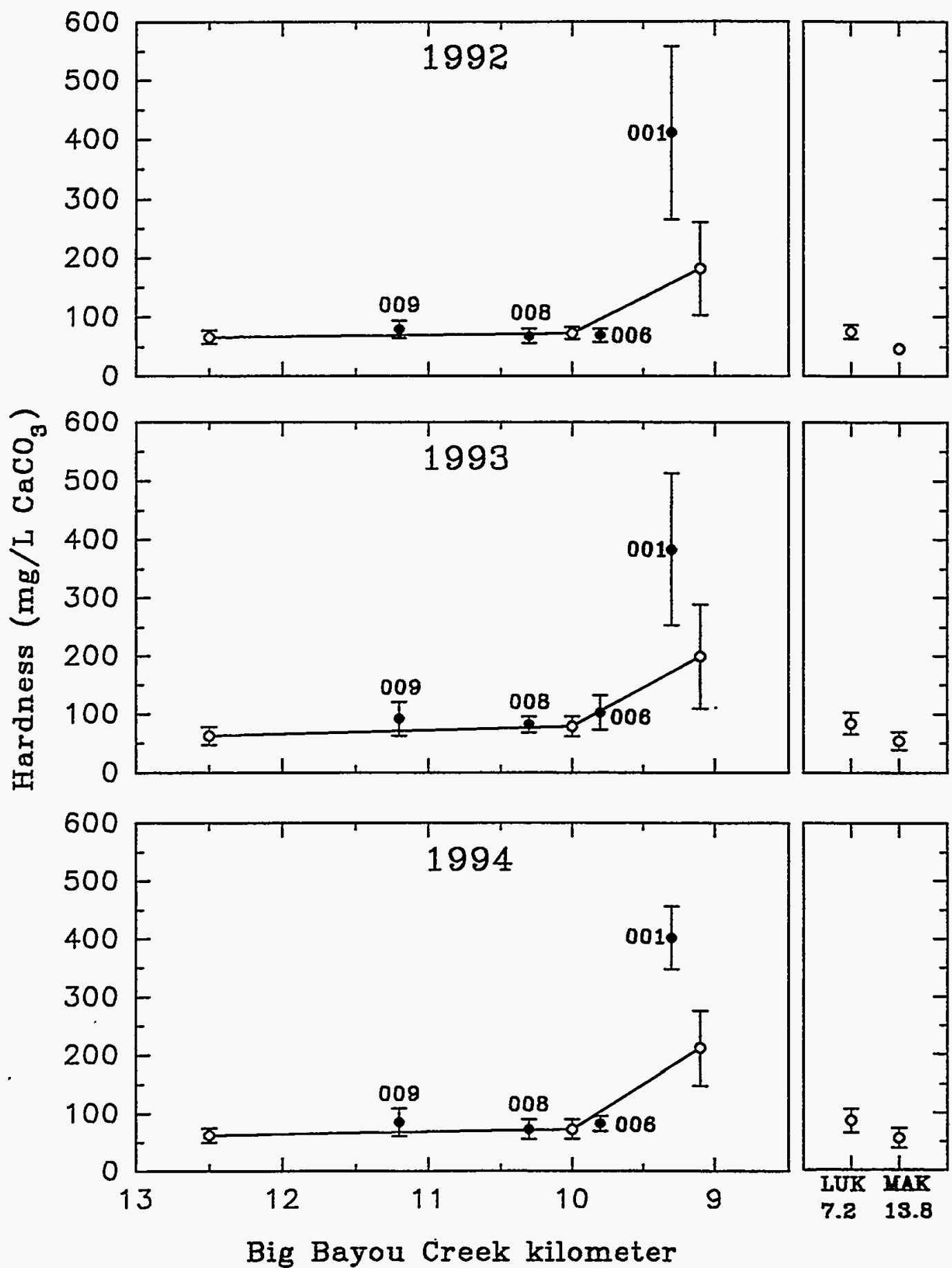

Figure 3.4. Summary of hardness (mean \pm SD) at Big Bayou Creek, Little Bayou Creek (LUK), and Massac Creek (MAK) sites. Mean ( $\left.{ }_{ \pm} S D\right)$ value of continuously flowing outfalls is also shown. 
Table 3.11. Mean conductivity ( $\mu \mathrm{S} / \mathrm{cm} ; n=7$ ) measured at each site and comparison of means (Tukey's Studentized Range test)

\begin{tabular}{|c|c|c|c|c|c|}
\hline \multirow[b]{2}{*}{ Test } & \multicolumn{5}{|c|}{ Site $^{a}$} \\
\hline & BBK 12.5 & BBK 10.0 & BBK 9.1 & LUK 7.2 & MAK 13.8 \\
\hline \multicolumn{6}{|c|}{ March 10-16, 1994} \\
\hline Mean & 135 & 158 & 299 & 175 & 137 \\
\hline Comparison & B & B & A & B & $\mathrm{B}$ \\
\hline \multicolumn{6}{|c|}{ May 26-June 1, 1994} \\
\hline Mean & 253 & 262 & 796 & 327 & 136 \\
\hline Comparison & B & B & A & $B$ & $\mathrm{C}$ \\
\hline \multicolumn{6}{|c|}{ August 11-17, 1994} \\
\hline Mean & 240 & 209 & 848 & 246 & 129 \\
\hline Comparison & B & B & A & B & $\mathrm{C}$ \\
\hline \multicolumn{6}{|c|}{ October 27-November 2, 1994} \\
\hline Mean & 240 & 244 & 766 & 278 & 140 \\
\hline Comparison & $\mathrm{C}$ & C. & A & B & $\mathrm{D}$ \\
\hline
\end{tabular}

Note: Sites with the same letter are not significantly different. kilometer.

${ }^{a} \mathrm{BBK}=\mathrm{Big}$ Bayou Creek kilometer, LUK = Little Bayou Creek kilometer, MAK = Massac Creek

consistently distinguishable from all other sites. In August 1994, conductivity was fourfold higher at BBK $12.5(209 \mu \mathrm{S} / \mathrm{cm})$ than at BBK $10.0(848 \mu \mathrm{S} / \mathrm{cm})$.

The mean pH at BBK 9.1 was also higher than at BBK 10.0 for each year (Fig. 3.2). For three of the in 1994, mean $\mathrm{pH}$ at BBK 9.1 was significantly higher (range $=8.07-8.13$ S.U.) than $\mathrm{pH}$ at all other sites (range $=7.13-7.71$ S.U.). In most of the 1994 tests, $\mathrm{pH}$ at BBK 10.0, BBK 12.5, and LUK 7.2 was not significantly different from $\mathrm{pH}$ at the reference site (MAK 13.8; Table 3.12).

Unlike conductivity and $\mathrm{pH}$ which increased with distance downstream, alkalinity decreased with distance downstream each year (Fig. 3.3). For three of the tests conducted in 1994, alkalinity at BBK 10.0 was significantly lower (range $\doteq 27-39 \mathrm{mg} / \mathrm{L}$ ) than alkalinity at BBK 12.5 (range = 69-72 mg/L; Table 3.13). During the March 1994 test, there was little difference in alkalinity among sites (range $=25-35 \mathrm{mg} / \mathrm{L}$ ). Alkalinity at LUK 7.2 was similar to that at BBK 9.1 during two tests (Table 3.13). For three tests, 
Table 3.12. Mean pH (S. U.; $n=7$ ) measured at each site and comparison of means (Tukey's Studentized Range test)

\begin{tabular}{lccccc}
\hline & \multicolumn{5}{c}{ Site $^{a}$} \\
\cline { 2 - 6 } Test & BBK 12.5 & BBK 10.0 & BBK 9.1 & LUK 7.2 & MAK 13.8 \\
\hline $\begin{array}{l}\text { March 10-16, 1994 } \\
\text { Mean }\end{array}$ & 7.09 & 7.21 & 7.34 & 7.19 & 7.16 \\
Comparison & B & A,B & A & A,B & A,B \\
May 26-June 1, 1994 & & & & & \\
Mean & 7.48 & 7.31 & 8.11 & 7.53 & 7.13 \\
Comparison & B & B,C & A & B & C \\
August 11-17, 1994 & & & & & \\
Mean & 7.55 & 7.26 & 8.13 & 7.33 & 7.18 \\
Comparison & B & C & A & C & C \\
October 27-November 2,1994 & & & & & \\
Mean & 7.71 & 7.59 & 8.07 & 7.61 & 7.44 \\
Comparison & B & B & A & B & B \\
\hline
\end{tabular}

Note: Sites with the same letter are not significantly different.

${ }^{a} \mathrm{BBK}=$ Big Bayou Creek kilometer, LUK = Little Bayou Creek kilometer, MAK = Massac Creek kilometer.

mean alkalinity at the reference site (MAK 13.8) was not significantly different from mean alkalinity at BBK 9.1 (Table 3.13).

The trends in hardness were similar to those for conductivity, in that there was little difference in hardness from BBK 12.5 downstream to BBK 10.0 and hardness increased three to four fold from BBK 10.0 downstream to BBK 9.1 (Fig. 3.4). In August, 1994, for example, mean hardness was $67 \mathrm{mg} / \mathrm{L}$ at BBK 12.5, $66 \mathrm{mg} / \mathrm{L}$ at BBK 10.0, and $270 \mathrm{mg} / \mathrm{L}$ at BBK 9.1. For all tests conducted in 1994, mean hardness at BBK 9.1 was significantly higher than hardness at all other sites and ranged from 118-270 mg/L (Table 3.14). Hardness at LUK 7.2 was similar to that at BBK 10.0 and BBK 9.1 (Table 3.14). In three tests, mean hardness at the reference site (53-66 mg/L) was not different than at BBK 10.0 (66-75 mg/L; Table 3.14). 
Table 3.13. Mean alkalinity ( $\mathrm{mg} / \mathrm{L}$ as $\mathrm{CaCO}_{3} ; n=7$ ) measured at each site and comparison of means (Tukey's Studentized Range test)

\begin{tabular}{lccccc}
\hline & \multicolumn{5}{c}{ Site $^{a}$} \\
\cline { 2 - 6 } Test & BBK 12.5 & BBK 10.0 & BBK 9.I & LUK 7.2 & MAK 13.8 \\
\hline March 10-16, 1994 & 25 & 31 & 32 & 35 & 27 \\
$\quad$ Mean & B & A,B & A,B & A & A,B \\
Comparison & & & & & \\
May 26-June 1, 1994 & 69 & 39 & 40 & 54 & 37 \\
Mean & A & C & C & B & C \\
Comparison & & & & & \\
August 11-17, 1994 & 74 & 27 & 33 & 31 & 38 \\
Mean & A & D & C & C & B \\
Comparison & & & & & \\
October 27-November 2,1994 & 72 & 36 & 36 & 29 & 36 \\
Mean & A & B & B & C & B \\
Comparison & &
\end{tabular}

Note: Sites with the same letter are not significantly different. kilometer.

${ }^{a}$ BBK $=$ Big Bayou Creek kilometer, LUK = Little Bayou Creek kilometer, MAK = Massac Creek

During the 1994 tests, mean temperature at the reference site (MAK 13.8) was never significantly different from mean temperature at BBK 12.5 (Table 3.15). During the March and August tests, temperature was not different among any sites (Table 3.15). In March, mean temperatures ranged from 4.9 to $6.5^{\circ} \mathrm{C}$; in August, mean temperatures ranged from 21.9 to $25.8^{\circ} \mathrm{C}$. During the May and October tests, mean temperature at $\mathrm{BBK} 9.1\left(21.5^{\circ} \mathrm{C}\right.$ and $\left.14.3^{\circ} \mathrm{C}\right)$ was significantly higher than temperature at BBK 12.5 $\left(17.7^{\circ} \mathrm{C}\right.$ and $\left.9.9^{\circ} \mathrm{C}\right)$. Mean temperature at LUK 7.2 was higher than the reference site during the October test (Table 3.15).

\subsubsection{Discussion}

During 1994, there was no evidence of toxicity to fathead minnows in laboratory tests of water from any site in Big Bayou Creek or Little Bayou Creek. This is based on a comparison of survival in the water from the site with survival in water from the reference 
Table 3.14. Mean hardness (mg/L as $\mathrm{CaCO}_{3} ; n=7$ ) measured at each site and comparison of means (Tukey's Studentized Range test)

\begin{tabular}{lccccc}
\hline & \multicolumn{5}{c}{ Site $^{a}$} \\
\cline { 2 - 6 } Test & BBK 12.5 & BBK 10.0 & BBK 9.1 & LUK 7.2 & MAK 13.8 \\
\hline $\begin{array}{l}\text { March 10-16, 1994 } \\
\text { Mean }\end{array}$ & 59 & 75 & 115 & 87 & 66 \\
Comparison & B & B & A & A,B & B \\
May 26-June 1, 1994 & B & & & & \\
Mean & 63 & 79 & 240 & 92 & 46 \\
Comparison & C,D & B,C & A & B & D \\
August 11-17, 1994 & & & & & \\
Mean & 67 & 66 & 270 & 79 & 53 \\
Comparison & B & B & A & B & B \\
October 27-November 2,1994 & & & & & \\
Mean & 62 & 73 & 221 & 85 & 57 \\
Comparison & C & B,C & A & B & C \\
\hline
\end{tabular}

Note: Sites with the same letter are not significantly different.

${ }^{a}$ BBK $=$ Big Bayou Creek kilometer, LUK = Little Bayou Creek kilometer, MAK = Massac Creek kilometer.

site (MAK 13.8). Similar results were found during 1991-93: fathead minnow survival and growth in the water from the sites near PGDP were typically equal to or greater than survival or growth in wæler from the reference site (Kszos 1994).

The influence of discharges from PGDP on water chemistry of Big Bayou and Little Bayou creeks is shown by the increase or decrease in conductivity, hardness, alkalinity, $\mathrm{pH}$ and temperature at sites downstream of those discharges. Conductivity and hardness were significantly greater at BBK 9.1 than at BBK 10.0; effluent from Outfalls 001 and 006 enter Big Bayou Creek between these two sites (Fig. 2.2). Chemistry data collected during toxicity tests of these two effluents and ambient sites shows that Outfall 001 has much higher conductivity and hardness values than 006 (Table 3.5) or BBK 10.0 (Tables 3.11 and 3.14). Thus, effluent from Outfall 001 has the most influence on the increased conductivity and hardness at BBK 9.1. The $\mathrm{pH}$ at BBK 9.1 is often distinguishable from $\mathrm{pH}$ at $\mathrm{BBK}$ 10.0. In this case, $\mathrm{pH}$ measured during toxicity tests (Table 3.5.) show that 
Table 3.15. Mean temperature $\left({ }^{\circ} \mathrm{C} ; n=7\right)$ measured at each site and comparison of means (Tukey's Studentized Range test)

\begin{tabular}{|c|c|c|c|c|c|}
\hline \multirow[b]{2}{*}{ Test } & \multicolumn{5}{|c|}{ Site $^{a}$} \\
\hline & BBK 12.5 & BBK 10.0 & BBK 9.1 & LUK 7.2 & MAK 13.8 \\
\hline \multicolumn{6}{|c|}{ March 10-16, 1994} \\
\hline Mean & 4.9 & 5.5 & 6.4 & 6.5 & 5.9 \\
\hline Comparison & A & $A$ & A & A & A \\
\hline \multicolumn{6}{|c|}{ May 26-June 1, 1994} \\
\hline Miean & 17.7 & 20.5 & 21.5 & 20.7 & 18.7 \\
\hline Comparison & B & $A, B$ & $\mathrm{~A}$ & $A, B$ & $A, B$ \\
\hline \multicolumn{6}{|c|}{ August 11-17, 1994} \\
\hline Mean & 21.9 & 25.6 & 25.8 & 24.0 & 24.8 \\
\hline Comparison & A & A & A & A & A \\
\hline \multicolumn{6}{|c|}{ October 27-November 2, 1994} \\
\hline Mean & 9.9 & 14.8 & 14.3 & 13.2 & 10.1 \\
\hline Comparison & B & A & A & A & B \\
\hline
\end{tabular}

Note: Sites with the same letter are not significantly different. kilometer.

${ }^{\circ} \mathrm{BBK}=\mathrm{Big}$ Bayou Creek kilometer, LUK = Little Bayou Creek kilometer, MAK = Massac Creek

Outfall 006 has the highest $\mathrm{pH}$ and therefore had greater influence on instream $\mathrm{pH}$. Alkalinity was significantly higher at BBK 10.0 than at BBK 12.5 , but was not different from alkalinity at BBK 9.1. Effluent from Outfalls 008 and 009 enter Big Bayou Creek between these two sites (Fig. 2.2). Both outfalls have alkalinity approximately equal to BBK 10.0 and less than BBK 12.5. In 1994, temperature differences among sites were found during the spring and fall.

\subsection{SUMMARY}

During 1994, there was no evidence of toxicity in effluent samples from Outfall 001. Effluent from Outfalls 008, 006, and 011 exceeded the permit limit for one or two tests, but no toxicity was observed in tests conducted after the exceedances. Effluent from Outfall 009 exceeded the permit limit four times in 1994. Toxicity identification procedures identified that minnow mortality may be due to suspended solids or to a 
particle-bound contaminant but results were not conclusive. For all tests conducted since 1991, Outfall 001 had the highest mean conductivity and hardness. Outfall 006 had the highest mean $\mathrm{pH}$ and outfall 008 had the lowest alkalinity of any of the continuously flowing outfalls. Effluent samples from the intermittent outfalls were toxic to Ceriodaphnia during only one test (Outfall 018 in September, 1994); however the TUc for minnows was frequently $>1.0$ for several of the intermittent outfalls. Ranking the intermittently flowing outfalls in terms of mean TUc and frequency of TUc $>1.0$ identified that Outfall 017 ranked the highest for mean TUc and for the overall sum of ranks.

During 1994, there was no evidence of chronic toxicity to fathead minnows for any of the ambient sites. This is consistent with findings from 1991-93 (Kszos et al. 1994). Thus, toxicity to minnows observed in effluent from the continuously flowing outfalls is not observed in instream samples. The influence of effluent from Outfall 001 on the water chemistry of Big Bayou Creek was evident in the increase in $\mathrm{pH}$, conductivity and hardness between BBK 10.0 and BBK 9.1. In addition, alkalinity is lower at BBK 10.0 than at BBK 12.5.

Because of the high frequency of TUc $>1.0$ at Outfall 009 during 1994, an additional ambient site will be included for fathead minnow toxicity tests during 1995 . The site will be located at BBK 10.8 which is below Outfall 009 and above Outfall 008. The site at BBK 10.0 which was eliminated during 1994 was located below both of these outfalls. Water chemistry will continue to be measured at BBK 10.0. 



\title{
4. BIOACCUMULATION
}

\author{
G. R. Southworth and M. J. Peterson
}

\subsection{INTRODUCTION}

Bioaccumulation monitoring conducted to date as part of the Biological Monitoring Plan at PGDP identified PCB contamination in fish in Big Bayou Creek and Little Bayou Creek as major concerns (Birge et al. 1990, 1992; Kszos 1993, 1994). Mercury concentrations in fish from Big Bayou Creek were found to be higher in fish collected downstream from PGDP. Jischarges than in fish from an upstream site (Birge et al. 1990, 1992; Kszos 1993, 1994), but the difference was not large and mercury concentrations in fish were well below both the FDA limit (FDA 1984a) and the EPA risk assessment guidelines (EPA 1990). Concentrations of various metals in fish from Big Bayou Creek and Little Bayou Creek were well below levels of concern for human consumption.

The objectives of the 1993-94 bioaccumulation monitoring were (1) to continue PCB tracking studies in fish from Big Bayou Creek and Little Bayou Creek, (2) to track elevated mercury concentrations in fish in Big Bayou Creek, and (3) conduct screening analyses to detect other contaminants that may be of concern to consumers of fish from these streams.

\subsection{STUDY SITES}

Longear sunfish (Lepomis megalotis) were collected for PCB analysis at BBK 12.5 (the upstream reference site on Big Bayou Creek), BBK 10.0, BBK 9.1, and BBK 2.8 on Big Bayou Creek below PGDP, and LUK 9.0 and LUK 4.3 on Little Bayou Creek (Fig. 2.2). Longear sunfish were also taken for mercury analysis at BBK 12.5, BBK 10.0, BBK 9.1, BBK 2.8, MAK 13.8 (local reference site, Fig. 2.1). Hinds Creek in Anderson County, Tennessee, served as a source of uncontaminated reference fish. This stream has been used as a reference site for monitoring conducted at DOE facilities in Oak Ridge since 1985, and concentrations of various metals and organic contaminants in fish from this site are well characterized (Ashwood 1994). Longear sunfish were also sampled from LUK 7.2 and BBK 9.1 for contaminant screening analyses. Spotted bass, Micropterus 
punctulatus, were collected, when present, from BBK 9.1 and LUK 4.3. The length of stream sampled at each site varied with the degree of difficulty in obtaining fish but was held to less than or equal to $1000 \mathrm{~m}$. The site at BBK 10.0 was constrained to the reach between PGDP outfalls 008 and 006 (Fig. 2.2). The BBK 9.1 site encompassed the reach from BBK 9.1 up to outfall 001 (Fig. 2.2). Bass require large pools and deeper water. Because such habitat is scarce at sites in Big Bayou Creek close to PGDP, a 1000-m reach below BBK 9.1 that contains such habitat was used for collection.

In Little Bayou Creek, the very sharp decrease in PCB contamination in fish between LUK 9.0 and LUK 7.2 (LB2 and LB3 in Birge et al. 1990, 1992) required that collections be confined to a relatively short reach near LUK 9.0 at the expense of expanding the reach downstream in order to obtain larger fish of a single species. This site was restricted to approximately $250 \mathrm{~m}$ from outfall 011 downstream to LUK 9.0. The downstream site included $1000 \mathrm{~m}$ centered at LUK 4.3.

\subsection{MATERTALS AND METHODS}

Concentrations of contaminants in sunfish provide an effective monitor of temporal and spatial changes in contamination within stream fishes but do not provide a direct estimate of the maximum concentrations that may be present in stream biota. Larger, older, fattier fish, such as carp (Cyprinus carpio), black bass (Micropterus spp.), and catfish (Ictalurus spp.) accumulate several times higher contaminant concentrations under the same exposure conditions (Southworth 1990). Although concentrations in these larger species can be inferred from concentrations in sunfish, direct measurement provides a more reliable estimate.

Fish were collected by backpack electrofishing. Eight fish were taken from each site for PCB and mercury analysis and four fish taken for screening analyses. Collections of spotted bass (Micropterus punctulatus) for PCB and mercury monitoring were made on October 13-14, 1993, in Big Bayou Creek (BBK 9.1) and Little Bayou Creek (LUK 4.3). Eight longear sunfish were obtained at all sites for PCB monitoring at the same time. Collections of sunfish were restricted whenever possible to fish of a size large enough to be taken by sport fisherman in order to minimize effects of covariance between size and contaminant concentrations and to provide data directly applicable to assessing risks to 
people who might eat fish from these sources. High fish densities at most sites enabled the collection of eight specimens of sunfish $235 \mathrm{~g}$ at all sites except LUK 9.0 (the site closest to PGDP where habitat is extremely limited). No carp were found in either Big Bayou Creek or Little Bayou Creek; therefore eight spotted bass were taken at BBK 9.1 as a substitute. Neither species was found in Little Bayou Creek. Spotted bass are abundant in Big Bayou Creek downstream from PGDP, and the fish attain large enough size to make the creek an attractive sport fishing resource. This species is probably the most likely species in the creek to be eaten in significant numbers by anglers.

Longear sunfish were collected in Big Bayou Creek and Little Bayou Creek on May 2-3, 1994, as part of routine twice yearly monitoring of PCB concentrations in this species. Fish were also taken for mercury analysis at BBK 12.5, BBK 10.0, BBK 9.1, LUK 7.2, and MAK 13.8 (local reference site) on May 2-3, 1994. Floodwaters of the Ohio River again inundated the lower site on Big Bayou Creek (BBK2.8) in May 1994 (as they had in spring 1993), and turbid water prevented successful collection of sunfish at that site on a return visit in June 1994. Each fish was individually tagged with a unique four-digit tag wired to the lower jaw and placed on ice in a labeled ice chest. Fish were held on ice overnight and processed within 48 hours. Each fish was weighed and measured, then fileted, scaled, and rinsed in process tap water. Samples of sunfish for specific analyses were excised, wrapped in heavy duty aluminum foil, labeled, and frozen on dry ice (if processed on site) or in a standard freezer at $-15^{\circ} \mathrm{C}$. For larger fish (bass), filets were wrapped and labeled as were sunfish samples, but at a later date the frozen filets were partially thawed, cut into $2-$ to $4-\mathrm{cm}$ pieces, and homogenized by passing each sample three times through a hand meat grinder. A 25-g sample of the ground tissue was wrapped in heavy duty aluminum foil, labeled, frozen, and submitted to ORNL Analytical Chemistry Division for PCB analyses. Any remaining tissue from filets of sunfish or larger fish was wrapped in foil, labeled, and placed in the freezer for short-term archival storage.

$\mathrm{PCB} /$ pesticide determinations in fish were conducted by capillary column gas chromatography/electron capture (GC/ECD) detection using a method based on EPA procedure PPB 12/83 (EPA 1984), which involves homogenizing the sample in anhydrous sodium sulfate, extraction with methylene chloride, cleanup using column chromatography, and GC/ECD. When pesticide screening was not needed (PCBs only), analyses were conducted using a modification to this method in which sulfuric acid partitioning is used 
as a cleanup step to destroy lipids (Mid-America Group, 1989). Fish were analyzed for total mercury by cold vapor atomic absorption spectrophotometry following digestion in HNO3/H2SO4 (EPA 1991, procedure 245.6), for arsenic, cadmium, chromium, copper, lead, nickel, selenium, silver, vanadium, and uranium by inductively coupled plasma/mass spectrometry (EPA 1991, procedures 200.3, 200.8) and for zinc by inductively coupled plasma/optical emission spectrometry (EPA 1991, procedure 200.11). Radionuclides were detected by gamma scintillation spectrometry.

Quality assurance was maintained by a combination of blind duplicate analyses, analysis of biological reference standards and uncontaminated fish, and determination of recoveries of analyte spikes to uncontaminated fish. Results are summarized in Appendix C.

Statistical evaluations of mercury data were made using SAS and SPSS procedures and software (SAS 1985a,b; Norusis 1993) for ANOVA, Tukey's Multiple Comparison Test, and the calculation of mean, standard error, and standard deviation. Statistical comparisons were not used for PCB data because of the huge rumber of samples in which PCB concentrations were below the limit of detection. Tests for homogeneity of variance among various data groups were conducted using Levene's test on untransformed and $\log _{e}$ transformed variables (Sokal and Rohlf 1981). Dunnett's Test was used to compare means of various groups with reference sites (Zar 1984). The level of significance used for all statistical tests was $5 \%(p<0.05)$.

\subsection{RESULTS}

\subsubsection{PCBs}

Fall 1993. Results of PCB analyses of sunfish collected from Big Bayou Creek and Little Bayou Creek in October 1993 are presented in Tables 4.1 and C.1. Detectable concentrations of PCBs were found in sunfish at BBK 9.1 and BBK 10.0. PCB concentrations in sunfish from Little Bayou Creek (LUK 9.0) near PGDP were much higher than in Big Bayou Creek, averaging $0.75 \mu \mathrm{g} / \mathrm{g}$. The mean concentration dropped sharply with distance downstream, averaging only $0.14 \mu \mathrm{g} / \mathrm{g}$ at $\mathrm{BBK}$ 4.3. Composition of the PCB mixtures found in sunfish resembled Aroclor 1254 and 1260 at most sites, with less chlorinated constituents (Aroclor 1248) occurring in samples from LUK 9.0 and BBK 9.1. 
Table 4.1. Mean concentrations of PCBs ( $\mu \mathrm{g} / \mathrm{g}$ wet weight) in longear sunfish from streams near PGDP, October 1993

\begin{tabular}{llcccc}
\hline Site & Species $^{a}$ & Mean & SE & Range & n \\
\hline BBK 12.5 & LNGEAR & BLD & $\ldots$ & $<0.07-<0.09$ & 8 \\
BBK 10.0 & LNGEAR & 0.06 & 0.01 & $<0.06-0.12$ & 8 \\
BBK 9.1 & LNGEAR & 0.16 & 0.04 & $0.04-0.34$ & 8 \\
& SPOBASS & 0.23 & 0.04 & $0.10-0.44$ & 8 \\
BBK 2.8 & LNGEAR & BLD & $\ldots$ & $<0.06-<0.10$ & 8 \\
LUK 9.0 & LNGEAR & 0.75 & 0.17 & $0.24-1.67$ & 8 \\
LUK 4.3 & LNGEAR & 0.14 & 0.04 & $<0.08-0.29$ & 8 \\
& SPOBASS & 0.44 & 0.13 & $0.03-0.95$ & $6^{b}$ \\
HindsCr & REDBRE & BLD & $\ldots$ & $<0.09-<0.13$ & 6 \\
\hline
\end{tabular}

${ }^{a}$ LNGEAR = Longear sunfish (Lepomis megalotis); SPOBASS = Spotted bass (Micropterus punctulatus); REDBRE = Redbreast sunfish (Lepomis auritus).

${ }^{b}$ One of six fish was from LUK 7.2.

Spotted bass from Big Bayou Creek (BBK 9.1) averaged $( \pm \mathrm{SE}) 0.23 \pm 0.04 \mu \mathrm{g} / \mathrm{g}$ PCBs, about 50\% higher than longear sunfish. Concentrations in the eight fish ranged from 0.10 to $0.44 \mu \mathrm{g} / \mathrm{g}$, primarily as highly chlorinated materials similar to Aroclor 1254/1260 (Table C.1). Although it was expected that bass would contain higher concentrations than sunfish because of its trophic position, the similarity in lipid content of the two species in Big Bayou Creek may partially explain why PCB concentrations in bass were not higher. PCB concentrations in spotted bass from Little Bayou Creek were higher, averaging $0.44 \pm 0.13 \mu \mathrm{g} / \mathrm{g}$ in fish from LUK 4.3-LUK 7.2 (5 of 6 from LUK 4.3). The difference between PCB levels in bass and sunfish was closer to that expected at this site. $\mathrm{PCB}$ concentrations in individual fish ranged from 0.03 to $0.95 \mu \mathrm{g} / \mathrm{g}$, with mixture compositions spanning the range from Aroclor 1248/1260.

Spring 1994. In spring 1994, PCB contamination was again evident in longear sunfish collected from both Big Bayou Creek and Little Bayou Creek (Tables 4.2 and C.1). The 
Table 4.2. Mean concentrations of PCBs ( $\mu \mathrm{g} / \mathrm{g}$ wet weight) in longear sunfish from streams near PGDP, March 1994

\begin{tabular}{lcccc}
\hline Site & Mean & SE & Range & $\mathbf{n}$ \\
\hline BBK 12.5 & BLD & $\ldots$ & $<0.05-<0.17$ & 8 \\
BBK 10.0 & 0.14 & 0.035 & $0.04-0.33$ & 8 \\
BBK 9.1 & 0.19 & 0.054 & $0.03-0.50$ & 8 \\
LUK 9.0 & 1.41 & 0.42 & $0.08-3.42$ & 8 \\
LUK 7.2 & 0.37 & 0.12 & $<0.13-0.62$ & 4 \\
LUK 4.3 & 0.21 & 0.06 & $0.03-0.61$ & 8 \\
HindsCr & BLD & $\cdots$ & $<0.07-<0.12$ & 5 \\
\hline
\end{tabular}

${ }^{a}$ Redbreast sunfish, Lepomis auritus.

constituents of the PCB mixtures extracted from fish most closely resembled Aroclor 1254 and 1260. Lower chlorinated PCBs were found in abundance only in fish from LUK 9.0.

As was the case in all previous sampling (Birge et al. 1990, 1992; Kszos 1993), the highest mean concentration occurred in fish from the site in Little Bayou Creek immediately downstream from outfall 011 (LUK 9.0). The level of contamination in sunfish from Little Bayou Creek declined substantially farther downstream at LUK 4.3, a pattern also observed consistently in previous monitoring (Birge et al. 1990, 1992; Kszos 1993, 1994), and in fall 1993. In Big Bayou Creek, the highest mean PCB concentration was again found in fish from BBK 9.1, below outfall 001, but fish from BBK 10.0 also contained PCB contamination (Table 4.2). In spring 1993, contamination was not obvious in sunfish from LUK 4.3 (Kszos 1994), but PCBs were clearly evident in fall 1993 and spring 1994. This gives credence to the hypothesis that the absence of PCB contamination in spring 1993 may have been related to the extended period of flooding in spring 1993 at this site, during which Big Bayou Creek fish populations may have exchanged with Ohio River populations.

Mean concentrations of PCBs in sunfish varied considerably among sampling periods in previous monitoring in Big Bayou and Little Bayou creeks, with no apparent temporal 
trend or pattern (Birge et al. 1990, 1992; Kszos 1993)). Generally, when higher PCB concentrations were observed in sunfish, lower chlorinated constituents (Aroclor 1248) were present in substantial proportions, and PCBs were detected in aqueous effluent samples. Results of the October 1993 and April 1994 sampling reaffirm the variable nature of PCB contamination in stream sunfish and suggest continuing inputs to both Big and Little Bayou creeks from PGDP discharges or contaminated sediments in the immediate vicinity of those discharges. The strong downstream gradient in PCB contamination in sunfish, along with the close association between degree of contamination and proximity to outfalls demonstrated to be PCB sources in the past, suggests that the pattern of contamination is sustained by continuing low-level contamination of waters discharged to the creeks, rather than a result of residual PCB contamination in sediments of the creeks themselves. PCB residues in upstream ditch or pond sediments could act as primary continuing sources, or various in-plant sources of fugitive PCBs may continue to contribute concentrations below levels detectable in aqueous phase monitoring. PCB concentrations of about $0.3 \mu \mathrm{g} / \mathrm{g}$ in fish having $1 \%$ lipids would imply aqueous phase PCB concentrations of roughly $0.03 \mu \mathrm{g} / \mathrm{L}$ (using concentration factor $=10,000$ from EPA 1990).

\subsubsection{Mercury}

Mercury concentrations in fish from Big Bayou Creek were found to be somewhat higher downstream from PGDP than upstream in previous monitoring (Birge et al. 1990, 1992; Kszos 1993, 1994). Fish from all sites contained concentrations of mercury that appeared to be elevated relative to reference sites in East Tennessee.

The results of mercury monitoring in longear sunfish in April 1994 confirmed the findings of previous studies (Birge et al. 1992, Kszos 1993, 1994) that concentrations in fish from Big Bayou Creek were somewhat higher downstream from PGDP than upstream (Tables 4.3 and C.1). Mean mercury concentrations in sunfish were somewhat lower than those observed previously, ranging from a maximum of $0.24 \mu \mathrm{g} / \mathrm{g}$ at BBK 9.1 to $0.08 \mu \mathrm{g} / \mathrm{g}$ at BBK 12.5, upstream from PGDP. In 1993, mercury concentrations in longear sunfish at those sites were 0.37 and $0.10 \mu \mathrm{g} / \mathrm{g}$ respectively. Previous sampling (Birge et al. 1992, Kszos 1993, 1994) suggested that background or reference site concentrations of mercury 
Table 4.3. Mean concentrations of total mercury ( $\mu \mathrm{g} / \mathrm{g}$ wet wt) in longear sunfish and spotted bass from streams near PGDP, May 1994

\begin{tabular}{|c|c|c|c|c|c|c|c|}
\hline Site & Species $^{a}$ & Mean & SE & Range & $\mathrm{n}$ & $\begin{array}{l}\text { Tukey } \\
\text { group }\end{array}$ & $\begin{array}{c}\text { Dunnett's } \\
\text { test }^{c}\end{array}$ \\
\hline BBK 12.5 & LNGEAR & 0.08 & 0.004 & $0.07-0.10$ & 8 & B & ref \\
\hline BBK 10.0 & LNGEAR & 0.24 & 0.05 & $0.11-0.53$ & 8 & A & $\mathbf{S}$ \\
\hline BBK 9.1 & $\begin{array}{l}\text { LNGEAR } \\
\text { SPOBASS }\end{array}$ & $\begin{array}{l}0.21 \\
0.61\end{array}$ & $\begin{array}{l}0.02 \\
0.06\end{array}$ & $\begin{array}{l}0.15-0.29 \\
0.44-0.95\end{array}$ & $\begin{array}{l}8 \\
8\end{array}$ & $\begin{array}{l}A \\
-\end{array}$ & $\begin{array}{l}S \\
-\end{array}$ \\
\hline LUK $\quad 7.2$ & LNGEAR & 0.09 & 0.004 & $0.68-0.10$ & 4 & B & NS \\
\hline Massac Cr & LNGEAR & 0.13 & 0.01 & $0.07-0.18$ & 8 & $A, B$ & ref \\
\hline HindsCr & REDBRE & 0.10 & 0.03 & $0.05-0.18$ & 4 & B & $\begin{array}{c}\text { excluded } \\
. \quad .\end{array}$ \\
\hline
\end{tabular}

"LNGEAR = Longear sunfish (Lepomis megalotis); SPOBASS = Spotted bass (Micropterus punctulatus); REDBRE = Redbreast sunfish (Lepomis auritus).

${ }^{b}$ Groups separated by results of Tukey's Multiple Comparison Test on $\log _{e}$-transformed data. Mean concentrations are similar at sites having the same letter grouping, $p<0.05$.

'Results of one-tailed Dunnett's Test for comparing group means with a local reference site mean (ref) using $\log _{e}$-transformed data. Data from Massac $\mathrm{Cr}$ and $\mathrm{BBK} 12.5$ were pooled to compute the reference site mean. $S$ indicates statistically significant difference, $p<0.05$.

in streams near PGDP were elevated relative to concentrations of mercury typical of fish from uncontaminated streams in East Tennessee; therefore, a second local reference site, Massac Creek, was sampled to help determine the appropriate reference concentration. The mean concentration of mercury in redbreast sunfish from Hinds Creek, Tennessee was again lower than that observed in Massac Creek (Table 4.3), but was not less than that at BBK 12.5 Statistical comparison of mean mercury concentrations in fish from Big Bayou Creek, Massac Creek, and Hinds Creek (Tukey's Test) indicated that the Hinds Creek sunfish did not differ significantly from the Kentucky reference sites (Table 4.3). Mercury concentrations in fish from all sites in Big Bayou Creek below PGDP were similar. Because previously mercury concentrations in both Kentucky reference sites were similar, and much different from the Tennessee reference site, data from the two Kentucky sites (BBK 12.5, Massac Cr) were combined as a local reference collection for comparison with Big Bayou Creek sites below PGDP. Dunnett's test indicated that mean mercury concentrations in fish from the sites in Big Bayou Creek downstream from PGDP 
exceeded that in local reference site fish again in 1994. Results of mercury monitoring in sunfish from LUK 7.2 again indicated background mercury concentrations (Tables 4.3 and C.1) typical of reference site fish.

Because the bioaccumulation of methylmercury by fish is predominantly a food chain mediated process, predatory species that occupy trophic positious at or near the top of the aquatic food web would be expected to contain higher concentrations of mercury than species lower in the food chain. Spotted bass in Big Bayou Creek occupy that role of terminal predator. Mercury concentrations in spotted bass from BBK 9.1 averaged $0.61 \pm$ $0.06 \mu \mathrm{g} / \mathrm{g}$ (range, $0.44-0.95 \mu \mathrm{g} / \mathrm{g}$ ). One fish in the collection approached the FDA action level $(1 \mu \mathrm{g} / \mathrm{g})$, but the rest were below $0.7 \mu \mathrm{g} / \mathrm{g}$. Such concentrations are not unexpected given concentrations of about $0.2-0.5 \mu \mathrm{g} / \mathrm{g}$ in sunfish, which probably provide a reasonable estimate of mercury concentrations in bass food organisms. Thus, mercury concentrations in bass that are double those of sunfish are a reasonable consequence of the higher trophic position of bass. Mercury concentrations in bass collected from ponds on the West Kentucky Wildlife Management Area in 1993 were very similar to mercury concentrations in bass from Big Bayou Creek, averaging about $0.7 \mu \mathrm{g} / \mathrm{g}$ (Kornegay et al. 1994), giving further credence to the hypothesis that the geochemistry of surface waters in this region favors the production and accumulation of mercury from natural sources.

As noted previously (Kszos 1994), the slightly elevated concentrations of mercury in fish from Big Bayou Creek below PGDP may be a result of mercury in PGDP effluents, but they may also be a consequence of differences in the biogeochemical processing of mercury downstream from the plant. The bioaccumulation of mercury is a complex process, in which inorganic mercury is converted to methylmercury by microorganisms, and the methylmercury is then accumulated via food chain processes. Mercury concentrations in fish would be affected by factors that alter the rate at which naturally occurring mercury is converted to methyl mercury, or by changes in food chain structure that induce fish at some locations to feed on more highly contaminated prey. Naturally occurring mercury appears to be more bivavailable in streams near PGDP than in some other parts of the country (Lowe et al. 1985). Thus, it is possible that elevated mercury concentrations in fish in Big Bayou Creek are a consequence of changes in water chemistry or invertebrate community structure downstream from PGDP. 


\subsubsection{Screening studies}

\subsubsection{Metals}

Concentrations of metals measured in filets of longear sunfish from Big Bayou Creek and Little Bayou Creek are listed in Tables 4.4 and C.2. Levels are typical of those observed in previous monitoring (Birge et al. 1990, Kszos 1993, 1994), and generally differ little (with several exceptions) from concentrations observed in fish from the Hinds Creek, Tennessee, reference site. Concentrations of arsenic, cadmium, copper, lead, selenium, and zinc were lower than the national geometric mean concentrations (Table 4.4) observed for whole body analyses of fish in the USFWS National Contaminant Biomonitoring Program (Lowe et al. 1985). Concentrations of antimony, cadmium, chromium, nickel, selenium, and silver were well below screening levels used in the EPA Integrated Risk Information System (IRIS) (EPA 1990). Beryllium was not detected in PGDP fish (beryllium detection limit was at the IRIS screening level; arsenic, for which the detection limit was $10 \mathrm{X}$ screening level, was found at concentrations near the limit of detection in one sample). Those metals for which IRIS screening levels are not published (copper, lead, thallium, uranium, and zinc were found at concentrations similar to or lower than typically occur in food such as marine fish or mammalian muscle (Bowen 1979).

Measurement of detectable concentrations of uranium (Table 4.4) in fish from Little Bayou Creek is consistent with the observed elevated concentrations of uranium in this creek (Kornegay et al. 1994) and the results of previous monitoring of fish (Kszos 1993; 1994). Uranium has a low bioconcentration factor, consequently concentrations in fish would be expected to fluctuate rapidly in response to changing aqueous phase concentrations. Uranium measurements in fish thus provide little time averaging of exposure, and variation in yearly measurements cannot be used to infer long-term trends in exposure.

\subsubsection{Chlorinated pesticides}

No chlorinated pesticides were detected in fish from Big Bayou Creek or Little Bayou Creek. These results are consistent with previous monitoring (Kszos 1992, 1993). 
Table 4.4. Mean metal concentrations ( $\mu \mathrm{g} / \mathrm{g}$ wet weight) $\pm \mathrm{SE}$ in longear sunfish from streams at PGDP, April 1994. $N=4$ except where noted. If $\geq 50 \%$ of results are below detection limit, range is given. NS = not sampled, ND = not determined

\begin{tabular}{|c|c|c|c|c|c|}
\hline \multirow[b]{2}{*}{ Metal } & \multicolumn{5}{|c|}{ Site } \\
\hline & BBK 9.1 & LUK 7.2 & HindsCr ${ }^{a}$ & $\mathrm{NCBP}^{b}$ & $\mathrm{EPA}^{c}$ \\
\hline Antimony & $<0.5$ & $<0.5$ & $<0.5$ & NS & 43.1 \\
\hline Arsenic & $<0.05-0.06^{d}$ & $<0.05$ & $<0.05$ & 0.16 & 0.006 \\
\hline Beryllium & $<0.003$ & $<0.003$ & $<0.003$ & NS & 0.0025 \\
\hline Cadmium & $<0.2$ & $<0.2$ & $<0.2$ & 0.04 & 10.8 \\
\hline Chromium & $<0.5-3.0^{d}$ & $<0.5$ & $<0.5$ & NS & 10,800 \\
\hline Copper & $<0.5$ & $<0.5$ & $<0.5$ & 0.86 & ND \\
\hline Lead & $<0.5$ & $<0.5$ & $<0.5$ & 0.19 & $\mathrm{ND}$ \\
\hline Nickel & $<0.5$ & $<0.5$ & $<0.5$ & NS & 2.15 \\
\hline Selenium & $<0.5-0.61^{d}$ & $0.60 \pm 0.05$ & $<0.5$ & 0.46 & 5.4 \\
\hline Silver & $<0.2-0.48^{d}$ & $<0.2$ & $<0.2$ & NS & 2.48 \\
\hline Thallium & $<0.02$ & $<0.02$ & $<0.02$ & NS & $\mathrm{ND}$ \\
\hline Uranium & $0.004 \pm 0.0001$ & $0.025 \pm 0.0017$ & $<0.003$ & NS & ND \\
\hline Zinc & $10.1 \pm 0.58$ & $9.6 \pm 0.38$ & $8.4 \pm 1.6$ & 25.6 & $\mathrm{ND}$ \\
\hline
\end{tabular}

${ }^{\circ}$ Reference stream, Anderson Co., $\mathrm{Tn} ; \mathrm{N}=2$.

${ }^{b}$ Mean concentration of metals collected for the National Contaminant Biomonitoring Program (NCBP) (Lowe et al. 1985).

'EPA Integrated Risk Information System screening levels (EPA 1990).

${ }^{d}$ Single value exceeded detection limit.

Two values exceeded detection limit.

\subsubsection{Radionuclides}

Gamma spectroscopy of freeze-dried fish samples found detectable concentrations of only naturally occurring $\mathrm{K}-40$ in fish, with a single exception. That fish, from LUK 7.2, contained $0.07 \mathrm{pCi} / \mathrm{g}$ wet wt cesium- 134. This isotope would not be expected at PGDP, and the result is presumed to be anomalous. 


\subsection{Future studies}

Annual screening for chlorinated pesticides will be dropped. An adequate body of data currently exists to indicate that these substances are not present at concentrations of concern in fish from sites at PGDP. Twice annual PCB tracking studies will continue. The monitoring site at BBK 2.8 will be dropped. High water commonly makes this site inaccessible, and it is not necessary to continue to demonstrate that concentrations of PCBs decrease strikingly between BBK 9.1 and LUK 2.8. Annual mercury monitoring in bass and sunfish will continue at BBK 9.1 and LUK 7.2 but be discontinued at other sites except Massac Creek and BBK 12.5 reference sites. Screening analyses for metals and radionuclides have demonstrated that these substances do not accumulate appreciably in muscle of fish from streams at PGDP. However, because discharge of metals in effluents is an NPDES concern at PGDP, annual monitoring is of value in demonstrating that fish are uncontaminated.

Beaver activity on both Big Bayou Creek and Little Bayou Creek has expanded considerably in recent years, and dams have modified habitat in several sites. Such dams may have a significant effect on the retention of sediment associated contaminants in both creeks, and may make it more difficult to observe rapid improvement in PCB contamination in fish following successful reduction of PCB inputs. Fish populations appear to be considerably lower in ponds behind these dams than in free flowing stretches of stream. It may be necessary to revise sampling strategies and site selection in the future if such habitat modifications continue to expand. 


\title{
5. ECOLOGICAL MONITORING STUDIES
}

\author{
M. G. Ryon and M. R. Smith
}

\subsection{FISHES (M. G. Ryon)}

\subsubsection{Introduction}

Fish population and community studies can be used to assess the ecological effects of changes in water quality and habitat. These studies offer several advantages over other indicators of environmental quality (see Karr et al. 1986, Karr 1987) and are especially relevant to assessment of the biotic integrity of Little Bayou and Big Bayou creeks because both creeks receive point and nonpoint impacts. Monitoring of fish communities has been used by the Biological Monitoring and Abatement Program (BMAP) in ESD for receiving streams at ORNL (Loar et al. 1991); K-25 Site (Loar et al. 1992, Ryon 1993a); the Portsmouth, Ohio, facility (Ryon, 1994); and the Y-12 Plant (Loar et al. 1989, Ryon 1992a, Southworth et al. 1992), with some programs operational since 1984. Changes in the fish communities in these systems have indicated recovery (Ryon 1994d) as well as documented impacts (Ryon 1994c, 1993b).

The objectives of the instream fish monitoring task were (1) to characterize spatial and temporal patterns in the distribution and abundance of fishes in Little Bayou and Big Bayou creeks and (2) to document the effects of PGDP operations on fish community structure and function.

\subsubsection{Study Sites}

Quantitative sampling of the fish community was conducted at five sites. Three sites are located on Big Bayou Creek (BBK 12.5, BBK 10.0, and BBK 9.1; Fig. 2.2), one on Little Bayou Creek (LUK 7.2, Fig. 2.2), and one offsite reference station on Massac Creek (MAK 13.8, Fig. 2.1). MAK 13.8 was chosen as a reference site for BBK 9.1 and BBK 10.0. The upper site on Big Bayou Creek (BBK 12.5) was selected as a smaller reference site to be comparable to LUK 7.2. A qualitative sampling site (LUK 4.3) was established to evaluate the fish community in this area in response to earlier concerns of possible PGDP impacts (see Ryon 1994a). 


\subsubsection{Materials and Methods}

Quantitative sampling of the fish populations at four sites in the Bayou Creek watershed (BBK 12.5, BBK 10.0, BBK 9.1, and LUK 7.2) and at one site in a reference stream, Massac Creek (MAK 13.8), was conducted by electrofishing on March 7, 22-23 and September 11-13, 1994. Data from these samples were used to estimate species richness, population size (numbers and biomass per unit area), and calculate annual production. Fish sampling sites either overlapped or were within $100 \mathrm{~m}$ of the sites included in the benthic macroinvertebrate monitoring task. Qualitative fish sampling was conducted by electrofishing on March 22, 1994. Data from this sample were used to determine the species richness and number of specimens (relative abundance) based on sampling a known length of stream. All field sampling was conducted according to standard operating procedures (Ryon 1992b).

\subsubsection{Quantitative field sampling procedures}

All stream sampling was conducted using two or three Smith-Root Model 15A backpack electrofishers, depending on stream size. Each unit can deliver up to $1200 \mathrm{~V}$ of pulsed direct current in order to stun fish.

After 0.64-cm-mesh seines were placed across the upper and lower boundaries of the fish sampling site to restrict fish movement, a five- to nine-person sampling team electrofished the site in an upstream direction on three consecutive passes. Stunned fish were collected and stored, by pass, in seine-net holding pens $(0.64-\mathrm{cm}$-diam mesh) or in buckets during further sampling.

Following the electrofishing, fish were anesthetized with MS-222 (tricaine methanesulfonate), identified, measured (total length), and weighed using Pesola spring scales. Individuals were recorded by 1-cm size classes and species. After ten individuals of a species-size class were measured and weighed, additional members of that size class were only measured. Length-weight regressions based on the weighed individuals were used to estimate missing weight data. Representative specimens of each species were also kept in a voucher collection to verify species identifications.

After processing fish from all passes, the fish were allowed to fully recover from the anesthesia and returned to the stream. Any additional mortality that occurred as a result of processing was noted at that time. Following completion of fish sampling, the length, 
mean width, mean depth, and pool:riffle ratio of the sampling reach were measured at each site.

\subsubsection{Qualitative field sampling procedures}

Qualitative sampling involved electrofishing a limited length of stream for one pass and collecting all stunned fish. A five-person sampling team electrofished upstream for approximately $1 \mathrm{~h}$ using two Smith-Root backpack electrofishers. Sampling always started at the same stream location and proceeded through a known length of stream. Stunned fish were netted, placed in buckets, and given to a two- to three-person shore crew for processing. The shore crew counted and identified all specimens; easily identifiable species were immediately released downstream from the sampling crew. Species that were more difficult to identify were preserved in $10 \%$ formaldehyde and taken to the ESD laboratory for positive identification. Representative specimens of each species were also kept in a voucher collection to verify species identifications. The duration of the electrofishing effort (in minutes) and the length of stream (in meters) sampled were recorded.

\subsubsection{Data analysis}

Population Size. Quantitative species population estimates were calculated using the method of Carle and Strub (1978). Biomass was estimated by multiplying the population estimate by the mean weight per size class. To calculate density and biomass per unit area, total numbers and biomass were divided by the surface area (in square meters) of the study reach. These data were compiled and analyzed by a comprehensive Fortran 77 program developed by ESD staff (Railsback et al. 1989). Qualitative samples were compared using total number of species and specimens and the relative abundance of the specimens. Relative abundance of species was rated as follows: 1 specimen $=$ rare, 2 to 20 specimens $=$ uncommon, 21 to 100 specimens $=$ common, and $>100$ specimens $=$ abundant.

Annual Production. Annual production was estimated at each site using a sizefrequency method (Garman and Waters 1983) as modified by Railsback et al. (1989). Production was calculated for the period between the spring 1993 and spring 1994 sampling dates. 


\subsubsection{Results}

The physical parameters of the sample sites showed only minor differences between the March (spring) and September (fall) samples (Table 5.1). Most sites were deeper and wider in spring than in fall samples, similar to the pattern seen in previous years (Ryon 1994a,e).

\subsubsection{Quantitative sampling}

Species richness and composition. A total of 30 fish species were found at the 5 sites on Big Bayou Creek, Little Bayou Creek, and Massac Creek (Table 5.2) for the March and September 1994 samples. BBK 9.1 and BBK 10.0 had 18 and 15 species for the two sampling seasons, compared to 25 species at the reference stream, MAK 13.8. The LUK 7.2 site had 20 species during the year, while the comparable reference site, BBK 12.5 had 16 species. Mean species richness for MAK 13.8, BBK 9.1, and BBK 10.0 was 21.0, 14.5, and 11.0 respectively (Table 5.3). At LUK 7.2 and BBK 12.5, the mean richness was 14.0 and 13.5 respectively. At most sites, species richness was higher in the September samples than in March. However, at LUK 7.2, species richness declined during the year with a drop of 12 species (Table 5.3). The core species assemblage at all sites included central stoneroller (Campostoma anomalum), creek chub (Semotilus atromaculatus), yellow bullhead (Ameiurus natalis), blackspotted topminnow (Fundulus olivaceus), creek chubsucker (Erimyzon oblongus), green sunfish (Lepomis cyanellus), and longear sunfish (L. megalotis). Seven species were judged to be sensitive to water quality and/or habitat degradation (see Karr et al. 1986; Ohio EPA 1987, 1988) and seven were rated as tolerant to such conditions (Appendix D, Table D.1).

The lowest site on Big Bayou Creek, BBK 9.1, had severaI species which are more common in larger streams such as bigmouth buffalo (Ictiobus cyprinellus) and black bullhead (Ameiurus melas). These species were not taken at upstream Big Bayou Creek sites. BBK 9.1 had low numbers of cyprinid (four) and percid (0) species but higher levels of catostomid (four), and centrarchid (six) species. The number of sensitive species (three) was less than the number of species tolerant (four) of habitat degradation and/or pollution. The fish community composition at BBK 9.1 included representatives of all trophic levels. Piscivores or top carnivores included two species, largemouth bass (Micropterus salmoides), and spotted bass (M. punctulatus). Benthic insectivores, a feeding 
Table 5.1. Lengths, mean width, mean depth, surface area, and pool-riffle ratio of fish sampling sites in Big Bayon Creek, Little Bayou Creek, and a reference stream, Massac Creek, for March and September 1994

\begin{tabular}{lccccc}
\hline Site $^{a}$ & $\begin{array}{c}\text { Length } \\
(\mathrm{m})\end{array}$ & $\begin{array}{c}\text { Mean width } \\
(\mathrm{m})\end{array}$ & $\begin{array}{c}\text { Mean depth } \\
(\mathrm{cm})\end{array}$ & $\begin{array}{c}\text { Surface } \\
\text { area } \\
\left(\mathrm{m}^{2}\right)\end{array}$ & $\begin{array}{c}\text { Pool-riffle } \\
\text { ratio }\end{array}$ \\
\hline March 1994 & & & & & \\
BBK 9.1 & 99 & 6.9 & 25.3 & 683 & 1.0 \\
BBK 10.0 & 101 & 4.1 & 10.3 & 414 & 0.7 \\
BBK 12.5 & 111 & 6.1 & 10.0 & 677 & 1.9 \\
LUK 7.2 & 115 & 3.5 & 7.3 & 403 & 0.3 \\
MAK 13.8 & 96 & 5.6 & 15.6 & 538 & 0.7 \\
September 1994 & & & & & \\
BBK 9.1 & 105 & 6.1 & 19.2 & 641 & 1.1 \\
BBK 10.0 & 110 & 4.4 & 10.8 & 484 & 0.9 \\
BBK 12.5 & 85 & 5.5 & 9.3 & 468 & 3.0 \\
LUK 7.2 & 109 & 3.1 & 7.1 & 338 & 0.9 \\
MAK 13.8 & 89 & 5.0 & 11.2 & 445 & 1.4 \\
\hline
\end{tabular}

${ }^{a}$ Site designations are Big Bayou Creek kilometer (BBK), Little Bayou Creek kilometer (LUK), and Massac Creek kilometer (MirK).

guild that can reflect impacts on the benthic macroinvertebrate community (Miller et al. 1988), were represented by two species. There were seven species classified as generalist feeders, which are species that are capable of switching easily between food items and therefore can be more successful in streams exposed to a variety of stresses (Leonard and Orth 1986).

BBK 10.0 had low numbers of catostomid (one) and percid species (0), but moderate numbers of cyprinid (six) and centrarchid species (five). However, there were no sensitive species and four tolerant species. The trophic composition of the community at BBK 10.0 included two piscivores (the bass species), two benthic insectivores, and four generalist feeders.

Compared to the MAK 13.8 reference, the two lower Big Bayou Creek sites showed some degradation. The reference site had higher numbers of cyprinid (nine), catostomid (four), and percid (three) species, with the same level of centrarchid species (five). MAK 13.8 also had more sensitive species (seven) and similar numbers of tolerant species (five). Trophically, MAK 13.8 had fewer piscivore species (one), similar numbers of generalist feeders (seven), and three times as many benthic insectivores (six) as the Big Bayou Creek sites. 
Table 5.2. Species composition of quantitative samples in Big Bayou Creek, Little Bayou Creek, and a reference stream, Massac Creek, March and September 1994

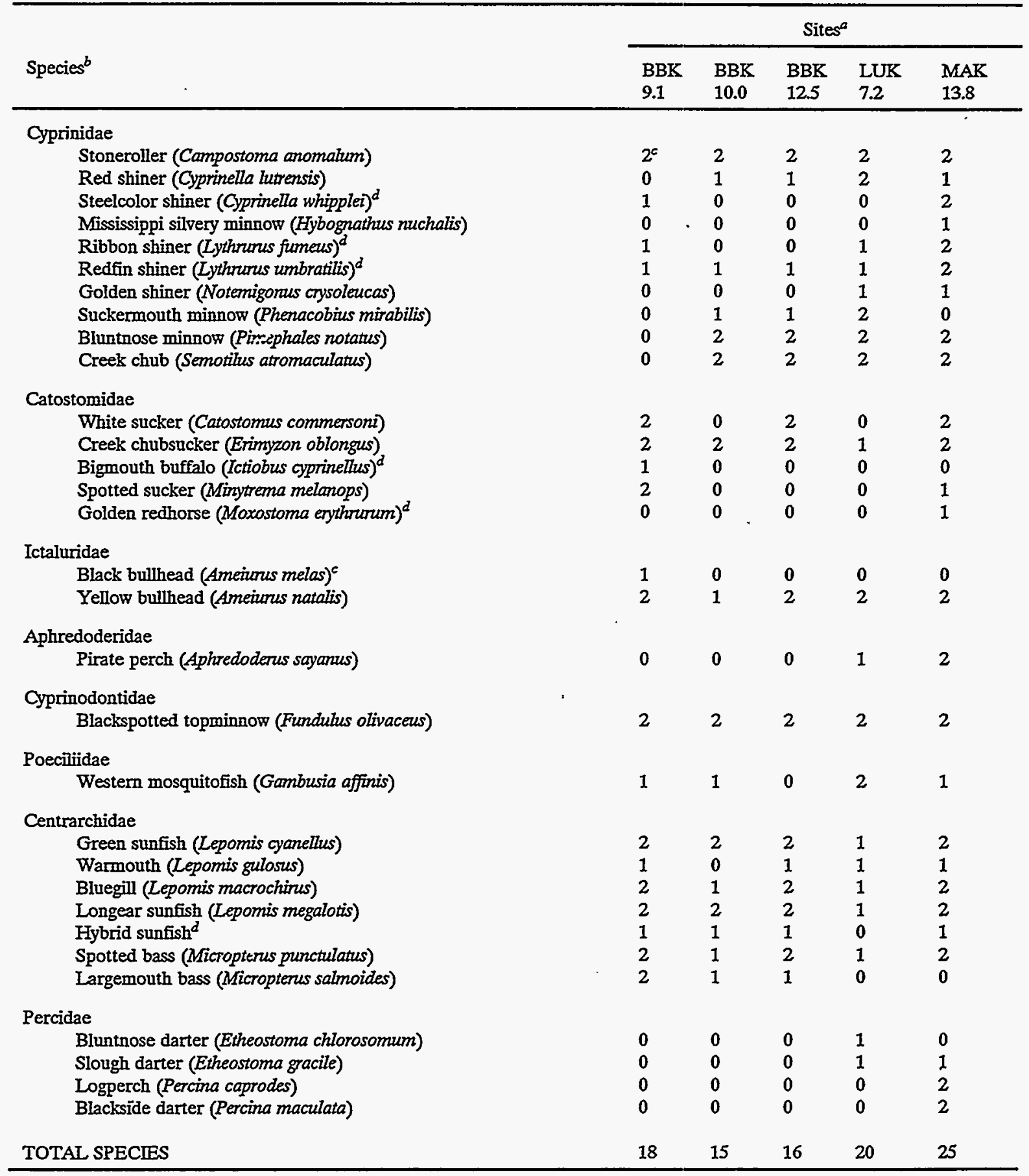

aBBK = Big Bayou Creek kilometer, LUK = Little Bayou Creek kilometer, MAK = Massac Creek kilometer. ${ }^{b}$ Common and scientific names according to the American Fisheries Society (Robbins et al. 1991).

Numbers represent the number of sampling periods $(N=2)$ that a given species was collected at the site and a zero indicates that the species was not collected.

${ }^{d}$ Species identification confirmed by Dr. David A. Etnier, Department of Zoology, University of Tennessee. 
Table 5.3. Total fish density (individuals $\left./ \mathrm{m}^{2}\right)$, biomass $\left(\mathrm{g} / \mathrm{m}^{2}\right)$, and species richness for March and September 1994 at sampling sites ${ }^{a}$ in Big Bayou Creek, Little Bayou Creek, and a reference stream, Massac Creek

\begin{tabular}{lccccc}
\hline Sampling periods & BBK 9.1 & BBK 10.0 & BBK 12.5 & LUK 7.2 & MAK 13.8 \\
\hline March 1994 & & & & & \\
$\quad$ Density & 0.97 & 1.36 & 3.09 & 3.82 & 1.49 \\
Biomass & 16.93 & 7.81 & 16.57 & 6.98 & 6.83 \\
Species richness & 13 & 10 & 12 & 20 & 17 \\
& & & & & \\
September 1994 & 1.19 & 5.57 & 4.26 & 3.76 & 5.74 \\
Density & 14.45 & 15.10 & 10.22 & 5.86 & 17.75 \\
Biomass & 16 & 12 & 15 & 8 & 25 \\
Species richness & & & & & \\
& 1.08 & 3.47 & 3.68 & 3.79 & 3.62 \\
Means 1994 & 15.69 & 11.46 & 13.40 & 6.42 & 12.29 \\
$\quad$ Density & 14.5 & 11.0 & 13.5 & 14.0 & 21.0 \\
Biomass & & & &
\end{tabular}
kilometer.

${ }^{a} \mathrm{BBK}=$ Big Bayou Creek kilometer, LUK = Little Bayou Creek kilometer, MAK = Massac Creek

The LUK 7.2 site maintained high levels of cyprinid (eight) and centrarchid (five) species with one catostomid. LUK 7.2 had four tolerant and two sensitive species. The trophic composition of the fish community at LUK 7.2 included one piscivore, four benthic insectivores, and five generalist feeders. By comparison, the BBK 12.5 reference site had similar numbers of cyprinid (six), centrarchid (six), and catostomid (two) species. There were no sensitive species and a higher number of tolerant species (five). Trophically, the fish community at BBK 12.5 reflected the headwater influence, with six generalist feeders, two piscivores, and only two benthic insectivores. In headwater habitats, generalist feeders have a decided advantage because they can utilize terrestrial sources of food much easier than can benthic insectivores.

Density. Quantitative estimates of density were higher at most sites during the September samples than during the March samples (Table 5.3). This was the pattern in previous PGDP samples (Ryon 1994a,e) and has been the dominant pattern for the BMAP sampling conducted at the approximately 50 sites in the Oak Ridge, Tennessee, area since 1985 (Loar 1992, Ryon 1992c, Southworth et al. 1992). The higher fall density reflects recruitment of fish into the community and normally occurs at all sites, unless a 
substantial impact has occurred. The only exception was a slight decline in density at LUK 7.2.

The highest total density values were at MAK 13.8 and at BBK 12.5 during September sampling. The densities at BBK 9.1 were about one-half to two-thirds of the levels at BBK 10.0 and showed less variation between sampling seasons. The MAK 13.8 reference had levels similar to BBK 10.0 in March and September samples (Table 5.3).

Densities of individual species varied slightly between sites, with less variation among the two species with the highest values (Appendix D, Tables D.2 and D.4). During all sampling seasons at BBK 9.1, BBK 10.0, and MAK 13.8, the species present in highest or next highest numbers were the central stoneroller or longear sunfish. The high densities of central stoneroller (a scraping herbivore) in Big Bayou Creek probably reflected greater algal growth resulting from nutrient enrichment by PGDP discharges. The longear sunfish is a generalist feeder and the primary centrarchid in the PGDP area streams. At LUK 7.2, the species with the highest densities were bluntnose minnow (Pimephales notatus), blackspotted topminnow, and green sunfish (Tables D.2 and D.4). The BBK 12.5 reference site was similar to downstream Big Bayou Creek sites with highest densities for longear sunfish and central stoneroller.

Biomass. Unlike the density estimates, quantitative estimates of total fish biomass were not consistently higher in September samples than in March samples (Table 5.3). The highest biomass levels were at BBK 9.1 and MAK 13.8. Mean fish biomass at MAK 13.8 was similar to the biomass at the lower Big Bayou Creek sites, because of a decline from previous years in the Big Bayou Creek values. Mean fish biomass at LUK 7.2 was half the mean fish biomass at the BBK 12.5 reference site.

Each site was evaluated for the species that constituted the two highest biomass values during each sample period. The longear sunfish species contributed the highest or next highest biomass at every site except LUK 7.2 (Tables D.3 and D.5). Other fish species that were among the two highest biomass contributors included bluegill (Lepomis macrochirus) or spotted bass at BBK 9.1, and central stoneroller at BBK 10.0, MAK 13.8, and BBK 12.5. At LUK 7.2, the two highest biomass contributors varied among the creek chub, green sunfish, bluntnose minnow, or central stoneroller.

Production. Production values were calculated for the spring 1993 to spring 1994

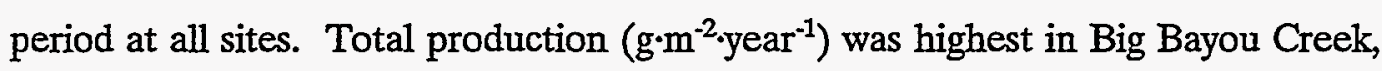


increasing upstream (Table 5.4). The production at BBK 9.1 and BBK 10.0 was more than twice that at the reference site, MAK 13.8. The principal difference between production at BBK 9.1 and MAK 13.8 was the tremendously high levels for sunfish species, especially longear sunfish at BBK 9.1. At BBK 10.0, the higher production was dominated by the contribution of the central stoneroller. Production at LUK 7.2 was only a third of that found at BBK 12.5 (Table 5.4). A ten-fold difference in production of central stoneroller, longear sunfish, and yellow bullhead accounted for the majority of the disparity. The higher level of production at BBK 9.1 and BBK 10.0 might be expected given the other signs of enrichment; however, the overall high production throughout the Big Bayou Creek system was unexpected.

The production found in these streams was within the range of production values found in warmwater streams of the southeastern United States, including production estimates generated by similar methods at Oak Ridge monitoring sites (Table 5.5 in Ryon 1994e). Estimates of production in southeastern reference streams varied from 2.02 to $27.12 \mathrm{~g} \cdot \mathrm{m}^{-2} \cdot \mathrm{year}^{-1}$ compared to 4.22 to $15.30 \mathrm{~g} \cdot \mathrm{m}^{-2} \cdot \mathrm{year}^{-1}$ at PGDP area reference streams. Similarly, production at sites downstream of plant discharges ranged from 3.06 to $27.38 \mathrm{~g} \cdot \mathrm{m}^{-2} \cdot$ year $^{-1}$ in the southeast v 6.80 to $10.59 \mathrm{~g} \cdot \mathrm{m}^{-2} \cdot$ year $^{-1}$ in Big Bayou Creek watershed.

\subsubsection{Qualitative sampling}

During qualitative sampling conducted on lower Little Bayou Creek (LUK 4.3) in March, totals of 35 species and 1225 specimens were taken (Table 5-5). These levels far exceeded the previous patterns in past samples from this site (Fig. 5-1). The numbers of species and specimens were about 1.5 times greater than any previous sample. Also, the catch per unit effort was the highest measured since sampling was initiated at this site. The survey found six new species not taken in previous qualitative surveys of LUK 4.3, including the river shiner (Notropis blennius), two suckers (goldcn redhorse Moxostoma erythrurum and black buffalo Ictiobus niger), two darters (logperch Percina caprodes and mud darter Etheostoma asprigene) and one sunfish (orangespotted Lepomis humilis). The 
Table 5.4. Fish annual production $\left(\mathrm{g}_{\mathrm{m}} \mathrm{m} / \mathrm{yr}\right)$ in Big Bayou Creek, Little Bayou Creek, and a reference stream, Massac Creek, March 1993 to March 1994

\begin{tabular}{|c|c|c|c|c|c|}
\hline \multirow[b]{2}{*}{ Species $^{b}$} & \multicolumn{5}{|c|}{ Sites $^{a}$} \\
\hline & BBK 9.1 & BBK 10.0 & BBK 12.5 & LUK 7.2 & MAK 13.8 \\
\hline Stoneroller & 1.20 & 10.41 & 7.81 & 0.38 & 1.11 \\
\hline Red shiner & 0 & -0.01 & 0.01 & 0.12 & - \\
\hline Steelcolor shiner & $-<0.01$ & - & - & - & $<0.01$ \\
\hline Ribbon shiner & - & - & $-<0.01$ & -0.01 & 0.04 \\
\hline Redfin shiner & 0 & 0 & $-<0.01$ & 0.02 & -0.04 \\
\hline Golden shiner & - & - & - & $-<0.01$ & - \\
\hline Suckermouth minnow & - & $<0.01$ & 0.02 & 0.22 & -0.01 \\
\hline Bluntnose minnow & - & 0 & 0.23 & 3.96 & 0.32 \\
\hline Creek chub & $-<0.01$ & $-<0.01$ & 0.54 & 0.57 & 0.01 \\
\hline White sucker & -0.68 & - & -0.02 & - & 0.02 \\
\hline Creek chubsucker & 0.02 & 0 & 0.08 & -0.02 & $<0.01$ \\
\hline Black redhorse & - & - & - & - & -0.18 \\
\hline Golden redhorse & - & - & - & - & -0.13 \\
\hline Yellow bullhead & 0.01 & - & 0.66 & -0.03 & 0.12 \\
\hline Pirate perch & - & - & - & -0.10 & -0.02 \\
\hline Blackspotted topminnot & 0.01 & 0.01 & 0.21 & 0.46 & 0.14 \\
\hline Western mosquitofish & - & - & - & $-<0.01$ & - \\
\hline Green sunfish & 0.29 & -0.08 & 1.02 & 0.73 & 0.05 \\
\hline Warmouth & -0.01 & - & 0 & -0.04 & $-<0.01$ \\
\hline Bluegill & 0.06 & $-<0.01$ & -0.01 & 0 & $<0.01$ \\
\hline Longear sunfish & 8.27 & 0.28 & 4.73 & 0.49 & 2.85 \\
\hline Spotted bass & 0.63 & -0.02 & 0.02 & $-<0.01$ & -0.03 \\
\hline Largemouth bass & -0.03 & - & - & - & -0.02 \\
\hline Bluntnose darter & - & - & - & 0.02 & 0 \\
\hline Slough darter & - & - & - & 0.03 & - \\
\hline Blackside darter & - & - & - & - & -0.01 \\
\hline Total production & 9.77 & 10.59 & 15.30 & 6.80 & 4.22 \\
\hline
\end{tabular}

${ }^{a} \mathrm{BBK}=$ Big Bayou Creek kilometer, LUK $=$ Little Bayou Creek kilometer, MAK $=$ Massac Creek kilometer.

${ }^{b}$ Common and scientific names according to the American Fisheries Society (Robbins et al.1991).

'Species identification confirmed by Dr. David A. Etnier, Department of Zoology, University of

Tennessee. 
Table 5.5. Species composition of the qualitative fish sampling conducted on Little Bayou Creek, March 22, 1994

Species identifications were performed in the field and/or confirmed in the laboratory on preserved specimens collected during the surveys

\begin{tabular}{|c|c|c|}
\hline Species $^{b}$ & $\begin{array}{l}\text { Number of } \\
\text { specimens }\end{array}$ & $\begin{array}{c}\text { Relative } \\
\text { abundance }\end{array}$ \\
\hline \multicolumn{3}{|l|}{ Clupeidae } \\
\hline Gizzard shad (Dorosoma cepedianum) & 154 & $\mathrm{~A}$ \\
\hline \multicolumn{3}{|l|}{ Cyprinidae } \\
\hline Red shiner (Cyprinella lutrensis) & 8 & UC \\
\hline Spotfin shiner (Cyprinella spiloptera) ${ }^{d}$ & 29 & $\mathrm{C}$ \\
\hline Steelcolor shiner (Cyprinella whipplei) ${ }^{d}$ & 1 & $\mathbf{R}$ \\
\hline Common carp (Cyprinus carpio) & 4 & UC \\
\hline Mississippi silvery minnow (Hybognathus nuchalis) & 458 & $A$ \\
\hline Ribbon shiner (Lythrurus fumeus) $)^{d}$ & 29 & $\mathrm{C}$ \\
\hline Redfin shiner (Lythrurus imbratilis) & 8 & $\mathrm{UC}$ \\
\hline Golden shiner (Notemigonus crysoleucas) & 2 & UC \\
\hline Emerald shiner (Notropis atherinoides) ${ }^{d}$ & 34 & C \\
\hline River shiner (Notropis blennius) ${ }^{d}$ & 9 & $\mathrm{UC}$ \\
\hline Suckermouth minnow (Phenacobius mirabilis) & 2 & UC \\
\hline Bluntnose minnow (Pimephales notatus) & 124 & A \\
\hline Creek chub (Semotilus atromaculatus) & 5 & UC \\
\hline \multicolumn{3}{|l|}{ Catostomidae } \\
\hline Creek chubsucker (Erimyzon oblongus) & 3 & UC \\
\hline Black buffalo (Ictiobus niger) ${ }^{d}$ & 2 & UC \\
\hline Spotted sucker (Minytrema melanops) & 7 & UC \\
\hline Golden redhorse (Moxostoma erythrurum) & 1 & $\mathrm{R}$ \\
\hline \multicolumn{3}{|l|}{ Ictaluridae } \\
\hline Yellow bullhead (Ameiumus natalis) & 4 & UC \\
\hline \multicolumn{3}{|l|}{ Aphredoderidae } \\
\hline Pirate perch (Aphredoderus sayanus) & 11 & UC \\
\hline \multicolumn{3}{|l|}{ Cyprinodontidae } \\
\hline Blackspotted topminnow (Fundulus olivaceus) & 57 & $\mathrm{C}$ \\
\hline \multicolumn{3}{|l|}{ Poeciliidae } \\
\hline Western mosquitofish (Gambusia affinis) & 3 & UC \\
\hline \multicolumn{3}{|l|}{ Centrarchidae } \\
\hline Flier (Centrarchus macropterus) & 23 & C \\
\hline Green sunfish (Leponis cyanellus) & 39 & C \\
\hline Warmouth (Lepomis gulosus) & 5 & UC \\
\hline Bluegill (Lepomis macrochinus) & 32 & C \\
\hline Longear sunfish (Lepomis megalotis) & 135 & A \\
\hline Orangespotted sunfish (Lepomis humilis) ${ }^{d}$ & 4 & UC \\
\hline Spotted bass (Micropterus punctulatus) & 11 & UC \\
\hline Largemouth bass (Micropterus salmoides) & 1 & $\mathrm{R}$ \\
\hline White crappie (Pomoxis annularis) & 3 & UC \\
\hline \multicolumn{3}{|l|}{ Percidae } \\
\hline Mud darter (Etheostoma asprigene) ${ }^{d}$ & 3 & UC \\
\hline Bluntnose darter (Etheostoma chlorosomum) & 10 & UC \\
\hline Slough darter (Etheostoma gracile) & 3 & UC \\
\hline Logperch (Percina caprodes) & 1 & $\mathbf{R}$ \\
\hline
\end{tabular}


Table 5.5 (continued)

\begin{tabular}{lcc}
\hline Species $^{b}$ & $\begin{array}{c}\text { Number of } \\
\text { specimens }\end{array}$ & $\begin{array}{c}\text { Relative } \\
\text { abundance }\end{array}$ \\
\hline TOTAL SPECIES & 35 & \\
TOTAL SPECIMENS & 1225 & \\
CATCH PER EFFORT (FISH/MIN) & 7.5 & \\
\hline
\end{tabular}

${ }^{a}$ Two electroshockers used for $150 \mathrm{~m}$ and $82 \mathrm{~min}$.

${ }^{b}$ Common and scientifie names according to the American Fisheries Society (Robins et al. 1991).

${ }^{C}$ Relative abundance is defined as: rare (R) 1 specimen; uncommon (UC) 2-20 specimens; common (C) 21-99 specimens; and abundant $(A)>99$ specimens.

${ }^{d}$ Species identification were confirmed by Dr. David A. Etnier, Department of Zoology, University of Tennessee.

community represented by this sample included 13 minnow species, four sucker species, seven sunfish species, and four darter species. When the sample was analyzed for the sensitivity of species to pollution and/or environmental degradation, there were five species intolerant of such stressors and seven tolerant species.

This latest survey at LUK 4.3 underscored the general lack of a visible impact in this section of Little Bayou Creek. Although previous surveys suggested some impacts from PGDP operations (Birge et al. 1990), sampling conducted by ORNL has not substantiated this conclusion (Ryon 1994a,e). During the six surveys conducted by ORNL, a total of 40 species have been taken in this section of Little Bayou Creek, with no fewer than 20 species in any one sample. These surveys have always revealed a diverse fish community, with good representation of intolerant species and a range of trophic levels and feeding guilds. The high species richness and number of intolerant species in this latest sample supported the initial ORNL assessment of a healthy fish community at LUK 4.3. The qualitative sampling has demonstrated that the fish community in this section of Little Bayou Creek appears to be beyond the range of influence of the PGDP. Therefore, qualitative sampling was discontinued at this site in 1994, based on the 2-year sampling history at this site and the diversity represented by the latest sample.

\subsubsection{Discussion}

Data on the fish communities of Big Bayou Creek and Little Bayou Creek downstream of PGDP were compared to data from reference sites located on Big Bayou 

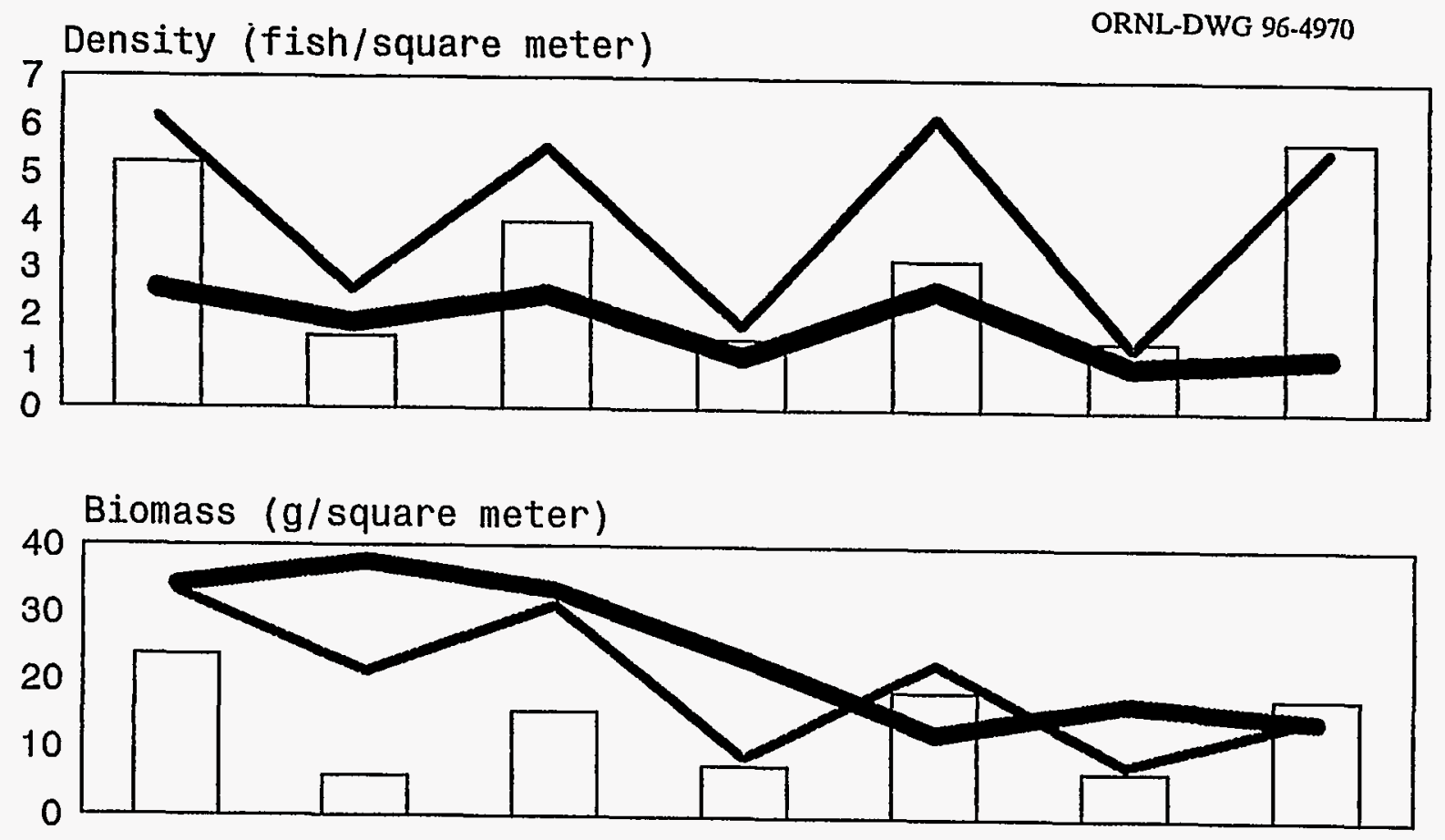

=BBK 9.1

$=$ BBK 10.0

$\square$ पAK 13.8

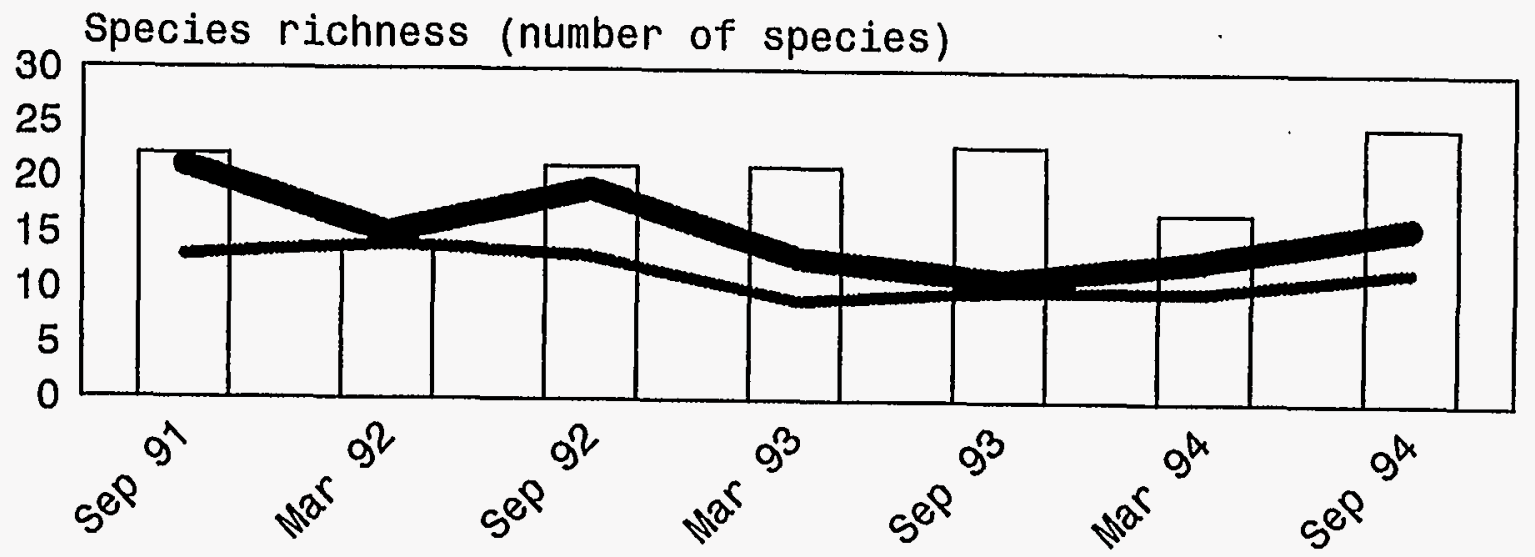

Fig. 5.1. Species richness, biomass, and density at Big Bayou Creek sites and reference. 
Creek above PGDP and on Massac Creek. These comparisons indicated a slight but noticeable degradation in the communities downstream of PGDP.

Data indicated that the effects on the fish community were greatest just downstream from PGDP at BBK 10.0. The fish community at this site had a low mean and total species richness in comparison with MAK 13.8. There were no sensitive species, while tolerant species were more abundant here than at the reference site. The number of benthic insectivores was low, although the number of species in other feeding guilds was similar to levels seen at MAK 13.8. Density at BBK 10.0 was similar to or higher than that at the reference site, with a correspondingly high biomass. Compared to sampling in 1991 and 1992 (Ryon 1904a), BBK 10.0 has experienced a slight decline in biomass (Fig. 5.1). Overall the fish community at BBK 10.0 has demonstrated shortcomings.

The fish community at BBK 9.1 showed signs of impact similar to the level seen at BBK 10.0. Mean and total species richness were lower than at MAK 13.8. Although there were fewer sensitive species and at lower densities at BBK 9.1 than at MAK 13.8, more sensitive species were found at BBK 9.1 than at BBK 10.0. The tolerant species were common and abundant. Density was less than or equal to that at MAK 13.8, and species richness were slightly increased (Fig. 5.1) from 1993.

The fish community at LUK 7.2 was similar to the BBK 12.5 reference, with perhaps some species deficiencies. The mean species richness values were similar to those of the reference site but with a noticeable decline in fall 1994. Biomass were lower than at BBK 12.5. Since 1991, species richness and biomass have increased slightly (Fig. 5.2). However, in the fall 1994 sample species richness declined to the lowest level seen in sampling at LUK 7.2 (Fig. 5.2). This precipitous decline was not seen in density or biomass values. During the fall sampling, a noticeable increase in sediment level was observed at LUK 7.2.

The downstream qualitative site, LUK 4.3, did not appear to be affected by plant operations. Species richness was higher (Fig. 5.3) than that found in earlier sampling (Ryon 1994a,e), particularly in terms of sensitive species. The community was well represented in all families and significant absences in feeding guilds were not demonstrated. The relative abundance and catch-per-effort data were the highest seen at this site (Fig. 5.3). Thus, the community at LUK 4.3 appeared to be minimally affected by PGDP operations. The increases seen at this site followed a period of high water in the 

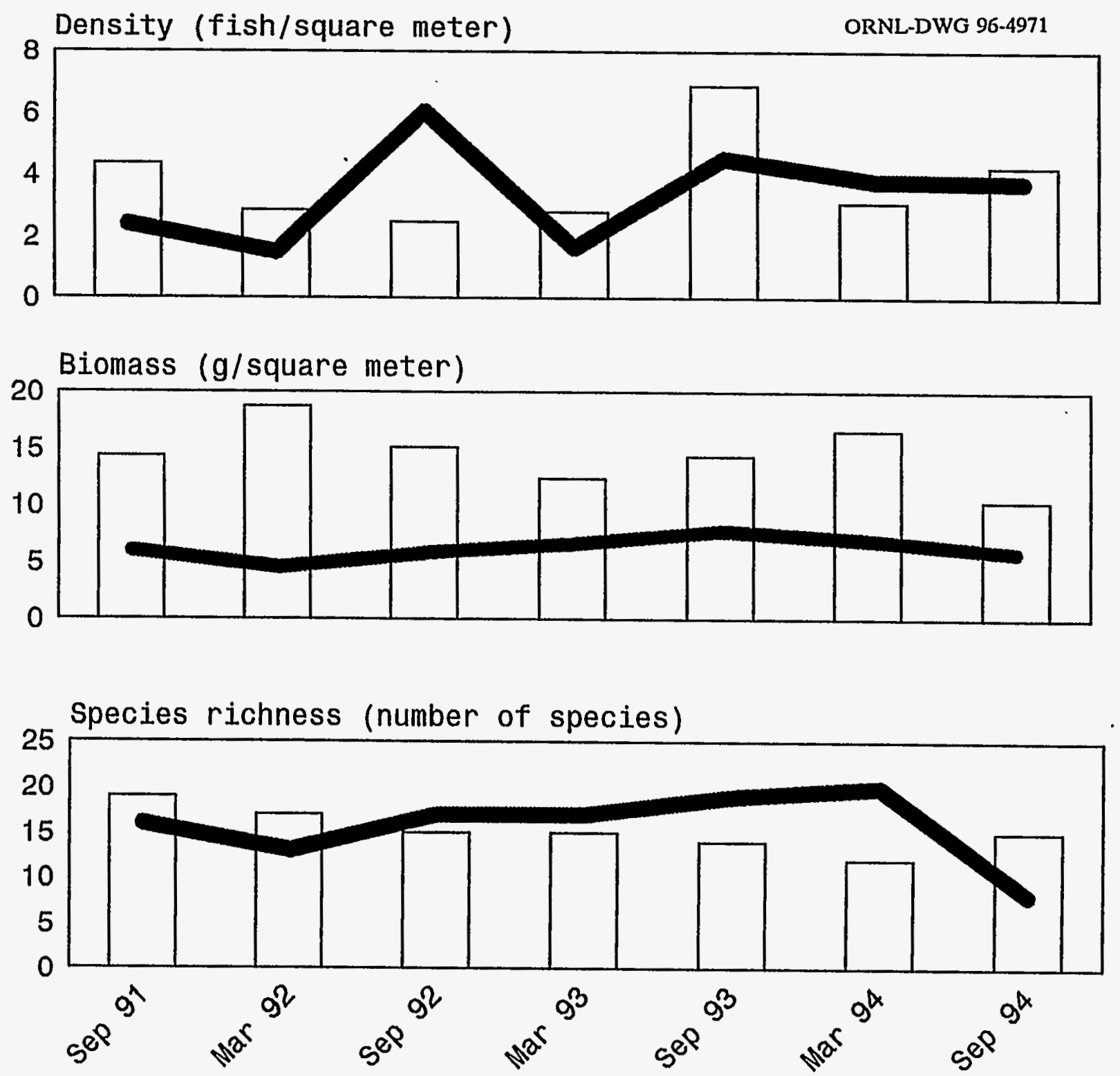

Fig. 5.2. Species richness, biomass, density at Little Bayou Creek site and reference. 

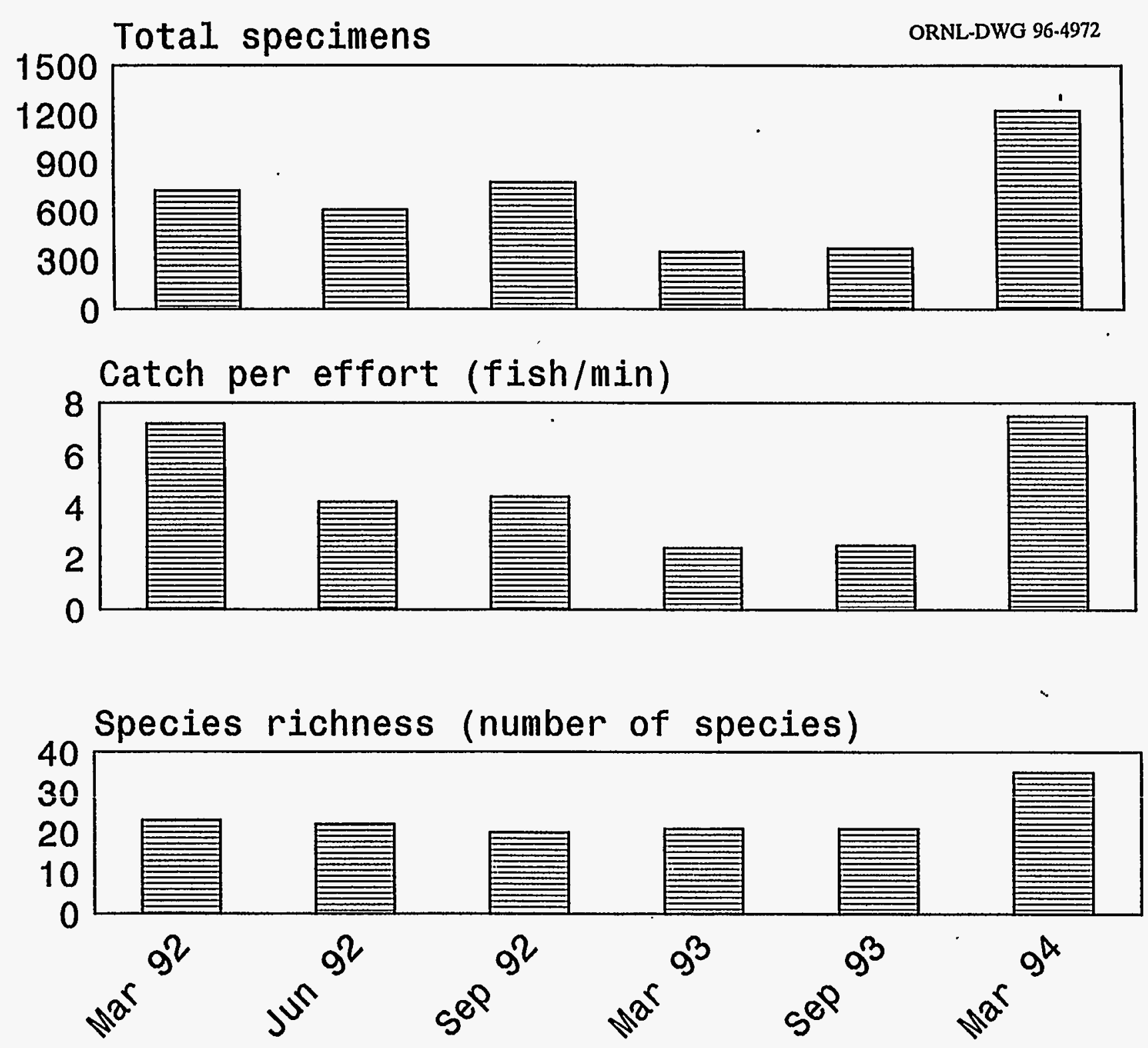

Fig. 5.3. Species richness, catch per effort, and total specimens at Little Bayou Creek qualitative site. 
Ohio River. The increases reflect the site's proximity to this species source area and suggest that the river has a greater influence than PGDP at this point in Little Bayou Creek.

Monitoring of the fish communities associated with PGDP streams indicated some depressed conditions but did not specifically identify causative agents. The impacts were limited to sites closest to the plant, which suggests that PGDP activities may be the cause. The low species richness and lack of sensitive species may be caused by poor water quality or may reflect degraded habitat conditions. Biomass and density respond quickly to improvements in degracied conditions and it will be important to follow changes in these parameters, particularly at the most stressed sites. Later, the return of sensitive species or changes in proportions of feeding guilds (e.g., an increase in benthic insectivores) would be another signal of improvement in water quality.

\subsection{BENTHIC MACROINVERTEBRATES (M. R. Smith)}

\subsubsection{Introduction}

Benthic macroinvertebrates are organisms which inhabit the bottom substrates of freshwater systems for at least part of their life cycle and include aquatic insects, mollusks, annelids, and crustaceans. Because these organisms exhibit a diversity of physiological and morphological attributes, the analysis of benthic macroinvertebrate community composition can be used to assess the impacts of anthropogenic stressors on aquatic systems (Pontasch and Cairns 1989).

The objectives of the benthic macroinvertebrate monitoring task were to (1) aid in evaluating the ecological health of two streams (Big Bayou Creek and Little Bayou Creek) that receive effluents from the PGDP and (2) to document any changes in macroinvertebrate community composition resulting from pollution abatement programs and/or changes in operations at PGDP.

Presented in this report are the results of analyses on samples taken from September 1991 to March 1994.

\subsubsection{Materials and Methods}

Benthic macroinvertebrate samples have been collected quarterly (March, June, September, and December) since September 1991 from three sites on Big Bayou Creek 
(BBK 9.1, BBK 10.0, and BBK 12.5) and one site each on Little Bayou Creek (LUK 7.2) and Massac Creek (MAK 13.8) (Figs. 2.1 and 2.2). Two sites, BBK 12.5 and MAK 13.8, served as reference sites; BBK 12.5 is located upstream of all PGDP discharges, while MAK 13.8 is located outside the PGDP boundary. Because riffle areas of streams generally possess the greatest variety of benthic organisms, including those considered to be sensitive to stress, samples were collected from riffles only. The locations of sampling sites were based not only on their proximity to major effluent discharges but also on the presence, similarity, and quality of riffle habitat.

At each site, three random samples were taken with a Surber sampler $\left(0.09 \mathrm{~m}^{2}\right)$ equipped with a 363- $\mu \mathrm{m}$ mesh net. Samples were placed in pre-labeled, polyurethanecoated, glass jars and preserved with $\sim 80 \%$ ethyl alcohol (ETOH). To prevent sample decomposition, the ETOH in each jar was replaced within 7 days of collection. Coincident with sample collection, water quality aspects (dissolved oxygen, conductivity, temperature, and $\mathrm{pH}$ ) were measured with a Horiba U-7 Water Quality Checker.

Selected physical attributes (distance from a permanent headstake at the base of the riffle, substrate size and embeddedness, flow rate, and water depth) were obtained for each sample prior to collection. A detailed description of procedures employed for site evaluation and sample coilection, storage, and maintenance can be found in Smith (1992).

Laboratory processing consisted of washing the samples in a U. S. Standard No. 60mesh (250- $\mu \mathrm{m}$ openings) sieve and placing small portions of the sample in a white, waterfilled tray for removal of organisms from the debris. This process was repeated until all organisms were removed from the sample. Organisms were then identified to the lowest practical taxon and enumerated. Details of laboratory sample piocessing are available in Wojtowicz and Smith (1992). Samples from the four sampling periods of the first sampling year (September 1991 to August 1992) were processed to provide baseline information. Samples obtained during March and September of the following sampling years were processed, with samples from June and December being archived according to proscribed procedures (Smith 1992). These samples will not be processed unless further resolution of results are needed.

Data analysis was performed with the aid of Statistical Analysis System software and procedures (SAS 1985a, 1985b). Statistical analyses consisted of both descriptive and parametric techniques. A two-way ANOVA with site and sampling date as the main 
effects was performed on density, total richness, and EPT richness (the total number of Ephemeroptera, Plecoptera, and Trichoptera taxa), with $p \leq 0.05$ being considered statistically significant. Prior to performing the ANOVAs, values for each response were transformed [i.e. $\log _{10}(X+1)$ for density values, and square root of $\mathrm{X}$ for both total and EPT richness values, where $\mathrm{X}=$ the individual observed values for density, taxonomic richness, and EPT richness; Elliot 1977]. Due to the considerable temporal variation that was obvious from the mean values and the outcome of the ANOVAs (i.e., significant interaction between site and sampling date), results of the ANOVAs provided little useful information on significant spatial or temporal trends, and thus will not be discussed further. Descriptive techniques included the determination of mean values for density, total richness, and EPT richness for each site and date.

\section{2 .3 Results}

\subsubsection{Taxonomic composition}

A checklist of benthic macroinvertebrate taxa collected at each site from September 1991 through March 1994 is presented in Appendix E, Table E.1. Taxonomic composition at all sites was generally similar, with most of the major taxonomic groups having one or more representatives at each site. Big Bayou Creek sites generally had a similar number of Ephemeroptera (mayfly) taxa present throughout each year, while Little Bayou Creek and Massac Creek had fewer Ephemeroptera taxa. Taxa such as Baetis sp. (Baetidae) and Caenis sp. (Caenidae) were fairly ubiquitous, being present at all sites throughout this period. Oligochaetes (aquatic worms) were present at all sites, as were the four major groups representing the midge family, Chironomidae (Chironomini, Orthocladiinae, Tanypodinae, and Tanytarsini).

The order Trichoptera (caddisflies) also had a fairly similar number of taxa both spatially and temporally at all sites. The caddisfly family Hydropsychidae was represented by two genera, Cheumaiopsyche and Hydropsyche, and while Cheumatopsyche were collected at all sites during the three years included in this report, Hydropsyche were not collected at BBK 10.0.

More taxa of the order Plecoptera (stone flies) were present at the two reference sites (BBK 12.5 and MAK 13.8) than at the remaining sites, however, their occurrence 
varied temporally at $\mathrm{BBK} 12.5$ and $\mathrm{MAK} 13.8$, with no taxon being collected consistently at these sites.

Two genera in the order Coleoptera (beetles) were generally present at all sites. Berosus (Hydrophilidae), were present at all sites, while Stenelmis (Elmidae) were collected at all sites during sampling years one (September 1991-August 1992) and three (September 1993-March 1994), but were absent from samples collected at BBK 10.0, BBK 12.5, and MAK 13.8 during sampling year two (September 1992-August 1993).

\subsubsection{Abundance}

Total density. Mean densities (number of organisms $/ 0.1 \mathrm{~m}^{2}$ ) for each site during each sampling period from September 1991 to March 1994 are presented in Fig. 5.4. Densities tended to be highest at BBK 9.1 and BBK 10.0, with these sites exhibiting the two highest densities on five of the eight sampling dates (September 1991, December 1991, March 1992, September 1992, and September 1993). Exceṕt for MAK 13.8, all sites exhibited increases in density in March 1992, particularly BBK 9.1 and BBK 10.0, where average densities were 7306.5 and 6866.6 organisms $/ 0.1 \mathrm{~m}^{2}$, respectively. In contrast to March 1992, densities at BBK 9.1 and BBK 10.0 were at their lowest in March 1993, and were only slightly higher in March 1994 (Fig. 5.4).

The reference site on Big Bayou Creek (BBK 12.5) also exhibited a substantial increase in density in March 1992, but unlike the sites downstream (BBK 10.0 and BBK 9.1) the trend of increasing density at BBK 12.5 continued into the following sampling period (June 1992) (Fig. 5.4). Density values decreased substantially at BBK 12.5 in September 1992, and then exhibited slight increases in each of the following sampling periods.

LUK 7.2 exhibited fairly low densities throughout the study period, with the highest values occurring in March 1992 (1205 organisms/0.1 $\mathrm{m}^{2}$ ). Densities declined in the following sampling period (June 1992), but remained higher than in 1991 throughout the remainder of the study, and were comparable to those observed at BBK 12.5 for the balance of the study period.

Densities at the reference site, MAK 13.8, were below 200 organisms $/ 0.1 \mathrm{~m}^{2}$ on four sampling dates (December 1992, March 1992, March 1993, and March 1994). The lowest density ( 5.0 organisms $/ 0.1 \mathrm{~m}^{2}$ ) was observed in March 1993 when densities at the other 


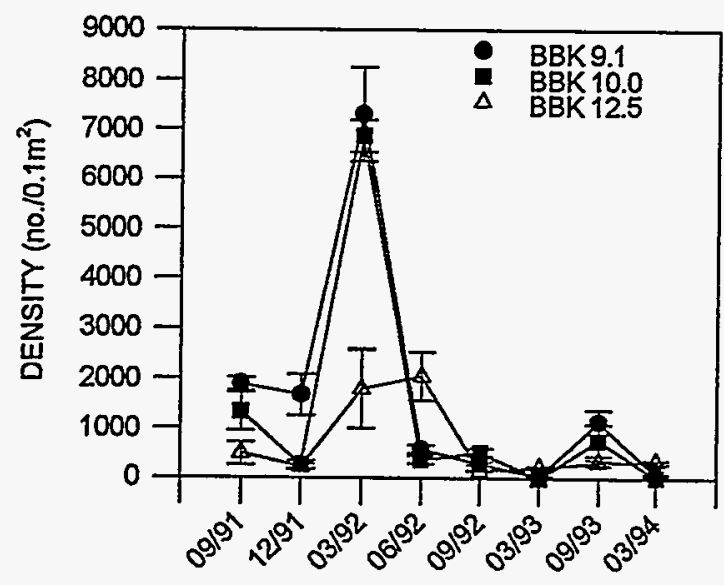

ORNL-DWG 96-4973
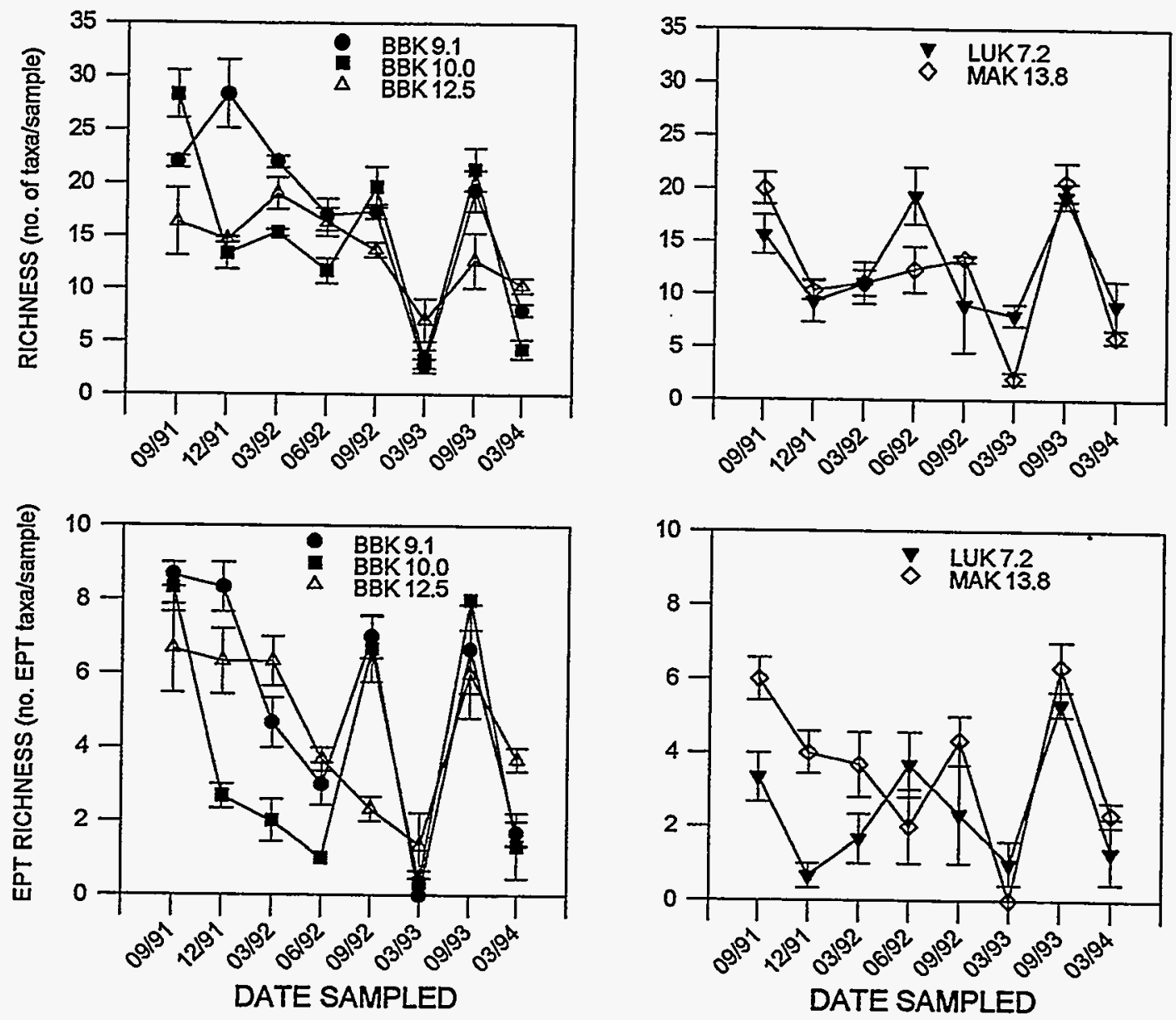

Fig. 5.4. Mean total density, mean total tichness, and mean richness of the Ephemeroptera, Plecoptera, and Trichoptera (EPT richness) of the benthic macroinvertebrate communities in Big Bayou Creek, Little Bayou Creek, and Massac Creek, September 1991 to March 1994. BBK = Big Bayou Creek kilometer; LUK = Little Bayou Creek kilometer; MAK = Massac Creek kilometer. 
four sites were also at their lowest, while the highest density occurred during the sampling period that followed (448.2 organisms/0.1 $\mathrm{m}^{2}$ in September 1993). Densities at this site remained low and fairly stable throughout the entire study period.

Relative abundance. The percent composition of five major categories of macroinvertebrates at each study site is presented in Fig. 5.5. As would be expected, the composition of the benthic macroinvertebrate community at each of the five sites exhibited considerable temporal variability.

The EPT category is comprised of aquatic insects in the orders Ephemeroptera (mayflies), Plecoptera (stone flies), and Trichoptera (caddisflies), which are generally considered to be pollution intolerant (e.g., Lenat 1988). Comparing the relative abundance of pollution sensitive organisms to those taxa considered to be relatively tolerant (e.g., Chironomidae, Planariidae, and Oligochaeta) can be helpful in assessing the relative health of a site. Planariidae were numerically prominent at all Big Bayou Creek sites on several sampling dates, frequently exceeding $20 \%$ of the mean density. In contrast, planariians were not collected at the other two sites (LUK 7.3 and MAK 13.8) during any sampling period (Fig. 5.5).

At BBK 9.1, the downstream most site on Big Bayou Creek, Chironomidae were the numerically dominant taxa in four sampling periods (December 1991, September 1992, March 1993, and March 1994), and while other organisms comprised at least $30 \%$ of the total present on three of these dates (December 1991, September 1992, and March 1994), in March 1993, chironomids composed over 94\% of all organisms present. EPT taxa were numerically dominant in two sampling periods (September 1991 and September 1993), while Oligochaetes and Planariidae were the numerically dominant taxa in one sampling period each ( $-20 \%$ in March 1992 and $-35 \%$ in June 1992 respectively). Of the taxa categorized in the "other taxa" no individual taxon or major taxonomic group exceeded $12 \%$ of the total.

Although the relative amounts differed, the patterns of numerical dominance at BBK 10.0 and BBK 9.1 were very similar. The taxa numerically dominating differed on only one date (December 1991), when the Planariidae were the most abundant taxa at BBK 10.0 (39.7\%), and the Chironomidae were the most abundant at BBK 9.1 (34.1\%). Coleoptera were present in higher numbers at this site, when compared to BBK 9.1, with densities between $5 \%$ and $10 \%$ on three sampling periods (December 1991, September 

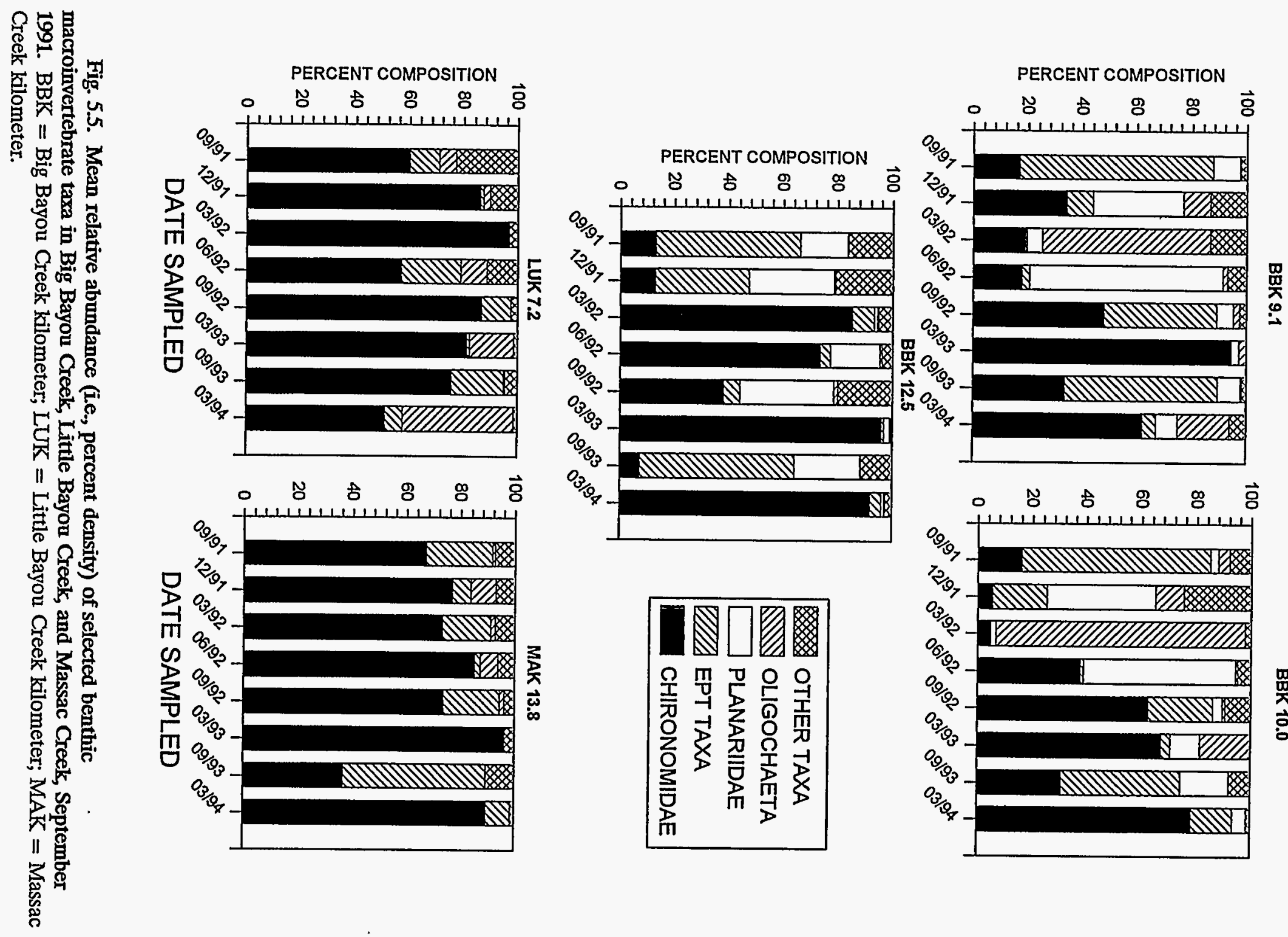
1992, and September 1993). As at BBK 9.1, none of the "other taxa" present composed over $10 \%$ of the total number of organisms.

Chironomidae (midges) were the most numerically abundant taxa at BBK 12.5, the reference site on Big Bayou Creek, on five of the eight sampling dates (March 1992, June 1992, September 1992, March 1993, and March 1994), with the remaining three dates numerically dominated by EPT taxa. During each of the three March sampling periods, chironomids made up over $85 \%$ of the total number of organisms collected at this site. Coleoptera taxa contributed over $10 \%$ of total organisms/sample during the three September sampling periods (September 1991, September 1992, and September 1993) but were present in low numbers on all other sampling dates.

The site on Little Bayou Creek (LUK 7.2) was numerically dominated by Chironomidae throughout the study period, with percentages never falling below $50 \%$. EPT taxa never exceeded $22 \%$ of total organisms, while Planariidae were absent on all but one date (June 1992), when they made up $0.2 \%$ of the total number of organisms collected. Oligochaetes were also present in low numbers on most dates, with contributions exceeding 10\% on only two dates (March 1993 and March 1994). Coleoptera comprised $15.6 \%$ of the total number of organisms present during the September 1991 sampling period, but in subsequent periods never exceeded 3\% of total organisms. With few exceptions, most taxa categorized with the "other taxa" generally comprised much less than $5 \%$ of the total density.

Chironomidae were the numerically dominant taxonomic group at MAK 13.8, the reference site on Massac Creek on all but one sampling date. EPT taxa were the numerically dominant organisms on one sampling date (September 1993), when they accounted for $52.9 \%$ of the total number of organisms present, and except for June 1992 and March 1993, they comprised from 6.8 to $52.9 \%$ of the total. Oligochaetes were minor contributors to overall densities at this site, with the highest percentage being $9.2 \%$ in December 1991.

\subsubsection{Richness}

Total Richness. Total richness generally exhibited temporal variations at most sites, with some seasonal trends apparently developing after September 1992 (Fig. 5.4). 
BBK 9.1 had the highest mean number of taxa/0.1 $\mathrm{m}^{2}$ of all sites on two sampling dates (December 1991 and March 1992). Richness values during the September sampling periods were stable from year to year, with a difference of only 1.3 between the low and high mean values. This site exhibited a substantial reduction in richness from September 1992 to March 1993 (6.5X decrease), and a much lesser drop from September 1993 to March of 1994 (2.4X decrease).

Throughout the study, BBK 10.0 exhibited the highest total richness values of any site in each September sampling period, with the number of taxa/sample varying by only a factor of 1.4. A notable reduction in taxa/0.1 $\mathrm{m}^{2}$ was observed from September to March of both 1993 and 1994, as was the case at BBK 9.1.

Although the reference site, BBK 12.5 , had the highest nuinber of taxa/0.1 $\mathrm{m}^{2}$ on only one sampling date (March 1994), total richness at this site did not exhibit the level of fluctuation observed at the other Big Bayou Creek sites. Lowest total richness was observed in March 1993 (7.0 taxa/0.1 m²), while highest richness values occurred in March of 1992 (19.0 taxa/0.1 $\mathrm{m}^{2}$ ), a difference of only 2.7X. In contrast, BBK 9.1 exhibited a 10.6X difference between highest (28.3 in December 1991) and lowest total richness (2.67 in March 1993), and the difference between highest (28.3 in September 1991) and lowest total richness (3.33 in March 1993) at BBK 10.0 was 8.5X.

Total richness values at LUK 7.2 were more stable than at any other site in the study, with only a $2.4 \mathrm{X}$ difference between the highest (19.3 in both June 1992 and September 1993) and lowest total richness value (8.0 in March 1993). However, total richness values were also among the lowest on many sampling dates (September 1991, December 1991, March 1992, and September 1992).

MAK 13.8 exhibited a moderate amount of seasonal fluctuation prior to March 1993. Richness values at this site were generally among the lowest recorded among all sites and sampling dates. Richness levels were highest at this site during the September sampling dates, while richness numbers during the March sampling periods were generally among the lowest levels observed at any site (Fig. 5.4).

EPT Richness. Overall trends in EPT richness were similar to those seen in total richness at most sites, with numbers generally highest in September and lowest in March of each year (Fig. 5.4). With the exception of LUK 7.2, all sites experienced their lowest numbers of EPT taxa in March 1993 (ranging from 0 taxa/0.1 $\mathrm{m}^{2}$ at BBK 9.1 and 
MAK 13.8 to $1.33 / 0.1 \mathrm{~m}^{2}$ at BBK 12.5). EPT richness at LUK 7.2 was the lowest in December $1991\left(0.67\right.$ taxa/0.1 $\left.\mathrm{m}^{2}\right)$.

BBK 9.1 had the greatest number of EPT taxa $/ 0.1 \mathrm{~m}^{2}$ on three of the eight sampling dates (September 1991, December 1991, and September 1992). As was the case with total richness, EPT richness remained fairly stable across the September sampling periods, while being much more variable across the March sampling periods.

BBK 10.0 exhibited seasonal patterns similar to BBK 9.1, in that EPT richness was generally highest in September and lowest in March of each year. BBK 10.0 had the highest numbers of EPT taxa/0.1 $\mathrm{m}^{2}$ of any site in September 1993, although numbers in the following sampling period were among the lowest of any site.

EPT taxa values at BBK 12.5 appeared to vary more from year to year than seasonally. For example, the difference in EPT taxa/0.1 $\mathrm{m}^{2}$ between September 1991 and March 1992 was 0.4 taxa/0.1 $\mathrm{m}^{2}$ and the difference in EPT taxa/0.1 $\mathrm{m}^{2}$ between September 1992 and March 1993 was 1.0 taxa/0.1 $\mathrm{m}^{2}$, while the difference from September 1991 to September 1992 was 4.3 taxa/0.1 $\mathrm{m}^{2}$, and from March 1991 to March 1992 was 5.0. BBK 12.5 had the highest number of EPT taxa/0.1 $\mathrm{m}^{2}$, of any site in March 1992, March 1993, and March 1994.

The number of EPT taxa/0.1 $\mathrm{m}^{2}$ was generally low at LUK. 7.2 relative to the other sites, with this site having either the lowest number of EPT taxa (September 1991, December 1991, and March 1992) or sharing the lowest number with another site (September 1992 with BBK 12.5 and March 1994 with BBK 10.0) on five of the eight sampling dates.

MAK 13.8 experienced seasonal fluctuations in EPT taxa numbers, with the greatest number of taxa being found in September of each year. Levels generally fell within the ranges observed at the other sites in each sampling period, except in March 1993 when no EPT taxa were collected.

\subsubsection{Discussion}

Densities were generally higher during most of the study period at BBK 9.1 and BBK 10.0, when compared to the reference sites, suggesting nutrient enrichment. In addition, the substantial increase in density, which occurred at both sites in March 1992, suggests a substantial increase in nutrient availability occurring from December 1991 to 
March 1992. Both BBK 9.1 and BBK 10.0 had relatively high total and EPT richness levels compared to the other sites, and although there was more seasonal fluctuation occurring at these sites relative to the reference sites utilized in this study, the benthic macroinvertebrate communities at both BBK 9.1 and BBK 10.0 appear to be relatively stable.

Conversely, LUK 7.2 exhibited relatively low densities $/ 0.1 \mathrm{~m}^{2}$ and EPT richness throughout the study. The Chironomidae constituted the majority of organisms present, and as noted by Hynes (1974), some taxa within this group are able to exploit areas unsuitable for organisms sensitive to adverse changes in water quality. These results strongly suggest that this site is impacted, which in a previous report (Kszos et al. 1994) was attributed to the effluents originating at outfall 011 . However, a possible factor contributing to the depauperate community at this site may be a lack of suitable substrate. Bedrock was the primary substrate occurring at this site, with gravel and rubble being sparsely distributed. Substrate is one of the primary factors determining the population, composition, structure, and distribution of aquatic insects (e.g., Hynes 1970, Minshall 1984). The bedrock that predominated at this site may have had some effect on both the numbers and diversity of organisms present.

Taxonomic composition at the reference site on Massac Creek (MAK 13.8) was similar to that of LUK 7.2, with Chironomidae taxa being the most prevalent on seven of eight sampling dates. Densities tended to be among the lowest observed at any site throughout the study, however, EPT and total richness values were not substantially lower than those observed at the other reference site (BBK 12.5) on any sampling date. The persistently low densities and predominance of chironomids in combination with a relatively diverse benthic and fish community (see Sect. 5.1) suggest that this site is probably moderately impacted but is still able to support a relatively healthy fish community.

Finally, a substantial reduction in density $/ 0.1 \mathrm{~m}^{2}$, total richness, and EPT richness occurred at most sites included in this study in March 1993. A precipitation event, including both rain (1.10 inches) and snow (7.2 inches), occurred on February 25, 1993, and is a possible contributing factor to the observed decreases. This reduction was ephemeral, as all parameters had returned to near pre-March 1993 levels by the following sampling period, indicating no long-term impacts to the study sites. 


\subsubsection{Summary and Conclusions}

Analysis of benthic macroinvertebrate data for the Big Bayou Creek sites indicates that, although there are differences between the three sampling locations on this stream, there is no strong evidence for a significant impact at any site. High densities at both BBK 9.1 and BBK 10.0, relative to the reference sites, suggest the presence of an organically enriched environment.

The site located on Little Bayou Creek (LUK 7.2) appears to be moderately impacted by a toxicant, as evidenced by low density and richness values. The suspected source of this toxicant has been identified as outfall 011 . However, the presence of poor habitat at this site cannot be discounted.

Although MAK 13.8 does not appear to support large numbers of benthic macroinvertebrates, the relatively diverse community present validates its usefulness as a reference site. 


\section{REFERENCES}

Ashwood, T. L. (ed.). 1994. Eighth Annual Report on the ORNL Biological Monitoring and Abatement Program. ORNL/TM-12767. Oak Ridge National Laboratory, Oak Ridge, Tenn. (draft report).

Becker, G. C. 1983. Fishes of Wisconsin. University of Wisconsin Press, Madison, Wisconsin. $1052 \mathrm{pp}$.

Birge, W. J., D. P. Price, D. P. Keogh, J. A. Zuiderveen, and M. D. Kercher. 1992. Biological Monitoring Program for the Paducah Gaseous Diffusion Plant. Annual Report for Study Period, October 1990 through March 31, 1992. University of Kentucky, Lexington, Kentucky. 183 pp plus appendixes.

Birge, W. J., T. M. Short, and J. E. Lauth. 1990. Biological monitoring program for the Paducah Gaseous Diffusion Plant: Three-year draft report. University of Kentucky, Lexington, Kentucky.

Bowen, H. J. M. 1979. Environmental Chemistry of the Elements. Academic Press, London, U.K. 333 pp.

Burr, B. M. and M. L. Warren. 1986. A Distributional Atlas of Kentucky Fishes.

Kentucky Nature Preserves Commission, Scientific and Technical Series Number 4, Frankfort, Kentucky.

Carle, F. L., and M. R. Strub. 1978. A new method for estimating population size from removal data. Biometrics 34:621-630.

CH2M Hill. 1991. Results of the Site Investigation, Phase I, at the Paducah Gaseous Diffusion Plant, Kentucky, KY/ER-4, Paducah Gaseous Diffusion Plant, Paducah Kentucky.

Cross, F. B., and J. T. Collins. 1975. Fishes in Kansas. The University of Kansas Museum of Natural History and State Biological Survey, Lawrence, Kansas. D'Appolonia. June 1983. Final Report, Groundwater Monitoring Program, PGDP, Paducah, Kentucky, Project 82-1397, ESO 15603, Paducah Gaseous Diffusion Plant, Paducah, Kentucky. 
Elliot, J. M. 1977. Some methods for the statistical analysis of benthic invertebrate samples. Science Publication No. 25. Freshwater Biological Association, Ambleside, England.

EPA (Environmental Protection Agency 1980). Interim methods for the sampling and analysis of priority pollutants in sediments and fish tissues. EPA 600/4-81-055. Environmental Monitoring and Support Laboratory, U. S. Environmental Protection Agency, Cincinnati, Ohio. 60 pp.

EPA (Environmental Protection Agency) 1984. Extraction and analysis of priority pollutants in biological tissue, method PPB 12/83. EPA 600/4-81-055. Environmental Services Division, Region IV, U. S. Environmental Protection Agency, Athens, Georgia. Mimeo, $10 \mathrm{pp}$.

EPA (Environmental Protection Agency). 1990. Region IV Toxic Substances Spreadsheet. U.S. Environmental Protection Agency, Region IV, Atlanta, Georgia. July 1990. Unpublished memeo, $8 \mathrm{pp}$.

Etnier, D. A., and W. C. Starnes. 1993. The Fishes of Tennessee. The University of Tennessee Press, Knoxville, Tennessee.

Food and Drug Administration (FDA). 1984a. Polychlorinated biphenyls in fish and shellfish: reduction of tolerances, Final Decision. Fed. Regist. 49: 21514-21520.

Food and Drug Administration (FDA). 1984b. Action level for methylmercury in fish. Fed. Regist. 49: 45663.

Garman, G. C., and T. F. Waters. 1983. Use of the size-frequency (Hynes) methods to estimate annual production of a stream fish population. Can. J. Fish. Manag. 6:176-182.

GeoTrans, Inc. 1990. Numerical Modeling of Groundwater Flow at the Paducah Gaseous Diffusion Plant, Phase I and II. Sterling, Kentucky.

Hynes, H. B. N. 1970. The Ecology of Running Waters. University of Toronto Press. Toronto, Canada.

Hynes, H. B. N. 1974. The Biology of Polluted Waters. University of Toronto Press. Toronto, Canada.

Karr, J. R., K D. Fausch. P. L. Angermeier, P. R. Yant, and I. J. Schlosser. 1986. Assessing biological integrity in running waters: A method and its rationale. Illinois Natural History Survey Special Publication 5. 
Karr, J. R. 1987. Biological monitoring and assessment: a conceptual framework. Environ. Manag. 11:249-256.

Kornegay, F. C., D. C. West, W. D. Malis, and C. M. Horak. 1993. Paducah Gaseous Diffusion Report Environmental Report for 1992. ES/ESH-36 KY/E-164.

Environmental, Safety, and Health Compliance and Environmental Management Staffs, Martin Marietta Energy Systems, Inc., Oak Ridge, Tennessee, and Paducah, Kentucky.

Kornegay, F. C, D. C. West, T. G. Jett, and M. F. Williams. 1992. Paducah Gaseous Diffusion Plant Environmental Report for 1991. ES/ESH-22/V3. Environmental, Safety, and Health Compliance and Environmental Staffs, Martin Marietta Energy Systems., Oak Ridgs, Tennessee, and Paducah, Kentucky.

Kszos, L. A., A. J. Stewart, L. F. Wicker, L. E. Roberson, and T. L. Phipps. 1989. Environmental Sciences Division Toxicology Laboratory Quality Assurance Program. QAP-X-89-ES-002. Oak Ridge National Laboratory, Oak Ridge, Tennessee.

Kszos, L. A., R. L. Hinzman, M. J. Peterson, M. G. Ryon, J. G. Smith, and

G. R. Southworth. 1994. Report on the Biological Monituring Program at Paducah Gaseous Diffusion Plant, December 1992 to December 1993. ORNL/TM-12716. Oak Ridge National Laboratory. Oak Ridge, Tenn.

Kszos, L. A., R. L. Hinzman, T. G. Jett, M. J. Peterson, M. G. Ryon, J. G. Smith, and G. R. Southworth. 1994. Report on the Biological Monitoring Program at Paducah Gaseous Diffusion Plant, December 1990 to November 1992. ORNL/TM-12338. Oak Ridge National Laboratory. Oak Ridge, Tenn.

Lee, D. S., C. R. Gilbert, C. H. Hocutt, R. E. Jenkins, D. E. McAllister, and J. R. Stauffer, Jr. 1980. Atlas of North American Freshwater Fishes. North Carolina Biological Survey Publication 1980-12, North Carolina State Museum of Natural History, North Carolina.

Lenat, D. R. 1988. Water quality assessment of streams using a qualitative collection method for benthic macroinvertebrates. J. North Am. Benthol. Soc. 7:222-233. Leonard, P. M., and D. J. Orth. 1986. Application and testing of an Index of Biotic Integrity in small, coldwater streams. Trans. Am. Fish. Soc. 115:401-414. 
Loar, J. M. 1992. Fishes. In Loar, J. M. et al. First Report on the Oak Ridge Y-12 Plant Biological Monitoring and Abatement Program for East Fork Poplar Creek. Y/TS-886. Oak Ridge Y-12 Plant. Oak Ridge, Tenn.

Loar, J. M., S. M. Adams, L. J. Allison, J. M. Giddings, J. F. McCarthy, G. R. Southworth, J. G. Smith, and A. J. Stewart. 1989. The Oak Ridge Y-12 Plant Biological Monitoring and Abatement Program for East Fork Poplar Creek. ORNL/TM-10265. Oak Ridge National Laboratory. Oak Ridge, Tenn.

Loar, J. M., S. M. Adams, L. J. Allison, B. G. Blaylock, H. L. Boston, M. A. Huston, B. L. Kimmel, J. T. Kitchings, C. R. Olsen, J. G. Smith, G. R. Southworth, A. J. Stewart, B. T. Walton. 1991. Oak Ridge National Laboratory Biological Monitoring and Abatement Program for White Oak Creek. Watershed and the Clinch River. ORNL/TM-10370. Oak Ridge National Laboratory. Oak Ridge, Tenn. Loar, J. M., S. M. Adams, L. A. Kszos, M. G. Ryon, J. G. Smith, G. R. Southworth, A. J. Stewart. 1992. Oak Ridge Gaseous Diffusion Plant Biological Monitoring and Abatement Program for Mitchell Branch. ORNL/TM-11965. Oak Ridge National Laboratory. Oak Ridge, Tenn.

Lowe T. P., T. W. May, W. G. Brumbaugh, and D. A. Kane. 1985. National Contaminant Biomonitoring Program: Concentrations of seven elements in freshwater fish, 1978-1981. Arch. Environ. Contam. Toxicol. 14:363-388.

Mid-America Fish Contaminants Group. 1989. Extraction and analysis of acid stable organochlorine pesticides/PCBs in biological tissue. Unpublished mimeo, $6 \mathrm{pp}$. Miller, D. L., P. M. Leonard, R. M. Hughes, J. R. Karr, P. B. Moyle, L. H. Schrader, B. A. Thompson, R. A. Daniels, K. D. Fausch, G. A. Fitzhugh, J. R. Gammon, D. B. Halliwell, P. L. Angermeier, and D. J. Orth. 1988. Regional application of an Index of Biotic Integrity for use in water resource management. Fisheries 13(5):12-20.

Minshall, G. W. 1984. Aquatic insect-substratum relationships, pp. 358-400. In V. H. Resh and D. M. Rosenberg (eds.), The Ecology of Aquatic Insects. Praeger Publishers, New York. 
NCRP (National Council on Radiation Protection and Measurements). 1984. Radiological Assessment: Predicting the Transport, Bioaccumulation, and Uptake by Man of Radionuclides Released to the Environment. National Council on Radiation Protection and Measurements, Bethesda, MD. 300 pp.

Norusis, M. J. 1993. SPSS: SPSS for Windows, Base System User's Guide, Release 6.0. SPSS Inc. Chicago, Illinois.

Oakes, T. W., D. J. Ashburn, and F. M. O'Hara. 1987. Environmental Surveillance of the U.S. Department of Energy Paducah Reservation and Surrounding Environs During 1986. ES/E3H-1/N3, Paducah, Kentucky.

Ohio, EPA (Environmental Protection Agency). 1987. Biological Criteria for the Protection of Aquatic Life: Volume III. Standardized Biological Field Sampling and Laboratory Methods for Assessing Fish and Microinvertebrate Community. Ohio Environmental Protection Agency, Division of Water Quality Monitoring and Assessment, Columbus, Ohio.

Ohio, EPA (Environmental Protection Agency). 1988. Biological Criteria for the

Protection of Aquatic Life: Volume II. User's Manual for Biological Field Assessment of Ohio Surface Streams. Ohio Environmental Protection Agency, Division of Water Quality Monitoring and Assessment, Columbus, Ohio.

Olive, W. W. 1980. Geologic Maps of the Jackson Purchase Region, Kentucky. U.S. Geological Survey Miscellaneous Investigations Series, Map I-1217. U.S. Geological Survey, Reston, Virginia.

Omerik, J. M. 1987. Annuals of the Association of American Geographers. Ecoregions of the Conterminous United States. 77:118-125.

Pflieger, W. L. 1975. The Fishes of Missouri. Missouri Department of Conservation, Western Publishing Co., Missouri.

Pontasch, K. W., and J. Cairns, Jr. 1989. Establishing and maintaining laboratory-based microcosms of riffle insect communities: their potential for multispecies toxicity tests. Hydrobiologia 175:49-60.

Railsback, S. F., B. D. Holcomb, and M. G. Ryon. 1989. A Computer Program for Estimating Fish Population Sizes and Annual Productions Raters. ORNL/TM-11061. Oak Ridge National Laboratory, Oak Ridge, Tenn. 
Robbins, C. R., R. M. Bailey, C. E. Bond, J. R. Brooker, E. A. Lachner, R. N. Lea, and W. B. Scott. 1991. Common and Scientific Names of Fishes of the United States and Canada. 5th Edition. American Fisheries Society Spec. Pub. 20. Bethesda, MD. Robison, H. W. and T. M. Buchanan. 1988. Fishes of Arkansas. University of Arkansas Press.

Ryon, M. G. 1992a. Fishes. In M. G. Ryon et al. 1992. Ecological Effects of Contaminants in McCoy Branch, 1989-1990. ORNL/TM-11926. Oak Ridge National Laboratory. Oak Ridge, Tenn.

Ryon, M. G. 1992b. Biological Monitoring and Abatement Programs: Fiș community studies project, Quality Assurance Plan and Standard Operating Procedures. ORNL/FPO-QAP-X-90-ES-067. Oak Ridge National Laboratory, Oak Ridge, Tennessee.

Ryon, M. G. 1992c. Fishes. In J. M. Loar et al. 1992. First Annual Report on the Biological Monitoring and Abatement Program at Oak Ridge National Laboratory. ORNL/TM-10399. Oak Ridge National Laboratory. Oak Ridge, Tenn.

Ryon, M. G. 1993a. Fishes. In L. A. Kszos et al. 1993 Biological Monitoring and Abatement Program for the Oak Ridge K-25 Site. K/EM-24/R2. Oak Ridge National Laboratory. Oak Ridge, Tenn.

Ryon, M. G. 1993b. Fishes. In J. G. Smith et al. 1993. First Report on the Oak Ridge K-25 Site Biological Monitoring and Abatement Program for Mitchell Branch. ORNL/TM-11073. Oak Ridge National Laboratory. Oak Ridge, Tenn.

Ryon, M. G. 1994a. Fishes. In L. A. Kszos et al. Report on the Biological Monitoring Program at Paducak Gaseous Diffusion Plant, December 1990 to November 1992. 1994. ORNL/TM-12338. Oak Ridge National Laboratory. Oak Ridge, Tenn.

Ryon, M. G: 1994b. Fishes. In J. G. Smith et al. Second Report on the Oak Ridge K25 Site Biological Monitoring and Abatement Program for Mitchell Branch. 1994. ORNL/TM-12150. Oak Ridge National Laboratory. Oak Ridge, Tenn.

Ryon, M. G. 1994c. Fishes. In J. M. Loar et al. 1994. Fourth Report on the Oak Ridge National Laboratory Biological Monitoring and Abatement Program for White Oak Creek Watershed and the Clinch River. ORNL/TM-11544. Oak Ridge National Laboratory. Oak Ridge, Tenn. 
Ryon, M. G. 1994d. Fishes. In J. M. Loar et al. 1994. Third Report on the Oak Ridge National Laboratory Biological Monitoring and Abatement Program for White Oak Creek Watershed and the Clinch River. ORNL/TM-11358. Oak Ridge National Laboratory. Oak Ridge, Tenn.

Ryon, M. G. 1994e. Fishes. In L. A. Kszos et al. Report on the Biological Monitoring Program at Paducah Gaseous Diffusion Plant, December 1992 to November 1993. ORNL/TM-12716. Oak Ridge National Laboratory. Oak Ridge, Tenn.

SAS Institute, Inc. 1985a. SAS User's Guide: Basics, 1985 ed., SAS Institute, Inc., Cary, North Carolina.

SAS Institute, Inc. 1985b. SAS User's Guide: Statistics, Version 5 Edition. SAS Institute, Inc., Cary, North Carolina.

Smith, J. G. 1992. Biological Monitoring and Abatement Program (BMAP) Benthic Macroinvertebrate Monitoring Project Sample Collection and Storage QA Plan. QAP-X-90-ES-068. Oak Ridge National Laboratory, Oak Ridge, Tenn.

Smith, P. W. 1979. The Fishes of Mlinois. University of Mllinois Press, Urbana, Mllinois.

Sokal, R. R., and F. J. Rohlf. 1981. Biometry. W. H. Freman and Company, San Francisco.

Southworh, G. R. 1990. PCB concentrations in stream sunfish (Lepomis auritus) in relation to proximity to chronic point sources. Water, Air and Soil Pollution 51: 287-296.

Southworth, G. R., J. M. Loar, M. G. Ryon, J. G. Smith, A. J. Stewart, and J. A. Burris. 1992. Ecological effects of contaminants and remedial actions in Bear Creek. ORNL/TM-11977. Oak Ridge National Laboratory, Oak Ridge, Tenn.

Trautman, M. B. 1981. The Fishes of Ohio. Ohio State University Press, Columbus, Ohio.

TERRAN. 1990. Aquifer Assessment Report-Groundwater Monitoring Phase II. C-404 Aquifer Testing Program. ESO 16749. Kettering, Ohio.

U.S. Department of Commerce, Bureau of the Census. April 1991. 1990 Census of Population and Housing Public Law 94-171 Data. Washington, D.C. 
Weber, C. I., W. H. Peltier, T. J. Norberg-King, W. B. Horning II, F. A. Kessler, J. R. Menkedick, T. W. Neiheisel, P. A. Lewis, D. J. Klemm, Q. H. Pickering, E. L. Robinson, J. M. Lazorchak, L. J. Wymer and R. W. Freyberg. 1989. Shortterm methods for estimating the chronic toxicity of effluents and receiving waters to freshwater organisms, 2nd ed. EPA/600/4-89/001. U.S. Environmental Protection Agency, Cincinnati, Ohio.

Wojtowicz, J. A., and J. G. Smith. 1992. Biological Monitoring and Abatement Program (BMAP) Benthic Macroinvertebrate Monitoring Project Sample Processing QA Plan. QAP-X-91-ES- Carolina.

Zar, J. H. 1984. Biostatistical Analysis. Prentice Hall, Inc., Englewood Cliffs, New Jersey. 
Appendix A

SUMMARY STATISTICS FOR WATER QUALITY PARAMETERS AT KPDES PERMITTED OUTFALLS 

Table A.1. Water quality parameters measured at Kentucky Pollutant Discharge Elimination System permitted outfall K-001 in 1994

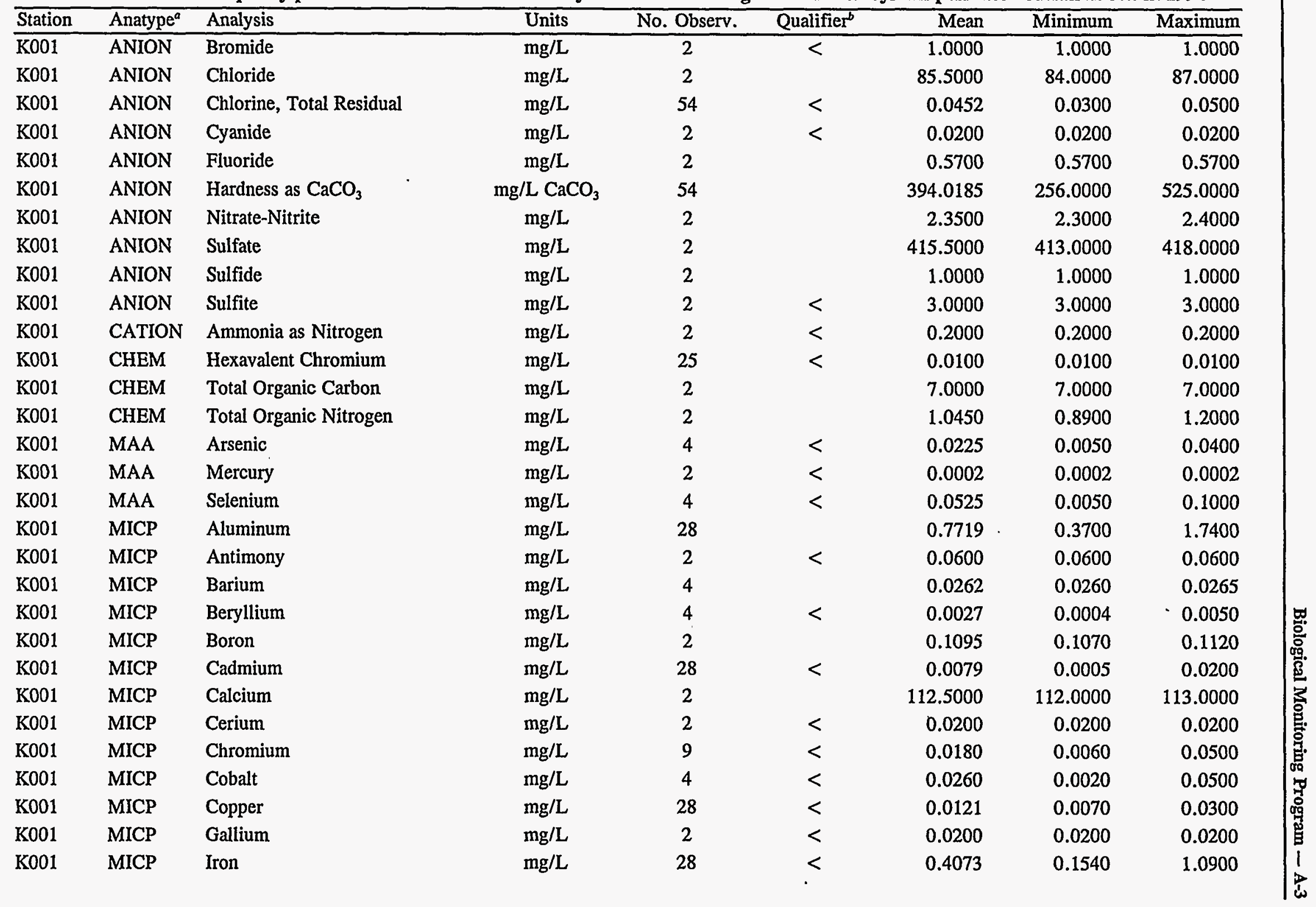


Table A.1 (continued)

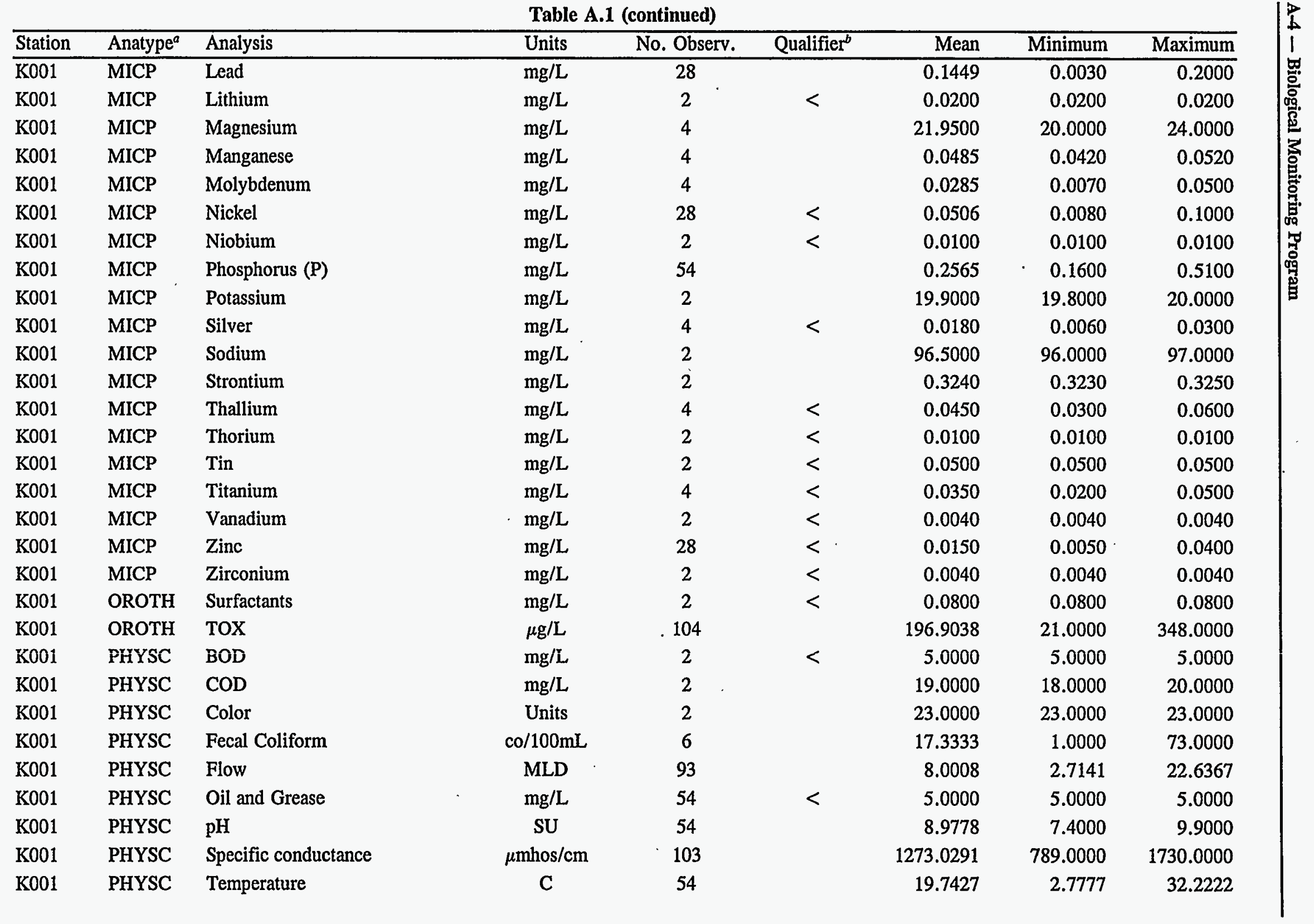


Table A.1 (continued)

\begin{tabular}{|c|c|c|c|c|c|c|c|c|}
\hline Station & Anatype $^{a}$ & Analysis & Units & No. Observ. & Qualifier $^{b}$ & Mean & Minimum & Maximum \\
\hline K001 & PHYSC & Total Suspended Solids & $\mathrm{mg} / \mathrm{L}$ & 54 & & 23.0000 & 5.0000 & 100.0000 \\
\hline K001 & PPCB & Acenaphthene & $\mu \mathrm{g} / \mathrm{L}$ & 2 & $<$ & 10.0000 & 10.0000 & 10.0000 \\
\hline K001 & PPCB & Acenaphthylene & $\mu \mathrm{g} / \mathrm{L}$ & 2 & $<$ & 10.0000 & 10.0000 & 10.0000 \\
\hline K001 & PPCB & PCB & $\mu \mathrm{g} / \mathrm{L}$ & 13 & $<$ & 0.0973 & 0.0650 & 0.1000 \\
\hline K001 & RADS & $\% \mathrm{U}-235$ & Wt \% & 34 & & 0.5492 & 0.4010 & 0.7310 \\
\hline K001 & RADS & $\% \mathrm{U}-235$ & Wt \% & 6 & & 0.4535 & 0.3000 & 0.5730 \\
\hline K001 & RADS & Gross Alpha & $\mathrm{pCi} / \mathrm{L}$ & 2 & & 5.5000 & 5.4000 & 5.6000 \\
\hline K001 & RADS & Gross Beta & $\mathrm{pCi} / \mathrm{L}$ & 2 & & 76.0000 & 73.0000 & 79.0000 \\
\hline K001 & RADS & Neptunium-237 & $\mathrm{pCi} / \mathrm{L}$ & 4 & & -0.0500 & -0.6000 & 0.6000 \\
\hline K001 & RADS & Plutonium-239 & $\mathrm{pCi} / \mathrm{L}$ & 5 & & 0.0200 & 0.0000 & 0.1000 \\
\hline K001 & RADS & Rad Alpha & $\mathrm{pCi} / \mathrm{ml}$ & 13 & $<$ & 1.0000 & 1.0000 & 1.0000 \\
\hline K001 & RADS & Rad Beta & $\mathrm{pCi} / \mathrm{ml}$ & 13 & $<$ & 1.0000 & 1.0000 & 1.0000 \\
\hline K001 & RADS & Radium-226 & $\mathrm{pCi} / \mathrm{L}$ & 2 & & 0.0000 & 0.0000 & 0.0000 \\
\hline KO01 & RADS & Suspended Alpha & $\mathrm{pCi} / \mathrm{L}$ & 42 & & 1.2071 & -1.4000 & 6.6000 \\
\hline K001 & RADS & Suspended Beta & $\mathrm{pCi} / \mathrm{L}$ & 42 & & 5.8881 & -1.0000 & 22.0000 \\
\hline K001 & RADS & Technetium-99 & $\mathrm{pCi} / \mathrm{L}$ & 52 & & 21.3846 & 1.0000 & 53.0000 \\
\hline K001 & RADS & Thorium-230 & $\mathrm{pCi} / \mathrm{L}$ & 5 & & 0.2000 & 0.0000 & 0.8000 \\
\hline K001 & RADS & Total Radium & $\mathrm{pCi} / \mathrm{L}$ & 2 & & 2.2500 & 1.8000 & 2.7000 \\
\hline K001 & RADS & Uranium & $\mathrm{mg} / \mathrm{L}$ & 108 & & 0.0266 & 0.0010 & 0.1400 \\
\hline K001 & RADSD & Dissolved Alpha & $\mathrm{pCi} / \mathrm{L}$ & 42 & & 4.7286 & -0.2000 & 36.8000 \\
\hline K001 & RADSD & Dissolved Beta & $\mathrm{pCi} / \mathrm{L}$ & 42 & & 83.6905 & 5.0000 & 118.0000 \\
\hline K001 & SVOA & 1,2,4-Trichlorobenzene & $\mu \mathrm{g} / \mathrm{L}$ & 2 & $<$ & 10.0000 & 10.0000 & 10.0000 \\
\hline K001 & SVOA & 1,2-Diphenylhydrazine & $\mu \mathrm{g} / \mathrm{L}$ & 2 & $<$ & 10.0000 & 10.0000 & 10.0000 \\
\hline K001 & SVOA & 2,4,6-Trichlorophenol & $\mu \mathrm{g} / \mathrm{L}$ & 2 & $<$ & 10.0000 & 10.0000 & 10.0000 \\
\hline K001 & SVOA & 2,4-Dichlorophenol & $\mu \mathrm{g} / \mathrm{L}$ & 2 & $<$ & 10.0000 & 10.0000 & 10.0000 \\
\hline K001 & SVOA & 2,4-Dimethylphenol & $\mu \mathrm{g} / \mathrm{L}$ & 2 & $<$ & 10.0000 & 10.0000 & 10.0000 \\
\hline K001 & SVOA & 2,4-Dinitrophenol & $\mu \mathrm{g} / \mathrm{L}$ & 2 & $<$ & 10.0000 & 10.0000 & 10.0000 \\
\hline K001 & SVOA & 2,4-Dinitrotoluene & $\mu \mathrm{g} / \mathrm{L}$ & 2 & $<$ & 10.0000 & 10.0000 & 10.0000 \\
\hline K001 & SVOA & 2,6-Dinitrotoluene & $\mu \mathrm{g} / \mathrm{L}$ & 2 & $<$ & 10.0000 & 10.0000 & 10.0000 \\
\hline K001 & SVOA & 2-Chloroethyl Vinyl Ether & $\mu \mathrm{g} / \mathrm{L}$ & 2 & $<$ & 10.0000 & 10.0000 & 10.0000 \\
\hline
\end{tabular}


Table A.1 (continued)

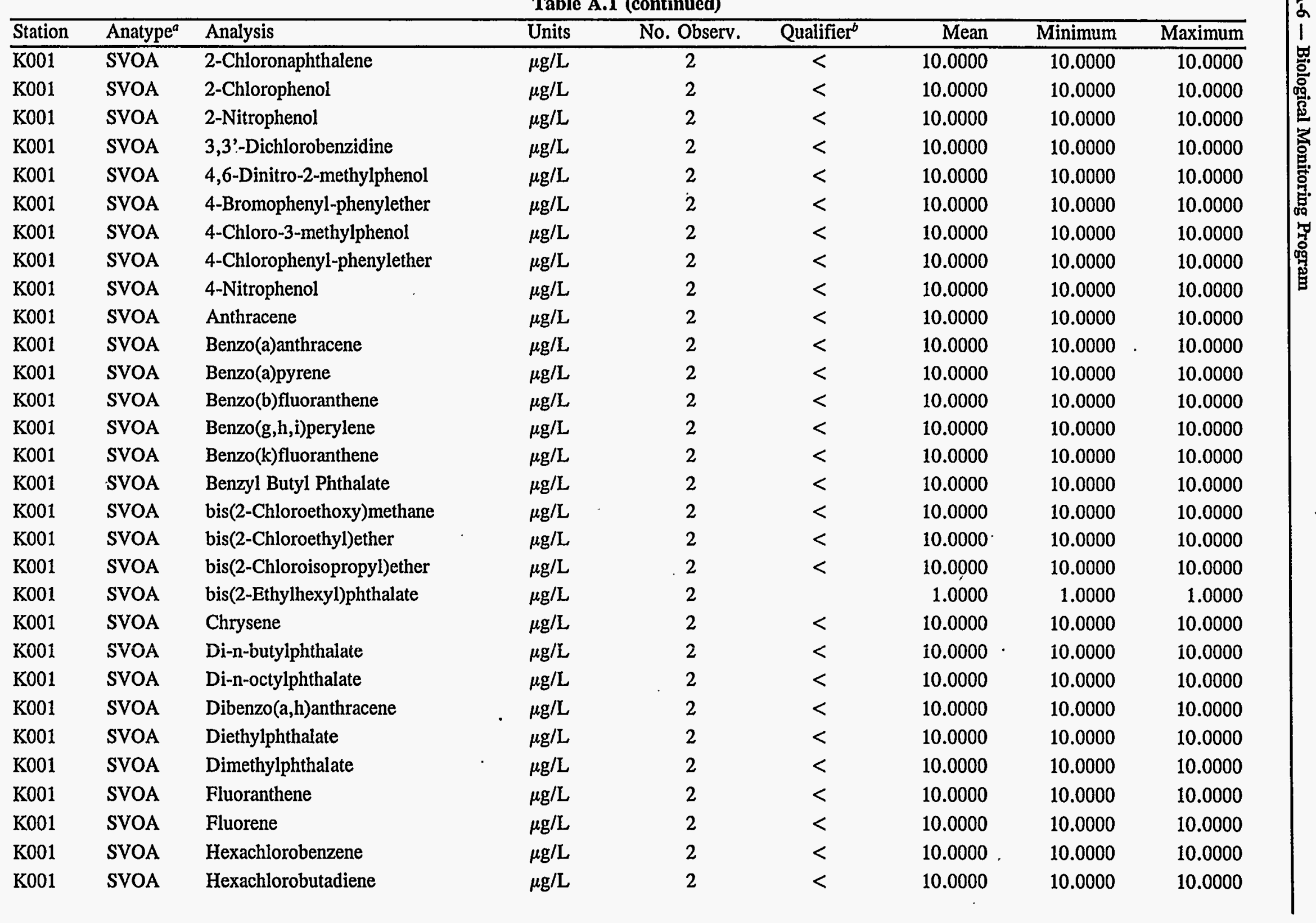


Table A.1 (continued)

\begin{tabular}{|c|c|c|c|c|c|c|c|c|}
\hline Station & Anatype $^{a}$ & Analysis & Units & No. Observ. & Qualifier $^{b}$ & Mean & Minimum & Maximum \\
\hline $\mathrm{K} 001$ & SVOA & Hexachlorocyclopentadiene & $\mu \mathrm{g} / \mathrm{L}$ & 2 & $<$ & 10.0000 & 10.0000 & 10.0000 \\
\hline K001 & SVOA & Hexachloroethane & $\mu \mathrm{g} / \mathrm{L}$ & 2 & $<$ & 10.0000 & 10.0000 & 10.0000 \\
\hline K001 & SVOA & Indeno(1,2,3-cd)pyrene & $\mu \mathrm{g} / \mathrm{L}$ & 2 & $<$ & 10.0000 & 10.0000 & 10.0000 \\
\hline K001 & SVOA & N-Nitroso-di-n-propylamine & $\mu \mathrm{g} / \mathrm{L}$ & 2 & $<$ & 10.0000 & 10.0000 & 10.0000 \\
\hline K001 & SVOA & N-Nitrosodimethylamine & $\mu \mathrm{g} / \mathrm{L}$ & 2 & $<$ & 10.0000 & 10.0000 & 10.0000 \\
\hline K001 & SVOA & N-Nitrosodiphenylamine & $\mu \mathrm{g} / \mathrm{L}$ & 2 & $<$ & 10.0000 & 10.0000 & 10.0000 \\
\hline K001 & SVOA & Nitrobenzene & $\mu \mathrm{g} / \mathrm{L}$ & 2 & $<$ & 10.0000 & 10.0000 & 10.0000 \\
\hline K001 & SVOA & Pentachlorophenol & $\mu \mathrm{g} / \mathrm{L}$ & 2 & $<$ & 10.0000 & 10.0000 & 10.0000 \\
\hline K001 & SVOA & Phenanthrene & $\mu \mathrm{g} / \mathrm{L}$ & 2 & $<$ & 10.0000 & 10.0000 & 10.0000 \\
\hline K001 & SVOA & Phenol & $\mu \mathrm{g} / \mathrm{L}$ & 4 & $<$ & 7.5000 & 5.0000 & 10.0000 \\
\hline K001 & SVOA & Pyrene & $\mu \mathrm{g} / \mathrm{L}$ & 2 & $<$ & 10.0000 & 10.0000 & 10.0000 \\
\hline K001 & VOA & 1,1,1-Trichloroethane & $\mu \mathrm{g} / \mathrm{L}$ & 2 & $<$ & 10.0000 & 10.0000 & 10.0000 \\
\hline K001 & VOA & 1,2-Dichlorobenzene & $\mu \mathrm{g} / \mathrm{L}$ & 2 & $<$ & 10.0000 & 10.0000 & 10.0000 \\
\hline K001 & VOA & 1,2-Dichloroethane & $\mu \mathrm{g} / \mathrm{L}$ & 2 & $<$ & 10.0000 & 10.0000 & 10.0000 \\
\hline K001 & VOA & 1,2-Dichloropropane & $\mu \mathrm{g} / \mathrm{L}$ & 2 & $<$ & 10.0000 & 10.0000 & 10.0000 \\
\hline K001 & VOA & 1,3-Dichlorobenzene & $\mu \mathrm{g} / \mathrm{L}$ & 2 & $<$ & 10.0000 & 10.0000 & 10.0000 \\
\hline K001 & VOA & 1,4-Dichlorobenzene & $\mu \mathrm{g} / \mathrm{L}$ & 2 & $<$ & 10.0000 & 10.0000 & 10.0000 \\
\hline K001 & VOA & Acetone & $\mu \mathrm{g} / \mathrm{L}$ & 12 & $<$ & 1000.0000 & 1000.0000 & 1000.0000 \\
\hline K001 & VOA & Acrolein & $\mu \mathrm{g} / \mathrm{L}$ & 2 & $<$ & 10.0000 & 10.0000 & 10.0000 \\
\hline K001 & VOA & Acrylonitrile & $\mu \mathrm{g} / \mathrm{L}$ & 2 & $<$ & 10.0000 & 10.0000 & 10.0000 \\
\hline K001 & VOA & Benzene & $\mu \mathrm{g} / \mathrm{L}$ & 2 & $<$ & 10.0000 & 10.0000 & 10.0000 \\
\hline K001 & VOA & Benzidine & $\mu \mathrm{g} / \mathrm{L}$ & 2 & $<$ & 10.0000 & 10.0000 & 10.0000 \\
\hline K001 & VOA & Bromodichloromethane & $\mu \mathrm{g} / \mathrm{L}$ & 2 & $<$ & 10.0000 & 10.0000 & 10.0000 \\
\hline
\end{tabular}


Table A.1 (continued)

\begin{tabular}{|c|c|c|c|c|c|c|c|c|}
\hline Station & Anatype $^{a}$ & Analysis & Units & No. Observ. & Qualifier $^{b}$ & Mean & Minimum & Maximum \\
\hline K001 & VOA & Bromomethane & $\mu \mathrm{g} / \mathrm{L}$ & 2 & $<$ & 10.0000 & 10.0000 & 10.0000 \\
\hline K001 & VOA & Carbon Tetrachloride & $\mu \mathrm{g} / \mathrm{L}$ & 2 & $<$ & 10.0000 & 10.0000 & 10.0000 \\
\hline K001 & VOA & Chlorobenzene & $\mu \mathrm{g} / \mathrm{L}$ & 2 & $<$ & 10.0000 & 10.0000 & 10.0000 \\
\hline K001 & VOA & Chloroethane & $\mu \mathrm{g} / \mathrm{L}$ & 2 & $<$ & 10.0000 & 10.0000 & 10.0000 \\
\hline K001 & VOA & Chloroform & $\mu \mathrm{g} / \mathrm{L}$ & 2 & $<$ & 10.0000 & 10.0000 & 10.0000 \\
\hline K001 & VOA & Chloromethane & $\mu \mathrm{g} / \mathrm{L}$ & 2 & $<$ & 10.0000 & 10.0000 & 10.0000 \\
\hline K001 & VOA & cis-1,3-Dichloropropene & $\mu \mathrm{g} / \mathrm{L}$ & 2 & $<$ & 10.0000 & 10.0000 & 10.0000 \\
\hline K001 & VOA & Dibromochloromethane & $\mu \mathrm{g} / \mathrm{L}$ & 2 & $<$ & 10.0000 & 10.0000 & 10.0000 \\
\hline K001 & VOA & Dichlorodifluoromethane & $\mu \mathrm{g} / \mathrm{L}$ & 2 & $<$ & 10.0000 & 10.0000 & 10.0000 \\
\hline K001 & VOA & Ethylbenzene & $\mu \mathrm{g} / \mathrm{L}$ & 2 & $<$ & 10.0000 & 10.0000 & 10.0000 \\
\hline K001 & VOA & Isopropanol & $\mu \mathrm{g} / \mathrm{L}$ & 12 & $<$ & 1000.0000 & 1000.0000 & 1000.0000 \\
\hline K001 & VOA & Methylene Chloride & $\mu \mathrm{g} / \mathrm{L}$ & 2 & $<$ & 10.0000 & 10.0000 & 10.0000 \\
\hline K001 & VOA & Tetrachlorodibenzo-p-dioxin & $\mathrm{ng} / \mathrm{L}$ & 2 & $<$ & 0.7300 & 0.6100 & 0.8500 \\
\hline K001 & VOA & Tetrachloroethene & $\mu \mathrm{g} / \mathrm{L}$ & 2 & $<$ & 10.0000 & 10.0000 & 10.0000 \\
\hline K001 & VOA & Toluene & $\mu \mathrm{g} / \mathrm{L}$ & 2 & $<$ & 10.0000 & 10.0000 & 10.0000 \\
\hline K001 & VOA & Trans-1,2-Dichloroethene & $\mu \mathrm{g} / \mathrm{L}$ & 2 & $<$ & 10.0000 & 10.0000 & 10.0000 \\
\hline K001 & VOA & Trans-1,3-Dichloropropene & $\mu \mathrm{g} / \mathrm{L}$ & 2 & $<$ & 10.0000 & 10.0000 & 10.0000 \\
\hline K001 & VOA & Trichloroethene & $\mu \mathrm{g} / \mathrm{L}$ & 15 & $<$ & 2.2000 & 1.0000 & 10.0000 \\
\hline K001 & VOA & Trichlorofluoromethane & $\mu \mathrm{g} / \mathrm{L}$ & 2 & $<$ & 10.0000 & 10.0000 & 10.0000 \\
\hline K001 & VOA & Vinyl Chloride & $\mu \mathrm{g} / \mathrm{L}$ & 2 & $<$ & 10.0000 & 10.0000 & 10.0000 \\
\hline
\end{tabular}

Note: Data provided by L. S. Crabtree, Information Services, Paducah Gaseous Diffusion Plant.

${ }^{a}$ ANION $=$ a negatively charged ion; CATION $=$ a positively charged ion; CHEM $=$ chemical parameters; $M A A=$ metals by atomic absorption; MIC $=$ metals by inductively-coupled plasma/mass spectroscopy; OROTH = other organics, PHYSC $=$ physical and field measurements; PPCB = pesticides/polychlorinated biphenyls; RADS = radiochemical analysis; RADSD $=$ radiochemical analysis, dissolved; SVOA $=$ semivolatile organics; VOA $=$ volatile organics.

${ }^{b} \mathrm{~A}$ " $<$ " qualifier was added to the mean when $\geq 50 \%$ of the observations had " $<$ " qualifiers. 
Table A.2. Water quality parameters measured at Kentucky Pollutant Discharge Elimination System permitted outfall 002 in 1994

\begin{tabular}{|c|c|c|c|c|c|c|c|c|}
\hline Station & Anatype $^{a}$ & Analysis & Units & No. Observ. & Qualifier $^{b}$ & Mean & Minimum & Maximum \\
\hline $\mathrm{K} 002$ & ANION & Bromide & $\mathrm{mg} / \mathrm{L}$ & 1 & $<$ & 1.0000 & 1.0000 & 1.0000 \\
\hline K002 & ANION & Chloride & $\mathrm{mg} / \mathrm{L}$ & 1 & & 7.0000 & 7.0000 & 7.0000 \\
\hline K002 & ANION & Chlorine, Total Residual & $\mathrm{mg} / \mathrm{L}$ & 15 & $<$ & 0.0493 & 0.0300 & 0.1000 \\
\hline K002 & ANION & Cyanide & $\mathrm{mg} / \mathrm{L}$ & 1 & $<$ & 0.0200 & 0.0200 & 0.0200 \\
\hline K002 & ANION & Fluoride & $\mathrm{mg} / \mathrm{L}$ & 1 & & 0.2400 & 0.2400 & 0.2400 \\
\hline $\mathrm{K} 002$ & ANION & Hardness as $\mathrm{CaCO}_{3}$ & $\mathrm{mg} / \mathrm{L} \mathrm{CaCO}$ & 14 & & 99.4286 & 32.0000 & 316.0000 \\
\hline K002 & ANION & Nitrate-Nitrite & $\mathrm{mg} / \mathrm{L}$ & 1 & & 0.3100 & 0.3100 & 0.3100 \\
\hline K002 & ANION & Sulfate & $\mathrm{mg} / \mathrm{L}$ & 1 & & 31.0000 & 31.0000 & 31.0000 \\
\hline $\mathrm{K} 002$ & ANION & Sulfide & $\mathrm{mg} / \mathrm{L}$ & 1 & $<$ & 1.0000 & 1.0000 & 1.0000 \\
\hline K002 & ANION & Sulfite & $\mathrm{mg} / \mathrm{L}$ & 1 & $<$ & 3.0000 & 3.0000 & 3.0000 \\
\hline $\mathrm{K} 002$ & CATION & Ammonia as Nitrogen & $\mathrm{mg} / \mathrm{L}$ & 1 & $<$ & 0.2000 & 0.2000 & 0.2000 \\
\hline K002 & CHEM & Total Organic Carbon & $\mathrm{mg} / \mathrm{L}$ & 1 & & 8.0000 & 8.0000 & 8.0000 \\
\hline $\mathrm{K} 002$ & CHEM & Total Organic Nitrogen & $\mathrm{mg} / \mathrm{L}$ & 1 & & 0.6700 & 0.6700 & 0.6700 \\
\hline K002 & MAA & Arsenic & $\mathrm{mg} / \mathrm{L}$ & 2 & $<$ & 0.0225 & 0.0050 & 0.0400 \\
\hline K002 & MAA & Mercury & $\mathrm{mg} / \mathrm{L}$ & 1 & $<$ & 0.0002 & 0.0002 & 0.0002 \\
\hline K002 & MAA & Selenium & $\mathrm{mg} / \mathrm{L}$ & 2 & $<$ & 0.0525 & 0.0050 & 0.1000 \\
\hline $\mathrm{K} 002$ & MICP & Aluminum & $\mathrm{mg} / \mathrm{L}$ & 15 & & 2.6600 & 1.0200 & 9.8900 \\
\hline $\mathrm{KOO2}$ & MICP & Antimony & $\mathrm{mg} / \mathrm{L}$ & 1 & $<$ & 0.0600 & 0.0600 & 0.0600 \\
\hline K002 & MICP & Barium & $\mathrm{mg} / \mathrm{L}$ & 2 & & 0.0497 & 0.0494 & 0.0500 \\
\hline K002 & MICP & Beryllium & $\mathrm{mg} / \mathrm{L}$ & 2 & $<$ & 0.0027 & 0.0004 & 0.0050 \\
\hline K002 & MICP & Boron & $\mathrm{mg} / \mathrm{L}$ & 1 & & 0.0340 & 0.0340 & 0.0340 \\
\hline K002 & MICP & Cadmium & $\mathrm{mg} / \mathrm{L}$ & 15 & $<$ & 0.0085 & 0.0005 & 0.0120 \\
\hline $\mathrm{K} 002$ & MICP & Calcium & $\mathrm{mg} / \mathrm{L}$ & 1 & & 29.7000 & 29.7000 & 29.7000 \\
\hline K002 & MICP & Cerium & $\mathrm{mg} / \mathrm{L}$ & 1 & $<$ & 0.0200 & 0.0200 & 0.0200 \\
\hline $\mathrm{K} 002$ & MICP & Chromium & $\mathrm{mg} / \mathrm{L}$ & 15 & $<$ & 0.0536 & 0.0070 & 0.2470 \\
\hline K002 & MICP & Cobalt & $\mathrm{mg} / \mathrm{L}$ & 2 & $<$ & 0.0260 & 0.0020 & 0.0500 \\
\hline $\mathrm{KOO} 2$ & MICP & Copper & $\mathrm{mg} / \mathrm{L}$ & 15 & & 0.0287 & 0.0090 & 0.2220 \\
\hline $\mathrm{K} 002$ & MICP & Gallium & $\mathrm{mg} / \mathrm{L}$ & 1 & $<$ & 0.0200 & 0.0200 & 0.0200 \\
\hline K002 & MICP & Iron & $\mathrm{mg} / \mathrm{L}$ & 15 & & 2.7434 & 0.6490 & 16.6000 \\
\hline
\end{tabular}


Table A.2 (continued)

\begin{tabular}{|c|c|c|c|c|c|c|c|c|}
\hline Station & Anatype $^{a}$ & Analysis & Units & No. Observ. & Qualifier $^{b}$ & Mean & Minimum & Maximum \\
\hline$\overline{\mathrm{K} 002}$ & MICP & Lead & $\mathrm{mg} / \mathrm{L}$ & 15 & $<$ & 0.1771 & 0.0030 & 0.5100 \\
\hline K002 & MICP & Lithium & $\mathrm{mg} / \mathrm{L}$ & 1 & $<$ & 0.0200 & 0.0200 & 0.0200 \\
\hline K002 & MICP & Magnesium & $\mathrm{mg} / \mathrm{L}$ & 2 & & 4.7850 & 4.6100 & 4.9600 \\
\hline K002 & MICP & Manganese & $\mathrm{mg} / \mathrm{L}$ & 2 & & 0.0240 & 0.0230 & 0.0250 \\
\hline K002 & MICP & Molybdenum & $\mathrm{mg} / \mathrm{L}$ & 2 & $<$ & 0.0280 & 0.0060 & 0.0500 \\
\hline K002 & MICP & Nickel & $\mathrm{mg} / \mathrm{L}$ & 15 & $<$ & 0.0505 & 0.0080 & 0.1000 \\
\hline K002 & MICP & Niobium & $\mathrm{mg} / \mathrm{L}$ & 1 & $<$ & 0.0100 & 0.0100 & 0.0100 \\
\hline K002 & MICP & Phosphorus (P) & $\mathrm{mg} / \mathrm{L}$ & 14 & & 0.6343 & 0.1500 & 4.7900 \\
\hline K002 & MICP & Potassium & $\mathrm{mg} / \mathrm{L}$ & 1 & & 3.1000 & 3.1000 & 3.1000 \\
\hline K002 & MICP & Silver & $\mathrm{mg} / \mathrm{L}$ & 2 & $<$ & 0.0180 & 0.0060 & 0.0300 \\
\hline K002 & MICP & Sodium & $\mathrm{mg} / \mathrm{L}$ & 1 & & 8.6600 & 8.6600 & 8.6600 \\
\hline K002 & MICP & Strontium & $\mathrm{mg} / \mathrm{L}$ & 1 & & 0.1440 & 0.1440 & 0.1440 \\
\hline K002 & MICP & Thallium & $\mathrm{mg} / \mathrm{L}$ & 2 & $<$ & 0.0450 & 0.0300 & 0.0600 \\
\hline K002 & MICP & Thorium & $\mathrm{mg} / \mathrm{L}$ & 1 & $<$ & 0.0100 & 0.0100 & 0.0100 \\
\hline K002 & MICP & Tin & $\mathrm{mg} / \mathrm{L}$ & 1 & $<$ & 0.0500 & 0.0500 & 0.0500 \\
\hline K002 & MICP & Titanium & $\mathrm{mg} / \mathrm{L}$ & 2 & & 0.0350 & 0.0200 & 0.0500 \\
\hline K002 & MICP & Vanadium & $\mathrm{mg} / \mathrm{L}$ & 1 & $<$ & 0.0040 & 0.0040 & 0.0040 \\
\hline K002 & MICP & Zinc & $\mathrm{mg} / \mathrm{L}$ & 15 & & 0.0461 & 0.0120 & 0.2730 \\
\hline K002 & MICP & Zirconium & $\mathrm{mg} / \mathrm{L}$ & 1 & $<$ & 0.0040 & 0.0040 & 0.0040 \\
\hline K002 & OROTH & Surfactants & $\mathrm{mg} / \mathrm{L}$ & 1 & $<$ & 0.0800 & 0.0800 & 0.0800 \\
\hline K002 & PHYSC & BOD & $\mathrm{mg} / \mathrm{L}$ & 1 & $<$ & 5.0000 & 5.0000 & 5.0000 \\
\hline KOO2 & PHYSC & COD & $\mathrm{mg} / \mathrm{L}$ & 1 & & 25.0000 & 25.0000 & 25.0000 \\
\hline K002 & PHYSC & Color & Units & 1 & & 60.0000 & 60.0000 & 60.0000 \\
\hline K002 & PHYSC & Dissolved Oxygen & $\mathrm{mg} / \mathrm{L}$ & 53 & & 4.5051 & 3.9300 & 8.0300 \\
\hline K002 & PHYSC & Fecal Coliform & $\mathrm{co} / 100 \mathrm{~mL}$ & 2 & & 1955.0000 & 410.0000 & 3500.0000 \\
\hline K002 & PHYSC & Flow & MLD & 43 & & 1.2621 & 0.0113 & 7.7979 \\
\hline K002 & PHYSC & Oil and Grease & $\mathrm{mg} / \mathrm{L}$ & 14 & $<$ & 5.1357 & 5.0000 & 6.9000 \\
\hline K002 & PHYSC & $\mathrm{pH}$ & SU & 14 & & 7.7643 & 6.4000 & 8.9000 \\
\hline K002 & PHYSC & Temperature & $\mathrm{C}$ & 68 & & 31.0612 & 1.6666 & 37.7222 \\
\hline K002 & PHYSC & Total Suspended Solids & $\mathrm{mg} / \mathrm{L}$ & 14 & & 62.5000 & 4.0000 & 592.0000 \\
\hline
\end{tabular}


Table A.2 (continued)

\begin{tabular}{|c|c|c|c|c|c|c|c|c|}
\hline Station & Anatype $^{a}$ & Analysis & Units & No. Observ. & Qualifier $^{b}$ & Mean & Minimum & Maximum \\
\hline K002 & PPCB & Acenaphthene & $\mu \mathrm{g} / \mathrm{L}$ & 1 & $<$ & 10.0000 & 10.0000 & 10.0000 \\
\hline K002 & PPCB & Acenaphthylene & $\mu \mathrm{g} / \mathrm{L}$ & 1 & $<$ & 10.0000 & 10.0000 & 10.0000 \\
\hline $\mathrm{K} 002$ & PPCB & PCB & $\mu \mathrm{g} / \mathrm{L}$ & 14 & $<$ & 0.0850 & 0.0650 & 0.1000 \\
\hline K002 & RADS & $\%$ U-235 & Wt \% & 3 & & 0.5743 & 0.5140 & 0.6630 \\
\hline K002 & RADS & $\%$ U-235 & Wt \% & 2 & & 0.2255 & 0.2120 & 0.2390 \\
\hline $\mathrm{K} 002$ & RADS & Gross Alpha & $\mathrm{pCi} / \mathrm{L}$ & 1 & & 1.7000 & 1.7000 & 1.7000 \\
\hline K002 & RADS & Gross Beta & $\mathrm{pCi} / \mathrm{L}$ & 1 & & 8.0000 & 8.0000 & 8.0000 \\
\hline $\mathrm{K} 002$ & RADS & Neptunium-237 & $\mathrm{pCi} / \mathrm{L}$ & 7 & & 0.1000 & -0.4000 & 0.7000 \\
\hline $\mathrm{K} 002$ & RADS & Plutonium-239 & $\mathrm{pCi} / \mathrm{L}$ & 7 & & 0.0000 & 0.0000 & 0.0000 \\
\hline $\mathrm{K} 002$ & RADS & Rad Alpha & $\mathrm{pCi} / \mathrm{ml}$ & 3 & $<$ & 1.0000 & 1.0000 & 1.0000 \\
\hline $\mathrm{KOO2}$ & RADS & Rad Beta & $\mathrm{pCi} / \mathrm{ml}$ & 3 & $<$ & 1.0000 & 1.0000 & 1.0000 \\
\hline $\mathrm{K} 002$ & RADS & Radium-226 & $\mathrm{pCi} / \mathrm{L}$ & 1 & & 0.0000 & 0.0000 & 0.0000 \\
\hline K002 & RADS & Suspended Alpha & $\mathrm{pCi} / \mathrm{L}$ & 7 & & 0.8857 & -1.0000 & 3.2000 \\
\hline $\mathrm{K} 002$ & RADS & Suspended Beta & $\mathrm{pCi} / \mathrm{L}$ & 7 & & 3.8571 & -2.0000 & 9.0000 \\
\hline $\mathrm{K} 002$ & RADS & Technetium-99 & $\mathrm{pCi} / \mathrm{L}$ & 7 & & 10.1429 & 2.0000 & 33.0000 \\
\hline K002 & RADS & Thorium-230 & $\mathrm{pCi} / \mathrm{L}$ & 7 & & 0.2000 & 0.1000 & 0.6000 \\
\hline K002 & RADS & Total Radium & $\mathrm{pCi} / \mathrm{L}$ & 1 & & 0.7000 & 0.7000 & 0.7000 \\
\hline $\mathrm{KOO2}$ & RADS & Uranium & $\mathrm{mg} / \mathrm{L}$ & 9 & & 0.0212 & 0.0010 & 0.0970 \\
\hline $\mathrm{K} 002$ & RADSD & Dissolved Alpha & $\mathrm{pCi} / \mathrm{L}$ & 7 & & 1.7429 & 0.7000 & 2.6000 \\
\hline K002 & RADSD & Dissolved Beta & $\mathrm{pCi} / \mathrm{L}$ & 7 & & 9.0000 & 4.0000 & 19.0000 \\
\hline K002 & SVOA & 1,2,4-Trichlorobenzene & $\mu \mathrm{g} / \mathrm{L}$ & 1 & $<$ & 10.0000 & 10.0000 & 10.0000 \\
\hline K002 & SVOA & 1,2-Diphenylhydrazine & $\mu \mathrm{g} / \mathrm{L}$ & 1 & $<$ & 10.0000 & 10.0000 & 10.0000 \\
\hline $\mathrm{KOO2}$ & SVOA & 2,4,6-Trichlorophenol & $\mu \mathrm{g} / \mathrm{L}$ & 1 & $<$ & 10.0000 & 10.0000 & 10.0000 \\
\hline K002 & SVOA & 2,4-Dichlorophenol & $\mu \mathrm{g} / \mathrm{L}$ & 1 & $<$ & 10.0000 & 10.0000 & 10.0000 \\
\hline $\mathrm{K} 002$ & SVOA & 2,4-Dimethylphenol & $\mu \mathrm{g} / \mathrm{L}$ & 1 & $<$ & 10.0000 & 10.0000 & 10.0000 \\
\hline $\mathrm{K} 002$ & SVOA & 2,4-Dinitrophenol & $\mu \mathrm{g} / \mathrm{L}$ & 1 & $<$ & 10.0000 & 10.0000 & 10.0000 \\
\hline K002 & SVOA & 2,4-Dinitrotoluene & $\mu \mathrm{g} / \mathrm{L}$ & 1 & $<$ & 10.0000 & 10.0000 & 10.0000 \\
\hline $\mathrm{KOO2}$ & SVOA & 2,6-Dinitrotoluene & $\mu \mathrm{g} / \mathrm{L}$ & 1 & $<$ & 10.0000 & 10.0000 & 10.0000 \\
\hline $\mathrm{KOO2}$ & SVOA & 2-Chloroethyl Vinyl Ether & $\mu \mathrm{g} / \mathrm{L}$ & 1 & $<$ & 10.0000 & 10.0000 & 10.0000 \\
\hline K002 & SVOA & 2-Chloronaphthalene & $\mu \mathrm{g} / \mathrm{L}$ & 1 & $<$ & 10.0000 & 10.0000 & 10.0000 \\
\hline
\end{tabular}


Table A.2 (continued)

\begin{tabular}{|c|c|c|c|c|c|c|c|c|}
\hline Station & Anatype ${ }^{a}$ & Analysis & Units & No. Observ. & Qualifier $^{b}$ & Mean & Minimum & Maximum \\
\hline$\overline{\mathrm{K} 002}$ & SVOA & 2-Chlorophenol & $\mu \mathrm{g} / \mathrm{L}$ & 1 & $<$ & 10.0000 & 10.0000 & 10.0000 \\
\hline K002 & SVOA & 2-Nitrophenol & $\mu \mathrm{g} / \mathrm{L}$ & 1 & $<$ & 10.0000 & 10.0000 & 10.0000 \\
\hline K002 & SVOA & 3,3'-Dichlorobenzidine & $\mu \mathrm{g} / \mathrm{L}$ & 1 & $<$ & 10.0000 & 10.0000 & 10.0000 \\
\hline K002 & SVOA $^{\circ}$ & 4,6-Dinitro-2-methylphenol & $\mu \mathrm{g} / \mathrm{L}$ & 1 & $<$ & 10.0000 & 10.0000 & 10.0000 \\
\hline K002 & SVOA & 4-Bromophenyl-phenylether & $\mu \mathrm{g} / \mathrm{L}$ & 1 & $<$ & 10.0000 & 10.0000 & 10.0000 \\
\hline K002 & SVOA & 4-Chloro-3-methylphenol & $\mu \mathrm{g} / \mathrm{L}$ & 1 & $<$ & 10.0000 & 10.0000 & 10.0000 \\
\hline K002 & SVOA & 4-Chlorophenyl-phenylether & $\mu \mathrm{g} / \mathrm{L}$ & 1 & $<$ & 10.0000 & 10.0000 & 10.0000 \\
\hline K002 & SVOA & 4-Nitrophenol & $\mu \mathrm{g} / \mathrm{L}$ & 1 & $<$ & 10.0000 & 10.0000 & 10.0000 \\
\hline K002 & SVOA & Anthracene & $\mu \mathrm{g} / \mathrm{L}$ & 1 & $<$ & 10.0000 & 10.0000 & 10.0000 \\
\hline K002 & SVOA & Benzo(a)anthracene & $\mu \mathrm{g} / \mathrm{L}$ & 1 & $<$ & 10.0000 & 10.0000 & 10.0000 \\
\hline K002 & SVOA & Benzo(a)pyrene & $\mu \mathrm{g} / \mathrm{L}$ & 1 & $<$ & 10.0000 & 10.0000 & 10.0000 \\
\hline K002 & SVOA & Benzo(b)fluoranthene & $\mu \mathrm{g} / \mathrm{L}$ & 1 & $<$ & 10.0000 & 10.0000 & 10.0000 \\
\hline K002 & SVOA & Benzo(g,h,i)perylene & $\mu \mathrm{g} / \mathrm{L}$ & 1 & $<$ & 10.0000 & 10.0000 & 10.0000 \\
\hline K002 & SVOA & Benzo(k)fluoranthene & $\mu \mathrm{g} / \mathrm{L}$ & 1 & $<$ & 10.0000 & 10.0000 & 10.0000 \\
\hline K002 & SVOA & Benzyl Butyl Phthalate & $\mu \mathrm{g} / \mathrm{L}$ & 1 & $<$ & 10.0000 & 10.0000 & 10.0000 \\
\hline K002 & SVOA & bis(2-Chloroethoxy)methane & $\mu \mathrm{g} / \mathrm{L}$ & 1 & $<$ & 10.0000 & 10.0000 & 10.0000 \\
\hline K002 & SVOA & bis(2-Chloroethyl)ether & $\mu \mathrm{g} / \mathrm{L}$ & 1 & $<$ & 10.0000 & 10.0000 & 10.0000 \\
\hline K002 & SVOA & bis(2-Chloroisopropyl)ether & $\mu \mathrm{g} / \mathrm{L}$ & 1 & $<$ & 10.0000 & 10.0000 & 10.0000 \\
\hline K002 & SVOA & bis(2-Ethylhexyl)phthalate & $\mu \mathrm{g} / \mathrm{L}$ & 1 & & 3.0000 & 3.0000 & 3.0000 \\
\hline K002 & SVOA & Chrysene & $\mu \mathrm{g} / \mathrm{L}$ & 1 & $<$ & 10.0000 & 10.0000 & 10.0000 \\
\hline K002 & SVOA & Di-n-butylphthalate & $\mu \mathrm{g} / \mathrm{L}$ & 1 & $<$ & 10.0000 & 10.0000 & 10.0000 \\
\hline K002 & SVOA & Di-ni-octylphthalate & $\mu \mathrm{g} / \mathrm{L}$ & 1 & $<$ & 10.0000 & 10.0000 & 10.0000 \\
\hline K002 & SVOA & Dibenzo(a,h)anthracene & $\mu \mathrm{g} / \mathrm{L}$ & 1 & $<$ & 10.0000 & 10.0000 & 10.0000 \\
\hline K002 & SVOA & Diethylphthalate & $\mu \mathrm{g} / \mathrm{L}$ & 1 & $<$ & 10.0000 & 10.0000 & 10.0000 \\
\hline K002 & SVOA & Dimethylphthalate & $\mu \mathrm{g} / \mathrm{L}$ & 1 & $<$ & 10.0000 & 10.0000 & 10.0000 \\
\hline K002 & SVOA & Fluoranthene & $\mu \mathrm{g} / \mathrm{L}$ & 1 & $<$ & 10.0000 & 10.0000 & 10.0000 \\
\hline K002 & SVOA & Fluorene & $\mu \mathrm{g} / \mathrm{L}$ & 1 & $<$ & 10.0000 & 10.0000 & 10.0000 \\
\hline K002 & SVOA & Hexachlorobenzene & $\mu \mathrm{g} / \mathrm{L}$ & 1 & $<$ & 10.0000 & 10.0000 & 10.0000 \\
\hline K002 & SVOA & Hexachlorobutadiene & $\mu \mathrm{g} / \mathrm{L}$ & 1 & $<$ & 10.0000 & 10.0000 & 10.0000 \\
\hline K002 & SVOA & Hexachlorocyclopentadiene & $\mu \mathrm{g} / \mathrm{L}$ & 1 & $<$ & 10.0000 & 10.0000 & 10.0000 \\
\hline
\end{tabular}


Table A.2 (continued)

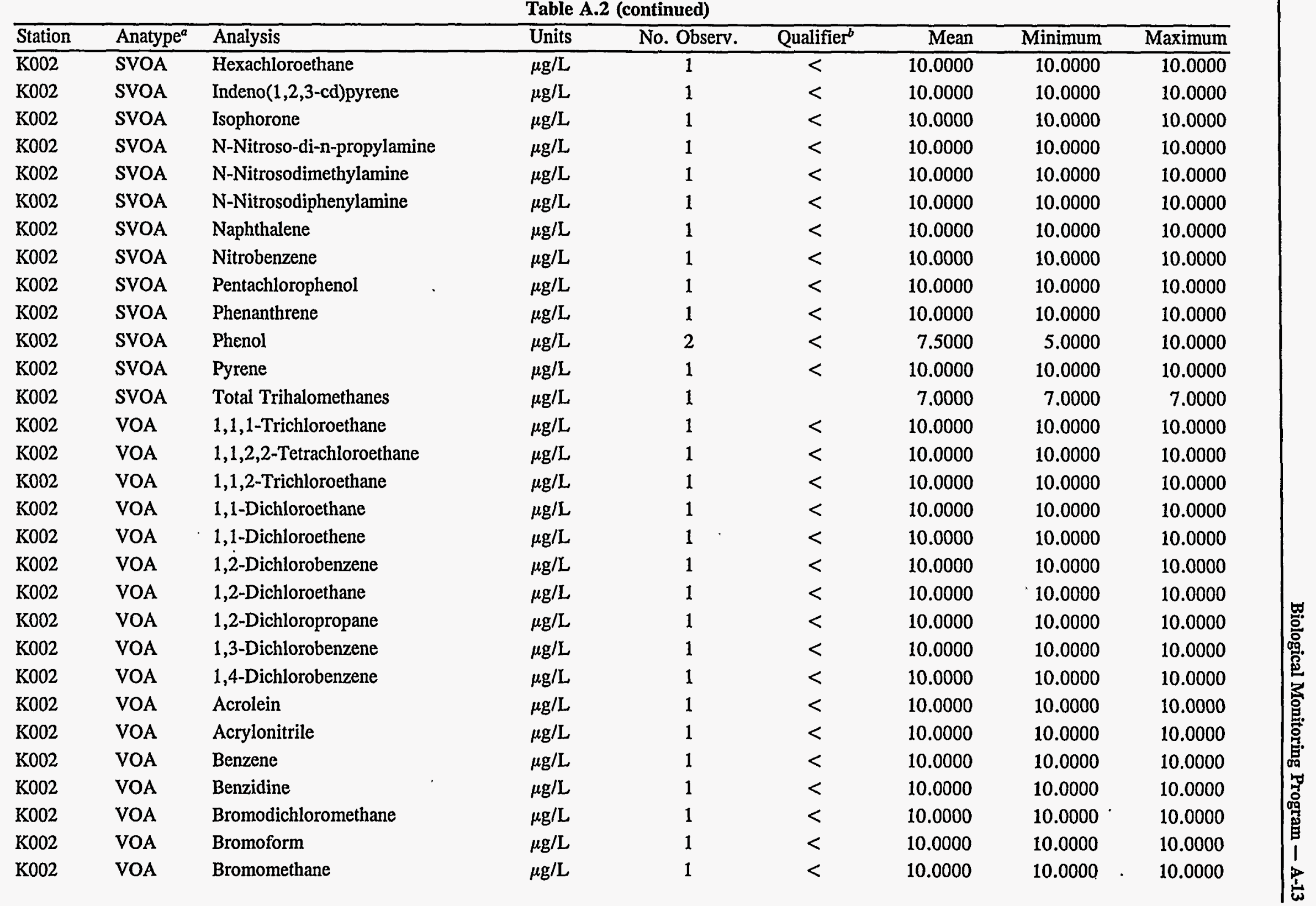




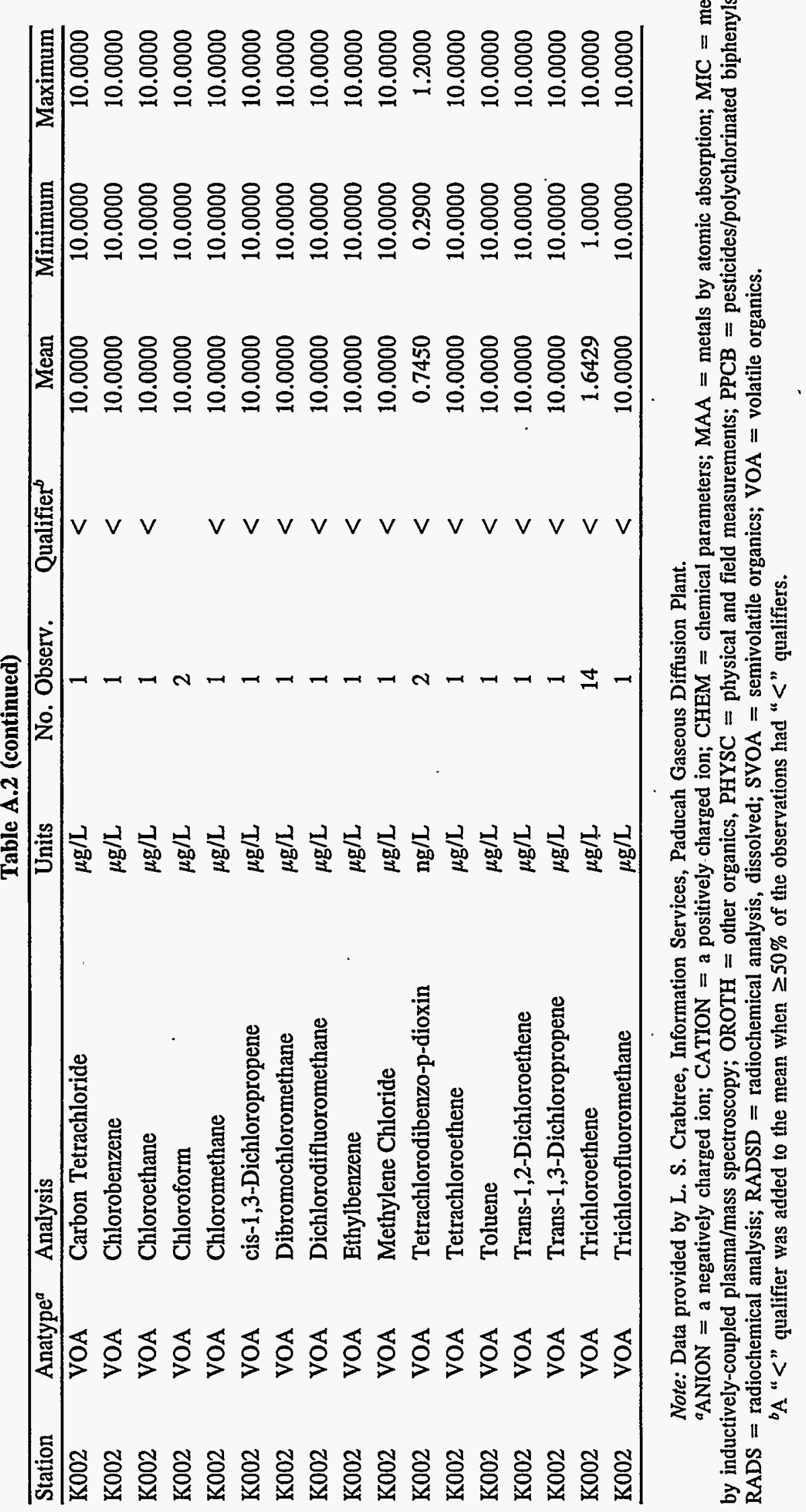


Table A.3. Water quality parameters measured at Kentucky Pollutant Discharge Elimination System permitted outfall 004 in 1994

\begin{tabular}{|c|c|c|c|c|c|c|c|c|}
\hline Station & Anatype $^{a}$ & Analysis & Units & No. Observ. & Qualifier $^{b}$ & Mean & Minimum & $\overline{\text { Maximum }}$ \\
\hline K004 & ANION & Bromide & $\mathrm{mg} / \mathrm{L}$ & 1 & $<$ & 1.0000 & 1.0000 & 1.0000 \\
\hline K004 & ANION & Chloride & $\mathrm{mg} / \mathrm{L}$ & 1 & & 24.0000 & 24.0000 & 24.0000 \\
\hline K004 & ANION & Chlorine, Total Residual & $\mathrm{mg} / \mathrm{L}$ & 1 & $<$ & 0.0500 & 0.0500 & 0.0500 \\
\hline K004 & ANION & Cyanide & $\mathrm{mg} / \mathrm{L}$ & 1 & $<$ & 0.0200 & 0.0200 & 0.0200 \\
\hline K004 & ANION & Fluoride & $\mathrm{mg} / \mathrm{L}$ & 1 & & 0.1600 & 0.1600 & 0.1600 \\
\hline K004 & ANION & Hardness as $\mathrm{CaCO}_{3}$ & $\mathrm{mg} / \mathrm{L} \mathrm{CaCO} \mathrm{Ca}_{3}$ & 1 & & 92.0000 & 92.0000 & 92.0000 \\
\hline K004 & ANION & Nitrate-Nitrite & $\mathrm{mg} / \mathrm{L}$ & 1 & & 2.1000 & 2.1000 & 2.1000 \\
\hline K004 & ANION & Sulfate & $\mathrm{mg} / \mathrm{L}$ & 1 & & 29.0000 & 29.0000 & 29.0000 \\
\hline K004 & ANION & Sulfide & $\mathrm{mg} / \mathrm{L}$ & 1 & & 2.0000 & 2.0000 & 2.0000 \\
\hline K004 & ANION & Sulfite & $\mathrm{mg} / \mathrm{L}$ & 1 & $<$ & 3.0000 & 3.0000 & 3.0000 \\
\hline K004 & CATION & Ammonia as Nitrogen & $\mathrm{mg} / \mathrm{L}$ & 1 & $<$ & 1.7000 & 1.7000 & 1.7000 \\
\hline K004 & CHEM & Total Organic Carbon & $\mathrm{mg} / \mathrm{L}$ & 1 & & 7.0000 & 7.0000 & 7.0000 \\
\hline K004 & CHEM & Total Organic Nitrogen & $\mathrm{mg} / \mathrm{L}$ & 1 & & 2.8000 & 2.8000 & 2.8000 \\
\hline K004 & MAA & Arsenic & $\mathrm{mg} / \mathrm{L}$ & 2 & $<$ & 0.0225 & 0.0050 & 0.0400 \\
\hline K004 & MAA & Mercury & $\mathrm{mg} / \mathrm{L}$ & 1 & $<$ & 0.0002 & 0.0002 & 0.0002 \\
\hline K004 & MAA & Selenium & $\mathrm{mg} / \mathrm{L}$ & 2 & $<$ & 0.0525 & 0.0050 & 0.1000 \\
\hline K004 & MICP & Aluminum & $\mathrm{mg} / \mathrm{L}$ & 2 & & 0.1150 & 0.0700 & 0.1600 \\
\hline K004 & MICP & Antimony & $\mathrm{mg} / \mathrm{L}$ & 1. & $<$ & 0.0600 & 0.0600 & 0.0600 \\
\hline K004 & MICP & Barium & $\mathrm{mg} / \mathrm{L}$ & 2 & & 0.0175 & 0.0160 & 0.0190 \\
\hline K004 & MICP & Beryllium & $\mathrm{mg} / \mathrm{L}$ & 2 & $<$ & 0.0027 & 0.0004 & 0.0050 \\
\hline K004 & MICP & Boron & $\mathrm{mg} / \mathrm{L}$ & 1 & & 0.0190 & 0.0190 & 0.0190 \\
\hline K004 & MICP & Cadmium & $\mathrm{mg} / \mathrm{L}$ & 2 & $<$ & 0.0070 & 0.0040 & 0.0100 \\
\hline K004 & MICP & Calcium & $\mathrm{mg} / \mathrm{L}$ & 1 & & 20.2000 & 20.2000 & 20.2000 \\
\hline K004 & MICP & Cerium & $\mathrm{mg} / \mathrm{L}$ & 1 & $<$ & 0.0200 & 0.0200 & 0.0200 \\
\hline K004 & MICP & Chromium & $\mathrm{mg} / \mathrm{L}$ & 2 & $<$ & 0.0280 & 0.0060 & 0.0500 \\
\hline K004 & MICP & Cobalt & $\mathrm{mg} / \mathrm{L}$ & 2 & $<$ & 0.0260 & 0.0020 & 0.0500 \\
\hline K004 & MICP & Copper & $\mathrm{mg} / \mathrm{L}$ & 2 & & 0.0115 & 0.0100 & 0.0130 \\
\hline K004 & MICP & Gallium & $\mathrm{mg} / \mathrm{L}$ & 1 & $<$ & 0.0200 & 0.0200 & 0.0200 \\
\hline K004 & MICP & Iron & $\mathrm{mg} / \mathrm{L}$ & 2 & & 0.4260 & 0.3620 & 0.4900 \\
\hline
\end{tabular}


Table A.3 (continued)

\begin{tabular}{|c|c|c|c|c|c|c|c|c|}
\hline Station & Anatype $^{a}$ & Analysis & Units & No. Observ. & Qualifier $^{b}$ & Mean & Minimum & Maximum \\
\hline K004 & MICP & Lead & $\mathrm{mg} / \mathrm{L}$ & 2 & $<$ & 0.1100 & 0.0200 & 0.2000 \\
\hline K004 & MICP & Lithium & $\mathrm{mg} / \mathrm{L}$ & 1 & $<$ & 0.0200 & 0.0200 & 0.0200 \\
\hline K004 & MICP & Magnesium & $\mathrm{mg} / \mathrm{L}$ & 2 & & 4.4100 & 4.1900 & 4.6300 \\
\hline K004 & MICP & Manganese & $\mathrm{mg} / \mathrm{L}$ & 2 & & 0.0410 & 0.0340 & 0.0480 \\
\hline $\mathrm{K} 004$ & MICP & Molybdenum & $\mathrm{mg} / \mathrm{L}$ & 2 & & 0.0295 & 0.0090 & 0.0500 \\
\hline K004 & MICP & Nickel & $\mathrm{mg} / \mathrm{L}$ & 2 & $<$ & 0.0290 & 0.0080 & 0.0500 \\
\hline K004 & MICP & Niobium & $\mathrm{mg} / \mathrm{L}$ & 1 & $<$ & 0.0100 & 0.0100 & 0.0100 \\
\hline K004 & MICP & Phosphorus (P) & $\mathrm{mg} / \mathrm{L}$ & 1 & & 1.0700 & 1.0700 & 1.0700 \\
\hline K004 & MICP & Potassium & $\mathrm{mg} / \mathrm{L}$ & 1 & & 4.5000 & 4.5000 & 4.5000 \\
\hline K004 & MICP & Silver & $\mathrm{mg} / \mathrm{L}$ & 2 & $<$ & 0.0180 & 0.0060 & 0.0300 \\
\hline K004 & MICP & Sodium & $\mathrm{mg} / \mathrm{L}$ & 1 & & 28.0000 & 28.0000 & 28.0000 \\
\hline $\mathrm{K} 004$ & MICP & Strontium & $\mathrm{mg} / \mathrm{L}$ & 1 & & 0.1820 & 0.1820 & 0.1820 \\
\hline K004 & MICP & Thallium & $\mathrm{mg} / \mathrm{L}$ & 2 & $<$ & 0.0450 & 0.0300 & 0.0600 \\
\hline K004 & MICP & Thorium & $\mathrm{mg} / \mathrm{L}$ & 1 & $<$ & 0.0100 & 0.0100 & 0.0100 \\
\hline K004 & MICP & Tin & $\mathrm{mg} / \mathrm{L}$ & 1 & $<$ & 0.0500 & 0.0500 & 0.0500 \\
\hline K004 & MICP & Titanium & $\mathrm{mg} / \mathrm{L}$ & 2 & $<$ & 0.0350 & 0.0200 & 0.0500 \\
\hline K004 & MICP & Vanadium & $\mathrm{mg} / \mathrm{L}$ & 1 & $<$ & 0.0040 & 0.0040 & 0.0040 \\
\hline K004 & MICP & Zinc & $\mathrm{mg} / \mathrm{L}$ & 2 & & 0.0435 & 0.0400 & 0.0470 \\
\hline K004 & MICP & Zirconium & $\mathrm{mg} / \mathrm{L}$ & 1 & $<$ & 0.0040 & 0.0040 & 0.0040 \\
\hline K004 & OROTH & Surfactants & $\mathrm{mg} / \mathrm{L}$ & 1 & & 0.1000 & 0.1000 & 0.1000 \\
\hline K004 & PHYSC & BOD & $\mathrm{mg} / \mathrm{L}$ & 25 & & 9.3200 & 5.0000 & 20.0000 \\
\hline K004 & PHYSC & COD & $\mathrm{mg} / \mathrm{L}$ & 1 & & 35.0000 & 35.0000 & 35.0000 \\
\hline K004 & PHYSC & Color & Units & 1 & & 22.0000 & 22.0000 & 22.0000 \\
\hline K004 & PHYSC & Fecal Coliform & $\mathrm{co} / 100 \mathrm{~mL}$ & 27 & & 3.4074 & 1.0000 & 12.0000 \\
\hline K004 & PHYSC & Flow & MLD & 25 & & 1.1806 & 0.8971 & 1.8169 \\
\hline K004 & PHYSC & Oil and Grease & $\mathrm{mg} / \mathrm{L}$ & 1 & $<$ & 5.0000 & 5.0000 & 5.0000 \\
\hline K004 & PHYSC & $\mathrm{pH}$ & SU & 25 & & 7.2280 & 6.6000 & 8.1000 \\
\hline K004 & PHYSC & Temperature & $\mathrm{C}$ & 1 & & 14.4444 & 14.4444 & 14.4444 \\
\hline K004 & PHYSC & Total Suspended Solids & $\mathrm{mg} / \mathrm{L}$ & 1 & & 11.0000 & 11.0000 & 11.0000 \\
\hline K004 & PPCB & Acenaphthene & $\mu \mathrm{g} / \mathrm{L}$ & 1 & $<$ & 10.0000 & 10.0000 & 10.0000 \\
\hline
\end{tabular}


Table A.3 (continued)

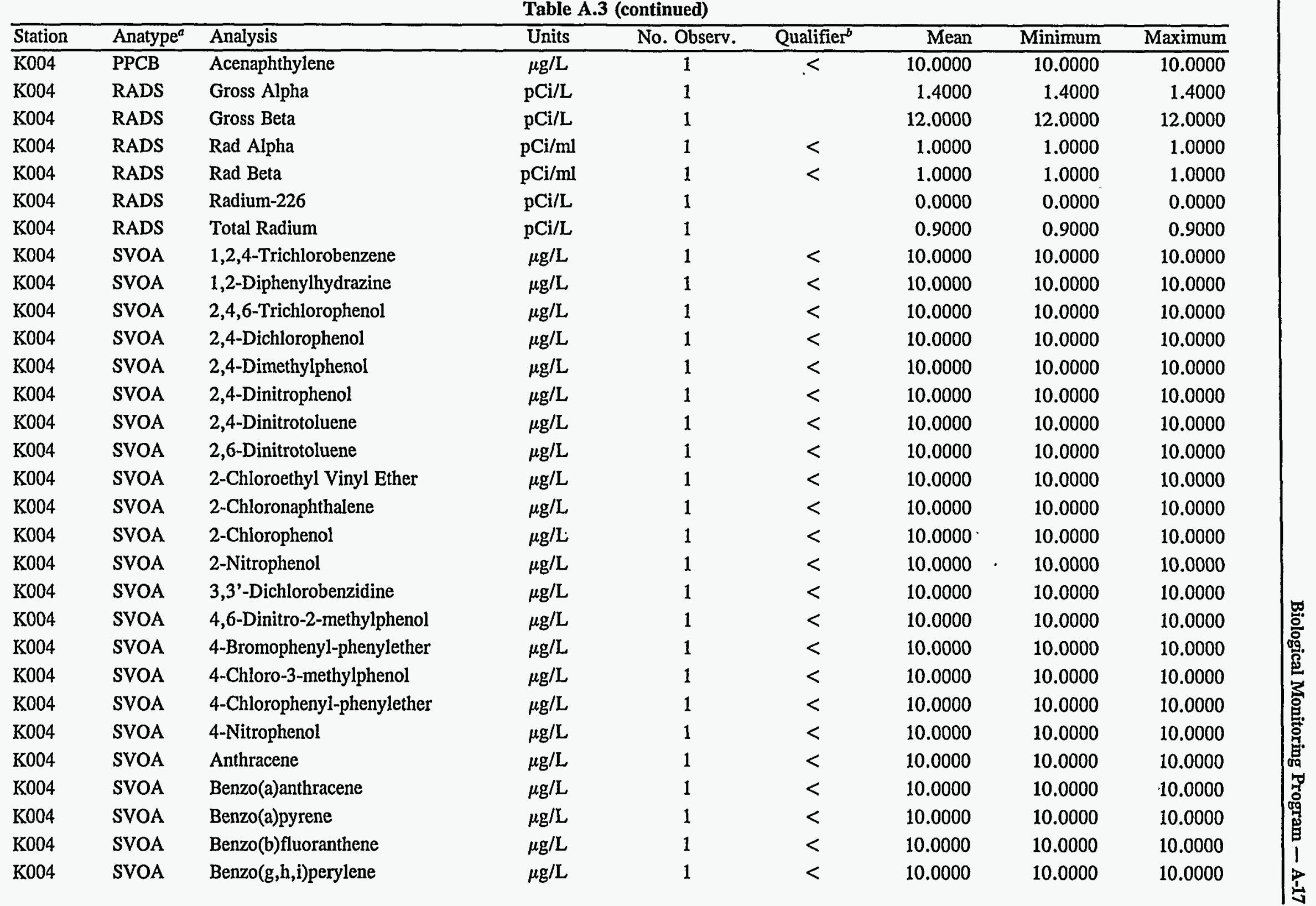




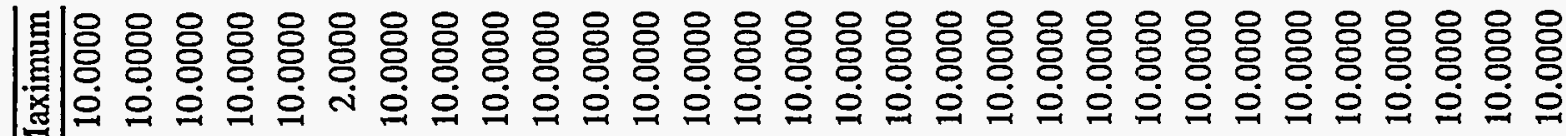

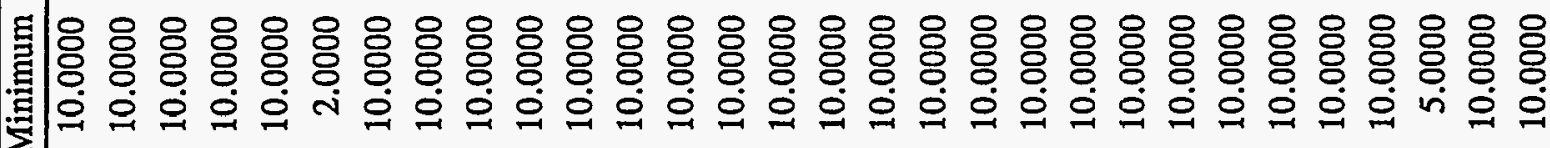

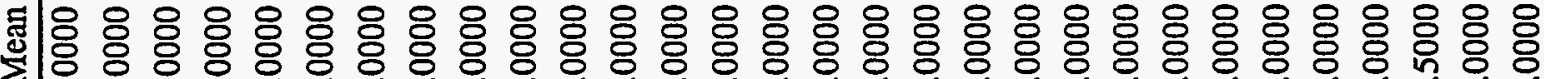

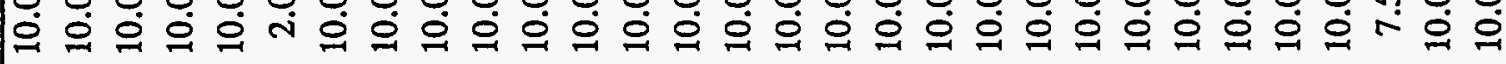

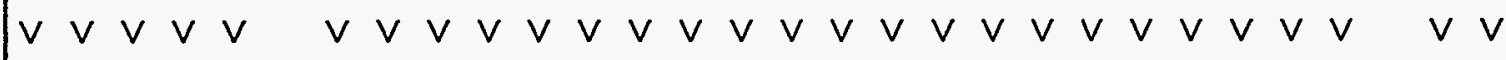

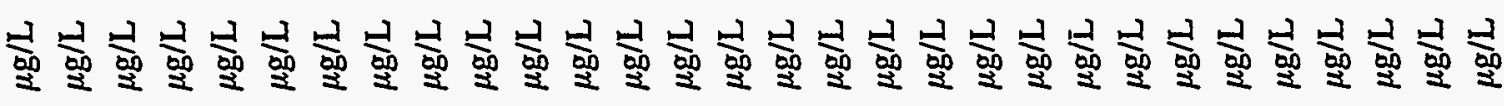

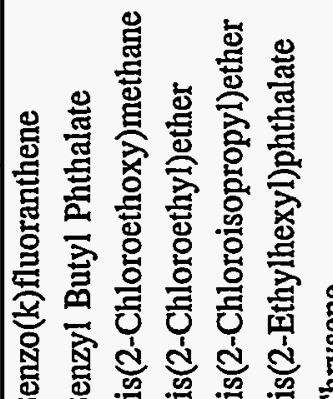
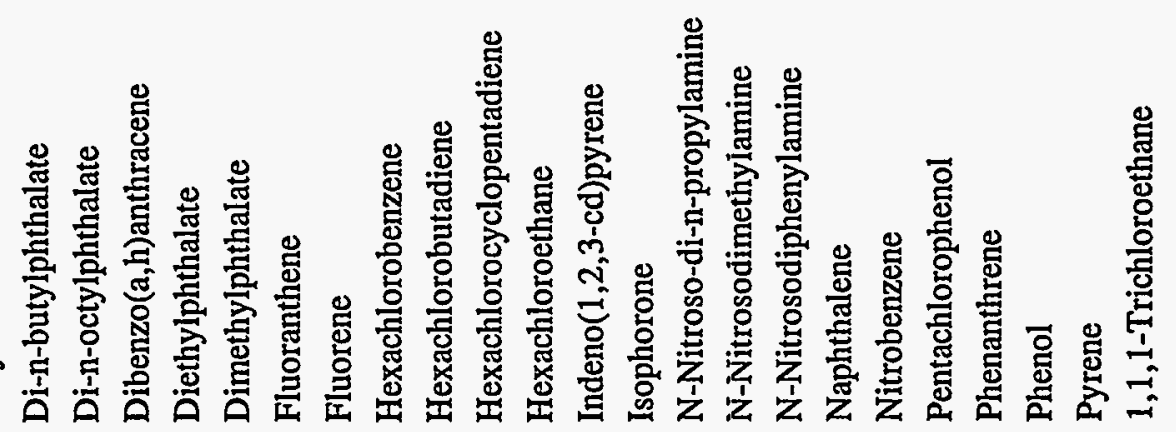

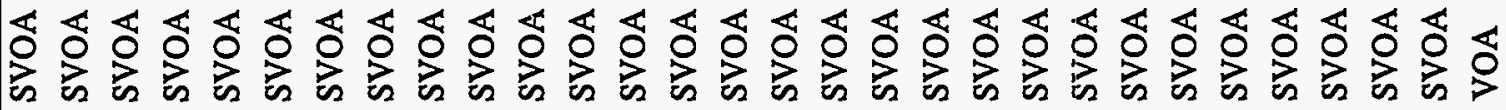


Table A.3 (continued)

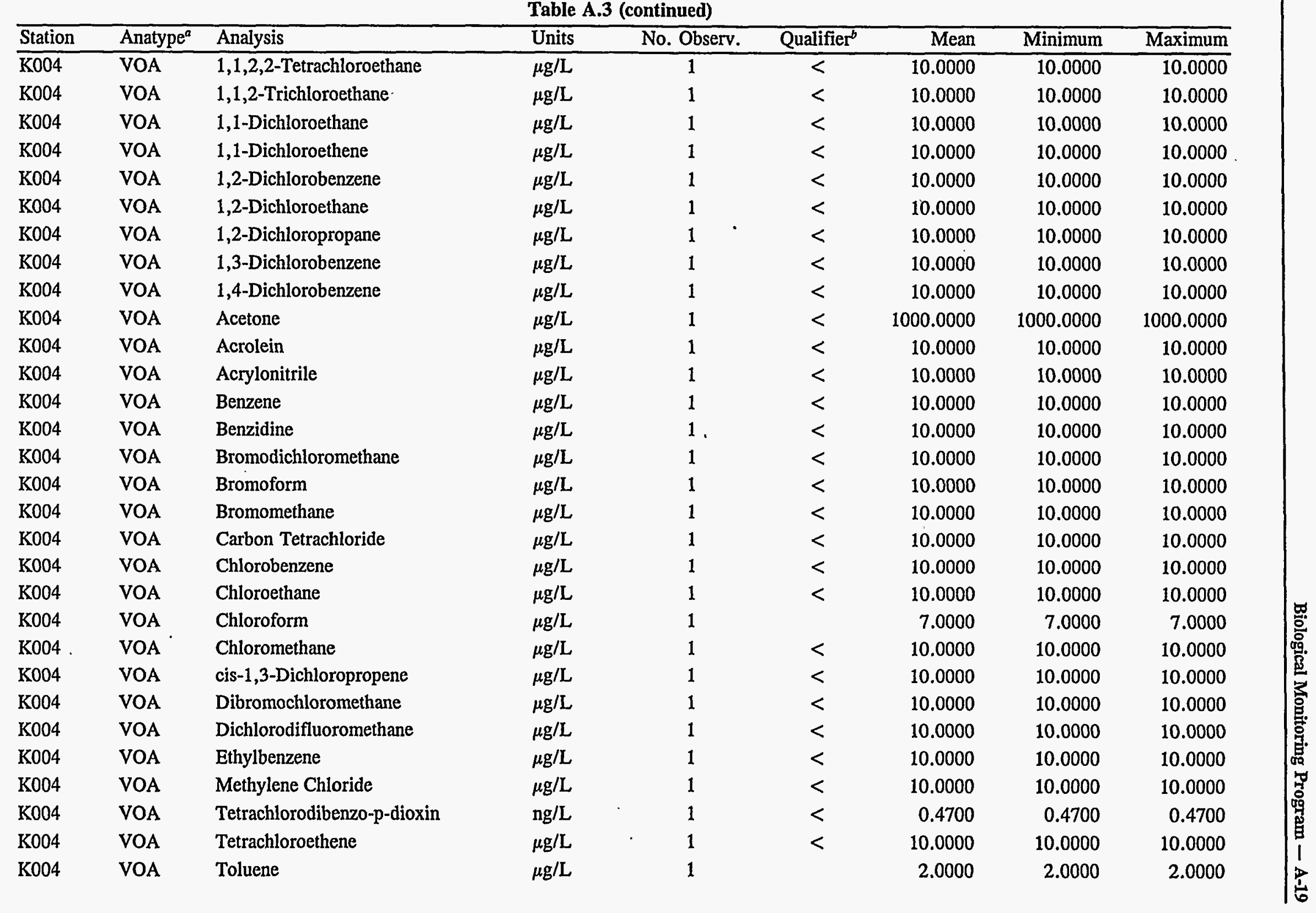


Table A.3 (continued)

\begin{tabular}{|c|c|c|c|c|c|c|c|c|}
\hline Station & Anatype & Analysis & Units & No. Observ. & Qualifier $^{b}$ & Mean & Minimum & Maximum \\
\hline K004 & VOA & Trans-1,2-Dichloroethene & $\mu \mathrm{g} / \mathrm{L}$ & 1 & $<$ & 10.0000 & 10.0000 & 10.0000 \\
\hline K004 & VOA & Trans-1,3-Dichloropropene & $\mu \mathrm{g} / \mathrm{L}$ & 1 & $<$ & 10.0000 & 10.0000 & 10.0000 \\
\hline K004 & VOA & Trichloroethene & $\mu \mathrm{g} / \mathrm{L}$ & 1 & $<$ & 10.0000 & 10.0000 & 10.0000 \\
\hline K004 & VOA & Trichlorofluoromethane & $\mu \mathrm{g} / \mathrm{L}$ & 1 & $<$ & 10.0000 & 10.0000 & 10.0000 \\
\hline K004 & VOA & Vinyl Chloride & $\mu \mathrm{g} / \mathrm{L}$ & 1 & $<$ & 10.0000 & 10.0000 & 10.0000 \\
\hline
\end{tabular}

Note: Data provided by L. S. Crabtree, Information Services, Paducah Gaseous Diffusion Plant.

${ }^{a} \mathrm{ANION}=$ a negatively charged ion; CATION $=$ a positively charged ion; CHEM = chemical parameters; MAA $=$ metals by atomic absorption; MIC = metals by inductively-coupled plasma/mass spectroscopy; OROTH = other organics, PHYSC = physical and field measurements; PPCB = pesticides/polychlorinated biphenyls; RADS = radiochemical analysis; RADSD = radiochemical analysis, dissolved; SVOA = semivolatile organics; VOA = volatile organics

"A " $<$ " qualifier was added to the mean when $\geq 50 \%$ of the observations had " $<$ " qualifiers. 
Table A.4. Water quality parameters measured at Kentucky Pollutant Discharge Elimination System permitted outfall 006 in 1994

\begin{tabular}{|c|c|c|c|c|c|c|c|c|}
\hline Station & Anatype ${ }^{a}$ & Analysis & Units & No. Observ. & Qualifier $^{b}$ & Mean & Minimum & Maximum \\
\hline $\mathrm{K} 006$ & ANION & Bromide & $\mathrm{mg} / \mathrm{L}$ & 1 & $<$ & 1.0000 & 1.0000 & 1.0000 \\
\hline K006 & ANION & Chloride & $\mathrm{mg} / \mathrm{L}$ & 1 & & 8.0000 & 8.0000 & 8.0000 \\
\hline K006 & ANION & Chlorine, Total Residual & $\mathrm{mg} / \mathrm{L}$ & 53 & $<$ & 0.0451 & 0.0300 & 0.0500 \\
\hline K006 & ANION & Cyanide & $\mathrm{mg} / \mathrm{L}$ & 1 & $<$ & 0.0200 & 0.0200 & 0.0200 \\
\hline K006 & ANION & Fluoride & $\mathrm{mg} / \mathrm{L}$ & 1 & & 0.1000 & 0.1000 & 0.1000 \\
\hline K006 & ANION & Hardness as $\mathrm{CaCO}_{3}$ & $\mathrm{mg} / \mathrm{L} \mathrm{CaCO}{ }_{3}$ & 53 & & 73.1887 & 54.0000 & 114.0000 \\
\hline K006 & ANION & Nitrate-Nitrite & $\mathrm{mg} / \mathrm{L}$ & 1 & & 0.4300 & 0.4300 & 0.4300 \\
\hline K006 & ANION & Sulfate & $\mathrm{mg} / \mathrm{L}$ & 1 & & 19.0000 & 19.0000 & 19.0000 \\
\hline K006 & ANION & Sulfide & $\mathrm{mg} / \mathrm{L}$ & 1 & $<$ & 1.0000 & 1.0000 & 1.0000 \\
\hline K006 & ANION & Sulfite & $\mathrm{mg} / \mathrm{L}$ & 1 & $<$ & 3.0000 & 3.0000 & 3.0000 \\
\hline K006 & CATION & Ammonia as Nitrogen & $\mathrm{mg} / \mathrm{L}$ & 1 & $<$ & 0.2000 & 0.2000 & 0.2000 \\
\hline K006 & CHEM & Total Organic Carbon & $\mathrm{mg} / \mathrm{L}$ & 1 & & 4.0000 & 4.0000 & 4.0000 \\
\hline K006 & CHEM & Total Organic Nitrogen & $\mathrm{mg} / \mathrm{L}$ & 1 & & 0.6800 & 0.6800 & 0.6800 \\
\hline K006 & MAA & Arsenic & $\mathrm{mg} / \mathrm{L}$ & 2 & $<$ & 0.0225 & 0.0050 & 0.0400 \\
\hline K006 & MAA & Mercury & $\mathrm{mg} / \mathrm{L}$ & 1 & $<$ & 0.0002 & 0.0002 & 0.0002 \\
\hline K006 & MAA & Selenium & $\mathrm{mg} / \mathrm{L}$ & 2 & $<$ & 0.0525 & 0.0050 & 0.1000 \\
\hline K006 & MICP & Aluminum & $\mathrm{mg} / \mathrm{L}$ & 26 & & 0.5993 & 0.2100 & 1.1800 \\
\hline K006 & MICP & Antimony & $\mathrm{mg} / \mathrm{L}$ & 1 & $<$ & 0.0600 & 0.0600 & 0.0600 \\
\hline K006 & MICP & Barium & $\mathrm{mg} / \mathrm{L}$ & 2 & & 0.0219 & 0.0218 & 0.0220 \\
\hline K006 & MICP & Beryllium & $\mathrm{mg} / \mathrm{L}$ & 2 & $<$ & 0.0027 & 0.0004 & 0.0050 \\
\hline K006 & MICP & Boron & $\mathrm{mg} / \mathrm{L}$ & 1 & & 0.0130 & 0.0130 & 0.0130 \\
\hline K006 & MICP & Cadmium & $\mathrm{mg} / \mathrm{L}$ & 26 & $<$ & 0.0080 & 0.0005 & 0.0200 \\
\hline K006 & MICP & Calcium & $\mathrm{mg} / \mathrm{L}$ & 1 & & 17.2000 & 17.2000 & 17.2000 \\
\hline K006 & MICP & Cerium & $\mathrm{mg} / \mathrm{L}$ & 1 & $<$ & 0.0200 & 0.0200 & 0.0200 \\
\hline K006 & MICP & Chromium & $\mathrm{mg} / \mathrm{L}$ & 26 & $<$ & 0.0391 & 0.0060 & 0.0500 \\
\hline K006 & MICP & Cobalt & $\mathrm{mg} / \mathrm{L}$ & 2 & $<$ & 0.0260 & 0.0020 & 0.0500 \\
\hline K006 & MICP & Copper & $\mathrm{mg} / \mathrm{L}$ & 26 & $<$ & 0.0111 & 0.0060 & 0.0190 \\
\hline K006 & MICP & Gallium & $\mathrm{mg} / \mathrm{L}$ & 1 & $<$ & 0.0200 & 0.0200 & 0.0200 \\
\hline K.006 & MICP & Iron & $\mathrm{mg} / \mathrm{L}$ & 26 & & 0.7371 & 0.3330 & 1.3000 \\
\hline
\end{tabular}


Table A.4 (continued)

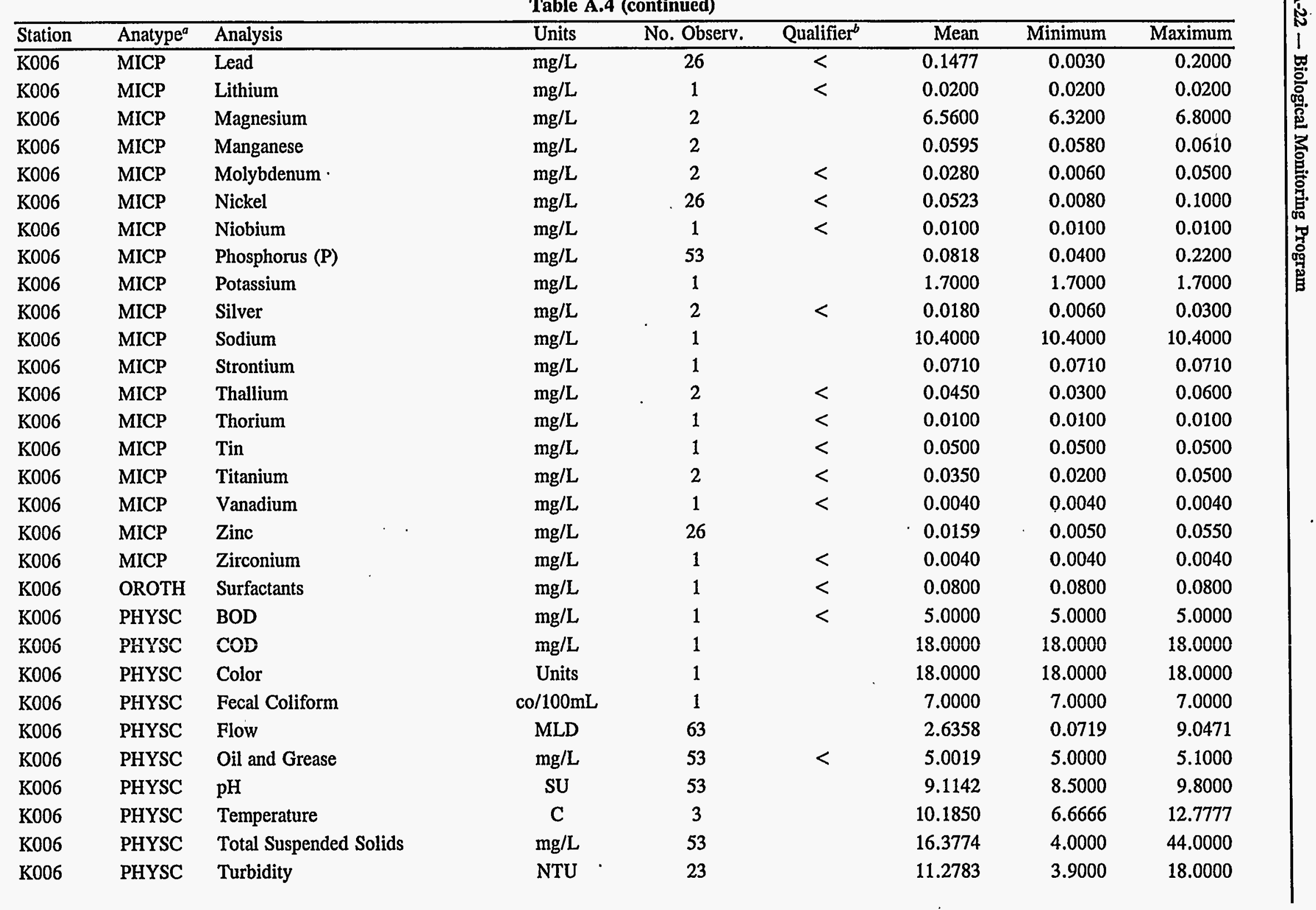


Table A.4 (continued)

\begin{tabular}{|c|c|c|c|c|c|c|c|c|}
\hline Station & Anatype $^{a}$ & Analysis & Units & No. Observ. & Qualifier ${ }^{b}$ & Mean & Minimum & Maximum \\
\hline K006 & PPCB & Acenaphthene & $\mu \mathrm{g} / \mathrm{L}$ & 1 & $<$ & 10.0000 & 10.0000 & 10.0000 \\
\hline K006 & PPCB & Acenaphthylene & $\mu \mathrm{g} / \mathrm{L}$ & 1 & $<$ & 10.0000 & 10.0000 & 10.0000 \\
\hline K006 & PPCB & PCB & $\mu \mathrm{g} / \mathrm{L}$ & 12 & $<$ & 0.0942 & 0.0650 & 0.1000 \\
\hline K006 & RADS & Gross Beta & $\mathrm{pCi} / \mathrm{L}$ & 1 & & 4.0000 & 4.0000 & 4.0000 \\
\hline K006 & RADS & Rad Alpha & $\mathrm{pCi} / \mathrm{ml}$ & 24 & $<$ & 1.0000 & 1.0000 & 1.0000 \\
\hline K006 & RADS & Total Radium & $\mathrm{pCi} / \mathrm{L}$ & 1 & & 0.3000 & 0.3000 & 0.3000 \\
\hline K006 & SVOA & 1,2,4-Trichlorobenzene & $\mu \mathrm{g} / \mathrm{L}$ & 1 & $<$ & 10.0000 & 10.0000 & 10.0000 \\
\hline K006 & SVOA & 1,2-Diphenylhydrazine & $\mu \mathrm{g} / \mathrm{L}$ & 1 & $<$ & 10.0000 & 10.0000 & 10.0000 \\
\hline K006 & SVOA & 2,4,6-Trichlorophenol & $\mu \mathrm{g} / \mathrm{L}$ & 1 & $<$ & 10.0000 & 10.0000 & 10.0000 \\
\hline K006 & SVOA & 2,4-Dichlorophenol & $\mu \mathrm{g} / \mathrm{L}$ & 1 & $<$ & 10.0000 & 10.0000 & 10.0000 \\
\hline K006 & SVOA & 2,4-Dimethylphenol & $\mu \mathrm{g} / \mathrm{L}$ & 1 & $<$ & 10.0000 & 10.0000 & 10.0000 \\
\hline K006 & SVOA & 2-Chloronaphthalene & $\mu \mathrm{g} / \mathrm{L}$ & 1 & $<$ & 10.0000 & 10.0000 & 10.0000 \\
\hline K006 & SVOA & 2-Chlorophenol & $\mu \mathrm{g} / \mathrm{L}$ & 1 & $<$ & 10.0000 & 10.0000 & 10.0000 \\
\hline K006 & SVOA & 2-Nitrophenol & $\mu \mathrm{g} / \mathrm{L}$ & 1 & $<$ & 10.0000 & 10.0000 & 10.0000 \\
\hline K006 & SVOA & 3,3'-Dichlorobenzidine & $\mu \mathrm{g} / \mathrm{L}$ & 1 & $<$ & 10.0000 & 10.0000 & 10.0000 \\
\hline K006 & SVOA & 4,6-Dinitro-2-methylphenol & $\mu \mathrm{g} / \mathrm{L}$ & 1 & $<$ & 10.0000 & 10.0000 & 10.0000 \\
\hline K006 & SVOA & 4-Bromophenyl-phenylether & $\mu \mathrm{g} / \mathrm{L}$ & 1 & $<$ & 10.0000 & 10.0000 & 10.0000 \\
\hline K006 & SVOA & 4-Chloro-3-methylphenol & $\mu \mathrm{g} / \mathrm{L}$ & 1 & $<$ & 10.0000 & 10.0000 & 10.0000 \\
\hline K006 & SVOA & 4-Chlorophenyl-phenylether & $\mu \mathrm{g} / \mathrm{L}$ & 1 & $<$ & 10.0000 & 10.0000 & 10.0000 \\
\hline K006 & SVOA & 4-Nitrophenol & $\mu \mathrm{g} / \mathrm{L}$ & 1 & $<$ & 10.0000 & 10.0000 & 10.0000 \\
\hline K006 & SVOA & Anthracene & $\mu \mathrm{g} / \mathrm{L}$ & 1 & $<$ & 10.0000 & 10.0000 & 10.0000 \\
\hline K006 & SVOA & Benzo(a)anthracene & $\mu \mathrm{g} / \mathrm{L}$ & 1 & $<$ & 10.0000 & 10.0000 & 10.0000 \\
\hline
\end{tabular}


Table A.4 (continued)

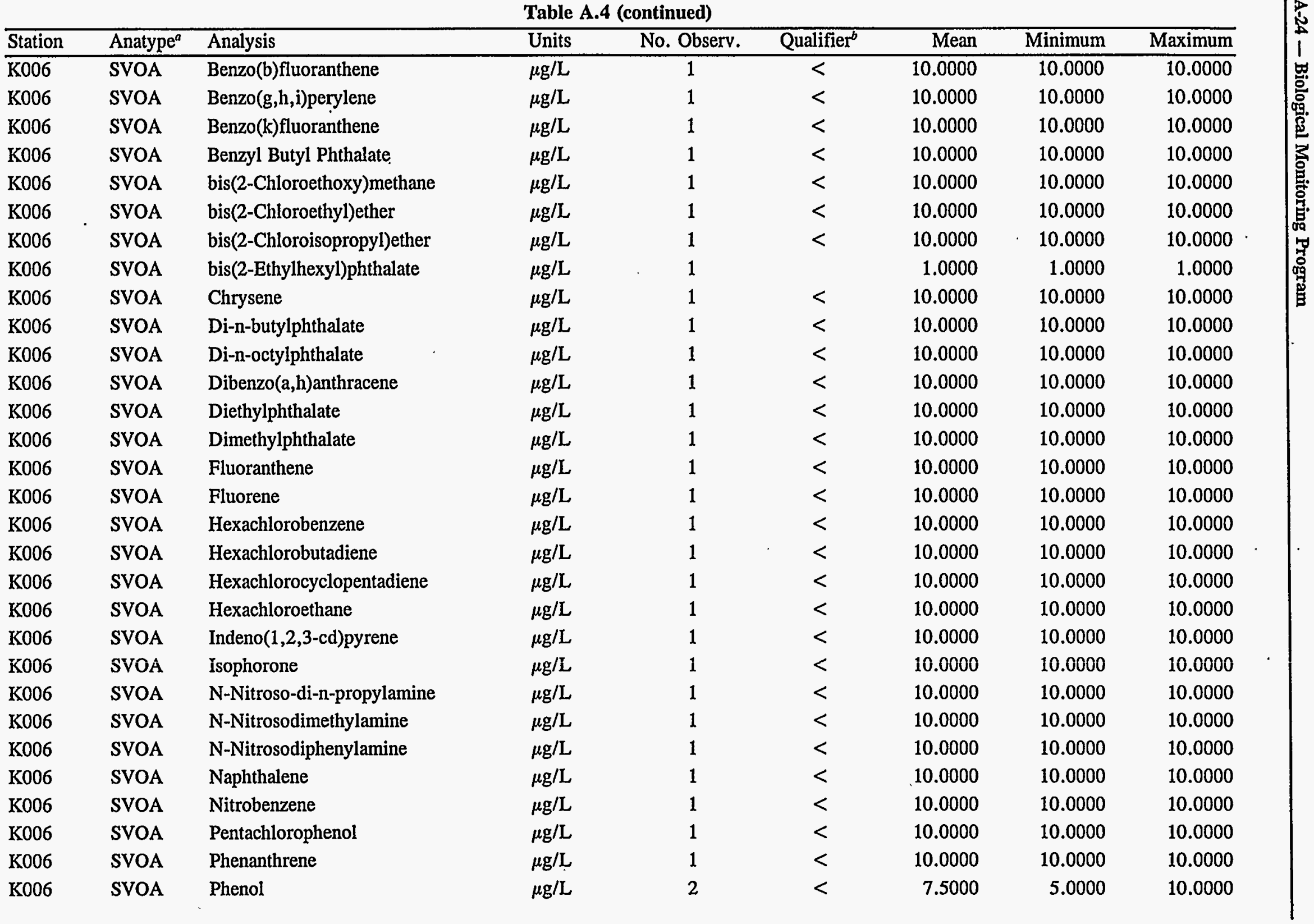


Table A.4 (continued)

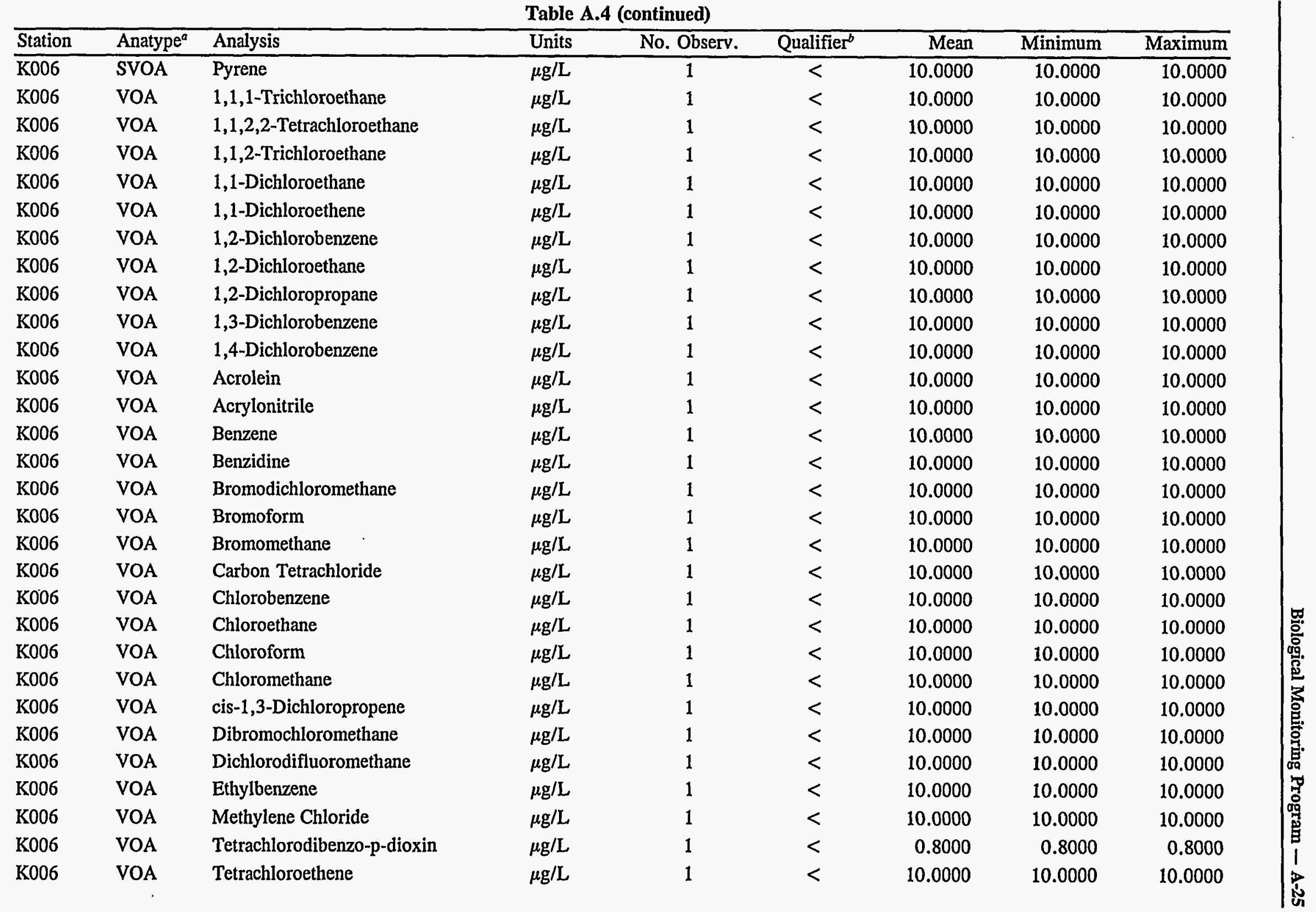


Table A.4 (continued)

\begin{tabular}{|c|c|c|c|c|c|c|c|c|}
\hline Station & Anatype $^{a}$ & Analysis & Units & No. Observ. & Qualifier $^{b}$ & Mean & Minimum & Maximum \\
\hline$\overline{\mathrm{K} 006}$ & VOA & Toluene & $\mu \mathrm{g} / \mathrm{L}$ & 1 & $<$ & 10.0000 & 10.0000 & 10.0000 \\
\hline K006 & VOA & Trans-1,2-Dichloroethene & $\mu \mathrm{g} / \mathrm{L}$ & 1 & $<$ & 10.0000 & 10.0000 & 10.0000 \\
\hline K006 & VOA & Trans-1,3-Dichloropropene & $\mu \mathrm{g} / \mathrm{L}$ & 1 & $<$ & 10.0000 & 10.0000 & 10.0000 \\
\hline K006 & VOA & Trichloroethene & $\mu \mathrm{g} / \mathrm{L}$ & 1 & $<$ & 10.0000 & 10.0000 & 10.0000 \\
\hline K006 & VOA & Trichlorofluoromethane & $\mu \mathrm{g} / \mathrm{L}$ & 1 & $<$ & 10.0000 & 10.0000 & 10.0000 \\
\hline K006 & VOA & Vinyl Chloride & $\mu \mathrm{g} / \mathrm{L}$ & 1 & $<$ & 10.0000 & 10.0000 & 10.0000 \\
\hline
\end{tabular}

Note: Data provided by L. S. Crabtree, Information Services, Paducah Gaseous Diffusion Plant.

${ }^{a}$ ANION = a negatively charged ion; CATION = a positively charged ion; CHEM = chemical parameters; MAA = metals by atomic absorption; MIC = metals by inductively-coupled plasma/mass spectroscopy; OROTH = other organics, PHYSC = physical and field measurements; PPCB = pesticides/polychlorinated biphenyls; RADS = radiochemical analysis; RADSD = radiochemical analysis, dissolved; $S V O A=$ semivolatile organics; VOA $=$ volatile organics.

"A " $<$ " qualifier was added to the mean when $\geq 50 \%$ of the observations had " $<$ " qualifiers. 
Table A.5. Water quality parameters measured at Kentucky Pollutant Discharge Elimination System permitted outfall 008 in 1994

\begin{tabular}{|c|c|c|c|c|c|c|c|c|}
\hline Station & Anatype $^{a}$ & Analysis & Units & No. Observ. & Qualifier & Mean & Minimum & Maximum \\
\hline K008 & ANION & Bromide & $\mathrm{mg} / \mathrm{L}$ & 1 & $<$ & 1.0000 & 1.0000 & 1.0000 \\
\hline K008 & ANION & Chloride & $\mathrm{mg} / \mathrm{L}$ & 1 & & 19.0000 & 19.0000 & 19.0000 \\
\hline K008 & ANION & Chlorine, Total Residual & $\mathrm{mg} / \mathrm{L}$ & 53 & $<$ & 0.0451 & 0.0300 & 0.0500 \\
\hline K008 & ANION & Cyanide & $\mathrm{mg} / \mathrm{L}$ & 1 & $<$ & 0.0200 & 0.0200 & 0.0200 \\
\hline K008 & ANION & Fluoride & $\mathrm{mg} / \mathrm{L}$ & 1 & & 0.1600 & 0.1600 & 0.1600 \\
\hline K008 & ANION & Hardness as $\mathrm{CaCO}_{3}$ & $\mathrm{mg} / \mathrm{L} \mathrm{CaCO}{ }_{3}$ & 53 & & 65.0189 & 44.0000 & 94.0000 \\
\hline K008 & ANION & Nitrate-Nitrite & $\mathrm{mg} / \mathrm{L}$ & 1 & & 1.2000 & 1.2000 & 1.2000 \\
\hline K008 & ANION & Sulfate & $\mathrm{mg} / \mathrm{L}$ & 1 & & 36.0000 & 36.0000 & 36.0000 \\
\hline K008 & ANION & Sulfide & $\mathrm{mg} / \mathrm{L}$ & 1 & & 1.1000 & 1.1000 & 1.1000 \\
\hline K008 & ANION & Sulfite & $\mathrm{mg} / \mathrm{L}$ & 1 & $<$ & 3.0000 & 3.0000 & 3.0000 \\
\hline K008 & CATION & Ammonia as Nitrogen & $\mathrm{mg} / \mathrm{L}$ & 1 & & 0.8200 & 0.8200 & 0.8200 \\
\hline K008 & CHEM & Total Organic Carbon & $\mathrm{mg} / \mathrm{L}$ & 1 & & 4.0000 & 4.0000 & 4.0000 \\
\hline K008 & CHEM & Total Organic Nitrogen & $\mathrm{mg} / \mathrm{L}$ & 1 & & 1.4000 & 1.4000 & 1.4000 \\
\hline K008 & MAA & Arsenic & $\mathrm{mg} / \mathrm{L}$ & 2 & $<$ & 0.0225 & 0.0050 & 0.0400 \\
\hline K008 & MAA & Mercury & $\mathrm{mg} / \mathrm{L}$ & 1 & $<$ & 0.0002 & 0.0002 & 0.0002 \\
\hline K008 & MAA & Selenium & $\mathrm{mg} / \mathrm{L}$ & 2 & $<$ & 0.0525 & 0.0050 & 0.1000 \\
\hline K008 & MICP & Aluminum & $\mathrm{mg} / \mathrm{L}$ & 26 & & 0.3170 & 0.0800 & 0.8750 \\
\hline K008 & MICP & Antimony & $\mathrm{mg} / \mathrm{L}$ & 1 & $<$ & 0.0600 & 0.0600 & 0.0600 \\
\hline K008 & MICP & Barium & $\mathrm{mg} / \mathrm{L}$ & 2 & & 0.0159 & 0.0158 & 0.0160 \\
\hline K008 & MICP & Beryllium & $\mathrm{mg} / \mathrm{L}$ & 2 & $<$ & 0.0027 & 0.0004 & 0.0050 \\
\hline K008 & MICP & Boron & $\mathrm{mg} / \mathrm{L}$ & 1 & & 0.0170 & 0.0170 & 0.0170 \\
\hline K008 & MICP & Cadmium & $\mathrm{mg} / \mathrm{L}$ & 26 & $<$ & 0.0082 & 0.0005 & 0.0250 \\
\hline K008 & MICP & Calcium & $\mathrm{mg} / \mathrm{L}$ & 1 & & 18.7000 & 18.7000 & 18.7000 \\
\hline K008 & MICP & Cerium & $\mathrm{mg} / \mathrm{L}$ & 1 & $<$ & 0.0200 & 0.0200 & 0.0200 \\
\hline K008 & MICP & Chromium & $\mathrm{mg} / \mathrm{L}$ & 26 & $<$ & 0.0391 & 0.0060 & 0.0500 \\
\hline K008 & MICP & Cobalt & $\mathrm{mg} / \mathrm{L}$ & 2 & $<$ & 0.0260 & 0.0020 & 0.0500 \\
\hline K008 & MICP & Copper & $\mathrm{mg} / \mathrm{L}$ & 26 & $<$ & 0.0112 & 0.0060 & 0.0250 \\
\hline K008 & MICP & Gallium & $\mathrm{mg} / \mathrm{L}$ & 1 & $<$ & 0.0200 & 0.0200 & 0.0200 \\
\hline K008 & MICP & Iron & $\mathrm{mg} / \mathrm{L}$ & 26 & & 0.2530 & 0.1360 & 0.6900 \\
\hline
\end{tabular}


Table A.5 (continued)

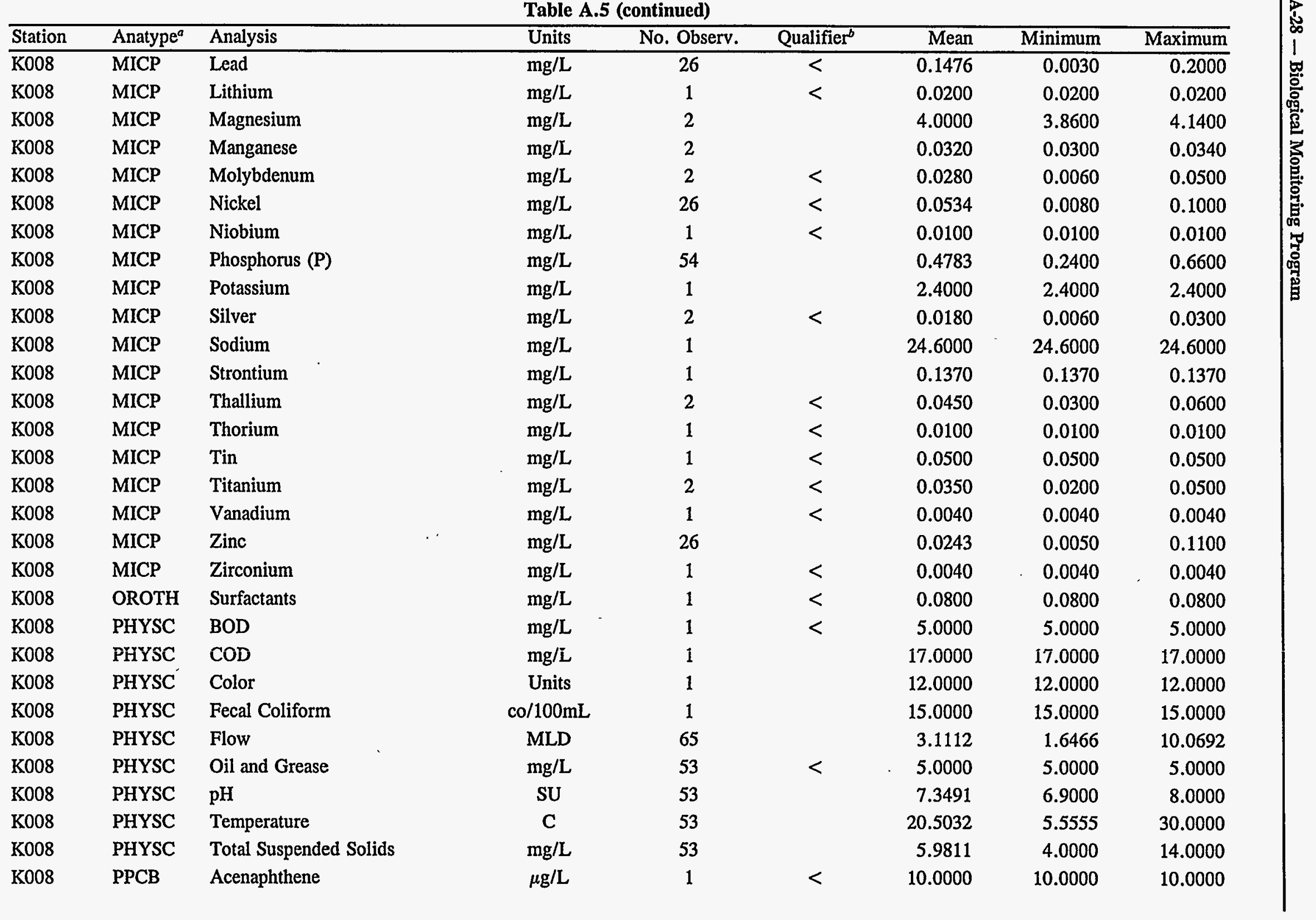


Table A.5 (continued)

\begin{tabular}{|c|c|c|c|c|c|c|c|c|}
\hline Station & Anatype $^{a}$ & Analysis & Units & No. Observ. & Qualifier $^{b}$ & Mean & Minimum & Maximum \\
\hline K008 & PPCB & Acenaphthylene & $\mu \mathrm{g} / \mathrm{L}$ & 1 & $<$ & 10.0000 & 10.0000 & 10.0000 \\
\hline K008 & PPCB & $\mathrm{PCB}$ & $\mu \mathrm{g} / \mathrm{L}$ & 12 & $<$ & 0.0942 & 0.0650 & 0.1000 \\
\hline K008 & RADS & $\%$ U-235 & Wt $\%$ & 5 & & 0.5978 & 0.5520 & 0.6490 \\
\hline K008 & RADS & Gross Alpha & $\mathrm{pCi} / \mathrm{L}$ & 1 & & 5.0000 & 5.0000 & 5.0000 \\
\hline K008 & RADS & Gross Beta & $\mathrm{pCi} / \mathrm{L}$ & 1 & & 13.0000 & 13.0000 & 13.0000 \\
\hline K008 & RADS & Rad Alpha & $\mathrm{pCi} / \mathrm{ml}$ & 20 & $<$ & 1.0000 & 1.0000 & 1.0000 \\
\hline K008 & RADS & Rad Beta & $\mathrm{pCi} / \mathrm{ml}$ & 20 & $<$ & 1.0000 & 1.0000 & 1.0000 \\
\hline K008 & RADS & Radium-226 & $\mathrm{pCi} / \mathrm{L}$ & 1 & & 0.0000 & 0.0000 & 0.0000 \\
\hline K008 & RADS & Suspended Alpha & $\mathrm{pCi} / \mathrm{L}$ & 5 & & 0.3000 & -0.9000 & 2.0000 \\
\hline K008 & RADS & Suspended Beta & $\mathrm{pCi} / \mathrm{L}$ & 5 & & 8.2000 & 2.0000 & 13.0000 \\
\hline K008 & RADS & Technetium-99 & $\mathrm{pCi} / \mathrm{L}$ & 12 & & 10.1667 & 0.0000 & 30.0000 \\
\hline K008 & RADSD & Dissolved Alpha & $\mathrm{pCi} / \mathrm{L}$ & 5 & & 2.2000 & -1.0000 & 5.0000 \\
\hline K008 & RADSD & Dissolved Beta & $\mathrm{pCi} / \mathrm{L}$ & 5 & & 35.2000 & 8.0000 & 117.0000 \\
\hline K008 & SVOA & 1,2,4-Trichlorobenzene & $\mu \mathrm{g} / \mathrm{L}$ & 1 & $<$ & 10.0000 & 10.0000 & 10.0000 \\
\hline K008 & SVOA & 1,2-Diphenylhydrazine & $\mu \mathrm{g} / \mathrm{L}$ & 1 & $<$ & 10.0000 & 10.0000 & 10.0000 \\
\hline K008 & SVOA & 2,4,6-Trichlorophenol & $\mu \mathrm{g} / \mathrm{L}$ & 1 & $<$ & 10.0000 & 10.0000 & 10.0000 \\
\hline K008 & SVOA & 2,4-Dichlorophenol & $\mu \mathrm{g} / \mathrm{L}$ & 1 & $<$ & 10.0000 & 10.0000 & 10.0000 \\
\hline K008 & SVOA & 2,4-Dimethylphenol & $\mu \mathrm{g} / \mathrm{L}$ & 1 & $<$ & 10.0000 & 10.0000 & 10.0000 \\
\hline K008 & SVOA & 2,4-Dinitrophenol & $\mu \mathrm{g} / \mathrm{L}$ & 1 & $<$ & 10.0000 & 10.0000 & 10.0000 \\
\hline K008 & SVOA & 2,4-Dinitrotoluene & $\mu \mathrm{g} / \mathrm{L}$ & 1 & $<$ & 10.0000 & 10.0000 & 10.0000 \\
\hline K008 & SVOA & 2,6-Dinitrotoluene & $\mu \mathrm{g} / \mathrm{L}$ & 1 & $<$ & 10.0000 & 10.0000 & 10.0000 \\
\hline K008 & SVOA & 2-Chloroethyl Vinyl Ether & $\mu \mathrm{g} / \mathrm{L}$ & 1 & $<$ & 10.0000 & 10.0000 & 10.0000 \\
\hline K008 & SVOA & 2-Chloronaphthalene & $\mu \mathrm{g} / \mathrm{L}$ & 1 & $<$ & 10.0000 & 10.0000 & 10.0000 \\
\hline
\end{tabular}



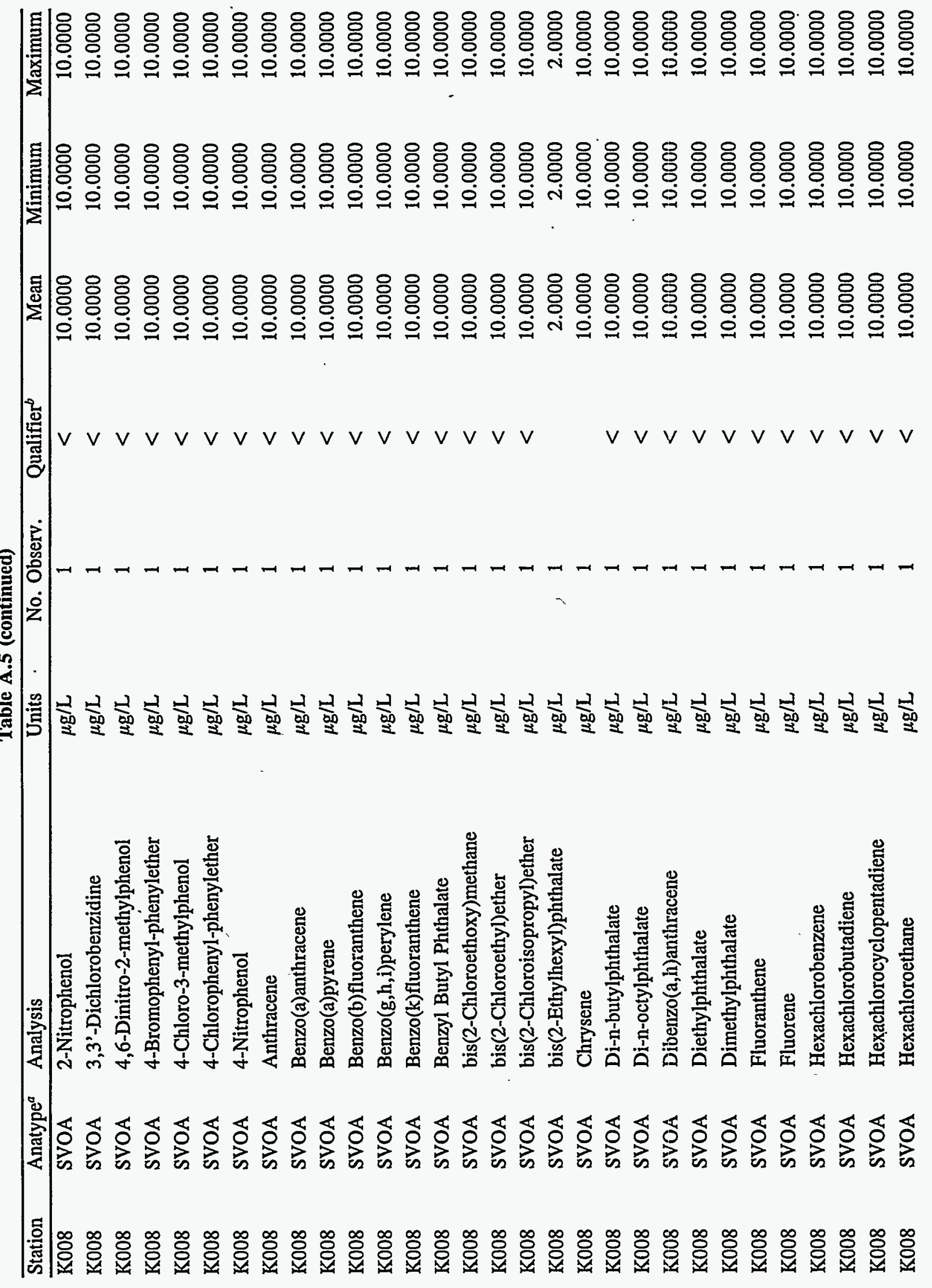


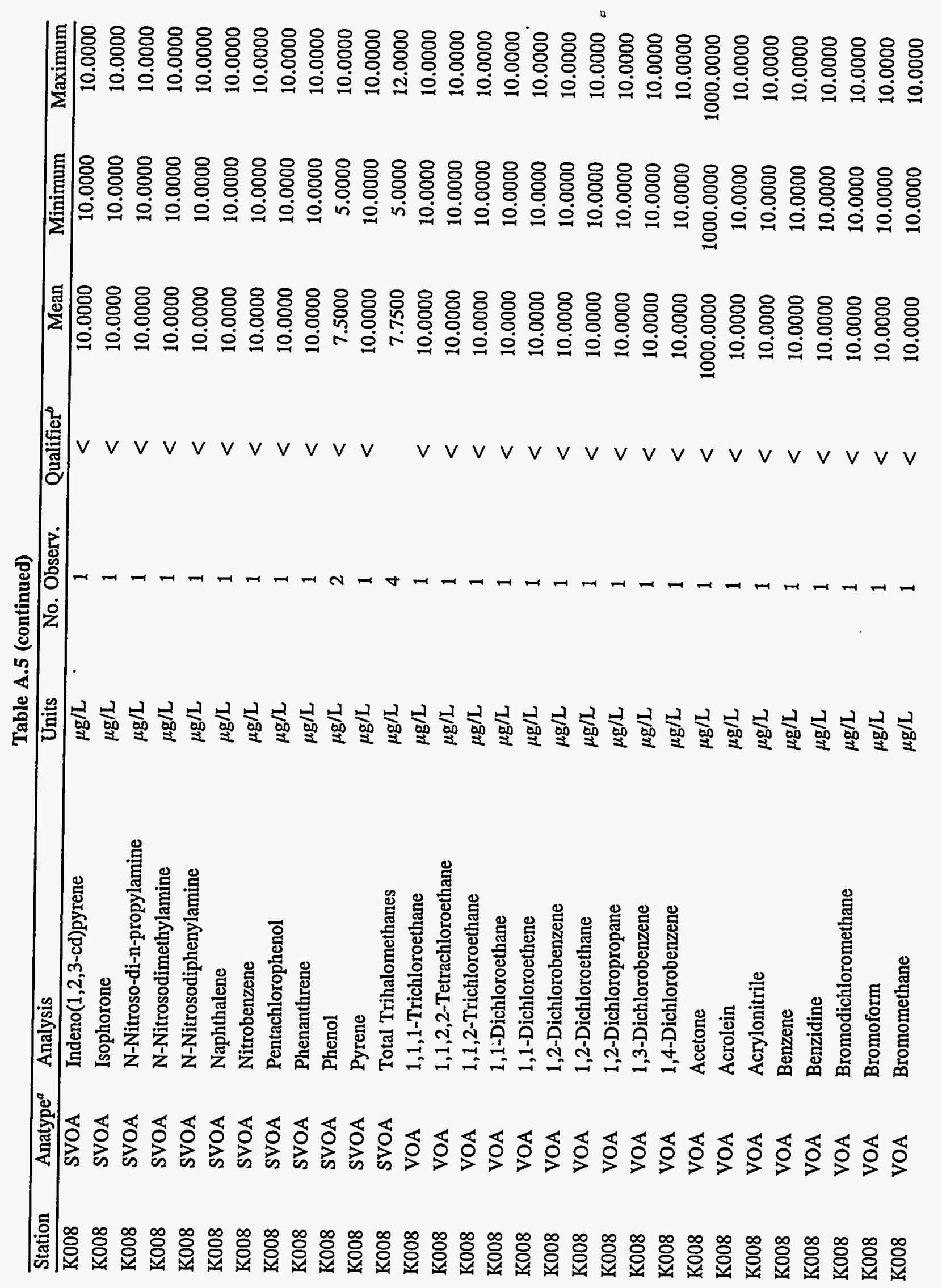


Table A.5 (continued)

\begin{tabular}{|c|c|c|c|c|c|c|c|c|}
\hline Station & Anatype $^{a}$ & Analysis & Units & No. Observ. & Qualifier $^{b}$ & Mean & Minimum & Maximum \\
\hline$\overline{\mathrm{K} 008}$ & VOA & Carbon Tetrachloride & $\mu \mathrm{g} / \mathrm{L}$ & 1 & $<$ & 10.0000 & 10.0000 & 10.0000 \\
\hline K008 & VOA & Chlorobenzene & $\mu g / L$ & 1 & $<$ & 10.0000 & 10.0000 & 10.0000 \\
\hline K008 & VOA & Chloroethane & $\mu \mathrm{g} / \mathrm{L}$ & 1 & $<$ & 10.0000 & 10.0000 & 10.0000 \\
\hline K008 & VOA & Chloroform & $\mu \mathrm{g} / \mathrm{L}$ & 2 & & 5.5000 & 5.0000 & 6.0000 \\
\hline K008 & VOA & Chloromethane & $\mu \mathrm{g} / \mathrm{L}$ & 1 & $<$ & 10.0000 & 10.0000 & 10.0000 \\
\hline K008 & VOA & cis-1,3-Dichloropropene & $\mu \mathrm{g} / \mathrm{L}$ & 1 & $<$ & 10.0000 & 10.0000 & 10.0000 \\
\hline K008 & VOA & Dibromochloromethane & $\mu \mathrm{g} / \mathrm{L}$ & 1 & $<$ & 10.0000 & 10.0000 & 10.0000 \\
\hline K008 & VOA & Dichlorodifluoromethane & $\mu \mathrm{g} / \mathrm{L}$ & 1 & $<$ & 10.0000 & 10.0000 & 10.0000 \\
\hline K008 & VOA & Ethylbenzene & $\mu \mathrm{g} / \mathrm{L}$ & 1 & $<$ & 10.0000 & 10.0000 & 10.0000 \\
\hline K008 & VOA & Methylene Chloride & $\mu \mathrm{g} / \mathrm{L}$ & 1 & $<$ & 10.0000 & 10.0000 & 10.0000 \\
\hline K008 & VOA & Tetrachlorodibenzo-p-dioxin & $\mu \mathrm{g} / \mathrm{L}$ & 1 & $<$ & 0.6000 & 0.6000 & 0.6000 \\
\hline K008 & VOA & Tetrachloroethene & $\mu \mathrm{g} / \mathrm{L}$ & 1 & $<$ & 10.0000 & 10.0000 & 10.0000 \\
\hline K008 & VOA & Toluene & $\mu \mathrm{g} / \mathrm{L}$ & 1 & $<$ & 10.0000 & 10.0000 & 10.0000 \\
\hline K008 & VOA & Trans-1,2-Dichloroethene & $\mu \mathrm{g} / \mathrm{L}$ & 1 & $<$ & 10.0000 & 10.0000 & 10.0000 \\
\hline K008 & VOA & Tans-1,3-Dichloropropene & $\mu \mathrm{g} / \mathrm{L}$ & 1 & $<$ & 10.0000 & 10.0000 & 10.0000 \\
\hline K008 & VOA & Trichloroethene & $\mu \mathrm{g} / \mathrm{L}$ & 14 & $<$ & 1.6429 & 1.0000 & 10.0000 \\
\hline K008 & VOA & Trichlorofluoromethane & $\mu \mathrm{g} / \mathrm{L}$ & 1 & $<$ & 10.0000 & 10.0000 & 10.0000 \\
\hline K008 & VOA & Vinyl Chloride & $\mu \mathrm{g} / \mathrm{L}$ & 1 & $<$ & 10.0000 & 10.0000 & 10.0000 \\
\hline
\end{tabular}

Note: Data provided by L. S. Crabtree, Information Services, Paducah Gaseous Diffusion Plant.

${ }^{a}$ ANION $=$ a negatively charged ion; CATION $=$ a positively charged ion; CHEM $=$ chemical parameters; $M A A=$ metals by atomic absorption; MIC $=$ metals by inductively-coupled plasma/mass spectroscopy; OROTH = other organics, PHYSC = physical and field measurements; PPCB = pesticides/polychlorinated biphenyls; RADS = radiochemical analysis; RADSD $=$ radiochemical analysis, dissolved; SVOA $=$ semivolatile organics; VOA $=$ volatile organics.

${ }^{b} \mathrm{~A}$ " $<$ " qualifier was added to the mean when $\geq 50 \%$ of the observations had " $<$ " qualifiers. 
Table A.6. Water quality parameters measured at Kentucky Pollutant Discharge Elimination System permitted outfall 009 in 1994

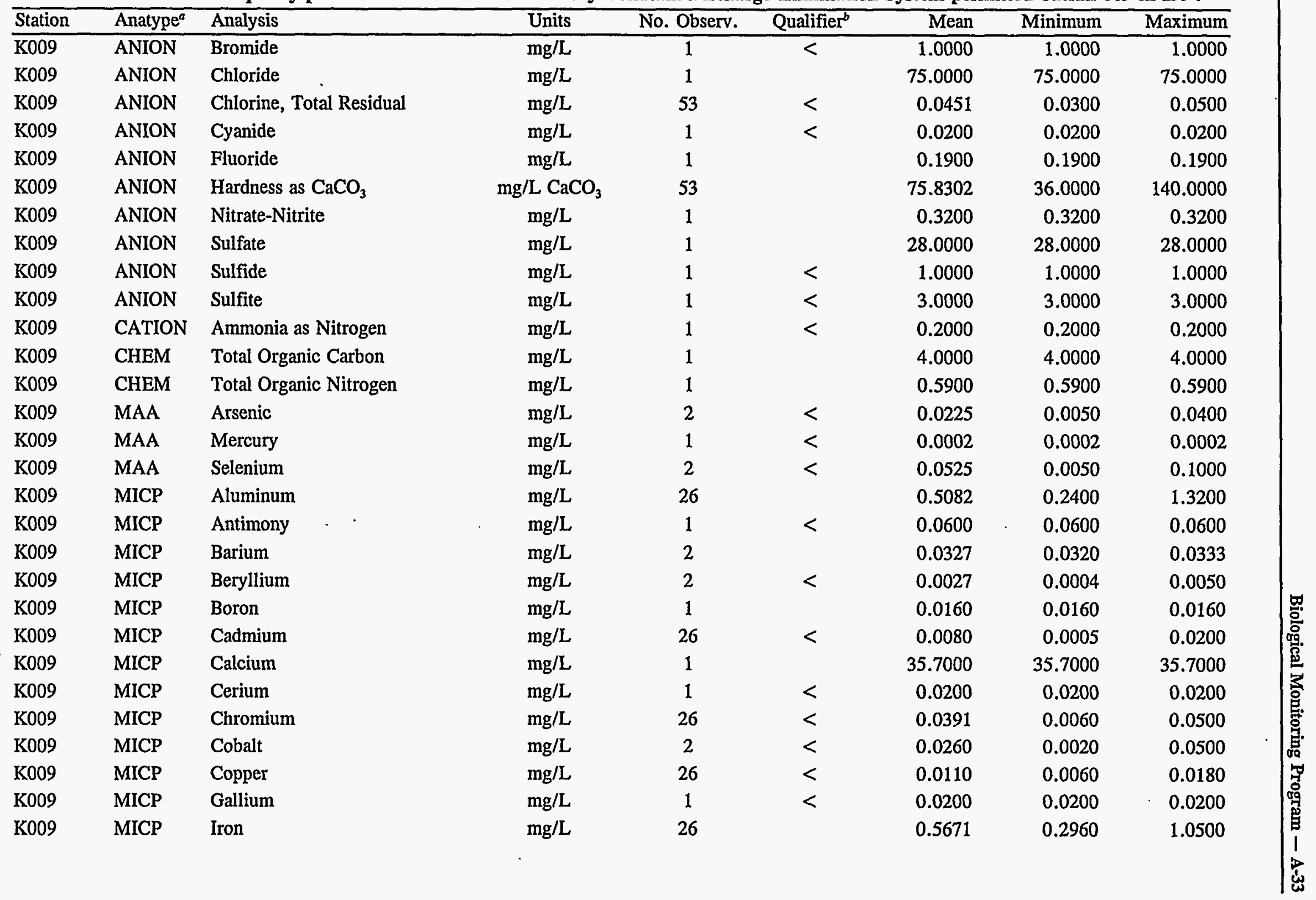




\begin{tabular}{|c|c|c|c|c|c|c|c|c|}
\hline $8888^{\circ} 8 Z$ & LLLL'Z & I0DL'9I & & $\varepsilon S$ & ว & 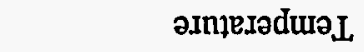 & DSAHd & $600 \mathrm{X}$ \\
\hline $0000^{\circ} \mathrm{S}$ & $0000^{\circ} \mathrm{s}$ & $0000^{\circ} \mathrm{s}$ & $>$ & $\varepsilon S$ & T/ฉిu & 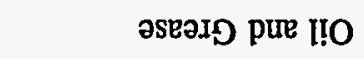 & DSAHd & $600 \mathrm{X}$ \\
\hline 9LEO'ZI & $\varepsilon Z 8 \varepsilon^{\circ} 0$ & $8 S 88^{\circ} 0$ & & \$9 & ดวW & MOII & DSXHd & $600 \times$ \\
\hline $0000^{\circ} \varsigma 乙$ & $0000^{\circ} \subseteq \mathcal{Z}$ & $0000^{\circ} \mathrm{SZ}$ & & $I$ & Turoot/os & 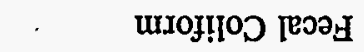 & DSXHd & $600 \mathrm{X}$ \\
\hline $0000^{\circ} \mathrm{s}$ & $0000^{\circ} \mathrm{s}$ & $0000^{\circ} \mathrm{s}$ & $>$ & I & $7 / 8 ̊ \mathrm{u}$ & वOg & PSX̣Hd & $600 \times$ \\
\hline $0080^{\circ} 0$ & $0080^{\circ} 0$ & $0080^{\circ} 0$ & $>$ & I & $7 / \not ึ น u$ & słureiorjins & НLOХO & $600 \mathrm{X}$ \\
\hline $0 \triangleright 00^{\circ} 0$ & $0+00^{\circ} 0$ & $0+00^{\circ} 0$ & $>$ & I & T/ฉిu & ưnṭuos!t!Z & dDIW & $600 \mathrm{X}$ \\
\hline $06 I^{\circ} 0$ & $0 S 00^{\circ} 0$. & $2620^{\circ} 0$ & & 92 & $7 / \not ึ u$ & ou! Z & dDIN & $600 \mathrm{Y}$ \\
\hline $0 \triangleright 00^{\circ} 0$ & $0+000^{\circ} 0$ & $0+00^{\circ} 0$ & $>$ & I & $7 / 8 ̊ u r$ & unțpue $_{\Lambda}$ & dDIN & $600 \mathrm{X}$ \\
\hline $0 \varepsilon 8 Z^{\circ} 0$ & $0 \varepsilon 8 Z^{\circ} 0$ & $0 \varepsilon 8 Z^{\circ} 0$ & & I & $7 / 8 \mathrm{um}$ & unṇuouss & dOIN & $600 \mathrm{X}$ \\
\hline $000 L^{\circ} \mathrm{ZS}$ & $000 L^{\circ} Z S$ & $000 L \mathrm{ZS}$ & & I & $\mathrm{T} / 8 \mathrm{sur}$ & urn!pos & dDIN & $600 \mathrm{Y}$ \\
\hline $00 E 0^{\circ} 0$ & $0900^{\circ} 0$ & $0810^{\circ} 0$ & $>$ & $Z$ & $7 / 8$ ur & 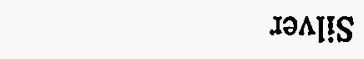 & dDIW & $600 \mathrm{X}$ \\
\hline $000 z \cdot \tau$ & $000 z^{\prime} z$ & $000 z \cdot \tau$ & & $\mathfrak{I}$ & $7 / 8$ ur & un!̣ssejod & dDIN & $600 \mathrm{X}$ \\
\hline $00 s 0^{\circ} 0$ & $00 \angle 0^{\circ} 0$ & $9 \mathrm{zt} \mathrm{I}^{\circ} 0$ & & $\varepsilon S$ & $7 / 8 \mathrm{ur}$ & (d) snroydsoyd & dDIN & $600 \mathrm{x}$ \\
\hline $0010^{\circ} 0$ & $0010^{\circ} 0$ & $0010^{\circ} 0$ & $>$ & I & T/8̊u & un!̣qo!n & dDIW & $600 \times$ \\
\hline $000 I^{\circ} 0$ & $0800^{\circ} 0$ & $\downarrow \varepsilon S 0^{\circ} 0$ & $>$ & $9 z$ & T/శిน & [əХण!N & dDIW & $600 \mathrm{X}$ \\
\hline $00 S 0^{\circ} 0$ & $0900^{\circ} 0$ & $08 z 0^{\circ} 0$ & $>$ & $z$ & T/\$ిน & ưnuəpq $\Lambda_{[}$[OW & dDIN & $600 X$ \\
\hline $0 \mathrm{LII}^{\circ} \mathrm{O}$ & 0 otito & SSII0 & & $\tau$ & T/\$ిur & วsəureฮిน์W & dDIN & $600 \times 1$ \\
\hline $0028^{\circ} \mathrm{L}$ & $00 t z \cdot L$ & $00 E S^{\circ} L$ & & $\tau$ & $7 / 8$ su & un!̣səuవిల్N & dDIW & $600 \mathrm{XI}$ \\
\hline $0020^{\circ} 0$ & $00 z 0^{\circ} 0$ & $00 z 0^{\circ} 0$ & $>$ & $I$ & 7/8̂u & นทก!นเ!ฺ & dDIW & $600 \mathrm{X}$ \\
\hline
\end{tabular}


Table A.6 (continued)

\begin{tabular}{|c|c|c|c|c|c|c|c|c|}
\hline Station & Anatype $^{b}$ & Analysis & Units & No. Observ. & Qualifier $^{b}$ & Mean & Minimum & Maximum \\
\hline K009 & PPCB & Acenaphthene & $\mu \mathrm{g} / \mathrm{L}$ & 1 & $<$ & 10.0000 & 10.0000 & 10.0000 \\
\hline K009 & PPCB & Acenaphthylene & $\mu \mathrm{g} / \mathrm{L}$ & 1 & $<$ & 10.0000 & 10.0000 & 10.0000 \\
\hline K009 & PPCB & PCB & $\mu \mathrm{g} / \mathrm{L}$ & 12 & $<$ & 0.0942 & 0.0650 & 0.1000 \\
\hline K009 & RADS & $\% \mathrm{U}-235$ & Wt \% & 1 & & 0.7150 & 0.7150 & 0.7150 \\
\hline K009 & RADS & Gross Alpha & $\mathrm{pCi} / \mathrm{L}$ & 1 & & 6.8000 & 6.8000 & 6.8000 \\
\hline K009 & RADS & Gross Beta & $\mathrm{pCi} / \mathrm{L}$ & 1 & & 28.0000 & 28.0000 & 28.0000 \\
\hline K009 & RADS & Rad Alpha & $\mathrm{pCi} / \mathrm{ml}$ & 25 & $<$ & 1.0000 & 1.0000 & 1.0000 \\
\hline K009 & RADS & Rad Beta & $\mathrm{pCi} / \mathrm{ml}$ & 25 & $<$ & 1.0000 & 1.0000 & 1.0000 \\
\hline K009 & RADS & Radium-226 & $\mathrm{pCi} / \mathrm{L}$ & 1 & & 0.0000 & 0.0000 & 0.0000 \\
\hline K009 & RADS & Suspended Alpha & $\mathrm{pCi} / \mathrm{L}$ & 5 & & -0.0200 & -1.2000 & 1.2000 \\
\hline K009 & RADS & Suspended Beta & $\mathrm{pCi} / \mathrm{L}$ & 5 & & 4.8000 & 1.0000 & 7.0000 \\
\hline K009 & RADS & Technetium-99 & $\mathrm{pCi} / \mathrm{L}$ & 12 & & 8.6667 & 0.0000 & 20.0000 \\
\hline K009 & RADSD & Dissolved Beta & $\mathrm{pCi} / \mathrm{L}$ & 5 & & 15.4000 & 9.0000 & 27.0000 \\
\hline K009 & SVOA & 1,2,4-Trichlorobenzene & $\mu \mathrm{g} / \mathrm{L}$ & 1 & $<$ & 10.0000 & 10.0000 & 10.0000 \\
\hline K009 & SVOA & 1,2-Diphenylhydrazine & $\mu \mathrm{g} / \mathrm{L}$ & 1 & $<$ & 10.0000 & 10.0000 & 10.0000 \\
\hline K009 & SVOA & 2,4,6-Trichlorophenol & $\mu \mathrm{g} / \mathrm{L}$ & 1 & $<$ & 10.0000 & 10.0000 & 10.0000 \\
\hline K009 & SVOA & 2,4-Dichlorophenol & $\mu \mathrm{g} / \mathrm{L}$ & 1 & $<$ & 10.0000 & 10.0000 & 10.0000 \\
\hline K009 & SVOA & 2,4-Dimethylphenol & $\mu \mathrm{g} / \mathrm{L}$ & 1 & $<$ & 10.0000 & 10.0000 & 10.0000 \\
\hline K009 & SVOA & 2,4-Dinitrophenol & $\mu \mathrm{g} / \mathrm{L}$ & 1 & $<$ & 10.0000 & 10.0000 & 10.0000 \\
\hline K009 & SVOA & 2,4-Dinitrotoluene & $\mu \mathrm{g} / \mathrm{L}$ & 1 & $<$ & 10.0000 & 10.0000 & 10.0000 \\
\hline K009 & SVOA & 2,6-Dinitrotoluene & $\mu \mathrm{g} / \mathrm{L}$ & 1 & $<$ & 10.0000 & 10.0000 & 10.0000 \\
\hline K009 & SVOA & 2-Chloroethyl Vinyl Ether & $\mu \mathrm{g} / \mathrm{L}$ & 1 & $<$ & 10.0000 & 10.0000 & 10.0000 \\
\hline K009 & SVOA & 2-Chloronaphthalene & $\mu \mathrm{g} / \mathrm{L}$ & 1 & $<$ & 10.0000 & 10.0000 & 10.0000 \\
\hline
\end{tabular}


Table A.6 (continued)

\begin{tabular}{|c|c|c|c|c|c|c|c|c|}
\hline Station & Anatype $^{b}$ & Analysis & Units & No. Observ. & Qualifier $^{b}$ & Mean & Minimum & Maximum \\
\hline K009 & SVOA & 2-Nitrophenol & $\mu \mathrm{g} / \mathrm{L}$ & 1 & $<$ & 10.0000 & 10.0000 & 10.0000 \\
\hline K009 & SVOA & 3,3'-Dichlorobenzidine & $\mu \mathrm{g} / \mathrm{L}$ & 1 & $<$ & 10.0000 & 10.0000 & 10.0000 \\
\hline K009 & SVOA & 4,6-Dinitro-2-methylphenol & $\mu \mathrm{g} / \mathrm{L}$ & 1 & $<$ & 10.0000 & 10.0000 & 10.0000 \\
\hline K009 & SVOA & 4-Bromophenyl-phenylether & $\mu \mathrm{g} / \mathrm{L}$ & 1 & $<$ & 10.0000 & 10.0000 & 10.0000 \\
\hline K009 & SVOA & 4-Chloro-3-methylphenol & $\mu \mathrm{g} / \mathrm{L}$ & 1 & $<$ & 10.0000 & 10.0000 & 10.0000 \\
\hline K009 & SVOA & 4-Chlorophenyl-phenylether & $\mu \mathrm{g} / \mathrm{L}$ & 1 & $<$ & 10.0000 & 10.0000 & 10.0000 \\
\hline K009 & SVOA & 4-Nitrophenol & $\mu \mathrm{g} / \mathrm{L}$ & 1 & $<$ & 10.0000 & 10.0000 & 10.0000 \\
\hline K009 & SVOA & Anthracene & $\mu \mathrm{g} / \mathrm{L}$ & 1 & $<$ & 10.0000 & 10.0000 & 10.0000 \\
\hline K009 & SVOA & Benzo(a)anthracene & $\mu \mathrm{g} / \mathrm{L}$ & 1 & $<$ & 10.0000 & 10.0000 & 10.0000 \\
\hline K009 & SVOA & Benzo(a)pyrene & $\mu \mathrm{g} / \mathrm{L}$ & 1 & $<$ & 10.0000 & 10.0000 & 10.0000 \\
\hline K009 & SVOA & Benzo(b)fluoranthene & $\mu \mathrm{g} / \mathrm{L}$ & 1 & $<$ & 10.0000 & 10.0000 & 10.0000 \\
\hline K009 & SVOA & Benzo(g,h,i)perylene & $\mu \mathrm{g} / \mathrm{L}$ & 1 & $<$ & 10.0000 & 10.0000 & 10.0000 \\
\hline K009 & SVOA & Benzo(k)fluoranthene & $\mu \mathrm{g} / \mathrm{L}$ & 1 & $<$ & 10.0000 & 10.0000 & 10.0000 \\
\hline K009 & SVOA & Benzyl Butyl Phthalate & $\mu \mathrm{g} / \mathrm{L}$ & 1 & $<$ & 10.0000 & 10.0000 & 10.0000 \\
\hline K009 & SVOA & bis(2-Chloroethoxy)methane & $\mu \mathrm{g} / \mathrm{L}$ & 1 & $<$ & 10.0000 & 10.0000 & 10.0000 \\
\hline K009 & SVOA & bis(2-Chloroethyl)ether & $\mu \mathrm{g} / \mathrm{L}$ & 1 & $<$ & 10.0000 & 10.0000 & 10.0000 \\
\hline K009 & SVOA & bis(2-Chloroisopropyl)ether & $\mu \mathrm{g} / \mathrm{L}$ & 1 & $<$ & 10.0000 & 10.0000 & 10.0000 \\
\hline K009 & SVOA & bis(2-Ethylhexyl)phthalate & $\mu \mathrm{g} / \mathrm{L}$ & 1 & $\cdot$ & 1.0000 & 1.0000 & 1.0000 \\
\hline K009 & SVOA & Chrysene & $\mu \mathrm{g} / \mathrm{L}$ & 1 & $<$ & 10.0000 & 10.0000 & 10.0000 \\
\hline K009 & SVOA & Di-n-butylphthalate & $\mu \mathrm{g} / \mathrm{L}$ & 1 & $<$ & 10.0000 & 10.0000 & 10.0000 \\
\hline K009 & SVOA & Di-n-octylphthalate & $\mu \mathrm{g} / \mathrm{L}$ & 1 & $<$ & 10.0000 & 10.0000 & 10.0000 \\
\hline K009 & SVOA & Dibenzo(a,h)anthracene & $\mu \mathrm{g} / \mathrm{L}$ & 1 & $<$ & 10.0000 & 10.0000 & 10.0000 \\
\hline K009 & SVOA & Diethylphthalate & $\mu \mathrm{g} / \mathrm{L}$ & 1 & $<$ & 10.0000 & 10.0000 & 10.0000 \\
\hline K009 & SVOA & Dimethylphthalate & $\mu \mathrm{g} / \mathrm{L}$ & 1 & $<$ & 10.0000 & 10.0000 & 10.0000 \\
\hline K009 & SVOA & Fluoranthene & $\mu \mathrm{g} / \mathrm{L}$ & 1 & $<$ & 10.0000 & 10.0000 & 10.0000 \\
\hline K009 & SVOA & Fluorene & $\mu \mathrm{g} / \mathrm{L}$ & 1 & $<$ & 10.0000 & 10.0000 & 10.0000 \\
\hline K009 & SVOA & Hexachlorobenzene & $\mu \mathrm{g} / \mathrm{L}$ & 1 & $<$ & 10.0000 & 10.0000 & 10.0000 \\
\hline K009 & SVOA & Hexachlorobutadiene & $\mu \mathrm{g} / \mathrm{L}$ & 1 & $<$ & 10.0000 & 10.0000 & 10.0000 \\
\hline K009 & SVOA & Hexachlorocyclopentadiene & $\mu \mathrm{g} / \mathrm{L}$ & 1 & $<$ & 10.0000 & 10.0000 & 10.0000 \\
\hline K009 & SVOA & Hexachloroethane & $\mu \mathrm{g} / \mathrm{L}$ & 1 & $<$ & 10.0000 & 10.0000 & 10.0000 \\
\hline
\end{tabular}




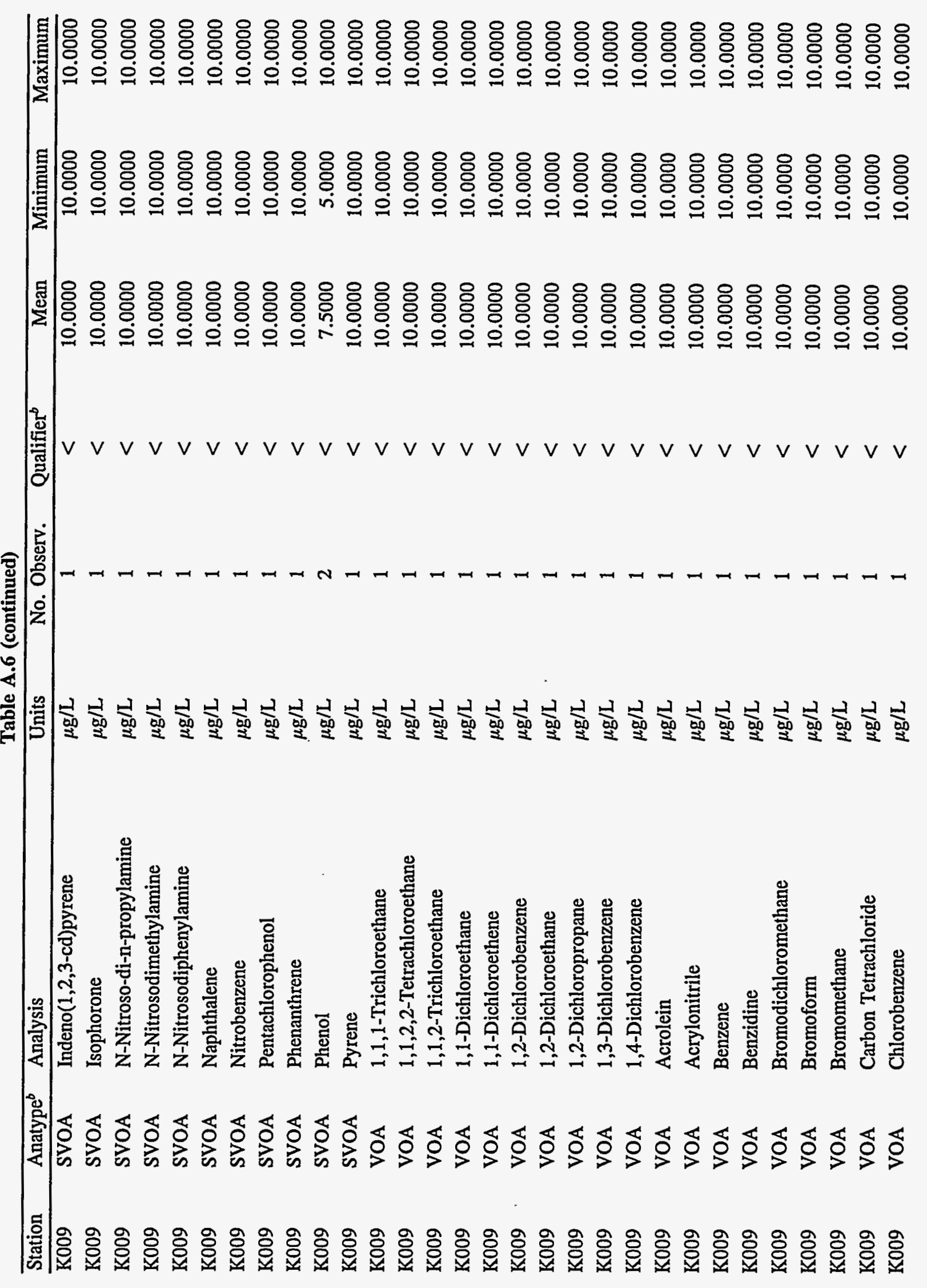


Table A.6 (continued)

\begin{tabular}{|c|c|c|c|c|c|c|c|c|}
\hline Station & Anatype $^{b}$ & Analysis & Units & No. Observ. & Qualifier $^{b}$ & Mean & Minimum & Maximum \\
\hline $\bar{K} 009$ & VOA & Chloroethane & $\mu \mathrm{g} / \mathrm{L}$ & 1 & $<$ & 10.0000 & 10.0000 & 10.0000 \\
\hline K009 & VOA & Chloroform & $\mu \mathrm{g} / \mathrm{L}$ & 1 & $<$ & 1.0000 & 1.0000 & 1.0000 \\
\hline K009 & VOA & Chloromethane & $\mu \mathrm{g} / \mathrm{L}$ & 1 & $<$ & 10.0000 & 10.0000 & 10.0000 \\
\hline K009 & VOA & cis-1,3-Dichloropropene & $\mu \mathrm{g} / \mathrm{L}$ & 1 & $<$ & 10.0000 & 10.0000 & 10.0000 \\
\hline K009 & VOA & Dibromochloromethane & $\mu \mathrm{g} / \mathrm{L}$ & 1 & $<$ & 10.0000 & 10.0000 & 10.0000 \\
\hline K009 & VOA & Dichlorodifluoromethane & $\mu \mathrm{g} / \mathrm{L}$ & 1 & $<$ & 10.0000 & 10.0000 & 10.0000 \\
\hline K009 & VOA & Ethylbenzene & $\mu \mathrm{g} / \mathrm{L}$ & 1 & $<$ & 10.0000 & 10.0000 & 10.0000 \\
\hline K009 & VOA & Methylene Chloride & $\mu \mathrm{g} / \mathrm{L}$ & 1 & $<$ & 10.0000 & 10.0000 & 10.0000 \\
\hline K009 & VOA & Tetrachlorodibenzo-p-dioxin & $\mathrm{ng} / \mathrm{L}$ & 1 & $<$ & 0.7400 & 0.7400 & 0.7400 \\
\hline K009 & VOA & Tetrachloroethene & $\mu \mathrm{g} / \mathrm{L}$ & 1 & $<$ & 10.0000 & 10.0000 & 10.0000 \\
\hline K009 & VOA & Toluene & $\mu \mathrm{g} / \mathrm{L}$ & 1 & $<$ & 10.0000 & 10.0000 & 10.0000 \\
\hline K009 & VOA & Trans-1,2-Dichloroethene & $\mu \mathrm{g} / \mathrm{L}$ & 1 & $<$ & 10.0000 & 10.0000 & 10.0000 \\
\hline K009 & VOA & Tans-1,3-Dichloropropene & $\mu \mathrm{g} / \mathrm{L}$ & 1 & $<$ & 10.0000 & 10.0000 & 10.0000 \\
\hline K009 & VOA & Trichloroethene & $\mu \mathrm{g} / \mathrm{L}$ & 13 & $<$ & 1.6923 & 1.0000 & 10.0000 \\
\hline K009 & VOA & Trichlorofluoromethane & $\mu \mathrm{g} / \mathrm{L}$ & 1 & $<$ & 10.0000 & 10.0000 & 10.0000 \\
\hline K009 & VOA & Vinyl Chloride & $\mu \mathrm{g} / \mathrm{L}$ & 1 & $<$ & 10.0000 & 10.0000 & 10.0000 \\
\hline
\end{tabular}

Note: Data provided by L. S. Crabtree, Information Services, Paducah Gaseous Diffusion Plant.

${ }^{a}$ ANION $=$ a negatively charged ion; CATION $=$ a positively charged ion; $\mathrm{CHEM}=$ chemical parameters; MAA $=$ metals by atomic absorption; MIC $=$ metals by inductively-coupled plasma/mass spectroscopy; OROTH $=$ other organics, PHYSC $=$ physical and field measurements; PPCB $=$ pesticides/polychlorinated biphenyls; RADS = radiochemical analysis; RADSD $=$ radiochemical analysis, dissolved; $S V O A=$ semivolatile organics; VOA $=$ volatile organics.

${ }^{b} \mathrm{~A}$ " $<$ " qualifier was added to the mean when $\geq 50 \%$ of the observations had " $<$ " qualifiers. 
Table A.7. Water quality parameters measured at Kentucky Pollutant Discharge Elimination System permitted outfall 010 in 1994

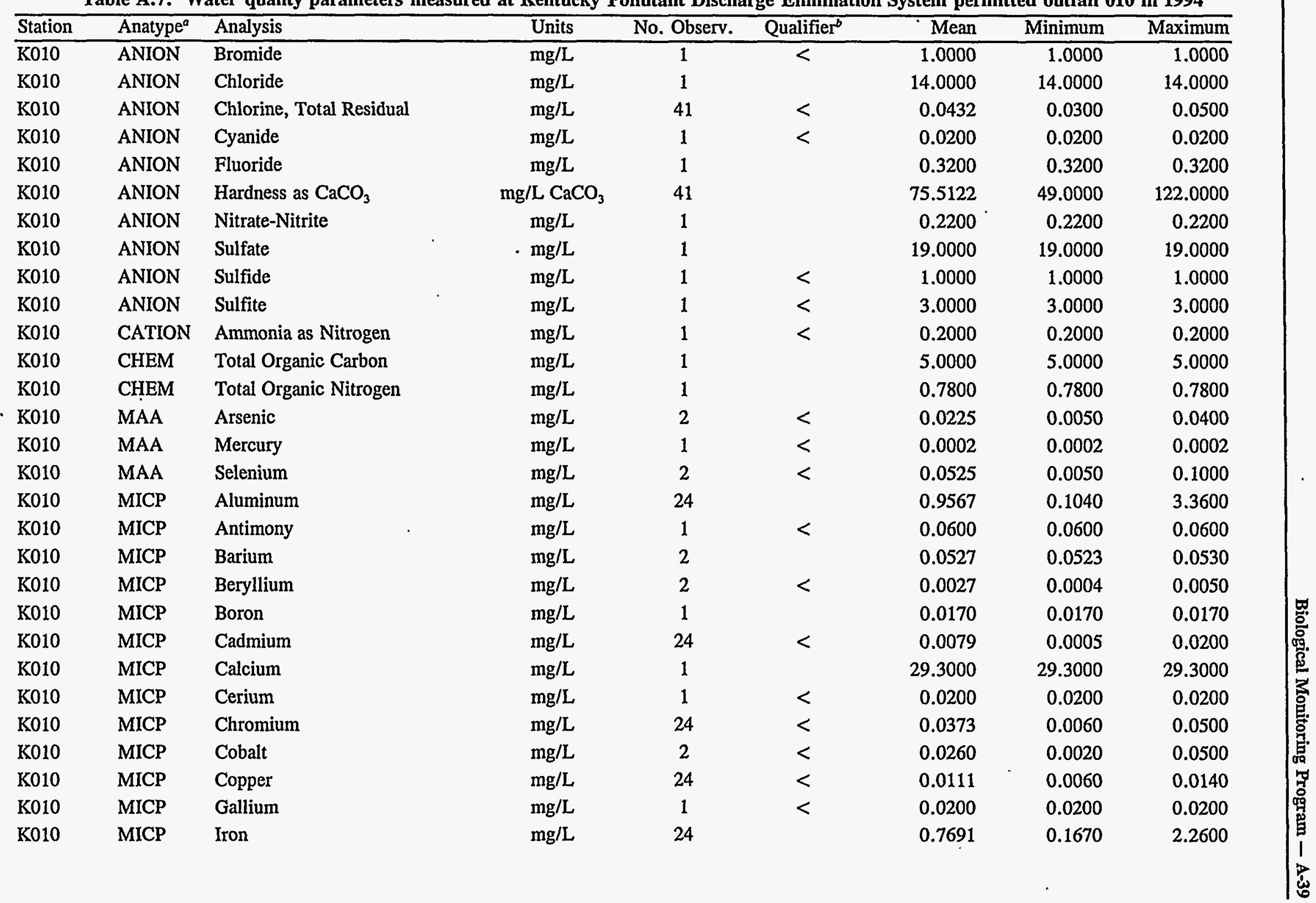


Table A.7 (continued)

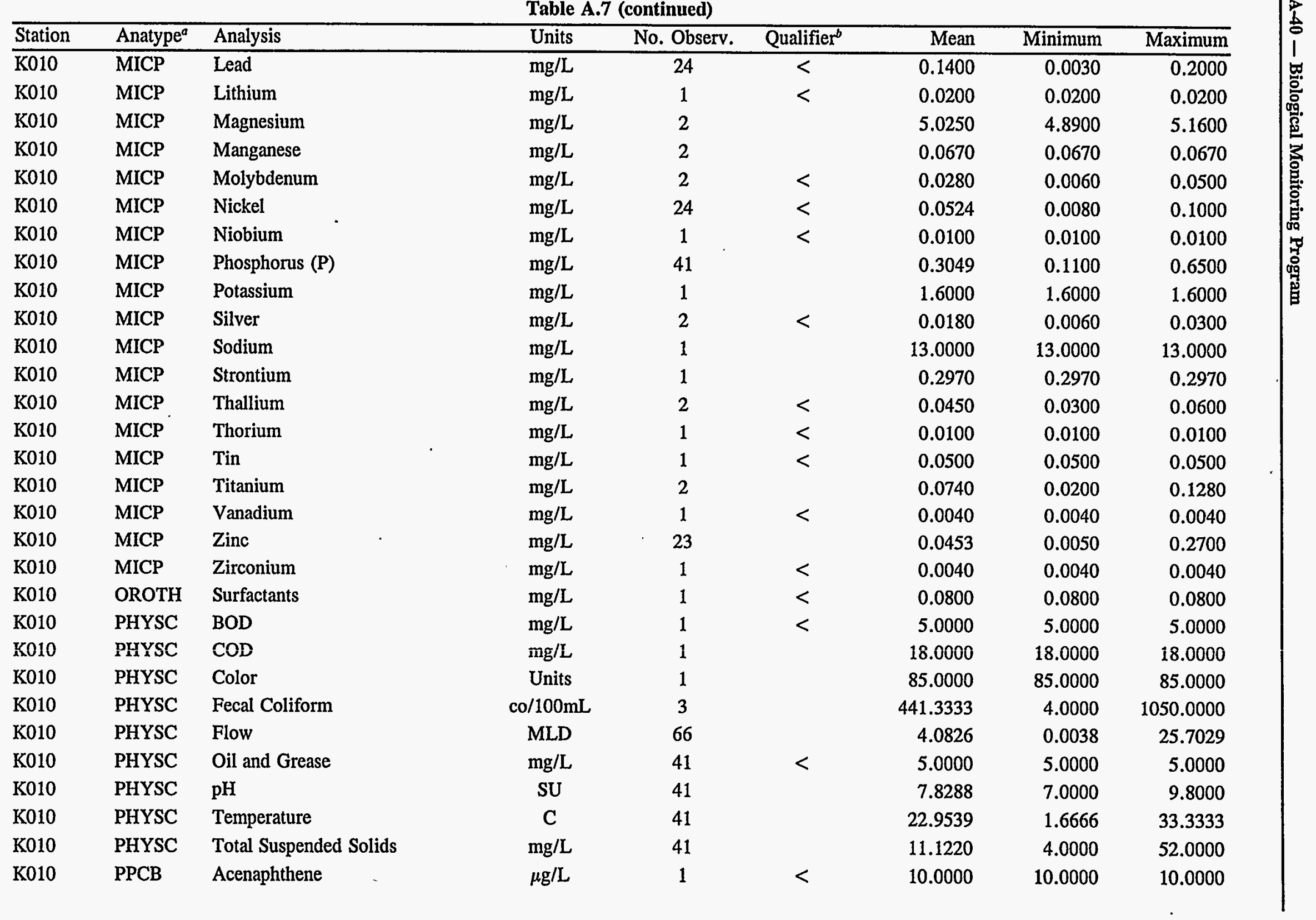


Table A.7 (continued)

\begin{tabular}{|c|c|c|c|c|c|c|c|c|}
\hline Station & Anatype $^{a}$ & Analysis & Units & No. Observ. & Qualifier $^{b}$ & Mean & Minimum & Maximum \\
\hline K010 & PPCB & Acenaphthylene & $\mu \mathrm{g} / \mathrm{L}$ & 1 & $<$ & 10.0000 & 10.0000 & 10.0000 \\
\hline K010 & PPCB & PCB & $\mu \mathrm{g} / \mathrm{L}$ & 13 & $<$ & 0.0892 & 0.0650 & 0.1000 \\
\hline K010 & RADS & $\%$ U-235 & Wt $\%$ & 18 & & 0.3766 & 0.2330 & 0.6510 \\
\hline K010 & RADS & Gross Alpha & $\mathrm{pCi} / \mathrm{L}$ & 1 & & 6.4000 & 6.4000 & 6.4000 \\
\hline K010 & RADS & Gross Beta & $\mathrm{pCi} / \mathrm{L}$ & 1 & & 27.0000 & 27.0000 & 27.0000 \\
\hline K010 & RADS & Neptunium-237 & $\mathrm{pCi} / \mathrm{L}$ & 5 & & 0.2600 & -0.1000 & 0.6000 \\
\hline K010 & RADS & Rad Alpha & $\mathrm{pCi} / \mathrm{ml}$ & 10 & $<$ & 1.0000 & 1.0000 & 1.0000 \\
\hline K010 & RADS & Rad Beta & $\mathrm{pCi} / \mathrm{ml}$ & 10 & $<$ & 1.0000 & 1.0000 & 1.0000 \\
\hline K010 & RADS & Radium-226 & $\mathrm{pCi} / \mathrm{L}$ & 1 & & 0.0000 & 0.0000 & 0.0000 \\
\hline K010 & RADS & Suspended Alpha & $\mathrm{pCi} / \mathrm{L}$ & 11 & & 0.4545 & -1.3000 & 1.5000 \\
\hline K010 & RADS & Suspended Beta & $\mathrm{pCi} / \mathrm{L}$ & 11 & & 5.0909 & 2.0000 & 9.0000 \\
\hline K010 & RADS & Technetium-99 & $\mathrm{pCi} / \mathrm{L}$ & 40 & & 8.7750 & 0.0000 & 26.0000 \\
\hline K010 & RADSD & Dissolved Beta & $\mathrm{pCi} / \mathrm{L}$ & 11 & & 65.8182 & 2.0000 & 620.0000 \\
\hline K010 & SVOA & 1,2,4-Trichlorobenzene & $\mu \mathrm{g} / \mathrm{L}$ & 1 & $<$ & 10.0000 & 10.0000 & 10.0000 \\
\hline K010 & SVOA & 1,2-Diphenylhydrazine & $\mu \mathrm{g} / \mathrm{L}$ & 1 & $<$ & 10.0000 & 10.0000 & 10.0000 \\
\hline K010 & SVOA & 2,4,6-Trichlorophenol & $\mu \mathrm{g} / \mathrm{L}$ & 1 & $<$ & 10.0000 & 10.0000 & 10.0000 \\
\hline K010 & SVOA & 2,4-Dichlorophenol & $\mu \mathrm{g} / \mathrm{L}$ & 1 & $<$ & 10.0000 & 10.0000 & 10.0000 \\
\hline K010 & SVOA & 2,4-Dimethylphenol & $\mu \mathrm{g} / \mathrm{L}$ & 1 & $<$ & 10.0000 & 10.0000 & 10.0000 \\
\hline K010 & SVOA & 2,4-Dinitrophenol & $\mu \mathrm{g} / \mathrm{L}$ & 1 & $<$ & 10.0000 & 10.0000 & 10.0000 \\
\hline K010 & SVOA & 2,4-Dinitrotoluene & $\mu \mathrm{g} / \mathrm{L}$ & 1 & $<$ & 10.0000 & 10.0000 & 10.0000 \\
\hline K010 & SVOA & 2,6-Dinitrotoluene & $\mu \mathrm{g} / \mathrm{L}$ & 1 & $<$ & 10.0000 & 10.0000 & 10.0000 \\
\hline K010 & SVOA & 2-Chloroethyl Vinyl Ether & $\mu \mathrm{g} / \mathrm{L}$ & 1 & $<$ & 10.0000 & 10.0000 & 10.0000 \\
\hline K010 & SVOA & 2-Chloronaphthalene & $\mu \mathrm{g} / \mathrm{L}$ & 1 & $<$ & 10.0000 & 10.0000 & 10.0000 \\
\hline
\end{tabular}


Table A.7 (continued)

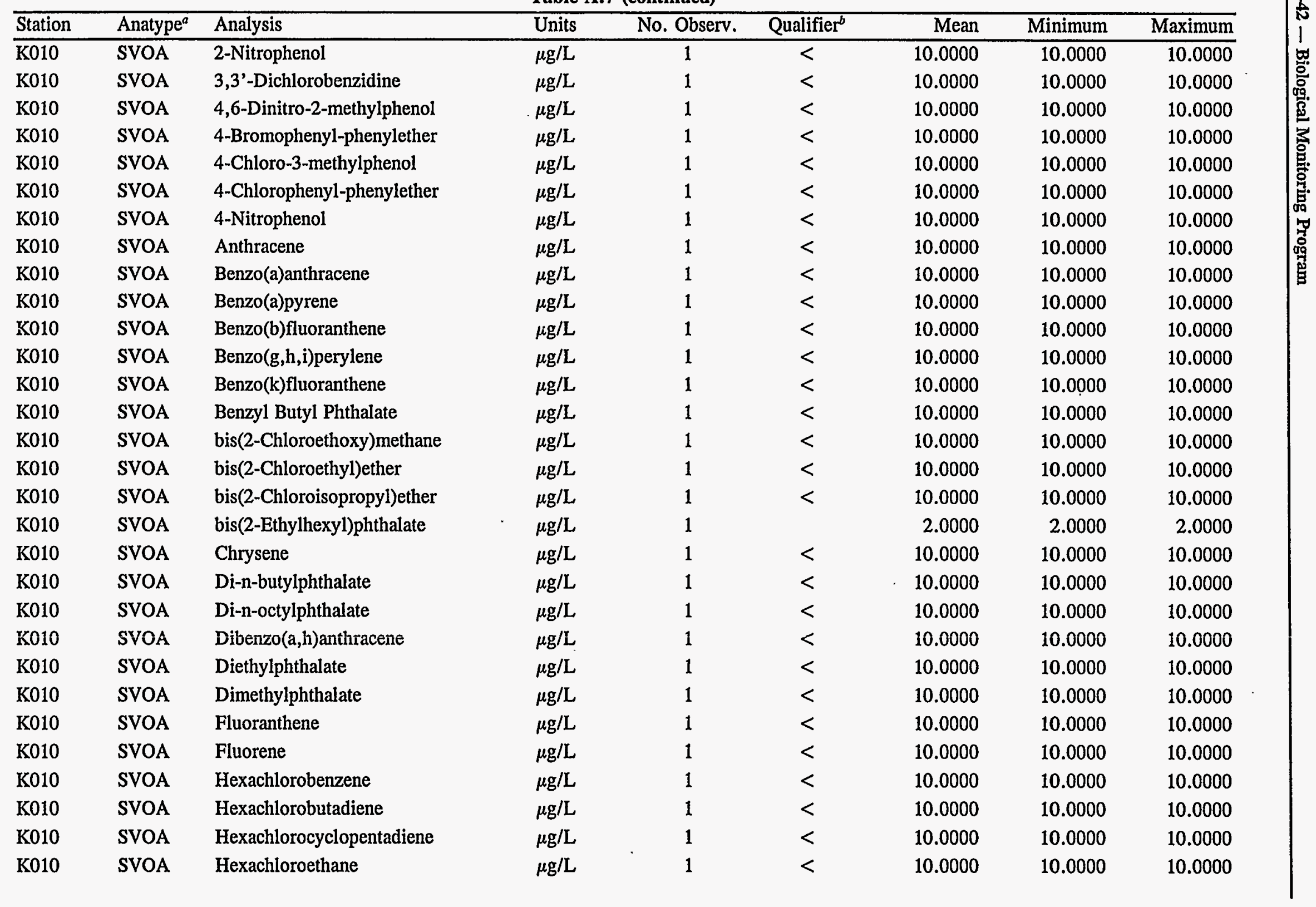


Table A.7 (continued)

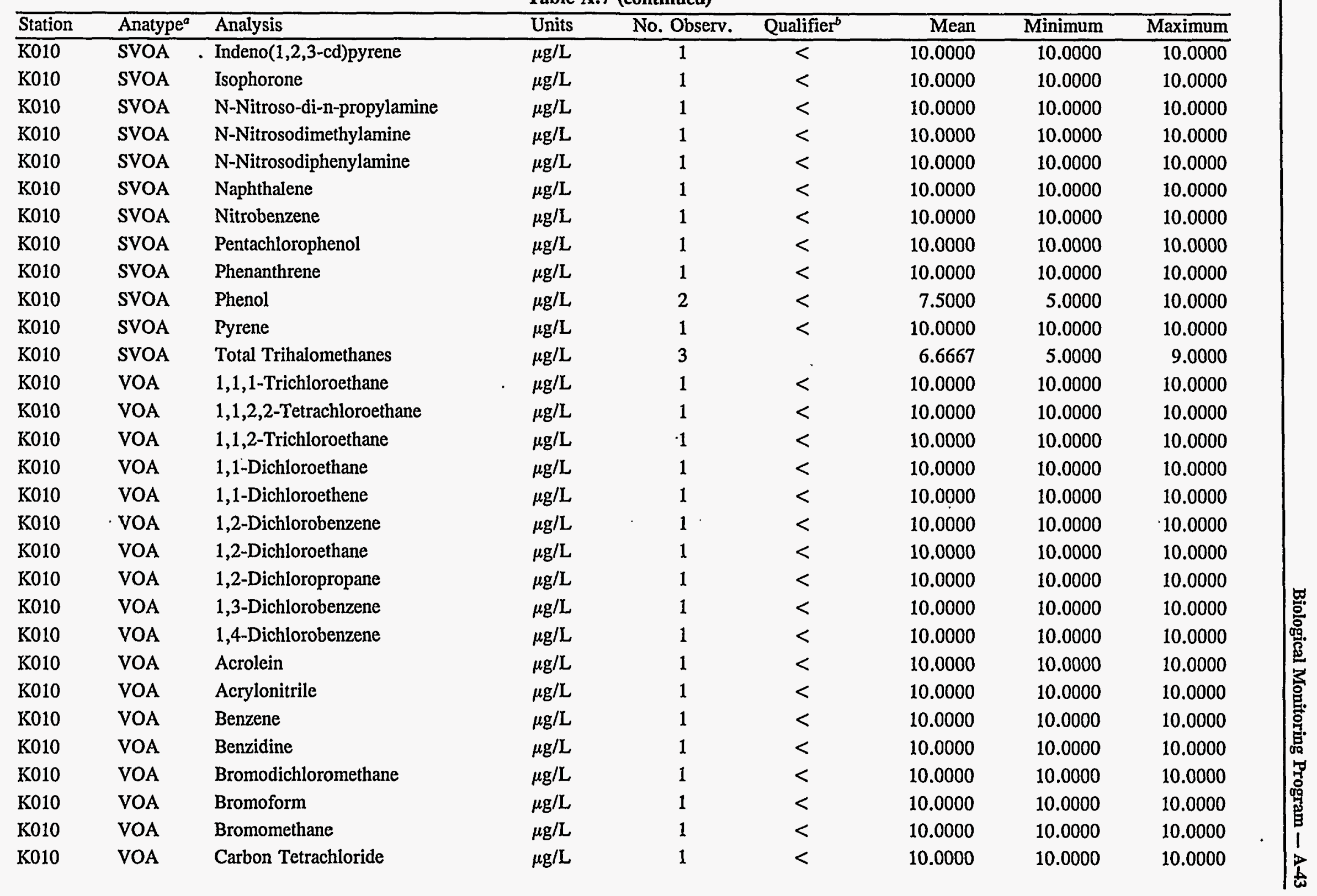


Table A.7 (continued)

\begin{tabular}{|c|c|c|c|c|c|c|c|c|}
\hline Station & Anatype $^{a}$ & Analysis & Units & No. Observ. & Qualifier $^{b}$ & Mean & Minimum & Maximum \\
\hline K010 & VOA & Chlorobenzene & $\mu \mathrm{g} / \mathrm{L}$ & 1 & $<$ & 10.0000 & 10.0000 & 10.0000 \\
\hline K010 & VOA & Chloroethane & $\mu \mathrm{g} / \mathrm{L}$ & 1 & $<$ & 10.0000 & 10.0000 & 10.0000 \\
\hline K010 & VOA & Chloroform & $\mu \mathrm{g} / \mathrm{L}$ & 4 & & 8.5000 & 5.0000 & 14.0000 \\
\hline K010 & VOA & Chloromethane & $\mu \mathrm{g} / \mathrm{L}$ & 1 & $<$ & 10.0000 & 10.0000 & 10.0000 \\
\hline K010 & VOA & cis-1,3-Dichloropropene & $\mu \mathrm{g} / \mathrm{L}$ & 1 & $<$ & 10.0000 & 10.0000 & 10.0000 \\
\hline K010 & VOA & Dibromochloromethane & $\mu \mathrm{g} / \mathrm{L}$ & 1 & $<$ & 10.0000 & 10.0000 & 10.0000 \\
\hline K010 & VOA & Dichlorodifluoromethane & $\mu \mathrm{g} / \mathrm{L}$ & 2 & & 7.5000 & 5.0000 & 10.0000 \\
\hline K010 & VOA & Ethylbenzene & $\mu \mathrm{g} / \mathrm{L}$ & 1 & $<$ & 10.0000 & 10.0000 & 10.0000 \\
\hline K010 & VOA & Methylene Chloride & $\mu \mathrm{g} / \mathrm{L}$ & 1 & $<$ & 10.0000 & 10.0000 & 10.0000 \\
\hline K010 & VOA & Tetrachlorodibenzo-p-dioxin & $\mathrm{ng} / \mathrm{L}$ & 2 & $<$ & 0.8100 & 0.4200 & 1.2000 \\
\hline K010 & VOA & Tetrachloroethene & $\mu \mathrm{g} / \mathrm{L}$ & 1 & $<$ & 10.0000 & 10.0000 & 10.0000 \\
\hline K010 & VOA & Toluene & $\mu \mathrm{g} / \mathrm{L}$ & 1 & $<$ & 10.0000 & 10.0000 & 10.0000 \\
\hline K010 & VOA & Trans-1,2-Dichloroethene & $\mu \mathrm{g} / \mathrm{L}$ & 1 & $<$ & 10.0000 & 10.0000 & 10.0000 \\
\hline K010 & VOA & Trans-1,3-Dichloropropene & $\mu \mathrm{g} / \mathrm{L}$ & 1 & $<$ & 10.0000 & 10.0000 & 10.0000 \\
\hline K010 & VOA & Trichloroethene & $\mu \mathrm{g} / \mathrm{L}$ & 15 & $<$ & 1.7333 & 1.0000 & 10.0000 \\
\hline K010 & VOA & Trichlorofluoromethane & $\mu \mathrm{g} / \mathrm{L}$ & 1 & $<$ & 10.0000 & 10.0000 & 10.0000 \\
\hline K010 & VOA & Vinyl Chloride & $\mu \mathrm{g} / \mathrm{L}$ & 1 & $<$ & 10.0000 & 10.0000 & 10.0000 \\
\hline
\end{tabular}

Note: Data provided by L. S. Crabtree, Information Services, Paducah Gaseous Diffusion Plant.

${ }^{a}$ ANION = a negatively charged ion; CATION = a positively charged ion; CHEM $=$ chemical parameters; MAA $=$ metals by atomic absorption; MIC $=$ metals by inductively-coupled plasma/mass spectroscopy; OROTH = other organics, PHYSC = physical and field measurements; PPCB = pesticides/polychlorinated biphenyls; RADS = radiochemical analysis; RADSD = radiochemical analysis, dissolved; SVOA = semivolatile organics; VOA = volatile organics.

${ }^{\circ} \mathrm{A}$ " $<$ " qualifier was added to the mean when $\geq 50 \%$ of the observations had " $<$ " qualifiers. 
Table A.8. Water quality parameters measured at Kentucky Pollutant Discharge Elimination System permitted outfall 011 in 1994

\begin{tabular}{|c|c|c|c|c|c|c|c|c|}
\hline Station & Anatype $^{a}$ & Analysis & Units & No. Observ. & Qualifier $^{b}$ & Mean & Minimum & Maximum \\
\hline K011 & ANION & Chloride & $\mathrm{mg} / \mathrm{L}$ & 1 & & 23 & 23.0000 & 23.0000 \\
\hline K011 & ANION & Cyanide & $\mathrm{mg} / \mathrm{L}$ & 1 & $<$ & 0.02 & 0.0200 & 0.0200 \\
\hline K011 & ANION & Fluoride & $\mathrm{mg} / \mathrm{L}$ & 1 & & 0.32 & 0.3200 & 0.3200 \\
\hline K011 & ANION & Hardness as $\mathrm{CaCO}_{3}$ & $\mathrm{mg} / \mathrm{L} \mathrm{CaCO}{ }_{3}$ & 27 & & 84.9259 & 32.0000 & 152.0000 \\
\hline K011 & ANION & Sulfide & $\mathrm{mg} / \mathrm{L}$ & 1 & $<$ & 1 & 1.0000 & 1.0000 \\
\hline K011 & ANION & Sulfite & $\mathrm{mg} / \mathrm{L}$ & 1 & $<$ & 3 & 3.0000 & 3.0000 \\
\hline K011 & CATION & Ammonia as Nitrogen & $\mathrm{mg} / \mathrm{L}$ & 1 & $<$ & 0.2 & 0.2000 & 0.2000 \\
\hline K011 & CHEM & Total Organic Carbon & $\mathrm{mg} / \mathrm{L}$ & 1 & & 5 & 5.0000 & 5.0000 \\
\hline K011 & CHEM & Total Organic Nitrogen & $\mathrm{mg} / \mathrm{L}$ & 1 & & 0.71 & 0.7100 & 0.7100 \\
\hline K011 & MICP & Antimony & $\mathrm{mg} / \mathrm{L}$ & 1 & $<$ & 0.06 & 0.0600 & 0.0600 \\
\hline K011 & MICP & Barium & $\mathrm{mg} / \mathrm{L}$ & 2 & & 0.0352 & 0.0344 & 0.0360 \\
\hline K011 & MICP & Beryllium & $\mathrm{mg} / \mathrm{L}$ & 2 & $<$ & 0.0027 & 0.0004 & 0.0050 \\
\hline K011 & MICP & Boron & $\mathrm{mg} / \mathrm{L}$ & 1 & & 0.032 & 0.0320 & 0.0320 \\
\hline K011 & MICP & Cadmium & $\mathrm{mg} / \mathrm{L}$ & 18 & $<$ & 0.0081 & 0.0005 & 0.0100 \\
\hline K011 & MICP & Calcium & $\mathrm{mg} / \mathrm{L}$ & 1 & & 34.4 & 34.4000 & 34.4000 \\
\hline K011 & MICP & Cerium & $\mathrm{mg} / \mathrm{L}$ & 1 & $<$ & 0.02 & 0.0200 & 0.0200 \\
\hline K011 & MICP & Chromium & $\mathrm{mg} / \mathrm{L}$ & 18 & $<$ & 0.0412 & 0.0100 & 0.0500 \\
\hline K011 & MICP & Cobalt & $\mathrm{mg} / \mathrm{L}$ & 2 & $<$ & 0.026 & 0.0020 & 0.0500 \\
\hline K011 & MICP & Copper & $\mathrm{mg} / \mathrm{L}$ & 18 & $<$ & 0.0123 & 0.0100 & 0.0330 \\
\hline K011 & MICP & Gallium & $\mathrm{mg} / \mathrm{L}$ & 1 & $<$ & 0.0200 & 0.0200 & 0.0200 \\
\hline
\end{tabular}


Table A.8 (continued)

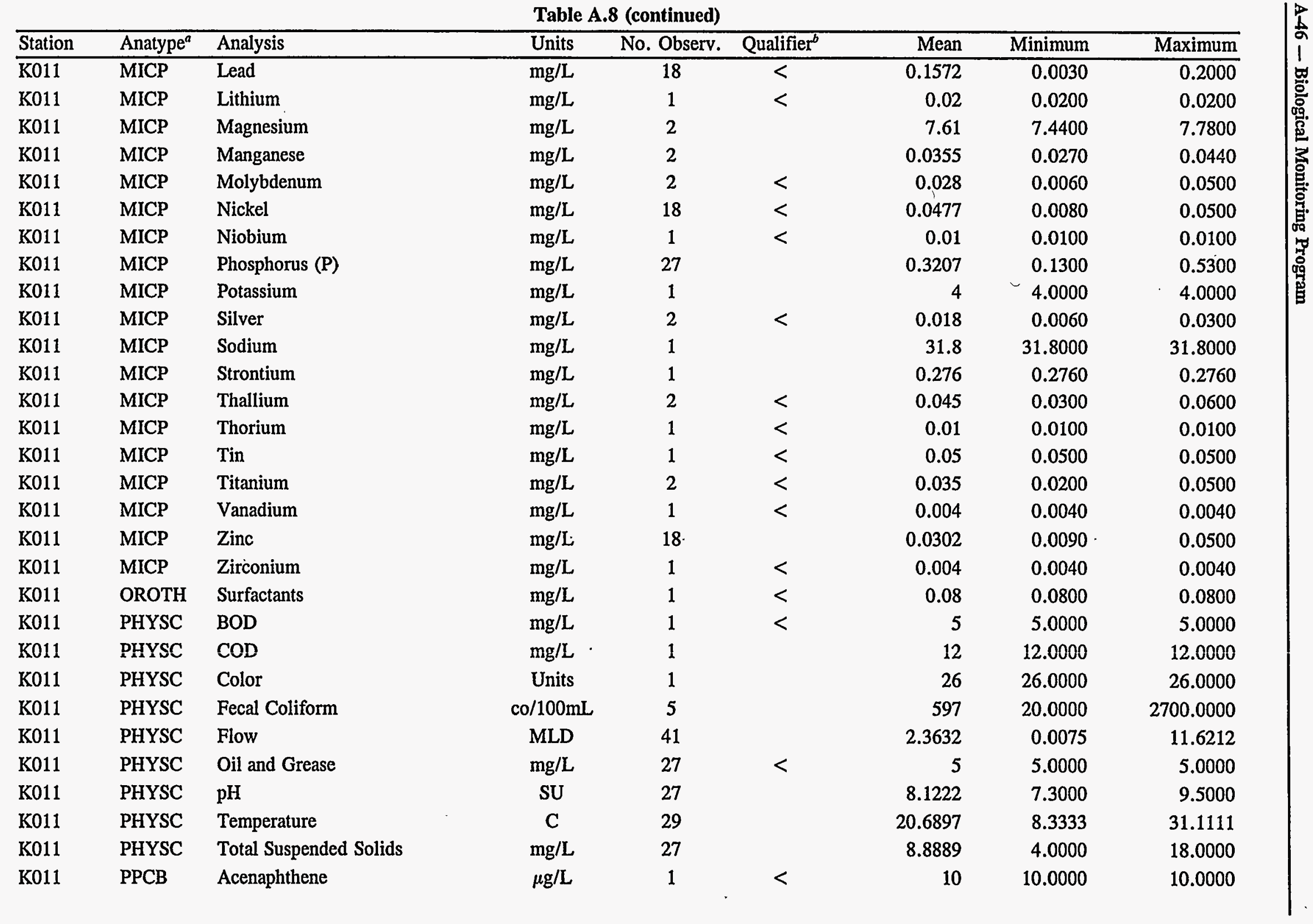


Table A.8 (continued)

\begin{tabular}{|c|c|c|c|c|c|c|c|c|}
\hline Station & Anatype $^{a}$ & Analysis & Units & No. Observ. & Qualifier $^{b}$ & Mean & Minimum & Maximum \\
\hline K011 & PPCB & Acenaphthylene & $\mu \mathrm{g} / \mathrm{L}$ & 1 & $<$ & 10 & 10.0000 & 10.0000 \\
\hline K011 & PPCB & PCB & $\mu \mathrm{g} / \mathrm{kg}^{\mathrm{c}}$ & 9 & & 8844.4444 & 1600.0000 & 27500.0000 \\
\hline K011 & PPCB & PCB & $\mu \mathrm{g} / \mathrm{L}$ & 18 & & 0.1396 & 0.0650 & 0.6000 \\
\hline K011 & РPCB & PCB-1248 & $\mu \mathrm{g} / \mathrm{L}$ & 2 & & 0.09 & 0.0800 & 0.1000 \\
\hline K011 & PPCB & PCB-1254 & $\mu \mathrm{g} / \mathrm{kg}^{c}$ & 8 & & 2587.5 & 700.0000 & 6000.0000 \\
\hline K011 & PPCB & PCB-1260 & $\mu \mathrm{g} / \mathrm{kg}^{\mathrm{c}}$ & 9 & & 3000 & 900.0000 & 7500.0000 \\
\hline K011 & RADS & $\%$ U-235 & Wt \% & 1 & & 0.205 & 0.2050 & 0.2050 \\
\hline K011 & RADS & Gross Alpha & $\mathrm{pCi} / \mathrm{L}$ & 2 & & 19.75 & 5.2000 & 34.3000 \\
\hline K011 & RADS & Gross Beta & $\mathrm{pCi} / \mathrm{L}$ & 2 & & 27 & 27.0000 & 27.0000 \\
\hline K011 & RADS & Neptunium-237 & $\mathrm{pCi} / \mathrm{L}$ & 6 & & 0.1 & -0.4000 & 0.6000 \\
\hline K011 & RADS & Plutonium-239 & $\mathrm{pCi} / \mathrm{L}$ & 6 & & 0 & 0.0000 & 0.0000 \\
\hline K011 & RADS & Radium-226 & $\mathrm{pCi} / \mathrm{L}$ & 1 & & 0 & 0.0000 & 0.0000 \\
\hline K011 & RADS & Suspended Alpha & $\mathrm{pCi} / \mathrm{L}$ & 14 & & 1.4 & -2.1000 & 4.9000 \\
\hline K011 & RADS & Suspended Beta & $\mathrm{pCi} / \mathrm{L}$ & 14 & & 8.9286 & 1.0000 & 29.0000 \\
\hline K011 & RADS & Technetium-99 & $\mathrm{pCi} / \mathrm{L}$ & 26 & & 5.5769 & 0.0000 & 22.0000 \\
\hline K011 & RADS & Thorium-230 & $\mathrm{pCi} / \mathrm{L}$ & 6 & & 0.1167 & 0.0000 & 0.4000 \\
\hline K011 & RADS & Total Radium & $\mathrm{pCi} / \mathrm{L}$ & 1 & & 0.4 & 0.4000 & 0.4000 \\
\hline K011 & RADS & Uranium & $\mathrm{mg} / \mathrm{L}$ & 27 & & 0.0706 & 0.0150 & 0.2100 \\
\hline K011 & RADSD & Dissolved Alpha & $\mathrm{pCi} / \mathrm{L}$ & 14 & & 7.3143 & 1.4000 & 46.2000 \\
\hline K011 & RADSD & Dissolved Beta & $\mathrm{pCi} / \mathrm{L}$ & 14 & & 18.6429 & 9.0000 & 41.0000 \\
\hline K011 & SVOA & 1,2,4-Trichlorobenzene & $\mu \mathrm{g} / \mathrm{L}$ & 1 & $<$ & 10 & 10.0000 & 10.0000 \\
\hline K011 & SVOA & 1,2-Diphenylhydrazine & $\mu \mathrm{g} / \mathrm{L}$ & 1 & $<$ & 10 & 10.0000 & 10.0000 \\
\hline
\end{tabular}


Table A.8 (continued)

\begin{tabular}{|c|c|c|c|c|c|c|c|c|}
\hline Station & Anatype $^{a}$ & Analysis & Units & No. Observ. & Qualifier $^{b}$ & Mean & Minimum & Maximum \\
\hline K011 & SVOA & 2,4-Dichlorophenol & $\mu \mathrm{g} / \mathrm{L}$ & 1 & $<$ & 10 & 10.0000 & 10.0000 \\
\hline K011 & SVOA & 2,4-Dimethylphenol & $\mu \mathrm{g} / \mathrm{L}$ & 1 & $<$ & 10 & 10.0000 & 10.0000 \\
\hline K011 & SVOA & 2,4-Dinitrophenol & $\mu \mathrm{g} / \mathrm{L}$ & 1 & $<$ & 10 & 10.0000 & 10.0000 \\
\hline K011 & SVOA & 2,4-Dinitrotoluene & $\mu \mathrm{g} / \mathrm{L}$ & 1 & $<$ & 10 & 10.0000 & 10.0000 \\
\hline K011 & SVOA & 2,6-Dinitrotoluene & $\mu \mathrm{g} / \mathrm{L}$ & 1 & $<$ & 10 & 10.0000 & 10.0000 \\
\hline K011 & SVOA & 2-Chloroethyl Vinyl Ether & $\mu \mathrm{g} / \mathrm{L}$ & 1 & $<$ & 10 & 10.0000 & 10.0000 \\
\hline K011 & SVOA & 2-Chloronaphthalene & $\mu \mathrm{g} / \mathrm{L}$ & 1 & $<$ & 10 & 10.0000 & 10.0000 \\
\hline K011 & SVOA & 2-Chlorophenol & $\mu \mathrm{g} / \mathrm{L}$ & 1 & $<$ & 10 & 10.0000 & 10.0000 \\
\hline K011 & SVOA & 2-Nitrophenol & $\mu \mathrm{g} / \mathrm{L}$ & 1 & $<$ & 10 & 10.0000 & 10.0000 \\
\hline K011 & SVOA & 3,3'-Dichlorobenzidine & $\mu \mathrm{g} / \mathrm{L}$ & 1 & $<$ & 10 & 10.0000 & 10.0000 \\
\hline K011 & SVOA & 4,6-Dinitro-2-methylphenol & $\mu \mathrm{g} / \mathrm{L}$ & 1 & $<$ & 10 & 10.0000 & 10.0000 \\
\hline K011 & SVOA & 4-Bromophenyl-phenylether & $\mu \mathrm{g} / \mathrm{L}$ & 1 & $<$ & 10 & 10.0000 & 10.0000 \\
\hline K011 & SVOA & 4-Chloro-3-methylphenol & $\mu \mathrm{g} / \mathrm{L}$ & 1 & $<$ & 10 & 10.0000 & 10.0000 \\
\hline K011 & SVOA & 4-Chlorophenyl-phenylether & $\mu \mathrm{g} / \mathrm{L}$ & 1 & $<$ & 10 & 10.0000 & 10.0000 \\
\hline K011 & SVOA & 4-Nitrophenol & $\mu \mathrm{g} / \mathrm{L}$ & 1 & $<$ & 10 & 10.0000 & 10.0000 \\
\hline K011 & SVOA & Anthracene & $\mu \mathrm{g} / \mathrm{L}$ & 1 & $<$ & 10 & 10.0000 & 10.0000 \\
\hline K011 & SVOA & Benzo(a)anthracene & $\mu \mathrm{g} / \mathrm{L}$ & 1 & $<$ & 10 & 10.0000 & 10.0000 \\
\hline K011 & SVOA & Benzo(a)pyrene & $\mu \mathrm{g} / \mathrm{L}$ & 1 & $<$ & 10 & 10.0000 & 10.0000 \\
\hline K011 & SVOA & Benzo(b)fluoranthene & $\mu \mathrm{g} / \mathrm{L}$ & 1 & $<$ & 10 & 10.0000 & 10.0000 \\
\hline K011 & SVOA & Benzo(g,h,i)perylene & $\mu \mathrm{g} / \mathrm{L}$ & 1 & $<$ & 10 & 10.0000 & 10.0000 \\
\hline K011 & SVOA & Benzo(k)fluoranthene & $\mu \mathrm{g} / \mathrm{L}$ & 1 & $<$ & 10 & 10.0000 & 10.0000 \\
\hline K011 & SVOA & Denzyl Butyl Phthalate & $\mu \mathrm{g} / \mathrm{L}$ & 1 & $<$ & 10 & 10.0000 & 10.0000 \\
\hline K011 & SVOA & bis(2-Chloroethoxy)methane & $\mu \mathrm{g} / \mathrm{L}$ & 1 & $<$ & 10 & 10.0000 & 10.0000 \\
\hline K011 & SVOA & bis(2-Chloroethyl)ether & $\mu \mathrm{g} / \mathrm{L}$ & 1 & $<$ & 10 & 10.0000 & 10.0000 \\
\hline K011 & SVOA & bis(2-Chloroisopropyl)ether & $\mu \mathrm{g} / \mathrm{L}$ & 1 & $<$ & 10 & 10.0000 & 10.0000 \\
\hline K011 & SVOA & bis(2-Ethylhexyl)phthalate & $\mu \mathrm{g} / \mathrm{L}$ & 1 & & 2.0000 & 2.0000 & 2.0000 \\
\hline K011 & SVOA & Chrysene & $\mu \mathrm{g} / \mathrm{L}$ & 1 & $<$ & 10 & 10.0000 & 10.0000 \\
\hline K011 & SVOA & Di-n-butylphthalate & $\mu \mathrm{g} / \mathrm{L}$ & 1 & $<$ & 10 & 10.0000 & 10.0000 \\
\hline K011 & SVOA & Di-n-octylphthalate & $\mu \mathrm{g} / \mathrm{L}$ & 1 & $<$ & 10 & 10.0000 & 10.0000 \\
\hline K011 & SVOA & Dibenzo(a,h)anthracene & $\mu \mathrm{g} / \mathrm{L}$ & 1 & $<$ & 10 & 10.0000 & 10.0000 \\
\hline
\end{tabular}


Table A.8 (continued)

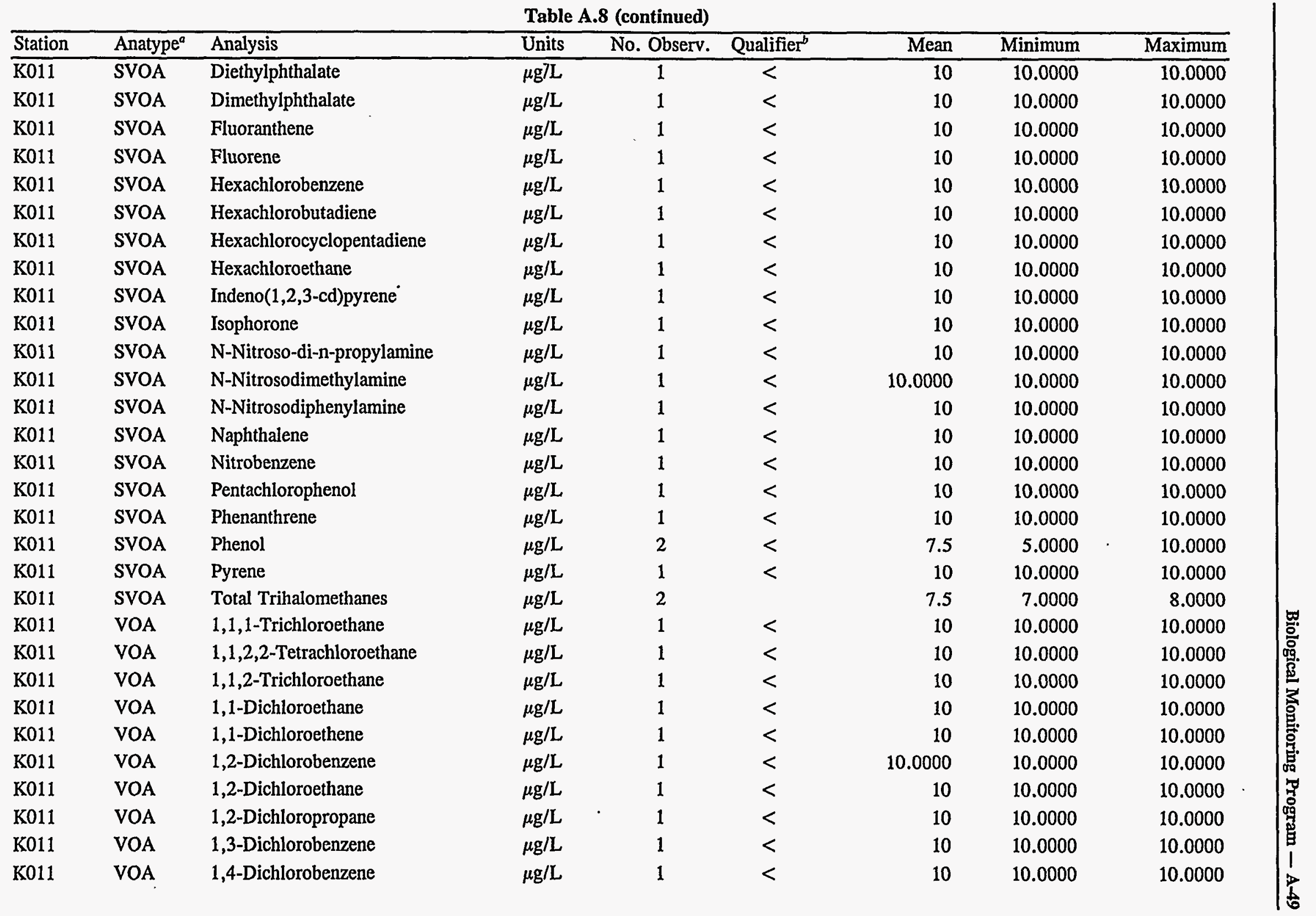


Table A.8 (continued)

\begin{tabular}{|c|c|c|c|c|c|c|c|c|}
\hline Station & Anatype $^{a}$ & Analysis & Units & No. Observ. & Qualifier $^{b}$ & Mean & Minimum & Maximum \\
\hline K011 & $\mathrm{VOA}$ & Acrolein & $\mu \mathrm{g} / \mathrm{L}$ & 1 & $<$ & 10 & 10.0000 & 10.0000 \\
\hline K011 & VOA & Acrylonitrile & $\mu \mathrm{g} / \mathrm{L}$ & 1 & $<$ & 10 & 10.0000 & 10.0000 \\
\hline K011 & VOA & Benzene & $\mu \mathrm{g} / \mathrm{L}$ & 1 & $<$ & 10 & 10.0000 & 10.0000 \\
\hline K011 & VOA & Benzidine & $\mu \mathrm{g} / \mathrm{L}$ & 1 & $<$ & 10 & 10.0000 & 10.0000 \\
\hline K011 & VOA & Bromodichloromethane & $\mu \mathrm{g} / \mathrm{L}$ & 1 & $<$ & 10 & 10.0000 & 10.0000 \\
\hline K011 & VOA & Bromoform & $\mu \mathrm{g} / \mathrm{L}$ & 1 & $<$ & 10 & 10.0000 & 10.0000 \\
\hline K011 & VOA & Bromomethane & $\mu \mathrm{g} / \mathrm{L}$ & 1 & $<$ & 10 & 10.0000 & 10.0000 \\
\hline K011 & VOA & Carbon Tetrachloride & $\mu \mathrm{g} / \mathrm{L}$ & 1 & $<$ & 10 & 10.0000 & 10.0000 \\
\hline K011 & VOA & Chlorobenzene & $\mu \mathrm{g} / \mathrm{L}$ & 1 & $<$ & 10 & 10.0000 & 10.0000 \\
\hline K011 & VOA & Chloroethane & $\mu \mathrm{g} / \mathrm{L}$ & 1 & $<$ & 10 & 10.0000 & 10.0000 \\
\hline K011 & VOA & Chloroform & $\mu \mathrm{g} / \mathrm{L}$ & 3 & & 4.6667 & 2.0000 & 8.0000 \\
\hline K011 & VOA & Chloromethane & $\mu \mathrm{g} / \mathrm{L}$ & 1 & $<$ & 10 & 10.0000 & 10.0000 \\
\hline K011 & VOA & cis-1,2-dichloroethene & $\mu \mathrm{g} / \mathrm{L}$ & 2 & & 5 & 3.0000 & 7.0000 \\
\hline K011 & VOA & cis-1,3-Dichloropropene & $\mu \mathrm{g} / \mathrm{L}$ & 1 & $<$ & 10 & 10.0000 & 10.0000 \\
\hline K011 & VOA & Dibromochloromethane & $\mu \mathrm{g} / \mathrm{L}$ & 1 & $<$ & 10 & 10.0000 & 10.0000 \\
\hline K011 & VOA & Dichlorodifluoromethane & $\mu \mathrm{g} / \mathrm{L}$ & 2 & & 7 & 4.0000 & 10.0000 \\
\hline K011 & VOA & Ethylbenzene & $\mu \mathrm{g} / \mathrm{L}$ & 1 & $<$ & 10 & 10.0000 & 10.0000 \\
\hline K011 & VOA & Methylene Chloride & $\mu \mathrm{g} / \mathrm{L}$ & 1 & $<$ & 10 & 10.0000 & 10.0000 \\
\hline K011 & VOA & Tetrachlorodibenzo-p-dioxin & $\mathrm{ng} / \mathrm{L}$ & 2 & $<$ & 0.68 & 0.2600 & 1.1000 \\
\hline K011 & VOA & Tetrachloroethene & $\mu \mathrm{g} / \mathrm{L}$ & 1 & $<$ & 10 & 10.0000 & 10.0000 \\
\hline K011 & VOA & Toluene & $\mu \mathrm{g} / \mathrm{L}$ & 1 & $<$ & 10 & 10.0000 & 10.0000 \\
\hline K011 & VOA & Trans-1,2-Dichloroethene & $\mu \mathrm{g} / \mathrm{L}$ & 1 & $<$ & 10 & 10.0000 & 10.0000 \\
\hline K011 & VOA & Trans-1,3-Dichloropropene & $\mu \mathrm{g} / \mathrm{L}$ & 1 & $<$ & 10 & 10.0000 & 10.0000 \\
\hline K011 & VOA & Trichloroethene & $\mu \mathrm{g} / \mathrm{L}$ & 14 & & 3 & 1.0000 & 8.0000 \\
\hline K011 & VOA & Trichlorofluoromethane & $\mu \mathrm{g} / \mathrm{L}$ & 1 & $<$ & 10 & 10.0000 & 10.0000 \\
\hline K011 & VOA & Vinyl Chloride & $\mu \mathrm{g} / \mathrm{L}$ & 1 & $<$ & 10.0000 & 10.0000 & 10.0000 \\
\hline
\end{tabular}

Note: Data provided by L. S. Crabtree, Information Services, Paducah Gaseous Diffusion Plant.

${ }^{a}$ ANION $=$ a negatively charged ion; CATION = a positively charged ion; CHEM $=$ chemical parameters; MAA $=$ metals by atomic absorption; MIC $=$ metals by inductively-coupled plasma/mass spectroscopy; OROTH = other organics, PHYSC = physical and field measurements; PPCB = pesticides/polychlorinated biphenyls; RADS = radiochemical analysis; RADSD = radiochemical analysis, dissolved; SVOA = semivolatile organics; VOA = volatile organics.

${ }^{b} \mathrm{~A}$ " $<$ " qualifier was added to the mean when $\geq 50 \%$ of the observations had " $<$ " qualifiers.

'Sediment data. 
Table A.9. Water quality parameters measured at Kentucky Pollutant Discharge Elimination System permitted outfall 012

\begin{tabular}{|c|c|c|c|c|c|c|c|c|}
\hline Station & Anatype $^{a}$ & Analysis & Units & No. Observ. & Qualifier $^{b}$ & Mean & Minimum & Maximum \\
\hline $\mathrm{K} 012$ & ANION & Bromide & $\mathrm{mg} / \mathrm{L}$ & 1 & $<$ & 1.0000 & 1.0000 & 1.0000 \\
\hline K012 & ANION & Chloride & $\mathrm{mg} / \mathrm{L}$ & 1 & $<$ & 16.0000 & 16.0000 & 16.0000 \\
\hline K012 & ANION & Chlorine, Total Residual & $\mathrm{mg} / \mathrm{L}$ & 12 & $<$ & 0.0450 & 0.0300 & 0.0500 \\
\hline K012 & ANION & Cyanide & $\mathrm{mg} / \mathrm{L}$ & 1 & $<$ & 0.0200 & 0.0200 & 0.0200 \\
\hline K012 & ANION & Fluoride & $\mathrm{mg} / \mathrm{L}$ & 1 & $<$ & 0.3200 & 0.3200 & 0.3200 \\
\hline K012 & ANION & Hardness as $\mathrm{CaCO}_{3}$ & $\mathrm{mg} / \mathrm{L} \mathrm{CaCO}_{3}$ & 11 & $<$ & 107.6364 & 60.0000 & 166.0000 \\
\hline K012 & ANION & Nitrate-Nitrite & $\mathrm{mg} / \mathrm{L}$ & 1 & $<$ & 0.3600 & 0.3600 & 0.3600 \\
\hline K012 & ANION & Sulfate & $\mathrm{mg} / \mathrm{L}$ & 1 & $<$ & 29.0000 & 29.0000 & 29.0000 \\
\hline K012 & ANION & Sulfide & $\mathrm{mg} / \mathrm{L}$ & 1 & $<$ & 1.0000 & 1.0000 & 1.0000 \\
\hline K012 & ANION & Sulfite & $\mathrm{mg} / \mathrm{L}$ & 1 & $<$ & 3.0000 & 3.0000 & 3.0000 \\
\hline K012 & CATION & Ammonia as Nitrogen & $\mathrm{mg} / \mathrm{L}$ & 1 & $<$ & 0.2000 & 0.2000 & 0.2000 \\
\hline K012 & CHEM & Total Organic Carbon & $\mathrm{mg} / \mathrm{L}$ & 1 & $<$ & 6.0000 & 6.0000 & 6.0000 \\
\hline K012 & CHEM & Total Organic Nitrogen & $\mathrm{mg} / \mathrm{L}$ & 1 & $<$ & 0.7000 & 0.7000 & 0.7000 \\
\hline K012 & MAA & Arsenic & $\mathrm{mg} / \mathrm{L}^{\circ}$ & 2 & $<$ & 0.0225 & 0.0050 & 0.0400 \\
\hline K012 & MAA & Mercury & $\mathrm{mg} / \mathrm{L}$ & 1 & $<$ & 0.0002 & 0.0002 & 0.0002 \\
\hline K012 & MAA & Selenium & $\mathrm{mg} / \mathrm{L}$ & 2 & $<$ & 0.0525 & 0.0050 & 0.1000 \\
\hline K012 & $\mathrm{MICP}$ & Aluminum & $\mathrm{mg} / \mathrm{L}$ & 12 & $<$ & 1.5579 & 0.4510 & 5.4000 \\
\hline K012 & MICP & Antimony & $\mathrm{mg} / \mathrm{L}$ & 1 & $<$ & 0.0600 & 0.0600 & 0.0600 \\
\hline K012 & MICP & Barium & $\mathrm{mg} / \mathrm{L}$ & 2 & $<$ & 0.0638 & 0.0630 & 0.0645 \\
\hline K012 & MICP & Beryllium & $\mathrm{mg} / \mathrm{L}$ & 2 & $<$ & 0.0027 & 0.0004 & 0.0050 \\
\hline K012 & MICP & Boron & $\mathrm{mg} / \mathrm{L}$ & 1 & $<$ & 0.0230 & 0.0230 & 0.0230 \\
\hline K012 & MICP & Cadmium & $\mathrm{mg} / \mathrm{L}$ & 12 & $<$ & 0.0071 & 0.0005 & 0.0100 \\
\hline K012 & MICP & Calcium & $\mathrm{mg} / \mathrm{L}$ & 1 & $<$ & 43.3000 & 43.3000 & 43.3000 \\
\hline K012 & MICP & Cerium & $\mathrm{mg} / \mathrm{L}$ & 1 & $<$ & 0.0200 & 0.0200 & 0.0200 \\
\hline K012 & MICP & Chromium & $\mathrm{mg} / \mathrm{L}$ & 12 & $<$ & 0.0398 & 0.0060 & 0.0920 \\
\hline K012 & MICP & Cobalt & $\mathrm{mg} / \mathrm{L}$ & 2 & $<$ & 0.0260 & 0.0020 & 0.0500 \\
\hline K012 & MICP & Copper & $\mathrm{mg} / \mathrm{L}$ & 12 & $<$ & 0.0122 & 0.0060 & 0.0300 \\
\hline K012 & MICP & Gallium & $\mathrm{mg} / \mathrm{L}$ & 1 & $<$ & 0.0200 & 0.0200 & 0.0200 \\
\hline K012 & MICP & Iron & $\mathrm{mg} / \mathrm{L}$ & 12 & $<$ & 1.3170 & 0.3800 & 4.3000 \\
\hline K012 & MICP & Lead & $\mathrm{mg} / \mathrm{L}$ & 12 & $<$ & 0.1358 & 0.0030 & 0.2000 \\
\hline
\end{tabular}


Table A.9 (continued)

\begin{tabular}{|c|c|c|c|c|c|c|c|c|}
\hline Station & Anatype $^{a}$ & Analysis & Units & No. Observ. & Qualifier $^{b}$ & Mean & Minimum & Maximum \\
\hline K012 & MICP & Lithium & $\mathrm{mg} / \mathrm{L}$ & 1 & $<$ & 0.0200 & 0.0200 & 0.0200 \\
\hline K012 & MICP & Magnesium & $\mathrm{mg} / \mathrm{L}$ & 2 & $<$ & 6.7550 & 6.5200 & 6.9900 \\
\hline K012 & MICP & Manganese & $\mathrm{mg} / \mathrm{L}$ & 2 & $<$ & 0.1715 & 0.1680 & 0.1750 \\
\hline K012 & MICP & Molybdenum & $\mathrm{mg} / \mathrm{L}$ & 2 & $<$ & 0.0280 & 0.0060 & 0.0500 \\
\hline K012 & MICP & Nickel & $\mathrm{mg} / \mathrm{L}$ & 12 & $<$ & 0.0528 & 0.0080 & 0.1250 \\
\hline K012 & MICP & Niobium & $\mathrm{mg} / \mathrm{L}$ & 1 & $<$ & 0.0100 & 0.0100 & 0.0100 \\
\hline K012 & MICP & Phosphorus (P) & $\mathrm{mg} / \mathrm{L}$ & .12 & $<$ & 0.2542 & 0.1200 & 0.6400 \\
\hline K012 & MICP & Potassium & $\mathrm{mg} / \mathrm{L}$ & 1 & $<$ & 1.2000 & 1.2000 & 1.2000 \\
\hline K012 & MICP & Silver & $\mathrm{mg} / \mathrm{L}$ & 2 & $<$ & 0.0180 & 0.0060 & 0.0300 \\
\hline K012 & MICP & Sodium & $\mathrm{mg} / \mathrm{L}$ & 1 & $<$ & 20.9000 & 20.9000 & 20.9000 \\
\hline K012 & MICP & Strontium & $\mathrm{mg} / \mathrm{L}$ & 1 & $<$ & 0.3330 & 0.3330 & 0.3330 \\
\hline K012 & MICP & Thallium & $\mathrm{mg} / \mathrm{L}$ & 2 & $<$ & 0.0450 & 0.0300 & 0.0600 \\
\hline K012 & MICP & Thorium & $\mathrm{mg} / \mathrm{L}$ & 1 & $<$ & 0.0100 & 0.0100 & 0.0100 \\
\hline K012 & MICP & Tin & $\mathrm{mg} / \mathrm{L}$ & 1 & $<$ & 0.0500 & 0.0500 & 0.0500 \\
\hline K012 & MICP & Titanium & $\mathrm{mg} / \mathrm{L}$ & 2 & $<$ & 0.0350 & 0.0200 & 0.0500 \\
\hline K012 & MICP & Vanadium & $\mathrm{mg} / \mathrm{L}$ & 1 & $<$ & 0.0040 & 0.0040 & 0.0040 \\
\hline K012 & MICP & Zinc & $\mathrm{mg} / \mathrm{L}$ & 12 & $<$ & 0.0982 & 0.0360 & 0.3570 \\
\hline K012 & $\mathrm{MICP}$ & Zirconium & $\mathrm{mg} / \mathrm{L}$ & 1 & $<$ & 0.0040 & 0.0040 & 0.0040 \\
\hline K012 & OROTH & Surfactants & $\mathrm{mg} / \mathrm{L}$ & 1 & $<$ & 0.0800 & 0.0800 & 0.0800 \\
\hline K012 & PHYSC & $\mathrm{BOD}$ & $\mathrm{mg} / \mathrm{L}$ & 1 & $<$ & 5.0000 & 5.0000 & 5.0000 \\
\hline K012 & PHYSC & COD & $\mathrm{mg} / \mathrm{L}$ & 1 & $<$ & 11.0000 & 11.0000 & 11.0000 \\
\hline K012 & PHYSC & Color & Units & 1 & $<$ & 55.0000 & 55.0000 & 55.0000 \\
\hline K012 & PHYSC & Fecal Coliform & $\mathrm{co} / 100 \mathrm{~mL}$ & 2 & $<$ & 660.0000 & 270.0000 & 1050.0000 \\
\hline K012 & PHYSC & Flow & MLD & 12 & $<$ & 7.0400 & 0.2082 & 22.0689 \\
\hline K012 & PHYSC & Oil and Grease & $\mathrm{mg} / \mathrm{L}$ & 13 & $<$ & 5.8615 & 5.0000 & 14.6000 \\
\hline K012 & PHYSC & $\mathrm{pH}$ & SU & 11 & $<$ & 7.5091 & 7.4000 & 8.0000 \\
\hline K012 & PHYSC & Temperature & $\mathrm{C}$ & 11 & $<$ & 14.7475 & 2.7778 & 30.5556 \\
\hline K012 & PHYSC & Total Suspended Solids & $\mathrm{mg} / \mathrm{L}$ & 12 & $<$ & 94.2500 & 7.0000 & 813.0000 \\
\hline K012 & PPCB & Acenaphthene & $\mathrm{ug} / \mathrm{L}$ & 1 & $<$ & 10.0000 & 10.0000 & 10.0000 \\
\hline
\end{tabular}


Table A.9 (continued)

\begin{tabular}{|c|c|c|c|c|c|c|c|c|}
\hline Station & Anatype $^{a}$ & Analysis & Units & No. Observ. & Qualifier $^{b}$ & Mean & Minimum & Maximum \\
\hline K012 & PPCB & Acenaphthylene & $\mathrm{ug} / \mathrm{L}$ & 1 & $<$ & 10.0000 & 10.0000 & 10.0000 \\
\hline K012 & PPCB & $\mathrm{PCB}$ & $\mathrm{ug} / \mathrm{L}$ & 12 & $<$ & 0.1029 & 0.0650 & 0.2600 \\
\hline K012 & PPCB & PCB-1016 & ug/L & 1 & $<$ & 0.2600 & 0.2600 & 0.2600 \\
\hline K012 & PPCB & PCB-1260 & $\mathrm{ug} / \mathrm{L}$ & 1 & $<$ & 0.0800 & 0.0800 & 0.0800 \\
\hline K012 & RADS & $\% . U-235$ & Wt \% & 1 & $<$ & 0.3820 & 0.3820 & 0.3820 \\
\hline K012 & RADS & Gross Alpha & $\mathrm{pCi} / \mathrm{L}$ & 1 & $<$ & 2.5000 & 2.5000 & 2.5000 \\
\hline K012 & RADS & Gross Beta & $\mathrm{pCi} / \mathrm{L}$ & 1 & $<$ & 4.0000 & 4.0000 & 4.0000 \\
\hline K012 & RADS & Neptunium-237 & $\mathrm{pCi} / \mathrm{L}$ & 4 & $<$ & 0.0750 & -0.2000 & 0.3000 \\
\hline K012 & RADS & Plutonium-239 & $\mathrm{pCi} / \mathrm{L}$ & 4 & $<$ & 0.0000 & 0.0000 & 0.0000 \\
\hline K012 & RADS & Rad Alpha & $\mathrm{pCi} / \mathrm{ml}$ & 3 & $<$ & 1.0000 & 1.0000 & 1.0000 \\
\hline K012 & RADS & Rad Beta & $\mathrm{pCi} / \mathrm{ml}$ & 3 & $<$ & 1.0000 & 1.0000 & 1.0000 \\
\hline K012 & RADS & Radium-226 & $\mathrm{pCi} / \mathrm{L}$ & 1 & $<$ & 0.0000 & 0.0000 & 0.0000 \\
\hline K012 & RADS & Suspended Alpha & $\mathrm{pCi} / \mathrm{L}$ & 4 & $<$ & -0.1750 & -1.5000 & 1.1000 \\
\hline K012 & RADS & Suspended Beta & $\mathrm{pCi} / \mathrm{L}$ & 4 & $<$ & 3.7500 & -1.0000 & 6.0000 \\
\hline K012 & RADS & Technetium-99 & $\mathrm{pCi} / \mathrm{L}$ & 4 & $<$ & 10.2500 & 0.0000 & 21.0000 \\
\hline K012 & RADS & Thorium-230 & $\mathrm{pCi} / \mathrm{L}$ & 4 & $<$ & 0.1750 & 0.1000 & 0.4000 \\
\hline K012 & RADS & Toṭal Radium & $\mathrm{pCi} / \mathrm{L}$ & 1 & $<$ & 0.6000 & 0.6000 & 0.6000 \\
\hline K012 & RADS & Uranium & $\mathrm{mg} / \mathrm{L}$ & 4 & $<$ & 0.0070 & 0.0050 & 0.0090 \\
\hline K012 & RADSD & Dissolved Alpha & $\mathrm{pCi} / \mathrm{L}$ & 4 & $<$ & 0.8750 & -1.5000 & 2.4000 \\
\hline K012 & RADSD & Dissolved Beta & $\mathrm{pCi} / \mathrm{L}$ & 4 & $<$ & 7.2500 & 2.0000 & 13.0000 \\
\hline K012 & SVOA & 1,2,4-Trichlorobenzene & $\mathrm{ug} / \mathrm{L}$ & 1 & $<$ & 10.0000 & 10.0000 & 10.0000 \\
\hline K012 & SVOA & 1,2-Diphenylhydrazine & $\mathrm{ug} / \mathrm{L}$ & 1 & $<$ & 10.0000 & 10.0000 & 10.0000 \\
\hline K012 & SVOA & 2,4,6-Trichlorophenol & $\mathrm{ug} / \mathrm{L}$ & 1 & $<$ & 10.0000 & 10.0000 & 10.0000 \\
\hline K012 & SVOA & 2,4-Dichlorophenol & $\mathrm{ug} / \mathrm{L}$ & 1 & $<$ & 10.0000 & 10.0000 & 10.0000 \\
\hline K012 & SVOA & 2,4-Dimethylphenol & $\mathrm{ug} / \mathrm{L}$ & 1 & $<$ & 10.0000 & 10.0000 & 10.0000 \\
\hline K012 & SVOA & 2,4-Dinitrophenol & $\mathrm{ug} / \mathrm{L}$ & 1 & $<$ & 10.0000 & 10.0000 & 10.0000 \\
\hline K012 & SVOA & 2,4-Dinitrotoluene & $\mathrm{ug} / \mathrm{L}$ & 1 & $<$ & 10.0000 & 10.0000 & 10.0000 \\
\hline K012 & SVOA & 2,6-Dinitrotoluene & $u g / L$ & 1 & $<$ & 10.0000 & 10.0000 & 10.0000 \\
\hline K012 & SVOA & 2-Chloroethyl Vinyl Ether & $\mathrm{ug} / \mathrm{L}$ & 1 & $<$ & 10.0000 & 10.0000 & 10.0000 \\
\hline
\end{tabular}


Table A.9 (continued)

\begin{tabular}{|c|c|c|c|c|c|c|c|c|}
\hline Station & Anatype $^{a}$ & Analysis & Units & No. Observ. & Qualifier $^{b}$ & Mean & Minimum & Maximum \\
\hline K012 & SVOA & 2-Chloronaphthalene & $\mathrm{ug} / \mathrm{L}$ & 1 & $<$ & 10.0000 & 10.0000 & 10.0000 \\
\hline K012 & SVOA & 2-Chlorophenol & $\mathrm{ug} / \mathrm{L}$ & 1 & $<$ & 10.0000 & 10.0000 & 10.0000 \\
\hline K012 & SVOA & 2-Nitrophenol & $\mathrm{ug} / \mathrm{L}$ & 1 & $<$ & 10.0000 & 10.0000 & 10.0000 \\
\hline K012 & SVOA & 3,3'-Dichlorobenzidine & $u g / L$ & 1 & $<$ & 10.0000 & 10.0000 & 10.0000 \\
\hline K012 & SVOA & 4,6-Dinitro-2-methylphenol & $\mathrm{ug} / \mathrm{L}$ & 1 & $<$ & 10.0000 & 10.0000 & 10.0000 \\
\hline K012 & SVOA & 4-Bromophenyl-phenylether & $\mathrm{ug} / \mathrm{L}$ & 1 & $<$ & 10.0000 & 10.0000 & 10.0000 \\
\hline K012 & SVOA & 4-Chloro-3-methylphenol & $\mathrm{ug} / \mathrm{L}$ & 1 & $<$ & 10.0000 & 10.0000 & 10.0000 \\
\hline K012 & SVOA & 4-Chlorophenyl-phenylether & $\mathrm{ug} / \mathrm{L}$ & 1 & $<$ & 10.0000 & 10.0000 & 10.0000 \\
\hline K012 & SVOA & 4-Nitrophenol & $\mathrm{ug} / \mathrm{L}$ & 1 & $<$ & 10.0000 & 10.0000 & 10.0000 \\
\hline K012 & SVOA & Anthracene & $\mathrm{ug} / \mathrm{L}$ & 1 & $<$ & 10.0000 & 10.0000 & 10.0000 \\
\hline K012 & SVOA & Benzo(a)anthracene & $\mathrm{ug} / \mathrm{L}$ & 1 & $<$ & 10.0000 & 10.0000 & 10.0000 \\
\hline K012 & SVOA & Benzo(a)pyrene & $\mathrm{ug} / \mathrm{L}$ & 1 & $<$ & 10.0000 & 10.0000 & 10.0000 \\
\hline K012 & SVOA & Benzo(b)fluoranthene & $\mathrm{ug} / \mathrm{L}$ & 1 & $<$ & 10.0000 & 10.0000 & 10.0000 \\
\hline K012 & SVOA & $\operatorname{Benzo}(\mathrm{g}, \mathrm{h}, \mathrm{i})$ perylene & $\mathrm{ug} / \mathrm{L}$ & 1 & $<$ & 10.0000 & 10.0000 & 10.0000 \\
\hline K012 & SVOA & Benzo(k)fluoranthene & $\mathrm{ug} / \mathrm{L}$ & 1 & $<$ & 10.0000 & 10.0000 & 10.0000 \\
\hline K012 & SVOA & Benzyl Butyl Phthalate & $\mathrm{ug} / \mathrm{L}$ & 1 & $<$ & 10.0000 & 10.0000 & 10.0000 \\
\hline K012 & SVOA & bis(2-Chloroethoxy)methane & $\mathrm{ug} / \mathrm{L}$ & 1 & $<$ & 10.0000 & 10.0000 & 10.0000 \\
\hline K012 & SVOA & bis(2-Chloroethyl)ether & $\mathrm{ug} / \mathrm{L}$ & 1 & $<$ & 10.0000 & 10.0000 & 10.0000 \\
\hline K012 & SVOA & bis(2-Chloroisopropyl)ether & $\mathrm{ug} / \mathrm{L}$ & 1 & $<$ & 10.0000 & 10.0000 & 10.0000 \\
\hline K012 & SVOA & bis(2-Ethylhexyl)phthalate & $\mathrm{ug} / \mathrm{L}$ & 1 & $<$ & 2.0000 & 2.0000 & 2.0000 \\
\hline K012 & SVOA & Chrysene & $\mathrm{ug} / \mathrm{L}$ & 1 & $<$ & 10.0000 & 10.0000 & 10.0000 \\
\hline K012 & SVOA & Di-n-butylphthalate & $\mathrm{ug} / \mathrm{L}$ & 1 & $<$ & 10.0000 & 10.0000 & 10.0000 \\
\hline K012 & SVOA & Di-n-octylphthalate & $\mathrm{ug} / \mathrm{L}$ & 1 & $<$ & 10.0000 & 10.0000 & 10.0000 \\
\hline K012 & SVOA & Dibenzo(a,h)anthracene & $\mathrm{ug} / \mathrm{L}$ & 1 & $<$ & 10.0000 & 10.0000 & 10.0000 \\
\hline K012 & SVOA & Diethylphthalate & $\mathrm{ug} / \mathrm{L}$ & 1 & $<$ & 10.0000 & 10.0000 & 10.0000 \\
\hline K012 & SVOA & Dimethylphthalate & $\mathrm{ug} / \mathrm{L}$ & 1 & $<$ & 10.0000 & 10.0000 & 10.0000 \\
\hline K012 & SVOA & Fluoranthene & $\mathrm{ug} / \mathrm{L}$ & 1 & $<$ & 10.0000 & 10.0000 & 10.0000 \\
\hline K012 & SVOA & Fluorene & $\mathrm{ug} / \mathrm{L}$ & 1 & $<$ & 10.0000 & 10.0000 & 10.0000 \\
\hline K012 & SVOA & Hexachlorobenzene & $\mathrm{ug} / \mathrm{L}$ & 1 & $<$ & 10.0000 & 10.0000 & 10.0000 \\
\hline
\end{tabular}


Table A.9 (continued)

\begin{tabular}{|c|c|c|c|c|c|c|c|c|}
\hline Station & Anatype $^{a}$ & Analyșis & Units & No. Observ. & Qualifier $^{b}$ & Mean & Minimum & Maximum \\
\hline K012 & SVOA & Hexachlorobutadiene & $\mathrm{ug} / \mathrm{L}$ & 1 & $<$ & 10.0000 & 10.0000 & 10.0000 \\
\hline K012 & SVOA & Hexachlorocyclopentadiene & $\mathrm{ug} / \mathrm{L}$ & 1 & $<$ & 10.0000 & 10.0000 & 10.0000 \\
\hline K012 & SVOA & Hexachloroethane & $\mathrm{ug} / \mathrm{L}$ & 1 & $<$ & 10.0000 & 10.0000 & 10.0000 \\
\hline K012 & SVOA & Indeno(1,2,3-cd)pyrene & $\mathrm{ug} / \mathrm{L}$ & 1 & $<$ & 10.0000 & 10.0000 & 10.0000 \\
\hline K012 & SVOA & Isophorone & $\mathrm{ug} / \mathrm{L}$ & 1 & $<$ & 10.0000 & 10.0000 & 10.0000 \\
\hline K012 & SVOA & N-Nitroso-di-n-propylamine & $\mathrm{ug} / \mathrm{L}$ & 1 & $<$ & 10.0000 & 10.0000 & 10.0000 \\
\hline K012 & SVOA & N-Nitrosodimethylamine & $\mathrm{ug} / \mathrm{L}$ & 1 & $<$ & 10.0000 & 10.0000 & 10.0000 \\
\hline K012 & SVOA & $\mathrm{N}$-Nitrosodiphenylamine & $\mathrm{ug} / \mathrm{L}$ & 1 & $<$ & 10.0000 & 10.0000 & 10.0000 \\
\hline K012 & SVOA & Naphthalene & ug/L & 1 & $<$ & 10.0000 & 10.0000 & 10.0000 \\
\hline K012 & SVOA & Nitrobenzene & $\mathrm{ug} / \mathrm{L}$ & 1 & $<$ & 10.0000 & 10.0000 & 10.0000 \\
\hline K012 & SVOA & Pentachiorophenol & $\mathrm{ug} / \mathrm{L}$ & 1 & $<$ & 10.0000 & 10.0000 & 10.0000 \\
\hline K012 & SVOA & Phenanthrene & $\mathrm{ug} / \mathrm{L}$ & 1 & $<$ & 10.0000 & 10.0000 & 10.0000 \\
\hline K012 & SVOA & Phenol & $\mathrm{ug} / \mathrm{L}$ & 2 & $<$ & 7.5000 & 5.0000 & 10.0000 \\
\hline K012 & SVOA & Pyrene & $\mathrm{ug} / \mathrm{L}$ & 1 & $<$ & 10.0000 & 10.0000 & 10.0000 \\
\hline K012 & VOA & 1,1,1-Trichloroethane & $\mathrm{ug} / \mathrm{L}$ & 1 & $<$ & 10.0000 & 10.0000 & 10.0000 \\
\hline K012 & VOA & 1,1,2,2-Tetrachloroethane & $\mathrm{ug} / \mathrm{L}$ & 1 & $<$ & 10.0000 & 10.0000 & 10.0000 \\
\hline K012 & VOA & 1,1,2-Trichloroethane & $\mathrm{ug} / \mathrm{L}$ & 1 & $<$ & 10.0000 & 10.0000 & 10.0000 \\
\hline K012 & VOA & 1,1-Dichloroethane & $\mathrm{ug} / \mathrm{L}$ & 1 & $<$ & 10.0000 & 10.0000 & 10.0000 \\
\hline K012 & VOA & 1,1-Dichloroethene & $\mathrm{ug} / \mathrm{L}$ & 1 & $<$ & 10.0000 & 10.0000 & 10.0000 \\
\hline K012 & VOA & 1,2-Dichlorobenzene & $\mathrm{ug} / \mathrm{L}$ & 1 & $<$ & 10.0000 & 10.0000 & 10.0000 \\
\hline K012 & VOA & 1,2-Dichloroethane & ug/L & 1 & $<$ & 10.0000 & 10.0000 & 10.0000 \\
\hline K012 & VOA & 1,2-Dichloropropane & $\mathrm{ug} / \mathrm{L}$ & 1 & $<$ & 10.0000 & 10.0000 & 10.0000 \\
\hline K012 & VOA & 1,3-Dichlorobenzene & ug/L & 1 & $<$ & 10.0000 & 10.0000 & 10.0000 \\
\hline K012 & VOA & 1,4-Dichlorobenzene & $\mathrm{ug} / \mathrm{L}$ & 1 & $<$ & 10.0000 & 10.0000 & 10.0000 \\
\hline K012 & VOA & Acrolein & $\mathrm{ug} / \mathrm{L}$ & 1 & $<$ & 10.0000 & 10.0000 & 10.0000 \\
\hline K012 & VOA & Acrylonitrile & $\mathrm{ug} / \mathrm{L}$ & 1 & $<$ & 10.0000 & 10.0000 & 10.0000 \\
\hline K012 & VOA & Benzene & $\mathrm{ug} / \mathrm{L}$ & 1 & $<$ & 10.0000 & 10.0000 & 10.0000 \\
\hline K012 & VOA & Benzidine & $\mathrm{ug} / \mathrm{L}$ & 1 & $<$ & 10.0000 & 10.0000 & 10.0000 \\
\hline K012 & VOA & Bromodichloromethane & $u g / L$ & 1 & $<$ & 10.0000 & 10.0000 & 10.0000 \\
\hline
\end{tabular}


Table A.9 (continued)

\begin{tabular}{|c|c|c|c|c|c|c|c|c|}
\hline Station & Anatype $^{a}$ & Analysis & Units & No. Observ. & Qualifier ${ }^{b}$ & Mean & Minimum & Maximum \\
\hline $\mathrm{K} 012$ & VOA & Bromoform & $\mathrm{ug} / \mathrm{L}$ & 1 & $<$ & 10.0000 & 10.0000 & 10.0000 \\
\hline K012 & VOA & Bromomethane & ug/L & 1 & $<$ & 10.0000 & 10.0000 & 10.0000 \\
\hline K012 & VOA & Carbon Tetrachloride & $\mathrm{ug} / \mathrm{L}$ & 1 & $<$ & 10.0000 & 10.0000 & 10.0000 \\
\hline K012 & VOA & Chlorobenzene & $\mathrm{ug} / \mathrm{L}$ & 1 & $<$ & 10.0000 & 10.0000 & 10.0000 \\
\hline K012 & VOA & Chloroethane & $\mathrm{ug} / \mathrm{L}$ & 1 & $<$ & 10.0000 & 10.0000 & 10.0000 \\
\hline K012 & VOA & Chloroform & $\mathrm{ug} / \mathrm{L}$ & 1 & $<$ & 10.0000 & 10.0000 & 10.0000 \\
\hline K012 & VOA & Chloromethane & $\mathrm{ug} / \mathrm{L}$ & 1 & $<$ & 10.0000 & 10.0000 & 10.0000 \\
\hline K012 & VOA & cis-1,3-Dichloropropene & $\mathrm{ug} / \mathrm{L}$ & 1 & $<$ & 10.0000 & 10.0000 & 10.0000 \\
\hline K012 & VOA & Dibromochloromethane & $\mathrm{ug} / \mathrm{L}$ & 1 & $<$ & 10.0000 & 10.0000 & 10.0000 \\
\hline K012 & VOA & Dichlorodifluoromethane & $\mathrm{ug} / \mathrm{L}$ & 1 & $<$ & 10.0000 & 10.0000 & 10.0000 \\
\hline K012 & VOA & Ethylbenzene & $\mathrm{ug} / \mathrm{L}$ & 1 & $<$ & 10.0000 & 10.0000 & 10.0000 \\
\hline K012 & VOA & Methylene Chloride & $\mathrm{ug} / \mathrm{L}$ & 1 & $<$ & 10.0000 & 10.0000 & 10.0000 \\
\hline K012 & VOA & Tetrachlorodibenzo-p-dioxin & $\mathrm{ng} / \mathrm{L}$ & 2 & $<$ & 0.6200 & 0.2600 & 0.9800 \\
\hline K012 & VOA & Tetrachloroethene & $\mathrm{ug} / \mathrm{L}$ & 1 & $<$ & 10.0000 & 10.0000 & 10.0000 \\
\hline K012 & VOA & Toluene & $\mathrm{ug} / \mathrm{L}$ & 1 & $<$ & 10.0000 & 10.0000 & 10.0000 \\
\hline K012 & VOA & Trans-1,2-Dichloroethene & $\mathrm{ug} / \mathrm{L}$ & 1 & $<$ & 10.0000 & 10.0000 & 10.0000 \\
\hline K012 & VOA & trans-1,3-Dichloropropene & ug/L & 1 & $<$ & 10.0000 & 10.0000 & 10.0000 \\
\hline K012 & VOA & Trichloroethene & $\mathrm{ug} / \mathrm{L}$ & 11 & $<$ & 1.8182 & 1.0000 & 10.0000 \\
\hline K012 & VOA & Trichlorofluoromethane & $\mathrm{ug} / \mathrm{L}$ & 1 & $<$ & 10.0000 & 10.0000 & 10.0000 \\
\hline $\mathrm{K} 012$ & VOA & Vinyl Chloride & $\mathrm{ug} / \mathrm{L}$ & 1 & $<$ & 10.0000 & 10.0000 & 10.0000 \\
\hline
\end{tabular}

Note: Data provided by L. S. Crabtree, Information Services, Paducah Gaseous Diffusion Plant.

${ }^{a}$ ANION $=$ a negatively charged ion; CATION $=$ a positively charged ion; CHEM $=$ chemical parameters; MAA $=$ metals by atomic absorption; MIC $=$ metals by inductively-coupled plasma/mass spectroscopy; OROTH $=$ other organics, PHYSC $=$ physical and field measurements; PPCB = pesticides/polychlorinated biphenyls; RADS $=$ radiochemical analysis; RADSD $=$ radiochemical analysis, dissolved; $S V O A=$ semivolatile organics; VOA $=$ volatile organics.

${ }^{\prime A}$ " $<$ " qualifier was added to the mean when $\geq 50 \%$ of the observations had " $<$ " qualifiers. 
Table A.10. Water quality parameters measured at Kentucky Pollutant Discharge Elimination System permitted outfall 013 in 1994

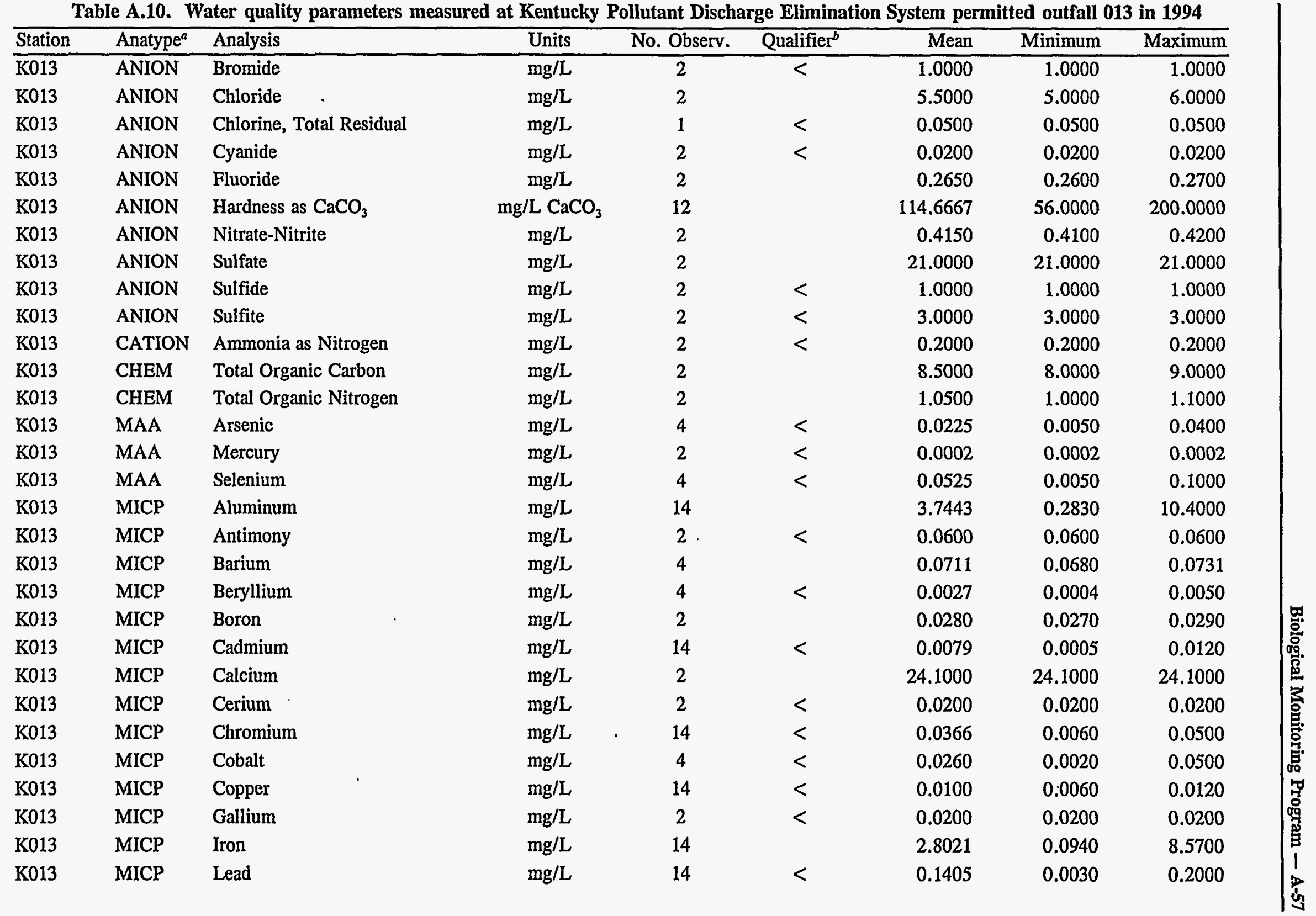


Table A.10 (continued)

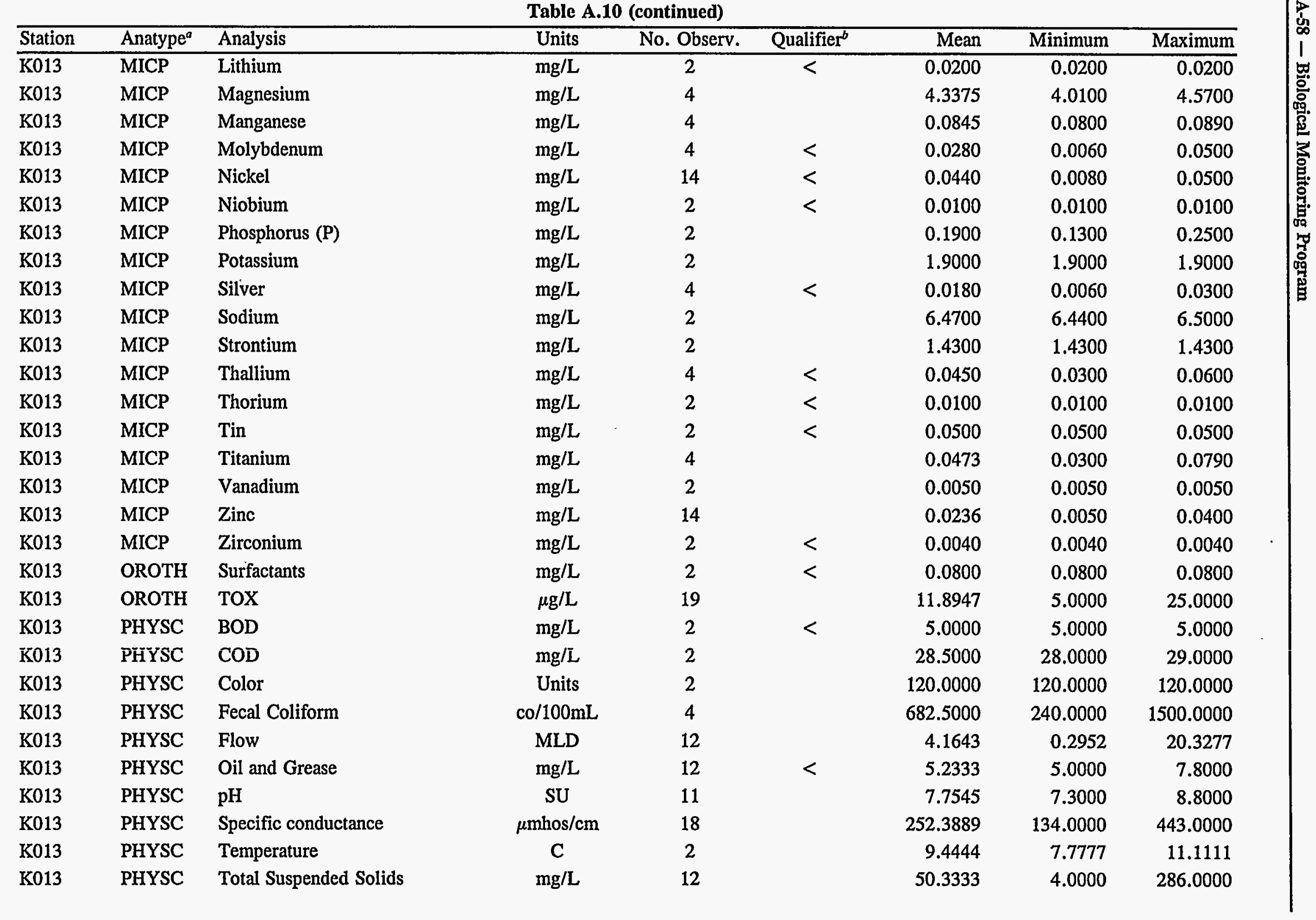


Table A.10 (continued)

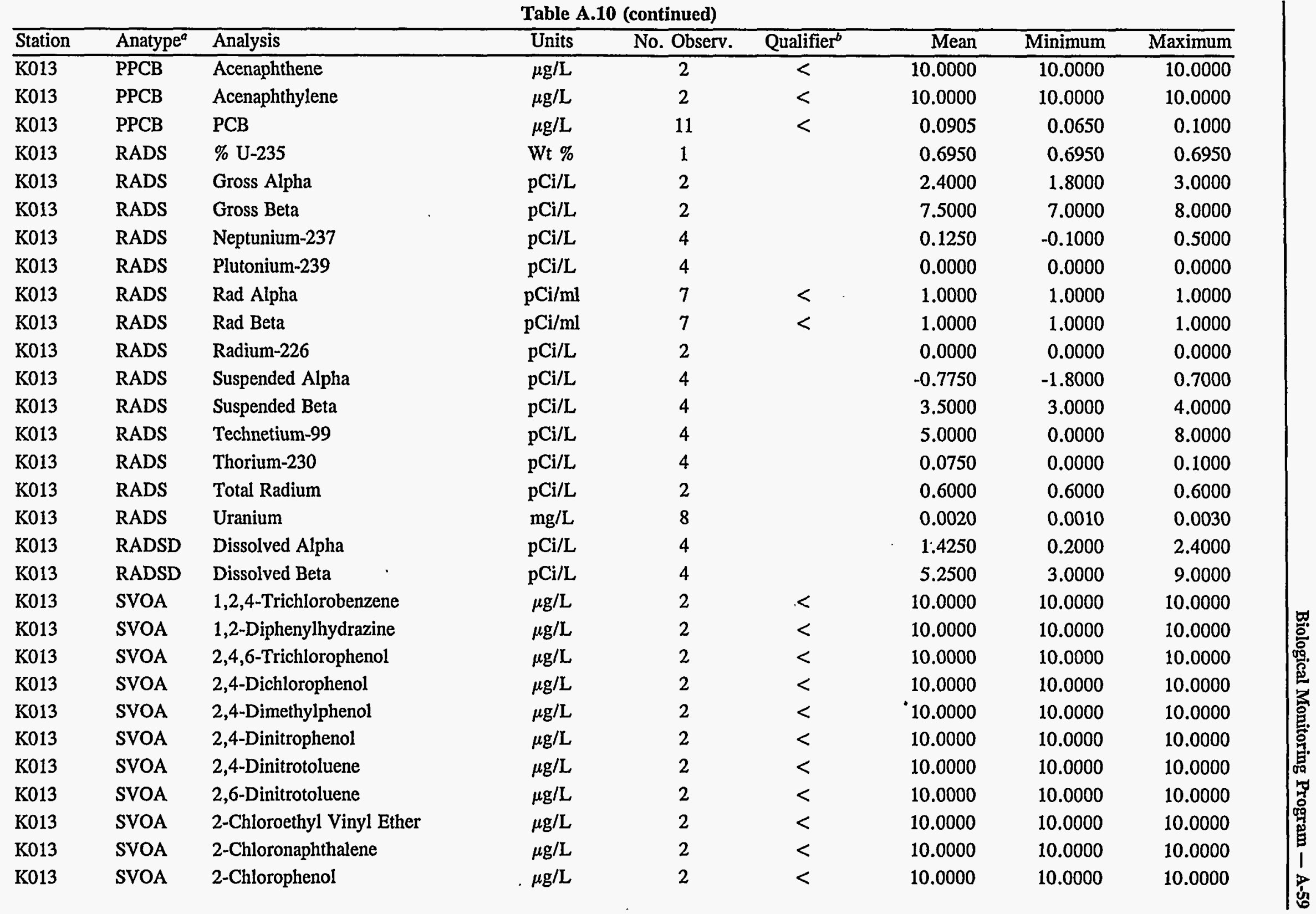


Table A.10 (continued)

\begin{tabular}{|c|c|c|c|c|c|c|c|c|}
\hline Station & Anatype $^{a}$ & Analysis & Units & No. Observ. & Qualifier $^{b}$ & Mean & Minimum & Maximum \\
\hline K013 & SVOA & 2-Nitrophenol & $\mu \mathrm{g} / \mathrm{L}$ & 2 & $<$ & 10.0000 & 10.0000 & 10.0000 \\
\hline K013 & SVOA & 3,3'-Dichlorobenzidine & $\mu \mathrm{g} / \mathrm{L}$ & 2 & $<$ & 10.0000 & 10.0000 & 10.0000 \\
\hline K013 & SVOA & 4,6-Dinitro-2-methylphenol & $\mu \mathrm{g} / \mathrm{L}$ & 2 & $<$ & 10.0000 & 10.0000 & 10.0000 \\
\hline K013 & SVOA & 4-Bromophenyl-phenylether & $\mu \mathrm{g} / \mathrm{L}$ & 2 & $<$ & 10.0000 & 10.0000 & 10.0000 \\
\hline K013 & SVOA & 4-Chloro-3-methylphenol & $\mu \mathrm{g} / \mathrm{L}$ & 2 & $<$ & 10.0000 & 10.0000 & 10.0000 \\
\hline K013 & SVOA & 4-Chlorophenyl-phenylether & $\mu \mathrm{g} / \mathrm{L}$ & 2 & $<$ & 10.0000 & 10.0000 & 10.0000 \\
\hline K013 & SVOA & 4-Nitrophenol & $\mu \mathrm{g} / \mathrm{L}$ & 2 & $<$ & 10.0000 & 10.0000 & 10.0000 \\
\hline K013 & SVOA & Anthracene & $\mu \mathrm{g} / \mathrm{L}$ & 2 & $<$ & 10.0000 & 10.0000 & 10.0000 \\
\hline K013 & SVOA & Benzo(a)anthracene & $\mu \mathrm{g} / \mathrm{L}$ & 2 & $<$ & 10.0000 & 10.0000 & 10.0000 \\
\hline K013 & SVOA & Benzo(a)pyrene & $\mu \mathrm{g} / \mathrm{L}$ & 2 & $<$ & 10.0000 & 10.0000 & 10.0000 \\
\hline K013 & SVOA & Benzo(b)fluoranthene & $\mu \mathrm{g} / \mathrm{L}$ & 2 & $<$ & 10.0000 & 10.0000 & 10.0000 \\
\hline K013 & SVOA & Benzo( $g, h, i)$ perylene & $\mu \mathrm{g} / \mathrm{L}$ & 2 & $<$ & 10.0000 & 10.0000 & 10.0000 \\
\hline K013 & SVOA & Benzo(k)fluoranthene & $\mu \mathrm{g} / \mathrm{L}$ & 2 & $<$ & 10.0000 & 10.0000 & 10.0000 \\
\hline K013 & SVOA & Benzyl Butyl Phthalate & $\mu \mathrm{g} / \mathrm{L}$ & 2 & $<$ & 10.0000 & 10.0000 & 10.0000 \\
\hline K013 & SVOA & bis(2-Chloroethoxy)methane & $\mu \mathrm{g} / \mathrm{L}$ & 2 & $<$ & 10.0000 & 10.0000 & 10.0000 \\
\hline K013 & SVOA & bis(2-Chloroethyl)ether & $\mu \mathrm{g} / \mathrm{L}$ & 2 & $<$ & 10.0000 & 10.0000 & 10.0000 \\
\hline K013 & SVOA & bis(2-Chloroisopropyl)ether & $\mu \mathrm{g} / \mathrm{L}$ & 2 & $<$ & 10.0000 & 10.0000 & 10.0000 \\
\hline K013 & SVOA & bis(2-Ethylhexyl)phthalate & $\mu \mathrm{g} / \mathrm{L}$ & 2 & . & 4.0000 & 2.0000 & 6.0000 \\
\hline K013 & SVOA & Chrysene & $\mu \mathrm{g} / \mathrm{L}$ & 2 & $<$ & 10.0000 & 10.0000 & 10.0000 \\
\hline K013 & SVOA & Di-n-butylphthalate & $\mu \mathrm{g} / \mathrm{L}$ & 2 & $<$ & 10.0000 & 10.0000 & 10.0000 \\
\hline K013 & SVOA & Di-n-octylphthalate & $\mu \mathrm{g} / \mathrm{L}$ & 2 & $<$ & 10.0000 & 10.0000 & 10.0000 \\
\hline K013 & SVOA & Dibenzo(a,h)anthracene & $\mu \mathrm{g} / \mathrm{L}$ & 2 & $<$ & 10.0000 & 10.0000 & 10.0000 \\
\hline K013 & SVOA & Diethylphthalate & $\mu \mathrm{g} / \mathrm{L}$ & 2 & $<$ & 10.0000 & 10.0000 & 10.0000 \\
\hline K013 & SVOA & Dimethylphthalate & $\mu \mathrm{g} / \mathrm{L}$ & 2 & $<$ & 10.0000 & 10.0000 & 10.0000 \\
\hline K013 & SVOA & Fluoranthene & $\mu \mathrm{g} / \mathrm{L}$ & 2 & $<$ & 10.0000 & 10.0000 & 10.0000 \\
\hline K013 & SVOA & Fluorene & $\mu \mathrm{g} / \mathrm{L}$ & 2 & $<$ & 10.0000 & 10.0000 & 10.0000 \\
\hline K013 & SVOA & Hexachlorobenzene & $\mu \mathrm{g} / \mathrm{L}$ & 2 & $<$ & 10.0000 & 10.0000 & 10.0000 \\
\hline K013 & SVOA & Hexachlorobutadiene & $\mu \mathrm{g} / \mathrm{L}$ & 2 & $<$ & 10.0000 & 10.0000 & 10.0000 \\
\hline K013 & SVOA & Hexachlorocyclopentadiene & $\mu \mathrm{g} / \mathrm{L}$ & 2 & $<$ & 10.0000 & 10.0000 & 10.0000 \\
\hline K013 & SVOA & Hexachloroethane & $\mu \mathrm{g} / \mathrm{L}$ & 2 & $<$ & 10.0000 & 10.0000 & 10.0000 \\
\hline
\end{tabular}


Table A.10 (continued)

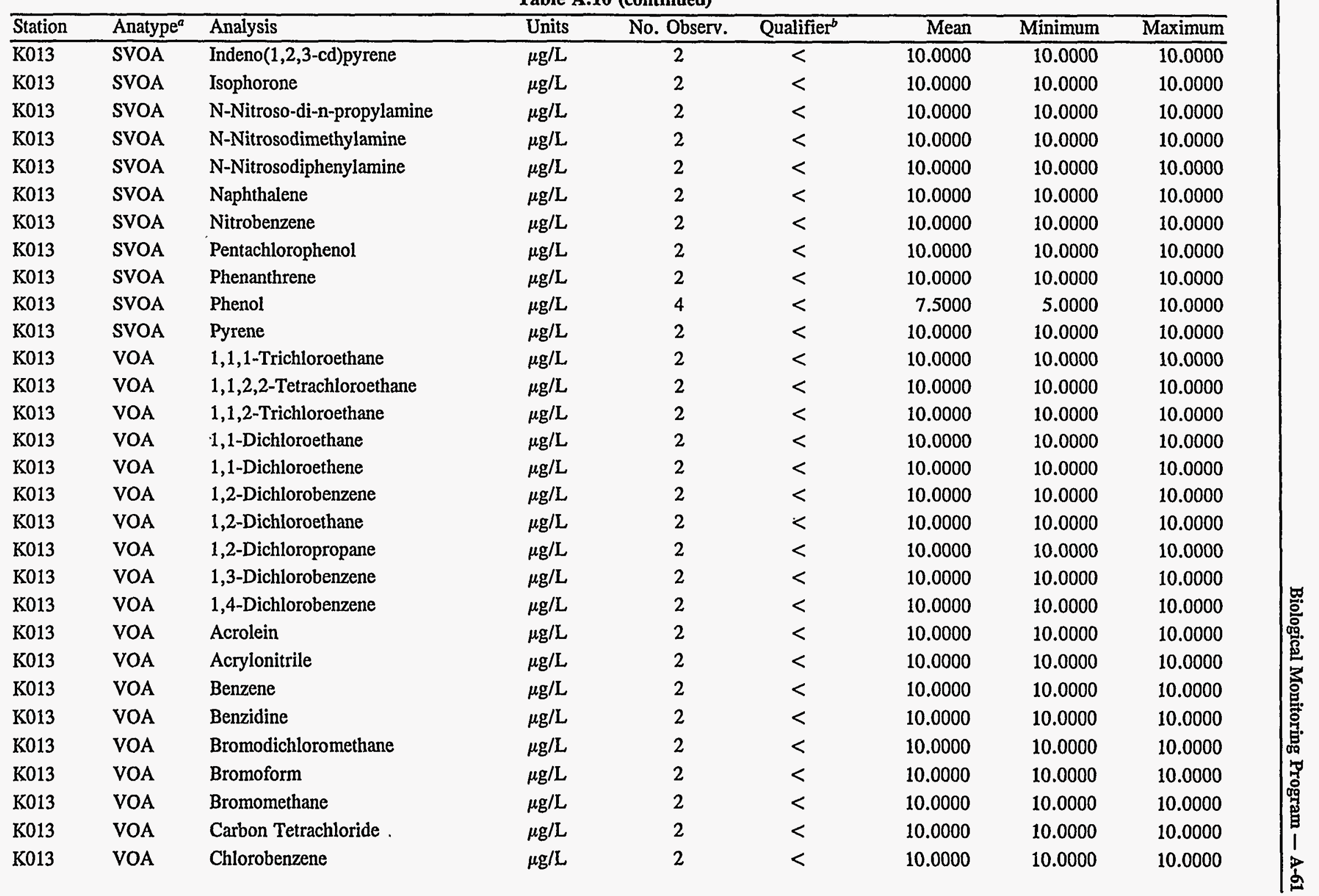




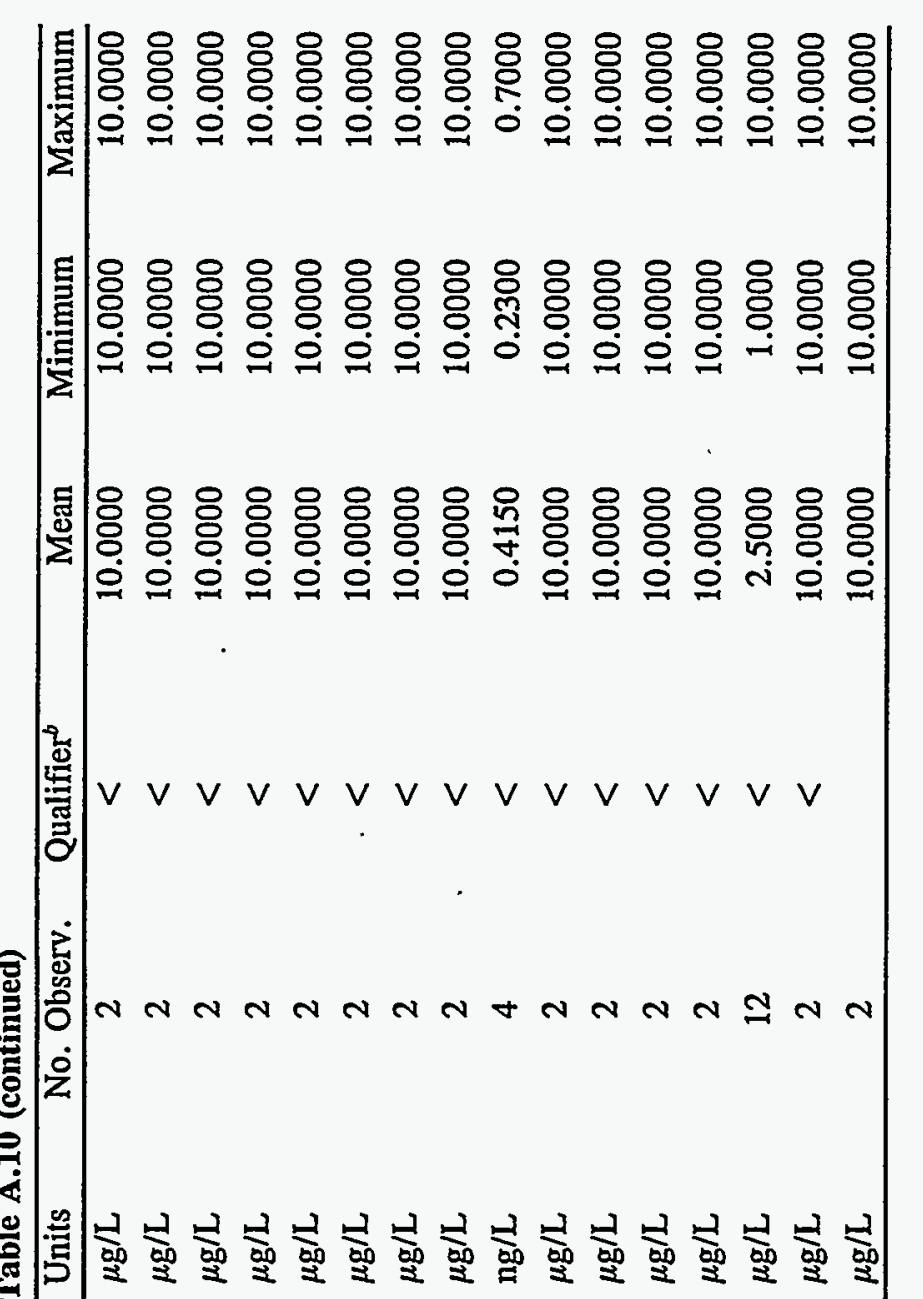

旁紧

II $\ddot{\ddot{g}}$

啳

范泀

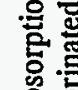

융

을

옹

交曾

帘

II II 总

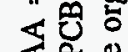

$\sum$ A

is 骂

氖

氮总灾

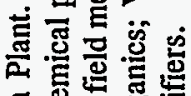

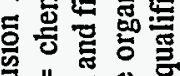

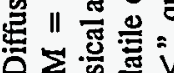

ดี 造

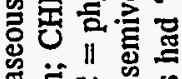

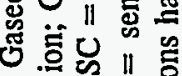

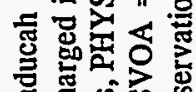

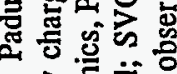

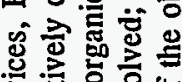

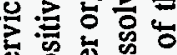

造总兽

들 II II

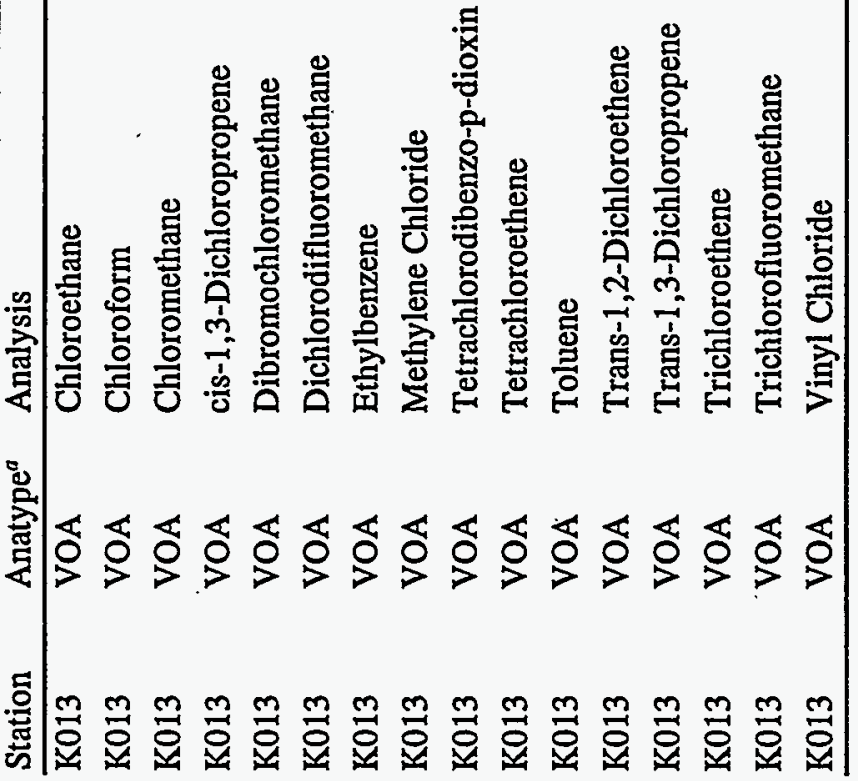

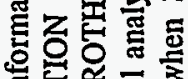

运药菏

ง芯㒸

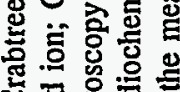

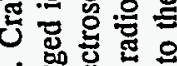

疒整总 11 䙳

성

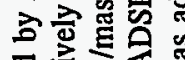

氙芯远

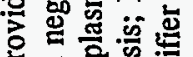

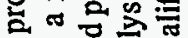

표 II 总预

คั 页总

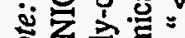

之完它

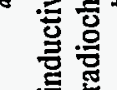

흐 II 
Table A.11. Water quality parameters measured at Kentucky Pollutant Discharge Elimination System permitted outfall 014 in 1994

\begin{tabular}{|c|c|c|c|c|c|c|c|c|}
\hline Station & Anatype $^{a}$ & Analysis & Units & No. Observ. & Qualifier $^{b}$ & Mean & Minimum & Maximum \\
\hline $\mathrm{K} 014$ & ANION & Chlorine, Total Residual & $\mathrm{mg} / \mathrm{L}$ & 19 & $<$ & 0.0500 & 0.0500 & 0.0500 \\
\hline K014 & ANION & Hardness as $\mathrm{CaCO}_{3}$ & $\mathrm{mg} / \mathrm{L} \mathrm{CaCO}{ }_{3}$ & 19 & & 72.4211 & 52.0000 & 130.0000 \\
\hline K014 & MICP & Aluminum & $\mathrm{mg} / \mathrm{L}$ & 10 & & 0.4809 & 0.1200 & 1.2900 \\
\hline K014 & MICP & Cadmium & $\mathrm{mg} / \mathrm{L}$ & 10 & $<$ & 0.0100 & 0.0100 & 0.0100 \\
\hline K014 & MICP & Chromium & $\mathrm{mg} / \mathrm{L}$ & 10 & $<$ & 0.0500 & 0.0500 & 0.0500 \\
\hline K014 & MICP & Copper & $\mathrm{mg} / \mathrm{L}$ & 10 & $<$ & 0.0108 & 0.0100 & 0.0180 \\
\hline K014 & MICP & Iron & $\mathrm{mg} / \mathrm{L}$ & 10 & . & 1.1171 & 0.1680 & 3.0200 \\
\hline K014 & MICP & Lead & $\mathrm{mg} / \mathrm{L}$ & 10 & $<$ & 0.2000 & 0.2000 & 0.2000 \\
\hline K014 & MICP & Nickel & $\mathrm{mg} / \mathrm{L}$ & 10 & $<$ & 0.0500 & 0.0500 & 0.0500 \\
\hline K014 & MICP & Phosphorus (P) & $\mathrm{mg} / \mathrm{L}$ & 10 & & 0.2300 & 0.1300 & 0.3500 \\
\hline K014 & MICP & Zinc & $\mathrm{mg} / \mathrm{L}$ & 10 & & 0.0109 & 0.0050 & 0.0300 \\
\hline K014 & PHYSC & Flow & MLD & 17 & & 0.7199 & 0.4088 & 0.9993 \\
\hline K014 & PHYSC & Oil and Grease & $\mathrm{mg} / \mathrm{L}$ & 19 & $<$ & 5.0000 & 5.0000 & 5.0000 \\
\hline K014 & PHYSC & $\mathrm{pH}$ & SU & 19 & & 8.0053 & 7.0000 & 9.2000 \\
\hline K014 & PHYSC & Total Suspended Solids & $\mathrm{mg} / \mathrm{L}$ & 19 & & 7.4211 & 4.0000 & 27.0000 \\
\hline K014 & PHYSC & Turbidity & NTU & 15 & & 3.6720 & 0.3800 & 7.1000 \\
\hline K014 & PPCB & PCB & $\mu \mathrm{g} / \mathrm{L}$ & 5 & $<$ & 0.1000 & 0.1000 & 0.1000 \\
\hline K014 & RADS & Suspended Alpha & $\mathrm{pCi} / \mathrm{L}$ & 1 & & 0.7000 & 0.7000 & 0.7000 \\
\hline K014 & RADS & Suspended Beta & $\mathrm{pCi} / \mathrm{L}$ & 1 & & 3.0000 & 3.0000 & 3.0000 \\
\hline K014 & RADS & Uranium & $\mathrm{mg} / \mathrm{L}$ & 1 & $<$ & 0.0010 & 0.0010 & 0.0010 \\
\hline K014 & RADSD & Dissolved Alpha & $\mathrm{pCi} / \mathrm{L}$ & 1 & & 1.1000 & 1.1000 & 1.1000 \\
\hline K014 & RADSD & Dissolved Beta & $\mathrm{pCi} / \mathrm{L}$ & 1 & & 3.0000 & 3.0000 & 3.0000 \\
\hline
\end{tabular}

Note: Data provided by L. S. Crabtree, Information Services, Paducah Gaseous Diffusion Plant.

${ }^{a} \mathrm{ANION}=$ a negatively charged ion; CATION $=$ a positively charged ion; CHEM $=$ chemical parameters; $\mathrm{MICP}=$ metals by inductively-coupled plasma/mass spectroscopy; PHYSC = physical and field measurements; PPCB = pesticides/polychlorinated biphenyls; RADS = radiochemical analysis; RADSD = radiochemical analysis, dissolved.

${ }^{b} \mathrm{~A}$ " $<"$ qualifier was added to the mean when $\geq 50 \%$ of the observations had " $<$ " qualifiers. 
Table A.12. Water quality parameters measured at Kentucky Pollutant Discharge Elimination System permitted outfall 015 in 1994

\begin{tabular}{|c|c|c|c|c|c|c|c|c|}
\hline Station & Anatype $^{a}$ & Analysis & Units & No. Observ. & Qualifier $^{b}$ & Mean & Minimum & Maximum \\
\hline K015 & ANION & Bromide & $\mathrm{mg} / \mathrm{L}$ & 1 & $<$ & 1.0000 & 1.0000 & 1.0000 \\
\hline K015 & ANION & Chloride & $\mathrm{mg} / \mathrm{L}$ & 1 & & 24.0000 & 24.0000 & 24.0000 \\
\hline K015 & ANION & Chlorine, Total Residual & $\mathrm{mg} / \mathrm{L}$ & 1 & $<$ & 0.0500 & 0.0500 & 0.0500 \\
\hline K015 & ANION & Cyanide & $\mathrm{mg} / \mathrm{L}$ & 1 & $<$ & 0.0200 & 0.0200 & 0.0200 \\
\hline K015 & ANION & Fluoride & $\mathrm{mg} / \mathrm{L}$ & 1 & & 0.7100 & 0.7100 & 0.7100 \\
\hline K015 & ANION & Hardness as $\mathrm{CaCO}_{3}$ & $\mathrm{mg} / \mathrm{L} \mathrm{CaCO}{ }_{3}$ & 11 & & 140.0000 & 62.0000 & 260.0000 \\
\hline K015 & ANION & Nitrate-Nitrite & $\mathrm{mg} / \mathrm{L}$ & 1 & & 0.0600 & 0.0600 & 0.0600 \\
\hline K015 & ANION & Sulfate & $\mathrm{mg} / \mathrm{L}$ & 1 & & 88.0000 & 88.0000 & 88.0000 \\
\hline K015 & ANION & Sulfide & $\mathrm{mg} / \mathrm{L}$ & 1 & $<$ & 1.0000 & 1.0000 & 1.0000 \\
\hline K015 & ANION & Sulfite & $\mathrm{mg} / \mathrm{L}$ & 1 & $<$ & 3.0000 & 3.0000 & 3.0000 \\
\hline K015 & CATION & Ammonia as Nitrogen & $\mathrm{mg} / \mathrm{L}$ & 1 & $<$ & 0.2000 & 0.2000 & 0.2000 \\
\hline K015 & CHEM & Total Organic Carbon & $\mathrm{mg} / \mathrm{L}$ & 1 & & 7.0000 & 7.0000 & 7.0000 \\
\hline K015 & CHEM & Total Organic Nitrogen & $\mathrm{mg} / \mathrm{L}$ & 1 & & 0.7000 & 0.7000 & 0.7000 \\
\hline K015 & MAA & Arsenic & $\mathrm{mg} / \mathrm{L}$ & 2 & $<$ & 0.0225 & 0.0050 & 0.0400 \\
\hline K015 & MAA & Mercury & $\mathrm{mg} / \mathrm{L}$ & 1 & $<$ & 0.0002 & 0.0002 & 0.0002 \\
\hline K015 & MAA & Selenium & $\mathrm{mg} / \mathrm{L}$ & 2 & $<$ & 0.0525 & 0.0050 & 0.1000 \\
\hline K015 & MICP & Aluminum & $\mathrm{mg} / \mathrm{L}$ & 12 & & 2.8890 & 0.6100 & 15.0000 \\
\hline K015 & MICP & Antimony & $\mathrm{mg} / \mathrm{L}$ & 1 & $<$ & 0.0600 & 0.0600 & 0.0600 \\
\hline K015 & MICP & Barium & $\mathrm{mg} / \mathrm{L}$ & 2 & & 0.0551 & 0.0540 & 0.0562 \\
\hline K015 & MICP & Beryllium & $\mathrm{mg} / \mathrm{L}$ & 2 & $<$ & 0.0027 & 0.0004 & 0.0050 \\
\hline K015 & MICP & Boron & $\mathrm{mg} / \mathrm{L}$ & 1 & & 0.0370 & 0.0370 & 0.0370 \\
\hline K015 & MICP & Cadmium & $\mathrm{mg} / \mathrm{L}$ & 12 & $<$ & 0.0081 & 0.0005 & 0.0120 \\
\hline K015 & MICP & Calcium & $\mathrm{mg} / \mathrm{L}$ & 1 & & 72.2000 & 72.2000 & 72.2000 \\
\hline K015 & MICP & Cerium & $\mathrm{mg} / \mathrm{L}$ & 1 & $<$ & 0.0200 & 0.0200 & 0.0200 \\
\hline K015 & MICP & Chromium & $\mathrm{mg} / \mathrm{L}$ & 12 & $<$ & 0.0380 & 0.0060 & 0.0500 \\
\hline K015 & MICP & Cobalt & $\mathrm{mg} / \mathrm{L}$ & 2 & $<$ & 0.0260 & 0.0020 & 0.0500 \\
\hline K015 & MICP & Copper & $\mathrm{mg} / \mathrm{L}$ & 12 & $<$ & 0.0110 & 0.0060 & 0.0180 \\
\hline K015 & MICP & Gallium & $\mathrm{mg} / \mathrm{L}$ & 1 & $<$ & 0.0200 & 0.0200 & 0.0200 \\
\hline K015 & MICP & Iron & $\mathrm{mg} / \mathrm{L}$ & 12 & & 2.7458 & 0.2950 & 14.0000 \\
\hline
\end{tabular}


Table A.12 (continued)

\begin{tabular}{|c|c|c|c|c|c|c|c|c|}
\hline Station & Anatype $^{a}$ & Analysis & Units & No. Observ. & Qualifier & Mean & Minimum & Maximum \\
\hline K015 & $\mathrm{MICP}$ & Lead & $\mathrm{mg} / \mathrm{L}$ & 12 & $<$ & 0.1459 & 0.0030 & 0.2000 \\
\hline K015 & MICP & Lithium & $\mathrm{mg} / \mathrm{L}$ & 1 & $<$ & 0.0200 & 0.0200 & 0.0200 \\
\hline K015 & MICP & Magnesium & $\mathrm{mg} / \mathrm{L}$ & 2 & & 10.5500 & 10.1000 & 11.0000 \\
\hline K015 & MICP & Manganese & $\mathrm{mg} / \mathrm{L}$ & 2 & & 0.0150 & 0.0150 & 0.0150 \\
\hline K015 & MICP & Molybdenum & $\mathrm{mg} / \mathrm{L}$ & 2 & $<$ & 0.0280 & 0.0060 & 0.0500 \\
\hline K015 & MICP & Nickel & $\mathrm{mg} / \mathrm{L}$ & 12 & $<$ & 0.0465 & 0.0080 & 0.0500 \\
\hline K015 & MICP & Niobium & $\mathrm{mg} / \mathrm{L}$ & 1 & $<$ & 0.0100 & 0.0100 & 0.0100 \\
\hline K015 & MICP & Phosphorus (P) & $\mathrm{mg} / \mathrm{L}$ & 1 & & 0.1300 & 0.1300 & 0.1300 \\
\hline K015 & MICP & Potassium & $\mathrm{mg} / \mathrm{L}$ & 1 & & 1.3000 & 1.3000 & 1.3000 \\
\hline K015 & MICP & Silver & $\mathrm{mg} / \mathrm{L}$ & 2 & $<$ & 0.0180 & 0.0060 & 0.0300 \\
\hline K015 & MICP & Sodium & $\mathrm{mg} / \mathrm{L}$ & 1 & & 22.6000 & 22.6000 & 22.6000 \\
\hline K015 & MICP & Strontium & $\mathrm{mg} / \mathrm{L}$ & 1 & & 0.6320 & 0.6320 & 0.6320 \\
\hline K015 & MICP & Thallium & $\mathrm{mg} / \mathrm{L}$ & 2 & $<$ & 0.0450 & 0.0300 & 0.0600 \\
\hline K015 & MICP & Thorium & $\mathrm{mg} / \mathrm{L}$ & 1 & $<$ & 0.0100 & 0.0100 & 0.0100 \\
\hline K015 & MICP & Tin & $\mathrm{mg} / \mathrm{L}$ & 1 & $<$ & 0.0500 & 0.0500 & 0.0500 \\
\hline K015 & MICP & Titanium & $\mathrm{mg} / \mathrm{L}$ & 2 & $<$ & 0.0350 & 0.0200 & 0.0500 \\
\hline K015 & MICP & Vanadium & $\mathrm{mg} / \mathrm{L}$ & 1 & $<$ & 0.0040 & 0.0040 & 0.0040 \\
\hline K015 & MICP & Zinc & $\mathrm{mg} / \mathrm{L}$ & 12 & & 0.0230 & 0.0100 & 0.0400 \\
\hline K015 & MICP & Zirconium & $\mathrm{mg} / \mathrm{L}$ & 1 & $<$ & 0.0040 & 0.0040 & 0.0040 \\
\hline K015 & OROTH & Surfactants & $\mathrm{mg} / \mathrm{L}$ & 1 & $<$ & 0.0800 & 0.0800 & 0.0800 \\
\hline K015 & PHYSC & BOD & $\mathrm{mg} / \mathrm{L}$ & 1 & $<$ & 5.0000 & 5.0000 & 5.0000 \\
\hline K015 & PHYSC & COD & $\mathrm{mg} / \mathrm{L}$ & 1 & & 20.0000 & 20.0000 & 20.0000 \\
\hline K015 & PHYSC & Color & Units & 1 & & 55.0000 & 55.0000 & 55.0000 \\
\hline K015 & PHYSC & Fecal Coliform & $\mathrm{co} / 100 \mathrm{~mL}$ & 1 & & 40.0000 & 40.0000 & 40.0000 \\
\hline K015 & PHYSC & Flow & MLD & 11 & & 2.0831 & 0.3255 & 9.4635 \\
\hline K015 & PHYSC & Oil and Grease & $\mathrm{mg} / \mathrm{L}$ & 11 & $<$ & 5.0000 & 5.0000 & 5.0000 \\
\hline K015 & PHYSC & $\mathrm{pH}$ & SU & 11 & & 7.7455 & 6.9000 & 8.2000 \\
\hline K015 & PHYSC & Temperature & $\mathrm{C}$ & 2 & & 10.8333 & 7.2222 & 14.4444 \\
\hline K015 & PHYSC & Total Suspended Solids & $\mathrm{mg} / \mathrm{L}$ & 11 & & 44.0909 & 6.0000 & 161.0000 \\
\hline K015 & РPCB & Acenaphthene & $\mu \mathrm{g} / \mathrm{L}$ & 1 & $<$ & 10.0000 & 10.0000 & 10.0000 \\
\hline
\end{tabular}


Table A.12 (continued)

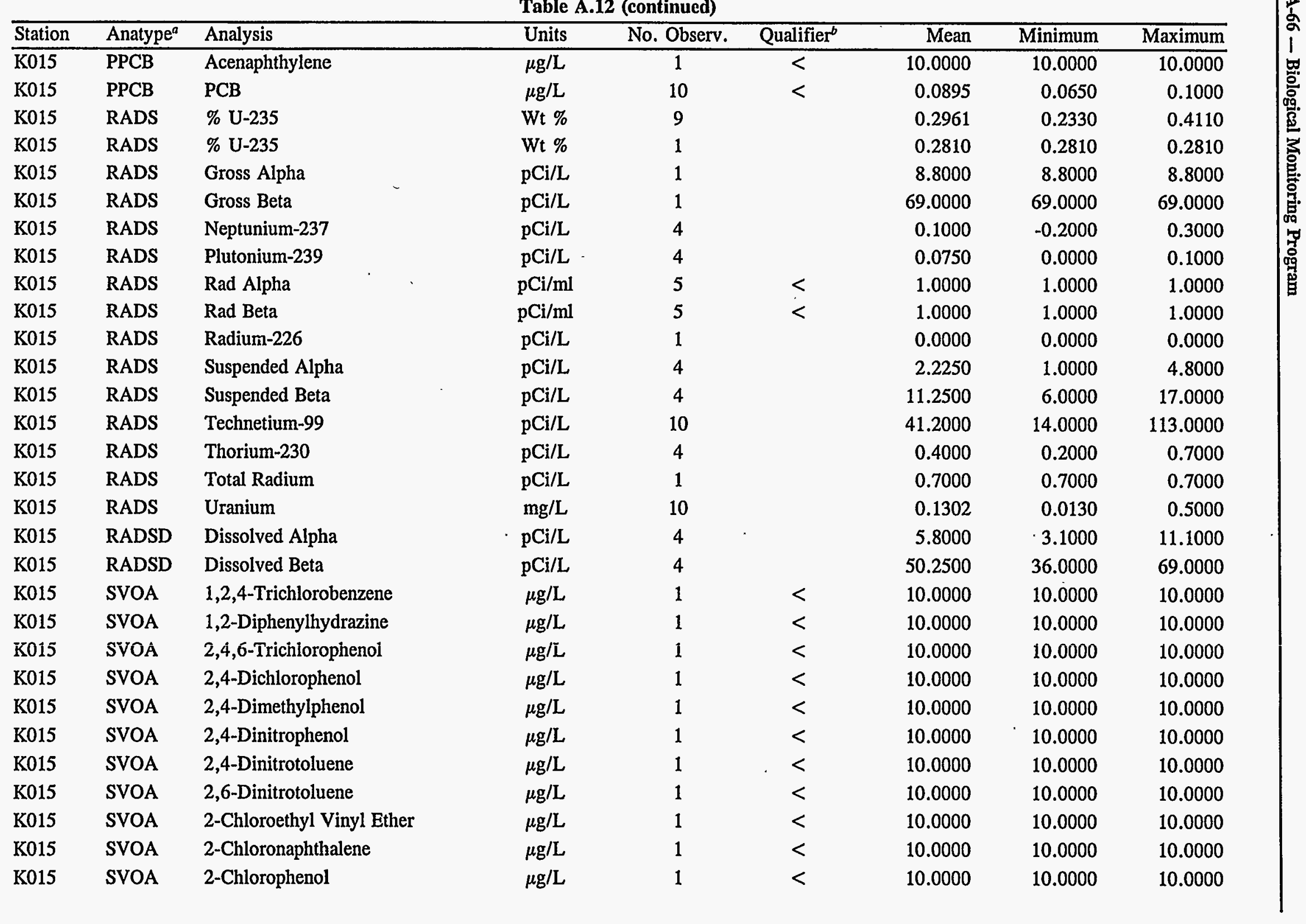


Table A.12 (continued)

\begin{tabular}{|c|c|c|c|c|c|c|c|c|}
\hline Station & Anatype $^{a}$ & Analysis & Units & No. Observ. & Qualifier $^{b}$ & Mean & Minimum & Maximum \\
\hline$\overline{\mathrm{K} 015}$ & SVOA & 2-Nitrophenol & $\mu \mathrm{g} / \mathrm{L}$ & 1 & $<$ & 10.0000 & 10.0000 & 10.0000 \\
\hline K015 & SVOA & 3,3'-Dichlorobenzidine & $\mu \mathrm{g} / \mathrm{L}$ & 1 & $<$ & 10.0000 & 10.0000 & 10.0000 \\
\hline K015 & SVOA & 4,6-Dinitro-2-methylphenol & $\mu \mathrm{g} / \mathrm{L}$ & 1 & $<$ & 10.0000 & 10.0000 & 10.0000 \\
\hline K015 & SVOA & 4-Chloro-3-methylphenol & $\mu \mathrm{g} / \mathrm{L}$ & 1 & $<$ & 10.0000 & 10.0000 & 10.0000 \\
\hline K015 & SVOA & 4-Chlorophenyl-phenylether & $\mu \mathrm{g} / \mathrm{L}$ & 1 & $<$ & 10.0000 & 10.0000 & 10.0000 \\
\hline K015 & SVOA & 4-Nitrophenol & $\mu \mathrm{g} / \mathrm{L}$ & 1 & $<$ & 10.0000 & 10.0000 & 10.0000 \\
\hline K015 & SVOA & Benzo(a)anthracene & $\mu \mathrm{g} / \mathrm{L}$ & 1 & $<$ & 10.0000 & 10.0000 & 10.0000 \\
\hline K015 & SVOA & Benzo(a)pyrene & $\mu \mathrm{g} / \mathrm{L}$ & 1 & $<$ & 10.0000 & 10.0000 & 10.0000 \\
\hline K015 & SVOA & Benzo(b)fluoranthene & $\mu \mathrm{g} / \mathrm{L}$ & 1 & $<$ & 10.0000 & 10.0000 & 10.0000 \\
\hline K015 & SVOA & Benzo(g,h,i)perylene & $\mu \mathrm{g} / \mathrm{L}$ & 1 & $<$ & 10.0000 & 10.0000 & 10.0000 \\
\hline K015 & SVOA & Benzo(k)fluoranthene & $\mu \mathrm{g} / \mathrm{L}$ & 1 & $<$ & 10.0000 & 10.0000 & 10.0000 \\
\hline K015 & SVOA & Benzyl Butyl Phthalate & $\mu \mathrm{g} / \mathrm{L}$ & 1 & $<$ & 10.0000 & 10.0000 & 10.0000 \\
\hline K015 & SVOA & Chrysene & $\mu \mathrm{g} / \mathrm{L}$ & 1 & $<$ & 10.0000 & 10.0000 & 10.0000 \\
\hline K015 & SVOA & Di-n-butylphthalate & $\mu \mathrm{g} / \mathrm{L}$ & 1 & $<$ & 10.0000 & 10.0000 & 10.0000 \\
\hline K015 & SVOA & Di-n-octylphthalate & $\mu \mathrm{g} / \mathrm{L}$ & 1 & $<$ & 10.0000 & 10.0000 & 10.0000 \\
\hline K015 & SVOA & Dibenzo(a,h)anthracene & $\mu \mathrm{g} / \mathrm{L}$ & 1 & $<$ & 10.0000 & 10.0000 & 10.0000 \\
\hline K015 & SVOA & Diethylphthalate & $\mu \mathrm{g} / \mathrm{L}$ & 1 & $<$ & 10.0000 & 10.0000 & 10.0000 \\
\hline K015 & SVOA & Dimethylphthalate & $\mu \mathrm{g} / \mathrm{L}$ & 1 & $<$ & 10.0000 & 10.0000 & 10.0000 \\
\hline K015 & SVOA & Fluoranthene & $\mu \mathrm{g} / \mathrm{L}$ & 1 & $<$ & 10.0000 & 10.0000 & 10.0000 \\
\hline K015 & SVOA & Fluorene & $\mu \mathrm{g} / \mathrm{L}$ & 1 & $<$ & 10.0000 & 10.0000 & 10.0000 \\
\hline K015 & SVOA & Hexachlorobenzene & $\mu \mathrm{g} / \mathrm{L}$ & 1 & $<$ & 10.0000 & 10.0000 & 10.0000 \\
\hline K015 & SVOA & Hexachlorobutadiene & $\mu \mathrm{g} / \mathrm{L}$ & 1 & $<$ & 10.0000 & 10.0000 & 10.0000 \\
\hline K015 & SVOA & Hexachlorocyclopentadiene & $\mu \mathrm{g} / \mathrm{L}$ & 1 & $<$ & 10.0000 & 10.0000 & 10.0000 \\
\hline
\end{tabular}


Table A.12 (continued)

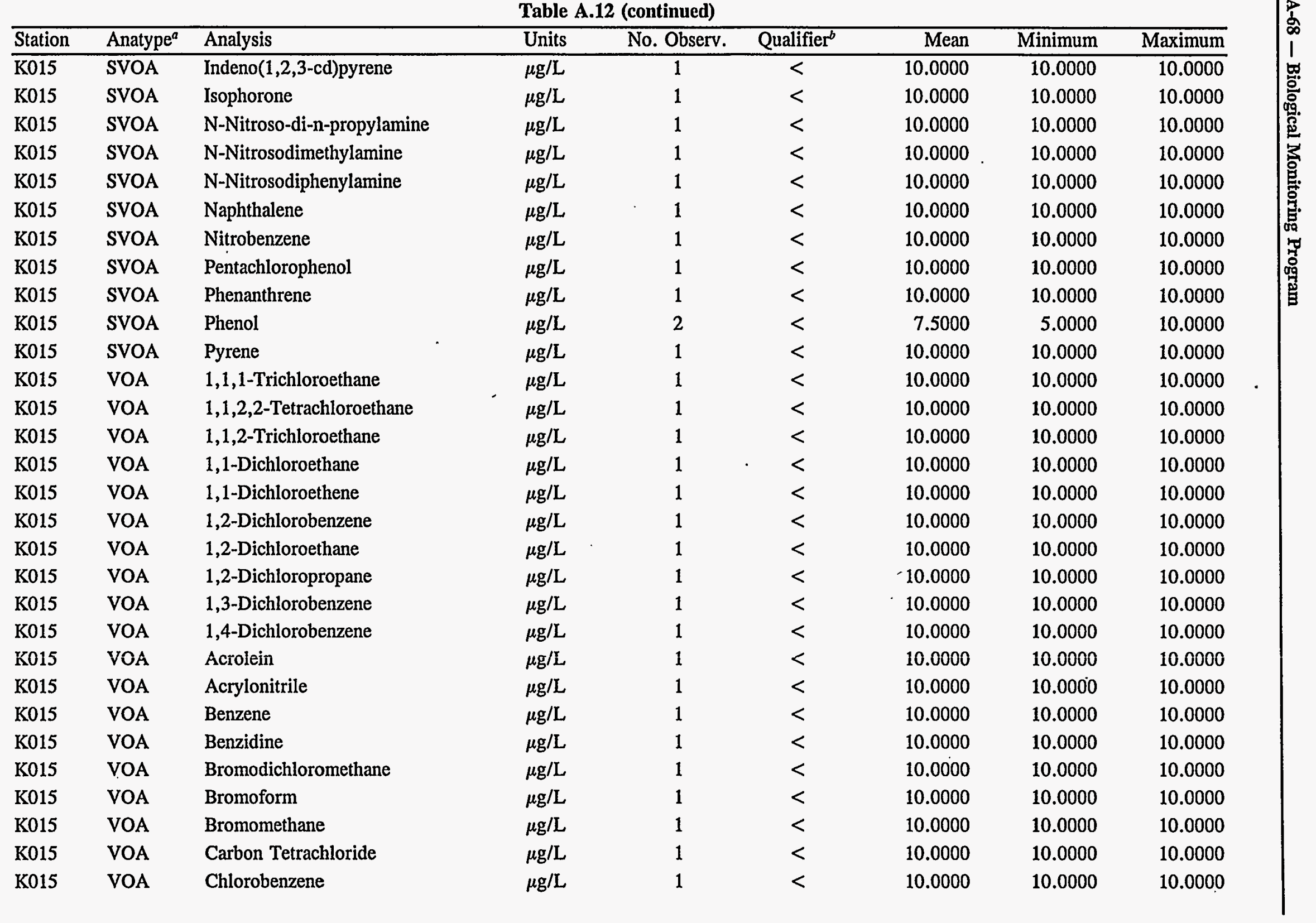


Table A.12 (continued)

\begin{tabular}{|c|c|c|c|c|c|c|c|c|}
\hline Station & Anatype $^{a}$ & Analysis & Units & No. Observ. & Qualifier $^{b}$ & Mean & Minimum & Maximum \\
\hline$\overline{\mathrm{K} 015}$ & VOA & Chloroethane & $\mu \mathrm{g} / \mathrm{L}$ & 1 & $<$ & 10.0000 & 10.0000 & 10.0000 \\
\hline K015 & VOA & Chloroform & $\mu \mathrm{g} / \mathrm{L}$ & 1 & $<$ & 10.0000 & 10.0000 & 10.0000 \\
\hline K015 & VOA & Chloromethane & $\mu \mathrm{g} / \mathrm{L}$ & 1 & $<$ & 10.0000 & 10.0000 & 10.0000 \\
\hline K015 & VOA & cis-1,3-Dichloropropene & $\mu \mathrm{g} / \mathrm{L}$ & 1 & $<$ & 10.0000 & 10.0000 & 10.0000 \\
\hline K015 & VOA & Dibromochloromethane & $\mu \mathrm{g} / \mathrm{L}$ & 1 & $<$ & 10.0000 & 10.0000 & 10.0000 \\
\hline K015 & VOA & Dichlorodifluoromethane & $\mu \mathrm{g} / \mathrm{L}$ & 1 & $<$ & 10.0000 & 10.0000 & 10.0000 \\
\hline K015 & VOA & Ethylbenzene & $\mu \mathrm{g} / \mathrm{L}$ & 1 & $<$ & 10.0000 & 10.0000 & 10.0000 \\
\hline K015 & VOA & Methylene Chloride & $\mu \mathrm{g} / \mathrm{L}$ & 1 & $<$ & 10.0000 & 10.0000 & 10.0000 \\
\hline K015 & VOA & Tetrachlorodibenzo-p-dioxin & $\mathrm{ng} / \mathrm{L}$ & 1 & $<$ & 0.8000 & 0.8000 & 0.8000 \\
\hline K015 & VOA & Tetrachloroethene & $\mu \mathrm{g} / \mathrm{L}$ & 1 & $<$ & 10.0000 & 10.0000 & 10.0000 \\
\hline K015 & VOA & Toluene & $\mu \mathrm{g} / \mathrm{L}$ & 1 & $<$ & 10.0000 & 10.0000 & 10.0000 \\
\hline K015 & VOA & Trans-1,2-Dichloroethene & $\mu \mathrm{g} / \mathrm{L}$ & 1 & $<$ & 10.0000 & 10.0000 & 10.0000 \\
\hline K015 & VOA & Trans-1,3-Dichloropropene & $\mu \mathrm{g} / \mathrm{L}$ & 1 & $<$ & 10.0000 & 10.0000 & 10.0000 \\
\hline K015 & VOA & Trichloroethene & $\mu \mathrm{g} / \mathrm{L}$ & 11 & $<$ & 1.8182 & 1.0000 & 10.0000 \\
\hline K015 & VOA & Trichlorofluoromethane & $\mu \mathrm{g} / \mathrm{L}$ & 1 & $<$ & 10.0000 & 10.0000 & 10.0000 \\
\hline K015 & VOA & Vinyl Chloride & $\mu \mathrm{g} / \mathrm{L}$ & 1 & $<$ & 10.0000 & 10.0000 & 10.0000 \\
\hline
\end{tabular}

Note: Data provided by L. S. Crabtree, Information Services, Paducah Gaseous Diffusion Plant.

${ }^{a} \mathrm{ANION}=$ a negatively charged ion; CATION $=$ a positively charged ion; $\mathrm{CHEM}=$ chemical parameters; MAA $=$ metals by atomic absorption; MIC $=$ metals by inductively-coupled plasma/mass spectroscopy; OROTH = other organics, PHYSC $=$ physical and field measurements; PPCB = pesticides/polychlorinated biphenyls; RADS $=$ radiochemical analysis; RADSD $=$ radiochemical analysis, dissolved; $S V O A=$ semivolatile organics; VOA $=$ volatile organics.

${ }^{\circ} \mathrm{A}$ " $<$ " qualifier was added to the mean when $\geq 50 \%$ of the observations had " $<$ " qualifiers. 
Table A.13. Water quality parameters measured at Kentucky Pollutant Discharge Elimination System permitted outfall 016 in 1994

\begin{tabular}{|c|c|c|c|c|c|c|c|c|}
\hline Station & Anatype $^{a}$ & Analysis & Units & No. Observ. & Qualifier $^{b}$ & Mean & Minimum & Maximum \\
\hline$\overline{\mathrm{K} 016}$ & ANION & Bromide & $\mathrm{mg} / \mathrm{L}$ & 1 & $<$ & 1.0000 & 1.0000 & 1.0000 \\
\hline K016 & ANION & Chloride & $\mathrm{mg} / \mathrm{L}$ & 1 & & 31.0000 & 31.0000 & 31.0000 \\
\hline K016 & ANION & Chlorine, Total Residual & $\mathrm{mg} / \mathrm{L}$ & 1 & $<$ & 0.0500 & 0.0500 & 0.0500 \\
\hline K016 & ANION & Cyanide & $\mathrm{mg} / \mathrm{L}$ & 1 & $<$ & 0.0200 & 0.0200 & 0.0200 \\
\hline K016 & ANION & Fluoride & $\mathrm{mg} / \mathrm{L}$ & 1 & & 0.3800 & 0.3800 & 0.3800 \\
\hline K016 & ANION & Hardness as $\mathrm{CaCO}_{3}$ & $\mathrm{mg} / \mathrm{L} \mathrm{CaCO}_{3}$ & 11 & & 182.0000 & 78.0000 & 306.0000 \\
\hline K016 & ANION & Nitrate-Nitrite & $\mathrm{mg} / \mathrm{L}$ & 1 & & 0.4900 & 0.4900 & 0.4900 \\
\hline K016 & ANION & Sulfate & $\mathrm{mg} / \mathrm{L}$ & 1 & & 45.0000 & 45.0000 & 45.0000 \\
\hline K016 & ANION & Sulfide & $\mathrm{mg} / \mathrm{L}$ & 1 & $<$ & 1.0000 & 1.0000 & 1.0000 \\
\hline K016 & ANION & Sulfite & $\mathrm{mg} / \mathrm{L}$ & 1 & $<$ & 3.0000 & 3.0000 & 3.0000 \\
\hline K016 & CATION & Ammonia as Nitrogen & $\mathrm{mg} / \mathrm{L}$ & 1 & $<$ & 0.2000 & 0.2000 & 0.2000 \\
\hline K016 & CHEM & Total Organic Carbon & $\mathrm{mg} / \mathrm{L}$ & 1 & & 6.0000 & 6.0000 & 6.0000 \\
\hline K016 & CHEM & Total Organic Nitrogen & $\mathrm{mg} / \mathrm{L}$ & 1 & & 0.9100 & 0.9100 & 0.9100 \\
\hline K016 & MAA & Arsenic & $\mathrm{mg} / \mathrm{L}$ & 2 & $<$ & 0.0225 & 0.0050 & 0.0400 \\
\hline K016 & MAA & Mercury & $\mathrm{mg} / \mathrm{L}$ & 1 & $<$ & 0.0002 & 0.0002 & 0.0002 \\
\hline K016 & MAA & Selenium & $\mathrm{mg} / \mathrm{L}$ & 2 & $<$ & 0.0525 & 0.0050 & 0.1000 \\
\hline K016 & MICP & Aluminum & $\mathrm{mg} / \mathrm{L}$ & 12 & & 1.9698 & 0.4300 & 5.2100 \\
\hline K016 & MICP & Antimony & $\mathrm{mg} / \mathrm{L}$ & 1 & $<$ & 0.0600 & 0.0600 & 0.0600 \\
\hline K016 & MICP & Barium & $\mathrm{mg} / \mathrm{L}$ & 2 & & 0.0647 & 0.0630 & 0.0663 \\
\hline K016 & MICP & Beryllium & $\mathrm{mg} / \mathrm{L}$ & 2 & $<$ & 0.0027 & 0.0004 & 0.0050 \\
\hline K016 & MICP & Boron & $\mathrm{mg} / \mathrm{L}$ & 1 & & 0.0190 & 0.0190 & 0.0190 \\
\hline K016 & MICP & Cadmium & $\mathrm{mg} / \mathrm{L}$ & 12 & $<$ & 0.0071 & 0.0005 & 0.0100 \\
\hline K016 & MICP & Calcium & $\mathrm{mg} / \mathrm{L}$ & 1 & & 51.7000 & 51.7000 & 51.7000 \\
\hline K016 & MICP & Cerium & $\mathrm{mg} / \mathrm{L}$ & 1 & $<$ & 0.0200 & 0.0200 & 0.0200 \\
\hline K016 & MICP & Chromium & $\mathrm{mg} / \mathrm{L}$ & 12 & $<$ & 0.0363 & 0.0060 & 0.0500 \\
\hline K016 & MICP & Cobalt & $\mathrm{mg} / \mathrm{L}$ & 2 & $<$ & 0.0260 & 0.0020 & 0.0500 \\
\hline K016 & MICP & Copper & $\mathrm{mg} / \mathrm{L}$ & 12 & $<$ & 0.0108 & 0.0060 & 0.0160 \\
\hline K016 & MICP & Gallium & $\mathrm{mg} / \mathrm{L}$ & 1 & $<$ & 0.0200 & 0.0200 & 0.0200 \\
\hline K016 & MICP & Iron & $\mathrm{mg} / \mathrm{L}$ & 12 & & 1.4119 & 0.2600 & 3.5500 \\
\hline
\end{tabular}


Table A.13 (continued)

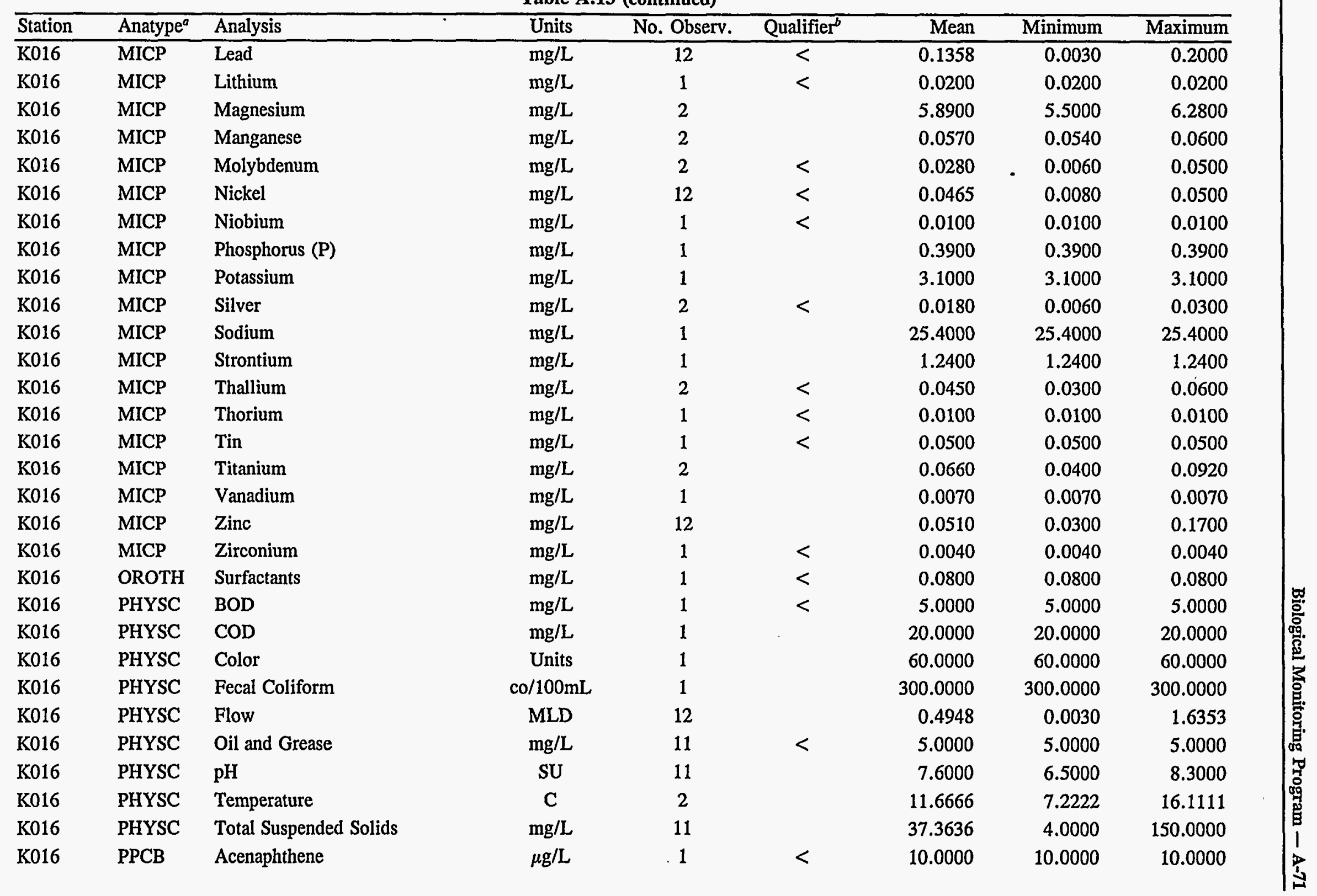


Table A.13 (continued)

\begin{tabular}{|c|c|c|c|c|c|c|c|c|}
\hline Station & Anatype $^{a}$ & Analysis & Units & No. Observ. & Qualifier $^{b}$ & Mean & Minimum & Maximum \\
\hline K016 & PPCB & Acenaphthylene & $\mu \mathrm{g} / \mathrm{L}$ & 1 & $<$ & 10.0000 & 10.0000 & 10.0000 \\
\hline K016 & РPCB & PCB & $\mu \mathrm{g} / \mathrm{L}$ & 8 & $<$ & 0.0913 & 0.0650 & 0.1000 \\
\hline K016 & RADS & $\%$ U-235 & Wt \% & 1 & & 0.4260 & 0.4260 & 0.4260 \\
\hline K016 & RADS & Gross Alpha & $\mathrm{pCi} / \mathrm{L}$ & 1 & & 0.2000 & 0.2000 & 0.2000 \\
\hline K016 & RADS & Gross Beta & $\mathrm{pCi} / \mathrm{L}$ & 1 & & 16.0000 & 16.0000 & 16.0000 \\
\hline K016 & RADS & Neptunium-237 & $\mathrm{pCi} / \mathrm{L}$ & 4 & & 0.0750 & -0.1000 & 0.2000 \\
\hline K016 & RADS & Plutonium-239 & $\mathrm{pCi} / \mathrm{L}$ & 4 & & 0.0000 & 0.0000 & 0.0000 \\
\hline K016 & RADS & Rad Alpha & $\mathrm{pCi} / \mathrm{ml}$ & 6 & $<$ & 1.0000 & 1.0000 & 1.0000 \\
\hline K016 & RADS & Rad Beta & $\mathrm{pCi} / \mathrm{ml}$ & 6 & $<$ & 1.0000 & 1.0000 & 1.0000 \\
\hline K016 & RADS & Radium-226 & $\mathrm{pCi} / \mathrm{L}$ & 1 & & 0.0000 & 0.0000 & 0.0000 \\
\hline K016 & RADS & Suspended Alpha & $\mathrm{pCi} / \mathrm{L}$ & 4 & & 1.3750 & -0.5000 & 3.1000 \\
\hline K016 & RADS & Suspended Beta & $\mathrm{pCi} / \mathrm{L}$ & 4 & & 3.7500 & -3.0000 & 9.0000 \\
\hline K016 & RADS & Technetium-99 & $\mathrm{pCi} / \mathrm{L}$ & 4 & . & 8.2500 & 0.0000 & 19.0000 \\
\hline K016 & RADS & Thorium-230 & $\mathrm{pCi} / \mathrm{L}$ & 4 & & 0.2500 & 0.1000 & 0.5000 \\
\hline K016 & RADS & Total Radium & $\mathrm{pCi} / \mathrm{L}$ & 1 & & 0.9000 & 0.9000 & 0.9000 \\
\hline K016 & RADS & Uranium & $\mathrm{mg} / \mathrm{L}$ & 4 & & 0.0040 & 0.0030 & 0.0050 \\
\hline K016 & RADSD & Dissolved Alpha & $\mathrm{pCi} / \mathrm{L}$ & 4 & & 0.7750 & -0.5000 & 2.6000 \\
\hline K016 & RADSD & Dissolved Beta & $\mathrm{pCi} / \mathrm{L}$ & 4 & & 9.7500 & 6.0000 & 15.0000 \\
\hline K016 & SVOA & 1,2,4-Trichlorobenzene & $\mu \mathrm{g} / \mathrm{L}$ & 1 & $<$ & 10.0000 & 10.0000 & 10.0000 \\
\hline K016 & SVOA & 1,2-Diphenylhydrazine & $\mu \mathrm{g} / \mathrm{L}$ & 1 & $<$ & 10.0000 & 10.0000 & 10.0000 \\
\hline K016 & SVOA & 2,4,6-Trichlorophenol & $\mu \mathrm{g} / \mathrm{L}$ & 1 & $<$ & 10.0000 & 10.0000 & 10.0000 \\
\hline K016 & SVOA & 2,4-Dichlorophenol & $\mu \mathrm{g} / \mathrm{L}$ & 1 & $<$ & 10.0000 & 10.0000 & 10.0000 \\
\hline K016 & SVOA & 2,4-Dimethylphenol & $\mu \mathrm{g} / \mathrm{L}$ & 1 & $<$ & 10.0000 & 10.0000 & 10.0000 \\
\hline K016 & SVOA & 2,4-Dinitrophenol & $\mu \mathrm{g} / \mathrm{L}$ & 1 & $<$ & 10.0000 & 10.0000 & 10.0000 \\
\hline K016 & SVOA & 2,4-Dinitrotoluene & $\mu \mathrm{g} / \mathrm{L}$ & 1 & $<$ & 10.0000 & 10.0000 & 10.0000 \\
\hline K016 & SVOA & 2,6-Dinitrotoluene & $\mu \mathrm{g} / \mathrm{L}$ & 1 & $<$ & 10.0000 & 10.0000 & 10.0000 \\
\hline K016 & SVOA & 2-Chloroethyl Vinyl Ether & $\mu \mathrm{g} / \mathrm{L}$ & 1 & $<$ & 10.0000 & 10.0000 & 10.0000 \\
\hline K016 & SVOA & 2-Chloronaphthalene & $\mu \mathrm{g} / \mathrm{L}$ & 1 & $<$ & 10.0000 & 10.0000 & 10.0000 \\
\hline K016 & SVOA & 2-Chlorophenol & $\mu \mathrm{g} / \mathrm{L}$ & 1 & $<$ & 10.0000 & 10.0000 & 10.0000 \\
\hline K016 & SVOA & 2-Nitrophenol & $\mu \mathrm{g} / \mathrm{L}$ & 1 & $<$ & 10.0000 & 10.0000 & 10.0000 \\
\hline
\end{tabular}


Table A.13 (continued)

\begin{tabular}{|c|c|c|c|c|c|c|c|c|}
\hline Station & Anatype $^{a}$ & Analysis & Units & No. Observ. & Qualifier $^{b}$ & Mean & Minimum & Maximum \\
\hline K016 & SVOA & 3,3'-Dichlorobenzidine & $\mu \mathrm{g} / \mathrm{L}$ & 1 & $<$ & 10.0000 & 10.0000 & 10.0000 \\
\hline K016 & SVOA & 4,6-Dinitro-2-methylphenol & $\mu \mathrm{g} / \mathrm{L}$ & 1 & $<$ & 10.0000 & 10.0000 & 10.0000 \\
\hline K016 & SVOA & 4-Bromophenyl-phenylether & $\mu \mathrm{g} / \mathrm{L}$ & 1 & $<$ & 10.0000 & 10.0000 & 10.0000 \\
\hline K016 & SVOA & 4-Chlorophenyl-phenylether & $\mu \mathrm{g} / \mathrm{L}$ & 1 & $<$ & 10.0000 & 10.0000 & 10.0000 \\
\hline K016 & SVOA & 4-Nitrophenol & $\mu \mathrm{g} / \mathrm{L}$ & 1 & $<$ & 10.0000 & 10.0000 & 10.0000 \\
\hline K016 & SVOA & Anthracene & $\mu \mathrm{g} / \mathrm{L}$ & 1 & $<$ & 10.0000 & 10.0000 & 10.0000 \\
\hline K016 & SVOA & Benzo(a)pyrene & $\mu \mathrm{g} / \mathrm{L}$ & 1 & $<$ & 10.0000 & 10.0000 & 10.0000 \\
\hline K016 & SVOA & Benzo(b)fluoranthene & $\mu \mathrm{g} / \mathrm{L}$ & 1 & $<$ & 10.0000 & 10.0000 & 10.0000 \\
\hline K016 & SVOA & Benzo(g,h,i)perylene & $\mu \mathrm{g} / \mathrm{L}$ & 1 & $<$ & 10.0000 & 10.0000 & 10.0000 \\
\hline K016 & SVOA & Benzo(k)fluoranthene & $\mu \mathrm{g} / \mathrm{L}$ & 1 & $<$ & 10.0000 & 10.0000 & 10.0000 \\
\hline K016 & SVOA & Benzyl Butyl Phthalate & $\mu \mathrm{g} / \mathrm{L}$ & 1 & $<$ & 10.0000 & 10.0000 & 10.0000 \\
\hline K016 & SVOA & bis(2-Chloroethoxy)methane & $\mu \mathrm{g} / \mathrm{L}$ & 1 & $<$ & 10.0000 & 10.0000 & 10.0000 \\
\hline K016 & SVOA & Di-n-butylphthalate & $\mu \mathrm{g} / \mathrm{L}$ & 1 & $<$ & 10.0000 & 10.0000 & 10.0000 \\
\hline K016 & SVOA & Di-n-octylphthalate & $\mu \mathrm{g} / \mathrm{L}$ & 1 & $<$ & 10.0000 & 10.0000 & 10.0000 \\
\hline K016 & SVOA & Dibenzo $(a, h)$ anthracene & $\mu \mathrm{g} / \mathrm{L}$ & 1 & $<$ & 10.0000 & 10.0000 & 10.0000 \\
\hline K016 & SVOA & Diethylphthalate & $\mu \mathrm{g} / \mathrm{L}$ & 1 & $<$ & 10.0000 & 10.0000 & 10.0000 \\
\hline K016 & SVOA & Dimethylphthalate & $\mu \mathrm{g} / \mathrm{L}$ & 1 & $<$ & 10.0000 & 10.0000 & 10.0000 \\
\hline K016 & SVOA & Fluoranthene & $\mu \mathrm{g} / \mathrm{L}$ & 1 & $<$ & 10.0000 & 10.0000 & 10.0000 \\
\hline K016 & SVOA & Fluorene & $\mu \mathrm{g} / \mathrm{L}$ & 1 & $<$ & 10.0000 & 10.0000 & 10.0000 \\
\hline K016 & SVOA & Hexachlorobenzene & $\mu \mathrm{g} / \mathrm{L}$ & 1 & $<$ & 10.0000 & 10.0000 & 10.0000 \\
\hline K016 & SVOA & Hexachlorobutadiene & $\mu \mathrm{g} / \mathrm{L}$ & 1 & $<$ & 10.0000 & 10.0000 & 10.0000 \\
\hline K016 & SVOA & Hexachlorocyclopentadiene & $\mu \mathrm{g} / \mathrm{L}$ & 1 & $<$ & 10.0000 & 10.0000 & 10.0000 \\
\hline K016 & SVOA & Hexachloroethane & $\mu \mathrm{g} / \mathrm{L}$ & 1 & $<$ & 10.0000 & 10.0000 & 10.0000 \\
\hline
\end{tabular}


Table A.13 (continued)

\begin{tabular}{|c|c|c|c|c|c|c|c|c|}
\hline Station & Anatype $^{a}$ & Analysis & Units & No. Observ. & Qualifier $^{b}$ & Mean & Minimum & Maximum \\
\hline K016 & SVOA & Isophorone & $\mu \mathrm{g} / \mathrm{L}$ & 1 & $<$ & 10.0000 & 10.0000 & 10.0000 \\
\hline K016 & SVOA & N-Nitroso-di-n-propylamine & $\mu \mathrm{g} / \mathrm{L}$ & 1 & $<$ & 10.0000 & 10.0000 & 10.0000 \\
\hline K016 & SVOA & N-Nitrosodimethylamine & $\mu \mathrm{g} / \mathrm{L}$ & 1 & $<$ & 10.0000 & 10.0000 & 10.0000 \\
\hline K016 & SVOA & N-Nitrosodiphenylamine & $\mu \mathrm{g} / \mathrm{L}$ & 1 & $<$ & 10.0000 & 10.0000 & 10.0000 \\
\hline K016 & SVOA & Naphthalene & $\mu \mathrm{g} / \mathrm{L}$ & 1 & $<$ & 10.0000 & 10.0000 & 10.0000 \\
\hline K016 & SVOA & Nitrobenzene & $\mu \mathrm{g} / \mathrm{L}$ & 1 & $<$ & 10.0000 & 10.0000 & 10.0000 \\
\hline K016 & SVOA & Pentachlorophenol & $\mu \mathrm{g} / \mathrm{L}$ & 1 & $<$ & 10.0000 & 10.0000 & 10.0000 \\
\hline K016 & SVOA & Phenanthrene & $\mu \mathrm{g} / \mathrm{L}$ & 1 & $<$ & 10.0000 & 10.0000 & 10.0000 \\
\hline K016 & SVOA & Phenol & $\mu \mathrm{g} / \mathrm{L}$ & 2 & $<$ & 7.5000 & 5.0000 & 10.0000 \\
\hline K016 & SVOA & Pyrene & $\mu \mathrm{g} / \mathrm{L}$ & 1 & $<$ & 10.0000 & 10.0000 & 10.0000 \\
\hline K016 & VOA & 1,1,1-Trichloroethane & $\mu \mathrm{g} / \mathrm{L}$ & 1 & $<$ & 10.0000 & 10.0000 & 10.0000 \\
\hline K016 & VOA & 1,1,2,2-Tetrachloroethane & $\mu \mathrm{g} / \mathrm{L}$ & 1 & $<$ & 10.0000 & 10.0000 & 10.0000 \\
\hline K016 & VOA & 1,1,2-Trichloroethane & $\mu \mathrm{g} / \mathrm{L}$ & 1 & $<$ & 10.0000 & 10.0000 & 10.0000 \\
\hline K016 & VOA & 1,1-Dichloroethane & $\mu \mathrm{g} / \mathrm{L}$ & 1 & $<$ & 10.0000 & 10.0000 & 10.0000 \\
\hline K016 & VOA & 1,1-Dichloroethene & $\mu \mathrm{g} / \mathrm{L}$ & 1 & $<$ & 10.0000 & 10.0000 & 10.0000 \\
\hline K016 & VOA & 1,2-Dichlorobenzene & $\mu \mathrm{g} / \mathrm{L}$ & 1 & $<$ & 10.0000 & 10.0000 & 10.0000 \\
\hline K016 & VOA & 1,2-Dichloroethane & $\mu \mathrm{g} / \mathrm{L}$ & 1 & $<$ & 10.0000 & 10.0000 & 10.0000 \\
\hline K016 & VOA & 1,2-Dichloropropane & $\mu \mathrm{g} / \mathrm{L}$ & 1 & $<$ & 10.0000 & 10.0000 & 10.0000 \\
\hline K016 & VOA & 1,3-Dichlorobenzene & $\mu \mathrm{g} / \mathrm{L}$ & 1 & $<$ & 10.0000 & 10.0000 & 10.0000 \\
\hline K016 & VOA & 1,4-Dichlorobenzene & $\mu \mathrm{g} / \mathrm{L}$ & 1 & $<$ & 10.0000 & 10.0000 & 10.0000 \\
\hline K016 & VOA & Acrolein & $\mu \mathrm{g} / \mathrm{L}$ & 1 & $<$ & 10.0000 & 10.0000 & 10.0000 \\
\hline K016 & VOA & Acrylonitrile & $\mu \mathrm{g} / \mathrm{L}$ & 1 & $<$ & 10.0000 & 10.0000 & 10.0000 \\
\hline K016 & VOA & Benzene & $\mu \mathrm{g} / \mathrm{L}$ & 1 & $<$ & 10.0000 & 10.0000 & 10.0000 \\
\hline K016 & VOA & Benzidine & $\mu \mathrm{g} / \mathrm{L}$ & 1 & $<$ & 10.0000 & 10.0000 & 10.0000 \\
\hline K016 & VOA & Bromodichloromethane & $\mu \mathrm{g} / \mathrm{L}$ & 1 & $<$ & 10.0000 & 10.0000 & 10.0000 \\
\hline K016 & VOA & Bromoform & $\mu \mathrm{g} / \mathrm{L}$ & 1 & $<$ & 10.0000 & 10.0000 & 10.0000 \\
\hline K016 & VOA & Bromomethane & $\mu \mathrm{g} / \mathrm{L}$ & 1 & $<$ & 10.0000 & 10.0000 & 10.0000 \\
\hline K016 & VOA & Carbon Tetrachloride & $\mu \mathrm{g} / \mathrm{L}$ & 1 & $<$ & 10.0000 & 10.0000 & 10.0000 \\
\hline K016 & VOA & Chlorobenzene & $\mu \mathrm{g} / \mathrm{L}$ & 1 & $<$ & 10.0000 & 10.0000 & 10.0000 \\
\hline K016 & VOA & Chloroethane & $\mu \mathrm{g} / \mathrm{L}$ & 1 & $<$ & 10.0000 & 10.0000 & 10.0000 \\
\hline
\end{tabular}


Table A.13 (continued)

\begin{tabular}{|c|c|c|c|c|c|c|c|c|}
\hline Station & Anatype $^{a}$ & Analysis & Units & No. Observ. & Qualifier $^{b}$ & Mean & Minimum & Maximum \\
\hline K016 & VOA & Chloroform & $\mu \mathrm{g} / \mathrm{L}$ & 1 & $<$ & 10.0000 & 10.0000 & 10.0000 \\
\hline K016 & VOA & Chloromethane & $\mu \mathrm{g} / \mathrm{L}$ & 1 & $<$ & 10.0000 & 10.0000 & 10.0000 \\
\hline K016 & VOA & cis-1,2-dichloroethene & $\mu \mathrm{g} / \mathrm{L}$ & 1 & & 48.0000 & 48.0000 & 48.0000 \\
\hline K016 & VOA & cis-1,3-Dichloropropene & $\mu \mathrm{g} / \mathrm{L}$ & 1 & $<$ & 10.0000 & 10.0000 & 10.0000 \\
\hline K016 & VOA & Dibromochloromethane & $\mu \mathrm{g} / \mathrm{L}$ & 1 & $<$ & 10.0000 & 10.0000 & 10.0000 \\
\hline K016 & VOA & Dichlorodifluoromethane & $\mu \mathrm{g} / \mathrm{L}$ & 1 & $<$ & 10.0000 & 10.0000 & 10.0000 \\
\hline K016 & VOA & Ethylbenzene & $\mu \mathrm{g} / \mathrm{L}$ & 1 & $<$ & 10.0000 & 10.0000 & 10.0000 \\
\hline K016 & VOA & Methylene Chloride & $\mu \mathrm{g} / \mathrm{L}$ & 1 & $<$ & 10.0000 & 10.0000 & 10.0000 \\
\hline K016 & VOA & Tetrachlorodibenzo-p-dioxin & $\mathrm{ng} / \mathrm{L}$ & 1 & & 0.4700 & 0.4700 & 0.4700 \\
\hline K016 & VOA & Tetrachloroethene & $\mu \mathrm{g} / \mathrm{L}$ & 1 & $<$ & 10.0000 & 10.0000 & 10.0000 \\
\hline K016 & VOA & Toluene & $\mu \mathrm{g} / \mathrm{L}$ & 1 & $<$ & 10.0000 & 10.0000 & 10.0000 \\
\hline K016 & VOA & Trans-1,2-Dichloroethene & $\mu \mathrm{g} / \mathrm{L}$ & 1 & $<$ & 10.0000 & 10.0000 & 10.0000 \\
\hline K016 & VOA & Trans-1,3-Dichloropropene & $\mu \mathrm{g} / \mathrm{L}$ & 1 & $<$ & 10.0000 & 10.0000 & 10.0000 \\
\hline K016 & VOA & Trichloroethene & $\mu \mathrm{g} / \mathrm{L}$ & 11 & $<$ & 1.8182 & 1.0000 & 10.0000 \\
\hline K016 & VOA & Trichlorofluoromethane & $\mu \mathrm{g} / \mathrm{L}$ & 1 & $<$ & 10.0000 & 10.0000 & 10.0000 \\
\hline K016 & VOA & Vinyl Chloride & $\mu \mathrm{g} / \mathrm{L}$ & 1 & $<$ & 10.0000 & 10.0000 & 10.0000 \\
\hline
\end{tabular}

Note: Data provided by L. S. Crabtree, Information Services, Paducah Gaseous Diffusion Plant.

${ }^{a}$ ANION $=$ a negatively charged ion; CATION $=$ a positively charged ion; $\mathrm{CHEM}=$ chemical parameters; $\mathrm{MAA}=$ metals by atomic absorption; MIC $=$ metals by inductively-coupled plasma/mass spectroscopy; OROTH = other organics, PHYSC $=$ physical and field measurements; PPCB = pesticides/polychlorinated biphenyls; RADS $=$ radiochemical analysis; RADSD = radiochemical analysis, dissolved; $S V O A=$ semivolatile organics; VOA $=$ volatile organics.

${ }^{b} \mathrm{~A}$ " $<$ " qualifier was added to the mean when $\geq 50 \%$ of the observations had " $<$ " qualifiers. 
Table A.14. Water quality parameters measured at Kentucky Pollutant Dischärge Elimination System permitted outfall 017 in 1994

\begin{tabular}{|c|c|c|c|c|c|c|c|c|}
\hline Station & Anatype $^{a}$ & Analysis & Units & No. Observ. & Qualifier $^{b}$ & Mean & Minimum & Maximum \\
\hline K017 & ANION & Bromide & $\mathrm{mg} / \mathrm{L}$ & 1 & $<$ & 1.0000 & 1.0000 & 1.0000 \\
\hline K017 & ANION & Chloride & $\mathrm{mg} / \mathrm{L}$ & 1 & & 12.0000 & 12.0000 & 12.0000 \\
\hline K017 & ANION & Chlorine, Total Residual & $\mathrm{mg} / \mathrm{L}$ & 1 & $<$ & 0.0500 & 0.0500 & 0.0500 \\
\hline K017 & ANION & Fluoride & $\mathrm{mg} / \mathrm{L}$ & 1 & & 0.4900 & 0.4900 & 0.4900 \\
\hline K017 & ANION & Hardness as $\mathrm{CaCO}_{3}$ & $\mathrm{mg} / \mathrm{L} \mathrm{CaCO}{ }_{3}$ & 11 & & 140.0000 & 64.0000 & 210.0000 \\
\hline K017 & ANION & Sulfide & $\mathrm{mg} / \mathrm{L}$ & 1 & $<$ & 1.0000 & 1.0000 & 1.0000 \\
\hline K017 & ANION & Sulfite & $\mathrm{mg} / \mathrm{L}$ & 1 & $<$ & 3.0000 & 3.0000 & 3.0000 \\
\hline K017 & CATION & Ammonia as Nitrogen & $\mathrm{mg} / \mathrm{L}$ & 1 & $<$ & 0.2000 & 0.2000 & 0.2000 \\
\hline K017 & CHEM & Total Organic Carbon & $\mathrm{mg} / \mathrm{L}$ & 1 & & 5.0000 & 5.0000 & 5.0000 \\
\hline K017 & CHEM & Total Organic Nitrogen & $\mathrm{mg} / \mathrm{L}$ & 1 & & 0.5600 & 0.5600 & 0.5600 \\
\hline K017 & MAA & Arsenic & $\mathrm{mg} / \mathrm{L}$ & 2 & $<$ & 0.0225 & 0.0050 & 0.0400 \\
\hline K017 & $\mathrm{MICP}$ & Barium & $\mathrm{mg} / \mathrm{L}$ & 2 & & 0.0589 & 0.0580 & 0.0598 \\
\hline K017 & MICP & Beryllium & $\mathrm{mg} / \mathrm{L}$ & 2 & $<$ & 0.0027 & 0.0004 & 0.0050 \\
\hline K017 & MICP & Boron & $\mathrm{mg} / \mathrm{L}$ & 1 & & 0.0210 & 0.0210 & 0.0210 \\
\hline K017 & MICP & Cadmium & $\mathrm{mg} / \mathrm{L}$ & 12 & $<$ & 0.0071 & 0.0005 & 0.0100 \\
\hline K017 & MICP & Calcium & $\mathrm{mg} / \mathrm{L}$ & 1 & & 52.9000 & 52.9000 & 52.9000 \\
\hline K017 & MICP & Cerium & $\mathrm{mg} / \mathrm{L}$ & 1 & $<$ & 0.0200 & 0.0200 & 0.0200 \\
\hline K017 & MICP & Chromium & $\mathrm{mg} / \mathrm{L}$ & 12 & $<$ & 0.0363 & 0.0060 & 0.0500 \\
\hline K017 & MICP & Cobalt & $\mathrm{mg} / \mathrm{L}$ & 2 & $<$ & 0.0260 & 0.0020 & 0.0500 \\
\hline K017 & MICP & Copper & $\mathrm{mg} / \mathrm{L}$ & 12 & $<$ & 0.0102 & 0.0060 & 0.0120 \\
\hline K017 & MICP & Gallium & $\mathrm{mg} / \mathrm{L}$ & 1 & $<$ & 0.0200 & 0.0200 & 0.0200 \\
\hline K017 & MICP & Iron & $\mathrm{mg} / \mathrm{L}$ & 12 & & 0.7240 & 0.1800 & 1.5000 \\
\hline
\end{tabular}


Table A.14 (continued)

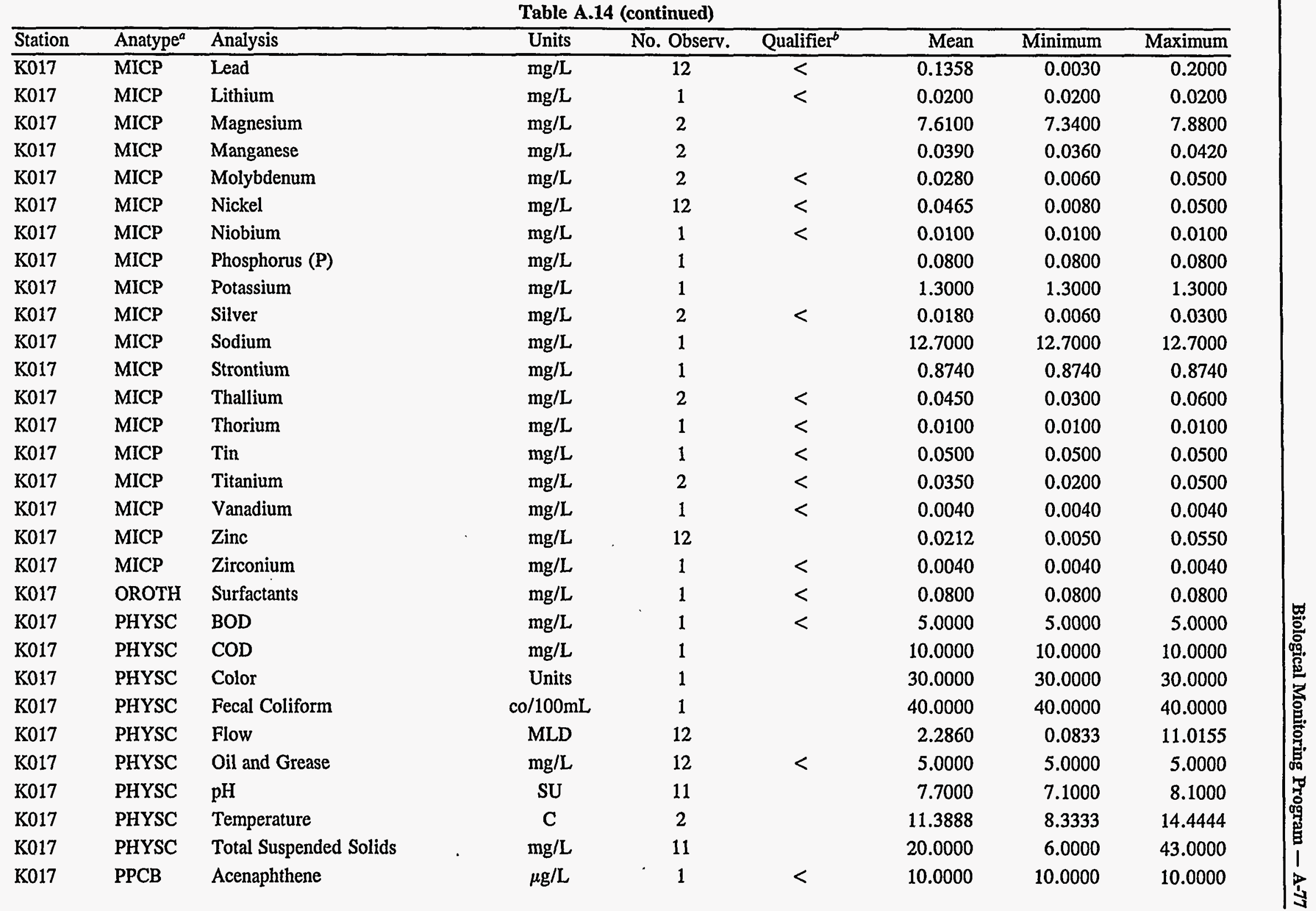


Table A.14 (continued)

\begin{tabular}{|c|c|c|c|c|c|c|c|c|}
\hline Station & Anatype $^{a}$ & Analysis & Units & No. Observ. & Qualifier $^{b}$ & Mean & Minimum & Maximum \\
\hline K017 & PPCB & Acenaphthylene & $\mu \mathrm{g} / \mathrm{L}$ & 1 & $<$ & 10.0000 & 10.0000 & 10.0000 \\
\hline K017 & РPCB & $\mathrm{PCB}$ & $\mu \mathrm{g} / \mathrm{L}$ & 10 & $<$ & 0.0895 & 0.0650 & 0.1000 \\
\hline K017 & RADS & Gross Alpha & $\mathrm{pCi} / \mathrm{L}$ & 1 & & 2.1000 & 2.1000 & 2.1000 \\
\hline K017 & RADS & Gross Beta & $\mathrm{pCi} / \mathrm{L}$ & 1 & & 9.0000 & 9.0000 & 9.0000 \\
\hline K017 & RADS & Neptunium-237. & $\mathrm{pCi} / \mathrm{L}$ & 4 & & 0.0750 & 0.0000 & 0.2000 \\
\hline K017 & RADS & Plutonium-239 & $\mathrm{pCi} / \mathrm{L}$ & 4 & & 0.0000 & 0.0000 & 0.0000 \\
\hline K017 & RADS & Rad Alpha & $\mathrm{pCi} / \mathrm{ml}$ & 5 & $<$ & 1.0000 & 1.0000 & 1.0000 \\
\hline K017 & RADS & Rad Beta & $\mathrm{pCi} / \mathrm{ml}$ & 5 & $<$ & 1.0000 & 1.0000 & 1.0000 \\
\hline K017 & RADS & Radium-226 & $\mathrm{pCi} / \mathrm{L}$ & 1 & & 0.0000 & 0.0000 & 0.0000 \\
\hline K017 & RADS & Suspended Alpha & $\mathrm{pCi} / \mathrm{L}$ & 4 & & -0.2750 & -1.3000 & 1.8000 \\
\hline K017 & RADS & Suspended Beta & $\mathrm{pCi} / \mathrm{L}$ & 4 & & 0.7500 & -4.0000 & 5.0000 \\
\hline K017 & RADS & Technetium-99 & $\mathrm{pCi} / \mathrm{L}$ & 4 & & 13.7500 & 0.0000 & 24.0000 \\
\hline K017 & RADS & Thorium-230 & $\mathrm{pCi} / \mathrm{L}$ & 4 & & 0.7500 & 0.1000 & 2.3000 \\
\hline K017 & RADS & Total Radium & $\mathrm{pCi} / \mathrm{L}$ & 1 & & 0.7000 & 0.7000 & 0.7000 \\
\hline K017 & RADS & Uranium & $\mathrm{mg} / \mathrm{L}$ & 4 & & 0.0055 & 0.0040 & 0.0080 \\
\hline K017 & RADSD & Dissolved Alpha & $\mathrm{pCi} / \mathrm{L}$ & 4 & & 2.3000 & 0.7000 & 3.4000 \\
\hline K017 & RADSD & Dissolved Beta & $\mathrm{pCi} / \mathrm{L}$ & 4 & & 8.2500 & 2.0000 & 13.0000 \\
\hline K017 & SVOA & 1,2,4-Trichlorobenzene & $\mu \mathrm{g} / \mathrm{L}$ & 1 & $<$ & 10.0000 & 10.0000 & 10.0000 \\
\hline K017 & SVOA & 1,2-Diphenylhydrazine & $\mu \mathrm{g} / \mathrm{L}$ & 1 & $<$ & 10.0000 & 10.0000 & 10.0000 \\
\hline K017 & SVOA & 2,4,6-Trichlorophenol & $\mu \mathrm{g} / \mathrm{L}$ & 1 & $<$ & 10.0000 & 10.0000 & 10.0000 \\
\hline K017 & SVOA & 2,4-Dichlorophenol & $\mu \mathrm{g} / \mathrm{L}$ & 1 & $<$ & 10.0000 & 10.0000 & 10.0000 \\
\hline K017 & SVOA & 2,4-Dimethylphenol & $\mu \mathrm{g} / \mathrm{L}$ & 1 & $<$ & 10.0000 & 10.0000 & 10.0000 \\
\hline K017 & SVOA & 2,4-Dinitrophenol & $\mu \mathrm{g} / \mathrm{L}$ & 1 & $<$ & 10.0000 & 10.0000 & 10.0000 \\
\hline K017 & SVOA & 2,4-Dinitrotoluene & $\mu \mathrm{g} / \mathrm{L}$ & 1 & $<$ & 10.0000 & 10.0000 & 10.0000 \\
\hline K017 & SVOA & 2,6-Dinitrotoluene & $\mu \mathrm{g} / \mathrm{L}$ & 1 & $<$ & 10.0000 & 10.0000 & 10.0000 \\
\hline K017 & SVOA & 2-Chloroethyl Vinyl Ether & $\mu \mathrm{g} / \mathrm{L}$ & 1 & $<$ & 10.0000 & 10.0000 & 10.0000 \\
\hline K017 & SVOA & 2-Chloronaphthalene & $\mu \mathrm{g} / \mathrm{L}$ & 1 & $<$ & 10.0000 & 10.0000 & 10.0000 \\
\hline K017 & SVOA & 2-Chlorophenol & $\mu \mathrm{g} / \mathrm{L}$ & 1 & $<$ & 10.0000 & 10.0000 & 10.0000 \\
\hline K017 & SVOA & 2-Nitrophenol & $\mu \mathrm{g} / \mathrm{L}$ & 1 & $<$ & 10.0000 & 10.0000 & 10.0000 \\
\hline K017 & SVOA & 3,3'-Dichlorobenzidine & $\mu \mathrm{g} / \mathrm{L}$ & 1 & $<$ & 10.0000 & 10.0000 & 10.0000 \\
\hline
\end{tabular}


Table A.14 (continued)

\begin{tabular}{|c|c|c|c|c|c|c|c|c|}
\hline Station & Anatype $^{a}$ & Analysis & Units & No. Observ. & Qualifier $^{b}$ & Mean & Minimum & Maximum \\
\hline K017 & SVOA & 4,6-Dinitro-2-methylphenol & $\mu \mathrm{g} / \mathrm{L}$ & 1 & $<$ & 10.0000 & 10.0000 & 10.0000 \\
\hline K017 & SVOA & 4-Bromophenyl-phenylether & $\mu \mathrm{g} / \mathrm{L}$ & 1 & $<$ & 10.0000 & 10.0000 & 10.0000 \\
\hline K017 & SVOA & 4-Chloro-3-methylphenol & $\mu \mathrm{g} / \mathrm{L}$ & 1 & $<$ & 10.0000 & 10.0000 & 10.0000 \\
\hline K017 & SVOA & 4-Nitrophenol & $\mu \mathrm{g} / \mathrm{L}$ & 1 & $<$ & 10.0000 & 10.0000 & 10.0000 \\
\hline K017 & SVOA & Anthracene & $\mu \mathrm{g} / \mathrm{L}$ & 1 & $<$ & 10.0000 & 10.0000 & 10.0000 \\
\hline K017 & SVOA & Benzo(b)fluoranthene & $\mu \mathrm{g} / \mathrm{L}$ & 1 & $<$ & 10.0000 & 10.0000 & 10.0000 \\
\hline K017 & SVOA & Benzo(g,h,i)perylene & $\mu \mathrm{g} / \mathrm{L}$ & 1 & $<$ & 10.0000 & 10.0000 & 10.0000 \\
\hline K017 & SVOA & Benzo(k)fluoranthene & $\mu \mathrm{g} / \mathrm{L}$ & 1 & $<$ & 10.0000 & 10.0000 & 10.0000 \\
\hline K017 & SVOA & Benzyl Butyl Phthalate & $\mu \mathrm{g} / \mathrm{L}$ & 1 & $<$ & 10.0000 & 10.0000 & 10.0000 \\
\hline K017 & SVOA & bis(2-Chloroethoxy)methane & $\mu \mathrm{g} / \mathrm{L}$ & 1 & $<$ & 10.0000 & 10.0000 & 10.0000 \\
\hline K017 & SVOA & bis(2-Chloroethyl)ether & $\mu \mathrm{g} / \mathrm{L}$ & 1 & $<$ & 10.0000 & 10.0000 & 10.0000 \\
\hline K017 & SVOA & Di-n-butylphthalate & $\mu \mathrm{g} / \mathrm{L}$ & 1 & $<$ & 10.0000 & 10.0000 & 10.0000 \\
\hline K017 & SVOA & Di-n-octylphthalate & $\mu \mathrm{g} / \mathrm{L}$ & 1 & $<$ & 10.0000 & 10.0000 & 10.0000 \\
\hline K017 & SVOA & Dibenzo(a,h)anthracene & $\mu \mathrm{g} / \mathrm{L}$ & 1 & $<$ & 10.0000 & 10.0000 & 10.0000 \\
\hline K017 & SVOA & Diethylphthalate & $\mu \mathrm{g} / \mathrm{L}$ & 1 & $<$ & 10.0000 & 10.0000 & 10.0000 \\
\hline K017 & SVOA & Dimethylphthalate & $\mu \mathrm{g} / \mathrm{L}$ & 1 & $<$ & 10.0000 & 10.0000 & 10.0000 \\
\hline K017 & SVOA & Fluoranthene & $\mu \mathrm{g} / \mathrm{L}$ & 1 & $<$ & 10.0000 & 10.0000 & 10.0000 \\
\hline K017 & SVOA & Fluorene & $\mu \mathrm{g} / \mathrm{L}$ & 1 & $<$ & 10.0000 & 10.0000 & 10.0000 \\
\hline K017 & SVOA & Hexachlorobenzene & $\mu \mathrm{g} / \mathrm{L}$ & 1 & $<$ & 10.0000 & 10.0000 & 10.0000 \\
\hline K017 & SVOA & Hexachlorobutadiene & $\mu \mathrm{g} / \mathrm{L}$ & 1 & $<$ & 10.0000 & 10.0000 & 10.0000 \\
\hline K017 & SVOA & Hexachlorocyclopentadiene & $\mu \mathrm{g} / \mathrm{L}$ & 1 & $<$ & 10.0000 & 10.0000 & 10.0000 \\
\hline K017 & SVOA & Hexachloroethane & $\mu \mathrm{g} / \mathrm{L}$ & 1 & $<$ & 10.0000 & 10.0000 & 10.0000 \\
\hline K017 & SVOA & Indeno(1,2,3-cd)pyrene & $\mu \mathrm{g} / \mathrm{L}$ & 1 & $<$ & 10.0000 & 10.0000 & 10.0000 \\
\hline
\end{tabular}




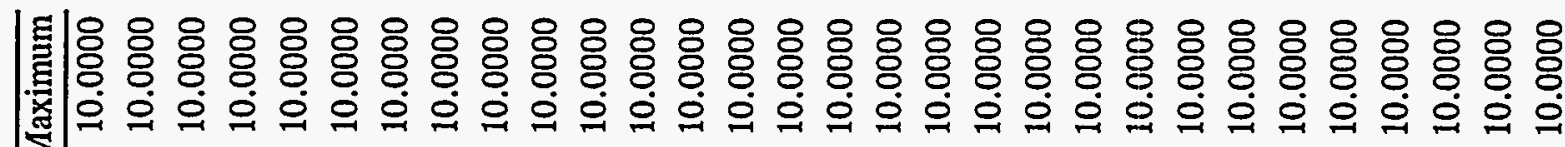

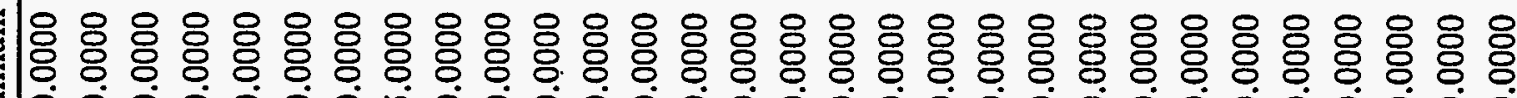

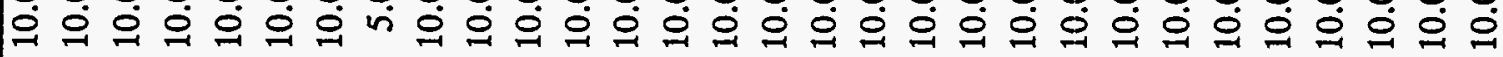

象

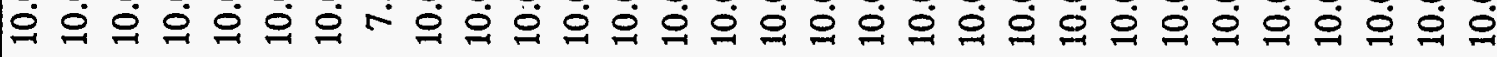

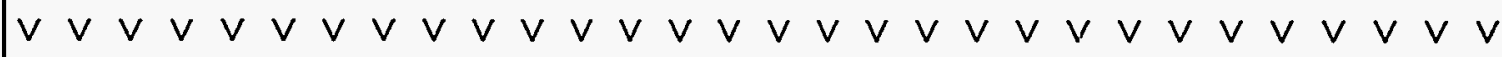

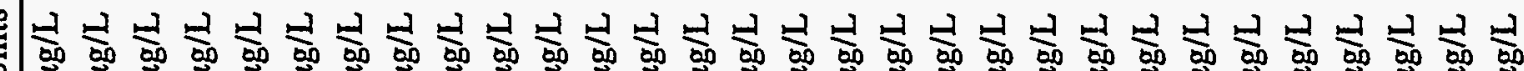

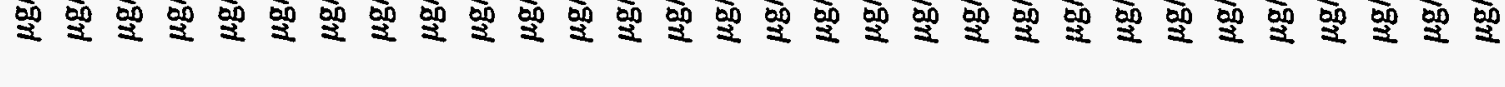

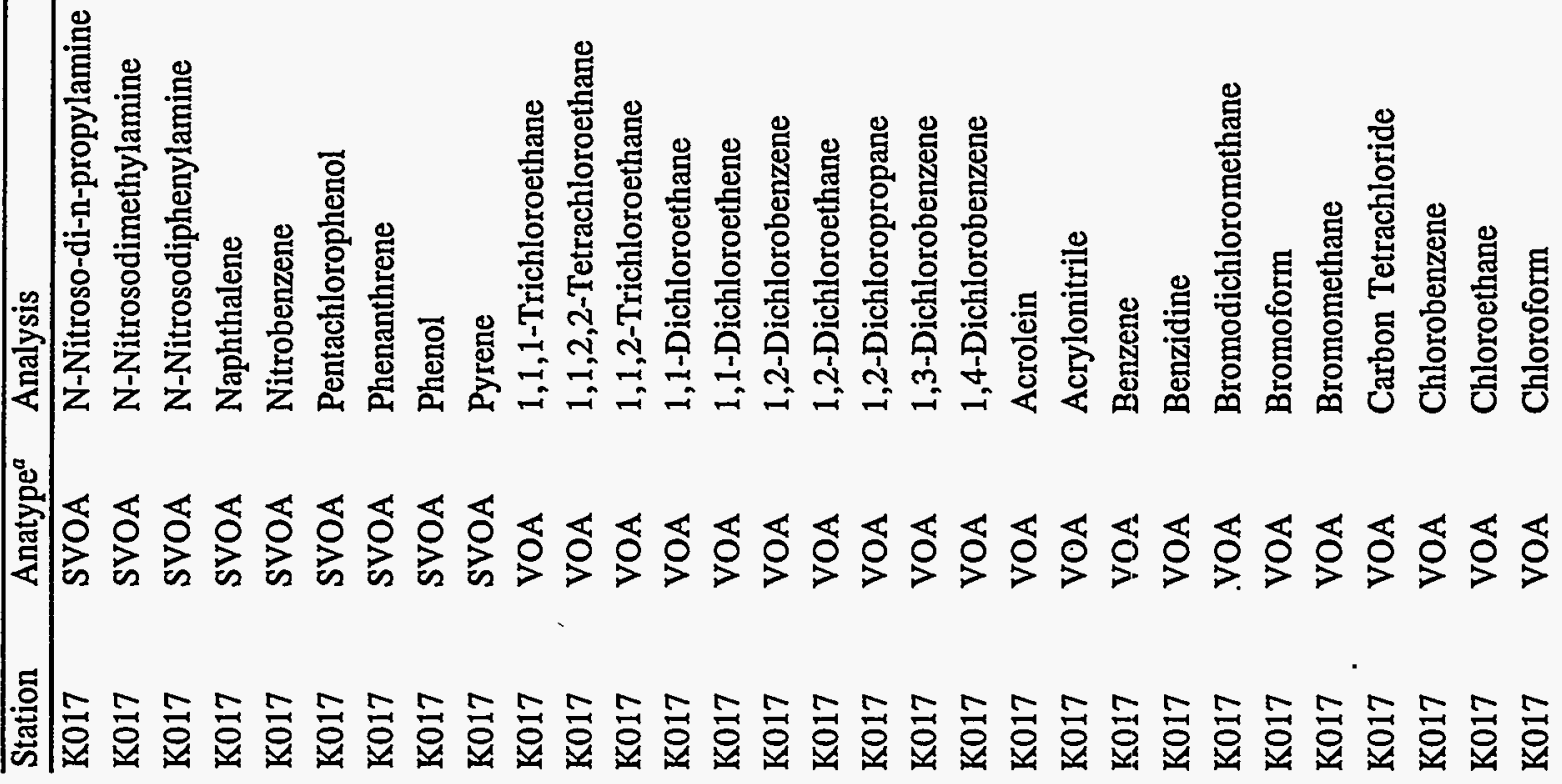


Table A.14 (continued)

\begin{tabular}{|c|c|c|c|c|c|c|c|c|}
\hline Station & Anatype $^{a}$ & Analysis & Units & No. Observ. & Qualifier $^{b}$ & Mean & Minimum & Maximum \\
\hline K017 & VOA & Chloromethane & $\mu \mathrm{g} / \mathrm{L}$ & 1 & $<$ & 10.0000 & 10.0000 & 10.0000 \\
\hline K017 & VOA & cis-1,3-Dichloropropene & $\mu \mathrm{g} / \mathrm{L}$ & 1 & $<$ & 10.0000 & 10.0000 & 10.0000 \\
\hline K017 & VOA & Dibromochloromethane & $\mu \mathrm{g} / \mathrm{L}$ & 1 & $<$ & 10.0000 & 10.0000 & 10.0000 \\
\hline K017 & VOA & Dichlorodifluoromethane & $\mu \mathrm{g} / \mathrm{L}$ & 1 & $<$ & 10.0000 & 10.0000 & 10.0000 \\
\hline K017 & VOA & Ethylbenzene & $\mu \mathrm{g} / \mathrm{L}$ & 1 & $<$ & 10.0000 & 10.0000 & 10.0000 \\
\hline K017 & VOA & Methylene Chloride & $\mu \mathrm{g} / \mathrm{L}$ & 1 & $<$ & 10.0000 & 10.0000 & 10.0000 \\
\hline K017 & VOA & Tetrachlorodibenzo-p-dioxin & $\mathrm{ng} / \mathrm{L}$ & 1 & $<$ & 0.9100 & 0.9100 & 0.9100 \\
\hline K017 & VOA & Tetrachloroethene & $\mu \mathrm{g} / \mathrm{L}$ & 1 & $<$ & 10.0000 & 10.0000 & 10.0000 \\
\hline K017 & VOA & Toluene & $\mu \mathrm{g} / \mathrm{L}$ & 1 & $<$ & 10.0000 & 10.0000 & 10.0000 \\
\hline K017 & VOA & Trans-1,2-Dichloroethene & $\mu \mathrm{g} / \mathrm{L}$ & 1 & $<$ & 10.0000 & 10.0000 & 10.0000 \\
\hline K017 & VOA & Trans-1,3-Dichloropropene & $\mu \mathrm{g} / \mathrm{L}$ & 1 & $<$ & 10.0000 & 10.0000 & 10.0000 \\
\hline K017 & VOA & Trichloroethene & $\mu \mathrm{g} / \mathrm{L}$ & 11 & $<$ & 1.8182 & 1.0000 & 10.0000 \\
\hline K017 & VOA & Trichlorofluoromethane & $\mu \mathrm{g} / \mathrm{L}$ & 1 & $<$ & 10.0000 & 10.0000 & 10.0000 \\
\hline K017 & VOA & Vinyl Chloride & $\mu \mathrm{g} / \mathrm{L}$ & 1 & $<$ & 10.0000 & 10.0000 & 10.0000 \\
\hline
\end{tabular}

Note: Data provided by L. S. Crabtree, Information Services, Paducah Gaseous Diffusion Plant.

${ }^{a}$ ANION $=$ a negatively charged ion; CATION $=$ a positively charged ion; CHEM $=$ chemical parameters; $M A A=$ metals by atomic absorption; MIC $=$ metals by inductively-coupled plasma/mass spectroscopy; OROTH = other organics, PHYSC = physical and field measurements; PPCB = pesticides/polychlorinated biphenyls; RADS $=$ radiochemical analysis; RADSD = radiochemical analysis, dissolved; SVOA = semivolatile organics; VOA = volatile organics.

${ }^{b} \mathrm{~A}$ " $<$ " qualifier was added to the mean when $\geq 50 \%$ of the observations had " $<$ " qualifiers. 
Table A.15. Water quality parameters measured at Kentucky Pollutant Discharge Elimination System permitted outfall 018 in 1994

\begin{tabular}{|c|c|c|c|c|c|c|c|c|}
\hline Station & Anatype $^{a}$ & Analysis & Units & No. Observ. & Qualifier ${ }^{b}$ & Mean & Minimum & Maximum \\
\hline K018 & ANION & Bromide & $\mathrm{mg} / \mathrm{L}$ & 1 & $<$ & 1.0000 & 1.0000 & 1.0000 \\
\hline K018 & ANION & Chloride & $\mathrm{mg} / \mathrm{L}$ & 1 & & 4.0000 & 4.0000 & 4.0000 \\
\hline K018 & ANION & Chlorine, Total Residual & $\mathrm{mg} / \mathrm{L}$ & 1 & $<$ & 0.0500 & 0.0500 & 0.0500 \\
\hline K018 & ANION & Cyanide & $\mathrm{mg} / \mathrm{L}$ & 1 & $<$ & 0.0200 & 0.0200 & 0.0200 \\
\hline K018 & ANION & Fluoride & $\mathrm{mg} / \mathrm{L}$ & 1 & & 0.3500 & 0.3500 & 0.3500 \\
\hline K018 & ANION & Hardness as $\mathrm{CaCO}_{3}$ & $\mathrm{mg} / \mathrm{L} \mathrm{CaCO}_{3}$ & 10 & & 90.0000 & 56.0000 & 162.0000 \\
\hline К018 & ANION & Nitrate-Nitrite & $\mathrm{mg} / \mathrm{L}$ & 1 & & 0.2500 & 0.2500 & 0.2500 \\
\hline K018 & ANION & Sulfate & $\mathrm{mg} / \mathrm{L}$ & 1 & & 15.0000 & 15.0000 & 15.0000 \\
\hline K018 & ANION & Sulfide & $\mathrm{mg} / \mathrm{L}$ & 1 & $<$ & 1.0000 & 1.0000 & 1.0000 \\
\hline K018 & ANION & Sulfite & $\mathrm{mg} / \mathrm{L}$ & 1 & $<$ & 3.0000 & 3.0000 & 3.0000 \\
\hline K018 & CATION & Ammonia as Nitrogen & $\mathrm{mg} / \mathrm{L}$ & 1 & $<$ & 0.2000 & 0.2000 & 0.2000 \\
\hline K018 & CHEM & Total Organic Carbon & $\mathrm{mg} / \mathrm{L}$ & 1 & & 10.0000 & 10.0000 & 10.0000 \\
\hline K018 & CHEM & Total Organic Nitrogen & $\mathrm{mg} / \mathrm{L}$ & 1 & & 1.1000 & 1.1000 & 1.1000 \\
\hline K018 & MAA & Arsenic & $\mathrm{mg} / \mathrm{L}$ & 2 & $<$ & 0.0225 & 0.0050 & 0.0400 \\
\hline K018 & MAA & Mercury & $\mathrm{mg} / \mathrm{L}$ & 1 & $<$ & 0.0002 & 0.0002 & 0.0002 \\
\hline K018 & MAA & Selenium & $\mathrm{mg} / \mathrm{L}$ & 2 & $<$ & 0.0525 & 0.0050 & 0.1000 \\
\hline K018 & MICP & Aluminum & $\mathrm{mg} / \mathrm{L}$ & 11 & & 3.3991 & 0.5280 & 15.0000 \\
\hline K018 & MICP & Antimony & $\mathrm{mg} / \mathrm{L}$ & 1 & $<$ & 0.0600 & 0.0600 & 0.0600 \\
\hline K018 & MICP & Barium & $\mathrm{mg} / \mathrm{L}$ & 2 & & 0.0597 & 0.0580 & 0.0613 \\
\hline K018 & MICP & Beryllium & $\mathrm{mg} / \mathrm{L}$ & 2 & $<$ & 0.0027 & 0.0004 & 0.0050 \\
\hline K018 & MICP & Boron & $\mathrm{mg} / \mathrm{L}$ & 1 & & 0.0720 & 0.0720 & 0.0720 \\
\hline K018 & MICP & Cadmium & $\mathrm{mg} / \mathrm{L}$ & 11 & $<$ & 0.0079 & 0.0005 & 0.0120 \\
\hline K018 & MICP & Calcium & $\mathrm{mg} / \mathrm{L}$ & 1 & & 20.1000 & 20.1000 & 20.1000 \\
\hline K018 & MICP & Cerium & $\mathrm{mg} / \mathrm{L}$ & 1 & $<$ & 0.0200 & 0.0200 & 0.0200 \\
\hline K018 & MICP & Chromium & $\mathrm{mg} / \mathrm{L}$ & 11 & $<$ & 0.0369 & 0.0060 & 0.0500 \\
\hline K018 & MICP & Cobalt & $\mathrm{mg} / \mathrm{L}$ & 2 & $<$ & 0.0260 & 0.0020 & 0.0500 \\
\hline K018 & MICP & Copper & $\mathrm{mg} / \mathrm{L}$ & 11 & $<$ & 0.0106 & 0.0060 & 0.0130 \\
\hline K018 & MICP & Gallium & $\mathrm{mg} / \mathrm{L}$ & 1 & $<$ & 0.0200 & 0.0200 & 0.0200 \\
\hline K018 & MICP & Iron & $\mathrm{mg} / \mathrm{L}$ & 11 & & 2.6294 & 0.2850 & 11.0000 \\
\hline
\end{tabular}


Table A.15 (continued)

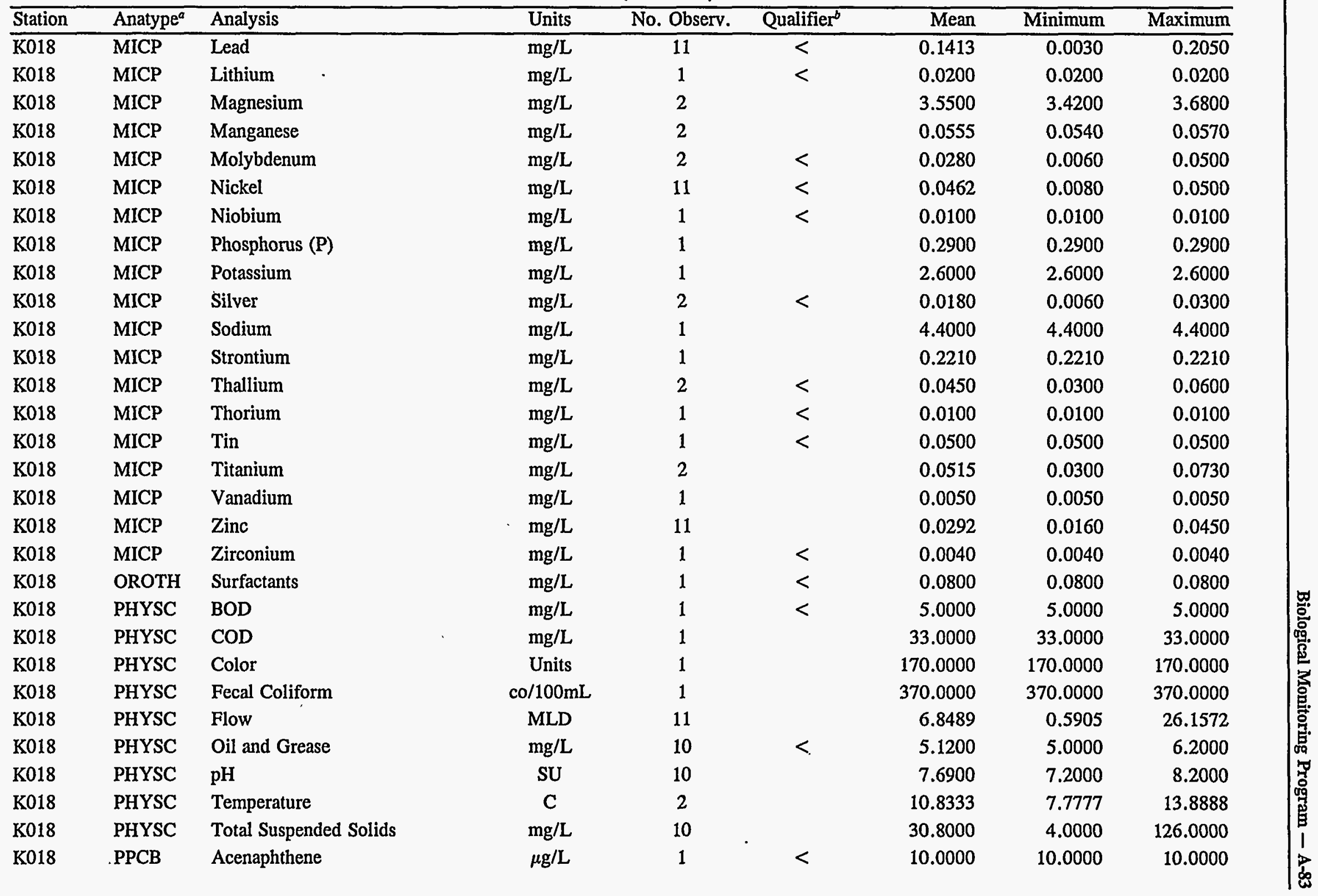


Table A.15 (continued)

\begin{tabular}{|c|c|c|c|c|c|c|c|c|}
\hline Station & Anatype $^{a}$ & Analysis & Units & No. Observ. & Qualifier $^{b}$ & Mean & Minimum & Maximum \\
\hline K018 & PPCB & Acenaphthylene & $\mu \mathrm{g} / \mathrm{L}$ & 1 & $<$ & 10.0000 & 10.0000 & 10.0000 \\
\hline K018 & PPCB & PCB & $\mu \mathrm{g} / \mathrm{L}$ & 10 & $<$ & 0.0930 & 0.0650 & 0.1000 \\
\hline K018 & RADS & $\%$ U-235 & Wt \% & 3 & & 0.5830 & 0.4370 & 0.7110 \\
\hline K018 & RADS & Gross Aipha & $\mathrm{pCi} / \mathrm{L}$ & 1 & & 4.3000 & 4.3000 & 4.3000 \\
\hline K018 & RADS & Gross Beta & $\mathrm{pCi} / \mathrm{L}$ & 1 & & 14.0000 & 14.0000 & 14.0000 \\
\hline K018 & RADS & Neptunium-237 & $\mathrm{pCi} / \mathrm{L}$ & 4 & & 0.1000 & 0.0000 & 0.3000 \\
\hline K018 & RADS & Plutonium-239 & $\mathrm{pCi} / \mathrm{L}$ & 4 & & 0.0250 & 0.0000 & 0.1000 \\
\hline K018 & RADS & Rad Alpha & $\mathrm{pCi} / \mathrm{ml}$ & 6 & $<$ & 1.0000 & 1.0000 & 1.0000 \\
\hline K018 & RADS & Rad Beta & $\mathrm{pCi} / \mathrm{ml}$ & 6 & $<$ & 1.0000 & 1.0000 & 1.0000 \\
\hline K018 & RADS & Radium-226 & $\mathrm{pCi} / \mathrm{L}$ & 1 & & 0.0000 & 0.0000 & 0.0000 \\
\hline K018 & RADS & Suspended Alpha & $\mathrm{pCi} / \mathrm{L}$ & 4 & & -0.5500 & -1.6000 & 0.7000 \\
\hline K018 & RADS & Suspended Beta & $\mathrm{pCi} / \mathrm{L}$ & 4 & & 2.7500 & 2.0000 & 4.0000 \\
\hline K018 & RADS & Technetium-99 & $\mathrm{pCi} / \mathrm{L}$ & 9 & & 29.5556 & 0.0000 & 69.0000 \\
\hline K018 & RADS & Thorium-230 & $\mathrm{pCi} / \mathrm{L}$ & 4 & & 0.4500 & 0.2000 & 1.0000 \\
\hline K018 & RADS & Total Radium & $\mathrm{pCi} / \mathrm{L}$ & 1 & & 0.9000 & 0.9000 & 0.9000 \\
\hline K018 & RADS & Uranium & $\mathrm{mg} / \mathrm{L}$ & 9 & & 0.0074 & 0.0030 & 0.0200 \\
\hline K018 & RADSD & Dissolved Alpha & $\mathrm{pCi} / \mathrm{L}$ & 4 & & 2.1500 & -0.9000 & 3.8000 \\
\hline K018 & RADSD & Dissolved Beta & $\mathrm{pCi} / \mathrm{L}$ & 4 & & 16.5000 & 9.0000 & 24.0000 \\
\hline K018 & SVOA & 1,2,4-Trichlorobenzene & $\mu \mathrm{g} / \mathrm{L}$ & 1 & $<$ & 10.0000 & 10.0000 & 10.0000 \\
\hline K018 & SVOA & 1,2-Diphenylhydrazine & $\mu \mathrm{g} / \mathrm{L}$ & 1 & $<$ & 10.0000 & 10.0000 & 10.0000 \\
\hline K018 & SVOA & 2,4,6-Trichlorophenol & $\mu \mathrm{g} / \mathrm{L}$ & 1 & $<$ & 10.0000 & 10.0000 & 10.0000 \\
\hline KO18 & SVOA & 2,4-Dichlorophenol & $\mu \mathrm{g} / \mathrm{L}$ & 1 & $<$ & 10.0000 & 10.0000 & 10.0000 \\
\hline K018 & SVOA & 2,4-Dimethylphenol & $\mu \mathrm{g} / \mathrm{L}$ & 1 & $<$ & 10.0000 & 10.0000 & 10.0000 \\
\hline K018 & SVOA & 2,4-Dinitrophenol & $\mu \mathrm{g} / \mathrm{L}$ & 1 & $<$ & 10.0000 & 10.0000 & 10.0000 \\
\hline K018 & SVOA & 2,4-Dinitrotoluene & $\mu \mathrm{g} / \mathrm{L}$ & 1 & $<$ & 10.0000 & 10.0000 & 10.0000 \\
\hline K018 & SVOA & 2,6-Dinitrotoluene & $\mu \mathrm{g} / \mathrm{L}$ & 1 & $<$ & 10.0000 & 10.0000 & 10.0000 \\
\hline K018 & SVOA & 2-Chloroethyl Vinyl Ether & $\mu \mathrm{g} / \mathrm{L}$ & 1 & $<$ & 10.0000 & 10.0000 & 10.0000 \\
\hline K018 & SVOA & 2-Chloronaphthalene & $\mu \mathrm{g} / \mathrm{L}$ & 1 & $<$ & 10.0000 & 10.0000 & 10.0000 \\
\hline K018 & SVOA & 2-Chlorophenol & $\mu \mathrm{g} / \mathrm{L}$ & 1 & $<$ & 10.0000 & 10.0000 & 10.0000 \\
\hline K018 & SVOA & 2-Nitrophenol & $\mu \mathrm{g} / \mathrm{L}$ & 1 & $<$ & 10.0000 & 10.0000 & 10.0000 \\
\hline
\end{tabular}


Table A.15 (continued)

\begin{tabular}{|c|c|c|c|c|c|c|c|c|}
\hline Station & Anatype $^{a}$ & Analysis & Units & No. Observ. & Qualifier $^{b}$ & Mean & Minimum & Maximum \\
\hline K018 & SVOA & 3,3'-Dichlorobenzidine & $\mu \mathrm{g} / \mathrm{L}$ & 1 & $<$ & 10.0000 & 10.0000 & 10.0000 \\
\hline K018 & SVOA & 4,6-Dinitro-2-methylphenol & $\mu \mathrm{g} / \mathrm{L}$ & 1 & $<$ & 10.0000 & 10.0000 & 10.0000 \\
\hline K018 & SVOA & 4-Bromophenyl-phenylether & $\mu \mathrm{g} / \mathrm{L}$ & 1 & $<$ & 10.0000 & 10.0000 & 10.0000 \\
\hline K018 & SVOA & 4-Chloro-3-methylphenol & $\mu \mathrm{g} / \mathrm{L}$ & 1 & $<$ & 10.0000 & 10.0000 & 10.0000 \\
\hline K018 & SVOA & 4-Chlorophenyl-phenylether & $\mu \mathrm{g} / \mathrm{L}$ & 1 & $<$ & 10.0000 & 10.0000 & 10.0000 \\
\hline K018 & SVOA & 4-Nitrophenol & $\mu \mathrm{g} / \mathrm{L}$ & 1 & $<$ & 10.0000 & 10.0000 & 10.0000 \\
\hline K018 & SVOA & Anthracene & $\mu \mathrm{g} / \mathrm{L}$ & 1 & $<$ & 10.0000 & 10.0000 & 10.0000 \\
\hline K018 & SVOA & Benzo(a)anthracene & $\mu \mathrm{g} / \mathrm{L}$ & 1 & $<$ & 10.0000 & 10.0000 & 10.0000 \\
\hline K018 & SVOA & Benzo(a)pyrene & $\mu \mathrm{g} / \mathrm{L}$ & 1 & $<$ & 10.0000 & 10.0000 & 10.0000 \\
\hline K018 & SVOA & Benzo(b)fluoranthene & $\mu \mathrm{g} / \mathrm{L}$ & 1 & $<$ & 10.0000 & 10.0000 & 10.0000 \\
\hline K018 & SVOA & Benzo(g,h,i)perylenc & $\mu \mathrm{g} / \mathrm{L}$ & 1 & $<$ & 10.0000 & 10.0000 & 10.0000 \\
\hline K018 & SVOA & Benzo(k)fluoranthene & $\mu \mathrm{g} / \mathrm{L}$ & 1 & $<$ & 10.0000 & 10.0000 & 10.0000 \\
\hline K018 & SVOA & Benzyl Butyl Phthalate & $\mu \mathrm{g} / \mathrm{L}$ & 1 & $<$ & 10.0000 & 10.0000 & 10.0000 \\
\hline K018 & SVOA & bis(2-Chloroethoxy)methane & $\mu \mathrm{g} / \mathrm{L}$ & 1 & $<$ & 10.0000 & 10.0000 & 10.0000 \\
\hline K018 & SVOA & bis(2-Chloroethyl)ether & $\mu \mathrm{g} / \mathrm{L}$ & 1 & $<$ & 10.0000 & 10.0000 & 10.0000 \\
\hline K018 & SVOA & bis(2-Chloroisopropyl)ether & $\mu \mathrm{g} / \mathrm{L}$ & 1 & $<$ & 10.0000 & 10.0000 & 10.0000 \\
\hline K018 & SVOA & bis(2-Ethylhexyl)phthalate & $\mu \mathrm{g} / \mathrm{L}$ & 1 & & 2.0000 & 2.0000 & 2.0000 \\
\hline K018 & SVOA & Chrysene & $\mu \mathrm{g} / \mathrm{L}$ & 1 & $<$ & 10.0000 & 10.0000 & 10.0000 \\
\hline K018 & SVOA & Di-n-butylphthalate & $\mu \mathrm{g} / \mathrm{L}$ & 1 & $<$ & 10.0000 & 10.0000 & 10.0000 \\
\hline K018 & SVOA & Di-n-octylphthalate & $\mu \mathrm{g} / \mathrm{L}$ & 1 & $<$ & 10.0000 & 10.0000 & 10.0000 \\
\hline K018 & SVOA & Dibenzo(a,h)anthracene & $\mu \mathrm{g} / \mathrm{L}$ & 1 & $<$ & 10.0000 & 10.0000 & 10.0000 \\
\hline K018 & SVOA & Diethylphthalate & $\mu \mathrm{g} / \mathrm{L}$ & 1 & $<$ & 10.0000 & 10.0000 & 10.0000 \\
\hline K018 & SVOA & Dimethylphthalate & $\mu \mathrm{g} / \mathrm{L}$ & 1 & $<$ & 10.0000 & 10.0000 & 10.0000 \\
\hline K018 & SVOA & Fluoranthene & $\mu \mathrm{g} / \mathrm{L}$ & 1 & $<$ & 10.0000 & 10.0000 & 10.0000 \\
\hline K018 & SVOA & Fluorene & $\mu \mathrm{g} / \mathrm{L}$ & 1 & $<$ & 10.0000 & 10.0000 & 10.0000 \\
\hline K018 & SVOA & Hexachlorobenzene & $\mu \mathrm{g} / \mathrm{L}$ & 1 & $<$ & 10.0000 & 10.0000 & 10.0000 \\
\hline K018 & SVOA & Hexachlorobutadiene & $\mu \mathrm{g} / \mathrm{L}$ & 1 & $<$ & 10.0000 & 10.0000 & 10.0000 \\
\hline K018 & SVOA & Hexachlorocyclopentadiene & $\mu \mathrm{g} / \mathrm{L}$ & 1 & $<$ & 10.0000 & 10.0000 & 10.0000 \\
\hline K018 & SVOA & Hexachloroethane & $\mu \mathrm{g} / \mathrm{L}$ & 1 & $<$ & 10.0000 & 10.0000 & 10.0000 \\
\hline K018 & SVOA & Indeno(1,2,3-cd)pyrene & $\mu \mathrm{g} / \mathrm{L}$ & 1 & $<$ & 10.0000 & 10.0000 & 10.0000 \\
\hline
\end{tabular}


Table A.15 (continued)

\begin{tabular}{|c|c|c|c|c|c|c|c|c|}
\hline Station & Anatype $^{a}$ & Analysis & Units & No. Observ. & Qualifier $^{b}$ & Mean & Minimum & Maximum \\
\hline K018 & SVOA & Isophorone & $\mu \mathrm{g} / \mathrm{L}$ & 1 & $<$ & 10.0000 & 10.0000 & 10.0000 \\
\hline K018 & SVOA & N-Nitroso-di-n-propylamine & $\mu \mathrm{g} / \mathrm{L}$ & 1 & $<$ & 10.0000 & 10.0000 & 10.0000 \\
\hline K018 & SVOA & N-Nitrosodimethylamine & $\mu \mathrm{g} / \mathrm{L}$ & 1 & $<$ & 10.0000 & 10.0000 & 10.0000 \\
\hline K018 & SVOA & N-Nitrosodiphenylamine & $\mu \mathrm{g} / \mathrm{L}$ & 1 & $<$ & 10.0000 & 10.0000 & 10.0000 \\
\hline K018 & SVOA & Naphthalene & $\mu \mathrm{g} / \mathrm{L}$ & 1 & $<$ & 10.0000 & 10.0000 & 10.0000 \\
\hline K018 & SVOA & Nitrobenzene & $\mu \mathrm{g} / \mathrm{L}$ & 1 & $<$ & 10.0000 & 10.0000 & 10.0000 \\
\hline K018 & SVOA & Pentachlorophenol & $\mu \mathrm{g} / \mathrm{L}$ & 1 & $<$ & 10.0000 & 10.0000 & 10.0000 \\
\hline K018 & SVOA & Phenanthrene & $\mu \mathrm{g} / \mathrm{L}$ & 1 & $<$ & 10.0000 & 10.0000 & 10.0000 \\
\hline K018 & SVOA & Phenol & $\mu \mathrm{g} / \mathrm{L}$ & 2 & $<$ & 7.5000 & 5.0000 & 10.0000 \\
\hline K018 & SVOA & Pyrene & $\mu \mathrm{g} / \mathrm{L}$ & 1 & $<$ & 10.0000 & 10.0000 & 10.0000 \\
\hline K018 & VOA & 1,1,1-Trichloroethane & $\mu \mathrm{g} / \mathrm{L}$ & 1 & $<$ & 10.0000 & 10.0000 & 10.0000 \\
\hline K018 & VOA & 1,1,2,2-Tetrachloroethane & $\mu \mathrm{g} / \mathrm{L}$ & 1 & $<$ & 10.0000 & 10.0000 & 10.0000 \\
\hline K018 & VOA & 1,1,2-Trichloroethane & $\mu \mathrm{g} / \mathrm{L}$ & 1 & $<$ & 10.0000 & 10.0000 & 10.0000 \\
\hline K018 & VOA & 1,1-Dichloroethane & $\mu \mathrm{g} / \mathrm{L}$ & 1 & $<$ & 10.0000 & 10.0000 & 10.0000 \\
\hline K018 & VOA & 1,1-Dichloroethene & $\mu \mathrm{g} / \mathrm{L}$ & 1 & $<$ & 10.0000 & 10.0000 & 10.0000 \\
\hline K018 & VOA & 1,2-Dichlorobenzene & $\mu \mathrm{g} / \mathrm{L}$ & 1 & $<$ & 10.0000 & 10.0000 & 10.0000 \\
\hline K018 & VOA & 1,2-Dichloroethane & $\mu \mathrm{g} / \mathrm{L}$ & 1 & $<$ & 10.0000 & 10.0000 & 10.0000 \\
\hline K018 & VOA & 1,2-Dichloropropane & $\mu \mathrm{g} / \mathrm{L}$ & 1 & $<$ & 10.0000 & 10.0000 & 10.0000 \\
\hline K018 & VOA & 1,3-Dichlorobenzene & $\mu \mathrm{g} / \mathrm{L}$ & 1 & $<$ & 10.0000 & 10.0000 & 10.0000 \\
\hline K018 & VOA & 1,4-Dichlorobenzene & $\mu \mathrm{g} / \mathrm{L}$ & 1 & $<$ & 10.0000 & 10.0000 & 10.0000 \\
\hline K018 & VOA & Acrolein & $\mu \mathrm{g} / \mathrm{L}$ & 1 & $<$ & 10.0000 & 10.0000 & 10.0000 \\
\hline K018 & VOA & Acrylonitrile & $\mu \mathrm{g} / \mathrm{L}$ & 1 & $<$ & 10.0000 & 10.0000 & 10.0000 \\
\hline K018 & VOA & Benzene & $\mu \mathrm{g} / \mathrm{L}$ & 1 & $<$ & 10.0000 & 10.0000 & 10.0000 \\
\hline K018 & VOA & Benzidine & $\mu \mathrm{g} / \mathrm{L}$ & 1 & $<$ & 10.0000 & 10.0000 & 10.0000 \\
\hline K018 & VOA & Bromodichloromethane & $\mu \mathrm{g} / \mathrm{L}$ & 1 & $<$ & 10.0000 & 10.0000 & 10.0000 \\
\hline K018 & VOA & Bromoform & $\mu \mathrm{g} / \mathrm{L}$ & 1 & $<$ & 10.0000 & 10.0000 & 10.0000 \\
\hline K018 & VOA & Bromomethane & $\mu \mathrm{g} / \mathrm{L}$ & 1 & $<$ & 10.0000 & 10.0000 & 10.0000 \\
\hline K018 & VOA & Carbon Tetrachloride & $\mu \mathrm{g} / \mathrm{L}$ & 1 & $<$ & 10.0000 & 10.0000 & 10.0000 \\
\hline K018 & VOA & Chlorobenzene & $\mu \mathrm{g} / \mathrm{L}$ & 1 & $<$ & 10.0000 & 10.0000 & 10.0000 \\
\hline K018 & VOA & Chloroethane & $\mu \mathrm{g} / \mathrm{L}$ & 1 & $<$ & 10.0000 & 10.0000 & 10.0000 \\
\hline
\end{tabular}


Table A.15 (continued)

\begin{tabular}{|c|c|c|c|c|c|c|c|c|}
\hline Station & Anatype $^{a}$ & Analysis & Units & No. Observ. & Qualifier $^{b}$ & Mean & Minimum & Maximum \\
\hline K018 & $\mathrm{VOA}$ & Chloroform & $\mu \mathrm{g} / \mathrm{L}$ & 1 & $<$ & 10.0000 & 10.0000 & 10.0000 \\
\hline K018 & VOA & Chloromethane & $\mu \mathrm{g} / \mathrm{L}$ & 1 & $<$ & 10.0000 & 10.0000 & 10.0000 \\
\hline K018 & VOA & cis-1,3-Dichloropropene & $\mu \mathrm{g} / \mathrm{L}$ & 1 & $<$ & 10.0000 & 10.0000 & 10.0000 \\
\hline K018 & VOA & Dibromochloromethane & $\mu \mathrm{g} / \mathrm{L}$ & 1 & $<$ & 10.0000 & 10.0000 & 10.0000 \\
\hline K018 & VOA & Dichlorodifluoromethane & $\mu \mathrm{g} / \mathrm{L}$ & 1 & $<$ & 10.0000 & 10.0000 & 10.0000 \\
\hline K018 & VOA & Ethylbenzene & $\mu \mathrm{g} / \mathrm{L}$ & 1 & $<$ & 10.0000 & 10.0000 & 10.0000 \\
\hline K018 & VOA & Methylene Chloride & $\mu \mathrm{g} / \mathrm{L}$ & 1 & $<$ & 10.0000 & 10.0000 & 10.0000 \\
\hline K018 & VOA & Tetrachlorodibenzo-p-dioxin & $\mathrm{ng} / \mathrm{L}$ & 1 & & 0.3800 & 0.3800 & 0.3800 \\
\hline K018 & VOA & Tetrachloroethene & $\mu \mathrm{g} / \mathrm{L}$ & 1 & $<$ & 10.0000 & 10.0000 & 10.0000 \\
\hline K018 & VOA & Toluene & $\mu \mathrm{g} / \mathrm{L}$ & 1 & $<$ & 10.0000 & 10.0000 & 10.0000 \\
\hline K018 & VOA & Trans-1,2-Dichloroethene & $\mu \mathrm{g} / \mathrm{L}$ & 1 & $<$ & 10.0000 & 10.0000 & 10.0000 \\
\hline K018 & VOA & Trans-1,3-Dichloropropene & $\mu \mathrm{g} / \mathrm{L}$ & 1 & $<$ & 10.0000 & 10.0000 & 10.0000 \\
\hline K018 & VOA & Trichloroethene & $\mu \mathrm{g} / \mathrm{L}$ & 10 & $<$ & 1.9000 & 1.0000 & 10.0000 \\
\hline K018 & VOA & Trichlorofluoromethane & $\mu \mathrm{g} / \mathrm{L}$ & 1 & $<$ & 10.0000 & 10.0000 & 10.0000 \\
\hline K018 & VOA & Vinyl Chloride & $\mu \mathrm{g} / \mathrm{L}$ & 1 & $<$ & 10.0000 & 10.0000 & 10.0000 \\
\hline
\end{tabular}

Note: Data provided by L. S. Crabtree, Information Services, Paducah Gaseous Diffusion Plant.

${ }^{a}$ ANION $=$ a negatively charged ion; CATION $=$ a positively charged ion; $\mathrm{CHEM}=$ chemical parameters; $\mathrm{MAA}=$ metals by atomic absorption; $\mathrm{MIC}=$ metals by inductively-coupled plasma/mass spectroscopy; OROTH $=$ other organics, PHYSC $=$ physical and field measurements; PPCB $=$ pesticides/polychlorinated biphenyls; RADS $=$ radiochemical analysis; RADSD = radiochemical analysis, dissolved; SVOA = semivolatile organics; VOA = volatile organics.

${ }^{\circ} \mathrm{A}$ " $<$ " qualifier was added to the mean when $\geq 50 \%$ of the observations had " $<$ " qualifiers. 

Appendix B

TOXICITY MONITORING 

Table B.1. Results of fathead minnow toxicity tests of continuously flowing effluents at the Paducah Gaseous Diffusion Plant

Tests conducted October 1991-November 1994

\begin{tabular}{|c|c|c|c|c|c|c|}
\hline \multirow[t]{2}{*}{ Date } & \multirow[t]{2}{*}{ Outfall } & \multirow[t]{2}{*}{ Conc. } & & \multicolumn{2}{|c|}{$\begin{array}{c}\text { Growth } \\
\text { (mg/larvae) }\end{array}$} \\
\hline & & & Mean & $\mathrm{SD}$ & Mean & SD \\
\hline \multirow[t]{31}{*}{ October 1991} & Control & 100 & 97.5 & 5.0 & 0.15 & 0.03 \\
\hline & 001 & 6 & 100.0 & 0.0 & 0.18 & 0.01 \\
\hline & & 12 & 95.0 & 10.0 & 0.20 & 0.04 \\
\hline & & 25 & 97.5 & 5.0 & 0.18 & 0.01 \\
\hline & & 50 & 82.5 & 5.0 & 0.12 & 0.03 \\
\hline & & 100 & 92.5 & 5.0 & 0.22 & 0.04 \\
\hline & 004 & 6 & 85.0 & 19.2 & 0.17 & 0.04 \\
\hline & & 12 & 97.5 & 5.0 & 0.19 & 0.04 \\
\hline & & 25 & 92.5 & 9.6 & 0.13 & 0.04 \\
\hline & & 50 & 87.5 & 12.6 & 0.18 & 0.01 \\
\hline & & 100 & 65.0 & 5.8 & 0.12 & 0.04 \\
\hline & 006 & 6 & 100.0 & 0.0 & 0.22 & 0.05 \\
\hline & & 12 & 97.5 & 5.0 & 0.20 & 0.04 \\
\hline & & 25 & 97.5 & 5.0 & 0.23 & 0.03 \\
\hline & & 50 & 72.5 & $48.6^{\circ}$ & 0.20 & 0.01 \\
\hline & & 100 & 92.5 & 9.6 & 0.16 & 0.05 \\
\hline & 008 & 6 & 95.0 & 10.0 & 0.14 & 0.01 \\
\hline & & 12 & 77.5 & 15.0 & 0.12 & 0.04 \\
\hline & & 25 & 57.5 & 43.5 & 0.12 & 0.02 \\
\hline & & 50 & 90.0 & 14.1 & 0.13 & 0.03 \\
\hline & & 100 & 72.5 & 26.3 & 0.11 & 0.02 \\
\hline & 009 & 6 & 87.5 & 12.6 & 0.16 & 0.03 \\
\hline & & 12 & 77.5 & 18.9 & 0.13 & 0.02 \\
\hline & & 25 & 82.5 & 9.6 & 0.13 & 0.06 \\
\hline & & 50 & 95.0 & 5.8 & 0.11 & 0.03 \\
\hline & & 100 & 95.0 & 5.8 & 0.13 & 0.03 \\
\hline & 011 & 6 & 92.5 & 5.0 & .0 .19 & 0.07 \\
\hline & & 12 & 95.0 & 5.8 & 0.13 & 0.06 \\
\hline & & 25 & 90.0 & 14.1 & 0.17 & 0.05 \\
\hline & & 50 & 90.0 & 8.2 & 0.18 & 0.02 \\
\hline & & 100 & 97.5 & 5.0 & 0.10 & 0.03 \\
\hline \multirow[t]{5}{*}{ February 1992} & Control & 100 & 97.5 & 5.0 & 0.48 & 0.06 \\
\hline & 001 & 25 & 97.5 & 5.0 & 0.50 & 0.08 \\
\hline & & 50 & 100.0 & 0.0 & 0.49 & 0.10 \\
\hline & & 100 & 87.5 & 12.6 & 0.63 & 0.07 \\
\hline & 004 & 25 & 100.0 & 0.0 & 0.33 & 0.08 \\
\hline
\end{tabular}


Table B.1 (continued)

\begin{tabular}{|c|c|c|c|c|c|c|}
\hline \multirow[t]{2}{*}{ Date } & \multirow[t]{2}{*}{ Outfall } & \multirow[t]{2}{*}{ Conc. } & \multicolumn{2}{|c|}{ Survival (\%) } & \multicolumn{2}{|c|}{$\begin{array}{c}\text { Growth } \\
\text { (mg/larvae) }\end{array}$} \\
\hline & & & Mean & $S D$ & Mean & SD \\
\hline & & 50 & 97.5 & 5.0 & 0.36 & 0.03 \\
\hline & & 100 & 95.0 & 5.8 & 0.38 & 0.09 \\
\hline & 006 & 25 & 97.5 & 5.0 & 0.34 & 0.09 \\
\hline & & 50 & 97.5 & 5.0 & 0.39 & 0.09 \\
\hline & & 100 & 97.5 & 5.0 & 0.35 & 0.07 \\
\hline & 008 & 12 & 60.0 & 42.4 & 0.47 & 0.06 \\
\hline & & 25 & 87.5 & 25.0 & 0.44 & 0.05 \\
\hline & & 50 & 80.0 & 21.6 & 0.44 & 0.03 \\
\hline & & 100 & 60.0 & 21.6 & 0.36 & 0.11 \\
\hline & 009 & 25 & 60.0 & 33.7 & 0.36 & 0.04 \\
\hline & & 50 & 80.0 & 8.2 & 0.33 & 0.05 \\
\hline & & 100 & 82.5 & 17.1 & 0.38 & 0.06 \\
\hline & 011 & 25 & 65.0 & 28.9 & 0.42 & 0.08 \\
\hline & & 50 & 65.0 & 5.8 & 0.30 & 0.08 \\
\hline & & 100 & 80.0 & 16.3 & 0.31 & 0.04 \\
\hline \multirow[t]{24}{*}{ May 1992} & Control & 100 & 97.5 & 5.0 & 0.17 & 0.02 \\
\hline & 001 & 12 & 100.0 & 0.0 & 0.19 & 0.04 \\
\hline & & 25 & 100.0 & 0.0 & 0.19 & 0.03 \\
\hline & & 50 & 92.5 & 9.6 & 0.23 & 0.04 \\
\hline & & 100 & 100.0 & 0.0 & 0.23 & 0.03 \\
\hline & 004 & 12 & 85.0 & 5.8 & 0.20 & 0.02 \\
\hline & & 25 & 85.0 & 10.0 & 0.17 & 0.05 \\
\hline & & 50 & 97.5 & 5.0 & 0.18 & 0.02 \\
\hline & & 100 & 97.5 & 5.0 & 0.15 & 0.03 \\
\hline & 006 & 12 & 72.5 & 22.2 & 0.26 & 0.06 \\
\hline & & 25 & 85.0 & 17.3 & 0.18 & 0.03 \\
\hline & & 50 & 97.5 & 5.0 & 0.16 & 0.03 \\
\hline & & 100 & 65.0 & 37.9 & 0.26 & 0.17 \\
\hline & 008 & 12 & 87.5 & 12.6 & 0.22 & 0.06 \\
\hline & & 25 & 72.5 & 22.2 & 0.23 & 0.05 \\
\hline & & 50 & 75.0 & 12.9 & 0.23 & 0.04 \\
\hline & & 100 & 80.0 & 14.1 & 0.21 & 0.08 \\
\hline & 009 & 12 & 92.5 & 5.0 & 0.24 & 0.02 \\
\hline & & 25 & 75.0 & 31.1 & 0.27 & 0.05 \\
\hline & & 50 & 60.0 & 39.2 & 0.30 & 0.08 \\
\hline & & 100 & 67.5 & 28.7 & 0.24 & 0.02 \\
\hline & 011 & 12 & 100.0 & 0.0 & 0.22 & 0.02 \\
\hline & & 25 & 100.0 & 0.0 & 0.23 & 0.02 \\
\hline & - & 50 & 95.0 & 10.0 & 0.27 & 0.03 \\
\hline
\end{tabular}


Table B.1 (continued)

\begin{tabular}{|c|c|c|c|c|c|c|}
\hline \multirow[t]{2}{*}{ Date } & \multirow[t]{2}{*}{ Outfall } & \multirow[t]{2}{*}{ Conc. } & \multicolumn{2}{|c|}{ Survival (\%) } & \multicolumn{2}{|c|}{$\begin{array}{c}\text { Growth } \\
\text { (mg/larvae) }\end{array}$} \\
\hline & & & Mean & SD & Mean & $\mathrm{SD}$ \\
\hline & & 100 & 97.5 & 5.0 & 0.20 & 0.04 \\
\hline \multirow[t]{25}{*}{ August 1992} & Control & 100 & 100.0 & 0.0 & 0.68 & 0.11 \\
\hline & 001 & 12 & 97.5 & 5.0 & 0.63 & 0.03 \\
\hline & & 25 & 90.0 & 8.2 & 0.67 & 0.09 \\
\hline & & 50 & 100.0 & 0.0 & 0.70 & 0.14 \\
\hline & & 100 & 100.0 & 0.0 & 0.68 & 0.07 \\
\hline & 004 & 12 & 100.0 & 0.0 & 0.60 & 0.10 \\
\hline & & 25 & 97.5 & 5.0 & 0.58 & 0.13 \\
\hline & & 50 & 100.0 & 0.0 & 0.56 & 0.12 \\
\hline & & 100 & 97.5 & 5.0 & 0.59 & 0.03 \\
\hline & 006 & 12 & 100.0 & 0.0 & 0.67 & 0.15 \\
\hline & & 25 & 100.0 & 0.0 & 0.67 & 0.03 \\
\hline & & 50 & 97.5 & 5.0 & 0.64 & 0.10 \\
\hline & & 100 & 100.0 & 0.0 & 0.62 & 0.10 \\
\hline & 008 & 12 & 97.5 & 5.0 & 0.69 & 0.09 \\
\hline & & 25 & 97.5 & 5.0 & 0.65 & 0.05 \\
\hline & & 50 & 100.0 & 0.0 & 0.65 & 0.06 \\
\hline & & 100 & 92.5 & 9.6 & 0.60 & 0.06 \\
\hline & 009 & 12 & 95.0 & 5.8 & 0.68 & 0.06 \\
\hline & & 25 & 97.5 & 5.0 & 0.61 & 0.11 \\
\hline & & 50 & 100.0 & 0.0 & 0.55 & 0.08 \\
\hline & & 100 & 100.0 & 0.0 & 0.65 & 0.05 \\
\hline & 011 & 12 & 100.0 & 0.0 & 0.64 & 0.10 \\
\hline & & 25 & 100.0 & 0.0 & 0.63 & 0.03 \\
\hline & & 50 & 100.0 & 0.0 & 0.59 & 0.03 \\
\hline & & 100 & 95.0 & 5.8 & 0.56 & 0.10 \\
\hline \multirow[t]{13}{*}{ October 1992} & Control & 100 & 100.0 & 0.0 & 0.47 & 0.02 \\
\hline & 001 & 12 & 92.5 & 5.0 & 0.56 & 0.05 \\
\hline & & 25 & 97.5 & 5.0 & 0.55 & 0.03 \\
\hline & & 50 & 97.5 & 5.0 & 0.51 & 0.06 \\
\hline & & 100 & 97.5 & 5.0 & 0.63 & 0.03 \\
\hline & 004 & 12 & 97.5 & 5.0 & 0.44 & 0.08 \\
\hline & & 25 & 100.0 & 0.0 & 0.48 & 0.04 \\
\hline & & 50 & 100.0 & 0.0 & 0.51 & 0.03 \\
\hline & & 100 & 100.0 & 0.0 & 0.48 & 0.02 \\
\hline & 006 & 12 & 100.0 & 0.0 & 0.53 & 0.05 \\
\hline & & 25 & 97.5 & 5.0 & 0.57 & 0.02 \\
\hline & & 50 & 100.0 & 0.0 & 0.62 & 0.03 \\
\hline & & 100 & 95.0 & 10.0 & 0.47 & 0.05 \\
\hline
\end{tabular}


Table B.1 (continued)

\begin{tabular}{|c|c|c|c|c|c|c|}
\hline \multirow[t]{2}{*}{ Date } & \multirow[t]{2}{*}{ Outfall } & \multirow[t]{2}{*}{ Conc. } & \multicolumn{2}{|c|}{ Survival (\%) } & \multicolumn{2}{|c|}{$\begin{array}{c}\text { Growth } \\
\text { (mg/larvae) }\end{array}$} \\
\hline & & & Mean & SD & Mean & SD \\
\hline & 008 & 12 & 100.0 & 0.0 & 0.49 & 0.04 \\
\hline & & 25 & 92.5 & 9.6 & 0.49 & 0.07 \\
\hline & & 50 & 100.0 & 0.0 & 0.52 & 0.07 \\
\hline & & 100 & 97.5 & 5.0 & 0.45 & 0.07 \\
\hline & 009 & 12 & 95.0 & 5.8 & 0.53 & 0.08 \\
\hline & & 25 & 82.5 & 28.7 & 0.55 & 0.07 \\
\hline & & 50 & 70.0 & 25.8 & 0.50 & 0.05 \\
\hline & & 100 & 82.5 & 9.6 & 0.47 & 0.08 \\
\hline & 011 & 12 & 90.0 & 8.2 & 0.51 & 0.05 \\
\hline & & 25 & 95.0 & 5.8 & 0.54 & 0.09 \\
\hline & & 50 & 97.5 & 5.0 & 0.49 & 0.02 \\
\hline & & 100 & 90.0 & 14.1 & 0.45 & 0.04 \\
\hline \multirow[t]{26}{*}{ February 1993} & Control & 100 & 92.5 & 9.6 & 0.63 & 0.09 \\
\hline & 001 & 6 & 92.5 & 5.0 & 0.68 & 0.07 \\
\hline & & 12 & 92.5 & 15.0 & 0.65 & 0.16 \\
\hline & & 25 & 87.5 & 15.0 & 0.62 & 0.03 \\
\hline & & 50 & 82.5 & 5.0 & 0.70 & 0.06 \\
\hline & & 100 & 92.5 & 5.0 & 0.68 & 0.03 \\
\hline & 006 & 6 & 92.5 & 9.6 & 0.66 & 0.10 \\
\hline & & 12 & 90.0 & 14.1 & 0.69 & 0.02 \\
\hline & & 25 & 92.5 & 9.6 & 0.64 & 0.06 \\
\hline & & 50 & 95.0 & 5.8 & 0.61 & 0.12 \\
\hline & & 100 & 95.0 & 10.0 & 0.62 & 0.03 \\
\hline & 008 & 6 & 85.0 & 12.9 & 0.73 & 0.06 \\
\hline & & 12 & 97.5 & 5.0 & 0.71 & 0.09 \\
\hline & & 25 & 97.5 & 5.0 & 0.77 & 0.11 \\
\hline & & 50 & 95.0 & 5.8 & 0.74 & 0.04 \\
\hline & & 100 & 95.0 & 5.8 & 0.70 & 0.07 \\
\hline & 009 & 6 & 97.5 & 5.0 & 0.75 & 0.03 \\
\hline & & 12 & 82.5 & 5.0 & 0.88 & 0.07 \\
\hline & & 25 & 85.0 & 12.9 & 0.78 & 0.05 \\
\hline & & 50 & 95.0 & 5.8 & 0.86 & 0.06 \\
\hline & & 100 & 95.0 & 5.8 & 0.78 & 0.05 \\
\hline & 011 & 6 & 82.5 & 9.6 & 0.79 & 0.04 \\
\hline & . & 12 & 92.5 & 9.6 & 0.80 & 0.06 \\
\hline & & 25 & 97.5 & 5.0 & 0.80 & 0.06 \\
\hline & & 50 & 95.0 & 10.0 & 0.89 & 0.03 \\
\hline & & 100 & 97.5 & 5.0 & 0.75 & 0.02 \\
\hline May 1993 & Control & 100 & 100.0 & 0.0 & 0.43 & 0.02 \\
\hline
\end{tabular}


Table B.1 (continued)

\begin{tabular}{|c|c|c|c|c|c|c|}
\hline \multirow[t]{2}{*}{ Date } & \multirow[t]{2}{*}{ Outfall } & \multirow[t]{2}{*}{ Conc. } & \multicolumn{2}{|c|}{ Survival (\%) } & \multicolumn{2}{|c|}{$\begin{array}{c}\text { Growth } \\
\text { (mg/larvae) }\end{array}$} \\
\hline & & & Mean & SD & Mean & SD \\
\hline & 001 & 6 & 87.5 & 9.6 & 0.37 & 0.01 \\
\hline & & 12 & 90.0 & 8.2 & 0.37 & 0.06 \\
\hline & & 25 & 92.5 & 5.0 & 0.43 & 0.05 \\
\hline & & 50 & 90.0 & 11.6 & 0.47 & 0.07 \\
\hline & & 100 & 92.5 & 9.6 & 0.49 & 0.10 \\
\hline & 006 & 6 & 100.0 & 0.0 & 0.45 & 0.03 \\
\hline & & 12 & 100.0 & 0.0 & 0.40 & 0.02 \\
\hline & & 25 & 80.0 & 33.7 & 0.48 & 0.09 \\
\hline & & 50 & 80.0 & 21.6 & 0.48 & 0.04 \\
\hline & & 100 & 97.5 & 5.0 & 0.42 & 0.05 \\
\hline & 008 & 6 & 90.0 & 14.1 & 0.47 & 0.05 \\
\hline & & 12 & 97.5 & 5.0 & 0.45 & 0.04 \\
\hline & & 25 & 90.0 & 0.0 & 0.52 & 0.07 \\
\hline & & 50 & 95.0 & 10.0 & 0.45 & 0.07 \\
\hline & & 100 & 92.5 & 9.6 & 0.52 & 0.08 \\
\hline & 009 & 6 & 95.0 & 10.0 & 0.43 & 0.04 \\
\hline & & 12 & 95.0 & 5.8 & 0.52 & 0.07 \\
\hline & & 25 & 87.5 & 5.0 & 0.49 & 0.06 \\
\hline & & 50 & 92.5 & 5.0 & 0.47 & 0.04 \\
\hline & & 100 & 90.0 & 14.1 & 0.43 & 0.08 \\
\hline & 011 & 6 & 100.0 & 0.0 & 0.47 & 0.02 \\
\hline & & 12 & 90.0 & 11.6 & 0.47 & 0.06 \\
\hline & . & 25 & 90.0 & 8.2 & 0.46 & 0.04 \\
\hline & & 50 & 95.0 & 5.8 & 0.46 & 0.03 \\
\hline & & 100 & 95.0 & 10.0 & 0.37 & 0.02 \\
\hline \multirow[t]{14}{*}{ August 1993} & Control & 100 & 97.5 & 5.0 & 0.36 & 0.05 \\
\hline & 001 & 6 & 97.5 & 5.0 & 0.41 & 0.02 \\
\hline & & 12 & 100.0 & 0.0 & 0.40 & 0.02 \\
\hline & & 25 & 92.5 & 15.0 & 0.40 & 0.04 \\
\hline & & 50 & 92.5 & 9.6 & 0.43 & 0.06 \\
\hline & & 100 & 100.0 & 0.0 & 0.43 & 0.02 \\
\hline & 006 & 6 & 95.0 & 5.8 & 0.40 & 0.04 \\
\hline & & 12 & 97.5 & 5.0 & 0.44 & 0.08 \\
\hline & & 25 & 97.5 & 5.0 & 0.44 & 0.03 \\
\hline & & 50 & 100.0 & 0.0 & 0.41 & 0.03 \\
\hline & & 100 & 92.5 & 9.6 & 0.43 & 0.07 \\
\hline & 008 & 6 & 95.0 & 10.0 & 0.36 & 0.05 \\
\hline & & 12 & 92.5 & 9.6 & 0.45 & 0.08 \\
\hline & & 25 & 100.0 & 0.0 & 0.39 & 0.01 \\
\hline
\end{tabular}


Table B.1 (continued)

\begin{tabular}{|c|c|c|c|c|c|c|}
\hline \multirow[t]{2}{*}{ Date } & \multirow[t]{2}{*}{ Outfall } & \multirow[t]{2}{*}{ Conc. } & \multicolumn{2}{|c|}{ Survival (\%) } & \multicolumn{2}{|c|}{$\begin{array}{c}\text { Growth } \\
\text { (mg/larvae) }\end{array}$} \\
\hline & & & Mean & SD & Mean & SD \\
\hline & & 50 & 92.5 & 15.0 & 0.40 & 0.05 \\
\hline & & 100 & 100.0 & 0.0 & 0.37 & 0.03 \\
\hline & 009 & 6 & 97.5 & 5.0 & 0.45 & 0.01 \\
\hline & & 12 & 95.0 & 5.8 & 0.41 & 0.02 \\
\hline & & 25 & 92.5 & 9.6 & 0.43 & 0.04 \\
\hline & & 50 & 90.0 & 8.2 & 0.48 & 0.03 \\
\hline & & 100 & 95.0 & 5.8 & 0.41 & 0.04 \\
\hline & 011 & 6 & 95.0 & 5.8 & 0.38 & 0.06 \\
\hline & & 12 & 100.0 & 0.0 & 0.41 & 0.02 \\
\hline & & 25 & 100.0 & 0.0 & 0.40 & 0.05 \\
\hline & & 50 & 92.5 & 5.0 & 0.45 & 0.03 \\
\hline & & 100 & 95.0 & 5.8 & 0.39 & 0.05 \\
\hline \multirow[t]{26}{*}{ October 1993} & ControI & 100 & 100.0 & 0.0 & 0.49 & 0.03 \\
\hline & 001 & 6 & 90.0 & 8.2 & 0.48 & 0.08 \\
\hline & & 12 & 100.0 & 0.0 & 0.46 & 0.02 \\
\hline & & 25 & 97.5 & 5.0 & 0.43 & 0.06 \\
\hline & & 50 & 92.5 & 9.6 & 0.42 & 0.06 \\
\hline & & 100 & 97.5 & 5.0 & 0.44 & 0.04 \\
\hline & 006 & 6 & 92.5 & 9.6 & 0.49 & 0.06 \\
\hline & & 12 & 100.0 & 0.0 & 0.48 & 0.03 \\
\hline & & 25 & 100.0 & 0.0 & 0.47 & 0.04 \\
\hline & & 50 & 95.0 & 5.8 & 0.47 & 0.06 \\
\hline & & 100 & 95.0 & 10.0 & 0.44 & 0.08 \\
\hline & 008 & 6 & 100.0 & 0.0 & 0.38 & 0.04 \\
\hline & & 12 & 100.0 & 0.0 & 0.42 & 0.01 \\
\hline & & 25 & 92.5 & 9.6 & 0.38 & 0.05 \\
\hline & & 50 & 97.5 & 5.0 & 0.39 & 0.04 \\
\hline & & 100 & 77.5 & 15.0 & 0.40 & 0.04 \\
\hline & 009 & 6 & 100.0 & 0.0 & 0.45 & 0.03 \\
\hline & & 12 & 97.5 & 5.0 & 0.43 & 0.05 \\
\hline & & 25 & 97.5 & 5.0 & 0.41 & 0.05 \\
\hline & & 50 & 92.5 & 5.0 & 0.41 & 0.07 \\
\hline & & 100 & 100.0 & 0.0 & 0.39 & 0.10 \\
\hline & 011 & 6 & 92.5 & 5.0 & 0.48 & 0.04 \\
\hline & & 12 & 90.0 & 14.1 & 0.47 & 0.02 \\
\hline & & 25 & 87.5 & 15.0 & 0.46 & 0.14 \\
\hline & & 50 & 85.0 & 12.9 & 0.44 & $0.05^{\circ}$ \\
\hline & & 100 & 82.5 & 12.6 & 0.49 & 0.03 \\
\hline December 1993 & Control & 100 & 85.0 & 5.8 & 0.29 & 0.03 \\
\hline
\end{tabular}


Table B.1 (continued)

\begin{tabular}{|c|c|c|c|c|c|c|}
\hline \multirow[t]{2}{*}{ Date } & \multirow[t]{2}{*}{ Outfall } & \multirow[t]{2}{*}{ Conc. } & \multicolumn{2}{|c|}{ Survival (\%) } & \multicolumn{2}{|c|}{$\begin{array}{c}\text { Growth } \\
\text { (mg/larvae) }\end{array}$} \\
\hline & & & Mean & $S D$ & Mean & SD \\
\hline & 008 & 6 & 90.0 & 11.6 & 0.30 & 0.05 \\
\hline & & 12 & 80.0 & 33.7 & 0.34 & 0.08 \\
\hline & & 25 & 57.5 & 12.6 & 0.40 & 0.07 \\
\hline & & 50 & 97.5 & 5.0 & 0.34 & 0.05 \\
\hline & & 100 & 77.5 & 20.6 & 0.33 & 0.05 \\
\hline \multirow[t]{16}{*}{ March 1994} & Control & 100 & 100.0 & 0.0 & 0.49 & 0.03 \\
\hline & 001 & 6 & 92.5 & 9.6 & 0.47 & 0.07 \\
\hline & & 12 & 90.0 & 8.2 & 0.44 & 0.06 \\
\hline & & 25 & 92.5 & 5.0 & 0.53 & 0.04 \\
\hline & & 50 & 65.0 & 37.0 & 0.45 & 0.15 \\
\hline & & 100 & 77.5 & 15.0 & 0.62 & 0.07 \\
\hline & 006 & 6 & 87.5 & 18.9 & 0.46 & 0.26 \\
\hline & & 12 & 97.5 & 5.0 & 0.48 & 0.03 \\
\hline & & 25 & 35.0 & 44.4 & 0.50 & 0.09 \\
\hline & & 50 & 57.5 & 39.5 & 0.53 & 0.09 \\
\hline & & 100 & 92.5 & 5.0 & 0.49 & 0.02 \\
\hline & 008 & 6 & 92.5 & 9.6 & 0.41 & 0.05 \\
\hline & & 12 & 85.0 & 23.8 & 0.43 & 0.02 \\
\hline & & 25 & 92.5 & 9.6 & 0.49 & 0.03 \\
\hline & & 50 & 97.5 & 5.0 & 0.45 & 0.05 \\
\hline & & 100 & 92.5 & 15.0 & 0.46 & 0.02 \\
\hline \multirow[t]{10}{*}{$\cdot$} & 009 & 6 & 95.0 & 5.8 & 0.43 & 0.05 \\
\hline & & 12 & 97.5 & 5.0 & 0.42 & 0.02 \\
\hline & & 25 & 80.0 & 40.0 & 0.44 & 0.04 \\
\hline & & 50 & 97.5 & 5.0 & 0.45 & 0.04 \\
\hline & & 100 & 92.5 & 15.0 & 0.46 & 0.02 \\
\hline & 011 & 6 & 57.5 & 46.5 & 0.41 & 0.03 \\
\hline & & 12 & 82.5 & 9.6 & 0.52 & 0.09 \\
\hline & & 25 & 62.5 & 28.7 & 0.54 & 0.05 \\
\hline & & 50 & 65.0 & 17.3 & 0.53 & 0.02 \\
\hline & & 100 & 62.5 & 35.0 & 0.59 & 0.16 \\
\hline \multirow[t]{8}{*}{ March 1994} & Control & 100 & 97.5 & 5.0 & 0.37 & 0.05 \\
\hline & 006 & 6 & 75.0 & 30.0 & 0.38 & 0.07 \\
\hline & & 12 & 40.0 & 35.6 & 0.44 & 0.16 \\
\hline & & 25 & 32.5 & 12.6 & 0.46 & 0.05 \\
\hline & & 50 & 35.0 & 12.9 & 0.45 & 0.05 \\
\hline & & 100 & 50.0 & 24.5 & 0.52 & 0.05 \\
\hline & 011 & 6 & 57.5 & 28.7 & 0.37 & 0.11 \\
\hline & & 12 & 52.5 & 26.3 & 0.43 & 0.11 \\
\hline
\end{tabular}


Table B.1 (continued)

\begin{tabular}{|c|c|c|c|c|c|c|}
\hline \multirow[t]{2}{*}{ Date } & \multirow[t]{2}{*}{ Outfall } & \multirow[t]{2}{*}{ Conc. } & \multicolumn{2}{|c|}{ Survival (\%) } & \multicolumn{2}{|c|}{$\begin{array}{c}\text { Growth } \\
\text { (mg/larvae) }\end{array}$} \\
\hline & & & Mean & $\mathrm{SD}$ & Mean & SD \\
\hline & & 25 & 27.5 & 25.0 & 0.43 & 0.12 \\
\hline & & 50 & 40.0 & 24.5 & 0.29 & 0.08 \\
\hline & & 100 & 32.5 & 22.2 & 0.39 & 0.24 \\
\hline \multirow[t]{11}{*}{ April 1994} & Control & 100 & 97.5 & 5.0 & 0.43 & 0.08 \\
\hline & 006 & 6 & 97.5 & 5.0 & 0.34 & 0.03 \\
\hline & & 12 & 92.5 & 5.0 & 0.34 & 0.08 \\
\hline & & 25 & 97.5 & 5.0 & 0.34 & 0.04 \\
\hline & & 50 & 82.5 & 22.2 & 0.45 & 0.04 \\
\hline & & 100 & 90.0 & 8.2 & 0.44 & 0.11 \\
\hline & 011 & 6 & 87.5 & 12.6 & 0.40 & 0.08 \\
\hline & & 12 & 92.5 & 5.0 & 0.42 & 0.13 \\
\hline & & 25 & 85.0 & 17.3 & 0.50 & 0.09 \\
\hline & & 50 & 100.0 & 0.0 & 0.44 & 0.04 \\
\hline & & 100 & 92.5 & 9.6 & 0.46 & 0.07 \\
\hline \multirow[t]{16}{*}{ May 1994} & Control & 100 & 97.5 & 5.0 & 0.38 & 0.03 \\
\hline & 001 & 6 & 92.5 & 9.6 & 0.48 & 0.05 \\
\hline & & 12 & 82.5 & 22.2 & 0.52 & 0.08 \\
\hline & & 25 & 97.5 & 5.0 & 0.53 & 0.04 \\
\hline & & 50 & 95.0 & 10.0 & 0.52 & 0.06 \\
\hline & & 100 & 95.0 & 10.0 & 0.51 & 0.05 \\
\hline & 008 & 6 & 100.0 & 0.0 & 0.49 & 0.02 \\
\hline & & 12 & 97.5 & 5.0 & 0.53 & 0.01 \\
\hline & & 25 & 92.5 & 15.0 & 0.52 & 0.03 \\
\hline & & 50 & 90.0 & 11.6 & 0.51 & 0.09 \\
\hline & & 100 & 60.0 & 36.5 & 0.45 & 0.07 \\
\hline & 009 & 6 & 95.0 & 5.8 & 0.51 & 0.05 \\
\hline & & 12 & 92.5 & 9.6 & 0.57 & 0.03 \\
\hline & & 25 & 75.0 & 12.9 & 0.57 & 0.05 \\
\hline & & 50 & 87.5 & 15.0 & 0.51 & 0.06 \\
\hline & & 100 & 77.5 & 9.6 & 0.43 & 0.02 \\
\hline \multirow[t]{9}{*}{ June 1994} & Control & 100 & 92.5 & 15.0 & 0.38 & 0.02 \\
\hline & 008 & 6 & 97.5 & 5.0 & 0.43 & 0.04 \\
\hline & & 12 & 92.5 & 5.0 & 0.43 & 0.08 \\
\hline & & 25 & 92.5 & 5.0 & 0.43 & 0.06 \\
\hline & & 50 & 95.0 & 10.0 & 0.40 & 0.02 \\
\hline & & 100 & 87.5 & 15.0 & 0.40 & 0.02 \\
\hline & 009 & 6 & 92.5 & 9.6 & 0.46 & 0.08 \\
\hline & & 12 & 97.5 & 5.0 & 0.45 & 0.02 \\
\hline & & 25 & 97.5 & 5.0 & 0.40 & 0.05 \\
\hline
\end{tabular}


Table B.1 (continued)

\begin{tabular}{|c|c|c|c|c|c|c|}
\hline \multirow[t]{2}{*}{ Date } & \multirow[t]{2}{*}{ Outfall } & \multirow[t]{2}{*}{ Conc. } & \multicolumn{2}{|c|}{ Survival (\%) } & \multicolumn{2}{|c|}{$\begin{array}{c}\text { Growth } \\
\text { (mg/larvae) }\end{array}$} \\
\hline & & & Mean & SD & Mean & SD \\
\hline & & 50 & 100.0 & 0.0 & 0.43 & 0.11 \\
\hline & & 100 & 97.5 & 5.0 & 0.38 & 0.05 \\
\hline \multirow[t]{26}{*}{ August 1994} & Control & 100 & 97.5 & 5.0 & 0.34 & 0.03 \\
\hline & 001 & 6 & 97.5 & 5.0 & 0.47 & 0.03 \\
\hline & & 12 & 97.5 & 5.0 & 0.42 & 0.03 \\
\hline & & 25 & 100.0 & 0.0 & 0.44 & 0.05 \\
\hline & & 50 & 92.5 & 15.0 & 0.44 & 0.04 \\
\hline & & 100 & 97.5 & 5.0 & 0.45 & 0.06 \\
\hline & 006 & 6 & 95.0 & 5.8 & 0.46 & 0.04 \\
\hline & & 12 & 100.0 & 0.0 & 0.45 & 0.03 \\
\hline & & 25 & 95.0 & 5.8 & 0.45 & 0.04 \\
\hline & & 50 & 100.0 & 0.0 & 0.45 & 0.06 \\
\hline & & 100 & 95.0 & 5.8 & 0.44 & 0.06 \\
\hline & 008 & 6 & 100.0 & 0.0 & 0.45 & 0.02 \\
\hline & & 12 & 97.5 & 5.0 & 0.38 & 0.03 \\
\hline & & 25 & 90.0 & 11.6 & 0.33 & 0.16 \\
\hline & & 50 & 97.5 & 5.0 & 0.40 & 0.05 \\
\hline & & 100 & 62.5 & 29.9 & 0.36 & 0.03 \\
\hline & 009 & 6 & 90.0 & 8.2 & 0.40 & 0.05 \\
\hline & & 12 & 100.0 & 0.0 & 0.42 & 0.04 \\
\hline & & 25 & 95.0 & 10.0 & 0.43 & 0.05 \\
\hline & & 50 & 80.0 & 27.1 & 0.38 & 0.13 \\
\hline & & 100 & 92.5 & 9.6 & 0.32 & 0.05 \\
\hline & 010 & 6 & 100.0 & 0.0 & 0.39 & 0.04 \\
\hline & & 12 & 100.0 & 0.0 & 0.42 & 0.04 \\
\hline & & 25 & 92.5 & 5.0 & 0.47 & 0.05 \\
\hline & & 50 & 97.5 & 5.0 & 0.40 & 0.02 \\
\hline & & 100 & 95.0 & 10.0 & 0.43 & 0.05 \\
\hline \multirow[t]{11}{*}{ September 1994} & Control & 100 & 100.0 & 0.0 & 0.50 & 0.03 \\
\hline & 008 & 6 & 95.0 & 5.8 & 0.50 & 0.08 \\
\hline & & 12 & 97.5 & 5.0 & 0.49 & 0.01 \\
\hline & & 25 & 95.0 & 5.8 & 0.51 & 0.05 \\
\hline & & 50 & 97.5 & 5.0 & 0.47 & 0.04 \\
\hline & & 100 & 90.0 & 8.2 & 0.46 & 0.04 \\
\hline & 009 & 6 & 100.0 & 0.0 & 0.50 & 0.05 \\
\hline & & 12 & 100.0 & 0.0 & 0.51 & 0.06 \\
\hline & & 25 & 97.5 & 5.0 & 0.50 & 0.05 \\
\hline & & 50 & 95.0 & 10.0 & 0.55 & 0.10 \\
\hline & & 100 & 85.0 & 17.3 & 0.57 & 0.07 \\
\hline
\end{tabular}


Table B.1 (continued)

\begin{tabular}{|c|c|c|c|c|c|c|}
\hline \multirow[t]{2}{*}{ Date } & \multirow[t]{2}{*}{ Outfall } & \multirow[t]{2}{*}{ Conc. } & \multicolumn{2}{|c|}{ Survival (\%) } & \multicolumn{2}{|c|}{$\begin{array}{c}\text { Growth } \\
\text { (mg/larvae) }\end{array}$} \\
\hline & & & Mean & SD & Mean & SD \\
\hline \multirow[t]{26}{*}{ October 1994} & Control & 100 & 100.0 & 0.0 & 0.53 & 0.04 \\
\hline & 001 & 6 & 100.0 & 0.0 & 0.68 & 0.10 \\
\hline & & 12 & 97.5 & 5.0 & 0.69 & 0.01 \\
\hline & & 25 & $97: 5$ & 5.0 & 0.72 & 0.06 \\
\hline & & 50 & 95.0 & 5.8 & 0.74 & 0.09 \\
\hline & & 100 & 82.5 & 20.6 & 0.78 & 0.08 \\
\hline & 006 & 6 & 100.0 & 0.0 & 0.57 & 0.08 \\
\hline & & 12 & 97.5 & 5.0 & 0.57 & 0.06 \\
\hline & & 25 & 97.5 & 5.0 & 0.68 & 0.05 \\
\hline & & 50 & 100.0 & 0.0 & 0.71 & 0.02 \\
\hline & & 100 & 97.5 & 5.0 & 0.69 & 0.06 \\
\hline & 008 & 6 & 95.0 & 5.8 & 0.51 & 0.05 \\
\hline & & 12 & 100.0 & 0.0 & 0.59 & 0.02 \\
\hline & & 25 & 100.0 & 0.0 & 0.63 & 0.08 \\
\hline & & 50 & 92.5 & 5.0 & 0.61 & 0.07 \\
\hline & & 100 & 95.0 & 5.8 & 0.56 & 0.05 \\
\hline & 009 & 6 & 90.0 & 20.0 & 0.66 & 0.09 \\
\hline & & 12 & 25.0 & 30.0 & 0.75 & 0.04 \\
\hline & & 25 & 57.5 & 39.5 & 0.75 & 0.07 \\
\hline & & 50 & 47.5 & 27.5 & 0.85 & 0.06 \\
\hline & & 100 & 15.0 & 17.3 & 1.03 & 0.38 \\
\hline & 010 & 6 & 100.0 & 0.0 & 0.62 & 0.06 \\
\hline & & 12 & 100.0 & 0.0 & 0.68 & 0.09 \\
\hline & & 25 & 100.0 & 0.0 & 0.63 & 0.03 \\
\hline & & 50 & 90.0 & 14.1 & 0.71 & 0.04 \\
\hline & & 100 & 90.0 & 11.6 & 0.69 & 0.10 \\
\hline \multirow[t]{6}{*}{ November 1994} & Control & 100 & 95.0 & 5.8 & 0.57 & 0.09 \\
\hline & 009 & 6 & 100.0 & 0.0 & 0.62 & 0.08 \\
\hline & & 12 & 75.0 & 43.6 & 0.71 & 0.17 \\
\hline & & 25 & 80.0 & 21.6 & 0.63 & 0.08 \\
\hline & & 50 & 30.0 & 25.8 & 0.77 & 0.19 \\
\hline & & 100 & 67.5 & 18.9 & 0.67 & 0.12 \\
\hline
\end{tabular}


Table B.2. Results of Ceriodaphnia toxicity tests of continuously flowing effluents at the Paducah Gaseous Diffusion Plant

Tests conducted October 1991-November 1994

\begin{tabular}{|c|c|c|c|c|c|}
\hline \multirow[t]{2}{*}{ Date } & \multirow[t]{2}{*}{ Outfall } & \multirow[t]{2}{*}{ Conc. } & \multirow{2}{*}{$\begin{array}{r}\text { Survival } \\
(\%)\end{array}$} & \multicolumn{2}{|c|}{$\begin{array}{l}\text { Offspring/surviving } \\
\text { female }\end{array}$} \\
\hline & & & & Mean & SD \\
\hline \multirow[t]{31}{*}{ October 1991} & Control & 100 & 100 & 19.90 & 9.89 \\
\hline & 001 & 6 & 90 & 28.00 & 8.25 \\
\hline & & 12 & 100 & 21.60 & 11.06 \\
\hline & ' & 25 & 90 & 34.33 & 5.10 \\
\hline & & 50 & 90 & 25.33 & 13.16 \\
\hline & & 100 & 80 & 29.63 & 9.98 \\
\hline & 004 & 6 & 100 & 34.90 & 5.95 \\
\hline & & 12 & 70 & 33.43 & 8.83 \\
\hline & & 25 & 70 & 29.43 & 11.75 \\
\hline & & 50 & 90 & 25.22 & 9.24 \\
\hline & & 100 & 80 & 30.38 & 10.14 \\
\hline & 006 & 6 & 90 & 31.11 & 4.94 \\
\hline & & 12 & 80 & 22.75 & 11.66 \\
\hline & & 25 & 90 & 25.78 & 12.72 \\
\hline & & 50 & 70 & 29.57 & 14.80 \\
\hline & & 100 & 90 & 29.78 & 8.70 \\
\hline & 008 & 6 & 60 & 14.83 & 5.91 \\
\hline & & 12 & 70 & 22.86 & 10.29 \\
\hline & & 25 & 100 & 29.00 & 8.23 \\
\hline & & 50 & 70 & 27.43 & 9.32 \\
\hline & & 100 & 100 & 36.90 & 6.15 \\
\hline & 009 & 6 & 100 & 27.20 & 10.17 \\
\hline & & 12 & 80 & 22.63 & 7.17 \\
\hline & & 25 & 100 & 27.30 & 7.27 \\
\hline & & 50 & 90 & 25.11 & 8.67 \\
\hline & & 100 & 100 & 32.30 & 5.46 \\
\hline & 011 & 6 & 100 & 28.20 & 10.81 \\
\hline & & 12 & 80 & 22.13 & 12.37 \\
\hline & & 25 & 100 & 39.70 & 3.86 \\
\hline & & 50 & 100 & 33.90 & 7.16 \\
\hline & & 100 & 90 & 38.89 & 8.55 \\
\hline \multirow[t]{5}{*}{ February 1992} & Control & 100 & 90 & 19.44 & 2.96 \\
\hline & 001 & 12 & 70 & 24.71 & 6.58 \\
\hline & & 25 & 90 & 29.00 & 6.63 \\
\hline & & 50 & 100 & 29.90 & 3.07 \\
\hline & & 100 & 100 & 30.00 & 5.93 \\
\hline
\end{tabular}


Table B.2 (continued)

\begin{tabular}{|c|c|c|c|c|c|}
\hline \multirow[t]{2}{*}{ Date } & \multirow[t]{2}{*}{ Outfall } & \multirow[t]{2}{*}{ Conc. } & \multirow{2}{*}{$\begin{array}{r}\text { Survival } \\
(\%)\end{array}$} & \multicolumn{2}{|c|}{$\begin{array}{c}\text { Offspring/surviving } \\
\text { female } \\
\end{array}$} \\
\hline & & & & Mean & SD \\
\hline & 004 & 12 & 80 & 24.38 & 3.20 \\
\hline & & 25 & 80 & 24.13 & 3.52 \\
\hline & & 50 & 100 & 18.50 & 6.40 \\
\hline & & 100 & 100 & 15.00 & 7.60 \\
\hline & 006 & 12 & 90 & 34.00 & 3.04 \\
\hline & & 25 & 100 & 32.60 & 6.40 \\
\hline & & 50 & 100 & 35.80 & 5.65 \\
\hline & & 100 & 80 & 3.50 & 2.98 \\
\hline & 008 & 12 & 80 & 33.13 & 10.06 \\
\hline & & 25 & 70 & 35.00 & 5.48 \\
\hline & & 50 & 100 & 32.40 & 9.11 \\
\hline & & 100 & 100 & 29.00 & 5.27 \\
\hline & 009 & 12 & 70 & 25.86 & 4.45 \\
\hline & & 25 & 90 & 29.11 & 9.75 \\
\hline & & 50 & 90 & 27.78 & 5.83 \\
\hline & & 100 & 90 & 27.89 & 4.31 \\
\hline & 011 & 12 & 60 & 23.33 & 4.76 \\
\hline & & 25 & 90 & 28.22 & 6.63 \\
\hline & & 50 & 90 & 31.56 & 9.46 \\
\hline & & 100 & 100 & 29.10 & 9.65 \\
\hline May 1992 & Control & 100 & 90 & 31.11 & 4.70 \\
\hline & 001 & 12 & 80 & 31.25 & 5.65 \\
\hline & & 25 & 90 & 23.56 & 7.73 \\
\hline & & 50 & 100 & 21.30 & 6.11 \\
\hline & & 100 & 90 & 19.11 & 7.25 \\
\hline & 004 & 12 & 90 & 31.67 & 4.44 \\
\hline & & 25 & 100 & 24.90 & 2.08 \\
\hline & & 50 & 100 & 32.80 & 8.87 \\
\hline & & 100 & 100 & 31.60 & 9.18 \\
\hline & 006 & 12 & 90 & 29.44 & 5.22 \\
\hline & & 25 & 90 & 29.44 & 5.64 \\
\hline & & 50 & 100 & 27.60 & 10.50 \\
\hline & & 100 & 100 & 30.60 & 4.86 \\
\hline & 008 & 12 & 100 & 30.40 & 1.71 \\
\hline & & 25 & 90 & 26.67 & 6.76 \\
\hline & & 50 & 100 & 25.60 & 7.79 \\
\hline & & 100 & 100 & 29.20 & 7.94 \\
\hline & 009 & 12 & 100 & 33.40 & 4.99 \\
\hline
\end{tabular}


Table B.2 (continued)

\begin{tabular}{|c|c|c|c|c|c|}
\hline \multirow[t]{2}{*}{ Date } & \multirow[t]{2}{*}{ Outfall } & \multirow[t]{2}{*}{ Conc. } & \multirow{2}{*}{$\begin{array}{c}\text { Survival } \\
(\%)\end{array}$} & \multicolumn{2}{|c|}{$\begin{array}{l}\text { Offspring/surviving } \\
\text { female }\end{array}$} \\
\hline & & & & Mean & SD \\
\hline & & 25 & 100 & 33.50 & 3.03 \\
\hline & & 50 & 100 & 32.20 & 3.19 \\
\hline & & 100 & 100 & 31.30 & 3.53 \\
\hline & 011 & 12 & 100 & 31.00 & 3.65 \\
\hline & & 25 & 90 & 33.11 & 5.69 \\
\hline & & 50 & 100 & 29.60 & 10.34 \\
\hline & & 100 & 100 & 31.00 & 6.53 \\
\hline \multirow[t]{25}{*}{ August 1992} & Control & 100 & 100 & 26.00 & 6.70 \\
\hline & 001 & 12 & 100 & 29.90 & 4.46 \\
\hline & & 25 & 100 & 34.90 & 4.58 \\
\hline & & 50 & 100 & 32.80 & 3.82 \\
\hline & & 100 & 100 & 32.40 & 2.46 \\
\hline & 004 & 12 & 100 & 32.20 & 8.22 \\
\hline & & 25 & 100 & 29.90 & 6.21 \\
\hline & & 50 & 10 & 14.00 & . \\
\hline & & 100 & 0 & . & . \\
\hline & 006 & 12 & 100 & 35.00 & 4.35 \\
\hline & & 25 & 100 & 35.30 & 4.72 \\
\hline & & 50 & 100 & 36.40 & 4.01 \\
\hline & & 100 & 100 & 34.30 & 3.53 \\
\hline & 008 & 12 & 90 & 27.00 & 9.71 \\
\hline & & 25 & 90 & 26.44 & 5.83 \\
\hline & & 50 & 100 & 21.60 & 10.13 \\
\hline & & 100 & 100 & 26.30 & 7.70 \\
\hline & 009 & 12 & 100 & 25.50 & 4.95 \\
\hline & & 25 & 90 & 24.44 & 5.25 \\
\hline & & 50 & 100 & 28.80 & 5.45 \\
\hline & & 100 & 100 & 30.80 & 5.88 \\
\hline & 011 & 12 & 100 & 27.60 & 4.27 \\
\hline & & 25 & 100 & 23.60 & 8.75 \\
\hline & & 50 & 80 & 28.00 & 8.38 \\
\hline & & 100 & 90 & 25.56 & 3.61 \\
\hline \multirow[t]{6}{*}{ October 1992} & Control & 100 & 90 & 26.56 & 8.26 \\
\hline & 001 & 12 & 100 & 28.80 & 5.25 \\
\hline & & 25 & 80 & 23.00 & 10.04 \\
\hline & & 50 & 100 & 32.10 & 6.84 \\
\hline & & 100 & 100 & 25.70 & 9.90 \\
\hline & 004 & 12 & 100 & 29.20 & 8.59 \\
\hline
\end{tabular}


Table B.2 (continued)

\begin{tabular}{|c|c|c|c|c|c|}
\hline \multirow[t]{2}{*}{ Date } & \multirow[t]{2}{*}{ Outfall } & \multirow[t]{2}{*}{ Conc. } & \multirow{2}{*}{$\begin{array}{r}\text { Survival } \\
(\%)\end{array}$} & \multicolumn{2}{|c|}{$\begin{array}{l}\text { Offspring/surviving } \\
\text { female }\end{array}$} \\
\hline & & & & Mean & SD \\
\hline & & 25 & 100 & 28.30 & 6.07 \\
\hline & & 50 & 100 & 27.40 & 8.18 \\
\hline & & 100 & 90 & 31.33 & 5.63 \\
\hline & 006 & 12 & 100 & 19.30 & 7.83 \\
\hline & & 25 & 100 & 31.00 & 7.66 \\
\hline & & 50 & 100 & 29.30 & 10.91 \\
\hline & & 100 & 100 & 29.40 & 8.06 \\
\hline & 008 & 12 & 100 & 29.80 & 5.14 \\
\hline & & 25 & 100 & 21.60 & 9.51 \\
\hline & & 50 & 100 & 23.50 & 8.61 \\
\hline & & 100 & 100 & 21.20 & 9.31 \\
\hline & 009 & 12 & 100 & 28.50 & 8.58 \\
\hline & & 25 & 100 & 30.40 & 8.00 \\
\hline & & 50 & 100 & 24.90 & 7.32 \\
\hline & & 100 & 100 & 20.60 & 13.22 \\
\hline & 011 & 12 & 100 & 27.20 & 6.73 \\
\hline & & 25 & 90 & 34.56 & 4.30 \\
\hline & & 50 & 100 & 27.60 & 7.40 \\
\hline & & 100 & 100 & 31.10 & 7.13 \\
\hline \multirow[t]{18}{*}{ February 1993} & Control & 100 & 90 & 27.67 & 4.58 \\
\hline & 001 & 6 & 90 & 31.11 & 5.53 \\
\hline & & 12 & 90 & 31.44 & 3.09 \\
\hline & & 25 & 100 & 36.20 & 4.34 \\
\hline & & 50 & 100 & 32.90 & 11.51 \\
\hline & & 100 & 100 & 34.40 & 4.60 \\
\hline & Control & 100 & 70 & 26.29 & 4.54 \\
\hline & 006 & 6 & 90 & 27.89 & 8.46 \\
\hline & & 12 & 90 & 30.22 & 4.79 \\
\hline & & 25 & 70 & 30.86 & 5.49 \\
\hline & & 50 & 70 & 26.43 & 8.58 \\
\hline & & 100 & 100 & 26.20 & 12.12 \\
\hline & Control & 100 & 100 & 33.30 & 4.60 \\
\hline & 008 & 6 & 100 & 27.70 & 9.98 \\
\hline & & 12 & 80 & 30.88 & 6.92 \\
\hline & & 25 & 100 & 28.30 & 10.03 \\
\hline & & 50 & 100 & 34.40 & 3.06 \\
\hline & & 100 & 90 & 31.33 & 3.67 \\
\hline
\end{tabular}


Table B.2 (continued)

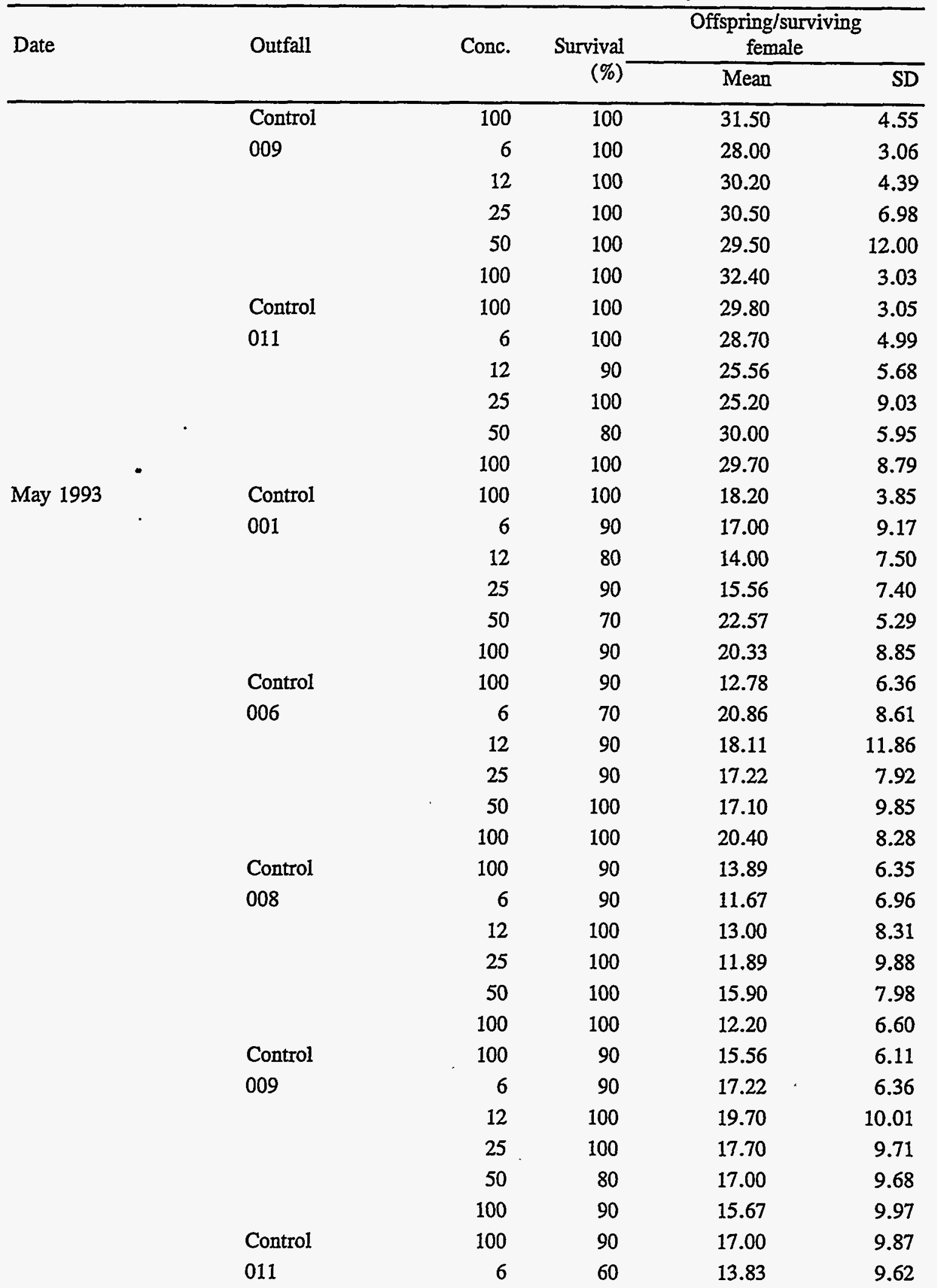


Table B.2 (continued)

\begin{tabular}{|c|c|c|c|c|c|c|}
\hline \multirow[t]{2}{*}{ Date } & \multirow[t]{2}{*}{ Outfall } & \multirow[t]{2}{*}{ Conc. } & \multirow{2}{*}{$\begin{array}{r}\text { Survival } \\
(\%)\end{array}$} & \multicolumn{3}{|c|}{$\begin{array}{l}\text { Offspring/surviving } \\
\text { female }\end{array}$} \\
\hline & & & & Mean & & SD \\
\hline & & 12 & 100 & 15.50 & & 11.09 \\
\hline & & 25 & 100 & 14.20 & & 9.96 \\
\hline & & 50 & 90 & 13.67 & & 11.09 \\
\hline & & 100 & 90 & 16.22 & & 5.26 \\
\hline \multirow[t]{18}{*}{ June 1993} & Control & 100 & 100 & 17.90 & & 5.93 \\
\hline & 006 & 6 & 90 & 20.78 & & 10.17 \\
\hline & & 12 & 100 & 24.90 & & 7.84 \\
\hline & & 25 & 100 & 29.00 & & 5.21 \\
\hline & & 50 & 100 & 27.20 & & 6.09 \\
\hline & & 100 & 90 & 29.11 & & 5.80 \\
\hline & Control & 100 & 100 & 23.30 & & 7.13 \\
\hline & 008 & 6 & 90 & 30.00 & $=$ & 10.44 \\
\hline & & 12 & 90 & 26.22 & & 8.5 .7 \\
\hline & & 25 & 90 & 26.00 & & 8.29 \\
\hline & & 50 & 90 & 29.56 & & 5.79 \\
\hline & & 100 & 100 & 28.10 & & 10.45 \\
\hline & Control & 100 & 90 & 25.00 & & 10.04 \\
\hline & 009 & 6 & 90 & 25.89 & & 12.99 \\
\hline & & 12 & 100 & 30.30 & & 5.66 \\
\hline & & 25 & 90 & 29.89 & & 4.81 \\
\hline & & 50 & 100 & 29.80 & & 4.89 \\
\hline & & 100 & 100 & 26.20 & & 4.59 \\
\hline \multirow[t]{16}{*}{ August 1993} & Control & 100 & 100 & 23.10 & & 7.43 \\
\hline & 001 & 6 & 100 & 20.80 & & 6.91 \\
\hline & & 12 & 100 & 19.70 & & 8.64 \\
\hline & & 25 & 80 & 21.25 & & 8.81 \\
\hline & & 50 & 100 & 24.20 & & 7.63 \\
\hline & & 100 & 70 & 24.57 & & 7.52 \\
\hline & Control & 100 & 100 & 24.40 & & 9.50 \\
\hline & 006 & 6 & 90 & 27.22 & & 10.45 \\
\hline & & 12 & 90 & 30.22 & & 4.44 \\
\hline & & 25 & 100 & 30.10 & & 10.03 \\
\hline & & 50 & 90 & 28.89 & & 10.73 \\
\hline & & 100 & 100 & 27.20 & & 9.76 \\
\hline & Control & 100 & 80 & 26.75 & & 3.69 \\
\hline & 008 & 6 & 100 & 23.30 & & 8.06 \\
\hline & & 12 & 100 & 27.60 & & 3.20 \\
\hline & & 25 & 100 & 22.90 & & 3.00 \\
\hline
\end{tabular}


Table B.2 (continued)

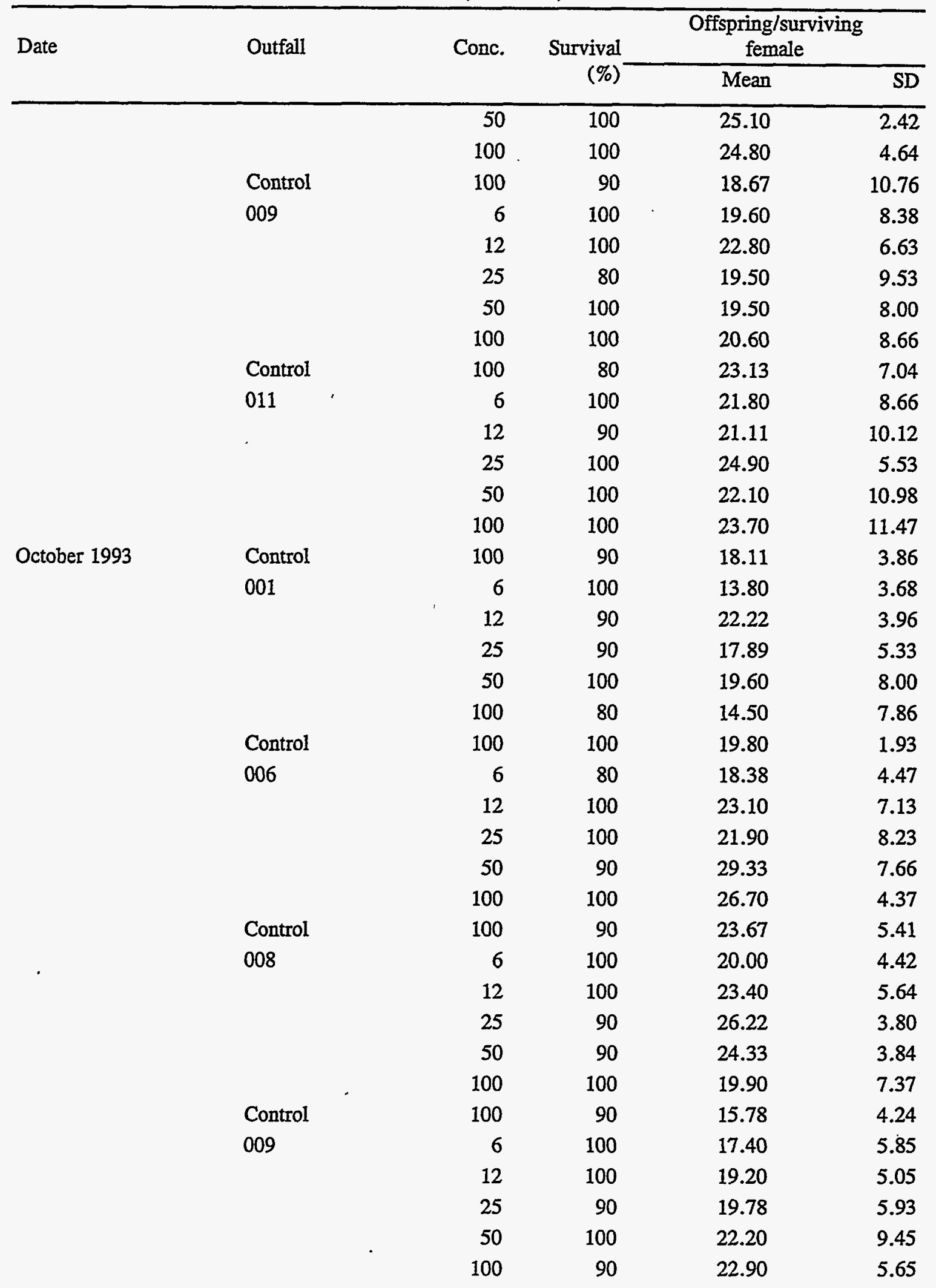


Table B.2 (continued)

\begin{tabular}{|c|c|c|c|c|c|}
\hline \multirow[t]{2}{*}{ Date } & \multirow[t]{2}{*}{ Outfall } & \multirow[t]{2}{*}{ Conc. } & \multirow{2}{*}{$\begin{array}{r}\text { Survival } \\
(\%)\end{array}$} & \multicolumn{2}{|c|}{$\begin{array}{c}\text { Offspring/surviving } \\
\text { female } \\
\end{array}$} \\
\hline & & & & Mean & SD \\
\hline & Control & 100 & 90 & 23.44 & 4.69 \\
\hline & 011 & 6 & 90 & 23.11 & 3.66 \\
\hline & & 12 & 100 & 24.90 & 3.07 \\
\hline & & 25 & 100 & .21 .80 & 5.94 \\
\hline & & 50 & 100 & 22.20 & 4.64 \\
\hline & & 100 & 100 & 21.10 & 8.41 \\
\hline \multirow[t]{30}{*}{ March 1994} & Control & 100 & 90 & 23.89 & 6.77 \\
\hline & 001 & 6 & 90 & 29.78 & 4.02 \\
\hline & & 12 & 100 & 35.30 & 6.99 \\
\hline & & 25 & 100 & 40.50 & 7.96 \\
\hline & & 50 & 100 & 49.00 & 3.06 \\
\hline & & 100 & 100 & 47.00 & 5.50 \\
\hline & Control & 100 & 100 & 18.20 & 3.26 \\
\hline & 006 & 6 & 100 & $26.70^{\circ}$ & 6.46 \\
\hline & & 12 & 100 & 33.10 & 7.89 \\
\hline & & 25 & 100 & 32.30 & 7.76 \\
\hline & & 50 & 100 & 40.10 & 10.30 \\
\hline & & 100 & 90 & 37.78 & 8.76 \\
\hline & Control & 100 & 90 & 17.78 & 5.76 \\
\hline & 008 & 6 & 100 & 26.10 & 4.93 \\
\hline & & 12 & 100 & 28.90 & 5.28 \\
\hline & & 25 & 90 & 31.44 & 9.77 \\
\hline & & 50 & 100 & 34.90 & 7.34 \\
\hline & & 100 & 100 & 36.40 & 5.25 \\
\hline & Control & 100 & 100 & 20.20 & 5.57 \\
\hline & 009 & 6 & 100 & 20.30 & 6.48 \\
\hline & & 12 & 100 & 19.60 & 4.79 \\
\hline & & 25 & 100 & 22.60 & 3.17 \\
\hline & & 50 & 90 & 20.11 & 4.51 \\
\hline & & 100 & 90 & 23.89 & 5.51 \\
\hline & Control & 100 & 90 & 18.00 & 2.18 \\
\hline & 011 & 6 & 90 & 20.11 & 4.68 \\
\hline & & 12 & 100 & 20.50 & 3.95 \\
\hline & & 25 & 90 & 20.33 & 3.97 \\
\hline & & 50 & 100 & 25.80 & 2.35 \\
\hline & & 100 & 100 & 28.60 & 3.41 \\
\hline \multirow[t]{2}{*}{ April 1994} & Control & 100 & 100 & 18.40 & 3.24 \\
\hline & 006 & 6 & 100 & 5.20 & 4.76 \\
\hline
\end{tabular}


Table B.2 (continued)

\begin{tabular}{|c|c|c|c|c|c|}
\hline \multirow[t]{2}{*}{ Date } & \multirow[t]{2}{*}{ Outfall } & \multirow[t]{2}{*}{ Conc. } & \multirow{2}{*}{$\begin{array}{r}\text { Survival } \\
(\%)\end{array}$} & \multicolumn{2}{|c|}{$\begin{array}{l}\text { Offspring/surviving } \\
\text { female } \\
\end{array}$} \\
\hline & & & & Mean & SD \\
\hline & & 12 & 90 & 7.33 & 4.66 \\
\hline & & 25 & 100 & 12.90 & 8.41 \\
\hline & & 50 & 100 & 23.40 & 8.73 \\
\hline & & 100 & 100 & 22.30 & 3.23 \\
\hline & 011 & 6 & 100 & 19.60 & 6.85 \\
\hline & & 12 & 100 & 22.10 & 6.64 \\
\hline & & 25 & 100 & 23.40 & 6.06 \\
\hline & & 50 & 80 & 27.75 & 2.55 \\
\hline & & 100 & 100 & 27.90 & 7.55 \\
\hline \multirow[t]{18}{*}{ May 1994} & Control & 100 & 80 & 12.88 & 3.04 \\
\hline & 001 & 6 & 80 & 16.38 & 4.66 \\
\hline & & 12 & 80 & 15.00 & 8.05 \\
\hline & & 25 & 90 & 23.56 & 5.00 \\
\hline & & 50 & 90 & 26.56 & 4.03 \\
\hline & & 100 & 60 & 23.67 & 9.67 \\
\hline & Control & 100 & 90 & 18.44 & 1.67 \\
\hline & 008 & 6 & 100 & 19.60 & 3.10 \\
\hline & & 12 & 100 & 21.20 & 3.55 \\
\hline & & 25 & 70 & 23.86 & 4.53 \\
\hline & & 50 & 90 & 25.44 & 3.47 \\
\hline & & 100 & 100 & 24.20 & 3.05 \\
\hline & Control & 100 & 100 & 19.10 & 3.28 \\
\hline & 009 & 6 & 100 & 22.90 & 2.33 \\
\hline & & 12 & 90 & 24.78 & 3.23 \\
\hline & & 25 & 100 & 26.20 & 4.89 \\
\hline & & 50 & 90 & 31.44 & 7.58 \\
\hline & & 100 & 100 & 26.00 & 8.99 \\
\hline \multirow[t]{11}{*}{ August 1994} & Control & 100 & 100 & 21.50 & 2.01 \\
\hline & 001 & 6 & 80 & 24.50 & 2.07 \\
\hline & & 12 & 100 & 24.00 & 2.74 \\
\hline & & 25 & 90 & 21.56 & 1.88 \\
\hline & & 50 & 100 & 19.30 & 2.16 \\
\hline & & 100 & 100 & 18.20 & 2.74 \\
\hline & Control & 100 & 100 & 23.50 & 1.84 \\
\hline & 006 & 6 & 100 & 26.00 & 3.53 \\
\hline & & 12 & 100 & 25.80 & 2.20 \\
\hline & & 25 & 100 & 26.70 & 3.27 \\
\hline & & 50 & 100 & 21.80 & 2.15 \\
\hline
\end{tabular}


Table B.2 (continued)

\begin{tabular}{|c|c|c|c|c|c|}
\hline \multirow[t]{2}{*}{ Date } & \multirow[t]{2}{*}{ Outfall } & \multirow[t]{2}{*}{ Conc. } & \multirow{2}{*}{$\begin{array}{r}\text { Survival } \\
(\%)\end{array}$} & \multicolumn{2}{|c|}{$\begin{array}{l}\text { Offspring/surviving } \\
\text { female }\end{array}$} \\
\hline & & & & Mean & SD \\
\hline & & 100 & 100 & 16.10 & 2.08 \\
\hline & Control & 100 & 100 & 21.70 & 2.21 \\
\hline & 008 & 6 & 90 & 26.67 & 1.80 \\
\hline & & 12 & 90 & 23.22 & 2.28 \\
\hline & & 25 & 100 & 21.80 & 6.05 \\
\hline & & 50 & 100 & 25.20 & 3.43 \\
\hline & & 100 & 90 & 19.11 & 3.92 \\
\hline & Control & 100 & 100 & 23.50 & 1.96 \\
\hline & 009 & 6 & 100 & 26.50 & 1.78 \\
\hline & & 12 & 100 & 28.30 & 1.34 \\
\hline & & 25 & 100 & 27.40 & 2.84 \\
\hline & & 50 & 100 & 29.00 & 2.31 \\
\hline & & 100 & 100 & 23.00 & 5.81 \\
\hline & Controi & 100 & 100 & 22.00 & 2.00 \\
\hline & 010 & 6 & 100 & 23.40 & 1.58 \\
\hline & & 12 & 100 & 24.70 & 2.98 \\
\hline & & 25 & 90 & 24.67 & 3.97 \\
\hline & & 50 & 100 & 28.10 & 2.60 \\
\hline & & 100 & 100 & 25.90 & 2.88 \\
\hline \multirow[t]{6}{*}{ September 1994} & Control & 100 & 100 & 28.90 & 4.38 \\
\hline & 006 & 6 & 100 & 30.30 & 3.09 \\
\hline & & 12 & 90 & 32.22 & 11.03 \\
\hline & & 25 & 100 & 32.80 & 5.90 \\
\hline & & 50 & 100 & 35.60 & 8.19 \\
\hline & & 100 & 100 & 34.70 & 7.15 \\
\hline \multirow[t]{12}{*}{ October 1994} & Control & 100 & 100 & 7.30 & 5.89 \\
\hline & 001 & 6 & 60 & 14.00 & 8.46 \\
\hline & & 12 & 100 & 18.80 & 7.28 \\
\hline & & 25 & 90 & 14.11 & 9.23 \\
\hline & & 50 & 90 & 21.11 & 10.01 \\
\hline & & 100 & 90 & 18.11 & 5.60 \\
\hline & Control & 100 & 100 & 22.60 & 6.13 \\
\hline & 006 & 6 & 100 & 19.50 & 11.02 \\
\hline & & 12 & 100 & 19.90 & 6.72 \\
\hline & & 25 & 100 & 24.70 & 7.02 \\
\hline & & 50 & 90 & 24.22 & 6.55 \\
\hline & & 100 & 100 & 28.20 & $4.73^{\circ}$ \\
\hline
\end{tabular}


Table B.2 (continued)

\begin{tabular}{|c|c|c|c|c|c|}
\hline \multirow[t]{2}{*}{ Date } & \multirow[t]{2}{*}{ Outfall } & \multirow[t]{2}{*}{ Conc. } & \multirow{2}{*}{$\begin{array}{r}\text { Survival } \\
(\%)\end{array}$} & \multicolumn{2}{|c|}{$\begin{array}{l}\text { Offspring/surviving } \\
\text { female }\end{array}$} \\
\hline & & & & Mean & SD \\
\hline & Control & 100 & 100 & 21.00 & 6.46 \\
\hline & 008 & 6 & 100 & 24.40 & 7.07 \\
\hline & & 12 & 100 & 18.80 & 8.28 \\
\hline & & 25 & 90 & 22.89 & 4.78 \\
\hline & & 50 & 90 & 28.56 & 4.39 \\
\hline & & 100 & 90 & 30.00 & 4.47 \\
\hline & Control & 100 & 100 & 27.70 & 6.43 \\
\hline & 009 & 6 & 100 & 29.30 & 5.29 \\
\hline & & 12 & 100 & 33.50 & 4.40 \\
\hline & & 25 & 100 & 33.20 & 5.96 \\
\hline & & 50 & 100 & 34.70 & 6.70 \\
\hline & & 100 & 100 & 32.20 & 4.98 \\
\hline & Control & 100 & 90 & 24.56 & 7.70 \\
\hline & 010 & 6 & 100 & 28.90 & 7.00 \\
\hline & & 12 & 100 & 32.40 & 6.60 \\
\hline & & 25 & 100 & 35.30 & 3.33 \\
\hline & & 50 & 100 & 37.90 & 6.95 \\
\hline & & 100 & 100 & 33.60 & 8.53 \\
\hline \multirow[t]{6}{*}{ November 1994} & Control & 100 & 100 & 23.70 & 3.47 \\
\hline & 001 & 6 & 100 & 24.60 & 4.45 \\
\hline & & 12 & 100 & 21.20 & 7.90 \\
\hline & & 25 & 100 & 20.90 & 6.21 \\
\hline & & 50 & 100 & 18.10 & 6.94 \\
\hline & & 100 & 100 & 19.30 & 6.27 \\
\hline
\end{tabular}


Table B.3. Summary of water chemistry analyses conducted during toxicity tests of continuously flowing effluents at the Paducah Gaseous Diffusion Plant Analyses conducted October 1991-November 1994

\begin{tabular}{|c|c|c|c|c|c|c|}
\hline $\begin{array}{l}\text { Water quality } \\
\text { parameter }\end{array}$ & Date & Outfall & Mean & $\mathrm{SD}$ & Min & Max \\
\hline \multirow{34}{*}{ pH (S.U.) } & October 1991 & 001 & 9.18 & 0.30 & 8.74 & 9.54 \\
\hline & & 004 & 7.53 & 0.09 & 7.42 & 7.68 \\
\hline & & 006 & 9.40 & 0.07 & 9.28 & 9.48 \\
\hline & & 008 & 7.51 & 0.06 & 7.43 & 7.61 \\
\hline & & 009 & 7.50 & 0.22 & 7.34 & 7.97 \\
\hline & & 011 & 7.79 & 0.10 & 7.69 & 7.95 \\
\hline & February 1992 & 001 & 7.90 & 0.18 & 7.71 & 8.23 \\
\hline & & 004 & 7.67 & 0.12 & 7.56 & 7.91 \\
\hline & & 006 & 9.48 & 0.20 & 9.19 & 9.72 \\
\hline & & 008 & 7.64 & 0.12 & 7.50 & 7.86 \\
\hline & & 009 & 7.96 & 0.22 & 7.54 & 8.25 \\
\hline & & 011 & 7.98 & 0.10 & 7.79 & 8.09 \\
\hline & May 1992 & 001 & 7.96 & 0.42 & 7.40 & 8.52 \\
\hline & & 004 & 7.41 & 0.09 & 7.29 & 7.55 \\
\hline & & 006 & 9.11 & 0.13 & 8.92 & 9.31 \\
\hline & & 008 & 7.23 & 0.08 & 7.11 & 7.32 \\
\hline & & 009 & 7.37 & 0.17 & 7.21 & 7.71 \\
\hline & & 011 & 7.69 & 0.07 & 7.62 & 7.79 \\
\hline & August 1992 & 001 & 8.24 & 0.67 & 7.42 & 8.82 \\
\hline & & 004 & 7.48 & 0.18 & 7.26 & 7.76 \\
\hline & & 006 & 8.96 & 0.18 & 8.63 & 9.20 \\
\hline & & 008 & 7.44 & 0.12 & 7.30 & 7.62 \\
\hline & & 009 & 7.71 & 0.16 & 7.49 & 7.92 \\
\hline & & 011 & 7.62 & 0.09 & 7.51 & 7.73 \\
\hline & October 1992 & 001 & 8.08 & 0.18 & 7.82 & 8.38 \\
\hline & & 004 & 7.50 & 0.11 & 7.37 & 7.68 \\
\hline & & 006 & 8.56 & 0.23 & 8.29 & 8.92 \\
\hline & & 008 & 7.37 & 0.14 & 7.17 & 7.57 \\
\hline & & 009 & 7.81 & 0.12 & 7.61 & 7.96 \\
\hline & & 011 & 8.00 & 0.33 & 7.72 & 8.67 \\
\hline & February 1993 & 001 & 7.59 & 0.07 & 7.46 & 7.68 \\
\hline & & 006 & 8.91 & 0.08 & 8.82 & 9.06 \\
\hline & & 008 & 7.40 & 0.10 & 7.27 & 7.54 \\
\hline & & 009 & 7.94 & 0.31 & 7.65 & 8.37 \\
\hline
\end{tabular}


Table B.3 (continued)

\begin{tabular}{|c|c|c|c|c|c|c|}
\hline $\begin{array}{l}\text { Water quality } \\
\text { parameter }\end{array}$ & Date & Outfall & Mean & $\mathrm{SD}$ & Min & Max \\
\hline & & 011 & 7.67 & 0.13 & 7.40 & 7.82 \\
\hline & May 1993 & 001 & 8.57 & 0.46 & 7.63 & 8.96 \\
\hline & & 006 & 8.51 & 0.32 & 7.87 & 8.76 \\
\hline & & 008 & 7.57 & 0.13 & 7.42 & 7.74 \\
\hline & & 009 & 7.73 & 0.17 & 7.47 & 7.94 \\
\hline & & 011 & 8.19 & 0.50 & 7.70 & 9.15 \\
\hline & June 1993 & 006 & 8.38 & 0.94 & 6.80 & 9.30 \\
\hline & & 008 & 7.41 & 0.46 & 6.90 & 8.20 \\
\hline & & 009 & 7.51 & 0.40 & 7.10 & 8.18 \\
\hline & August 1993 & 001 & 7.80 & 0.24 & 7.56 & 8.13 \\
\hline & & 006 & 9.27 & 0.08 & 9.14 & 9.36 \\
\hline & & 008 & 7.31 & 0.13 & 7.06 & 7.45 \\
\hline & & 009 & 7.61 & 0.07 & 7.54 & 7.76 \\
\hline & & 011 & 7.74 & 0.12 & 7.63 & 7.95 \\
\hline & October 1993 & 001 & 8.56 & 0.18 & 8.25 & 8.72 \\
\hline & & 006 & 8.54 & 0.21 & 8.21 & 8.78 \\
\hline & & 008 & 7.46 & 0.07 & 7.40 & 7.62 \\
\hline & & 009 & 7.68 & 0.12 & 7.54 & 7.88 \\
\hline & & 011 & 7.65 & 0.04 & 7.60 & 7.71 \\
\hline & December 1993 & 008 & 7.44 & 0.15 & 7.31 & 7.65 \\
\hline & March 1994 & 001 & 8.14 & 0.21 & 7.92 & 8.54 \\
\hline & & 006 & 8.74 & 0.08 & 8.66 & 8.88 \\
\hline & & 008 & 7.61 & 0.09 & 7.48 & 7.74 \\
\hline & & 009 & 8.09 & 0.36 & 7.67 & 8.65 \\
\hline & & 011 & 7.88 & 0.14 & 7.75 & 8.16 \\
\hline & March 1994 & 006 & 7.89 & 0.20 & 7.64 & 8.11 \\
\hline & & 011 & 7.65 & 0.24 & 7.39 & 8.02 \\
\hline & April 1994 & 006 & 8.55 & 0.25 & 8.17 & 8.84 \\
\hline & & 011 & 7.67 & 0.15 & 7.42 & 7.86 \\
\hline & May 1994 & 001 & 9.14 & 0.17 & 8.90 & 9.35 \\
\hline & & 008 & 7.35 & 0.11 & 7.19 & 7.50 \\
\hline & & 009 & 7.52 & 0.08 & 7.39 & 7.62 \\
\hline & June 1994 & 008 & 7.05 & 0.14 & 6.86 & 7.24 \\
\hline & & 009 & 7.51 & 0.10 & 7.38 & 7.64 \\
\hline & August 1994 & 001 & 9.19 & 0.08 & 9.09 & 9.32 \\
\hline & & 006 & 9.12 & 0.08 & 8.95 & 9.22 \\
\hline & & 008 & 7.15 & 0.09 & 7.01 & 7.29 \\
\hline & & 009 & 7.61 & 0.06 & 7.51 & 7.69 \\
\hline & & 010 & 7.52 & 0.18 & 7.27 & 7.84 \\
\hline & September 1994 & 006 & 7.85 & 0.22 & 7.67 & 8.19 \\
\hline
\end{tabular}


Table B.3 (continued)

\begin{tabular}{|c|c|c|c|c|c|c|}
\hline $\begin{array}{l}\text { Water quality } \\
\text { parameter }\end{array}$ & Date & Outfall & Mean & SD & Min & Max \\
\hline & & 008 & 7.13 & 0.25 & 6.95 & 7.66 \\
\hline & & 009 & 7.48 & 0.22 & 7.27 & 7.90 \\
\hline & October 1994 & 001 & 8.74 & 0.36 & 7.89 & 9.00 \\
\hline & & 006 & 8.70 & 0.23 & 8.34 & 8.99 \\
\hline & & 008 & 7.51 & 0.16 & 7.24 & 7.75 \\
\hline & & 009 & 8.22 & 0.35 & 7.77 & 8.83 \\
\hline & & 010 & 7.71 & 0.26 & 7.51 & 8.33 \\
\hline & November 1994 & 001 & 7.44 & 0.20 & 7.12 & 7.66 \\
\hline & & 009 & 7.51 & 0.15 & 7.30 & 7.72 \\
\hline Conductivity & October 1991 & 001 & 1562.71 & 158.13 & 1303 & 1728 \\
\hline \multirow[t]{30}{*}{$(\mu \mathrm{S} / \mathrm{cm})$} & & 004 & 355.57 & 30.34 & 320 & 392 \\
\hline & & 006 & 273.29 & 7.02 & 262 & 281 \\
\hline & & 008 & 313.14 & 19.14 & 288 & 350 \\
\hline & & 009 & 193.86 & 45.84 & 116 & 265 \\
\hline & & 011 & 258.00 & 11.86 & 239 & 273 \\
\hline & February 1992 & 001 & 900.71 & 104.96 & 782 & 1086 \\
\hline & & 004 & 286.71 & 18.20 & 259 & 302 \\
\hline & & 006 & 195.00 & 5.72 & 185 & 204 \\
\hline & & 008 & 247.14 & 25.75 & 208 & 279 \\
\hline & & 009 & 225.00 & 51.78 & 132 & 282 \\
\hline & & 011 & 228.57 & 24.79 & 191 & 260 \\
\hline & May 1992 & 001 & 1168.71 & 376.44 & 657 & 1561 \\
\hline & & 004 & 287.43 & 11.84 & 273 & 301 \\
\hline & & 006 & 236.43 & 4.12 & 228 & 240 \\
\hline & & 008 & 260.43 & 14.90 & 244 & 286 \\
\hline & & 009 & 223.00 & 8.54 & 210 & 233 \\
\hline & & 011 & 239.71 & 11.77 & 225 & 258 \\
\hline & August 1992 & 001 & 1262.29 & 450.64 & 586 & 1668 \\
\hline & & 004 & 234.57 & 17.36 & 213 & 257 \\
\hline & & 006 & 219.29 & 19.59 & 199 & 250 \\
\hline & & 008 & 210.14 & 19.45 & 177 & 233 \\
\hline & & , 009 & 209.86 & 19.15 & 175 & 232 \\
\hline & & 011 & 201.14 & 18.25 & 168 & 222 \\
\hline & October 1992 & 001 & 1782.00 & 95.01 & 1632 & 1867 \\
\hline & & 004 & 297.29 & 37.56 & 266 & 358 \\
\hline & & 006 & 208.14 & 6.69 & 198 & 217 \\
\hline & & 008 & 251.43 & 21.61 & 235 & 292 \\
\hline & & 009 & 259.43 & 25.15 & 219 & 296 \\
\hline & & 011 & 218.57 & 20.12 & 190 & 252 \\
\hline & February 1993 & 001 & 970.29 & 182.19 & 760 & 1214 \\
\hline
\end{tabular}


Table B.3 (continued)

\begin{tabular}{|c|c|c|c|c|c|c|}
\hline $\begin{array}{l}\text { Water quality } \\
\text { parameter }\end{array}$ & Date & Outfall & Mean & $\mathrm{SD}$ & Min & $\operatorname{Max}$ \\
\hline & \multirow{9}{*}{ May 1993} & 006 & 169.57 & 5.56 & 163 & 178 \\
\hline & & 008 & 263.57 & 88.42 & 212 & 461 \\
\hline & & 009 & 350.71 & 299.41 & 180 & 1020 \\
\hline & & 011 & 227.00 & 43.99 & 188 & 315 \\
\hline & & 001 & 1470.29 & 105.25 & 1246 & 1545 \\
\hline & & 006 & 269.00 & 3.96 & 264 & 274 \\
\hline & & 008 & 278.43 & 19.11 & 248 & 298 \\
\hline & & 009 & 339.86 & 124.79 & 206 & 578 \\
\hline & & 011 & 251.29 & 18.09 & 233 & 285 \\
\hline & \multirow[t]{3}{*}{ June 1993} & 006 & 246.50 & 41.71 & 167 & 281 \\
\hline & & 008 & 268.50 & 24.90 & 239 & 300 \\
\hline & & 009 & 215.00 & 43.10 & 151 & 255 \\
\hline & \multirow[t]{5}{*}{ August 1993} & 001 & 854.71 & 326.92 & 489 & 1300 \\
\hline & & 006 & 264.43 & 7.70 & 250 & 273 \\
\hline & & 008 & 256.29 & 21.65 & 234 & 288 \\
\hline & & 009 & 256.86 & 17.19 & 238 & 287 \\
\hline & & 011 & 233.29 & 20.57 & 200 & 255 \\
\hline & \multirow[t]{5}{*}{ October 1993} & 001 & 1422.57 & 153.29 & 1230 & 1622 \\
\hline & & 006 & 321.29 & 8.01 & 307 & 329 \\
\hline & & 008 & 306.43 & 20.98 & 277 & 331 \\
\hline & & 009 & 221.29 & 44.94 & 164 & 270 \\
\hline & & 011 & 301.71 & 22.54 & 270 & 330 \\
\hline & \multirow[t]{6}{*}{ December 1993} & 008 & 318.00 & 40.82 & 243 & 361 \\
\hline & & 001 & 1026.00 & 92.43 & 907 & 1148 \\
\hline & & 006 & 191.43 & 6.27 & 178 & 196 \\
\hline & & 008 & 310.43 & 42.88 & 262 & 376 \\
\hline & & 009 & 540.71 & 130.37 & 447 & 817 \\
\hline & & 011 & 329.29 & 73.25 & 263 & 475 \\
\hline & \multirow[t]{2}{*}{ March 1994} & 006 & 191.71 & 5.09 & 181 & 195 \\
\hline & & 011 & 340.43 & 99.26 & 248 & 491 \\
\hline & \multirow[t]{2}{*}{ April 1994} & 006 & 183.29 & 2.50 & 180 & 187 \\
\hline & & 011 & 224.00 & 32.17 & 173 & 269 \\
\hline & \multirow[t]{3}{*}{ May 1994} & 001 & 1323.86 & 51.68 & 1244 & 1384 \\
\hline & & 008 & 250.29 & 13.56 & 233 & 268 \\
\hline & & 009 & 285.14 & 32.17 & 257 & 354 \\
\hline & \multirow[t]{2}{*}{ June 1994} & 008 & 218.14 & 11.88 & 206 & 236 \\
\hline & & 009 & 210.86 & 9.49 & 194 & 224 \\
\hline & \multirow[t]{3}{*}{ August 1994} & 001 & 1251.43 & 19.90 & 1215 & 1271 \\
\hline & & 006 & 194.14 & 3.72 & 188 & 199 \\
\hline & & 008 & 207.86 & 15.09 & 187 & 229 \\
\hline
\end{tabular}


Table B.3 (continued)

\begin{tabular}{|c|c|c|c|c|c|c|}
\hline $\begin{array}{l}\text { Water quality } \\
\text { parameter }\end{array}$ & Date & Outfall & Mean & SD & Min & $\operatorname{Max}$ \\
\hline & & 009 & 187.00 & 7.96 & 176 & 197 \\
\hline & & 010 & 224.86 & 9.17 & 213 & 235 \\
\hline & September 1994 & 006 & 205.86 & 5.84 & 200 & 216 \\
\hline & & 008 & 256.00 & 7.14 & 242 & 265 \\
\hline & & 009 & 230.57 & 9.52 & 220 & 244 \\
\hline & October 1994 & 001 & 1338.75 & 83.82 & 1170 & 1452 \\
\hline & & 006 & 209.14 & 2.54 & 206 & 213 \\
\hline & & 008 & 244.25 & 11.12 & 229 & 259 \\
\hline & & 009 & 212.63 & 10.43 & 204 & 234 \\
\hline & & 010 & 266.63 & 15.45 & 243 & 288 \\
\hline & November 1994 & 001 & 1237.67 & 95.58 & 1098 & 1398 \\
\hline & & 009 & 211.57 & 31.32 & 166 & 240 \\
\hline Alkalinity & October 1991 & 001 & 32.29 & 4.07 & 28 & 39 \\
\hline \multirow[t]{27}{*}{$\left.(\mathrm{mg} / \mathrm{L} \mathrm{CaCO})_{3}\right)$} & & 004 & 42.86 & 4.74 & 38 & 50 \\
\hline & & 006 & 39.14 & 0.69 & 38 & 40 \\
\hline & & 008 & 36.14 & 3.80 & 31 & 42 \\
\hline & & 009 & 43.43 & 9.03 & 32 & 61 \\
\hline & & 011 & 42.14 & 6.44 & 34 & 49 \\
\hline & February 1992 & 001 & 39.43 & 4.83 & 32 & 46 \\
\hline & & 004 & 52.86 & 4.56 & 47 & 59 \\
\hline & & 006 & 41.43 & 7.72 & 36 & 58 \\
\hline & & 008 & 46.29 & 9.07 & 37 & 63 \\
\hline & & 009 & 69.00 & 21.91 & 39 & 110 \\
\hline & & 011 & 52.71 & 5.38 & 48 & 62 \\
\hline & May 1992 & 001 & 26.43 & 2.15 & 25 & 31 \\
\hline & & 004 & 35.00 & 3.27 & 31 & 39 \\
\hline & & 006 & 35.43 & 1.13 & 33 & 36 \\
\hline & & 008 & 30.29 & 3.55 & 26 & 36 \\
\hline & & 009 & 40.43 & 2.23 & 37 & 43 \\
\hline & & 011 & 31.43 & 2.30 & 30 & 36 \\
\hline & August 1992 & 001 & 29.71 & 1.98 & 27 & 33 \\
\hline & & 004 & 31.00 & 1.63 & 28 & 33 \\
\hline & & 006 & 35.14 & 2.12 & 33 & 38 \\
\hline & & 008 & 26.00 & 2.08 & 23 & 29 \\
\hline & & 009 & 42.43 & 2.30 & 38 & 45 \\
\hline & & 011 & 27.71 & 3.73 & 23 & 34 \\
\hline & October 1992 & 001 & 24.00 & 1.00 & 23 & 26 \\
\hline & & 004 & 36.86 & 2.97 & 33 & 41 \\
\hline & & 006 & 35.86 & 2.61 & 31 & 39 \\
\hline & & 008 & 27.43 & 2.07 & 24 & 29 \\
\hline
\end{tabular}


Table B.3 (continued)

\begin{tabular}{|c|c|c|c|c|c|c|}
\hline $\begin{array}{l}\text { Water quality } \\
\text { parameter }\end{array}$ & Date & Outfall & Mean & SD & Min & $\operatorname{Max}$ \\
\hline & & 009 & 56.57 & 12.07 & 39 & 68 \\
\hline & & 011 & 30.29 & 1.50 & 28 & 32 \\
\hline & February 1993 & 001 & 40.43 & 5.68 & 30 & 47 \\
\hline & & 006 & 44.14 & 1.57 & 41 & 46 \\
\hline & & 008 & 37.43 & 5.88 & 31 & 45 \\
\hline & & 009 & 54.57 & 14.20 & 37 & 73 \\
\hline & & 011 & 45.00 & 8.56 & 35 & 60 \\
\hline & May 1993 & 001 & 38.00 & 11.59 & 30 & 64 \\
\hline & & 006 & 69.29 & 5.19 & 59 & 76 \\
\hline & & 008 & 35.00 & 4.04 & 30 & 41 \\
\hline & & 009 & 99.57 & 69.40 & 45 & 233 \\
\hline & & 011 & 42.29 & 2.87 & 40 & 48 \\
\hline & June 1993 & 006 & 53.33 & 12.06 & 30 & 62 \\
\hline & & 008 & 42.33 & 11.33 & 30 & 62 \\
\hline & & 009 & 47.83 & 6.85 & 41 & 56 \\
\hline & August 1993 & 001 & 26.14 & 2.12 & 23 & 29 \\
\hline & & 006 & 46.57 & 1.27 & 45 & 49 \\
\hline & & 008 & 25.57 & 2.30 & 23 & 29 \\
\hline & & 009 & 47.00 & 11.45 & 37 & 70 \\
\hline & & 011 & 26.57 & 1.81 & 25 & 30 \\
\hline \multirow{20}{*}{$\cdot$} & October 1993 & 001 & 51.86 & 14.67 & 45 & 85 \\
\hline & & 006 & 86.00 & 1.41 & 84 & 88 \\
\hline & & 008 & 40.57 & 5.56 & 33 & 48 \\
\hline & & 009 & 45.29 & 3.35 & 40 & 49 \\
\hline & & 011 & 36.43 & 3.69 & 31 & 43 \\
\hline & December 1993 & 008 & 54.50 & 4.68 & 50 & 61 \\
\hline & March 1994 & 001 & 48.71 & 6.26 & 40 & 57 \\
\hline & & 006 & 61.86 & 2.34 & 57 & 64 \\
\hline & & 008 & 59.14 & 5.21 & 50 & 65 \\
\hline & & 009 & 79.57 & 21.85 & 41 & 102 \\
\hline & & 011 & 66.57 & 7.46 & 56 & 77 \\
\hline & March 1994 & 006 & 63.00 & 3.42 & 57 & 67 \\
\hline & & 011 & 55.00 & 12.68 & 43 & 72 \\
\hline & April 1994 & 006 & 58.86 & 1.86 & 57 & 62 \\
\hline & & 011 & 47.83 & 9.41 & 37 & 58 \\
\hline & May 1994 & 001 & 29.29 & 1.11 & 28 & 31 \\
\hline & & 008 & 28.57 & 3.60 & 25 & 33 \\
\hline & & 009 & 61.57 & 18.43 & 42 & 97 \\
\hline & June 1994 & 008 & 24.57 & 2.15 & 22 & 28 \\
\hline & & 009 & 41.14 & 1.95 & 38 & 43 \\
\hline
\end{tabular}


Table B.3 (continued)

\begin{tabular}{|c|c|c|c|c|c|c|}
\hline $\begin{array}{l}\text { Water quality } \\
\text { parameter }\end{array}$ & Date & Outfall & Mean & $\mathrm{SD}$ & Min & Max \\
\hline & August 1994 & 001 & 29.71 & 1.98 & 27 & 33 \\
\hline & & 006 & 48.00 & 1.00 & 47 & 50 \\
\hline & & 008 & 21.43 & 2.64 & 18 & 25 \\
\hline & & 009 & 31.57 & 0.53 & 31 & 32 \\
\hline & & 010 & 22.14 & 1.07 & 21 & 23 \\
\hline & September 1994 & 006 & 47.43 & 1.13 & 46 & 49 \\
\hline & & 008 & 24.29 & 3.04 & 20 & 28 \\
\hline & & 009 & 35.14 & 3.76 & 31 & 41 \\
\hline & October 1994 & 001 & 32.25 & 1.83 & 31 & 36 \\
\hline & & 006 & 40.14 & 2.54 & 36 & 44 \\
\hline & & 008 & 29.38 & 2.13 & 26 & 33 \\
\hline & & 009 & 34.50 & 3.46 & 30 & 42 \\
\hline & & 010 & 27.13 & 1.73 & 25 & 30 \\
\hline & November 1994 & 001 & 34.50 & 5.82 & 26 & 43 \\
\hline & & 009 & 41.86 & 7.60 & 32 & 53 \\
\hline Hardness & October 1991 & 001 & 444.71 & 42.21 & 364 & 487 \\
\hline \multirow[t]{24}{*}{$\left(\mathrm{mg} / \mathrm{L} \mathrm{CaCO}_{3}\right)$} & & 004 & 86.29 & 13.92 & 70 & 106 \\
\hline & & 006 & 75.43 & 7.55 & 68 & 88 \\
\hline & & 008 & 77.14 & 10.70 & 64 & 96 \\
\hline & & 009 & 63.71 & 14.07 & 44 & 90 \\
\hline & & 011 & 76.86 & 9.08 & 62 & 86 \\
\hline & February 1992 & 001 & 297.14 & 40.30 & 240 & 370 \\
\hline & & 004 & 81.14 & 7.01 & 74 & 96 \\
\hline & & 006 & 62.86 & 16.04 & 50 & 96 \\
\hline & & 008 & 74.57 & 13.60 & 60 & 102 \\
\hline & & 009 & 87.43 & 11.47 & 74 & 102 \\
\hline & & 011 & 82.00 & 11.14 & 74 & 104 \\
\hline & May 1992 & 001 & 416.57 & 166.14 & 188 & 660 \\
\hline & & 004 & 112.57 & 82.35 & 72 & 298 \\
\hline & & 006 & 72.86 & 2.54 & 70 & 76 \\
\hline & & 008 & 66.86 & 6.82 & 58 & 80 \\
\hline & & 009 & 73.43 & 5.00 & 68 & 82 \\
\hline & & 011 & 73.71 & 7.52 & 68 & 88 \\
\hline & August 1992 & 001 & 379.43 & 149.02 & 168 & 506 \\
\hline & & 004 & 64.00 & 5.89 & 56 & 70 \\
\hline & 1 & 006 & 64.57 & 6.60 & 58 & 76 \\
\hline & & 008 & 57.71 & 7.87 & 50 & 68 \\
\hline & & 009 & 68.29 & 7.06 & 56 & 76 \\
\hline & & 011 & 58.86 & 7.73 & 52 & 70 \\
\hline & October 1992 & 001 & 552.00 & 70.20 & 424 & 632 \\
\hline
\end{tabular}


Table B.3 (continued)

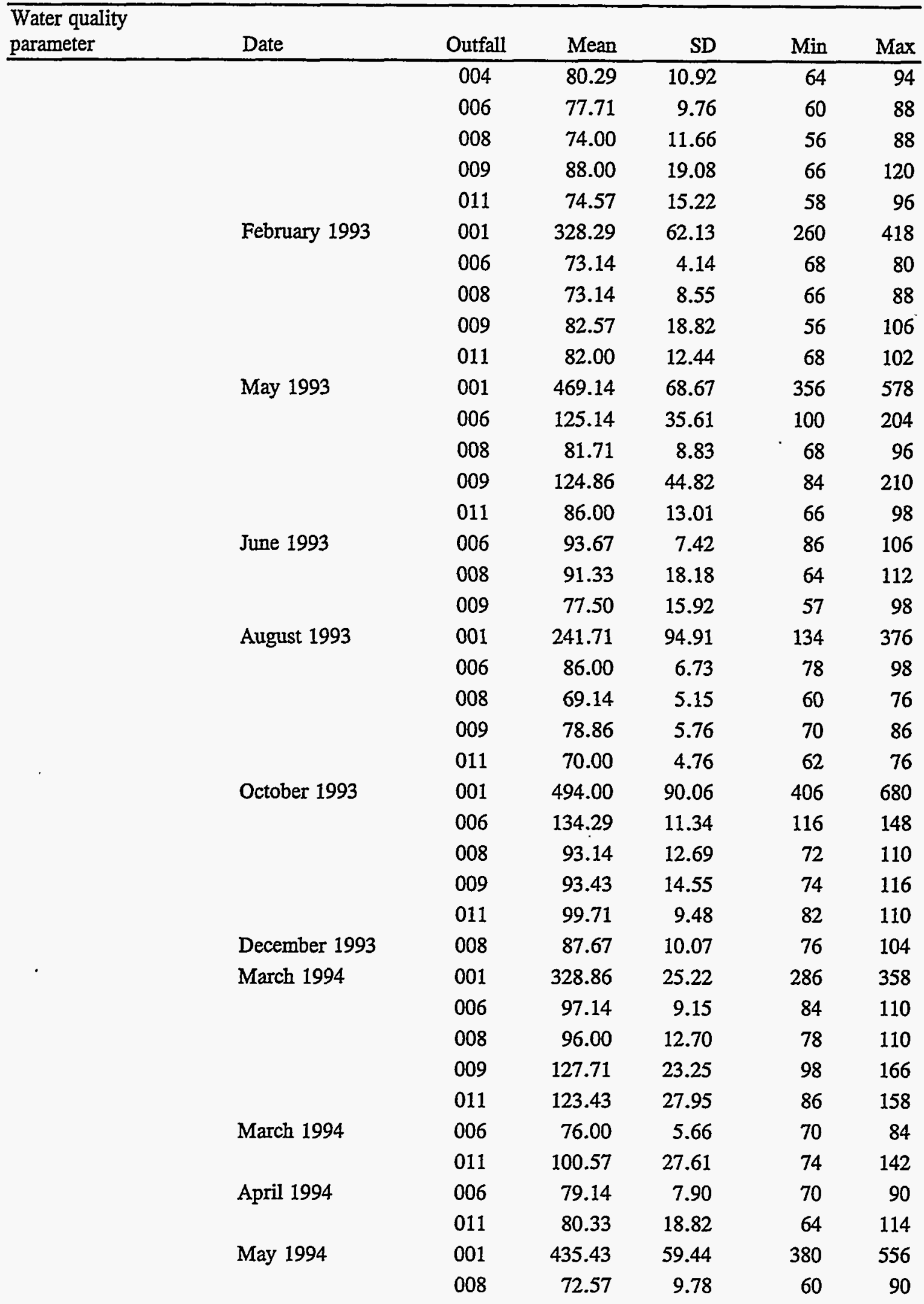


Table B.3 (continued)

\begin{tabular}{llrrrrr}
\hline $\begin{array}{l}\text { Water quality } \\
\text { parameter }\end{array}$ & Date & Outfall & Mean & SD & Min & Max \\
\hline & & 009 & 93.43 & 18.57 & 74 & 130 \\
& June 1994 & 008 & 63.43 & 9.00 & 54 & 80 \\
& & 009 & 71.71 & 4.68 & 64 & 78 \\
& August 1994 & 001 & 428.57 & 34.69 & 400 & 480 \\
& & 006 & 85.43 & 19.96 & 68 & 124 \\
& & 008 & 60.29 & 17.49 & 44 & 84 \\
& & 009 & 72.86 & 24.13 & 54 & 120 \\
& & 010 & 74.29 & 17.90 & 54 & 108 \\
& September 1994 & 006 & 83.43 & 8.38 & 76 & 96 \\
& & 008 & 75.71 & 16.43 & 44 & 98 \\
& 009 & 84.57 & 7.18 & 72 & 92 \\
& & 001 & 426.75 & 23.00 & 394 & 464 \\
& October 1994 & 006 & 76.86 & 13.61 & 60 & 92 \\
& & 008 & 72.00 & 13.56 & 56 & 96 \\
& & 009 & 70.25 & 8.91 & 60 & 84 \\
& & 010 & 89.75 & 22.15 & 70 & 140 \\
& & 001 & 384.33 & 37.00 & 344 & 438 \\
& & 009 & 79.86 & 13.52 & 56 & 94 \\
\hline
\end{tabular}


Table B.4. Results of Fathead minnow toxicity tests of intermittently flowing effluents at the Paducah Gaseous Diffusion Plant

Tests conducted December 1991-November 1994

\begin{tabular}{|c|c|c|c|c|c|c|}
\hline \multirow{2}{*}{ Date } & \multirow{2}{*}{ Outfall } & \multirow{2}{*}{ Conc. } & \multicolumn{2}{|c|}{ Survival (\%) } & \multicolumn{2}{|c|}{ Growth (mg/larvae) } \\
\hline & & & Mean & SD & Mean & SD \\
\hline \multirow[t]{21}{*}{ December 1991} & Control & 100 & 97.5 & 5.0 & 0.60 & 0.04 \\
\hline & 013 & 12 & 95.0 & 5.8 & 0.65 & 0.06 \\
\hline & & 25 & 92.5 & 15.0 & 0.57 & 0.08 \\
\hline & & 50 & 95.0 & 10.0 & 0.60 & 0.09 \\
\hline & & 100 & 97.5 & 5.0 & 0.61 & 0.04 \\
\hline & 015 & 12 & 95.0 & 5.8 & 0.66 & 0.03 \\
\hline & & 25 & 97.5 & 5.0 & 0.66 & 0.11 \\
\hline & & 50 & 95.0 & 5.8 & 0.60 & 0.05 \\
\hline & & 100 & 95.0 & 5.8 & 0.67 & 0.03 \\
\hline & 016 & 12 & 97.5 & 5.0 & 0.57 & 0.02 \\
\hline & & 25 & 92.5 & 5.0 & 0.63 & 0.08 \\
\hline & & 50 & 100.0 & 0.0 & 0.63 & 0.05 \\
\hline & & 100 & 95.0 & 5.8 & 0.68 & 0.05 \\
\hline & 017 & 12 & 87.5 & 12.6 & 0.64 & 0.03 \\
\hline & & 25 & 97.5 & 5.0 & 0.64 & 0.04 \\
\hline & & 50 & 97.5 & 5.0 & 0.65 & 0.07 \\
\hline & & 100 & 80.0 & 18.3 & 0.67 & 0.14 \\
\hline & 018 & 12 & 97.5 & 5.0 & 0.55 & 0.06 \\
\hline & & 25 & 100.0 & 0.0 & 0.57 & 0.05 \\
\hline & & 50 & 97.5 & 5.0 & 0.58 & 0.02 \\
\hline & & 100 & 100.0 & 0.0 & 0.68 & 0.08 \\
\hline \multirow[t]{17}{*}{ March 1992} & Control & 100 & 100.0 & 0.0 & 0.30 & 0.04 \\
\hline & 013 & 12 & 100.0 & 0.0 & 0.25 & 0.02 \\
\hline & & 25 & 82.5 & 9.6 & 0.24 & 0.02 \\
\hline & & 50 & 65.0 & 44.4 & 0.26 & 0.03 \\
\hline & & 100 & 37.5 & 33.0 & 0.35 & 0.12 \\
\hline & 015 & 12 & 95.0 & 5.8 & 0.25 & 0.04 \\
\hline & & 25 & 20.0 & 33.7 & 0.51 & 0.13 \\
\hline & & 50 & 67.5 & 45.7 & 0.29 & 0.03 \\
\hline & & 100 & 25.0 & 30.0 & 0.45 & 0.07 \\
\hline & 016 & 12 & 97.5 & 5.0 & 0.30 & 0.03 \\
\hline & & 25 & 87.5 & 15.0 & 0.32 & 0.03 \\
\hline & & 50 & 95.0 & 5.8 & 0.26 & 0.03 \\
\hline & & 100 & 67.5 & 32.0 & 0.26 & 0.03 \\
\hline & 017 & 12 & 87.5 & 9.6 & 0.33 & 0.06 \\
\hline & & 25 & 87.5 & 9.6 & 0.25 & 0.04 \\
\hline & & 50 & 57.5 & 40.3 & 0.23 & 0.08 \\
\hline & & 100 & 20.0 & 18.3 & 0.53 & 0.05 \\
\hline
\end{tabular}


Table B.4 (continued)

\begin{tabular}{|c|c|c|c|c|c|c|}
\hline \multirow{2}{*}{ Date } & \multirow{2}{*}{ Outfall } & \multirow{2}{*}{ Conc. - } & \multicolumn{2}{|c|}{ Survival (\%) } & \multicolumn{2}{|c|}{ Growth (mg/larvae) } \\
\hline & & & Méan & $\mathrm{SD}$ & Mean & SD \\
\hline & 018 & 12 & 92.5 & 15.0 & 0.35 & 0.03 \\
\hline & & 25 & 45.0 & 35.1 & 0.50 & 0.06 \\
\hline & & 50 & 7.5 & 9.6 & 0.61 & 0.34 \\
\hline & & 100 & 5.0 & 5.8 & 0.22 & 0.32 \\
\hline \multirow[t]{17}{*}{ June 1992} & Control & 100 & 97.5 & 5.0 & 0.47 & 0.03 \\
\hline & 013 & 12 & 95.0 & 10.0 & 0.43 & 0.02 \\
\hline & & 25 & 97.5 & 5.0 & 0.47 & 0.02 \\
\hline & & 50 & 82.5 & 23.6 & 0.46 & 0.04 \\
\hline & & 100 & 82.5 & 17.1 & 0.44 & 0.03 \\
\hline & 015 & 12 & 100.0 & 0.0 & 0.42 & 0.01 \\
\hline & & 25 & 100.0 & 0.0 & 0.47 & 0.05 \\
\hline & & 50 & 100.0 & 0.0 & 0.42 & 0.03 \\
\hline & & 100 & 97.5 & 5.0 & 0.47 & 0.05 \\
\hline & 017 & 12 & 97.5 & 5.0 & 0.45 & 0.03 \\
\hline & & 25 & 87.5 & 15.0 & 0.48 & 0.05 \\
\hline & & 50 & 95.0 & 10.0 & 0.50 & 0.05 \\
\hline & & 100 & 72.5 & 15.0 & 0.53 & 0.03 \\
\hline & 018 & 12 & 97.5 & 5.0 & 0.52 & 0.02 \\
\hline & & 25 & 95.0 & 10.0 & 0.51 & 0.03 \\
\hline & & 50 & 92.5 & 9.6 & 0.47 & 0.03 \\
\hline & & 100 & 97.5 & 5.0 & 0.49 & 0.08 \\
\hline \multirow[t]{19}{*}{ September 1992} & Control & 100 & 95.0 & 5.8 & 0.49 & 0.04 \\
\hline & 013 & 12 & 95.0 & 5.8 & 0.34 & 0.06 \\
\hline & & 25 & 97.5 & 5.0 & 0.40 & 0.02 \\
\hline & & 50 & 92.5 & 5.0 & 0.44 & 0.04 \\
\hline & & 100 & 87.5 & 5.0 & 0.49 & 0.05 \\
\hline & 015 & 12 & 95.0 & 5.8 & 0.51 & 0.07 \\
\hline & & 25 & 90.0 & 20.0 & 0.48 & 0.08 \\
\hline & & 50 & 90.0 & 8.2 & 0.44 & 0.02 \\
\hline & & 100 & 87.5 & 15.0 & 0.48 & 0.09 \\
\hline & 016 & 12 & 90.0 & 8.2 & 0.42 & 0.02 \\
\hline & & 25 & 97.5 & 5.0 & 0.44 & 0.05 \\
\hline & & 50 & 72.5 & 5.0 & 0.45 & 0.03 \\
\hline & & 100 & 92.5 & 9.6 & 0.54 & 0.09 \\
\hline & 017 & 12 & 72.5 & 35.9 & 0.58 & 0.09 \\
\hline & & 25 & 62.5 & 32.0 & 0.60 & 0.09 \\
\hline & & 50 & 57.5 & 15.0 & 0.61 & 0.04 \\
\hline & & 100 & 55.0 & 12.9 & 0.53 & 0.13 \\
\hline & 018 & 12 & 90.0 & 8.2 & 0.58 & 0.07 \\
\hline & & 25 & 92.5 & 5.0 & 0.54 & 0.02 \\
\hline
\end{tabular}


Table B.4 (continued)

\begin{tabular}{|c|c|c|c|c|c|c|}
\hline \multirow{2}{*}{ Date } & \multirow{2}{*}{ Outfall } & \multirow{2}{*}{ Conc. } & \multicolumn{2}{|c|}{ Survival (\%) } & \multicolumn{2}{|c|}{ Growth (mg/larvae) } \\
\hline & & & Mean & SD & Mean & SD \\
\hline & & 50 & 90.0 & 14.1 & 0.46 & 0.05 \\
\hline & & 100 & 92.5 & 5.0 & 0.54 & 0.05 \\
\hline \multirow[t]{21}{*}{ November 1992} & Control & 100 & 95.0 & 5.8 & 0.40 & 0.04 \\
\hline & 013 & 12 & 82.5 & 15.0 & 0.53 & 0.08 \\
\hline & & 25 & 90.0 & 0.0 & 0.44 & 0.05 \\
\hline & & 50 & 77.5 & 33.0 & 0.45 & 0.12 \\
\hline & & 100 & 42.5 & 26.3 & 0.42 & 0.25 \\
\hline & 015 & 12 & 95.0 & 5.8 & 0.40 & 0.06 \\
\hline & & 25 & 90.0 & 8.2 & 0.43 & 0.06 \\
\hline & & 50 & 100.0 & 0.0 & 0.43 & 0.11 \\
\hline & & 100 & 92.5 & 5.0 & 0.36 & 0.04 \\
\hline & 016 & 12 & 97.5 & 5.0 & 0.43 & 0.01 \\
\hline & & 25 & 82.5 & 17.1 & 0.42 & 0.10 \\
\hline & & 50 & 95.0 & 10.0 & 0.43 & 0.06 \\
\hline & & 100 & 75.0 & 20.8 & 0.37 & 0.04 \\
\hline & 017 & 12 & 97.5 & 5.0 & 0.39 & 0.12 \\
\hline & & 25 & 87.5 & 12.6 & 0.54 & 0.05 \\
\hline & & 50 & 92.5 & 9.6 & 0.49 & 0.09 \\
\hline & & 100 & 85.0 & 12.9 & 0.49 & 0.03 \\
\hline & 018 & 12 & 97.5 & 5.0 & 0.45 & 0.06 \\
\hline & & 25 & 100.0 & 0.0 & 0.39 & 0.05 \\
\hline & & 50 & 100.0 & 0.0 & 0.36 & 0.07 \\
\hline & & 100 & 72.5 & 22.2 & 0.34 & 0.08 \\
\hline \multirow[t]{16}{*}{ January 1993} & Control & 100 & 97.5 & 5.0 & 0.57 & 0.09 \\
\hline & 013 & 6 & 90.0 & 8.2 & 0.57 & 0.08 \\
\hline & & 12 & 92.5 & 5.0 & 0.67 & 0.03 \\
\hline & & 25 & 90.0 & 0.0 & 0.63 & 0.04 \\
\hline & & 50 & 85.0 & 17.3 & 0.57 & 0.09 \\
\hline & & 100 & 95.0 & 5.8 & 0.62 & 0.08 \\
\hline & 015 & 6 & 95.0 & 5.8 & 0.50 & 0.06 \\
\hline & & 12 & 72.5 & 35.9 & 0.56 & 0.17 \\
\hline & & 25 & 100.0 & 0.0 & 0.58 & 0.08 \\
\hline & & 50 & 77.5 & 12.6 & 0.60 & 0.08 \\
\hline & & 100 & 75.0 & 10.0 & 0.55 & 0.19 \\
\hline & 016 & 6 & 85.0 & 17.3 & 0.60 & 0.06 \\
\hline & & 12 & 95.0 & 5.8 & 0.61 & 0.08 \\
\hline & $\cdot$ & 25 & 82.5 & 12.6 & 0.62 & 0.09 \\
\hline & & 50 & 80.0 & 14.1 & 0.52 & 0.10 \\
\hline & & 100 & 75.0 & 12.9 & 0.61 & 0.11 \\
\hline
\end{tabular}


Table B.4 (continued)

\begin{tabular}{|c|c|c|c|c|c|c|}
\hline \multirow{2}{*}{ Date } & \multirow{2}{*}{ Outfall } & \multirow{2}{*}{ Conc. } & \multicolumn{2}{|c|}{ Survival (\%) } & \multicolumn{2}{|c|}{ Growth (mg/larvae) } \\
\hline & & & Mean & SD & Mean & $\mathrm{SD}$ \\
\hline & 017 & 6 & 90.0 & 8.2 & 0.45 & 0.07 \\
\hline & & 12 & 95.0 & 10.0 & 0.46 & 0.05 \\
\hline & & 25 & 95.0 & 10.0 & 0.50 & 0.05 \\
\hline & & 50 & 95.0 & 10.0 & 0.57 & 0.04 \\
\hline & & 100 & 87.5 & 9.6 & 0.55 & 0.08 \\
\hline & 018 & 6 & 100.0 & 0.0 & 0.52 & 0.06 \\
\hline & & 12 & 87.5 & 5.0 & 0.47 & 0.07 \\
\hline & & 25 & 90.0 & 8.2 & 0.48 & 0.05 \\
\hline & & 50 & 77.5 & 12.6 & 0.56 & 0.06 \\
\hline & & 100 & 92.5 & 5.0 & 0.48 & 0.02 \\
\hline \multirow[t]{26}{*}{ May 1993} & Control & 100 & 100.0 & 0.0 & 0.37 & 0.08 \\
\hline & 013 & 6 & 85.0 & 17.3 & 0.42 & 0.04 \\
\hline & & 12 & 77.5 & 26.3 & 0.45 & 0.08 \\
\hline & & 25 & 82.5 & 20.6 & 0.40 & 0.03 \\
\hline & & 50 & 87.5 & 9.6 & 0.45 & 0.05 \\
\hline & & 100 & 60.0 & 24.5 & 0.43 & 0.11 \\
\hline & 015 & 6 & 72.5 & 28.7 & 0.40 & 0.04 \\
\hline & & 12 & 87.5 & 9.6 & 0.39 & 0.14 \\
\hline & & 25 & 85.0 & 5.8 & 0.34 & 0.09 \\
\hline & & 50 & 65.0 & 12.9 & 0.41 & 0.02 \\
\hline & & 100 & 65.0 & 23.8 & 0.35 & 0.05 \\
\hline & 016 & 6 & 100.0 & 0.0 & 0.33 & 0.03 \\
\hline & & 12 & 82.5 & 9.6 & 0.55 & 0.14 \\
\hline & & 25 & 92.5 & 5.0 & 0.22 & 0.08 \\
\hline & & 50 & 90.0 & 8.2 & 0.46 & 0.03 \\
\hline & & 100 & 80.0 & 16.3 & 0.45 & 0.03 \\
\hline & 017 & 6 & 60.0 & 27.1 & 0.37 & 0.05 \\
\hline & & 12 & 60.0 & 14.1 & 0.37 & 0.10 \\
\hline & & 25 & 60.0 & 8.2 & 0.49 & 0.05 \\
\hline & & 50 & 55.0 & 12.9 & 0.45 & 0.08 \\
\hline & & 100 & 82.5 & 12.6 & 0.41 & 0.05 \\
\hline & 018 & 6 & 72.5 & 22.2 & 0.37 & 0.08 \\
\hline & & 12 & 55.0 & 17.3 & 0.39 & 0.12 \\
\hline & & 25 & 70.0 & 35.6 & 0.35 & 0.06 \\
\hline & & 50 & 67.5 & 20.6 & 0.34 & 0.10 \\
\hline & & 100 & 70.0 & 14.1 & 0.35 & 0.07 \\
\hline \multirow[t]{4}{*}{ September 1993} & Control & 100 & 95.0 & 10.0 & 0.33 & 0.03 \\
\hline & 013 & 6 & 92.5 & 15.0 & 0.40 & 0.11 \\
\hline & & 12 & 100.0 & 0.0 & 0.34 & 0.02 \\
\hline & & 25 & 82.5 & 22.2 & 0.42 & 0.05 \\
\hline
\end{tabular}


Table B.4 (continued)

\begin{tabular}{|c|c|c|c|c|c|c|}
\hline \multirow{2}{*}{ Date } & \multirow{2}{*}{ Outfall } & \multirow{2}{*}{ Conc. } & \multicolumn{2}{|c|}{ Survival (\%) } & \multicolumn{2}{|c|}{ Growth (mg/larvae) } \\
\hline & & & Mean & SD & Mean & $\mathrm{SD}$ \\
\hline & & 50 & 70.0 & 16.3 & 0.44 & 0.04 \\
\hline & & 100 & 70.0 & 28.3 & 0.36 & 0.08 \\
\hline & 015 & 6 & 90.0 & 14.1 & 0.37 & 0.07 \\
\hline & & 12 & 92.5 & 9.6 & 0.38 & 0.07 \\
\hline & & 25 & 92.5 & 9.6 & 0.36 & 0.05 \\
\hline & & 50 & 90.0 & 11.6 & 0.36 & 0.06 \\
\hline & & 100 & 87.5 & 15.0 & 0.38 & 0.03 \\
\hline & 016 & 6 & 95.0 & 5.8 & 0.46 & 0.07 \\
\hline & & 12 & 95.0 & 10.0 & 0.48 & 0.06 \\
\hline & & 25 & 100.0 & 0.0 & 0.46 & 0.10 \\
\hline & & 50 & 97.5 & 5.0 & 0.51 & 0.10 \\
\hline & & 100 & 90.0 & 14.1 & 0.53 & 0.04 \\
\hline & 017 & 6 & 100.0 & 0.0 & 0.55 & 0.04 \\
\hline & & 12 & 100.0 & 0.0 & 0.60 & 0.04 \\
\hline & & 25 & 92.5 & 15.0 & 0.59 & 0.05 \\
\hline & & 50 & 97.5 & 5.0 & 0.60 & 0.06 \\
\hline & & 100 & 90.0 & 14.1 & 0.61 & 0.06 \\
\hline \multirow[t]{5}{*}{. } & 018 & 6 & 97.5 & 5.0 & 0.60 & 0.05 \\
\hline & & 12 & 95.0 & 5.8 & 0.59 & 0.08 \\
\hline & & 25 & 100.0 & 0.0 & 0.62 & 0.02 \\
\hline & & 50 & 95.0 & 10.0 & 0.55 & 0.03 \\
\hline & & 100 & 100.0 & 0.0 & 0.59 & 0.03 \\
\hline \multirow[t]{18}{*}{ November 1993} & Control & 100 & 87.5 & 15.0 & 0.39 & 0.05 \\
\hline & 013 & 6 & 70.0 & 40.8 & 0.50 & 0.10 \\
\hline & & 12 & 75.0 & 12.9 & 0.46 & 0.06 \\
\hline & & 25 & 80.0 & 14.1 & 0.55 & 0.11 \\
\hline & & 50 & 65.0 & 12.9 & 0.46 & 0.05 \\
\hline & & 100 & 85.0 & 12.9 & 0.49 & 0.02 \\
\hline & 015 & 6 & 95.0 & 5.8 & 0.51 & 0.03 \\
\hline & & 12 & 90.0 & 14.1 & 0.49 & 0.04 \\
\hline & & 25 & 92.5 & 5.0 & 0.51 & 0.06 \\
\hline & & 50 & 87.5 & 5.0 & 0.55 & 0.08 \\
\hline & & 100 & 95.0 & 5.8 & 0.54 & 0.05 \\
\hline & 016 & $6^{\circ}$ & 92.5 & 9.6 & 0.62 & 0.08 \\
\hline & & 12 & 75.0 & 20.8 & 0.56 & 0.05 \\
\hline & & 25 & 65.0 & 12.9 & 0.48 & 0.08 \\
\hline & & 50 & 77.5 & 20.6 & 0.48 & 0.04 \\
\hline & & 100 & 87.5 & 5.0 & 0.49 & 0.12 \\
\hline & 017 & 6 & 60.0 & 45.5 & 0.59 & 0.04 \\
\hline & & 12 & 90.0 & 0.0 & 0.55 & 0.03 \\
\hline
\end{tabular}


Table B.4 (continued)

\begin{tabular}{|c|c|c|c|c|c|c|}
\hline \multirow{2}{*}{ Date } & \multirow{2}{*}{ Outfall } & \multirow{2}{*}{ Conc. } & \multicolumn{2}{|c|}{ Survival (\%) } & \multicolumn{2}{|c|}{ Growth (mg/larvae) } \\
\hline & & & Mean & SD & Mean & SD \\
\hline & & 25 & 35.0 & 45.1 & 0.54 & 0.11 \\
\hline & & 50 & 95.0 & 10.0 & 0.64 & 0.08 \\
\hline & & 100 & 85.0 & 12.9 & 0.61 & 0.08 \\
\hline & 018 & 6 & 95.0 & 5.8 & 0.57 & 0.06 \\
\hline & & 12 & 87.5 & 9.6 & 0.58 & 0.07 \\
\hline & & 25 & 97.5 & 5.0 & 0.59 & 0.03 \\
\hline & & 50 & 87.5 & 12.6 & 0.51 & 0.02 \\
\hline & & 100 & 72.5 & 23.6 & 0.58 & 0.06 \\
\hline \multirow[t]{26}{*}{ February 1994} & Control & 100 & 100.0 & 0.0 & 0.47 & 0.04 \\
\hline & 013 & 6 & 100.0 & 0.0 & 0.44 & 0.06 \\
\hline & & 12 & 55.0 & 33.2 & 0.42 & 0.02 \\
\hline & & 25 & 67.5 & 45.0 & 0.46 & 0.13 \\
\hline & & 50 & 62.5 & 42.7 & 0.46 & 0.06 \\
\hline & & 100 & 57.5 & 37.8 & 0.48 & 0.12 \\
\hline & 015 & 6 & 97.5 & 5.0 & 0.45 & 0.06 \\
\hline & & 12 & 100.0 & 0.0 & 0.45 & 0.04 \\
\hline & & 25 & 90.0 & 8.2 & 0.48 & 0.05 \\
\hline & & 50 & 72.5 & 15.0 & 0.50 & 0.06 \\
\hline & & 100 & 72.5 & 32.0 & 0.57 & 0.12 \\
\hline & 016 & 6 & 97.5 & 5.0 & 0.39 & 0.05 \\
\hline & & 12 & 95.0 & 5.8 & 0.41 & 0.03 \\
\hline & & 25 & 92.5 & 5.0 & 0.41 & 0.04 \\
\hline & & 50 & 97.5 & 5.0 & 0.42 & 0.04 \\
\hline & & 100 & 95.0 & 5.8 & 0.48 & 0.06 \\
\hline & 017 & 6 & 97.5 & 5.0 & 0.43 & 0.04 \\
\hline & & 12 & 95.0 & 5.8 & 0.41 & 0.03 \\
\hline & & 25 & 92.5 & 9.6 & 0.40 & 0.05 \\
\hline & & 50 & 75.0 & 50.0 & 0.42 & 0.12 \\
\hline & & 100 & 80.0 & 20.0 & 0.49 & 0.06 \\
\hline & 018 & 6 & 97.5 & 5.0 & 0.44 & 0.05 \\
\hline & & 12 & 95.0 & 5.8 & 0.43 & 0.05 \\
\hline & & 25 & 92.5 & 15.0 & 0.48 & 0.07 \\
\hline & & 50 & 100.0 & 0.0 & 0.45 & 0.02 \\
\hline & & 100 & 95.0 & 5.8 & 0.45 & 0.04 \\
\hline \multirow[t]{6}{*}{ April 1994} & Control & 100 & 92.5 & 5.0 & 0.36 & 0.01 \\
\hline & 013 & 6 & 97.5 & 5.0 & 0.36 & 0.01 \\
\hline & & 12 & 92.5 & 9.6 & 0.36 & 0.03 \\
\hline & & 25 & 90.0 & 14.1 & 0.38 & 0.02 \\
\hline & & 50 & 97.5 & 5.0 & 0.37 & 0.03 \\
\hline & & 100 & 87.5 & 12.6 & 0.38 & 0.07 \\
\hline
\end{tabular}


Table B.4 (continued)

\begin{tabular}{|c|c|c|c|c|c|c|}
\hline \multirow{2}{*}{ Date } & \multirow{2}{*}{ Outfall } & \multirow{2}{*}{ Conc.- } & \multicolumn{2}{|c|}{ Survival (\%) } & \multicolumn{2}{|c|}{ Growth (mg/larvae) } \\
\hline & & & Mean & SD & Mean & SD \\
\hline & 015 & 6 & 87.5 & 15.0 & 0.44 & 0.14 \\
\hline & & 12 & 35.0 & 12.9 & 0.35 & 0.19 \\
\hline & & 25 & 65.0 & 31.1 & 0.36 & 0.07 \\
\hline & & 50 & 65.0 & 33.2 & 0.46 & 0.05 \\
\hline & & 100 & 42.5 & 35.9 & 0.40 & 0.09 \\
\hline & 016 & 6 & 85.0 & 19.2 & 0.32 & 0.07 \\
\hline & & 12 & 95.0 & 5.8 & 0.34 & 0.02 \\
\hline & & 25 & 80.0 & 18.3 & 0.39 & 0.06 \\
\hline & & 50 & 82.5 & 23.6 & 0.44 & 0.04 \\
\hline & & 100 & 97.5 & 5.0 & 0.34 & 0.06 \\
\hline & 017 & 6 & 97.5 & 5.0 & 0.40 & 0.05 \\
\hline & & 12 & 92.5 & 9.6 & 0.41 & 0.08 \\
\hline & & 25 & 90.0 & 14.1 & 0.37 & 0.07 \\
\hline & & 50 & 85.0 & 23.8 & 0.38 & 0.08 \\
\hline & & 100 & 32.5 & 22.2 & 0.51 & 0.16 \\
\hline & 018 & 6 & 87.5 & 5.0 & 0.36 & 0.08 \\
\hline & & 12 & 85.0 & 12.9 & 0.39 & 0.04 \\
\hline & & 25 & 95.0 & 10.0 & 0.40 & 0.02 \\
\hline & & 50 & 92.5 & 5.0 & 0.42 & 0.03 \\
\hline & & 100 & 42.5 & 32.0 & 0.41 & 0.24 \\
\hline \multirow[t]{20}{*}{ September 1994} & Control & 100 & 92.6 & 9.5 & 6.76 & 12.83 \\
\hline & 013 & 12 & 100.0 & 0.0 & 0.34 & 0.03 \\
\hline & & 25 & 92.5 & 9.6 & 0.41 & 0.01 \\
\hline & & 50 & 90.0 & 14.1 & 0.40 & 0.02 \\
\hline & 015 & 12 & 100.0 & 0.0 & 0.36 & 0.07 \\
\hline & & 25 & 95.0 & 5.8 & 0.40 & 0.02 \\
\hline & & 50 & 97.5 & 5.0 & 0.45 & 0.02 \\
\hline & & 100 & 92.5 & 5.0 & 0.39 & 0.01 \\
\hline & 016 & 12 & 100.0 & 0.0 & 0.48 & 0.03 \\
\hline & & 25 & 97.5 & 5.0 & 0.47 & 0.06 \\
\hline & & 50 & 97.5 & 5.0 & 0.49 & 0.08 \\
\hline & & 100 & 87.5 & 9.6 & 0.52 & 0.06 \\
\hline & 017 & 6 & 87.5 & 9.6 & 0.38 & 0.07 \\
\hline & & 12 & 97.5 & 5.0 & 0.44 & 0.04 \\
\hline & & 25 & 87.5 & 15.0 & 0.42 & 0.04 \\
\hline & & 50 & 90.0 & 8.2 & 0.39 & 0.07 \\
\hline & & 100 & 95.0 & 5.8 & 0.37 & 0.06 \\
\hline & 018 & 6 & 92.5 & 9.6 & 0.39 & 0.03 \\
\hline & & 12 & 95.0 & 5.8 & 0.40 & 0.02 \\
\hline & & 25 & 95.0 & 10.0 & 0.44 & 0.03 \\
\hline
\end{tabular}


Table B.4 (continued)

\begin{tabular}{|c|c|c|c|c|c|c|}
\hline \multirow{2}{*}{ Date } & \multirow{2}{*}{ Outfall } & \multirow{2}{*}{ Conc. } & \multicolumn{2}{|c|}{ Survival (\%) } & \multicolumn{2}{|c|}{ Growth (mg/larvae) } \\
\hline & & & Mean & SD & Mean & $\mathrm{SD}$ \\
\hline & & 50 & 90.0 & 8.2 & 0.44 & 0.03 \\
\hline & & 100 & 85.0 & 5.8 & 0.40 & 0.08 \\
\hline \multirow[t]{17}{*}{ November 1994} & Control & 100 & 97.5 & 5.0 & 0.47 & 0.07 \\
\hline & 013 & 6 & 67.5 & 22.2 & 0.51 & 0.05 \\
\hline & & 12 & 57.5 & 42.7 & 0.57 & 0.13 \\
\hline & & 25 & 70.0 & 38.3 & 0.70 & 0.14 \\
\hline & & 50 & 55.0 & 34.2 & 0.58 & 0.10 \\
\hline & & 100 & 80.0 & 8.2 & 0.58 & 0.08 \\
\hline & 015 & 6 & 72.5 & 27.5 & 0.49 & 0.06 \\
\hline & & 12 & 50.0 & 35.6 & 0.56 & 0.07 \\
\hline & & 25 & 67.5 & 9.6 & 0.53 & 0.05 \\
\hline & & 50 & 72.5 & 31.0 & 0.63 & 0.07 \\
\hline & & 100 & 40.0 & 21.6 & 0.65 & 0.09 \\
\hline & 016 & 6 & 60.0 & 18.3 & 0.57 & 0.07 \\
\hline & & 12 & 47.5 & 37.8 & 0.66 & 0.31 \\
\hline & & 25 & 47.5 & 9.6 & 0.56 & 0.13 \\
\hline & & 50 & 52.5 & 22.2 & 0.57 & 0.10 \\
\hline & & 100 & 45.0 & 23.8 & 0.60 & 0.09 \\
\hline & 017 & 6 & 5.0 & 5.8 & 0.70 & 0.04 \\
\hline \multirow[t]{9}{*}{-} & & 12 & 2.5 & 5.0 & 0.49 & • \\
\hline & & 25 & 10.0 & 8.2 & 0.38 & 0.17 \\
\hline & & 50 & 7.5 & 9.6 & 0.32 & 0.02 \\
\hline & & 100 & 5.0 & 5.8 & 0.33 & 0.09 \\
\hline & 018 & 6 & 85.0 & 10.0 & 0.53 & 0.06 \\
\hline & & 12 & 82.5 & 5.0 & 0.59 & 0.07 \\
\hline & & 25 & 95.0 & 10.0 & 0.52 & 0.02 \\
\hline & & 50 & 82.5 & 23.6 & 0.59 & 0.07 \\
\hline & & 100 & 80.0 & 14.1 & 0.64 & 0.05 \\
\hline
\end{tabular}


Table B.5. Results of Ceriodaphnia toxicity tests of intermittently flowing effluents at the Paducah Gaseous Diffusion Plant

Tests conducted December 1991-November 1994

\begin{tabular}{|c|c|c|c|c|c|}
\hline \multirow[t]{2}{*}{ Date } & \multirow[t]{2}{*}{ Outfall } & \multirow[t]{2}{*}{ Conc. } & \multirow{2}{*}{$\begin{array}{l}\text { Survival } \\
(\%)\end{array}$} & \multicolumn{2}{|c|}{$\begin{array}{l}\text { Offspring/surviving } \\
\text { female }\end{array}$} \\
\hline & & & & Mean & SD \\
\hline \multirow[t]{21}{*}{ December 1991} & Control & 100 & 90 & 28.33 & 9.67 \\
\hline & 013 & 12 & 90 & 36.00 & 3.61 \\
\hline & & 25 & 100 & 36.10 & 4.09 \\
\hline & & 50 & 100 & 34.80 & 3.39 \\
\hline & & 100 & 100 & 36.00 & 4.76 \\
\hline & 015 & 12 & 90 & 34.22 & 5.85 \\
\hline & & 25 & 60 & 37.33 & 3.08 \\
\hline & & 50 & 90 & 33.67 & 5.24 \\
\hline & & 100 & 100 & 34.70 & 5.33 \\
\hline & 016 & 12 & 70 & 36.14 & 4.10 \\
\hline & & 25 & 80 & 36.00 & 5.81 \\
\hline & & 50 & 100 & 33.30 & 6.45 \\
\hline & & 100 & 100 & 33.50 & 3.41 \\
\hline & 017 & 12 & 90 & 28.56 & 4.64 \\
\hline & & 25 & 90 & 32.22 & 3.49 \\
\hline & & 50 & 70 & 33.00 & 5.16 \\
\hline & & 100 & 100 & 33.20 & 4.89 \\
\hline & 018 & 12 & 90 & 34.44 & 5.73 \\
\hline & & 25 & 90 & 33.11 & 4.14 \\
\hline & & 50 & 100 & 31.40 & 2.63 \\
\hline & & 100 & 90 & 32.67 & 3.32 \\
\hline \multirow[t]{16}{*}{ March 1992} & Control & 100 & 100 & 23.40 & 2.07 \\
\hline & 013 & 12. & 100 & 27.89 & 6.39 \\
\hline & & 25 & 90 & 20.13 & 9.46 \\
\hline & & 50 & 90 & 26.44 & 5.22 \\
\hline & & 100 & 80 & 26.25 & 5.34 \\
\hline & 015 & 12 & 70 & 25.57 & 8.34 \\
\hline & & 25 & 70 & 24.71 & 5.31 \\
\hline & & 50 & 100 & 22.60 & 5.58 \\
\hline & & 100 & 100 & 25.20 & 3.36 \\
\hline & 016 & 12 & 90 & 23.78 & 1.48 \\
\hline & & 25 & 100 & 25.60 & 2.76 \\
\hline & & 50 & 100 & 24.80 & 5.25 \\
\hline & & 100 & 100 & 25.30 & 3.77 \\
\hline & 017 & 12 & 100 & 22.30 & 5.68 \\
\hline & & 25 & 90 & 24.11 & 4.26 \\
\hline & & 50 & 100 & 21.80 & 8.77 \\
\hline
\end{tabular}


Table B.5. (continued)

\begin{tabular}{|c|c|c|c|c|c|}
\hline \multirow[t]{2}{*}{ Date } & \multirow[t]{2}{*}{ Outfall } & \multirow[t]{2}{*}{ Conc. } & \multirow{2}{*}{$\begin{array}{l}\text { Survival } \\
\text { (\%) }\end{array}$} & \multicolumn{2}{|c|}{$\begin{array}{l}\text { Offspring/surviving } \\
\text { female }\end{array}$} \\
\hline & & & & Mean & SD \\
\hline & & 100 & 80 & 27.63 & 3.34 \\
\hline & 018 & 12 & 100 & 23.30 & 9.89 \\
\hline & & 25 & 90 & 22.44 & 3.43 \\
\hline & & 50 & 100 & 24.40 & 3.72 \\
\hline & & 100 & 100 & 20.10 & 2.69 \\
\hline \multirow[t]{17}{*}{ June 1992} & Control & 100 & 80 & 31.88 & 3.72 \\
\hline & 013 & 12 & 80 & 36.88 & 2.30 \\
\hline & & 25 & 100 & 31.70 & 7.42 \\
\hline & & 50 & 100 & 32.60 & 6.82 \\
\hline & & 100 & 100 & 34.10 & 7.95 \\
\hline & 015 & 12 & 90 & 32.44 & 6.54 \\
\hline & & 25 & 90 & 31.22 & 3.19 \\
\hline & & 50 & 100 & 31.10 & 11.33 \\
\hline & & 100 & 90 & 28.33 & 6.71 \\
\hline & 017 & 12 & 100 & 28.60 & 7.53 \\
\hline & & 25 & 100 & 27.50 & 8.66 \\
\hline & & 50 & 100 & 27.40 & 8.49 \\
\hline & & 100 & 100 & 28.50 & 6.64 \\
\hline & 018 & 12 & 100 & 33.30 & 5.95 \\
\hline & & 25 & 100 & 32.60 & 3.78 \\
\hline & & 50 & 100 & 32.60 & 6.24 \\
\hline & & 100 & 90 & 37.44 & 8.00 \\
\hline \multirow[t]{17}{*}{ November 1992} & Control & 100 & 100 & 31.60 & 5.72 \\
\hline & 013 & 12 & 90 & 30.89 & 5.58 \\
\hline & & 25 & 100 & 30.70 & 7.20 \\
\hline & & 50 & 100 & 35.40 & 5.21 \\
\hline & & 100 & 100 & 34.70 & 6.57 \\
\hline & Control & 100 & 100 & 26.90 & 4.15 \\
\hline & 015 & 12 & 100 & 30.80 & 4.57 \\
\hline & & 25 & 100 & 31.10 & 4.38 \\
\hline & & 50 & 100 & 32.50 & 4.01 \\
\hline & & 100 & 100 & 32.70 & 5.58 \\
\hline & Control & 100 & 100 & 31.50 & 3.69 \\
\hline & 016 & 12 & 100 & 32.80 & 6.36 \\
\hline & & 25 & 100 & 34.89 & 3.55 \\
\hline & & 50 & 100 & 35.70 & 4.08 \\
\hline & 016 & $100^{\circ}$ & 90 & 31.56 & 5.85 \\
\hline & Control & 100 & 100 & 33.60 & 6.45 \\
\hline & 017 & 12 & 100 & 31.10 & 6.37 \\
\hline
\end{tabular}


Table B.5. (continued)

\begin{tabular}{|c|c|c|c|c|c|}
\hline \multirow[t]{2}{*}{ Date } & \multirow[t]{2}{*}{ Outfall } & \multirow[t]{2}{*}{ Conc. } & \multirow{2}{*}{$\begin{array}{l}\text { Survival } \\
(\%)\end{array}$} & \multicolumn{2}{|c|}{$\begin{array}{l}\text { Offspring/surviving } \\
\text { female }\end{array}$} \\
\hline & & & & Mean & $\mathrm{SD}$ \\
\hline & & 25 & 100 & 33.30 & 6.98 \\
\hline & & 50 & 80 & 32.13 & 5.14 \\
\hline & & 100 & 100 & 33.80 & 2.62 \\
\hline & Control & 100 & 80 & 34.38 & 2.50 \\
\hline & 018 & 12 & 90 & 33.89 & 5.60 \\
\hline & & 25 & 90 & 31.89 & 6.35 \\
\hline & & 50 & 90 & 31.33 & 5.81 \\
\hline & & 100 & 100 & 34.30 & 5.03 \\
\hline \multirow[t]{30}{*}{ January 1993} & Control & 100 & 100 & 27.70 & 7.90 \\
\hline & 013 & 6 & 70 & 24.50 & 4.04 \\
\hline & & 12 & 100 & 24.20 & 6.48 \\
\hline & & 25 & 100 & 22.13 & 5.72 \\
\hline & & 50 & 100 & 22.67 & 3.97 \\
\hline & & 100 & 100 & 21.00 & 6.04 \\
\hline & Control & 100 & 100 & 23.00 & 10.00 \\
\hline & 015 & 6 & 100 & 27.00 & 5.94 \\
\hline & & 12 & 100 & 31.30 & 3.53 \\
\hline & & 25 & 100 & 32.00 & 3.40 \\
\hline & & 50 & 100 & 30.40 & 5.87 \\
\hline & & 100 & 100 & 30.90 & 3.28 \\
\hline & Control & 100 & 80 & 26.38 & 2.62 \\
\hline & 016 & 6 & 100 & 22.40 & 3.47 \\
\hline & & 12 & 100 & 26.40 & 2.76 \\
\hline & & 25 & 100 & 23.40 & 3.50 \\
\hline & & 50 & 100 & 25.20 & 3.79 \\
\hline & & 100 & 100 & 23.60 & 3.75 \\
\hline & Control & 100 & 100 & 27.90 & 6.28 \\
\hline & 017 & 6 & 90 & 25.67 & 1.80 \\
\hline & & 12 & 90 & 24.89 & 4.70 \\
\hline & & 25 & 100 & 25.50 & 3.54 \\
\hline & & 50 & 100 & 22.90 & 3.28 \\
\hline & & 100 & 90 & 23.11 & 3.92 \\
\hline & Control & 100 & 100 & 29.80 & 4.96 \\
\hline & 018 & 6 & 90 & 29.33 & 11.16 \\
\hline & & 12 & 100 & 30.90 & 10.79 \\
\hline & & 25 & 100 & 28.60 & 8.85 \\
\hline & & 50 & 100 & 30.70 & 7.72 \\
\hline & & 100 & 100 & 33.10 & 4.46 \\
\hline
\end{tabular}


Table B.5. (continued)

\begin{tabular}{|c|c|c|c|c|c|}
\hline \multirow[t]{2}{*}{ Date } & \multirow[t]{2}{*}{ Outfall } & \multirow[t]{2}{*}{ Conc. } & \multirow{2}{*}{$\begin{array}{l}\text { Survival } \\
(\%)\end{array}$} & \multicolumn{2}{|c|}{$\begin{array}{l}\text { Offspring/surviving } \\
\text { female }\end{array}$} \\
\hline & & & & Mean & SD \\
\hline \multirow[t]{30}{*}{ May 1993} & Control & 100 & 90 & 32.67 & 6.50 \\
\hline & 013 & 6 & 100 & 33.80 & 3.88 \\
\hline & & 12 & 100 & 32.50 & 5.32 \\
\hline & & 25 & 100 & 30.80 & 3.26 \\
\hline & & 50 & 90 & 30.00 & 4.61 \\
\hline & & 100 & 100 & 26.30 & 3.50 \\
\hline & Control & 100 & 100 & 28.00 & 4.11 \\
\hline & 015 & 6 & 80 & 33.50 & 4.41 \\
\hline & & 12 & 100 & 33.60 & 3.27 \\
\hline & & 25 & 100 & 30.10 & 6.12 \\
\hline & & 50 & 100 & 29.20 & 5.75 \\
\hline & & 100 & 100 & 32.10 & 4.48 \\
\hline & Control & 100 & 100 & 37.50 & 3.17 \\
\hline & 016 & 6 & 80 & 36.88 & 5.06 \\
\hline & & 12 & 90 & 37.44 & 6.60 \\
\hline & & 25 & 90 & 38.00 & 4.77 \\
\hline & & 50 & 100 & 40.80 & 5.22 \\
\hline & & 100 & 100 & 38.60 & 11.46 \\
\hline & Control & 100 & 100 & 36.80 & 4.66 \\
\hline & 017 & 6 & 100 & 35.90 & 4.68 \\
\hline & & 12 & 100 & 40.70 & 4.50 \\
\hline & & 25 & 100 & 35.60 & 7.55 \\
\hline & & 50 & 100 & 34.80 & 4.54 \\
\hline & & 100 & 100 & 34.80 & 7.41 \\
\hline & Control & 100 & 100 & 35.30 & 5.06 \\
\hline & 018 & 6 & 100 & 30.50 & 5.17 \\
\hline & & 12 & 100 & 30.00 & 3.46 \\
\hline & & 25 & 100 & 28.80 & 4.44 \\
\hline & & 50 & 100 & 32.50 & 6.85 \\
\hline & & 100 & 100 & 29.60 & 3.75 \\
\hline \multirow[t]{9}{*}{ September 1993} & Control & 100 & 100 & 32.00 & 2.98 \\
\hline & 013 & 6 & 90 & 33.00 & 1.87 \\
\hline & & 12 & 100 & 30.10 & 4.38 \\
\hline & & 25 & 100 & 27.90 & 6.95 \\
\hline & & 50 & 100 & 30.00 & 5.75 \\
\hline & & 100 & 100 & 34.40 & 2.12 \\
\hline & Control & 100 & 90 & 27.80 & 4.05 \\
\hline & 015 & 6 & 90 & 30.80 & 3.16 \\
\hline & & 12 & 100 & 28.30 & 5.54 \\
\hline
\end{tabular}


Table B.5. (continued)

\begin{tabular}{|c|c|c|c|c|c|}
\hline \multirow[t]{2}{*}{ Date } & \multirow[t]{2}{*}{ Outfall } & \multirow[t]{2}{*}{ Conc. } & \multirow{2}{*}{$\begin{array}{c}\text { Survival } \\
\text { (\%) }\end{array}$} & \multicolumn{2}{|c|}{$\begin{array}{l}\text { Offspring/surviving } \\
\text { female } \\
\end{array}$} \\
\hline & & & & Mean & SD \\
\hline & & 25 & 100 & 31.70 & 3.77 \\
\hline & & 50 & 100 & 30.60 & 4.86 \\
\hline & & 100 & 100 & 30.60 & 5.10 \\
\hline & Control & 100 & 80 & 29.25 & 3.69 \\
\hline & 016 & 6 & 100 & 31.40 & 1.84 \\
\hline & & 12 & 80 & 31.63 & 5.32 \\
\hline & & 25 & 100 & 32.20 & 3.36 \\
\hline & & 50 & 100 & 31.50 & 4.38 \\
\hline & & 100 & 100 & 30.00 & 4.27 \\
\hline & Control & 100 & 80 & 27.38 & 2.92 \\
\hline & 017 & 6 & 100 & 25.80 & 9.43 \\
\hline & & 12 & 90 & 27.00 & 3.74 \\
\hline & & 25 & 100 & 28.80 & 4.02 \\
\hline & & 50 & 100 & 28.90 & 4.38 \\
\hline & & 100 & 100 & 28.30 & 5.42 \\
\hline & Control & 100 & 100 & 32.00 & 2.62 \\
\hline & 018 & 6 & 100 & 29.70 & 2.79 \\
\hline & 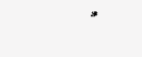 & 12 & 100 & 32.30 & 2.11 \\
\hline & & 25 & 100 & 29.50 & 4.53 \\
\hline & & 50 & 90 & 33.44 & 3.71 \\
\hline & & 100 & 100 & 35.10 & 3.25 \\
\hline \multirow[t]{18}{*}{ November 1993} & Control & 100 & 100 & 21.20 & 3.55 \\
\hline & 013 & 6 & 100 & 27.60 & 2.88 \\
\hline & & 12 & 90 & 25.00 & 6.67 \\
\hline & & 25 & 100 & 25.20 & 3.01 \\
\hline & & 50 & 100 & 25.10 & 4.63 \\
\hline & & 100 & 90 & 24.11 & 5.80 \\
\hline & Control & 100 & 100 & 24.90 & 3.45 \\
\hline & 015 & 6 & 100 & 24.10 & 7.95 \\
\hline & & 12 & 100 & 28.60 & 2.84 \\
\hline & & 25 & 100 & 28.80 & 4.64 \\
\hline & & 50 & 100 & 29.40 & 3.27 \\
\hline & & 100 & 100 & 27.00 & 1.83 \\
\hline & Control & 100 & 100 & 25.80 & 2.04 \\
\hline & 016 & 6 & 100 & 25.00 & 3.09 \\
\hline & & 12 & 100 & 25.30 & 2.26 \\
\hline & & 25 & 100 & 24.40 & 5.40 \\
\hline & & 50 & 100 & 28.60 & 3.17 \\
\hline & & 100 & 100 & 28.20 & 2.97 \\
\hline
\end{tabular}


Table B.5. (continued)

\begin{tabular}{|c|c|c|c|c|c|}
\hline \multirow[t]{2}{*}{ Date } & \multirow[t]{2}{*}{ Outfall } & \multirow[t]{2}{*}{ Conc. } & \multirow{2}{*}{$\begin{array}{l}\text { Survival } \\
(\%)\end{array}$} & \multicolumn{2}{|c|}{$\begin{array}{l}\text { Offspring/surviving } \\
\text { female } \\
\end{array}$} \\
\hline & & & & Mean & $\mathrm{SD}$ \\
\hline & Control & 100 & 100 & 23.80 & 2.04 \\
\hline & 017 & 6 & 100 & 25.40 & 2.80 \\
\hline & & 12 & 100 & 25.40 & 2.07 \\
\hline & & 25 & 100 & 26.40 & 3.03 \\
\hline & & 50 & 100 & 25.00 & 1.49 \\
\hline & & 100 & 100 & 23.50 & 2.59 \\
\hline & Control & 100 & 100 & 20.30 & 6.52 \\
\hline & 018 & 6 & 100 & 26.50 & 3.14 \\
\hline & & 12 & 100 & 25.70 & 3.65 \\
\hline & & $25^{\circ}$ & 100 & 27.40 & 2.27 \\
\hline & & 50 & 100 & 24.40 & 5.21 \\
\hline & & 100 & 80 & 23.00 & 4.57 \\
\hline \multirow[t]{27}{*}{ February 1994} & Control & 100 & 100 & 25.10 & 3.81 \\
\hline & 013 & 6 & 100 & 23.60 & 5.02 \\
\hline & & 12 & 100 & 25.90 & 4.23 \\
\hline & & 25 & 100 & 20.90 & 7.28 \\
\hline & & 50 & 100 & 22.50 & 5.62 \\
\hline & $\cdot$ & 100 & 100 & 18.60 & 7.03 \\
\hline & Control & 100 & 100 & 27.00 & 3.62 \\
\hline & 015 & 6 & 100 & 25.30 & 2.54 \\
\hline & & 12 & 100 & 25.30 & 4.16 \\
\hline & & 25 & 100 & 28.90 & 2.42 \\
\hline & & 50 & 100 & 24.90 & 4.20 \\
\hline & & 100 & 100 & 24.10 & 7.13 \\
\hline & Control & 100 & 90 & 26.56 & 4.88 \\
\hline & 016 & 6 & 90 & 30.11 & 8.12 \\
\hline & & 12 & 100 & 28.30 & 7.56 \\
\hline & & 25 & 100 & 30.90 & 6.05 \\
\hline & & 50 & 100 & 30.50 & 5.56 \\
\hline & & 100 & 100 & 26.60 & 3.89 \\
\hline & Control & 100 & 100 & 24.60 & 3.95 \\
\hline & 017 & 6 & 100 & 25.20 & 4.16 \\
\hline & & 12 & 100 & 25.40 & 4.86 \\
\hline & & 25 & 100 & 28.90 & 6.56 \\
\hline & & 50 & 100 & 19.70 & 7.02 \\
\hline & & 100 & 100 & 21.60 & 7.14 \\
\hline & Control & 100 & 100 & 17.90 & 4.61 \\
\hline & 018 & 6 & 100 & 18.70 & 4.55 \\
\hline & & 12 & 100 & 18.20 & 3.29 \\
\hline
\end{tabular}


Table B.5. (continued)

\begin{tabular}{|c|c|c|c|c|c|}
\hline \multirow[t]{2}{*}{ Date } & \multirow[t]{2}{*}{ Outfall } & \multirow[t]{2}{*}{ Conc. } & \multirow{2}{*}{$\begin{array}{l}\text { Survival } \\
(\%)\end{array}$} & \multicolumn{2}{|c|}{$\begin{array}{l}\text { Offspring/surviving } \\
\text { female }\end{array}$} \\
\hline & & & & Mean & SD \\
\hline & & 25 & 100 & 18.60 & 3.60 \\
\hline & & 50 & 100 & 22.00 & 3.09 \\
\hline & & 100 & 100 & 21.30 & 7.07 \\
\hline \multirow[t]{26}{*}{ April 1994} & Control & 100 & 100 & 24.70 & 4.08 \\
\hline & 013 & 6 & 90 & 24.20 & 2.90 \\
\hline & & 12 & 100 & 24.20 & 3.58 \\
\hline & & 25 & 100 & 23.80 & 3.12 \\
\hline & & 50 & 100 & 23.90 & 6.74 \\
\hline & & 100 & 100 & 24.30 & 4.83 \\
\hline & 015 & 6 & 100 & 25.80 & 10.63 \\
\hline & & 12 & 100 & 27.20 & 3.49 \\
\hline & & 25 & 100 & 28.00 & 3.57 \\
\hline & & 50 & 90 & 26.89 & 4.73 \\
\hline & & 100 & 100 & 26.40 & 5.34 \\
\hline & 016 & 6 & 100 & 22.90 & 6.01 \\
\hline & & 12 & 100 & 24.50 & 2.88 \\
\hline & & 25 & 100 & 22.90 & 3.63 \\
\hline & & 50 & 90 & 25.11 & 3.30 \\
\hline & & 100 & 100 & 19.60 & 7.96 \\
\hline & 017 & 6 & 100 & 17.89 & 4.51 \\
\hline & & 12 & 100 & 18.60 & 1.96 \\
\hline & & 25 & 100 & 22.67 & 10.75 \\
\hline & & 50 & 100 & 19.40 & 1.96 \\
\hline & & 100 & 100 & 22.50 & 8.06 \\
\hline & 018 & 6 & 90 & 22.67 & 2.18 \\
\hline & & 12 & 100 & 20.90 & 4.15 \\
\hline & & 25 & 100 & 22.80 & 5.53 \\
\hline & & 50 & 100 & 25.60 & 7.44 \\
\hline & & 100 & 90 & 24.22 & 5.02 \\
\hline \multirow[t]{10}{*}{ September 1994} & Control & 100 & 100 & 21.90 & 3.75 \\
\hline & 013 & 6 & 100 & 15.10 & 5.40 \\
\hline & & 12 & 100 & 22.20 & 3.71 \\
\hline & & 25 & 90 & 20.89 & 3.95 \\
\hline & & 50 & 90 & 22.67 & 3.67 \\
\hline & & 100 & 80 & 21.25 & 4.65 \\
\hline & Control & 100 & 100 & 20.70 & 1.64 \\
\hline & 015 & 6 & 90 & 21.56 & 5.83 \\
\hline & & 12 & 100 & 22.40 & 3.92 \\
\hline & & 25 & 90 & 22.78 & 2.86 \\
\hline
\end{tabular}


Table B.5. (continued)

\begin{tabular}{|c|c|c|c|c|c|}
\hline \multirow[t]{2}{*}{ Date } & \multirow[t]{2}{*}{ Outfall } & \multirow[t]{2}{*}{ Conc. } & \multirow{2}{*}{$\begin{array}{c}\text { Survival } \\
(\%)\end{array}$} & \multicolumn{2}{|c|}{$\begin{array}{l}\text { Offspring/surviving } \\
\text { female }\end{array}$} \\
\hline & & & & Mean & SD \\
\hline & & 50 & 100 & 24.90 & 2.08 \\
\hline & & 100 & 100 & 24.40 & 2.95 \\
\hline & Control & 100 & 100 & 22.50 & 3.47 \\
\hline & 016 & 6 & 100 & 20.30 & 10.00 \\
\hline & & 12 & 100 & 22.10 & 8.52 \\
\hline & & 25 & 100 & 28.40 & 4.45 \\
\hline & & 50 & 100 & 26.40 & 4.38 \\
\hline & . & 100 & 100 & 25.10 & 7.06 \\
\hline & Control & 100 & 100 & 20.30 & 5.29 \\
\hline & 017 & 6 & 100 & 7.80 & 4.78 \\
\hline & & 12 & 100 & 18.70 & 6.80 \\
\hline . & & 25 & 100 & 14.70 & 4.16 \\
\hline & & 50 & 90 & 19.33 & 4.64 \\
\hline & & 100 & 80 & 23.63 & 2.77 \\
\hline & Control & 100 & 100 & 20.50 & 2.22 \\
\hline & 018 & 6 & 100 & 21.40 & 7.52 \\
\hline & & 12 & 90 & 22.22 & 9.43 \\
\hline & & 25 & 10 & 22.00 & • \\
\hline & & 50 & 0 & . & • \\
\hline & & 100 & 0 & . & . \\
\hline \multirow[t]{19}{*}{ November 1994} & Control & 100 & 100 & 19.10 & 6.95 \\
\hline & 013 & 6 & 100 & 19.30 & 4.19 \\
\hline & & 12 & 100 & 21.20 & 2.62 \\
\hline & & 25 & 100 & 20.30 & 6.18 \\
\hline & & 50 & 100 & 23.20 & 4.13 \\
\hline & & 100 & 90 & 19.56 & 10.53 \\
\hline & Control & 100 & 100 & 20.30 & 5.91 \\
\hline & 015 & 6 & 100 & 21.70 & 2.26 \\
\hline & & 12 & 100 & 21.70 & 5.08 \\
\hline & & 25 & 90 & 23.44 & 2.83 \\
\hline & & 50 & 100 & 23.80 & 3.19 \\
\hline & & 100 & 90 & 22.56 & 2.51 \\
\hline & Control & 100 & 90 & 20.33 & 3.61 \\
\hline & 016 & 6 & 100 & 20.00 & 1.94 \\
\hline & & 12 & 90 & 23.00 & 3.28 \\
\hline & & 25 & 100 & 20.30 & 5.60 \\
\hline & & 50 & 100 & 22.10 & 2.88 \\
\hline & & 100 & 100 & 17.90 & 3.98 \\
\hline & Control & 100 & 100 & 20.80 & 2.90 \\
\hline
\end{tabular}


Appendix C

CONCENTRATIONS OF CONTAMINANTS IN INDIVIDUAL FISH AND QUALITY ASSURANCE SUMMARY 


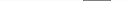




\section{QUALITY ASSURANCE SUMMARY}

Matrix spike recoveries averaged ( \pm SD) $90 \pm 18 \%(n=10)$. Spike recoveries in both the April 1994 and October 1993 samples averaged 90\%. Recoveries of decachlorobiphenyl (DCBP) internal recovery standards, added to each sample prior to extraction, were similar to PCB spikes, averaging $85 \pm 11 \%(n=87)$. The mean absolute difference between duplicate samples was $0.26 \pm 0.50 \mu \mathrm{g} / \mathrm{g}(n=12)$. Mean coefficient of variation among duplicates was $43 \%$. PCBs were not found in fish from uncontaminated reference sites (mean concentration $<0.10 \mu \mathrm{g} / \mathrm{g}, n=13$ ).

Overall, the PCB concentrations in fish at PGDP display a pattern expected from previous studies at Big Bayou and Little Bayou creeks and would not lead to any conclusions different from those made previously. Variability remains higher than desired but not atypical of PCB analyses of biological samples.

Analyses of standard reference mercury contaminated fish yielded results about $10 \%$ higher than the published true value of $2.52 \mu \mathrm{g} / \mathrm{g}$, averaging $2.77 \pm 0.03 \mu \mathrm{g} / \mathrm{g}(n=3)$. Mean absolute difference between duplicate samples was small, $0.03 \pm 0.04 \mu \mathrm{g} / \mathrm{g}(n=5)$, with a mean coefficient of variation of $8 \%$. Analyses of reference site samples averaged $0.10 \pm 0.06(n=4)$, a value similar to the long-term average at the Hinds Creek reference site $(0.09 \mu \mathrm{g} / \mathrm{g})$. In screening analyses, recoveries of matrix spike additions of metals to reference site fish ranged from a low of $78 \%$ for nickel and chromium to a high of $103 \%$ for uranium, with an overall average ( $\pm S D$ ) for all metals of $90 \pm 8 \%$. 
Table C.1. Concentrations of mercury and PCBs in individual fish collected from Big Bayou Creek and Little Bayou Creek near PGDP

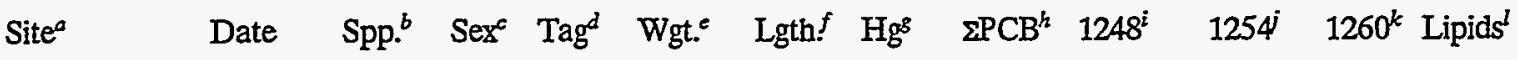

\begin{tabular}{|c|c|c|c|c|c|c|c|c|c|c|c|c|}
\hline BBK12.5 & $10 / 13 / 93$ & LNGEAR & M & 4980 & 52.3 & 14.5 & & $<0.08$ & $<0.04$ & $<0.08$ & $<0.08$ & 0.07 \\
\hline BBK12.5 & $10 / 13 / 93$ & LNGEAR & $M$ & 4981 & 57.9 & 13.4 & & $<0.08$ & $<0.04$ & $<0.08$ & $<0.08$ & 0.05 \\
\hline BBK12.5 & $10 / 13 / 93$ & LNGEAR & M & 4982 & 45.0 & 13.5 & & $<0.09$ & $<0.04$ & $<0.09$ & $<0.09$ & 0.11 \\
\hline BBK12.5 & $10 / 13 / 93$ & LNGEAR & $\mathbf{M}$ & 4983 & 36.0 & 12.6 & . & $<0.09$ & $<0.04$ & $<0.09$ & $<0.09$ & 0.05 \\
\hline BBK12.5 & $10 / 13 / 93$ & LNGEAR & $M$ & 4984 & 42.5 & 13.7 & & $<0.08$ & $<0.04$ & $<0.08$ & $<0.08$ & 0.05 \\
\hline BBK12.5 & $10 / 13 / 93$ & LNGEAR & $\mathbf{M}$ & 4985 & 46.7 & 13.9 & . & $<0.07$ & $<0.03$ & $<0.07$ & $<0.07$ & 0.18 \\
\hline BBK12.5 & $10 / 13 / 93$ & LNGEAR & $\mathbf{M}$ & 4986 & 48.2 & 13.7 & . & $<0.08$ & $<0.04$ & $<0.08$ & $<0.08$ & 0.17 \\
\hline BBK12.5 & $10 / 13 / 93$ & LNGEAR & $\mathbf{M}$ & 4987 & 43.4 & 13.4 & . & $<0.08$ & $<0.04$ & $<0.08$ & $<0.08$ & 0.07 \\
\hline BBK10.0 & $10 / 13 / 93$ & LNGEAR & $\mathbf{M}$ & 4610 & 45.9 & 13.3 & . & 0.07 & $<0.04$ & 0.05 & 0.02 & 0.20 \\
\hline BBK10.0 & $10 / 13 / 93$ & LNGEAR & $M$ & 4611 & 48.2 & 13.8 & . & $<0.07$ & $<0.03$ & $<0.07$ & $<0.07$ & 0.06 \\
\hline BBK10.0 & $10 / 13 / 93$ & LNGEAR & $M$ & 4612 & 43.4 & 13.0 & . & 0.07 & $<0.07$ & 0.04 & 0.03 & 0.16 \\
\hline BBK10.0 & 10/13/93 & LNGEAR & M & 4613 & 55.3 & 13.4 & . & 0.02 & $<0.03$ & $<0.06$ & 0.02 & 0.25 \\
\hline BBK10.0 & $10 / 13 / 93$ & LNGEAR & $\mathbf{M}$ & 4614 & 41.1 & 12.7 & . & 0.08 & 0.02 & 0.04 & 0.02 & 0.19 \\
\hline BBK10.0 & $10 / 13 / 93$ & INGEAR & $\mathbf{M}$ & 4615 & 45.4 & 13.2 & . & 0.12 & 0.03 & 0.06 & 0.03 & 0.30 \\
\hline BBK10.0 & $10 / 13 / 93$ & LNGEAR & M & 4616 & 52.5 & 13.8 & . & $<0.06$ & $<0.03$ & $<0.06$ & $<0.06$ & 0.10 \\
\hline BBK10.0 & $10 / 13 / 93$ & LNGEAR & $\mathbf{M}$ & 4617 & 42.4 & 13.1 & . & $<0.10$ & $<0.05$ & $<0.10$ & $<0.10$ & 0.06 \\
\hline BBK9.1 & $10 / 14 / 93$ & LNGEAR & M & 4970 & 46.1 & 13.6 & . & 0.06 & 0.01 & 0.01 & 0.04 & 0.10 \\
\hline BBK9.1 & $10 / 14 / 93$ & LNGEAR & $M$ & 4971 & 54.9 & 13.9 & . & 0.31 & 0.07 & 0.13 & 0.11 & 0.30 \\
\hline BBK9.1 & $10 / 14 / 93$ & LNGEAR & $M$ & 4972 & 52.7 & 13.6 & . & 0.04 & $<0.05$ & 0.03 & 0.01 & 0.00 \\
\hline BBK9.1 & $10 / 14 / 93$ & LNGEAR & $M$ & 4973 & 54.4 & 13.8 & . & 0.26 & 0.06 & 0.08 & 0.12 & 0.25 \\
\hline BBK9.1 & $10 / 14 / 93$ & LNGEAR & M & 4974 & 48.1 & 13.1 & . & 0.34 & 0.12 & 0.13 & 0.09 & 0.49 \\
\hline BBK9.1 & $10 / 14 / 93$ & LNGEAR & $\mathrm{M}$ & 4975 & 45.1 & 13.6 & . & 0.09 & 0.04 & 0.03 & 0.02 & 0.09 \\
\hline BBK9.1 & $10 / 14 / 93$ & LNGEAR & M & 4976 & 51.9 & 14.0 & . & 0.09 & 0.03 & 0.04 & 0.02 & 0.11 \\
\hline BBK9.1 & $10 / 14 / 93$ & LNGEAR & $M$ & 4977 & 54.7 & 13.6 & . & 0.08 & 0.03 & 0.03 & 0.02 & 0.10 \\
\hline BBK9.1 & $10 / 14 / 93$ & & $F$ & 4720 & 405 & 31.0 & 0.95 & 0.15 & 0.02 & 0.05 & 0.08 & 0.10 \\
\hline BBKO.1 & $10 / 14 / 93$ & SPBASS & $\mathrm{F}$ & 4721 & 493 & 34.2 & 0.58 & 0.18 & 0.03 & 0.07 & 0.08 & 0.14 \\
\hline BBK9.1 & $10 /$ & ASS & $\mathbf{M}$ & 4722 & 559 & 32.8 & 0.60 & 0.10 & 0.01 & 0.04 & 0.05 & 0.10 \\
\hline BBK9.1 & $10 / 14 / 93$ & SPBASS & $\mathbf{M}$ & 4723 & 349 & 29.1 & 0.6 & 0.44 & 0.06 & 0.18 & 0.20 & 0.19 \\
\hline BBK9.1 & $10 / 14 / 93$ & SPBASS & $\mathbf{M}$ & 4724 & 349 & 30.2 & 0.44 & 0.28 & 0.05 & 0.12 & 0.11 & 0.20 \\
\hline BBK9.1 & $10 / 14 / 93$ & SPBASS & $\mathrm{F}$ & 4725 & 587 & 34.1 & 0.59 & 0.12 & 0.02 & 0.05 & 0.05 & 0.21 \\
\hline BBK9.1 & $10 /$ & ASS & $\mathrm{F}$ & 4726 & 348 & 29.5 & 0.45 & 0.23 & 0.04 & 0.10 & 0.09 & 0.24 \\
\hline BBK9.1 & $10 / 14 / 93$ & SPBASS & $\mathrm{F}$ & 4727 & 480 & 32.6 & 0.60 & 0.35 & 0.04 & 0.10 & 0.11 & 0.11 \\
\hline BBK2.8 & & SEAR & $\mathrm{M}$ & 4770 & 58.7 & 14.4 & . & $<0.06$ & $<0.03$ & $<0.06$ & $<0.06$ & 0.06 \\
\hline BBK2.8 & & LNGEAR & $\mathrm{F}$ & 4771 & 37.4 & 12.3 & . & $<0.12$ & $<0.06$ & $<0.12$ & $<0.12$ & 0.15 \\
\hline BBK2.8 & $10 / 13 / 93$ & LNGEAR & $\mathrm{M}$ & 4772 & 40.8 & 12.8 & . & $<0.09$ & $<0.05$ & $<0.09$ & $<0.09$ & 0.29 \\
\hline BBK2.8 & $10 / 13 / 93$ & LNGEAR & $M$ & 4773 & 41.6 & 13.0 & . & $<0.09$ & $<0.05$ & $<0.09$ & $<0.09$ & 0.08 \\
\hline BBK2.8 & $10 / 13 / 93$ & LNGEAR & $M$ & 4774 & 63.2 & 15.2 & . & $<0.06$ & $<0.03$ & $<0.06$ & $<0.06$ & 0.17 \\
\hline BBK2.8 & $10 / 13 / 93$ & LNGEAR & $\mathrm{M}$ & 4775 & 68.6 & 15. & . & $<0.06$ & $<0.03$ & $<0.06$ & $<0.06$ & 0.09 \\
\hline BBK2.8 & $10 / 13 / 93$ & LNGEAR & $\mathrm{M}$ & 4776 & 49.0 & 13.8 & . & $<0.08$ & $<0.04$ & $<0.08$ & $<0.08$ & 0.13 \\
\hline BBK2.8 & $10 / 13 / 93$ & LNGEAR & $M$ & 4777 & 36.6 & 12.6 & . & $<0.10$ & $<0.05$ & $<0.10$ & $<0.10$ & 0.31 \\
\hline & & LNGEAR & $\mathbf{M}$ & 4800 & 57. & 14.0 & - & 0.63 & 0.19 & 0.25 & 0.19 & 0.06 \\
\hline LUKO. 0 & $10 / 14 / 93$ & LNGEAR & $\mathrm{M}$ & 4801 & 29.6 & 11.7 & . & 0.82 & 0.12 & 0.33 & 0.37 & 0.00 \\
\hline LUK9.0 & $10 / 14 / 93$ & LNGEAR & $\mathbf{M}$ & 4802 & 24.9 & 11.5 & . & 0.39 & $<0.04$ & $<0.09$ & 0.39 & 0.00 \\
\hline LUK9.0 & $10 / 14 / 93$ & LNGEAR & $\mathbf{M}$ & 4803 & 28.1 & 11.5 & . & 0.24 & $<0.07$ & $<0.14$ & 0.24 & 0.00 \\
\hline LUK9.0 & $10 / 14 / 93$ & LNGEAR & $\mathrm{M}$ & 4804 & 28.6 & 11.7 & . & 1.23 & 0.28 & $<0.05$ & 0.95 & 0.05 \\
\hline
\end{tabular}


Table C.1 (continued)

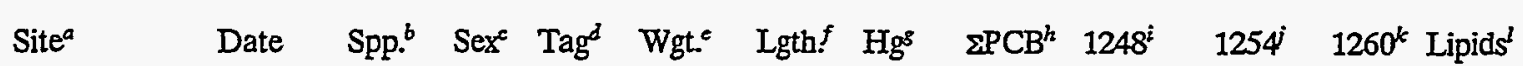

\begin{tabular}{|c|c|c|c|c|c|c|c|c|c|c|c|c|}
\hline LUK9.0 & $10 / 14 / 93$ & LNGEAR & M & 4805 & 27.8 & 11.4 & $\bullet$ & 1.67 & 0.84 & 0.83 & $<0.05$ & 0.37 \\
\hline LUKO.0 & $10 / 14 / 93$ & LNGEAR & $\mathrm{M}$ & 4806 & 27.8 & 11.6 & . & 0.65 & 0.10 & $<0.06$ & 0.55 & 0.04 \\
\hline LUK9.0 & $10 / 14 / 93$ & LNGEAR & $M$ & 4807 & 26.1 & 11.6 & . & 0.33 & 0.04 & $<0.07$ & 0.29 & \\
\hline UK7.2 & $10 / 14 / 93$ & SPBASS & $F$ & 4849 & 146 & 22.5 & . & 0.36 & 0.11 & 0.16 & 0.19 & 0.0 \\
\hline LUK4.3 & $10 / 14 / 93$ & SPBASS & M & 4850 & 385 & 30.9 & $\therefore$ & 0.21 & 0.03 & 0.08 & & 0.09 \\
\hline LUK4.3 & $10 / 14 / 93$ & SPBASS & $F$ & 4851 & 571 & 33.6 & . & 0.03 & $<0.01$ & 0.01 & 0.02 & 0.03 \\
\hline LUK4.3 & $10 / 14 / 93$ & SPBASS & $M$ & 4852 & 679 & 35.8 & . & 0.48 & 0.03 & 0.16 & 0.29 & 0.27 \\
\hline LUK4.3 & $10 / 14 / 93$ & SPBASS & $M$ & 4853 & 187 & 23.9 & . & 0.58 & 0.12 & 0.22 & 0.24 & 0.24 \\
\hline UK 4.3 & $10 / 14 / 93$ & SPBASS & F & 4854 & 217 & 25.2 & . & 0.95 & 0.24 & 0.39 & 0.32 & 0.60 \\
\hline UK 4.3 & $10 / 14 / 93$ & IEAR & $\mathbf{M}$ & 4870 & 37.3 & 13.0 & . & 0.04 & $<0.05$ & 0.03 & 0.01 & 0.04 \\
\hline LUK4.3 & $10 / 14 / 93$ & LNGEAR & $\mathrm{M}$ & 4871 & 42.7 & 12. & . & 0.13 & $<0.04$ & 0.07 & 0.06 & 0.52 \\
\hline LUK4.3 & $10 / 14 / 93$ & LNGEAR & $\mathrm{M}$ & 4872 & 38.9 & 13. & . & 0.29 & 0.04 & 0.16 & 0.09 & 0.02 \\
\hline LUK4.3 & $10 / 14 / 93$ & LNGEAR & $\mathbf{M}$ & 4873 & 38.4 & 13. & . & 0.18 & $<0.05$ & 0. & 0.05 & 0.06 \\
\hline LUK4.3 & $10 / 14$ & NGEAR & M & 4874 & 38.3 & 12. & . & 0.26 & 0. & 0.1 & 0.8 & 0.64 \\
\hline LUK4.3 & $10 / 14 / 93$ & NGEAR & $M$ & 4875 & 38.5 & 12. & . & 0.05 & $<0.05$ & 0.0 & 0.03 & 0.06 \\
\hline LUK4.3 & $10 / 14 / 93$ & LNGEAR & $\mathrm{F}$ & 4876 & 40.5 & 12. & . & $<0.08$ & $<0.04$ & $<0.08$ & $<0.08$ & 0.09 \\
\hline LUK4.3 & $10 / 14 / 93$ & LNGEAR & $\mathbf{M}$ & 4877 & 36.4 & 12.6 & - & 0.12 & $<0.05$ & 0.05 & 0.07 & 0.14 \\
\hline HINDSCR & & & $\mathrm{M}$ & 8065 & 65.5 & 16. & . & & 6 & 2 & & 0.00 \\
\hline HINDSC & $12 /$ & BRE & $F$ & 8066 & 51.3 & 14 & . & $<0.09$ & $<0$. & $<0$ & & 0.06 \\
\hline HINDSCR & $12 / 16 / 93$ & REDBRE & $M$ & 8067 & 39.2 & 13. & . & $<0.13$ & $<0.06$ & $<0.13$ & $<0.13$ & 0.08 \\
\hline HINDSC & $12 / 16 / 93$ & REDBRE & $\mathrm{F}$ & 8068 & 36. & 12 & . & $<0.12$ & $<0.06$ & 0.12 & & 0.05 \\
\hline HINDSC & $12 / 16 / 93$ & BRE & $F$ & 8070 & 47.3 & 14 & . & $<0.09$ & $<0.05$ & $<0.09$ & & 0.08 \\
\hline HINDSCR & $12 / 16 / 93$ & REDBRE & M & 8071 & 41.2 & 13.4 & - & $<0.10$ & $<0.05$ & $<0.10$ & $<0.10$ & 0.07 \\
\hline 3BK12.5 & $5 / 2 / 4$ & & M & 8310 & 84.9 & 15 & 0.08 & & & & & 0.73 \\
\hline BBK12.5 & $5 / 21$ & AAR & M & 8311 & 54.7 & 12 & .07 & $<0$ & $<0$ & & & 0.91 \\
\hline 3BK12.5 & $5 / 2 / 9$ & EAR & $\mathbf{M}$ & 8312 & 49.8 & 12. & 0.08 & $<0.07$ & $<0$. & $<0.07$ & & .40 \\
\hline BBK12.5 & $5 / 2$ & AAR & $\mathbf{M}$ & 8313 & 87. & 14 & & $<0.05$ & $<0$ & $<0.05$ & & 0.83 \\
\hline 3BK12.5 & $5 / 2 /$ & & $M$ & 8314 & 52.6 & & & & $<0$ & & & 1.10 \\
\hline BK12.5 & $5 / 21$ & AR & $\mathbf{M}$ & 8315 & 37.7 & 11. & .07 & $<0$ & $<0$ & & & 1.00 \\
\hline BBK12.5 & $5 / 2 / 94$ & EAR & $\mathbf{M}$ & 8316 & 67.6 & 14.2 & 0.09 & $<0.11$ & $<0.05$ & & $<0.11$ & 0.44 \\
\hline BBK12.5 & $5 / 2 / 94$ & LNGEAR & $\mathbf{M}$ & 8317 & 41.5 & 11.5 & 0.07 & $<0.17$ & $<0.08$ & $<0.17$ & $<0.17$ & 0.42 \\
\hline 3K10.0 & & & $\mathbf{M}$ & 83 & 57 & & & & & & & 27 \\
\hline BK10.0 & $5 / 3 /$ & AR & $\mathbf{M}$ & 8331 & 55. & & & & $<0$ & & & 0.42 \\
\hline BK10.0 & & & $\mathbf{M}$ & 8332 & 68.8 & & & & & $<0.11$ & .22 & 0.44 \\
\hline BK10.0 & $5 / 3 /$ & & M & 8333 & 62. & & & & & & & 0.37 \\
\hline BK10.0 & $5 / 3$ & AR & $\mathbf{M}$ & 8334 & 45. & & & & & & & .41 \\
\hline BBK10.0 & $5 / 3 / 94$ & & $\mathbf{M}$ & 8335 & 47.1 & 12 & & & $<0$ & 13 & 0.20 & 1.00 \\
\hline BK10.0 & & & $\mathrm{M}$ & 8336 & 70. & 14 & & & & & & 0.55 \\
\hline BBK10.0 & $5 / 3 / 94$ & LNGEAR & $\mathrm{M}$ & 8337 & 54.4 & 13.6 & 0.53 & 0.17 & $<0.10$ & 0.05 & 0.12 & 0.44 \\
\hline . & & & $\mathrm{M}$ & & & & & & & & & \\
\hline & & & $\mathbf{M}$ & 8351 & & & & & & & & 12 \\
\hline BK9.1 & $5 / 3 /$ & LNGEAR & $\mathbf{M}$ & 8352 & 80.5 & & & & & & & \\
\hline BKO.1 & & & $\mathbf{M}$ & 8353 & 53.4 & & & & & $<0.07$ & 0.10 & 0.09 \\
\hline & & & $\mathbf{M}$ & 8354 & 47.3 & & & & & & 0.09 & 0.11 \\
\hline BKO.1 & $5 / 3 / 94$ & LNGEAR & $M$ & 8355 & 86.4 & 15.1 & 0.16 & 0.03 & $<0.03$ & 0.03 & $<0.07$ & 0.59 \\
\hline
\end{tabular}


Table C.1 (continued)

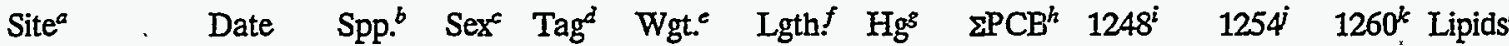

\begin{tabular}{|c|c|c|c|c|c|c|c|c|c|c|c|c|}
\hline BBK9.1 & $5 / 3 / 94$ & LNGEAR & $\mathbf{M}$ & 8356 & 48.0 & 13.0 & 0.26 & 0.50 & $<0.04$ & 0.19 & 0.32 & 0.86 \\
\hline BBK9.1 & $5 / 3 / 94$ & LNGEAR & $M$ & 8357 & 51.8 & 13.5 & 0.22 & 0.21 & $<0.05$ & 0.09 & 0.13 & 0.19 \\
\hline LUK9.0 & $5 / 3 / 94$ & LNGEAR & M & 8340 & 36.1 & 12.2 & . & 3.42 & $<0.05$ & 1.36 & 2.06 & 0.22 \\
\hline LUK9.0 & $5 / 3 / 94$ & LNGEAR & $\mathbf{M}$ & 8341 & 32.6 & 11.3 & . & 2.16 & 0.26 & 0.77 & 1.13 & 0.25 \\
\hline LUK9.0 & $5 / 3 / 94$ & LNGEAR & $\mathbf{M}$ & 8342 & 24.3 & 10.2 & . & 2.65 & 0.56 & 1.26 & 0.83 & 0.60 \\
\hline LUK9.0 & $5 / 3 / 94$ & LNGEAR & $\mathrm{F}$ & 8343 & 32.3 & 11.0 & . & 0.94 & 0.35 & 0.32 & 0.27 & 0.14 \\
\hline LUK9.0 & $5 / 3 / 94$ & LNGEAR & $\mathbf{M}$ & 8344 & 37.4 & 11.6 & . & 0.50 & 0.16 & 0.17 & 0.16 & 0.00 \\
\hline LUK9.0 & $5 / 3 / 94$ & LNGEAR & M & 8345 & 29.1 & 11.9 & . & 0.76 & $<0.07$ & 0.13 & 0.63 & 0.00 \\
\hline LUK9.0 & $5 / 3 / 94$ & LNGEAR & $\mathrm{F}$ & 8346 & 33.7 & 11.6 & . & 0.08 & 0.04 & 0.02 & 0.02 & 0.03 \\
\hline LUKO.0 & $5 / 3 / 94$ & LNGEAR & $\mathbf{M}$ & 8347 & 22.9 & 9.9 & . & 0.75 & 0.10 & 0.29 & 0.36 & 0.16 \\
\hline LUK7.2 & $5 / 2 / 94$ & LNGEAR & $\mathbf{M}$ & 4835 & 56.7 & 12.8 & 0.10 & $<0.13$ & $<0.06$ & $<0.13$ & $<0.13$ & 0.05 \\
\hline LUK7.2 & $5 / 2 / 94$ & LNGEAR & $\mathbf{M}$ & 4836 & 52.2 & 13.4 & 0.09 & 0.51 & 0.06 & 0.20 & 0.25 & 0.05 \\
\hline LUK7.2 & $5 / 2 / 94$ & LNGEAR & $\mathbf{M}$ & 4837 & 48.3 & 13.2 & 0.08 & 0.62 & 0.12 & 0.29 & 0.21 & 0.07 \\
\hline LUK7.2 & $5 / 2 / 94$ & LNGEAR & $\mathbf{M}$ & 4838 & 45.6 & 12.6 & 0.09 & 0.29 & $<0.09$ & 0.13 & 0.17 & 0.04 \\
\hline LUK4.3 & $5 / 2 / 94$ & LNGEAR & $\mathbf{M}$ & 8300 & 41.0 & 12.1 & . & 0.03 & $<0.05$ & 0.02 & 0.01 & 0.14 \\
\hline LUK4.3 & $5 / 2 / 94$ & LNGEAR & $\mathbf{M}$ & 8301 & 57.7 & 13.1 & . & 0.14 & 0.04 & 0.08 & 0.02 & 0.43 \\
\hline LUK4.3 & $5 / 2 / 94$ & LNGEAR & $\mathbf{M}$ & 8302 & 79.9 & 14.2 & . & 0.23 & 0.03 & 0.07 & 0.13 & 1.59 \\
\hline LUK4.3 & $5 / 2 / 94$ & LNGEAR & $\mathbf{M}$ & 8303 & 71.9 & 14.1 & . & 0.30 & 0.05 & 0.08 & 0.17 & 0.94 \\
\hline LUK4.3 & $5 / 2 / 94$ & LNGEAR & $\mathbf{M}$ & 8304 & 36.9 & 11.8 & . & 0.19 & $<0.05$ & 0.06 & 0.13 & 0.14 \\
\hline LUK4.3 & $5 / 2 / 94$ & LNGEAR & $\mathrm{F}$ & 8305 & 34.0 & 11.3 & . & 0.07 & $<0.07$ & 0.02 & 0.04 & 0.79 \\
\hline LUK4.3 & $5 / 2 / 94$ & LNGEAR & $\mathrm{F}$ & 8306 & 30.5 & 11.0 & . & 0.13 & $<0.07$ & 0.04 & 0.09 & 0.41 \\
\hline LUK4.3 & $5 / 2 / 94$ & LNGEAR & $\mathbf{M}$ & 8307 & 35.1 & 11.1 & & 0.61 & 0.08 & 0.19 & 0.33 & 1.03 \\
\hline MASSAC & $5 / 3 / 94$ & LNGEAR & M & 8320 & 32.6 & 11. & 0.07 & & . & . & & \\
\hline MASSAC & $5 / 3 / 94$ & LNGEAR & $\mathbf{M}$ & 8321 & 74.9 & 15.4 & 0.18 & . & . & . & . & . \\
\hline MASSAC & $5 / 3 / 94$ & LNGEAR & $\mathbf{M}$ & 8322 & 71.5 & 13.9 & 0.14 & & . & . & . & . \\
\hline MASSAC & $5 / 3 / 94$ & LNGEAR & $\mathbf{M}$ & 8323 & 43.2 & 12.1 & $0.1^{\prime}$ & . & - & . & . & . \\
\hline MASSAC & $5 / 3 / 94$ & LNGEAR & $\mathbf{M}$ & 8324 & 32.4 & 11.4 & 0.1 & . & . & . & . & . \\
\hline MASSAC & $5 / 3 / 94$ & LNGEAR & M & 8325 & 70.5 & 14.2 & 0.11 & . & . & . & . & . \\
\hline MASSAC & $5 / 3 / 94$ & LNGEAR & $\mathbf{M}$ & 8326 & 30.2 & 10. & 0.1 & & . & . & . & \\
\hline MASSAC & $5 / 3 / 94$ & LNGEAR & $\mathbf{M}$ & 8327 & 35.4 & 11.4 & 0.11 & . & . & . & . & . \\
\hline HINDSCR & $5 / 18 / 94$ & REDBRE & M & 8493 & 42.2 & 14.5 & 0.13 & & . & • & . & \\
\hline HINDSCR & $5 / 18 / 94$ & REDBRE & $F$ & 8480 & 30.6 & 11.3 & 0.05 & & . & & & \\
\hline HINDSCR & $5 / 18 / 94$ & REDBRE & $\mathbf{M}$ & 8490 & 108.7 & 17.6 & 0.05 & $<0.10$ & $<0.05$ & $<0.10$ & $<0.10$ & 0.42 \\
\hline HINDSCR & $5 / 18 / 94$ & REDBRE & $F$ & 8487 & 83.3 & 16.4 & 0.18 & $<0.12$ & $<0.06$ & $<0.12$ & $<0.12$ & 0.61 \\
\hline HINDSCR & $5 / 18 / 94$ & REDBRE & $\mathbf{F}$ & 8489 & 101.5 & 16.8 & . & $<0.07$ & $<0.03$ & $<0.07$ & $<0.07$ & 0.41 \\
\hline HINDSCR & $5 / 18 / 94$ & REDBRE & M & 8492 & 54.1 & 14.0 & . & $<0.12$ & $<0.06$ & $<0.12$ & $<0.12$ & 0.50 \\
\hline HINDSCR & $5 / 18 / 94$ & REDBRE & $\mathrm{F}$ & 8488 & 104.9 & 16.4 & . & $<0.08$ & $<0.04$ & $<0.08$ & $<0.08$ & 0.13 \\
\hline
\end{tabular}




\section{Table C.1 (continued)}

${ }^{a} \mathrm{BBK}=$ Big Bayou Creek kilometer; LUK = Little Bayou Creek kilometer; MAK = Massac Creek kilometer; HINDSCR $=$ Hinds Creek.

${ }^{b} \mathrm{Spp}=$ species, LNGEAR = Longear sunfish, Lepomis megalotus; REDBRE = redbreast sunfish, Lepomis auritus.

${ }^{i}$ Sex: $M=$ male; $F=$ female.

${ }^{d}$ Tag $=$ fish identification tag number.

Teight in grams.

fength $=$ total length, in centimeters.

${ }^{8} \mathrm{Hg}=$ total mercury concentration, micrograms per gram wet wt.

${ }^{2} \mathrm{ZPCB}=$ sum of $\mathrm{PCBs}$ quantified as specific Aroclor mixtures, micrograms per gram wet wt

$i_{1248}=$ PCBs quantified as sirnilar to Aroclor 1248 , micrograms per gram wet wh.

$j_{1254}=$ PCBs quantified as similar to Aroclor 1254, micrograms per gram wet wt.

${ }^{k_{1}} 1260=$ PCBs quantified as similar to Aroclor 1260 , micrograms per gram wet wt.

'Lipid $=$ Lipid content of fish fillet, percentage wet weight. 

Appendix D

SPECIES CHARACTERISTICS, DENSITY, AND BIOMASS FOR FISH COMMUNITY DATA COLLECTED FROM BIG BAYOU CREEK, LITTLE BAYOU CREEK, AND MASSAC CREEK DURING MARCH AND SEPTEMBER 1994 

Table D.1. Tolerance, feeding guilds and lithophilic spawners for species found in and near the drainages of Big Bayou Creek, Little Bayou Creek, and Massac Creek

\begin{tabular}{|c|c|c|c|}
\hline Species & Tolerance $^{a}$ & $\begin{array}{l}\text { Feedirg } \\
\text { guild }^{b}\end{array}$ & $\begin{array}{l}\text { Lithophilic } \\
\text { spawner }\end{array}$ \\
\hline Gizzard shad (Dorosoma cepedianum) & TOL & GEN & \\
\hline Goldfish (Carassius auratus) & TOL & GEN & \\
\hline Red shiner (Cyprinella lutrensis) & TOL & & \\
\hline Spotfin shiner (Cyprinella spiloptera) & TOL & & \\
\hline Steelcolor shiner (Cyprinella whipplei) & INTOL & & \\
\hline Common carp (Cyprinus carpio) & TOL & GEN & \\
\hline Ribbon shiner (Lythrurus fumeus) & INTOL & & \\
\hline Emerald shiner (Notropis atherinoides) & & & LITH \\
\hline River shiner (Notropis blennius) & & & LITH \\
\hline Sand shiner (Notropis stramineus) & INTOL & & \\
\hline Mimic shiner (Notropis volucellus) & INTOL & & \\
\hline Suckermouth minnow (Phenacobius mirabilis) & & BIN & LITH \\
\hline Fathead minnow (Pimephales promelas) & TOL & GEN & \\
\hline Creek chub (Semotilus atromaculatus) & TOL & GEN & \\
\hline White sucker (Catostomus commersoni) & TOL & GEN & LITH \\
\hline Creek chubsucker (Erimyzon oblongus) & & $\mathrm{BIN}$ & \\
\hline Spotted sucker (Minytrema melanops) & INTOL & GEN & LITH \\
\hline Black redhorse (Moxostoma duquesnel) & INTOL & BIN & LITH \\
\hline Golden redhorse (Moxostoma erythrurum) & INTOL & BIN & LITH \\
\hline Black bullhead (Ameiurus melas) & TOL & GEN & \\
\hline Yellow bullhead (Ameiurus natalis) & TOL & GEN & \\
\hline Tadpole madtom (Noturus gyrinus) & INTOL & BIN & \\
\hline Freckled madtom (Noturus nocturnus) & INTOL & BIN & \\
\hline Grass pickerel (Esox americanus vermiculatus) & & PIS & \\
\hline Pirate perch (Aphredoderus sayanus) & & BIN & \\
\hline Green sunfish (Lepomis cyanellus) & TOL & & \\
\hline Warmouth (Lepomis gulosus) & & GEN & \\
\hline Bluegill (Lepomis macrochirus) & & GEN & \\
\hline Longear sunfish (Lepomis megalotis) & & GEN & \\
\hline Spotted bass (Micropterus punctulatus) & & PIS & \\
\hline Largemouth bass (Micropterus salmoides) & & PIS & \\
\hline Mud darter (Etheostoma asprigene) & & BIN & LITH \\
\hline Bluntnose darter (Etheostoma chlorosomum) & INTOL & BIN & \\
\hline Slough darter (Etheostoma gracile) & & BIN & \\
\hline Logperch (Percina caprodes) & INTOL & BIN & LITH \\
\hline Blackside darter (Percina maculata) & INTOL & BIN & LITH \\
\hline
\end{tabular}

Tolerant (TOL) and sensitive (INTOL) species were tentatively identified for the Paducah area using collection records and text discussions in Becker (1983), Burr and Warren (1986), Cross and Collins (1975), Etnier and Starnes (1993), Karr et al. (1986), Lee et al. (1980), Ohio EPA (1987, 1988), Plfieger (1975), Robison and Buchanan (1988), Smith (1979), and Trautman (1981). Complete citations for references listed in this table may be found in Section 6 of this report.

${ }^{\circ}$ Feeding guilds are assigned to categories of interest in assessing impacts. Guilds include species that are primarily generalists (GEN), fign that feed on many types of food items and from many areas of the stream; benthic insectivores (BIN), those that eat macroinvertebrates associated with bottom substrates; and piscivores (PIS), fish that eat other fish.

Lithophilic spawners (LITH) are species that release eggs randomly or without parental care in or onto gravel substrates. These species are especially vulnerable to siltation or low dissolved oxygen conditions. 
Table D.2. Fish densities (number/m²) in Big Bayou Creek, Little Bayou Creek, and a reference stream, Massac Creek, March 1994

\begin{tabular}{|c|c|c|c|c|c|}
\hline \multirow[b]{2}{*}{ Species $^{b}$} & \multicolumn{5}{|c|}{ Sites $^{a}$} \\
\hline & BBK 9.1 & BBK 10.0 & BBK 12.5 & LUK 7.2 & MAK 13.8 \\
\hline Stoneroller & 0.32 & 1.18 & 1.67 & 0.21 & 0.60 \\
\hline Red shiner & - & 0.01 & - & 0.18 & - \\
\hline Steelcolor shiner & $<0.01$ & - & - & - & 0.01 \\
\hline Ribbon shiner & - & - & - & 0.07 & 0.01 \\
\hline Redfin shiner & - & $<0.01$ & - & 0.11 & 0.06 \\
\hline Golden shiner & - & - & - & $<0.01$ & - \\
\hline Suckermouth minnow & - & $<0.01$ & 0.01 & 0.16 & - \\
\hline Bluntnose minnow & - & $<0.01$ & 0.05 & 1.61 & 0.07 \\
\hline Creek chub & - & $<0.01$ & 0.25 & 0.21 & 0.03 \\
\hline White sucker & $<0.01$ & - & $<0.01$ & - & 0.01 \\
\hline Creek chubsucker & $<0.01$ & 0.01 & 0.05 & 0.01 & 0.01 \\
\hline Spotted sucker & $<0.01$ & - & - & - & - \\
\hline Yellow bullhead & 0.01 & - & 0.14 & 0.03 & 0.03 \\
\hline Pirate perch & - & - & - & 0.07 & 0.01 \\
\hline Blackspotted topminnow & 0.04 & 0.01 & 0.15 & 0.49 & 0.12 \\
\hline Western mosquitofish & - & - & - & 0.02 & - \\
\hline Green sunfish & 0.06 & 0.01 & 0.10 & 0.12 & 0.04 \\
\hline Warmouth & $<0.01$ & - & - & 0.02 & - \\
\hline Bluegill & 0.01 & - & 0.03 & $<0.01$ & 0.01 \\
\hline Longear sunfish & 0.50 & 0.13 & 0.62 & 0.27 & 0.43 \\
\hline Hybrid sunfish. & 0.01 & $<0.01$ & 0.01 & - & - \\
\hline Spotted bass & 0.01 & - & 0.01 & $<0.01$ & 0.01 \\
\hline Largemouth bass & $<0.01$ & - & - & - & - \\
\hline Bluntnose darter & - & - & - & 0.08 & - \\
\hline Slough darter & - & - & - & 0.16 & - \\
\hline Logperch & - & - & - & - & 0.01 \\
\hline Blackside darter & - & - & - & - & 0.03 \\
\hline Total density & 0.97 & 1.36 & 3.09 & 3.82 & 1.49 \\
\hline
\end{tabular}

${ }^{a} \mathrm{BBK}=$ Big Bayou Creek kilometer, LUK $=$ Little Bayou Creek kilometer, MAK $=$ Massac Creek kilometer.

${ }^{b}$ Common and scientific names according to the American Fisheries Society (Robbins et al. 1991). Tennessee.

'Species identification confirmed by Dr. David A. Etnier, Department of Zoology, University of 
Table D.3. Fish biomass ( $\mathrm{g}$ fish/m²) in Big Bayou Creek, Little Bayou Creek, and a reference stream, Massac Creek, March 1994

\begin{tabular}{|c|c|c|c|c|c|}
\hline \multirow[b]{2}{*}{ Species $^{b}$} & \multicolumn{5}{|c|}{ Sites $^{a}$} \\
\hline & BBK 9.1 & BBK 10.0 & BBK 12.5 & LUK 7.2 & MAK 13.8 \\
\hline Stoneroller & 0.79 & 6.39 & 6.84 & 0.31 & 1.25 \\
\hline Red shiner & - & 0.01 & - & 0.13 & - \\
\hline Steelcolor shiner & $<0.01$ & - & - & - & 0.04 \\
\hline Ribbon shiner & - & - & : & 0.05 & $<0.01$ \\
\hline Redfin shiner & - & $<0.01$ & - & 0.11 & 0.08 \\
\hline Golden shiner & - & - & - & 0.01 & - \\
\hline Suckermouth minnow & - & 0.01 & 0.07 & 0.48 & - \\
\hline Bluntnose minnow & - & $<0.01$ & 0.11 & 2.34 & 0.17 \\
\hline Creek chub & - & $<0.01$ & 1.09 & 0.47 & 0.10 \\
\hline White sucker & 1.55 & - & 0.13 & - & 0.56 \\
\hline Creek chubsucker & 0.20 & 0.01 & 0.33 & 0.14 & 0.15 \\
\hline Spotted sucker & 0.09 & - & - & - & - \\
\hline Yellow bullhead & 0.46 & - & 2.20 & 0.16 & 0.75 \\
\hline Pirate perch & - & - & - & 0.53 & 0.06 \\
\hline Blackspotted topminnow & 0.06 & 0.02 & 0.21 & 0.70 & 0.16 \\
\hline Western mosquitofish & - & - & - & 0.01 & - \\
\hline Green sunfish & 0.77 & 0.13 & 1.14 & 0.63 & 0.22 \\
\hline Warmouth & 0.09 & - & - & 0.24 & - \\
\hline Bluegill & 0.58 & - & 0.23 & $<0.01$ & 0.01 \\
\hline Longear sunfish & 9.67 & 1.07 & 3.66 & 0.44 & 2.83 \\
\hline Hybrid sunfish & 0.44 & 0.17 & 0.51 & - & - \\
\hline Spotted bass & 2.11 & - & 0.05 & 0.01 & 0.27 \\
\hline Largemouth bass & 0.12 & - & - & - & - \\
\hline Bluntnose darter & - & - & - & 0.07 & - \\
\hline Slough darter & - & - & - & 0.15 & - \\
\hline Logperch & - & - & - & - & 0.09 \\
\hline Blackside darter & - & - & - & - & 0.09 \\
\hline Total biomass & 16.93 & 7.81 & 16.57 & 6.98 & 6.83 \\
\hline
\end{tabular}
kilometer.

${ }^{a} \mathrm{BBK}=\mathrm{Big}$ Bayou Creek kilometer, LUK $=$ Little Bayou Creek kilometer, MAK $=$ Massac Creek

${ }^{b}$ Common and scientific names according to the American Fisheries Society (Robbins et al. 1991). Tennessee.

'Species identification confirmed by Dr. David A. Etnier, Department of Zoology, University of 
Table D.4. Fish densities (number/m²) in Big Bayou Creek, Little Bayou Creek, and a reference stream, Massac Creek, September 1994

\begin{tabular}{|c|c|c|c|c|c|}
\hline \multirow[b]{2}{*}{ Species $^{b}$} & \multicolumn{5}{|c|}{ Sites $^{a}$} \\
\hline & BBK 9.1 & BBK 10.0 & BBK 12.5 & LUK 7.2 & MAK 13.8 \\
\hline Stoneroller & 0.56 & 4.43 & 1.53 & 0.67 & 1.93 \\
\hline Red shiner & - & - & 0.06 & 0.63 & $<0.01$ \\
\hline Steelcolor shiner & - & - & - & - & 0.02 \\
\hline Miss. silvery minnow & - & - & - & - & 0.17 \\
\hline Ribbon shiner & 0.01 & - & - & - & $<0.01$ \\
\hline Redfin shiner & 0.06 & - & 0.05 & - & 0.08 \\
\hline Golden shiner & - & - & - & - & $<0.01$ \\
\hline Suckermouth minnow & - & - & - & 0.01 & - \\
\hline Bluntnose minnow & - & 0.01 & 0.13 & 0.88 & 0.12 \\
\hline Creek chub & - & 0.01 & 0.35 & 1.34 & 0.38 \\
\hline White sucker & $<0.01$ & - & $<0.01$ & - & 0.02 \\
\hline Creek chubsucker & 0.01 & 0.01 & 0.04 & - & 0.30 \\
\hline Bigmouth buffalo & $<0.01$ & - & - & - & - \\
\hline Spotted sucker & $<0.01$ & - & - & - & 0.01 \\
\hline Golden redhorse & - & - & - & - & 0.08 \\
\hline Black bullhead & $<0.01$ & - & - & - & - \\
\hline Yellow bullhead & 0.01 & 0.03 & 0.05 & 0.09 & 0.07 \\
\hline Pirate perch & - & - & - & - & 0.01 \\
\hline Blackspotted topminnow & 0.10 & 0.38 & 0.90 & 0.12 & 0.60 \\
\hline Western mosquitofish & 0.01 & 0.01 & - & 0.02 & 0.28 \\
\hline Green sunfish & 0.06 & 0.01 & 0.10 & - & 0.24 \\
\hline Warmouth & - & - & $<0.01$ & - & $<0.01$ \\
\hline Bluegill & 0.08 & 0.03 & 0.04 & - & 0.19 \\
\hline Longear sunfish & 0.27 & 0.61 & 0.96 & - & 1.20 \\
\hline Hybrid sunfish & & - & - & - & 0.01 \\
\hline Spotted bass & 0.01 & 0.04 & 0.05 & - & 0.02 \\
\hline Largemouth bass & 0.01 & $<0.01$ & $<0.01$ & - & - \\
\hline Slough darter & - & - & - & - & $<0.01$ \\
\hline Logperch & - & - & - & - & $<0.01$ \\
\hline Blackside darter & - & - & - & - & 0.01 \\
\hline Total density & 1.19 & 5.57 & 4.26 & 3.76 & 5.74 \\
\hline
\end{tabular}
kilometer.

${ }^{a} \mathrm{BBK}=$ Big Bayou Creek kilometer, LUK $=$ Little Bayou Creek kilometer, MAK = Massac Creek

${ }^{b}$ Common and scientific names according to the American Fisheries Society (Robbins et al. 1991).

'Species identification confirmed by Dr. David A. Etnier, Department of Zoology, University of Tennessee. 
Table D.5. Fish biomass ( $\mathrm{g}$ fish/m $\mathrm{m}^{2}$ ) in Big Bayou Creek, Little Bayou Creek, and a reference stream, Massac Creek, September 1994

\begin{tabular}{|c|c|c|c|c|c|}
\hline \multirow[b]{2}{*}{ Species $^{b}$} & \multicolumn{5}{|c|}{ Sites $^{a}$} \\
\hline & BBK 9.1 & BBK 10.0 & BBK 12.5 & LUK 7.2 & MAK 13.8 \\
\hline Stoneroller & 1.26 & 8.61 & 3.20 & 1.02 & 2.95 \\
\hline Red shiner & - & - & 0.08 & 0.20 & $<0.01$ \\
\hline Steelcolor shiner & - & - & - & - & 0.01 \\
\hline Miss. silvery minnow & - & - & - & - & 0.46 \\
\hline Ribbon shiner & $<0.01$ & - & - & - & $<0.01$ \\
\hline Redfin shiner & 0.05 & - & 0.03 & - & 0.07 \\
\hline Golden shiner & - & - & - & - & 0.03 \\
\hline Suckermouth minnow & - & - & - & 0.02 & - \\
\hline Bluntnose minnow & - & 0.01 & 0.15 & 0.64 & 0.15 \\
\hline Creek chub & - & 0.03 & 0.39 & 3.48 & 0.99 \\
\hline White sucker & 0.27 & - & 0.09 & - & 0.77 \\
\hline Creek chubsucker & 0.35 & 0.04 & 0.42 & - & 1.65 \\
\hline Bigmouth buffalo & 1.28 & - & - & - & - \\
\hline Spotted sucker & 1.22 & - & - & - & 0.35 \\
\hline Golden redhorse & - & - & - & - & 1.70 \\
\hline Black bullhead & 0.17 & - & - & - & 0.37 \\
\hline Yellow bullhead & 0.33 & 0.09 & 0.58 & 0.46 & \\
\hline Pirate perch & - & - & - & - & 0.06 \\
\hline Blackspotted topminnow & 0.13 & 0.30 & 0.80 & 0.03 & 0.68 \\
\hline Western mosquitofish & $<0.01$ & $<0.01$ & - & 0.01 & 0.07 \\
\hline Green sunfish & 1.46 & 0.18 & 0.81 & - & 1.07 \\
\hline Warmouth & - & - & 0.10 & - & 0.06 \\
\hline Bluegill & 2.84 & 0.32 & 0.40 & - & 0.93 \\
\hline Longear sunfish & 3.64 & 4.89 & 2.15 & - & 4.50 \\
\hline Hybrid sunfish & - & - & - & - & 0.23 \\
\hline Spotted bass & 0.91 & 0.60 & 0.32 & - & 0.58 \\
\hline Largemouth bass & 0.54 & 0.03 & 0.70 & - & - \\
\hline Slough darter & - & - & - & - & $<0.01$ \\
\hline Logperch & - & - & - & - & 0.04 \\
\hline Blackside darter & - & - & - & - & 0.03 \\
\hline Total biomass & 14.45 & 15.10 & 10.22 & 5.86 & 17.75 \\
\hline
\end{tabular}
kilometer.

${ }^{a}$ BBK $=$ Big Bayou Creek kilometer, LUK = Little Bayou Creek kilometer, MAK = Massac Creek

${ }^{b}$ Common and scientific names according to the American Fisheries Society (Robbins et al. 1991).

'Species identification confirmed by Dr. David A Etnier, Department of Zoology, University of Tennessee. 

Appendix E

CHECKLIST OF BENTHIC MACROINVERTEBRATE TAXA COLLECTED FROM BIG BAYOU CREEK, LITTLE BAYOU CREEK, AND MASSAC CREEK IN PADUCAH, KENTUCKY, SEPTEMBER 1991 TO MARCH 1994 


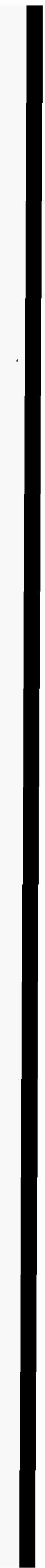


Table E.1. Checklist of benthic macroinvertebrate taxa collected from Big Bayou Creek, Little Bayou Creek, and Massac Creek in Paducah, Kentucky,

September 1991-June 1994

\begin{tabular}{|c|c|c|c|c|c|}
\hline \multirow[b]{2}{*}{ Taxon } & \multicolumn{5}{|c|}{ Site $^{a b b}$} \\
\hline & BBK 9.1 & BBK 10.0 & BBK 12.5 & LUK 7.2 & MAK 13.8 \\
\hline \multicolumn{6}{|l|}{ Coelenterata } \\
\hline $\begin{array}{l}\text { Hydrozoa } \\
\text { Hydridae }\end{array}$ & - & 2 & - & - & - \\
\hline Hydra & 1 & 1 & 2 & - & - \\
\hline \multicolumn{6}{|l|}{ Turbellaria } \\
\hline Planariidae & $1,2,3$ & $1,2,3$ & $1,2,3$ & 1 & - \\
\hline Nemertea & & 1,3 & $1,2,3$ & $1,2,3$ & $1,2,31,3$ \\
\hline Nematoda & & 1 & 1 & 1 & $1,21,2$ \\
\hline \multicolumn{6}{|l|}{ Annelida } \\
\hline $\begin{array}{l}\text { Hirudinea } \\
\text { Glossiphoniidae }\end{array}$ & & - & - & 3 & - \\
\hline Helobdella & - & 2,3 & - & - & - \\
\hline $\begin{array}{l}\text { Oligochaeta } \\
\text { Branchiura }\end{array}$ & $1,2,3$ & $1,2,3$ & $1,2,3$ & $1,2,3$ & $1,2,3$ \\
\hline sowerbyi & 2,3 & - & - & 1 & - \\
\hline $\begin{array}{l}\text { Crustacea } \\
\text { Amphipoda } \\
\text { Talitridae }\end{array}$ & & & & & \\
\hline Hyalella azteca & 1 & 1,2 & - & - & - \\
\hline Decapoda & & - & - & - & -1 \\
\hline Hydrachnida & 1 & 1 & - & - & - \\
\hline $\begin{array}{l}\text { Hydrachnidae } \\
\text { Hygrobatidae }\end{array}$ & - & - & 1 & 1,3 & 1,3 \\
\hline Atractides & 1 & - & 1 & - & 1,3 \\
\hline $\begin{array}{l}\text { Hygrobates } \\
\text { Lebertiidae }\end{array}$ & $1,2,3$ & $1,2,3$ & 1 & 1 & - \\
\hline $\begin{array}{c}\text { Lebertia } \\
\text { Limnesiidae }\end{array}$ & - & - & - & 3 & 1 \\
\hline $\begin{array}{l}\text { Limnesia } \\
\text { Pionidae }\end{array}$ & - & 2 & - & - & - \\
\hline $\begin{array}{l}\text { Piona } \\
\text { Torrenticolidae }\end{array}$ & 1 & - & - & - & - \\
\hline Torrenticola & 1,3 & $1,2,3$ & 3 & $1,2,3$ & $1,2,3$ \\
\hline
\end{tabular}


Table E1 (continued)

Site $^{a, b}$

Taxon

\begin{tabular}{lllll}
\hline BBK 9.1 & BBK 10.0 & BBK 12.5 & LUK 7.2 & MAK 13.8
\end{tabular}

Insecta

Ephemeroptera

Baetidae

Baetis

Pseudocloeon

Caenidae

Caenis

Heptageniidae

Stenacron

Stenonema

Oligoneuriidae

Isonychia

Tricorythidae

Tricorythodes

Odonata

Anisoptera

Gomphidae

Dromogomphus

Progomphus

Libellulidae

Erythemis simplicicollis

Libellula

Miathyria

Macromiidae

Macromia

Zygoptera

Calopterygidae

Calopteryx

Hetaerina

Coenagrionidae

Argia

Enallagma

Ischnura

$\begin{array}{ccccc}- & - & - & 3 & - \\ 1,2 & 1,2 & 1 & 1,3 & 1,2,3 \\ 1,2,3 & 1,2,3 & 1,2,3 & 1,2,3 & 1,2,3 \\ - & - & 1 & - & -\end{array}$

$\begin{array}{ccccc}1,2,3 & 1,2,3 & 1,2,3 & 1,2 & 1,2,3 \\ 1 & 1,2,3 & 1 & 1 & 1 \\ - & 2 & 3 & - & - \\ 1,2,3 & 1,2,3 & 1,3 & - & 1,2\end{array}$

$1,3 \quad 1$

$1,2,3 \quad 1,2,3 \quad 3$

$\begin{array}{ccccc} & - & 1,2 & 2 & - \\ - & - & - & 3 & - \\ 1 & - & - & - & - \\ - & - & - & 1,3 & 1\end{array}$


Table E1 (continued)

\begin{tabular}{|c|c|c|c|c|c|}
\hline \multirow[b]{2}{*}{ Taxon } & \multicolumn{5}{|c|}{ Site $e^{a, b}$} \\
\hline & BBK 9.1 & BBK 10.0 & BBK 12.5 & LUK 7.2 & MAK 13.8 \\
\hline Plecoptera & 1 & 1 & 1,3 & 1,2 & 1 \\
\hline Capniidae & - & 3 & 1,3 & 1 & 1,3 \\
\hline Allocapnia & - & 3 & 2 & - & 3 \\
\hline Leuctridae & - & - & 3 & - & - \\
\hline Nemouridae & 3 & - & 2 & -. & 3 \\
\hline $\begin{array}{l}\text { Amphinemura } \\
\text { Perlodidae }\end{array}$ & - & - & 1 & 1 & 1 \\
\hline Isoperla & - & - & 1 & - & - \\
\hline $\begin{array}{l}\text { Megaloptera } \\
\text { Corydalidae }\end{array}$ & & . & & & \\
\hline Corydalus cornutus & 3 & 1,3 & 1,3 & $1,2,3$ & - \\
\hline Trichoptera & 1 & $1,2,3$ & $1,2,3$ & 1 & $1,2,3$ \\
\hline Hydropsychidae & $1,2,3$ & $1,2,3$ & 3 & $1,2,3$ & $1,2,3$ \\
\hline Cheumatopsyche & $1,2,3$ & $1,2,3$ & 1,3 & $1,2,3$ & $1,2,3$ \\
\hline Hydropsyche & 1,2 & - & $1,2,3$ & $1,2,3$ & 1,3 \\
\hline Hydroptilidae & - & - & 2 & - & - \\
\hline $\begin{array}{l}\text { Hydroptila } \\
\text { Leptoceridae }\end{array}$ & 1 & 1 & 1,2 & 1,3 & - \\
\hline Oecetis & 1 & 1 & 1 & 1,3 & 1 \\
\hline Philopotamidae & 3 & - & - & - & - \\
\hline Chimarra & $1,2,3$ & $1,2,3$ & $1,2,3$ & 1 & 1,3 \\
\hline Polycentropodidae & 3 & - & - & - & - \\
\hline Polycentropus & - & - & 1 & - & - \\
\hline Coleoptera & & & & & \\
\hline Elmidae & 1 & - & - & - & - \\
\hline Dubiraphia & 1 & - & 1,2 & $1,2,3$ & - \\
\hline Optioservus & - & - & - & - & 1 \\
\hline $\begin{array}{l}\text { Stenelmis } \\
\text { Gyrinidae }\end{array}$ & $1,2,3$ & 1,3 & 1,3 & $1,2,3$ & 1,3 \\
\hline $\begin{array}{l}\text { Dineutus } \\
\text { Haliplidae }\end{array}$ & - & - & - & 1 & 1 \\
\hline Peltodytes & - & 1 & - & - & - \\
\hline Hydrophilidae & - & 2 & - & - & - \\
\hline Berosus & $1,2,3$ & $1,2,3$ & $1,2,3$ & $1,2,3$ & $1,2,3$ \\
\hline Enochrus & - & 1 & - & - & - \\
\hline Hydrobius & - & - & - & 1 & - \\
\hline
\end{tabular}


Table E.1 (continued)

Site ${ }^{a b}$

Taxon

BBK 9.1 $\quad$ BBK 10.0 $\quad$ BBK 12.5 $\quad$ LUK 7.2 $\quad$ MAK 13.8

Diptera

Ceratopogonidae Atrichopogon

Bezzia

Culicoides

Monohelea

Palpomyia

Probezzia

Chironomidae

Chironomini

Orthocladiinae

Tanypodinae

Tanytarsini

Empididae

Chelifera

Hemerodromia

Simuliidae

Simulium

Stegopterna

Tabanidae

Tabanus

Tipulidae

Erioptera

Helius

Limonia

Tipula
BBK 9.1 BBK 10.0

1
-
1
1
-
1

$1,2,3$

$1,2,3$

$1,2,3$

$1,2,3$

$1,2,3$

$1 \quad 1$

1,2

1

$1,2,3$

-

$\begin{array}{cc}1 & 1 \\ - & 1,2\end{array}$

- 1

- 1

$-\quad-$

- 2

1

$-$

$1,2,3$

$1,2,3$

$1,2,3$

$1,2,3$

$1,2,3$

$1,2,3$

-

1

$-$

1

, 2

1

$-$
3

11

- $\quad \overline{1}$

$1,2 \quad 1,2$

$1 \quad 1,2$

11

1,2
- $\quad-$

-

$1 \quad 1,2,3$

$1,3 \quad-$

- 1

1 -

$1,2,3 \quad 1,2,3$

$1,2,3 \quad 1,2,3$

$1,2,3 \quad 1,2,3$

$1,2,3 \quad 1,2,3$

$1,2,3 \quad 1,2,3$

$\begin{array}{lll}1,2,3 & 1,2,3 & 1,2,3 \\ 1,2,3 & 1,2,3 & 1,2,3\end{array}$

$\begin{array}{ccc}1 & - & - \\ 1,2 & 1,2 & 3 \\ 2,3 & 2 & - \\ 1,2 & 1,2 & 1,2,3 \\ 2 & - & -\end{array}$

- 1

2

-

-

-

3
3
3
3

$1,2,3$
-
3
-
-
-

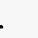

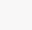

Mollusca

Gastropoda

Ancylidae

Ferrissia fragilis

Hydrobiidae

Lymnaeidae

Fossaria

Pseudosuccinea columella

Physidae

Physella

$\begin{array}{ccccc}- & - & - & 1,3 & 3 \\ 1 & 1 & 1 & 1,3 & 3 \\ - & - & - & 1 & - \\ - & - & - & 1 & - \\ - & - & - & 1 & - \\ - & - & - & 3 & 1 \\ - & 1,3 & - & 1 & 1,2\end{array}$


Table E.1 (continued)

Site $e^{a, b}$

Taxon

BBK 9.1

BBK 10.0

BBK 12.5

LUK 7.2

MAK 13.8

Gastropoda (continued)

Planorbidae

Gyraulus deflectus

Gyraulus parvus

Micromenetus

dilatatus

Micromenetus

$\begin{array}{cc}- & 1,3 \\ 1 & 3 \\ 1,3 & 1,3 \\ - & \end{array}$

Bivalvia

Corbiculidae

Corbicula fluminea

Sphaeriidae

Musculium

Pisidium

Sphaerium

$1,2,3$
2
1
-
1
kilometer.

${ }^{a} \mathrm{BBK}=$ Big Bayou Creek kilometer; LUK = Little Bayou Creek kilometer; MAK = Massac Creek

${ }^{b}$ The numbers associated with each taxon and site indicate the sampling years (i.e., the one year cycle beginning with the first collection date) that the taxon was collected at least once, with $1=$ September 1991-June 1992, 2 = September 1992 and March 1993, and 3 = September 1993 and March 1994. A blank indicates that a lower level of classification (e.g., family, genus, or species) was possible at one or more sites, and a dash ( - ) indicates that the taxon was not collected or that the taxon was not identified to a lower level at one or more sites. 
, 


\section{INTERNAL DISTRIBUTION}

1. L. D. Bates

2. B. K. Beane

3. B. A. Berven

4. S. W. Christensen

5. R. B. Cook

6. V. H. Dale

7. R. J. Devol

8. C. E. Duncan

9. R. C. Durfee

10. C. J. Ford

11. D. E. Fowler

12. G. A. Goslow

13. P. L. Henry

14. S. G. Hildebrand

15-24. R. L. Hinzman

25. G. K. Jacobs

26. D. S. Jones

27. B. L. Kimmel

28. E. H. Krieg, Jr.

29-38. L. A. Kszos

39. J. M. Loar

40. S. A. Meacham

41. F. R. O'Donnell

42-43. P. T. Owen
44. M. J. Peterson

45. R. B. Petrie

46. T. L. Phipps

47. D. E. Reichle

48. W. K. Roy

49. M. G. Ryon

50. T. K. Sawyer

51. E. M. Schilling

- 52. F. E. Sharples

53. D. S. Shriner

54. L. R. Shugart

55 J. G. Smith

56. M. R. Smith

57. G. R. Southworth

58. L. E. Stokes

59. J. R. Sumner

60. G. W. Suter

61-63. C. C. Travis

64. J. K. Williams

65. Central Research Library

66-81. ESD Library

82-83. Laboratory Records Dept.

84. Laboratory Records, ORNL-RC

85. ORNL Patent Section

86. ORNL Y-12 Technical Library

\section{EXTERNAL DISTRIBUTION}

87. D. L. Ashburn, Lockheed Martin, 761 Veterans Avenue, Kevil, KY 42053

88. M. Broido, Acting Director, Environmental Sciences Division, Department of Energy, 19901 Germantown Róad, Germantown, MD 20874

89. E. B. Bryant, Science Applications International Corporation, 301 Laboratory Road, Oak Ridge, TN 37931

90. F. A. Donath, Director, Institute for Environmental Education, Geological Society of America, 1006 Las Posas, San Clemente, CA 92673

91. D. W. Freckman, Director, College of Natural Resources, 101 Natural Resources Building, Colorado State University, Fort Collins, CO 80523

92. D. R. Guminski; Lockheed Martin, 761 Veterans Avenue, Kevil, KY 42053

93-97. V. W. Jones, Lockheed Martin Energy Systems, 761 Veterans Avenue, Kevil, KY 42053 
98. A. Patrinos, Associate Director, Environmental Sciences Division, Office of Health and Environmental Research, G-165, U.S. Department of Energy, Germantown, MD 20874

99. G. S. Sayler, Professor, 10515 Research Drive, Suite 100, The University of Tennessee, Knoxville, TN 37923-2567

100. Office of Assistant Manager for Energy Research and Development, U.S. Department of Energy Oak Ridge Operations, P.O. Box 2001, Oak Ridge, TN 37831-8600

101-102. Office of Scientific and Technical Information, P.O. Box 62, Oak Ridge, TN 37831 